UNIVERSIDAD DE SALAMANCA

DEPARTAMENTO DE LENGUA ESPAÑOLA

TESIS DOCTORAL

GENEROSA REY SÁNCHEZ

\title{
LENGUAS Y DIALECTOS HISPÁNICOS EN LOS VILLANCICOS DEL SIGLO DE ORO. EDICIÓN DE VILLANCICOS ESPAÑOLES DEL SIGLO XVII \\ (1621-1700)
}

GENEROSA REY SÁNCHEZ

Tutor:

Dr. D. Julio Borrego Nieto, Catedrático de Lengua Española de la Universidad de Salamanca.

Directores:

Dr. D. Ramón Mariño Paz, Profesor Titular de Filologías Gallega y Portuguesa de la Universidad de Santiago de Compostela.

Dr. D. José Ramón Morala Rodríguez, Catedrático de Lengua Española de la Universidad de León. 
INDICE

DEDICATORIA

AGRADECIMIENTOS

I. LOS VILLANCICOS EN LA ESPAÑA DEL SIGLO DE ORO

Autoría, representación y transmisión de los villancicos

Contexto histórico y mensaje de los villancicos del Siglo de Oro

Métrica y música

II. LENGUAS Y VARIEDADES LINGÜÍSTICAS DE LOS VILLANCICOS ESPAÑOLES DEL SIGLO DE ORO

Los lenguajes especiales y de minorías en la literatura castellana del Siglo de Oro

Rasgos dialectales. El asturleonés.

Los gallegos y el gallego

El hablar cortesano

A modo de conclusión

III. ANTOLOGÍA DE VILLANCICOS DEL SIGLO DE ORO

Normas de edición

IV. CONSIDERACIONES FINALES

V. BIBLIOGRAFÍA CONSULTADA 


\section{DEDICATORIA}

Al Excmo. Sr. D. José Luis Pensado Tomé, Profesor Emérito de la Universidad de Salamanca, eminente filólogo y excelente amigo, bajo cuya dirección se inició esta Tesis Doctoral y cuya memoria será siempre para mí imborrable. ¡Descanse en Paz.!

Carissimis patri et fratri Ioseph - Mariae, qui iam lucem Domini vident

D. D. L. M. 


\section{AGRADECIMIENTOS}

Al Excmo. Sr. D. José Luis Pensado Tomé, Profesor Emérito de la Universidad de Salamanca, por haber iniciado bajo su dirección esta tesis doctoral y por facilitarme toda clase de ayuda y además brindarme su noble amistad.

Al Dr. Darío Villanueva Prieto, Catedrático de Teoría de la Literatura de la Universidad de Santiago de Compostela, ex Rector de la misma y académico de la RAE, que tanto se interesó por el tema de los villancicos, y con su ayuda encontré director para este trabajo.

Al Dr. D. Ramón Mariño Paz, Profesor Titular de Filologías Gallega y Portuguesa de la Universidad de Santiago de Compostela, por aceptar la dirección de este trabajo.

Al Dr. José Ramón Morala Rodríguez, Catedrático de Lengua Española de la Universidad de León, por aceptar la codirección y por su ayuda constante.

Al Dr. D. Julio Borrego Nieto, Catedrático de Lengua Española de la Universidad de Salamanca, por haber aceptado ser tutor de este trabajo.

A la Dra. Doña Carmen Pensado Ruíz, Catedrática de Filología Románica de la Unversidad de Salamanca, por su amistad, por su cariño y su lealtad y por haberme infundido ánimos.

Al Dr. D. Salvador Gutiérrez Ordóñez, Catedrático de Lingüística General de la Universidad de León y académico de la RAE, por su ayuda y su amistad en el momento más difícil de este trabajo.

A la Dra. Doña Rosa Espinosa Elorza, Profesora Titular de Filología Española de la Universidad de Valladolid, por su ayuda, por infundirme siempre ánimos y por su espíritu optimista, que siempre comunica esperanza.

A Doña Amparo Sánchez Rubio, Jefe del Servicio de Préstamo de la Biblioteca Pública del Estado de Castilla y León, por haberme facilitado toda clase de ayudas en la búsqueda de la bibliografía.

A D. Pello Leiñena, del Archivo Vasco de la Música, que tuvo la gentileza de 
enviarme partituras musicales que nos informan sobre cómo era la música del villancico en las iglesias y en las catedrales, qué número de voces cantaban a coro y con qué instrumentos se acompañaban (sobre todo el arpa y el órgano).

Al Dr. D. José Varela Ortega, ex Director del Colegio de España en París, por permitirme la estancia en el Real Colegio, que me permitió acceder a la Biblioteca Nacional de Francia. 


\section{LOS VILLANCICOS EN LA ESPAÑA DEL SIGLO DE ORO}

\section{Autoría, representación y transmisión de los villancicos}

En la España del Siglo de Oro los villancicos se cantaban en las catedrales y en los conventos, especialmente en las grandes ciudades. Se interpretaban con voces de niño, a cinco y hasta siete voces y con variedad de instrumentos. Así se conseguía una nueva forma de hacer teatro en la iglesia y así se salvaguardó una parte importantísima del teatro nacional todavía tan poco estudiado: los pliegos de cordel.

No podemos olvidar que se trataba de composiciones destinadas a ser cantadas en los conventos y en las catedrales de España, precisamente por toda la geografía de la influencia. Sirva de ejemplo la ciudad de Sevilla, gran productora de villancicos y cabeza de una provincia andaluza que ocupa el sector más occidental de la depresión del río Guadalquivir y que a través de la Casa de Contratación fundada en 1503 logró monopolizar el comercio con América y se convirtió en uno de los centros comerciales y financieros más importantes de Europa. Pensemos también en la Real Capilla de su Magestad de Madrid o en el Real Convento de Nuestra Señora de la Merced, entre otros.

Los Maestros de Capilla eran normalmente los encargados de componer estos villancicos, que en origen debemos entender como "canciones propias de villanos". Esto, inevitablemente, nos invita a escribir algunas palabras sobre la autoría de tales composiciones.

Como hace años recordó Sánchez Romeralo (1969), en su Tesoro de la Lengua castellana de 1611 Sebastián de Covarrubias definía las villanescas como "canciones que suelen cantar los villanos cuando están en solaz” y apuntaba que los cortesanos habían dado en imitarlas. Poco después Gonzalo Correas decía en su Arte kastellana (1627) que eran "poesía mui antigua, i tan manual y fázil, que las compone la jente vulgar, i las canta". Pues bien, el Maestro Correas afirmaba que la gente del pueblo no solo las cantaba, sino que también las componía. Lejos de nosotros tal candidez, puesto que el término "popular" no 
deja de ser un tema particularmente vidrioso.

El pueblo no es solo una suma de individuos, sino una realidad en abstracto, una metáfora poética que se utiliza para construir una doctrina. No se sabe exactamente qué impulso individual está en la base del fenómeno colectivo. Si Herder llama a la poesía popular "poesía de la Naturaleza", tendríamos que convenir en que "la poesía popular" es superior a la poesía como Arte.

No podemos identificar lo popular con lo antiguo, ya que el pueblo no crea. La teoría de Bédier lo explica: la creación popular no existe, "le peuple ne crée pas". La poesía popular es un mito. Al lado de toda creación popular hay que pensar en un autor: el origen individual de toda creación poética. Concordamos, por tanto, con la famosa frase de Jules Tiersot: "Un canto, popular o no, tiene siempre una fecha, un autor, una patria". Toda creación es creación individual; el pueblo no crea; la llamada poesía popular es siempre de origen culto.

Tenemos infinidad de villancicos de autor, en los que consta el nombre del Maestro de Capilla, pero he aquí que otros muchos no lo declaran (tal vez fueran autores que ya gozaban de gran fama). Nuestra documentación procede del Catálogo de Villancicos de la Biblioteca Nacional Madrid, que se inicia con la descripción de los pliegos sueltos. ${ }^{1}$ Sobre el porqué de todos estos poemas tan diferentes cuyo denominador común lleva el nombre genérico de "villancicos" nos da la respuesta Querol Gavaldá (1982) en su estudio introductorio a la obra Villancicos polifónicos del Siglo XVII:

El villancico... es una forma abierta en los tres pequeños periodos o partes de que se compone: estribillo o refrán, la copla y la repetición del estribillo. Al decir forma musical abierta quiere decir que el estribillo musical puede admitir o acoger dos, tres, cuatro versos o los que sean (en el siglo XVII hay estribillos de hasta treinta versos), y con la estructura métrica y de rima que se quiera. Al músico le importaba muy poco el problema del esquema métrico literario, pues al fin y al cabo los musicará de acuerdo con las leyes específicas de la construcción musical, que está muy lejos de concordar con las estructuras poéticas y los intereses de los literatos...Para el músico el estribillo

\footnotetext{
${ }^{1}$ CATÁLOGO DE VILLANCICOS DE LA BIBLIOTECA NACIONAL SIGLO XVII, MINISTERIO DE CULTURA, MADRID, 1992.
} 
es simplemente el periodo musical que se repite obligatoriamente después de cantar la copla.

La música, una de las Bellas Artes, no puede alejarse de la obra de arte verbal literaria. No la vemos distante porque en la lengua poética abundan los grupos fónicos que también son cadencias, cadencias con musicalidad puestas en boca de quien tenga una pronunciación cuidada, y las lenguas en si mismas la tienen. Sirva de ejemplo el español, pues se sube una quinta en la frase interrogativa. Por consiguiente, pueden estar muy cerca estas dos Bellas Artes. Además, la prosa también tiene un ritmo interno.

Para ser Maestro de Capilla, no solo se exigía saber Música, sino que también era necesario saber Teología. En la actualidad es así: el Maestro de Capilla no solo sabe Música, sino que sabe también Teología. Las letras de los villancicos se componían para ser cantadas, siendo un tipo de poesía muy peculiar pensada especialmente para adaptarla a la música, y esa música se renovaba anualmente.

Durante el siglo XVII las oposiciones a Maestros de Capilla eran muy duras; tenían que componer villancicos y poner en música una serie de textos. El Cabildo se interesaba para que los villancicos fueran lucidos, tanto los villancicos de Navidad como los del Corpus. Incluso se les dispensaba de asistir al coro durante meses, mientras componían villancicos, y se les dejaba viajar a otros lugares para que pudieran trabajar con silencio y tranquilidad. Hasta tal punto tenían importancia los villancicos que se esperaba su estreno como se espera hoy el estreno de una ópera en la que canten Plácido Domingo o Los Tres Tenores... Nosotros defendemos que se trata de una cultura de masas, dirigida al pueblo, siempre con la finalidad docente de instruir y, en la mayoría de los casos, hacer reír.

En las catedrales ricas se costeaba la impresión de los textos de los villancicos. El título de los pliegos de cordel, según María Cruz García de Enterría, era "villancicos que se cantaron...", pero, pasada la segunda mitad del siglo XVI, para que el público pudiera seguir y comprender lo que se cantaba, pasaron a la fórmula "villancicos que se han de cantar". Y, como dice Querol, "los pliegos los repartían en bandejas de plata monaguillos vistosamente ataviados."

Lo más destacable de los villancicos del XVII era su componente escénico. Así aparecen mogigangas, bailes, coplas, jácaras. En esencia la palabra "jácara" parece ser que 
procede de jaque, chulo. Las jácaras eran obras que se desarrollaban en un ambiente de putas y rufianes, donde pueden abundar pendencias y malos tratos. Pero he aquí que la jácara se especializa y pasa al baile y logra recrear ese mundo tan especial, a veces infrahumano y sórdido. Se trata de un mundo del anti-héroe extremadamente degradado. Incluso a veces las jácaras se entremezclaban con entremeses y bailes, elevando todo este mundo a la categoría de lo alegre y del buen humor. Podemos afirmar que los antecedentes de las jácaras se pueden encontrar en las cancioncillas que intercalaban o servían de cierre a las obras teatrales de Juan de la Encina, tratándose de composiciones variadas que terminaban cantando la vida de jácaros y rufianes, de modo que la jácara se introduce en el teatro como música para cantar en escena. Era típico que un actor cantara la historia de los malhechores y delitos desarrollados en el mundo del hampa. El villancico no deja de ser una forma teatral de tono menor, tal como los diálogos burlescos y los coloquios pastoriles. Los villancicos forman parte de la literatura de los pliegos de cordel, y este tipo de literatura fue difundida a todas las capas populares. Los temas que cantaban los villancicos estaban en la calle: la noticia de moda mezclándose con los hechos más destacados de la época, el sitio de Viena, los viajes del rey, temas políticos o militares, coplillas que podían encerrar cierta sátira en tono menor de la política del momento...

Incluso existió un tipo de literatura misógina en la que las mujeres siempre resultaban mal paradas mientras los hombres pasaban por buenos... Era la vida propia del poder del hombre; las mujeres solían salir en las coplas muy perjudicadas.

El lujo era excesivo: trajes, criados, coches, carrozas... Destacaban el lenguaje del amor y la cultura del amor que superaban todo género de dudas. Era un tipo de poesía vendible, que servirá de base más tarde al triunfo del teatro nacional. El pliego suelto era la fuente donde bebía el pueblo español, que a su vez iba adquiriendo los conocimientos literarios y poéticos del momento. Puesto que no podían comprar libros voluminosos, compraban el pliego suelto y así conocían por poquísimo dinero las comedias que más les podían interesar.

Sin duda el pliego suelto tuvo una función educadora, pues llegó a servir de cartilla para que los niños aprendieran a leer durante varias generaciones. 
Los pliegos sueltos eran la literatura que leía el pueblo, la gente iletrada aunque no analfabeta, como apunta María Cruz García de Enterría (1973). Era un reflejo de la sociedad, porque la literatura abarcaba el mundo del teatro y esa faceta era precisamente una zona muy importante, ya que el Siglo de Oro no tuvo fronteras. Pensemos en Tirso de Molina, Calderón y Lope de Vega.

Los excelentes estudios de Antonio Rodríguez Moñino, Eugenio Asensio y Julio Caro Baroja lo confirman (entre otros estudiosos del tema que nos ocupa).

Le llamamos "pliego suelto" o poesía de cordel, para hablar de composiciones en verso. A través de este modelo de transmisión se conocieron romances, sátiras sociales, políticas, cantarcillos... Se vendían en cuadernillos de pocas hojas, asequibles al pobre poder económico de la masa de una población que, como decíamos anteriormente, era iletrada.

En cuanto al siglo XVII, existen pocos estudios sobre los pliegos de cordel, pero son muy importantes, tales como el de Eward M. Wilson, que analizó la colección que Samuel Pepys se llevó de España a finales del XVII y se encuentra ahora en Magdalen College de Cambridge. No deja se ser igualmente relevante que gracias a la transmisión de los pliegos de cordel hemos podido "salvar" y "conocer" textos antiguos de poesía. A lo largo del siglo XVI el buen gusto fue de carácter general, es decir, no fue patrimonio de unos pocos, sino que existía una selección valiosísima, un gusto popular, porque el pueblo se educaba en el arte literario. Este buen gusto está cargado de sentimiento grandilocuente, buscador de sensacionalismos $\mathrm{y}$, según Caro Baroja, "personal y vitalista", poco amigo de razonamientos y de análisis. De esta manera se va generando un tipo de divorcio entre el gusto oficial y el gusto popular, y, dentro de lo popular, una línea divisoria del buen gusto, el de las clases altas y el de las clases bajas. Es el pueblo el que conserva el buen sentido literario, igual que en la demosofía popular se conservan los refranes e incluso el lenguaje religioso (muy abundante en el idioma castellano) y, por supuesto, la fe católica.

¿Cuál sería la actitud con que los escritores españoles veían que su obra se expandía por toda la geografía popular y también por la geografía de la influencia (aunque no siempre) gracias a los pliegos de cordel? Sin duda el profesor Pensado Tomé, con su experiencia de eminente filólogo, conocía al dedillo infinidad de textos que él mismo había 
rastreado en la Biblioteca Nacional de Madrid, razón por la que me introdujo en este amplio campo lingüístico y literario. Este tipo de literaturas se consideraron marginales, y sin duda los bibliófilos de la segunda mitad del siglo XIX y los primeros del siglo XX han sido los que más han valorado las ediciones de los pliegos de cordel.

Una literatura popularizada, como la de los villancicos, nos dará la clave del siglo XVII para su estudio. Puede haber pliegos de diez hojas, cinco hojas y hasta veinte hojas como máximo, pero María Cruz García de Enterría sigue afirmando que resulta difícil creer que pudieran venderse pliegos de cordel superiores a veinte hojas.

El individualismo en que vive el hombre del periodo barroco incluso hace que se vaya perdiendo la sátira social. No llegamos a la sátira de Quevedo... Los pliegos de cordel tenían capacidad de sátira, pero, ya se sabe, ésta se va perdiendo a pesar de que la gran ciudad tiene un gran influjo sobre el vulgo. Karl Vossler así lo señaló, haciendo notar que se pierde por su falta de radicalismos religiosos, éticos, e incluso de carácter político. Además el pueblo tampoco podía ensañarse contra el caído, de ahí que existan razones de peso para que no se insistiera tanto en la sátira política y se insistiera mucho más en los sucesos nobles o relativos a personas de muchísima influencia social, que destacaban en la literatura de carácter estrictamente popular.

De todos modos, hubo pliegos de cordel hasta para El Príncipe. Se conocen unos diez sobre don Juan de Austria, los cuales están dirigidos a cantar las virtudes de don Juan, en la plenitud de su poder, cuando consigue el favor real.

No faltaron en el siglo XVII pliegos de cordel relativos al bandolerismo y a cantar las infidelidades de personalidades, pero siempre en tono menor. Pensamos que en este momento la literatura marginada se mueve en los villancicos, pues se escribían y se cantaban y viajaban de un sitio para otro. No cabe duda de que los villancicos tuvieron un gran auge. Así, sabemos que consta que a Portugal llegaron los pliegos de cordel sobre la Inmaculada Concepción, o para pedir por las benditas ánimas, sobre marqueses y personalidades de la época, canciones fúnebres, sobre felices sucesos... Se conservan en el catálogo de pliegos de cordel en la Universidad de Coimbra (Portugal).

Podemos hacer de los villancicos una lectura intertextual, dado que la intertextualidad orienta la lectura del texto. Es decir, estamos ante textos lingüísticos, 
poéticos y musicales, de manera que la intertextualidad es un fenómeno que orienta la lectura del texto, que gobierna su interpretación y que viene a ser lo contrario de la lectura lineal, de tal manera que podemos aplicarla a la lectura o a la audición musical. Incluso tenemos conocimiento de que existieron bailes, o mejor "danzas", con lo que se pretendía mezclar lo divino con lo profano, existiendo siempre un intento de divinización de los textos. A veces son cancioncillas tradicionales que resultan evocadoras. Los villancicos buscaban formas de divertimento, bailes, jácaras, cañas, y sirva de ejemplo una pícara escena de un romance viejo con solo dos octosílabos en la que unos monaguillos dicen:

$$
\begin{aligned}
& \text { Por decir "amén, amén" } \\
& \text { decían: “amor, amor". }
\end{aligned}
$$

El villancico, tal como lo conocemos, influyó en el cante jondo y, tratándose de los pliegos de cordel, hay que relacionar lo popular con lo culto, puesto que están llenos de ecos de una poesía cantada y otras veces recitada y leída. A pesar de que la literatura de pliegos de cordel es una literatura marginada y olvidada durante muchos años, hemos descubierto su gran elenco y su gran valor, tanto en lo literario como en lo lingüístico, en lo filosófico y en el ámbito de la teología y el arte musical, dado que los villancicos poseen una gran riqueza cultural del momento histórico que estudiamos, ya que cada texto está abierto y hace posible asimilar muchos otros textos interrelacionados. Además el pliego de cordel nos aporta datos, noticias y grandes recuerdos de la memoria poética y lingüística colectiva.

Los villancicos están relacionados con todo lo parateatral, íntimamente conectados con sus raíces originarias en las representaciones litúrgicas medievales: los tropos. Se componían villancicos para la consagración de una religiosa, para el Corpus y la Navidad.

\section{Contexto histórico y mensaje de los villancicos del Siglo de Oro}

Al comenzar el siglo XVII España es la primera potencia de Europa, pero, debido al proceso de descomposición, a medida que avanza el siglo la hegemonía española se va perdiendo poco a poco, muy a pesar de que los tercios españoles luchen con éxito en toda Europa y de que los barcos que vienen del Nuevo Mundo traigan no solo novedades, sino 
también inmensas riquezas. En efecto, frente a todo esto, son notorias la despoblación interior, las pestes y la bancarrota económica, que nos dejan una España que empieza a ser pobre... Además, la expulsión de los moriscos, unida a la anterior de los judíos, alejó de nosotros la mano de obra tan necesaria para mantener el trabajo cualificado.

Este panorama histórico desolador, conocido por todos, ya lo percibimos con claridad en el Lazarillo de Tormes de 1554, pero en el siglo XVII, y especialmente en su segunda mitad, cobrará tintes dramáticos. Los españoles se dan cuenta de la realidad que palpita en la vida diaria, el hambre, la pobreza, la falta de cultura... No hay cultura y, si la hay, es dirigida y, como es natural, la cultura nunca debe ser dirigida. Por eso el período barroco español se caracteriza por la desconfianza y la idea del desengaño, lo que hace que el hombre español de este momento se incline hacia un tipo de arte que gusta del retorcimiento, el ingenio, los contrastes, la complicación, como respuestas desesperanzadas al desencanto dominante.

Los villancicos nos muestran esa realidad espiritual y a la vez crítica, porque desde la iglesia se podían criticar conductas y posturas poco edificantes. Como casi siempre, la calidad de los resultados obtenidos era cuestión de genialidad individual. Eran los Maestros de Capilla los creadores que conocían a su asiduo público y le proporcionaban un espectáculo que el pueblo buscaba y pedía con avidez con el ánimo de divertirse.

En nuestra edición nos movemos en la lírica religiosa, pero veremos como dentro de la geografía de la influencia religiosa cabe todo, desde la sabiduría de la demosofía popular hasta la palabra culta, la sentencia del juez, la palabra científica del filósofo, la del compositor de música, la crítica social o la sonrisa de la desilusión: la ironía. Pero a veces también cabe la sátira porque cansa menos, e incluso el villancico de tipo "panfleto político" que se empleaba en las disputas de las iglesias más prestigiosas de España.

La Cruz, como dice San Pablo, es escándalo para los judíos, locura para los gentiles, pero para "los llamados" es fuerza y sabiduría de Dios. Dios no es indiferente al sufrimiento humano, pues en la Cruz Jesús asume el dolor del hombre. De ahí que los villancicos son a veces denuncia de las injusticias sociales: Jesús, hombre bueno y coherente, viene a salvar al género humano, para devolvernos la hermosura con que nos hizo a su imagen y semejanza. Por consiguiente, todos somos iguales todos ante Dios, sin 
diferencias de razas ni de lenguas ni costumbres ni condiciones sociales. Mediante la comunión mesiánica, esa comunión actual con el Mesías en su futuro reino de la que San Pablo sacará las consecuencias para la comunión con Él después de la muerte (aunque el antiguo esquema de la esperanza mesiánica no tratara de la situación de los muertos, antes de la parusía del Mesias), Jesús vence en la noche y en el frío del invierno. La Noche Santa de la Navidad nos trae la fe, la esperanza, la caridad cristiana, la belleza, y nos invita a una convivencia de amor, siendo su venida la incorporación del hijo de Dios a la humanidad.

El mensaje de los villancicos es siempre divino, es adorar al Niño Jesús en su venida al mundo, es para educar en la fe cristiana y en el magisterio de la Iglesia Católica, tiene siempre una finalidad didáscálica, aunque en muchas ocasiones la balanza se escora hacia la posibilidad de hacer reír. Pero, según la sabia definición machadiana, los villancicos son poesía y la poesía es literatura, y la literatura es palabra esencial en el tiempo... Y, en este caso, los villancicos también son música.

\section{Métrica y música}

En cuanto a la métrica, el villancico está muy próximo al zéjel o cantiga de villanos, forma popular que ha sido documentada mucho más tarde. En los cancioneros de los siglos XV y XVI aparecen villancicos bajo los nombres de "canción” y "cantiga", pero en el Cancionero General (1511) ya se encuentran con el nombre de "villancico", aunque no se refieren a la forma poemática, sino a unos cantarcillos populares propios de villanos o gente rústica que suelen ser de dos o tres versos y en ocasiones incluso más largos. Durante el reinado de los Reyes Católicos, el villancico se pone de moda en la corte, siendo muy cultivado por los poetas cortesanos.

En los siglos XV y XVI se cultivan en octosílabos y en menor medida en hexasílabos y un murmullo de seguidillas y otras métricas populares.

Los villancicos de tema gallego suelen tener el verso de gaita gallega. Muchas veces nos encontramos con polimetría libre y regulada. Así, las ensaladillas renacentistas son composiciones de temática narrativa cuya base métrica es el romance o romancillo acompañado de redondillas o coplas castellanas, incluyendo canciones trovadorescas o villancicos (Paraíso 2002: 344). 
En relación a la música de los villancicos poseemos un conocimiento de la realidad poético-musical de los siglos pasados.

La cantata como pieza sonada en oposición a una sonata abunda en el siglo XVII y el músico más notable autor de innumerables cantatas fue sin duda J. S. Bach, quien compuso cantatas profanas, campesinas y cantatas de café. Se conservan unas doscientas, con el texto fugado conjugado con recitativos, de manera que este genial compositor renueva sus viejas composiciones y literalmente las parodia llegando a parodiar 186 piezas bajo formas cerradas, arias y coros. Nunca J. S. Bach convertía obras sacras en profanas, de manera que entre cantatas, misas y motetes, junto con recitativos, ascienden a 936, utilizando los campos emocionales de la música más bella del Barroco en versiones del Oratorio de Navidad, cuyo modelo de música evangélica sacra permanece en nuestro tiempo (Otterbach 1990).

El villancico en España tiene mucho que ver con las cantatas, no tanto en el sentido de la imitación, sino como una forma singularizada de la música sacra. J. S. Bach fue criticado porque en su Oratorio de Navidad su música era más propia de la ópera que de la iglesia, pero toda la música que componía Bach era auténtica y la componía para mayor gloria de Dios. Incluso no solía hacer separación entre música clásica profana y música sacra, pues ésta también puede adoptar gestos de danza que nos pueden hacer sentir lo operesco de la Iglesia barroca. Tengamos en cuenta que el villancico procede de la lírica popular, la letra del villancico llevaba implícitamente una composición musical, de modo que el villancico es ante todo música, el villancico está siempre destinado al canto. Conocemos por las partituras musicales que el villancico policoral pierde fuerza a finales del siglo XVIII, prevaleciendo el unicoral frente a villancicos de doce voces, tres coros, y, a dieciseis, cuatro coros en la época de plenitud barroca. Curiosamente, el maestro de capilla Miguel Gómez Camargo (1690) cita villancicos a cuatro voces (1 coro) 9; villancicos a doce voces ( 3 coros) 10;

Villancicos a 8 voces $(2$ coros $) 169$

Villancicos a 16 voces $(4$ coros $) 2$.

En cuanto a la instrumentación, unas veces se ejecutaban con órgano solamente, otras con órgano y arpa, además de otros instrumentos acompañando o supliendo las voces 
con chirimías, cornetas y bajón.

José Martínez Arce (1690-1722) marca un nuevo hito en este tipo de música al emplear los siguientes instrumentos: órgano-arpa y clavicordio; órgano-arpa y violón; órgano-arpa y clarín.

En general los temas musicales en las misas eran melodías folclóricas. Como ejemplo sirva la Fiesta del Asno que se celebraba en Francia el 14 de enero, en la que un jumento entraba en la iglesia y asistía a la celebración de la misa, mezclándose las coplas en lengua vulgar con el canto litúrgico y en el que el ite missa est era reemplazado por tres sonoros rebuznos...

En el siglo XVI los intrumentos de viento más empleados eran el sacabuche o trombón primitivo, la corneta de madera, el bajón fagot, la flauta de pico o flauta dulce y la flauta travesera o la flauta alemana.

En el siglo XVII la música como lenguaje universal se enriquece con el violín, con organistas y calvistas o clavicembalistas eminentes, siendo tres países los que contribuyen al feliz resultado de la culminación sinfónica: Italia, Francia y Alemania. Los italianos con la sonata della chiesa (sonata de Iglesia).

Para conocer tan solo un poco la música religiosa española del siglo XVII serían necesarias infinidad de partituras con las que no contamos, ya que son fondos reservados musicales que forman parte del elenco del siglo XVII. Ahora bien, conocemos el nombre de más de 500 compositores españoles del siglo XVII, muy a pesar de que un considerable número de maestros de capilla y de organistas — que suponemos que componían músicani siquiera sabemos quiénes eran. Los autores anónimos sin duda son innumerables.

En la historia de la música religiosa del siglo XVII destacan los distintos géneros: la Misa, el Motete, los Salmos y los Villancicos.

Igual que en las demás artes, la música pierde la gravedad lírica y patética, pasando a un lenguaje musical de formas enfáticas y de escaso contenido del sentimiento que se denomina sentimiento de fondo.

La música eclesiástica del Barroco incluía estilos opuestos como las pasiones de Schütz y las cantatas de Bach. 
El villancico del siglo XVII es siempre del mismo tipo. Las piezas musicales son villancicos. En cuanto al texto, los hay profanos (son los llamados "Tonos humanos") y los hay "a lo divino". La técnica de los villancicos españoles es muy avanzada y tiene un sabor nacional inconfundible... En muchos villancicos se cantan varias coplas con música distinta buscando que cada una de ellas tenga una nueva combinación de voces. Sirva de ejemplo el concerto instrumental tipo Vivaldi, que suele acompañar al solista con arpa o con el órgano. Podemos afirmar que el colorido de los villancicos y su estructura nos ofrecen muy buenas calidades instrumentales. Transcritos para la pequeña orquesta, podemos asegurar que harían un buen papel en la música de cámara puesto que el diálogo entre solista o solistas y el tutti del coro es más frecuente y personal que en los demás géneros. El primer periodo es repetido íntegramente en por el coro. Podemos afirmar que el villancico se renueva una vez trazados los grandes rasgos y las formas ordinarias del villancico en el siglo XVII pueden reducirse a los esquemas A-B-A y A-B-A-C-A. Sin embargo, se observa en ellos, a través de la multiplicdad, una unidad temática de motivos, tonos, ritmos y espíritu desconocidos en el siglo anterior. Son famosos los compositores tales como Carlos Imaña, Mizieres, Veana Ruiz, Paredes y Galán entre otros muchos. Su valor artístico es muy superior a otros géneros de la época (Subirá 1953). La música en la Europa Occidental tuvo una gran difusión a través de los villancicos cantados en los conventos, en las catedrales y en las iglesias. Infinidad de villancicos fueron cantados en España, Francia, Bélgica, Polonia, Italia... Unas veinticinco nacionalidades cantan al Niño Dios en su lengua. 
II.

\section{LENGUAS Y VARIEDADES LINGÜÍSTICAS DE LOS VILLANCICOS ESPAÑOLES DEL SIGLO DE ORO}

Cuando hace años iniciamos la elaboración de nuestra tesis doctoral nos propusimos realizar el estudio de un corpus lingüístico y literario que se desarrolla durante siglo y medio con los villancicos de tema gallego, engarzados y relacionados como si se tratara de una nuda y entrelazada propiedad de los siglos XVI, XVII y XVIII, en los que los mejores ingenios de la época escriben villancicos para celebrar la venida de Jesucristo al mundo. Como apunta Rodrigues Lapa (1930), muchos de esos villancicos de tema gallego fueron escritos en castellano por individuos de lengua castellana que los componían para un público mayoritariamente castellanohablante. En conjunto, conformaban un corpus de estudio ya suficientemente rico, mas no tardamos en percatarnos de que en realidad se inscribían en el marco de una onda creativa más amplia que despertó nuestro interés y nos llevó a modificar nuestro proyecto de tesis bajo el nuevo título de Lenguas y dialectos hispánicos en los villancicos españoles del Siglo de Oro.

Desfilan por estas piezas poéticas individuos que hablaban diferentes lenguas o variedades lingüísticas de la época, en no pocos casos — aunque no siempre- propias de las clases más ínfimas o de los grupos más menospreciados de la sociedad de entonces: gallegos, sayagueses, vizcaínos, asturianos, gitanos, negros, franceses, portugueses, italianos e incluso alemanes. Casi siempre, tales variedades se presentan en estos textos como lenguas imaginarias con una gran dosis de castellanización. Se trata en la mayoría de los casos de lenguas imitadas o parodiadas, con muchas agresiones fonéticas a la norma castellana, casi siempre puestas en boca de los que, en su debilidad económica, no solamente son pobres, sino que también tienen una competencia lingüística inferior.

A menudo, el deseo de una liberación lleva a los gallegos a pedirle al Niño Dios que se haga gallego, como ellos. Quieren que Jesús nazca en Galicia, desnudo y sin zapatos, para que así su vida se asemeje más a la vida de los gallegos: que nazca entre los animales, tal como nacen, viven y mueren los gallegos, pero con la alegría que caracteriza a la tierra meiga y con una gran dosis de esperanza y de constancia. La constancia tiene el color del 
cielo y la alegría nace del corazón humilde y sencillo, que sufre y se alegra y sublima su sufrimiento a través de la fe. El gallego siempre viene de camiño, normalmente descalzo y con las botas al hombro, aunque a veces éstas no son para los pies, sino para el vino. No cabe duda de que los escritores del Siglo de Oro pintaron con las peores tintas la imagen del gallego, imagen que, como ha afirmado Pensado Tomé (1987),

aunque tuviese un leve fundamento, además de un tópico literario era también una medicina tópica para tranquilizar la mala conciencia que ese trato social despertaría en las gentes coetáneas. Su situación era consecuencia de su comportamiento, porque eran egoístas, ladrones de baja condición social. Pero no todos pensaban así, una mala conciencia se esconde detrás de todos esos tópicos justificativos, y viene a liberarse acudiendo al villancico de gallegos, haciendo que Jesús guste de ellos, pobres, humildes y desvalidos, y ellos gusten de Jesús, único refugio de una sociedad que les deprecia.

Así que el hecho de que el Fillo de Deus fuese hombre y además gallego se convertía en una especie de consuelo para estas gentes.

No cabe duda de que Galicia, como Asturias, también podía presumir de ser tierra de cristianos viejos, pero la palma en la ostentación de la condición hidalga se la llevaban, como también ha apuntado Pensado (1987), los portugueses, que solían ser asimismo presentados como modelos de arrojo y determinación:

Pois sois segundo dos tres,

portugués en fidalguía,

¡naon choreis, que é cobardía

que chore un rey portugués!

Fillo del Rey, naon choreis,

pois sois persoa real.

¡Ay, en Portugal,

chorar os fillos de os reys!

¡Ay, ta tatatan

$\tan$ ta,

ay, ay, ay, ay

tata tan! 
Parafraseando al eminente profesor Pensado, podemos decir que las rivalidades de las que se hicieron eco los villancicos eran nobles, estaban incluso teñidas de afecto y se utilizaban fundamentalmente con fines humorísticos, puesto que ante el Niño Dios quedaba excluida toda la maldad humana. Había un intento de hacer a Jesús gallego, portugués o de otras tierras, según los casos. Así, el gallego decía que había nacido en Compostela, el portugués que en Lisboa, y todos querían llevarlo "coa gente galega a nosa Lisboa". A este tópico responde el debate de los villancicos de la catedral de Segorbe, con una ensalada a cinco lenguas en la que no podía faltar el gallego:

Oygan que sale un gallego,

que viene a pedir también

al niño recién nacido,

y diz que suyo ha de ser.

(...)

Yo so un pobre galeguiño

que veño de miña terra

pur este bello minino

que ha nacido in Compostela;

e si hay queyn esto dudare,

afora le espeyro, veña,

que yo li daré a entendeyr,

queyn es a gente galega.

No falta tampoco el corito o asturiano:

Yo, señores, so corito,

y non teño mas de media testa,

perque la youtra metad

la juguey a la primiera.

Afirma Pensado (1987) que "el corito o asturiano" hace gala de su apodo diciendo que ha jugado la mitad de su cabeza, porque los asturianos no tienen cocote, es decir, tienen una cabeza partida por medio y, para que ambas mitades se puedan juntar como medias naranjas, están así, sin cocote, lisas y listas para ser unidas. 
Podemos afirmar que la hipercaracterización del lenguaje tenía una clara finalidad: hacer reír, de tal forma que todo contribuía al divertimento en la iglesia. Mucha gente que no pisaba la iglesia iba cuando sabía que iban a representar villancicos. Incluso los tuvieron que prohibir, porque el público en las catedrales se abalanzaba hacia la parte reservada a los canónigos. Felipe II, por Decreto de 11 de junio de 1596, los prohibió en la Real Capilla, pero al parecer no tuvo efecto dicha prohibición, pues la gente acudía igual. La risa en las representaciones procedía de una agudísima ironía y de abundantes juegos semánticos evocadores de las costumbres de cada lugar, de modo que los villancicos se propagaban como los cantos de ciego, de ciudad en ciudad...

\section{Los lenguajes especiales y de minorías en la literatura castellana del Siglo de Oro}

Al acercarnos a la lengua literaria del Siglo de Oro, vemos que el empleo de las lenguas minoritarias o marginales por parte de los autores es sumamente impreciso y está teñido por grandes dosis de subjetividad. Preferimos denominar estas lenguas minoritarias con el nombre de lenguajes especiales (Salvador Plans 2004).

Existe una gran variedad de registros que nos llevan de la mano desde el empleo de hablas jergales como la de germanía hasta la imitación de aspectos lingüísticos de minorías sociales (los negros, los gitanos o los moriscos) o bien a diversas peculiaridades de carácter regional entre las que podemos citar el vizcaíno. Debemos señalar el uso del sayagués, que posee un significado distinto, pues se trata de un lenguaje con una carga de intencionalidad vulgarizante, lleno de leonesismos pero con un gran arraigo en la tradición literaria. Suele tener carácter burlesco, aunque este rasgo puede variar en intensidad según sea el tipo concreto de habla.

Dentro del marco conceptual de los villancicos trataremos estos lenguajes especiales con la brevedad requerida, puesto que se trata de un proceso complejo y, al acercarnos a la lengua literaria del Siglo de Oro, el uso por parte de los autores es frecuente e inmensamente rico, recogiendo el habla dentro de una gran diversidad que permanece en la sociedad del momento a la que nos referimos.

Esta gran variedad de registros va desde las hablas jergales hasta la imitación de aspectos lingüísticos de minorías sociales, como son los negros, los gitanos o los moriscos 
e incluso ciertas variedades regionales como el vizcaíno. Veamos, a modo de ejemplo, lo que nos depara un villancico cantado en el Real Convento de Nuestra Señora de la Merced (Madrid) en 1680 en el que se nos habla de Vencerril de Campos.

En cuanto al lenguaje de los negros, digamos que este personaje inicialmente merece por nuestra parte una gran atención, ya que aparece como personaje cómico en la literatura portuguesa y en la poesía, tanto en España como en América. Tradicionalmente se suele afirmar que es un fenómeno de imitación fiel de una realidad lingüística. Parece ser que el primer contacto de estos negros con una lengua romance se produjo con el portugués y sería precisamente en Lisboa donde aprenderían las primeras palabras portuguesas antes de pasar por el mercado de Sevilla. Germán de Granda (1991) considera este modelo incompleto, pues cree que el habla de los negros no se formó básicamente durante el tiempo que estuvieron como esclavos en el Portugal metropolitano, sino que venía ya estructurada desde tierras africanas. En consecuencia, sería un "criollo" y —sigue afirmando este autor- los datos sociohistóricos son esclarecedores y demuestran que estas poblaciones negras tenían ya en África un contacto con una variedad de lengua portuguesa claramente "criolla".

En cuanto a los rasgos caracterizadores del habla de los negros, casi todos los autores coinciden en señalar los mismos rasgos fonéticos. En el vocalismo destaca la falta de diptongación (mandamento por mandamiento, terra por tierra, bosa por vuesa). Existe también una tendencia a utilizar la vocal $a$ frente a las vocales medias: así, tenemos samo por somos. En los villancicos hemos detectado culurada por colorada (un color muy vistoso del Barroco), plegolela por pregonera, Siolo por Señor, busamilce por vuesa mercé, ditinga por distinga, vamo de plisa por vamos de prisa, fablamo por hablamos, conservación de la F- inicial, sonorización de la /p/ (barados por parados)... Es frecuente el trueque de sibilantes, provocando casos tanto de seseo como de ceceo, aunque en los villancicos del Siglo de Oro es mucho más frecuente el ceceo, sobre todo cuando hablan las gitanas: así, tenemos corasón por corazón, zabe, zeñó...

Los cambios fonéticos en el habla de negros se suelen relacionar con los sistemas vocálicos de las lenguas nativas africanas. No es extraño que los negros canten al Niño Dios en una lengua que no es la suya y, aunque con interferencias, nos recuerdan el modo 
de hablar de una minoría étnica que reclama la nacionalidad para el Niño Jesús en África.

En cuanto al habla de los moriscos que cultivaron la literatura aljamiado-morisca, en los villancicos encontramos la palabra chequelio por chiquillo. Está claro que no sabían pronunciar las consonantes lateral y nasal palatal y que seseaban constantemente; así, se les conocía por pronunciar sebolla por cebolla, estrelilia por estrellita, camelios por camellos, senior por señor, nenio por niño. Las regiones de Valencia y Andalucía eran mucho más arabizadas $\mathrm{y}$, por consiguiente, eran más arabófonas, mientras que las regiones reconquistadas muy temprano, como Aragón o Castilla la Vieja, lo eran mucho menos.

En cuanto a la lengua de los gitanos, en los villancicos aparece una gitana ceceando. Su lenguaje es el de los cíngaros, un cierto lenguaje que también usan los ciegos por donde pasan y que a veces resulta una jerigonza difícil de entender. Veamos un ejemplo: enamoradito erez, en los ojueloz ze ve... Sin duda el texto que comentamos es de una época tardía, de cuando ya estaban los moriscos en Berbería, si bien la lengua del moresco tiene todas las características de una invención.

En definitiva, podemos afirmar que el lenguaje de los gitanos es un compedio de todo lo que oyen y viven. En los villancicos está hábilmente plasmado y caracterizado. La gitana se siente villana, como una situación social inferior, villana tengo de zer... Y el empleo de gitanismos, como diría Covarrubias, tira a la esclavona. Es escasa la aparición de personajes gitanos en Cervantes o Góngora, en cuyas obras su caracterización lingüística se limita al empleo del ceceo.

\section{Rasgos dialectales. El asturleonés.}

Por lo que se refiere a la inclusión de personajes que introducen variantes diatópicas, más que diastráticas, además de la presencia generalizada del gallego y de los gallegos, en los villancicos figuran con alguna frecuencia personajes asturianos y leoneses, estos especialmente representados por maragatos, sayagueses o, incluso, de Tierra de Campos. Cuando se trata de caracterizar lingüísticamente a personas con esta procedencia, se echa mano tanto de rasgos reales procedentes de las variedadades romances de estas zonas como de otros que, en muchas ocasiones, responden al tópico literario con el que fácilmente se les identifica. A ello se añaden rasgos que pertenecen sencillamente al 
castellano más arcaico, vulgar o coloquial pero sin una adscripción geográfica concreta, además de otros rasgos que, sin más, el autor confunde a la hora de intentar una caracterización geográfica, algo que, por otra parte, carecería de importancia sobre las tablas del escenario en la medida en que, aunque no fuera una caracterización correcta, serviría para que los espectadores identificaran sin mayor problema al personaje.

En el villancico $n^{\circ}$ VII escrito para el Real Convento de San Felipe en 1679, aparecen en escena un gallego y un asturiano. Pues bien, los textos con los que se hace intervenir al asturiano contienen algunos rasgos que sí responden a lo esperable pero, en otros casos, parece que su autor no tiene muy clara la diferencia entre gallego y asturiano.

Del primer tipo tenemos, por ejemplo, los cierres de vocal final (ninu garridu, curitu, chicu, zapatus, regalitu, bocaditus). Del segundo, llama la atención, por ejemplo, el uso del artículo gallego (os galegos, o portal, das montañas) o de formas verbales gallegas (beña 'venga', teña 'tenga', perdan 'pierdan') puestas en boca del personaje asturiano. No son los únicos casos: ambos utilizan la partícula pois 'pues' o los diptongos decrecientes (pandeiro, dous) que, en el caso del asturiano, solo tendría sentido para el área occidental, algo que no parece probable que el autor tratara de reflejar. En todo caso, es aún más característica la falta de cohesión interna, como puede verse en la forma en que citan la paja del pesebre. Mientras que el gallego, de acuerdo con lo esperable usa palla -al igual que mellor o escollido voces con las que comparte la secuencia /lj/- el asturiano usa paya (lo que sería una buena elección) pero también el castellano paja. Sin embargo, el propio asturiano usa también millor 'mejor' y, teniendo en cuenta que generalmente se le hace hablar con yeísmo (mantiya, gayegos, caien 'callen'), lo más probable es que el paya citado, más que una observación oportuna del resultado de /lj/ en asturiano, quizá solo sea un caso más de este supuesto yeísmo.

Más significativo de la falta de una identificción clara que los autores de villancicos de la época tienen de las características lingüísticas del dominio leonés o asturleonés es el villancico de 1680 cantado en el Real Convento de Nuestra Señora de la Merced.

En él intervienen un gallego, un asturiano y un maragato. Al maragato, es decir, 
leonés, se le invita a cantar "como maragato ... por el tono de Sayago" para cerrar su intervención con un "no hable más en margato". El tema que elige se refiere a Becerril de Campos, que en 1521, en la guerra de los Comuneros, no se entregó al Condestable de Castilla, don Íñigo Fernández de Velasco, que asaltó la localidad cogiendo prisionero a Juan de Figueroa, hermano del Duque de Arcos. Los rasgos más destacables qu el autor pone en su boca parecen responder más al tópico literario del sayagués o a la lengua de las zonas leonesas más castellanizadas (la referencia a Becerril puede ser significativa si tenemos en cuenta que la zona occidental de Campos pertenecía al obispado de León) que al que cabría esperar de alguien de la comarca de Astorga.

Con frecuencia se le caracteriza con algunos arcaísmos no especificamente leoneses (aqueste, aquessa, vos 'os', recibilda 'recibidla') u otros que pertenecen al tópico literario del sayagués (quijo 'quiso' lo utilizan también Lucas Fernández o Torres Naharro). Los rasgos más representados para los que efectivamente se puede hablar de una adscripción geográfica leonesa son los que presenta el uso del posesivo (al mi niño, de so padre), el uso de un /-e/ paragógica (lugare) o el mantenimiento de /f-/ (firmosa 'hermosa') si bien aquí es posible que, como en casos anteriores, el autor haya recurrido al arcaísmo. La frecuente vacilación en el uso de las vocales (Orraca, moger, firmosa) no responde en esta época a una variante diatópica clara por lo que es posible que se utilice más como un vulgarismo con el que se trata de caracterizar al personaje que como una marca dialectal. En general, puede decirse que al maragato se le representa con un tipo de lengua que poco o nada tiene que ver con los rasgos que tendría la lengua habitual de su comarca de origen.

Por su parte, al asturiano se le pide que "cante en corito" y, en un texto algo más amplio que el anterior, se reúnen abundantes rasgos y expresiones que pueden considerarse diatópicamente marcadas. Frente al maragato, vagamente identificable con el dominio leonés, el asturiano aparece hipercaracterizado en el plano lingüístico, si bien no siempre el autor atina con lo que podría considerarse asturiano.

Se registran en su intervención varios casos de palatalización de /n-/ (ñobedad, ñon, ñarizes, Noriega) y lo mismo ocurre con la /1-/ (llugar, lluengos, llargos, lluego, los artículos lla 'la', llos 'los', lles 'las' o el pronombre personal lle por le, que, en otras ocasiones, es ye, buscaronye). También en el plano fonético, se observa la variabilidad 
vocálica, especialmente en lo que atañe al cierre de la vocal final (raticu, sayu, altu, baqueru, negru, Reyis); la solución asturleonesa para /lj/ que aparece en fiyu 'hijo' o en ginoyos 'hinojos' -voz en la que también vemos el mantenimiento de $/ \mathrm{g}^{\mathrm{e}}-/$, aunque también aparece el castellano mijor; el mantenimiento de /f-/ (fazen, filera, falar, folganzia, fincaron), en el último ejemplo también con epéntesis de /i/. Como en el resto de los casos, no se trata de soluciones usadas de forma sistemática y, así, figuran también en boca del asturiano nuevo, negru, Natal, nieve, con /n-/ sin palatalizar, o, en el caso de la palatalización de /l-/ en el artículo, alternan formas caracterizadas con otras coincidentes con el castellano (la nieve, los Gallegos, las coses / lla folganzia, llos pendones, lles camisas). Esta variabilidad aparece igualmente en la mayoría de los fenómenos que se utilizan para caracterizar la lengua del asturiano que, por lo común, carece de regularidad.

Otros de los fenómenos representados son los plurales femeninos en /-es/ (castanueles 'castañuelas', les coses, fermoses, blanques, eren 'eran', estaben, pero lles camisas); la copulativa ya < et (Flayres foron, ya Flayres pasoren / Ya Frayres tornoren, ya Frayres que vàn), fragmento en el que también se observa el peculiar tratamiento de la tercera persona del verbo (pasoren, tornoren) o el paradigma del verbo ser (ye, yera pero eren 'eran'). Significativo es también el uso que se hace del paradigma del posesivo. Para la tercera persona utiliza de modo general la forma so /sos combinada con el femenino, pero usa su en el masculino (so manguiya, so grauedad, sos pelliciques, pero sus zirios). En la primera, con una curiosa mezcla de variantes centrales y occidentales, utiliza miou para el femenino y mio para el masculino (miou casa, miou bida, mio llugar, mio Iuan ñoriega). También es destacable la asimilación de preposición seguida de artículo (eña miou vida 'en la') que es más frecuente en el caso de per /por, con resultados no siempre coincidentes: polla mio alma, peila man dreyta, pella man riesga.

Entre los rasgos que caracterizan la lengua del asturiano y que, sin embargo, no parecen tener una clara correspondencia con la realidad lingüística, los más llamativos son la tendencia a convertirlos en yeístas, especialmente en los diminutivos en -illo (manguiya, teliya, cantorciyos) y la acumulación de determinados rasgos occidentales que, si bien puden corresponder al occidente de Asturias, no concuerdan con las referencias a Oviedo en el texto ni con las soluciones centrales del tipo de les coses. En este caso están los ejemplos con diptongos decrecientes, de los que algunos -como lleygar, lleyban- ni 
siquiera son etimológicos, (Ferreyra, dreita 'derecha', los posesivos del tipo de miou o el extraño Prouzezion 'procesión') y la solución sin palatalizar para el grupo /-kt-/ que encontramos en dreita o en muita, palabra esta que, sin embargo, en otros pasajes aparece con una forma más propia del asturiano (muyta cantidad / muncha verdad).

\section{Los gallegos y el gallego}

Como representantes de una población dispersa, analfabeta, dedicada en su inmensa mayoría a la agricultura y a la pesca y condenada a la emigración en busca de trabajos temporeros (cf. Saavedra 1994), los gallegos eran en la España de los siglos XVII y XVIII el prototipo de la gente pobre y vilipendiada. Por eso el Niño Jesús, desnudo, entre pajas o caminando descalzo, era "un galeguiño". Pensado Tomé (1985) articula una lúcida reflexión sobre la cuestión vinculándola al uso del idioma como indicativo de casta:

Los vemos [los villancicos], además de en castellano y portugués, en gallego, sayagués, biscainho, negro y gitano. Lo primero que a uno se le ocurre preguntar es por qué al Niño Dios no se le ha cantado en otras lenguas peninsulares como en catalán, valenciano, andaluz o vasco, porque no hace falta aclarar que el biscainho que aquí sale es el castellano hablado por las gentes de esa región, y lo mismo cabe decir del habla del negro (no habla en dialectos africanos) o del gitano (no utiliza íntegramente el caló). El lazo de unión o rasgo común a todas estas gentes insertas en la comunidad lingüística castellana o portuguesa es de tipo sociológico, no lingüístico. Forman una capa social muy baja, de nivel infrahumano, que se dedica a la servidumbre o a la rapiña; son unos marginados en donde el hambre, el frío, la desnudez y la miseria son rasgos definitorios. Pero aún entre las distintas comunidades se puede establecer cierto rango. A la cabeza de la miseria y servidumbre están los gallegos y sayagueses; a nivel más alto están los biscainhos. Más alto todavía quedan los gitanos. Y a los negritos se les reserva el papel de bueno e inocente salvaje, que tanto explotará el siglo XVIII, junto con los primeros románticos.

Era natural que toda esta capa social de marginados se ofreciese inevitablemente como paisaje actualizador del nacimiento del Hijo de Dios. El hombre, llevado por la pereza mental o por el cansancio de lo repetido, se siente con ganas, sobre todo en las épocas de decadencia, de actualizar el pasado; y así a la hora de celebrar el Nacimiento de 
Cristo, en vez de trasladarse imaginativamente al mundo romano que le vio nacer, prefiere desplazar a Cristo al mundo en que él vive. Esto es obra de clérigos y de gentes cultas. De una burguesía ciudadana ya un poco harta de pastorcitos que prefiere, para ejercer el deporte de la caridad, servirse de gallegos, sayagueses, vizcaínos, gitanos y negritos, y rebajar hasta esos niveles sociales el nacimiento de Cristo. No los había más bajos. Primero se presentaron con unas simples pinceladas lingüísticas: la lengua era suficientemente elocuente, pues todo lo daba a entender [...]. Luego se avanzó en el realismo: Cristo nacía desnudo, descalzo, entre animales, como aún nacían, vivían y morían los gallegos en su tierra y en la ajena.

También el realismo exige que esos gallegos hablen una lengua cargada de castellanismos, como el medio castellano exige para comunicarse, "un castrapo divino", que creemos sea consustancial a su origen, y que sería absurdo rectificarlo, pues tenía una función determinada, consoladora incluso: el encontrarse inferiores hasta en la competencia lingüística siempre lo fue.

La identificación de los lugares en los que se cantaron villancicos de gallegos refuerza, ciertamente, la argumentación de José Luis Pensado. Se dio concentración de villancicos de gallegos allí donde hubo oferta de trabajo temporero, allí donde el bracero gallego llegaba periódicamente y sus esfuerzos por hablar un idioma comprensible para quienes le rodeaban eran conocidos.

La posición del profesor Pensado cobra perfiles todavía más nítidos en una carta privada con la que quiso responder a un lector de La Voz de Galicia que se había dirigido a él para replicarle ${ }^{2}$. Decía así:

Cuando digo que este tipo de villancico es una moda lo digo en el exacto sentido del término, que es una variable, no una constante; y la constante histórica del nacimiento de Jesús en el pesebre y adorado por pastores no se podría alterar, por eso es razonable lo que dice usted, si bien yo no creí necesario señalarlo, por obvio: los pastores y las ovejas nunca podrían faltar.

La estética siempre intenta renovarse y la consciencia de novedad está señalada en estos versos: "Nueva introducción parece / mas no es mucha novedad / que no es morisca algazara / ni gerigonça boçal. / Gitanos van al pezebre / gallegos y todos van /

\footnotetext{
${ }^{2}$ Poseemos copia de dicha carta.
} 
y a donde gallegos entran / ¿quién hay que no pueda entrar?" (Real Capilla)

No olvido que los villancicos son espectáculos; sería más exacto o real decir que pueden convertirse en conmemorativos del nacimiento de Dios. Los pastores fueron vistos como representación del pueblo pobre, humilde, sincero, en contraste con el rico, soberbio y complicado. Cuando se despertó la realidad, el pastor resultaba zafio, grosero, inculto, y así asoma en los Autos y Farsas renacentistas.

No podía ser menos el gallego que venía, por metáfora sociológica, a ser paradigma de un Cristo en la sociedad hispánica del XVII-XVIII por su nacimiento y vida, y no podría faltar el desencanto de la magia barroca, y no falta el gallego, sucio, bruto, egoísta, ladrón, tramposo, etc.

De ese no me parece adecuado hablar en la prensa, aunque desdichadamente tengo material sobrado.

Por supuesto que las combinaciones en dosis diferentes de los dos tipos de interpretaciones de los pastores, negros, gitanos, gallegos, patanes, etc., la negativa y la positiva, no falta en los villancicos españoles: como ante el Niño Dios desfilaron desde los pastores a los Reyes, así ante él, en cualquier sociedad cristiana, puede desfilar cualquier tipo social caracterizado suficientemente: gitanos, negros, indianos, franceses e italianos (cerrajeros y peluqueros principalmente) que se presentan con determinadas notas lingüísticas caracterizadoras. No faltan ciegos, sordos, letrados, etc. y en su mayoría para ser ridiculizados, porque la sátira, aún en la Noche de Paz, gusta más y cansa menos que la alabanza.

Por supuesto que los villancicos surgen en torno al poder intelectual, clerical o político, y para otro poder, el del gusto (mejor que el de la plebe o el económico) o el del éxito, aunque haya que hablar en necio, o maldecir consolatorio, tan necesario como la creencia en la injusticia, que está al alcance de cualquiera.

A nuestro parecer, la tesis de Pensado queda corroborada plenamente con los textos que presentaremos en esta tesis.

Perdidas las funciones formales, literarias y no literarias, que había detentado en la Edad Media, hacia el final del siglo XV el gallego era ya presentado por Micer Gonzalo García de Santa María como una de las "torpes y groseras" variedades lingüísticas que entonces se hablaban en el Reino de Castilla: 
Hay allende eso en la misma Castilla, como son diversos reynos en uno ayuntados, algunas tan groseras y ásperas lenguas como es Galizia, Vizcaya, Asturias e Tierra de Campos, que ni aquellas, ni lo muy andaluz es hovido por lenguaje esmerado (in Pensado Tomé 1982: 86).

Alabanza desmedida del castellano y menosprecio rotundo de las otras variedades lingüísticas del reino fueron tópicos entonces muy cultivados. El papel que al idioma gallego le cupo desempeñar entonces fue el de una de esas "ásperas y groseras lenguas" denigradas por García de Santa María, el de dialecto vulgar impropio para la conversación instruída y la literatura seria. En no pocas ocasiones este tópico se asoció con el desdén de los gallegos, que solían ser presentados como individuos pobres, sucios o de pocas luces (cf. Mariño Paz 2008: 130-135).

Solo en el siglo XVIII aparecerá el primer gran defensor de la lengua gallega: el padre Martín Sarmiento, nacido en Villafranca del Bierzo en 1695, criado en Pontevedra hasta 1710 y fallecido en 1772 en Madrid, en donde vivió la mayor parte de su vida. Con el padre Fray Martín Sarmiento el gallego se viste de un ornato específico, de la nube y de la rosa que necesita el apasionado por la lengua materna, un sentimiento infinito que vaga en el pensamiento de este benedictino, una ilusión tan bella que permanece y no quiere morir mientras haya vida bajo el astro Sol; como si una nueva esperanza retornara y todo volviera a revivir y a ser lo mismo que en la infancia. De esta manera, el padre Sarmiento reivindicaba la enseñanza del gallego en la escuela, como un deseo de dignificar la lengua, incluso se preguntaba por qué les enseñaban a los niños el latín por medio de una lengua que desconocían o conocían mal: el castellano. El padre Sarmiento tenía la profunda ambición y la noble aspiración de que la lengua gallega fuese la lengua de los gallegos del siglo XVIII como lo había sido en la época de esplendor de la Edad Media.

\section{El hablar cortesano}

Junto a todas las variedades lingüísticas anteriormente reseñadas, hay también muchos villancicos en los que brilla con luz propia el habla cortesana del Siglo de Oro, sobre la que la que Cervantes vertió esclarecedoras reflexiones en El Quijote (II, 19).

Cervantes, entendiendo la novela como cajón de sastre donde cabe todo, como un 
cuento de cuentos, como una historia de muchas historias, nos muestra una gran variedad de estilos que confluyen (renacentista, manierismo, barroco...). En su obra los personajes hablan en un momento histórico de transición lingüística y de muchas vacilaciones debido a que no teníamos, como ahora, una lengua estándar.

Se ha hecho famoso y se ha difundido el conocimiento del pasaje en el que Sancho se excusa de sus disparates elocutivos, motivados, según él, "porque no me he criado en la corte, ni he estudiado en Salamanca, para saber si añado o quito alguna letra a mis vocablos", justificación que lo lleva a sentenciar que "no hay que obligar al sayagués a que hable como el toledano". Con mucha claridad nos indica Sancho que tampoco todos los toledanos aciertan en eso del hablar polido. De esta manera, Sancho aduce que también entre los toledanos existen diferencias "entre los que pasean todo el día por el claustro de la Iglesia Mayor" y quienes "se crían en las Tenerías y en Zocodover".

El escudero llena el aire de disparates cuando habla, porque su lenguaje es propio de los campesinos. Cervantes nos muestra la forma de hablar de los personajes y de una manera muy especial el interés que pone Sancho por expresarse bien, aunque, en ese intento de por hablar bien, a veces la gravedad con que pretende hacerlo se resuelve en comicidad... En todo caso, en El Quijote se nos advierte de que "el lenguaje puro, el propio, el elegante y claro está en los discretos cortesanos, aunque hayan nacido en Majalahonda. Dije discretos, porque hay muchos que no lo son y la discrección es la gramática del buen lenguaje, que se acompaña con el uso".

Nos podemos remontar al poeta Garcilaso de la Vega y a la traducción de $E l$ cortesano de Baltasare de Castiglione, traducido por Boscán: la huida de toda afectación... O a Juan de Valdés, que en El diálogo de la Lengua dice que su estilo es natural y sin afectación. En este entorno social y cultural situamos también las palabras de maese Pedro: "llaneza, muchacho, no te emcumbres, que toda afectación es mala...".

Los conceptos de discreto y de discreción son valores esenciales para el mejor novelista de todos los tiempos, que logra que todo el mundo conozca la lengua castellana como la "la Lengua de Cervantes". El Licenciado asiente a la creencia de Sancho sobre un atributo de los cortesanos que establece entre ellos discriminación precisamente basada en la discreción. Tal era la ambición de Cervantes de que su libro "llegase a ser el más 
hermoso, el más gallardo y el más discreto".

Dentro de esta explicación sobre la pureza del lenguaje, el Licenciado aporta un distinguido dato: que él ha estudiado una carrera universitaria en Salamanca, ciudad que, muy a pesar de no haber sido residencia real, es generalmente reconocida como asiento de hombre doctos y cuna del buen hablar. Por eso alardea el personaje al decir: "Picome algún tanto de decir mi razón con palabras claras, llanas y significantes". De esta manera nos muestra la validez de otro criterio que ayuda a apreciar de una manera inequívoca la excelencia idiomática.

En otro pasaje, don Quijote dice a Sancho (II, 12): "Cada día [...] te vas haciendo menos simple y más discreto". Sancho reconoce: "Sí, que algo se me ha de pegar de la discreción de vuestra merced". Cervantes pone en boca de don Quijote y rememora las veces en que Sancho ha querido hablar de oposición (como un opositor a cátedra universitria) y a lo cortesano.

Todos estos son testimonios que atestiguan el interés cervantino por alcanzar la belleza y la ejemplaridad idiomáticas en lo cortesano.

Parafraseando a González Ollé (2002), afirmamos que el deseo cervantino de hablar bien es el deseo de hablar como en la corte. Con todo, es necesario establecer precisiones sobre la naturaleza politico-social de la corte. Entendemos como tal la ciudad donde habitualmente residen los monarcas, por cuya razón resulta que el habla cortesana sería el habla utilizada en dicha ciudad. Ahora bien, los desplazamientos del rey eran frecuentes e implicaban el traslado de la corte, por lo que, como con toda agudeza apuntó, Fray Antonio de Guevara, el modelo debía buscarse antes en las personas del príncipe y de su séquito que en los usos propios del lugar en que en cada momento ellos residiesen: "La escuela universal de todo el mundo es la persona, casa y corte de los príncipes. Lo que dixeremos los emperadores, aquello dirán nuestros súbditos, lo que hiciéremos, harán".

Alfonso de Valdés, muy finamente, aporta sus recuerdos cortesanos cuando trata de mostrar los aspectos más destacados de su celo por el bien hacer y decir en la corte: "Tenía tanto cuidado en que mis cortesanos no hiciesen mal ni daño donde mi corte estaba o por donde pasaba, que no pareciera sino un convento de frailes". Y Juan de Valdés deja entrever la indeterminación geográfica de la corte: "Más quisiera satisfacer a Garcilaso de 
la Vega, con otros dos caballeros de la corte del Emperador que yo conozco".

Aproximadamente un siglo después, cuando ya la corte está instalada en Valladolid (1601-1606), Góngora critica de forma satírica la separación entre corte y capital. Claro que ya sabemos como vino la corte a Valladolid, cuyo inspirador fue el Duque de Lerma, y que no contaba la ciudad con palacios ni con lugares de solaz para el rey Felipe III. "LLegué a Valladolid; registré luego /.../. Busqué la corte en él, y yo estoy ciego / en la ciudad no está o se disimula". Un año más tarde, Lope de Vega muestra dicha diferenciación entre ambas: "Cuarenta años huésped fue [Madrid] de la corte. Bien se ve / que aposentarla podía".

La naturaleza itinerante de la corte nos hace evocar a Toledo, la ciudad que ha ejercido de modo consuetudinario la función política aunque solo en momentos muy limitados. Toledo, ciudad ennoblecida, conserva esa imagen primitiva durante siglos tras la reconquista de 1085. Persiste esa idea generalizada de su imagen costesana, como lo demuesta el concejo toledano al dirigirse a los Reyes Católicos en 1492 aduciendo que su ciudad era "la silla real donde dominaron los reyes nuestros mayores a todas las Españas", el lugar donde "se daban leyes", la ciudad de la que "todas las provincias aprendian la Lengua y costumbres". Sin duda se establecía así la primacía de su modalidad linguística, precisamente porque quienes allí mandaban utlizaban la lengua con preeminencia política y cultural. La corte española durante los siglos XVI y XVII, a la manera de las cortes europeas, protegía el carácter sacro de la monarquía, que consistía fundamentalmente ser centro del poder político y económico constituyendo un núcleo central tanto para los nacionales como para los países extranjeros.

Existen valiosos estudios sobre la figura del cortesano y del discreto, y este concepto resultaría muy largo de explicar. Con todo, no es imprudente señalar que durante los siglos XVI y XVII el calificativo discreto se le aplica constantemente a lo cortesano y no parece poseer el posterior significado de moderado, circunspecto y adecuado. Según Asensio, en el siglo XVI Damasio Frías "traza por primera vez un modelo de discreto y de esta manera se adelanta a las aspiraciones del siglo XVII". El oficio de discreto no es otro que el de, con un gentil y acertado discurso de la razón, saber acomodar las cosas de que se trata y tratar de ellas conforme al decoro del lugar, del tiempo o de las personas, del porqué y así de las demás cicunstancias. Entedemos que la discreción no es virtud: aunque trata de 
los medios y las maneras para bien, también trata de las cosas que son para el mal. Pero entre las claves del humanismo se incluye la idea de que la sabiduría solo es verdaderamente útil si a ella sigue la discreción, "cualidad determinante". Precisamente este concepto recorre todo el siglo XVI y el Barroco lo expande "como conjunto de todas las virtudes que adornan al hombre", por lo que apostillamos, con Lope de Vega, que "conmigo hablará en romance, / que es la Lengua con que me entiendo. / i Piensas tú que los que saben / Letras todos son discretos? / Pues cree que hay en Latín / muy gentiles majaderos".

El Quijote, parafraseando a Menéndez Pidal, es la coronación de todos los ideales de naturalidad selectiva que venían tomando diversas formas, es la cúpula que cierra el edificio estilístico del siglo XVI. Y es precisamente en este siglo cuando surge un gran fenómeno: la dignificación de lo popular.

El Quijote es un gran mundo de encrucijada entre oralidad y escritura, un conjunto de estilos literarios incardinados en el siglo XVI. Cervantes, con su sabia ironía, narra con puntualidad la una historia nueva y jamás vista, y lo hace buscando la representación de la lengua coloquial en un proceso de estilización característico de la lengua literaria.

Toda la obra cervantina es una composición docta, puesto que el creador literario tiene una misión didascálica, docente. Cervantes es un innovador del Léxico, ha pasado a la posteridad como modelo lingüístico, a pesar de que en su tiempo fue considerado $E l$ Quijote solo como un libro gracioso, de entretenimiento, basado precisamente en la figura de un paranoico. El Quijote es el gran libro de la vida.

Cervantes elevó la lengua castellana a la cima de todo esplendor. Su lenguaje cortesano y su lenguaje popular han influido en la obras de Galdós, de Camilo José Cela, triunfando los conceptos de discreto y de discreción como perfecciones sublimes y el concepto de cortesano como el ideal de prestigio al que aspira la Lengua literaria.

Cervantes, fracasado en la corte, fracasado como poeta, con infinidad de sufrimientos en su vida, con un gran humor y un gran optimismo que le hizo superar todos los reveses, nos ha dejado ese gran estilo que nos invita a que amemos nuestra lengua y la usemos correctamente, haciendo una peculiar distinción entre la lengua culta y la lengua popular, marcando así la consolidación y la valoración máxima de la expresión literaria de 
la que todos tomamos ejemplo y muy especialmente del habla cortesana, limpia de afectación y extremadamente sencilla.

La atención al esmero en el uso del lenguaje queda atestiguada en los textos literarios y didácticos desde muy temprano. Por esta vía se llega a la conclusión de que la lengua de la corte es la mejor de todas por la presencia de nobles y letrados. Por esta razón la norma cortesana conoce un gran auge durante los siglos XVI, XVII y primera mitad del XVIII: es el habla cortesana, característica propia de los nobles, no pocas veces ensalzada con desdén hacia el habla de los letrados que no han pasado por la corte.

\section{A modo de conclusión}

A modo de conclusión, diremos que hemos encontrado en nuestro trabajo distintos tipos de villancicos:

a) Villancicos de gallegos, de portugueses, de asturianos, de franceses o de italianos que conviven en un debate constante, en una pugna por hacer suyo al Niño Jesús.

b) Villancicos en castellano en los que la lengua de Cervantes es como el espejo del pueblo y cuya versificación está tan bien construida que nos recuerdan los versos de Lope de Vega, del gran sonetista Quevedo y de otros muchos creadores del Siglo de Oro.

c) Villancicos de debate, en los que participan tanto actores como músicos y cantores en varias lenguas, por lo general concebidos con la finalidad de hacer reír. No cabe duda: son manifestaciones de una cultura de entretenimiento dentro de la iglesia en la que el pueblo participa. 
ANTOLOGÍA DE VILLANCICOS DEL SIGLO DE ORO 


\section{Normas de edición}

Lo que ofrezco en este capítulo de la tesis es una amplia selección de los villancicos que, publicados en España a lo largo del siglo XVII, se encuentran hoy depositados en la Biblioteca Nacional de Madrid. Para realizar dicha selección he partido del Catálogo de Villancicos de la Biblioteca Nacional, siglo XVII que esta institución dio a la imprenta en el año $1992^{3}$. Aunque toda selección es inevitablemente subjetiva, creo que los villancicos que he elegido reúnen una notable riqueza informativa y permiten abordar con numerosos materiales el tema que he querido desarrollar en este trabajo.

Las ediciones que he hecho son muy conservadoras, es decir, con muy bajo nivel de intervención sobre las piezas que he transcrito. He actuado así porque estoy convencida de que, cuando se pretende que a partir de los textos editados se puedan hacer no solo estudios históricos o literarios, sino también análisis lingüísticos, resulta aconsejable realizar transcripciones fidedignas y poco intervencionistas que ofrezcan las máximas garantías y que, por consiguiente, no conduzcan al lingüista hacia conclusiones erróneas. Por esta razón, he respetado incluso la puntuación y el uso de mayúsculas y minúsculas de los impresos consultados, aunque no la unión y separación de palabras, que ha sido regularizada para facilitar la lectura: esparecido > es parecido, adado > a dado 'ha dado', en anosa terra > en a nosa terra, etc. Ahora bien, he conservado la disposición material de las palabras en el texto cuando esta pudiera tener algún valor lingüístico: así, en la estrofa “Todos os galegiños / vem de Galisa a veruos / y na vossa choupiña / tocano[s] seus instrumentos" no he segmentado tocano[s] en tocan o[s] porque en este caso la lección original del texto invita e leer la consonante nasal de la forma verbal como alveolar y no

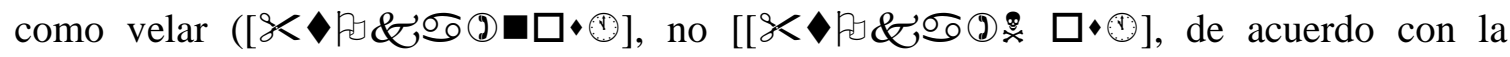
realización más extendida en el gallego moderno.

Los desdoblamientos de abreviaturas los he indicado entre corchetes y en letra cursiva: bi > bie[n], hõbre ho[m]bre, $\square$ ऊ > q[ue], ras > v[uest]ras, etc.

En letra redonda y entre corchetes he restituido las letras o palabras que faltan en los impresos y que son necesarias para dotar de sentido al texto: tocano seus intrumentos $>$ tocano[s] seus instrumentos.

Cuando su deterioro ha convertido en ilegible alguna parte de un impreso, he utilizado para indicarlo tres puntos entre corchetes: [...].

La ese alta la he transcrito siempre como $\langle$ s $>$.

\footnotetext{
${ }^{3}$ I. Ruiz de Elvira Serra (coord.), Catálogo de Villancicos de la Biblioteca Nacional, siglo XVII, Madrid, Biblioteca Nacional.
} 
Todos los villancicos editados van acompañados de información bibliográfica sobre el folleto en el que podrán encontrarse en la Biblioteca Nacional de Madrid. Solo para los dos últimos ignoramos su año de publicación. 


\section{VILLANCICOS QVE SE CANTARON EN EL GRAVE Y RELIGIOSO CONVENTO DE NUESTRA SEÑORA DEL CARMEN DE SEVILLA EN LOS MAYTINES, DE LA NATIVIDAD DE NUESTRO REDEMPTOR IESU CHRISTO.}

AÑNO DE 1621

\section{Nocturno.}

PAstores esta ocasion,

toda es de risa y conte[n]to pues dándonos Dios su Hijo nos da en el nuestro remedio, entretengamos la noche, con juegos de passatiempos.

2. Antón dice bien en todo,

3. Pues dize bie[n], va de juego

4. Que juego irá,

5. El del Soldado,

1. No, $\mathrm{q}[u e]$ aunq $[u e]$ el Infante tierno es un Soldado a nosotros

2. Despues jugarle podremos

5. Pues los propósitos vayan,

2. Al propósito no es bueno.

6. Pues qual irá,

2. El de las Letras,

1. Baya pues.

3. Empieça. 2. Empieço.

Deste nombre de IE S V S las çinco Letras tomemos,

1. La.Y. tomo,

4. Yo la E.

6. Yo la V. quiero

3. La esse prostera es mia

2. Pues ya las letras tenemos cada qual segun su letra, dé a el Niño, tres Epítetos.

1. Quales son. 
6. Dar por respuesta,

quien es, y a quien es misterio

se pareçe, y con que officio

viene desde el cielo, a el suelo.

1. Esta si, que es noche,

donde en naciendo

Dios dâ paz a la tierra,

y gloria a los Cielos.

2.Norabuena Pastores,

el Niño venga,

pues misterios tan altos,

su nombre encierra .

Copla.

3. Letra .Y. q[ue] os dize el niño

Que es justo, y q[ue] por estremo

se pareçe a Iosue,

y es su officio, el de Iuez recto

2. Y vos E. 4. q[ue] e $[n]$ su ser puro

es eterno, y que en efecto

a Efrain es parecido,

y es su officio enme $[n]$ dar yerros

1. Y vos .S. 5. Que es Señor

que se parece en ingenio,

A Salomón y es su officio,

salvador, de Almas y cuerpos.

4. Y vos V. 6. pues Verbo Dios

y q[ue] Vrias es su exe[m]plo

y que por officio tiene,

unir en amor los pechos.

2.Y vos la S. prostrera,

3. Ques soberano y supremo,

que se parece a san Son

1.Y officio, 3. Salvar su pueblo

errò erró, 5. Si q[ue] ya se a dicho

que es Salvador, 3. Yo co[n]fieso

6. Que ese por descuydo mio

pague la pena por ello.

3. Mas antes si alguna pena, 
por aber errado devo,

Dios por mi viene a pagarla.

Vitor, que a dado en lo cierto.

Esta s1. \&c.

Segundo Villancico.

ERA epilogo del Sol, un portal era compendio de inauditas maravillas, de inacesibles misterios. Era officina de amor, y de grandes Sacramentos que en el frio de Dios ho $[\mathrm{m}]$ bre region hallaron de fuego. Alli llenos de temor, que mejor dire respecto, si Querubes asistian, servian Angeles vellos.

El viento escuche animado voces atendi, diziendo, las glorias del Niño Dios, nuestros vienes y contentos.

Estrivillo.

Campanitas repican, suena[ $n]$, ay como haçen alegre el so[n]

fiestas son,

por mi Niño del Sielo se ordenan, ay q $[u e] \mathrm{e}[n]$ el ayre los ecos resuena $[n]$ $\mathrm{q}[u e]$ el oido de sones llenan, y de glorias el coraçon.

Coplas.

Aquel Niño hermoso,

hijo de la perla

siendo perla el mismo.

Y la concha de ella,

por quien perlas tantas, 
a montones ruedan,

aunque agora noçe

cantan pobreça.

Oy llegô a un pesebre,

tan dichosa tierra,

que antes diò la paja,

que tubo cosecha,

campanitas, \&C.

Tercero Villancico

Gallego,

POR un valle avajo avajo

por vn valle avajo, van,

juntas va $[n]$ las flores de asturias

saltan, corren brincan, burlan

las zagalas los ayudan,

todas a vailar madrugan,

caminando acia el Portal,

por un valle avajo van.

2. Los mancevos asturianos, que a Velen ${ }^{4}$ con las zagalas por ver al Niño del Cielo, sus aldeas desamparan. Apresurando Minguillo, el zagal de mayor gracia por Aventaxar el juego, esta letra bayla y canta, Sol Perulla, Perulla do monte que en un pesebriño, y ta $[n]$ vonitiño, y tan garridiño nace $\mathrm{e}[n]$ a tera, minino esta noite.

\section{Coplas.}

SOL perulla mira en la cueva parida de un mociño, una do $[n]$ cela, la linda morenica fermossa, y garrida, de a terra de asturias,

\footnotetext{
${ }^{4}$ En el impreso, Avelen.
} 
O mais craro norte,

Sol Perulla, Perulla do mo[n]te,

1. En el trage de su tierra,

uvino Maroto un Gallego,

hombre desnudo de voca,

pues siempre la trae a cueros

para dar fin a la fiesta,

trujo a otros de su pu[e]blo.

Ay de Tivino de esquivas

que plaga tenebra el Cielo

yà repican as sonaxas,

ya suena todo instrumento,

yâ si, a Maruca le diçe,

y ella le và respondiendo.

Coplas segundas

1. Ay maruca la mas polidaa do[n]de lo viste ao fillo de Maria

2. a meu maroto, el mas garrido

$\mathrm{e}[n]$ braços del alva le vi dormida

Sol Perulla \&C.

I1. Nocturno.

Quarto Villancico.

ZAgalexo, el de Maria,

$\mathrm{au}[n] \mathrm{q}[u e]$ a todos nos co[n]viene

ver hombre a su reverencia,

a mi en el Alma me duele.

El mundo señor chiquito,

a quien esta noche viene

tal està que en vez de mundo

immundo, a todos pareçe.

A el malo tiene en las cu[ $m]$ bres,

a el bueno avatido tiene,

que las virtudes del Alma,

fueron perseguidas siempre.

Los cargos de mayor honrra

en el estan de tal suerte

que con mas razon llamarse, 
cargos de consencia pueden.

De los pobres, no asen casso,

son mirelo en su mercede.

Que aunq[ue] Dios como esta pobre

le aposenta en un pesebre

no ay amigo para amigo,

Biblioteca Nacional (Madrid): VE/1309-4 (Barbieri)

. I NOCTURNO. "Pastores esta ocasión".

Rima asonante: A -B Octosílabos 
VILLANCICOS QVE SE CANTARON EN LA SANCTA IGLESIA MAYOR, EN LOS MAYTINES SOLEMNES, DEL SANTISSIMO NASCIMIENTO DE NUESTRO SEÑOR.

AÑNO 1626.

CON LICENCIA.

EN SEVILLA POR JUAN CABRERA.

FRONTERO DEL CORREO MAYOR ${ }^{5}$.

tende consideraçaõ

e não na boteis de la,

$\mathrm{q}[u e]$ se Deus e home $[m]$ por ela

e minino e chorarè.

II1. NOTVRNO.

VI1. Villancico

Gallego.

O Mancebino novo

$\mathrm{q}[u e]$ deitado està en portal

pois nace entre Galegos

el de amores morrerà.

Ay que lo vi que lo vejo

ay q[ue] lo vi, q[ue] lo vi, q[ue] lo creigo.

$\mathrm{Al}$ pequenino $\mathrm{q}[u e]$ baxa del Cielo

bordando los ca $[\mathrm{m}]$ pos, legra $[n]$ dos ve $[n]$ tos

ay que lo vi, que lo veyo

los Galeguiños le cantan contentos,

porque nos vene a donar el remedio,

ay lo que vi, que lo vi, que lo creigo.

Pois $\mathrm{q}[u e]$ conozco se deita en el seno,

\footnotetext{
${ }^{5}$ El texto està incompleto.
} 
chora $[n]$ do de amores te $[n]$ blando de yelo

ay que lo vi que lo veyo,

la sua may le aplica a lo peito

cerrando dois Soles rendidos al sueño

ay que lo vi, que lo vi, que lo creigo.

\section{VII1. Villancico.}

MArauillas dizen de vos

nacido galan

y mas dirán.

De v[uest $]$ ras glorias te $[m]$ pranas

$\mathrm{q}[u e]$ grandes y peregrinas

primero que por divinas

nos admiran por humanas,

diran que son soberanas

y que inmortales seran

y mas dirán.

Dizen $\mathrm{q}[u e]$ niño tan tierno, aveys del cielo rompido

los semblantes del olvido,

las coyundas del infierno,

y a las ondas del Iordan,

y mas dirán.

Dizen que el sustento humano

tiene en vos efeto y nombre,

y que por el bien del hombre

os transformais soberano,

oy en rubio y hermoso grano

y mañana en blanco pan,

y mas diran.

FIN.

Biblioteca Nacional (Madrid): VE 1309 (Barbieri)

Tercer Nocturno.VII Villancico Gallego "O Mancebino novo".

Versos endecasílabos y octosílabos. Rima asonante. 
VILLANCICOS QVE SE CANTARON EN LA SANTA YGLESIA DE SEVILLA EN

LA FESTIVIDAD DE LA PASQUA DE LOS SANTOS REYES.

AÑ̃ 1626

CON LICENCIA.

EN SEVILLA POR IUAN DE CABRERA. EN ESTE AÑO DICHO.

FRONTERO DE LAS CASAS DE EL CORREO MAYOR, JUNTO AL ESCUELA.

\section{Primer Villancico}

que todo parece guerra,

y quanto se mira es paz.

2 Cop. $\mathrm{Va}[n]$ exercitos nevados

dando guerra a los mortales,

1 esquadrones celestiales

vienen de paz coronados

2 esta[ $n]$ contra vn niño, armados

$\mathrm{q}[u e]$ aun no le ampara su tierra

y el mismo a quie $[n]$ haze $[n]$ guerra

es la paz q[ue] el cielo embia.

1 Celestial artilleria,

2 Todos pretenden vitoria,

$\mathrm{y}$ de ninguno es agena

1 publica el tiempo su pena,

y los Angeles su gloria

2 La noche escribe su historia,

con plumas de blanca nieve,

todo rigor se le atreve

y su amor le desafia,

1 celestial artilleria.

I1. Villancico.

GAleguiño si vindes

a matar as almas,

el que tras vosos ollos

no a menester armas.

Non boteis nas pallas

Galeguiño as perlas 
que se pode o mundo

abrasar con elas.

E pois ceos, è terra

vencedor vos chaman

el que tras vosos ollos

no à menester armas.

Si chorais de amores,

chorai muito en bora

mas sin pranto os estiman

as almas todas.

Mas si soys Galego

e Rey Soberaao

ante os Reyes de o mundo

non esteys chorando.

Risa soys de a terra

risa soys de o[s] ceos

vosa May, es aurora

é vos Sol Eterno.

E si a rindir vindes

Reyes das Arabias,

el que tras vosos ollos

no a menester armas.

Biblioteca Nacional (Madrid):VE 1309 (Barbieri). 
DISPUTA ENTRE GALLEGOS Y CORITOS (ASTURIANOS)

Traxen os botiños (zapatus)

que aunque gastan ò cuero en

xamais se le han vistu.

Gall.-Tocai Galeguiños, (Gaita

que os Curitos no baylan con

fino es con el cinchu.

Galle.- Nino, que en as palla os teinen ao frio,

Si en Galiza nacerais bus deira

millor portaliño.

ASTURIAS.-Caien os Gayegos

que pos Xesu Christu,

sein en Asturias nacera, estuvera

millor acoxido.

Gall.-Tocai Galeguiños,

que en Galiza más vale ha palla

que todos us Coritus.

Gall.- Cestiña os Galegos

os damos de oviños,

que traemos desde miña terra

Galegui Galeguiños \& C. 
VILLANCICOS QUE SE CANTARON EN EL AÑO 1629

VILLANCICO II1. Gallego.

Estrivillo.

CAnta e baila Domingo Mangueiro

que eu queiro ser ò tamborileiro.

Miña comadre, è miña viziña,

escoitaime esta ca[n]tiguiña.

Venan todos os Galegos,

vean o Fillo de Deus

nace muito pequeniño,

nace muito garridiño,

nace qual Fillo de Deus,

Fay o Gaiteiro, è canta,

è baila Domingo Mangueiro,

que eu queiro ser o tamborileiro.

\section{Coplas}

1. Nun Pesebre està o Miniño, o que os Reis aventalla, en ùa pouqujña palla, naceu como Galeguiño, non so he o garridiño, salto e brinco de pracer, porque Deus nos veu à ver en corpo manso Cordeiro.

E canta, è baila, \&c.

\section{Logo que nacido foy}

Deus como home chorava, è morto se imaginava, porque està con Deus o Boy, como à Mula no se doy, o Boy à mira de corno, à a Mula de retorno, lle bolve à anca mohina. Miña comadre, \&c. 
3. Vamos homes sin receos llevémosle de mel favos, pro Boy llevarèmos nabos, e pra Mula do c[en]teo ${ }^{6}$ : veres Angeles de o ceo dar no aire cabriolas, bailando con castañolas, è San Miguel o primeiro. E canta, è baila, \&c.

4. Si fazer queredes gentes o Fillo de Deus regalo, à sua May podres dàlo, que o Miniño non ten dentes: leite levay en presentes à Virgen, que o manten, porque sostento non ten mai que ùa Corderiña. Miña comadre, \&C.

5. Vendo os demos que son vaos, jà cobarde à Lucifer, despreciaron seu poder, é andoveron à paos, como vinieron as maos, Mahoma vn tizon arranca, Iudas sacao ùa tranca, è Barrabas vn lareiro. E canta, è baila, \&C.

6. Todos Pranetas con danças, acudieron à Belen, è a Lua bailou ben, que sabe boas mudanças, Libra con suas balanças à noyte baylou en peso, y o Miniño vendo esso

${ }^{6}$ En el original, cneteo. 
o celebrou con risiña.

Miña comadre, \&C.

SEGVNDO NOCTVRNO.

VILLANCICO IV.

Estrivillo

VEnid à ver prodigios,

Pastores, en Belén,

que en èl à media noche

vereis amanecer.

Que dizes Llorente?

Que has visto Gines?

En nuestras palabras

no puede caber,

ni en tierra, ni en cielo,

ni en todo el desvelo

de humano poder.

Dezidnoslo pues.

Que no, no, no,

que no puede ser,

pues solo la admiración

lo puede dar a entender.

Dezidlo pues, que nosotros

lo admirarèmos también.

Escuchad Pastores, Vaya pues,

honras y favores. Vaya pues,

que à los pecadores. Vaya pues,

quiere Dios hazer. Vaya pues,

$\mathrm{Y}$ admirense,

que solo la admiracion

lo puede dar à entender.

Coplas.

Fuimos à ver esta noche

vna parida en Belen:

IESVS, y què bello Niño!

Madre de Dios, què Muger!

Con los dos estava vn Viejo, 
$\mathrm{y}$ eran juntos todos tres,

vn pasmo, vna admiración,

IESVS, MARIA, y IOSEPH.

Vna voz nos llevò a verlo,

que segun cantò despues,

no es possible sino que era

el mismo Angel San Gabriel.

La noche estava muy fria,

$\mathrm{y}$ al ir corriendo tras èl,

en tanto calor entramos

que nos vino Dios à ver.

Entramos allà, y diximos,

viendo vna Mula, y vn Buey

y tal Niño en vn Pesebre:

Verbum caro factum est.

A remediar viene al mundo,

que tan perdido se vè,

y el remedio que ha de darnos,

Poder de Dios, y qual es!

Hombre à Dios vimos, y ay hombre

que lo niegue; mas yo sè,

que delante de nosotros

no lo diga en buena Fè.

En carne mortal le vimos,

mas hermoso que vn Clavel,

muy bello estarà en el cielo,

pero no tiene que ver.

Mundo, Belen es tu gloria,

Belen es todo tu ser,

Belen te trae el remedio

valgate Dios por Belen.

VILLANCICO V.

Estrivillo.

1. Coraçon que buelas cantando

$\mathrm{y}$ ansioso caminas

en busca de vn Dios,

como alegre cantas, y buelas, 
buelas, y ca $[n] \operatorname{tas}$ llora $[n]$ do tu error:

2.Mas si buelas por ver entre nieve temblando al Amor.

3. Canta canta, y celbra tu dicha

llora, llora, y publica el dolor.

Biblioteca Nacional (Madrid): VE/83.

Los versos en Gallego son de gaita gallega, a veces con rimas internas. Rima asonante en el estribillo, versos octosílabos. La estrofa por dos mudanzas, rimas entrecruzadas. 


\section{RAMILLETE}

DE DIVINAS

FLORES

PARA EL

DESENGAÑO

DE LA

VIDA HVMANA.

Recopiladas con diligencia de los mejores y más famosos poetas de nuestros tiempos, por P. F. G. C. D.

EN AMBERES,

Por Cesar Ioachim Trognesius,

M. DC. XXIX.

Cum gratia et Priuilegio.

<244> Villancicos a la Natiuidad de N. S..

2. Y yo todo quanto tengo,

Que es darle lo que me dio.

3. Pues oy para mi nacio,

le ofrezco vn humilde pecho.

4. A esse manjar està hecho

5.Yo sé que su Magestad

Le sabe bien humildad.

6. Si se la guisa aficion.

Venga pues, \&C.

Villancico en Gallego

AYudamelo a cantar moças,

Ayudamelo a cantar todas,

Folga meu corpo, y minha alma

De ver aqueste zagal,

Por minha fè que ha de ver

Entre todos lauro y palma,

Minha vida ten en calma,

Eyle de fazer muytas cousas,

Y ayudamelo a cantar moças,

Ayudamelo a cantar todas.

Outra bolta ey de cantar 
Por servir a vuestra Alteza,

Por minha fè que he boa peza,

y le tengo de adorar,

<245> Vengan los de mi logar

A ofrecer flores y rosas.

Y ayudamelo a cantar moças,

y ayudamelo a cantar todas.

Muyto me alegro por cierto,

En verlos en vn nacimiento,

Todo ò mundo esta contento,

Y ey de cantarle estas glosas,

$\mathrm{Y}$ ayudamelo a cantar moças,

$\mathrm{Y}$ ayudamelo a cantar todas.

\section{Otro en Portugues.}

FIdalgos, anday , anday,

Folijay, anday cominho.

Vereys un belo minino

Tamanho como seu pay.

Este minino naceo

Em o portal de Belem,

Ven para facernos ben

En una Virgen May en carno,

Esta si cantarem yo

A sua ditosa May.

Vereys un belo minino

Tamanho como seu pay.

Este minino fermoso,

Biblioteca Nacional (Madrid): VE/13589. "Y yo todo quanto tengo". 
VILLANCICOS QVE SE CANTARON EN EL REAL CONVENTO DE NVESTRA

SEÑORA DE LAS

Mercedes, Redempción de Captiuos, de san Pedro Nolasco, en la noche de la

Natiuidad de Nuestro Señor Iesu Christo del

año 1632.

CALENDA.

A DE la tierra soldados, no durmays mas centinela, que sulcan el mar mil velas que enemigos esforçados. Guiando van a Belen la Capitana también.

Toquen alarma toquen

Paz no aya mas, que los bellos Serafines resonando sus clarines, cantando van a compas.

Disponse el [...]

haganle todos la salua

pues en los braços del Alua nace la misma alegria.

\section{ESTRIBO}

Trompeticas sonoras tocad al albor, pues que dize la noche que ha nacido el Sol.

\section{COPLAS}

EL Sol que ocupa signo de Leo[n] ya de Virge [n] Signo dize[n] q[ue] ocupó; mas luziente sale que jamas se vio, y por nuestro bien mudò condicio[n], las penas del hombre se las vistio y sale a pagar qual su fiador.

A la noche alegre que el Sol embió, sus rayos, le embiò otro Sol mayor. 
Dichosa la haze con su resplandor vna Virgen pura poniendo vn Pastor; al yelo temblando vemos el calor, de riquezas lleno, del Cielo Señor, $\mathrm{Al}$ arma toquen al arma fiestas aya, y suertes brabas, mas si la del toro alabas, yo me atengo a la del buey, çagales a toda ley a mis maytines me aplico, y el Pastor a su pellico, y el Sacristan a su Coro sa[1]ga el toro, \&C.

\section{TERCERO VILLANCICO}

Galllego.

AY a Belen vámonos Galegos, $\mathrm{q}[u e]$ a vida de todos a la temos, ay, ay.

COPLAS.

AY Deus ha nacido la no campo, a verle cheguemos do poblado Ay, non serà largo o camiño, ay, si calabasina leva o viño, ay. Ay, belo menino le cantemos que alçaste as alma[s] o desterro, ay. AY a Belen, \&c.

Levay a[o] minino vma cuna, $\mathrm{q}[u e]$ en $[\mathrm{u}] \mathrm{n}$ pesebriño chora as culpas, ay, levay vmas puchas de fariña, que morre de fome sendo a vida, ay, levay condolida alma, e peyto, que tembra de frio sendo eterno, ay. Ay a Belen, \&C.

Segundo Nocturno.

QVARTO VILLANCICO. 
EN noche que todo es juegos,

el hombre quiero entablar, pues a enmendar el primero

oy nace el segundo Adan;

de juego vâ.

Todos. Vaya norabuena buen juego será.

1. Adan es el primer hombre,

la mano a Eua le dâ,

que le ha salido de flaco.

2. Mal juego tiene en verdad.

3. Perdiò.

2. Porque?

3. Por triunfar, que el que naciò de lo menos no ha de querer ser lo mas.

Todos. No ay mas hombre.

1. Espera que otro hombre ay que conuersacion tan noble no vn yerro la ha de acabar.

3. Quien es hombre?

4. Christo es hombre ya.

Todos. Perderà.

4. No harà.

3. Con que triunfos entra?

4. Con solo humildad.

Todos. Perderâ.

No harà, que por no tenerla se ha perdido Adan.

Todos. Perderà.

4. No harà que tres Reyes le entran,. y es cierto el ganar.

Todos. Perderà.

4. Pues que remedio tendrá?

\section{ESTRIBO.}

QVE pues hombre se ha hecho, y es del juego ley no se admiren todos

fueren contra el. 
COPLAS.

1. TIene espadas?

2. De justicia,

1. Tiene oros?

2. De piedad

1. Tiene copas?

2. De amargura.

1. Y braços?

2. De Humanidad.

1. Està baldado?

2. De bienes.

1. Tiene triunfos?

2. Los tendrà.

1. Reserua alguno?

2. A su Madre.

1. Buen juego es este.

2. No es tal, porq[ue] aunque es hombre co[m]prado la vida le ha de costar.

1. Empeçò triunfando? 2. No, que como empeçò a triunfar Adan y quedò perdido, el no triunfa por ganar.

1. Espadas juega?

2. Y tan fuertes, que a todos hizo temblar.

1. Quien saliò de oros?

2. Los Reyes.

1. Quien de copas?

2. La impiedad.

1. Tocò a los bastos?

2. No aora,

mas despues los tocará.

1. Baldaronle los tres Reyes?

2. Quisieronselos baldar, Herodes, que es la malilla, pretendiéndole arrastrar.

1. Tomô la vasa del hombre?

2. No, que el hombre supo mas, 
pero llevose de niños

mil vasas en su lugar.

3. Yo me gano, yo me gano.

4. Que triunfo tomando està

con tanto gusto?

3. Es el basto.

4. Buen palo.

3. En el morirâ.

4. A codillo tiran todos.

3. Chacho el mundo le ha de dar, porque pierda y todos ganen.

4. Bien juega.

3. Dizele mal.

4. Pues que remedio tendrá?

3. Que pues hombre se ha hecho,

Biblioteca Nacional. Madrid. VE/ 1309-1. "A de la tierra soldados". (Barbieri).

Versos isométricos. Rima asonante: aa:bccb:ba. 


\title{
VILLANCICOS QVE SE CANTARON
}

en la Santa Iglesia de Toledo Primada de las Españas, este año de mil y seiscientos y treinta y tres, en los Maytines del santíssimo Nacimiento de nuestro Señor Iesu

Christo.

CON LICENCIA:

En Toledo, por Iuan Ruiz de Pereda, Impressor del Rey nuestro Señor.

Este año de 1633.

\author{
Naon choreis meu bein, \\ mas chorar tan bein \\ os males acaba \\ Choraua, \&C. \\ Cantaron esta letrilla \\ los pastores a compas, \\ fue jaula de ruiseñores \\ el venturoso portal. \\ Entre pajas la gloria \\ me dà mi niño, \\ porque es todo esplendores, \\ amores, fauores, y flores \\ quanto en el miro. \\ Ya he hallado las indias \\ de mi desseo, \\ pues tes todo riquezas, \\ franquezas, bellezas, \\ grandezas todo su centro. \\ Este si que es amante \\ para quererse, \\ pues està tiritando, \\ llorando, temblando, vela $[n]$ do \\ solo por verme. \\ Por amante, y esposo \\ quiero escogello, \\ pues es todo precioso, \\ donoso, amoroso, y hermoso \\ quanto en el veo.
}




\section{I1. VILLANCICO.}

En metafora del Buen Retiro.

ALbricias, alegrias, regozijos, venid pastores de Bele $[n] \operatorname{co}[n]$ migo a ver vn pesebre el Buen Retiro.

Era de nuestros pecados fiador el Verbo diuino, por vna escritura antigua que su Padre eterno hizo. Y para satisfazerlos retirarse a Belen quiso, retiro, que aunque de pajas, fue llamado el Buen Retiro. Era Ioseph a este tiempo su priuado, y su valido, $\mathrm{y}$ assi le tocò en justicia la disposicion del sitio. Casi fuera de los muros de Belen, y su distrito, junto a vn prado, en vn pesebre se començò el edificio. Hizo vn jardín lo primero, tan hermoso, y tan florido, que era la rosa Maria, y el clauel era su hijo. Albricias, \&C. Estaua el jardin sin agua, y piadoso el Rey preuino cinco caudalosas fuentes al estanque del Bautismo. Fabricose vna gran plaça, en donde al recien nacido tres Reyes hizieron fiestas por el bien de auerle visto. $Y$ porque en casas Reales tiene el vso introduzido que aya estancias para fieras, y para pajaros nido. 
Aues tiene y animales, aues que cantan al Niño, $\mathrm{y}$ animales que le abriguen viendole llorar de frio.

Solo faltaua vn Leon, y por esso lo fue el Niño, y el Leon con su quartana, pues le rindiò mi delito. Este de nuestro remedio el mejor Retiro ha sido, pues basta a desempeñar de nuestras deudas a Christo. Albricias, \&C.

\section{II1. VILLANCICO,} Gallego.

AY fermosiño nace mi niño, ele querer ser Galeguiño, ay, ay Galeguiño nace en a nosa terra, que muyto se folga con a gente Galega.

ay Galeguiño nace, nora boa sexa, que en o pesebriño ten muyta grandeza:

Ay Galeguiño nace de madre donzela, facendo pucheros por miñas ofensas.

Ay fermosiño, \&C.

Ay Galeguiño nace fagamosle festas,

e veña Tosiño dando mil boltetas.

Ay Galeguiño nace entre duas bestas, que meus amoriños muytos asas le cuesta .

Ay Galeguiño nace derramando 
perlas,

que o conde de Lemos dize a sua

presença.

Ay fermosiño, \&C.

NOCTURNO I1.

II1. VILLANCICO

En Dialogo.

1.QVe es cosa, y cosa, Gines,

que aquel $\mathrm{q}[u e]$ desnudo estaua

no temblaua,

y puesto vn vestido mio

està temblando de frio.

2. Dios en carne humana es.

1. Pues como tiembla despues

que el vestido se vistió?

2. Porque es mortal

y el temblar al yelo, es mal.

que el vestido le pegò.

Biblioteca Nacional. Madrid. VE/88-1 "Naon choreis meu bein".

Versos octosílabos, rima asonante, romanceada, con estribillo. 


\section{VILLANCICOS QVE SE CANTARON EN}

la santa Iglesia de Toledo, Primada de las Españas, en los Maytines de el Nacimiento de nuestro Señor Iesu Christo

este año de M. D. C. XLI1.

CON LICENCIA,

Impressos en Toledo, por Iuan Ruiz de Pereda, Impressor del Rey

nuestro señor, este año de 1642.

\section{I1. Villancico Gallego}

Ay miño pai, chamaimo gaiteiro,

$\mathrm{q}[$ ue $]$ queiro bailar con sao Domingueiro.

Ay miño pai, pues quieren os ceos

que veña a Galicia tan vel ganadeiro.

Veñan gaitiñas bolando, corriendo,

que ven festejar Infante tan velo.

Ay miño pai, \&C.

Por fin de la colacion

salio a cantar, y bailar

vna Gitanilla hermosa,

atencion que empieça ya.

\section{Guana.}

No emboluaiz al Niño hermoza,

cara de roza, y clavel,

que quiero ver mi ventura

viendole la mano a el.

A tuz piez eztoi, mi Angel,

villana tengo de zer,

que me he de tomar la mano

quando tu me dez el pie.

Dadme hermoza vn real de plata, que la Cruz le quiero hazer, que con treinta le haran otra a sus añoz treinta y trez.

Que linda cara que tienez, 
como la cara tambien

az de tener laz coztumbrez,

loz hechoz az de tener.

Corta vida tienez, Angel,

maz aunque tan corta ez,

zegun la muerte dezeaz

larga te ha de parezer.

Enamoradito erez,

en los ojueloz ze ve,

tantaz quiero, quantaz veo,

por ti ze dirâ muy bien.

Por galan, y gentilhombre

merezez gentil muger,

la Gentilidad lo ez arto,

loz doz [...].

Tendraz vn gran dezafio,

luchando auras de venzer,

no zerà a brazo partido,

que a brazo clavado ez.

Vn Reyno en premio te aguarda

quando alla en tu Reyno eztez,

para que de mi te acuerdez

te digo memento mei.

Ezta limoznica pido,

mi emperador, y mi Rey,

mal aya quien mal te quiere,

y quien no dixere amen.

Que niño ta $[n]$ bello, ta $[n]$ lindo, y hermozo

bien mereze por lo graziozo,

$\mathrm{q}[u e]$ mil bendizionez, y graziaz le den.

Villancico tercero.

COn tal priessa, y fuego baxa

oy al mundo el Sol llorando,

que en si anegarle imagina

perla a perla, y rayo a rayo.

Llamas de cristal encienden

los abismos de su llanto, 
y por encubrir el fuego

quiso en agua disfrazarlo.

Con exercitos de lumbre

conquista los ayres claros,

que negras nuebes conspiran

armadas de copos blancos.

\section{Estriuo.}

1. Que se abrasa Belén en viuas llamas

toque $[n]$ a priessa a fuego, y eche $[n]$ agua:

mas no toquen, bueno está

pues el fuego es agua ya

con que ceba amor su fragua.

2. Si es diluuio, huyamos luego, fuego de Dios en el fuego,

fuego de alquitran parece,

pues con agua tanto crece.

1.0 que no lo entendeis vos, no es sino el llanto del Niño Dios, que es vn mar, que culpas anega, fuego que abrasa el alma de amor.

No haze herida al rayo hermoso

en los capitolios altos,

que como es rayo de amor

haze efecto en lo mas baxo.

Vn portal humilde escoge, donde si amorosos rayos

elados pechos encienden con agua intenta abrasarlos.

Ya la que sus ojos vierten la luz se paga en topacios, arde el mundo en viuas llamas, y assi dize alborotado.

Que se abrasa Belen, \&.c.

\section{NOCTVRNO.}

\section{Villancico quarto.}


1. LLegad pastores, llegad, $\mathrm{y}$ vereis vna novedad, que se descubre, y se esconde.

2. Donde?

1. En Belen agora estâ.

2. Que serà?

1. Adiuinadlo pastores, que es vn milagro de amores entre desdenes constante.

2. Si es amante?

1. No padece cuidados menores y su develo es mayor.

2. Si es pastor?

1. Tiene muy bello semblante, mas lindo le considero.

2. Si es Cordero?

1. Sale del vn resplandor, que nos baña de alegria.

2. Si es el día?

La verdad deciros quiero $\& C$.

es Cordero, Amante, y Pastor, y el dia mejor que tendran los hombres jamas, ques Dios, que es todo y es mas.

Coplas.

2. Dime que tiene de amante?

1. Lo que sufre por amor,

2. Y que tiene de Pastor?

1. El cuidado vigilante.

2. Y al Cordero semejante?

1. En que inocente padeç[e].

2. En que el dia se parece?

1. En que le anuncia vn luzero

La verdad deziros quiero, \&c.

2. Con ser amante, que quiere?

1. Mostrar su amor celestial.

2. Y en ser Cordero çagal?

1. La obediencia con que muere. 
2. Y en el ser Pastor, que infiere?

1. Que vela en defensa nuestra.

2. En ser el dia que muestra?

1. Que naciò su luz primero.

La verdad deziros quiero, \&C.

Biblioteca Nacional. Madrid. VE/88-9. "Ay miño pai”.

Versos octosílabicos, a veces se asemeja a una letrilla, rima asonante; otras veces es, romance con estribillo. Métricamente, el villancico tiene vuelta, y el zéjel no.

\section{VILLANCICOS QVE SE CANTARON}

en la santa Iglesia de Toledo, Primada de las Españas, la noche del Nacimiento de nuestro Señor Iesu Christo, este año

de 1644.

CON LICENCIA,

Impressos en Yoledo, por Iuan Ruiz de Pereda, Impressor del Rey nuestro señor, este año de 1644.

1.-ENcucha frautiyo Anton.

2.-Cayan diabro aquesa copriya,

Que canta lo Niño q[ue] tiene ali ya.

3.-Sa cantando Kirieleyson.

4.-Valante el diantle bobon, canta el Glolia en tierra, y sielo,

2. Pues yon toca lo molteruelo,

tu, tu, tu, gulungon, gulungon.

1.Que nase la vida.

2. Gulungon, gulungon.

1. Que rie la neglo.

2. Gulungon, gulungon.

1. Que canta lo sielo.

Gulungon, gulungon. 
Vsitu que samos oyendo,

tura cantemo,

tura baylemo.

2. Toca plima, toca tu.

1. Sanguangua, gulugu, gulugu.

Tanto sichiyo que canta

con pluma de olo me alegla,

y epanta cura la negla,

y a turo lo mundo epanta,

siquiyo no tene manta,

la paxa tene gergon.

2. Gulungon, gulungon, \&C.

Tiembla siquiyo de frio,

e menea las patiyas,

e como son siquitiyas

contenta, e [...],

den gana sichiyo mio

yo le de el culaton.

2. Gulungon, gulungon, \&c.

\section{II1. NOCTVRNO.}

\section{Septimo}

EL grano de quien se dize vale mas que cielo, y tierra, en tierra fecunda y Virgen un sabio labrador siembra.

Despues que estuuo sembrado los nueue meses en ella, aunque es fuego como grano la seca paxa le cerca.

Solo juzgamos que es trigo y tengo por cosa cierta es fuego, aunque aquesta noche sus paxas arder no vean.

Trigo ay en la paxa, y el fuego en ella, toquen a milagro pues nonse quema. 
No ay campanas en Belen

con que a milagro toquemos.

Pues ay musica de a doze

suplantas los instrumentos.

Tod. Tan; tan tan, dilin, dilin,

$\mathrm{Y}$ si lo inuidian las vozes

canten alegres con ellos

Tod. Dilin, dilin, tan, tan, tan.

Simples le miran Pastores

entre la paxa, y pudieran

llamarse ya labradores

pues gozan tales cosechas.

La labradora María

a limpiar el trigo empieça,

si puede auer que limpiar

en el que todo es pureza.

[...]

puede encerrarlo en la tierra.

porque en sus braços vio al Niño

y que en ellos tras si lleua

las almas de quien le mira,

preguntò desta manera.

Quien sois Niño hermoso?

Dios.

Quie $[n]$ os puso al frio co $[n]$ tanto rigor?

Amor.

Quien es el amante, dezidme su no[ $m]$ bre

El hombre.

Quien os traxo al suelo de alla de los cielos?

Zelos.

Que quereis del ho $[m]$ bre $\mathrm{q}[u e]$ essa mano llama?

El Alma.

$\mathrm{Q}[u e]$ le aueis de dar si ama co[n] desuelo?

El Cielo.

Maria en $\mathrm{q}[u e]$ os pone quando niño os faxa?

En la paxa.

Trigo ay en la paxa, \&c. 
Octauo Villancico Gallego.

AY miñas donas, tocay o pandeyro

$\mathrm{q}[u e]$ moiro de amores de o nino que queyro.

Estaua minino

metido en el seno,

qual suele entre Rosas

o blanco Cordeyro.

Tan rico de gracias,

que ya el vniuerso

por el ha gozado

la de Deus eterno.

Los peis se que pisan

cabeça de o demo,

ya no mays pecados

tendran os Galegos.

Qve viene a dar vida

tenemos por certo,

afora la morte,

viuir solo queyro.

Ay miñas donas, \&c.

Do seno de ò Padre

baxo el ben immenso

a vestirse humano

o nacar tan bello.

O may e fermosa

sabed, e creedlo,

tan ben preuenida

para o ben que vemos.

Quanto mays tirita,

y le abrasa o yelo,

de amores abrasa

a los compañeyros.

Que llora, y que rie

dizen os efeytos,

qual home se tiña,

qual Deus todo e ceylo:

Ay miñas donas, \&c.

FIN. 
Biblioteca Nacional. Madrid. "ENcucha frautiyo Anton". 
VILLANCICOS QVE SE CANTARON EN LA SANTA IGLESIA CATHEDRAL de Salamanca, en los maitines solemnissimos del Nacimiento de N. S. Iesu Christo, este año de 1646. Siendo en ella Maestro Capilla y Racionero el Licenciado

\section{Andres Barea.}

Dirigidos Al dean y Cauildo de dicha Santa Iglesia.

Visperas.

DE Peña en peña las ondas, corriendo rien y pasan y de flor en flor las aues, vuelan, suspenden, y cantan. De sombra en sombra la noche, con obediencias tempranas, coronan las nubes negras, destranjeras luzes pardas. De Rayo en Rayo amanece, nuebo Sol de luz tan alta que antes que lo sepa el dia, le muestra nacido el alua. De luz en luz lo insensible, tanta luz el cielo paga que aun lo incapaz de sentido, obrar no saue sin alma.

\section{Estriu[i]llo.}

Y Los cefiros dulces de la mañana jusgan vullen y trepan de Rama en Rama.

O que uien saludan al Alua, riçan las Olas uaten las Alas Ruiseñores y fuentes claras. siendo las aves siendo las aguas, clarines de pluma tro $[m]$ pas de plata. De dos en dos los zagales, dançando y uailando uaxan y el cielo, el tiempo y la noche, 
les enseñan las mudanças.

De mil en mil las deidades,

a la tierra trasladan

que si en ella Dios auita,

Soberano arroyuelo, $\& C$.

\section{Segundo noturno.}

Bamos a ver la riqueza del cielo

vn pesebre $\operatorname{co}[n]$ puertas de yelo

guarda joyas del cielo es.

* 2. Di lo que Bes.*

La gloria entre llanto y pena.

Di lo que bes.

Vna flor y vna Azuzena.

Di lo que bes.

Junto a el Sol luçir vna Estrella.

Di lo que bes.

Vna nina parida, y donçella.

$\mathrm{Q}[u e]$ admiras en ella, $\mathrm{q}[u e]$ adoras en el.

Vna perla huerfana, y vella

vn diamante claro y luciente,

tan raro y tan excelente,

que se ignora el precio del.

\section{Copla.}

Vi junto a el Sol vna Estrella, que luce y da resplandor, y por milagro maior el mismo Sol nacer della vi tantas gracias en ella, que todas las gracias es.

* Di lo que bes. *

[...]moza la ancianidad sin aparentes engaños, vn biejo con pocos años, y vn niño con mucha hedad Vi valida la humildad, y la soueruia a sus pies. 
* Di lo que bes.*

En vn portal vi postrado

el mas alto señorio,

al Sol elarse de frio,

y a lo diuino humanado,

el amor por si estimado

despreciado el interes.

*Di lo que bes.*

\section{Quarto Villancico ${ }^{7}$.}

* Ay leueme Deus

si a morena do Ceo

non tenu fillo

que todo galego.

Ay o que pariu,

è tan muyto garrido,

que toda galicia

non ten tal fillo.

Ay eu por seguir

co os Reyes a Estrela

perdin o meu burro

coa sua augadeira.

Ay Deus quen tubera

ventura co el,

è fora a muliña

do seu presebre.

Ay Folgense moito

os galegos lacayos,

que ja ten amo

galego e fidalgo.

*Ay lebeme Deus,

\section{Quinto Villancico.}

* Vn Cupido nos a nacido, que a el amor le lleua la flor,

\footnotetext{
${ }^{7}$ A la derecha, añadido a mano, se lee Gallego.
} 
mas Cupido que el amor, y mas amor que Cupido.

\section{Coplas}

Niño amor, y amor medrado del amor mismo trofeo, mas Cupido en el desseo, mas amor en el cuidado el yelo que mas armado de rigores apetece recien nacido le mece le arrulla recien dormido.

* Vn Cupido nos a nacido, \&C.

Perlas sus lagrimas hechas à este amor sirben de valas, buela coxidadas las alas, yere embainadas las flechas, fajas le ciñen estrechas, $\mathrm{y}$ en ellas hala prision el buelo del coraçon, y el aliento del sentido.

* Vn Cupido nos a nacido, \&C. No le mira quien no muere de aficion de lo que admira, que es amor con lo que tira, $y$ aficion con lo que yere, el erido se prefiere assi mismo sin herida, porque son cambios de vida los despojos del rendido.

* Vn Cupido nos a nacido, \&C.

Sexto Villancico.

Terzero noturno.

* Que dire de bos Dios mio, que sea nuebo, y lindo.

Copla. 
Si digo que en sitio breue,

el Cielo mil Cielos 11[...]be,

que la nieue a el Sol se atreue,

aun es frialdad sin la nieue

y mas que el Diziembre debe

hazer tiritar de frio.

* Que dire de bos Dios mio, \&C.

Si digo que en buestras huellas

miran a las pajas bellas

imbidiosas las Estrellas,

y que bos llorais centellas

reinranse de todo ellas,

como yo tambien me rio.

*Que dire, \&C.

Si digo que los Pastores

en la noche ven albores,

y escarchados lo alcohores

producen Mayos mejores,

ya es flor hablar de las flores,

y aun del hibierno es hastío.

Que dire, \&C.

\section{Si digo que Niño humano}

os mostrais Dios soberano,

es concepto muy hanziano,

pero muy cierto, y Cristiano,

y que siempre os ara en bano

negalle ningun Iudio.

Que diré de bos. \&C.

Biblioteca Nacional. Madrid (V/E 1196-1) "De Peña en peña las ondas".

Versos octosílabos, rima consonante en su mayor parte, aunque cambia cuando es letrilla con fines a veces satíricos.En el siglo XVII, letrillas especialmente líricas y religiosas. 
VILLANCICOS QVE SE CANTARON EN

la santa Iglesia de Toledo, Primada de las Españas, en la noche Buena, este año de 1647. Siendo en ella Racionero, y Maestro de Capilla, el Doctor Vicente Garcia, natural de la ciudad de Valencia.

PRIMER NOCTVRNO.

\section{LECCION PRIMERA.}

De la Redempcion del hombre,

que ha siglos que estâ en cadenas,

de la Trinidad del vno

la jornada se encomienda.

Fabricò vna hermosa Naue

con tanto aliño, y grandeza,

que todo el poder de Dios

no la pudo hazer más bella.

En veinte y cinco de Março,

tomando humana librea,

se embarcò Aue Maria

al darle solas dos letras.

Y la Naue de dones, y gracias llena,

dando Timón al Mar,

dio al veinto Velas,

porque el vie $[n]$ to en popa lleua en ella

el Aguja el Norte, y el Mar su estrella.

Ya de la playa parte

las montañas de vidrio rompiendo e[1] ayre

$\mathrm{y}$ al eco de sus vozes repite el valle.

Buen viage. Hao,

buela la Naue

sin que al verla bolar admire a nadie,

que no puede admirar bolar vna Aue.

\section{Texto}

Alegre el Mar en bonança

confiessa en su buena Estrella, 
que despues que nace el Nacar

nunca ha tenido tal Perla.

El llegar por Nauidad

se supo por cosa cierta,

que vn Montañes del Rey Primo

traxo por San Iuan la nueua.

En vn Portal toma puerto,

$\mathrm{y}$ apenas tocò la tierra,

quando haziendo el cielo salua

vozes dan, y gritos suenan.

Sube a la Gabia,

$\mathrm{q}[u e]$ del Vaxel la Aquilla toca en la playa.

A de la Naue. Hao.

A de la Playa. Hao.

A Marineros. Hao.

El viento es de Poniente;

Amayna la mayor, Iça el Trinquete,

larga la escolta,

$\mathrm{q}[u e]$ el cielo dize Paz y el suelo Gloria.

A prisa, Amayna, Iça, Aferra,

$\mathrm{y}$ en estas esperanças todos vozean,

A tierra, a tierra,

que ya su Redemptor pisa el arena.

El cielo està en la tierra,

pues ya su Capita $[n]$ desembarca en ella.

\section{SEGVNDO VILLANCICO}

\section{Lección segunda.}

1.-GAleguiño, escuytayme.

Marucà, que mandades?

2.-Galeguiños, alegrauos, que teño que contarvos.

3. Ay Marucà Maruquiña, cantalo la cantiña,

Ay Maruca Maruqueta, canta la Cançoneta,

La branca Paloma,

que vino de a serra 
con pequiño de ouro,

è prumas de a perlas.

Crauel encarnado

la branca Açuzena

pario en pesebriño

quedando Donceyla.

A ò me Nino, que nace

le abrigan dos bestias,

trillanle la palla

fazendole festas.

Vene tan garrido

a la nosa aldea,

que o fillo de ô Conde

a sus pies non chega.

Norabona veña

me Nino de os ceos

a pays a la terra,

veña norabona,

norabona veña.

Copla.

En vn Portaliño

chorando de peyna

por ô noso trage

se veste de xerga.

El cobo doneyro

de mallada nuesa

mays fermoso, è lindo

que el Sol, ni as estrelas.

Muytos Angeliños

as alas despregan,

e la pays nos cantan

en voz placenteyra.

Veñen desde Orense

hasta Compostela

para ver al Nino

Galegos, Galegas.

Las Pastoyras tudas

as cabañas deyxan, 
que por sua graça

de amor se amarteylan.

Norabona veña

Ay Marucà, \&c.

\section{II1. VILLANCICO}

Leccion tercera.

Matenmé e amor tus flechas, muera a dos Arpones tuyos, que morir con tal ventaja mas que rendimiento es triunfo.

Al mirar essos sollozos hallo esperanza, en que fundo, que los suspiros a tiempo cuestan poco, y valen mucho.

Cantale dulces amores el Angelico concurso, al que vistiendo a los cielos llora en vn Portal desnudo. Tus flechitas suspende ofendido, que no es triunfo matar vn rendido, y entre alfombras de flores Cisnes, y Ruyseñores, pues me abrasas el coraçon, cantaràn tus desvelos de tres en tres lloraràn mis desdenes de dos en dos.

Texto.

Matenme tus rendimientos, muera yo, pues que no es justo, que a pagar vn Iusto venga yerros mios tan injustos. Diganme mi bien tus perlas en desatados diluuios, como de tantas borrascas hallaron puerto seguro? Arda simple Salamandria en fuego que me consumo, 
y serè para tu cielo

Fènix de mejor trasumpto.

Dame vida, pues que tienes

en ella librado el gusto,

que si procuras mi vida,

la vida solo procuro.

Tus flechitas suspende ofendido, \&.C.

\section{SEGVNDO NOCTVRNO.}

\section{QUARTA LECCION.}

Villancico quarto.

PLimo Anton? A plimo Anton?

No le responde, no tiene lazon.

Que quele Plimo?

que pol Sesun Clica q[ue] como dolmirá

Pues como dolmirà en ta $[n]$ gla $[n]$ de co[n]te $[n]$ ta,

que vene Pastora a lu Nacimenta?

Vamo Plimo, y cantalemo.

No quelemo.

Puluque?

Yo se lo dilè.

Si baylamo, o no baylamo,

si cantamo, o no cantamo,

si dançamio, o no dançamo,

si tocamo, o no tocamo,

que reyro quanto hazemo.

lu Branquiya tura aleglia,

y no quielo que se ria,

que a lo veyaco tocemo.

Dexese de essa,

y hagamo a lo Niño fessa.

Que fessa halemo,

que gusto no le tenemo?

Quielé vn salao?

No tenemo lo camisao.

Quele foliya?

Dalemo melancolia.

Quele chacona? 
Tentalemo la plesona.

Quele lu cagayelo?

Tenemo poco dinelo.

Pues que quele Plimo?

Vn sonecito baylemo,

$\mathrm{q}[u e]$ le pi, le brin $\mathrm{q}[u e]$, le ande, y le buya lo pe,

que si venimo

turu lo Neglo de Santo Thome.

turu serà balabunda.

Ay que tunda, que tunda, que tunda,

ande tura la balahunda.

Biblioteca Nacional. Madrid (VE/88-14) "De la Redempcion del hombre".

Rima asonante, versos octosílabos, ensaladilla, varias lenguas. Imitación de la lengua castellana. 


\section{VILLANCICOS}

QVE SE CANTARON EN LA SANTA IGLESIA CATHEDRAL DE LA

Muy noble y leal Ciudad de Cadiz: la noche Buena, a honra y gloria del Nacimiento del Hijo de Dios, este año de mil y seiscientos y quarenta y siete.

Impressos en Cadiz por Francisco Iuan de Velasco, Impressor y Mercader de libros, en la plaça enfrente de la Carçel deste Presidio, este Año de 1647.

\section{NOCTVRNO}

Kalenda.

ROmped, Romped el cilencio,

los de la tierra pues ya

a vuestra prision promete

el cielo la libertad.

2. Quien suena tan dulce voz, en nuestro amargo pesar; que promete misteriosos remedios a nuestro mal?

1. El nuncio de vuestro bienes, pronostico celestial, que a vuestra guerra y desdichas viene a dar seguridad.

3. Como a de ser esse bien? que pues bien en el estàs, bien puedes a nuestros males mas bien del bien informar.

1. El cumplimiento dichoso en dizfraçada deydad, vereis mañana en la tierra; vereis del cielo la paz: alegres el bien cantad, pues la paz y la gloria esperais. 2. Venga el bien del cielo que la tierra aguarda, con sus dulces bienes, 
leyes de gracia.

1. Vendrà el prometido, en braços del Alva,

Sol que a la tiniebla

romperà la calma.

3. Venga en ora buena,

el bien de las almas,

que promete libres

con su mano franca.

con sus dulces bienes,

leyes de gracia.

\section{Copla.}

Vendrâ dizfraçado, de sombras humanas, despertando vivas muertas confianças; y naciendo humano, de eterno Monarcha. Haran sus acciones, divina probança, vida y luz intenta libraros mañana, en su amor seguras, del cielo obligadas. Porque su promesa, hizo fuerça tanta, que a humano le obliga divina palabra.

2. Venga el bien del cielo, \&.C.

\section{I1. VILLANCICO}

1. FOra pretos do camiño, que vn Fidalgo nobre bein.

2. No quelemo que a Belen, turo vamo a bel al niño.

1. Canto và pretos que tiño, en vosco esta miña espada. 
2. No hala no hala camalada, puque aunque neglo gente somo siolo, el que antes de imaginarlo, no ay en lo interior impulso, que se le pase por alto. El que se lo sabe todo, y sin aver estudiado, dando quinze y falta puede, llevarse el victor, y el lauro. Aquel en fin para quien, no ay calaboço cerrado, no ay valentia en azero, ni resistencia en espacio. El que por un pequè solo, perdona más desacatos, que tiene el cielo carbunclos, y que arenas tiene el charco. Afuera, afuera $\mathrm{q}[u e]$ sale el bravo. Mira pues alma si tienes, con el pesadumbre acaso, llega humilde, porque humilde sacaràs muy buen despacho.

Guardate de sus enojos, que si con ellos el braço, para castigarte mueve, tiene muy pesada mano.

Afuera, afuera, $\mathrm{q}[u e]$ sale el bravo.

\section{Estrivillo.}

1. Aquí los de la hoja, aqui los alentados, a resistir las yras, de este bravo.

Al campo, al campo, que un Niño desafia, ea valientes, ea soldados, provad aqui las fuerças 
de los braços.

2. No es acertado.

1. Si es acertado.

2. No es acertado resistir a quien riñe, siempre a su salvo.

\section{II1. NOCTVRNO}

VIII. VILLANCICO

ATrevido Diziembre $\mathrm{q}[u e]$ yelas

Cristales corrientes, suspende el rigor,

$\mathrm{q}[u e]$ tu escarcha te $[m]$ blando de frio,

tiene entre pajas el más bello Sol.

Nono.

$\mathrm{q}[u e]$ si tiembla no tiembla de frio, antes si llora $\operatorname{so}[n]$ perlas de amor.

Es tan grande tu impiedad, que me atrebo a dezir yo, que si alguna ay que le yguale, no ay otra que sa mayor.

Si hazes buscar a las fieras, abrigo en sus grutas oy, que mucho tiemble a tus yras, un Niño, aunque es Niño Dios.

De blanco las plantas vistes, pero con tanta orpresion, que por no sufrir tu nieve, perdonaran su candor.

Todo se aflige de verte, pasa qual viento veloz, pues de Dios lágrimas dulces, no ablandan tu condicion.

Atrevido Diziembre, \&. C.

Biblioteca Nacional. Madrid. VE/ 92-18 (1). Ejemplar incompleto "Romped, Romped el silencio". Rima asonante, en versos octosilábicos. 
VILLANCICOS QVE SE CANTARON EN LA IGLESIA PARROQVIAL de el señor san Miguel, de la ciudad de Xerez de la Frontera, en los Maitines de la Nauidad de nuestro señor Iesu Christo, este año de 1649.

Compuestos por el licenciado Francisco Barbosa Presbítero, Maestro de capilla, y sochante en la dicha Iglesia.

Dedicados a los curas, $y$ beneficiados de la dicha Iglesia. Impresso en Xèrez de la Frontera, por Diego Perez Estupiñan. Año 1650.

\section{SEÑORES,}

Para todos nace el niño Dios. Parvulus enim natus est nobis. Cap.9. Pero aunque es verdad que para todos nace, vemos que primero se manifiesta a los pastores. Luc. Cap. 2. pastores loquebantur ad inuicem. Y consultando a San Ambrosio lib. 2 in cap. Lu. dize. Pastores sunt Sacerdotes. De aqui colijo yo, que el niño Dios aunque nacio para todos, primero se manifestò a los pastores, esto es a los Sacerdotes, parece que lo explica el mesmo Ambrosio lib. 2. cap. Luc. à pastoribus (dize) populus ad Deircurcretiam congregatur. Pues según lo dicho, por quien con tanta calificacion puede entenderse este lugar como por los Señores Curas y Beneficiados, por cuya cuenta corre, el regimiento de las Iglesias, y cuidado de las Parroquias. Pues villancicos cantados en el nacimiento de vn Dios niño, que aunque nace para todos, en particular se manifiesta a los pastores, esto es, a los Sacerdotes, dire mejor (mouido del sentir de san Ambrosio) a los Curas y Beneficiados, a los que por su cuenta tienen el regimen, la vigilancia, el cuidado de las Iglesias, y de las almas, a quien con tanta propriedad se deue $[n]$ dedicar como a V. mercedes; atreuimiento es mio, pero con la confiança de la honra que siempre V. mercedes me hazen, se los dedico para que con su amparo lusgan, con su proteccion campeen, y lo logre el aplauso del acierto en la eleccion.

Capellan de V. mercedes que su mano besa. Francisco Barbosa.

\section{PRIMERO NOCTVRNO}

1. Villancico.

ARmado el norte de yelos contra vn portalillo pobre batalla intima a los campos, 
guerra pregona a los montes.

Airados los bientos gimen,

y turbado el Orisonte

al curso de tanto yelo

todo es nieve lo que expone.

En tropa marchan las nubes

luto fatal de los orbes,

y en tanto golfo de miedos

toda es confusion la noche.

El globo de las estrellas

vistiendo sombras mayores,

con las nieblas que le ocupan

tacitas luses descoge.

En agua buelta la nieue

es tormenta de las flores,

y en diluvios de christales

naufragio corren los montes.

Solitaria la campaña

miedos surca y viste horrores,

y en mudas bozes los vientos

hieren el mar golpe, a golpe.

Estribillo

Y todo el mundo a bozes

pide socorro que se anega el orbe,

y en vna chosa pobre

surgio el baxel de gracia e $[n]$ tre vnos mo[n]tes

y en sus palayas se expone

La gloria al cielo y la paz al ho $[m]$ bre,

salua, salua clarines, y atambones,

$\mathrm{q}[u e]$ oy nacio el dia y se murio la noche.

I1. VILLANCICO.

BRotò vna rosa, vn clauel

y es la gracia misteriosa,

que oy nace de la rosa,

y la rosa nacio del.

En la estancia pura y bella 
de la eterna primauera

nacio la rosa primera

del clauel que oy nacio della,

es marauilla el clavel,

y es la gracia misteriosa

que el oy nace \&.C.

II1. VILLANCICO.

Gallega.

AY cachopiño belo

dochome a Deus

como sois Galego.

Ay miño pay diuino

dochome a Deus

como sois Galegiño.

Ay cachopiño de oiro

dochome a Deus

como sois fermoso.

Ay miño pay de vida

dochome a Deus

como sois de Galicia.

No vosso portaliño

para ser pao de os ceos

naceis entre as espigas

que comen os Galegos.

Ay belo fermosiño

dochome a Deus que os vejo

no portaliño pobre

donde estais encuberto.

Eu vos teño nos ollos

porque dizen os cregos

que vos sois a lusiña

dos ollos con que vejo

Vestido de encarnado

en que estais encuberto

en galisa de graça

vos querem os galegos.

Todos os galegiños 
vem de Galisa a veruos

y na vossa choupiña

tocano[s] seus instrumentos.

Tocay ao marotiño

que eu tambem cantar queiro

huas copriñas nouas

que cantao $[n]$ os galegos.

Ay cachopiño \& C.

Bilbioteca Nacional. Madrid.VE/176-58. Vilancico 1. Nocturno."Armado el norte de yelos". Villancico en versos octosilábicos, rima asonantada, descriptivo. Parece bailable. 


\section{VILLANCICOS QVE SE CANTARON EN}

la santa Iglesia de Toledo, Primada de las Españas en la noche Buena, este presente año de 1649. Siendo en ella Racionero, y Maestro de Capilla, el Doctor Vicente Garcia natural de la Ciudad de Valencia.

\section{PRIMER NOCTVRNO}

\section{Leccion Primera.}

EN la primera batalla que se diò en la alta Esphera, el Angel perdiò la silla y sus soldados la empressa. Inobediente pretende que el hombre desobedezca, que por mal aconsejado pecò con desobediencia. Para remediar al hombre, y castigar la soberuia, del cielo partiò vn Infante, y pissar al mundo intenta.

Vn exercito tan grande consigo en campaña ostenta, que le ha temido el contrario, y le ha temblado la tierra.

Alarma, alarma, guerra, guerra, auisen los Clarines la pelea; resuene el parche, toquen las trompetas, ya el bro[n]ze anima, y el valor se alie[n]ta. Saluador es el nombre que diò su Alteza quando a la batalla su gente apresta.

Alarma, alarma, guerra, guerra.

Parte de la Infanteria le deguellan, $\mathrm{q}[u e]$ a fuego y sangre, batalla empieça. 
Balas preuiene el yelo,

suena la artilleria de los çielos.

Ya enuisten, ya se encuentran,

el yelo arroja lanças,

la nieue muestra picas;

fuego tira el amor, la furia iras

Y entre grita, y estrue $[n]$ do, penas y males

suena $[n]$ las vozes que van por el ayre,

viua la gala del tierno Infante.

Digan alegres, canten sonoras,

a los ho $[\mathrm{m}]$ bres paz, y a los cielos gloria

Y pues viene de paz a la sièrra,

y es la Perla que nace del Alua,

hagale la tierra salva

pues haze salua a la tierra.

TEXTO.

De la Magestad Diuina,

que siempre contigo lleua,

y la humanidad que goza

juntò dos naturalezas.

Santa Maria es el Puerto,

Ciudad adonde su Alteza

nueue meses ha gastado

mie $[n] \operatorname{tras} \mathrm{q}[u e]$ el marchar se apresta.

De cielo y tierra los Grandes

a darle obediencia llegan,

que como amoroso rinde,

hasta las almas sugeta.

Para alentar sus soldados

a saco les dâ la tierra,

queriendo que el hombre goze

de todos los frutos della.

Alarma, alarma, guerra, \& c.

\section{I1. VILLANCICO}

Leccion segunda

DE los cuidados rendido 
penando mi Niño està,

quien tiene de amor desvelos

bien puede ya suspirar.

Con los rigores del hombre

al llanto quiere apelar

pues finos Diamantes llora,

no le digan, no aya mas.

Ardientes centellas vierten

dos Soles de par en par,

donde es de Aljofar el fuego,

los rayos de qué seran?

Portento de amor ha sido

tanta lluvia de Cristal,

pues nunca a vista del Alua

le vimos al Sol llorar.

\section{Estriuillo.}

No lloreis diuinos Luzeros

si mis males quereis llorar, no lloreis pues naceis del Aurora,

Niño mio, no haya mas.

\section{Texto.}

A sus mexillas los ojos

de Perlas borraicas dan, y siendo quine peca el hombre;

el sufre la tempestad.

Su llanto enjuga el Aurora,

por ver, que quiere anegar

con raudales de Luzeros

breue Esphera de vn Portal.

Hermosa luz a la noche

tributa Sol celestial,

y entre diluvios de Estrellas

divina serenidad.

A pagar al mundo viene antiguas deudas de Adan,

fiança que tanto cuesta,

desvelos ha de costar. 
No lloreis divinos Luzeros, \& c.

II1. VILLANCICO.

Lección tercera. Ensaladilla.

A Ver en Belen vn Niño

todas las naciones fueron,

que como es Dios para todos

fue general el contento.

Vn Hidalgo Montañés

de las Asturias de Ouiedo

parte a Belen con su esposa,

a ver humanado al Verbo.

Muy preciados de lo noble,

y de hidalgos solariegos,

van a ver al Rey del cielo.

En busca van de su gracia

por acreditar su acierto

que quien èsta no consigue

desperdicia sus deseos.

Asturianos.

1. Ay Marnecâ si buscades gracias

vaite al Zagale $\mathrm{q}[u e]$ plora $\mathrm{e}[n]$ vnis pallas.

2. Ay mi Zagale, ò sol de a mañana,

donde se alverga? y ado $[n]$ nde desca $[n]$ sa?

1. Ay Marucâ, que entre dos alimañas

finca este Sol, que lo arrulla el Alua.

Copla.

1. Ay Marucà, que si yes galana,

vaite al Zagale, $\mathrm{q}[u e]$ es flor de las Mo[n]tañas.

2 . Ay quie $[n]$ le viera, y quien le adorara, que es $\operatorname{ta}[n]$ garrido, que roba mi alma.

1. Ay Marucà, que entre dos alimañas

finca este Sol, que lo arrulla el Alua.

Texto.

Con instrumentos acordes 
a adorar a Dios vinieron

Angeles de mil en mil,

Pastores de ciento en ciento.

Con esto al Portal llegaron

vna tropa de Gallegos,

que con afectos humildes

a su Madre la dixeron.

\section{Gallegos.}

Quein non vos ama Niña graciosa?

Quein no $[n]$ vos sirue la miña Señora?

\section{Copla.}

Frol de o campo

la cara de Aurora,

boca de operlas

a branca Paloma.

Quein non vos ama la Niña graciosa?

Quein non vos sirue la miña Señora?

Prosigue el Texto.

A Belen se va un Frances, quando a su consorte oluida, busca a Dios con mas acuerdo.

Llorando le habla su esposa

por ver ausentar so dueño,

y al partirse de Paris

tierna le canta estos versos.

Frances.

1. Si ti vas al bon Infant

lo Señor Ian de Dieu,

si vas a lexas terras,

que harè pobray de mi?

2. A Chiesus adorarè

la mi Mari Marti,

que morto està de frio,

darèle yo un vestit.

1. Si vas al bon Monsiur

lo Señor Ian de Diu, 
si no tornas a França,

que harè pobray de mi?

2. Si yo men vau a França

a la sopa de Chiesus,

si yo men vau a França,

no toranarè mays pius.

Copla.

1. Si ti partis a Belen

per ver al gran Delfin,

que farè yo tan sola

si ti alexas de mi?

2. El es fillo de lo Róy

di França, flor de Lys,

faraynos moltas gracias

quant entre per Paris.

1. Si a vn Pesebre a ver el Nat

ti vas por los camins;

si no tornas a França,

que haré pobra de mi?

2. Si yo men bau en França

a la sopa de Chiesus,

Si yo men bau en França

no tornarè mays pius.

Prosigue el Texto.

Con luz del cielo guiados

vinieron distantes pueblos

preguntando a los Pastores

por su Dios Infante tierno.

Y por dar fin a la fiesta,

de alados musicos diestros,

para cortejar al Niño

se oyeron estos acentos.

1. Quem vidistis Pastores?

dicite, annuntiate nobis

in terris quis apparuit?

2. Natum vidimus,

\& choros Angelorum 
collaudantes Dominum.

1. Dicite, quidnam vidistis?

$\&$ annu$[n]$ tiate Christi Natiuitate $[m]$.

2. Natum vidimus,

$\&$ choros Angelorum

collaudantes Dominum.

SEGVNDO NOCTVRNO.

Quarta Lección.

Villancico quarto. Vizcaino.

A Darle la bien venida

al Rey de la Magestad

llegò alegre vn Vizcaino

a media noche al Portal.

Alboroçado, y gozoso,

aunque al parecer boçal,

en su idioma mil requiebros

le dixo con humildad.

Con Retorica sencilla

al Niño se atreue a hablar,

que al verle Dios tan humano

no le assombrò lo Real.

Gracioso cantô vna letra,

y aunque no la dixo mal,

se conociô que entre todos

fue diestro en el porfiar.

Etela, Olà Pastores, Hao,

que Dios Niño nacidos Belen

ya Viscaya le estâs mas bien,

si Belen auer sido Bilbao.

Ola, que linda

miramos Do[n]zella q[ue] estamos parida

cuerpo de san,

que mi Niño graciosos

robamos el alma con solos los ojos.

Ay, si lloras lo Niño las culpas de $\operatorname{Ada}[n]$ dete[ $n]$ esse llanto, que al rostro le baxas, o juras a Diez de comerme las pajas, 
que llenos de perlas de Dios estân.

$$
\text { Copla. }
$$

Esta noche obscuro

Sol te naces clara, fuego te le yelas, yelo te le abrasas.

De ronda le vienes por ver vn Zagala, que bien te la obligas! que mal te las pagas. Aunque mucha yerro Viscaya trabajas, del hombre en la pecho mas ay que en Viscaya.

Cierrate las puertas tu querida ingrata, que no dâ a los buenos el tierra posada.

Vn mal Rey te harâ, (ò vida del alma) que dexes Iudios, que busques Gitanas. O quien fuera el Mula para tal jornada; mas pues tierno lloras, mira yo que cantas. Por el ayre buelas entre Coros varias auezillas muchos sin pico, y con alas. Si la frío sientes, como no te empañas? mas si vas desnudo al Amor retratas. Por hazerme ricos pobre te le baxas, cielo te le sobras, mantillas te faltas. 
En choça la posas,

(marauilla estraña;)

tu abres cielo al hombres,

ciérrate el su casa.

Ay diuino dueños,

con que tiernas ansias,

porque es piedra el hombre

dan tus ojos aguas.

Si entre bestias naces

solos yo faltaua,

mas pues dos te quedas,

ya no harèmos falta.

Etela, ola Pastores, \& c.

\section{QVINTA LECCION}

Villancico quinto.

CIsne hermoso de los cielos, que para Fenix naciste de vna Paloma sin mancha, Madre vna vez sempre Virge[ $n]$.

Si desnudo estâs sin alas, plumas el ayre te viste con penachos de Luzeros, y garçotas de Iazmines.

Preso el coraçon me lleuas por lo amoroso, y lo humilde, entre rigores de Nieue, y tormentos de Rubies.

\section{Estriuillo.}

Bate las alas Pajaro hermoso, que si de este cielo tu bajas, llamara $[n]$ te las fuentes, y los arroyos.

Gloria de nuestro Valle

llega a mis ojos,

porque anegues en ellos tus plumas de oro.

Tocaràn campanillas a fuego 
quando abrasan de nieue los copos.

Texto.

L[1]oras quando a penas naces,

y es tu llorar quando gimes,

que hasta la risa del Alua

hazes que el llanto te embidie.

Quanto mas el buelo abates

con todo el cielo compites,

que te corta Amor las alas

porque en vn Pesebre anides.

Si por hombres Fenix naces,

has de morir como Cisne,

que viues de lo que mueres,

$\mathrm{y}$ mueres de lo que viues.

Bate las alas Pajaro hermoso, \& c.

Biblioteca Nacional. Madrid (VE/88-16) 556-1 Primer Nocturno, Lección Primera. "En la primera batalla"

Métricamente, parece una canción paralelística, musicalidad, versos octosilábos, el más arraigado en la poesía popular. Rima asonante.Descriptivo, 8a, 8b. 
VILLANCICOS QVE SE CANTARON EN LA

Santa Iglesia de Toledo, Primada de las Españas, en la noche Buena, este año de 1651. Siendo en ella Maestro de Capilla Thomas

Micieces.

PRIMERO NOCTVRNO.

LECCION PRIMERA.

Villancico

1. Serafines se despeñan

de montañas de esplendor,

y entre el confuso rumor

de amor las glorias se empeña[n].

2. Todos sueñan, todos suenan.

1. Quien yerra la selua?

quien passa, quien es?

2. Es vn Rey a quien besan

Querubes a los pies.

1. [...] el Rey.

2. Pues quie $[n] \operatorname{co}[n]$ tra el Rey se atreue mostrando indecencia tal?

1. Vandoleros de cristal

con cararabinas de nieue.

2. Solo el tiempo el passo mueue.

$\mathrm{O}$ que rigores tan fieros,

En manos de Vandoleros

ha dado su Magestad.

Vandoleros, parad.

1. Logre el cielo su osadia.

2. Tengase la Carroça Maria.

2. Hasta mañana tenerse podrà.

1. Bien esta.

Rindase el Rey que se humana, que en allegando mañana

Dios dixo lo que sera.

Coplas. 
Esta noche, en vn Pesebre vn Niño yaze hombre, y Dios,

[...]

que desde entonzes las pajas

fueron de color del Sol.

Del alta Alemania baxa

a caça herido de amor,

y los elementos le hazen

con guerra contradicion.

La tierra le niega abrigo,

el ayre le acometio,

el agua se fue a los ojos,

el fuego hiriò el coraçon.

Temblando de todos juntos

pidio quartel, y le hallo

entre ouejas, que es Cordero,

y en compaña, que es León.

Mas que mucho se le atreuan

a quien blasona de Dios,

y apurado bien su Ser

no escoja que Dios crió.

2. El tiempo el passo impidió.

O que rigores $\tan$ fieros, \&.C.

\section{LECCION SEGVNDA.}

Villancico Segundo.

Entre dos Sordos.

Oygan, atiendan, mire $[n]$ vn poco, que esta noche en los Maitines

se alegran los Serafines,

y todo el mundo està loco:

y esta Nauidad,

por mas nouedad,

por no cantar quedo

se van a Toledo

dos Musicos de gran precio.

Sordo. 1. Vaya recio 2. Vaya recio.

[...] 
a cantar con alto tono

Iuntos. Aquí, aquí, q[ue] que ay dos sordos,

ca $[n] \operatorname{te}[n]$ recio y lo ente $[n] \operatorname{dera}[n]$ todos.

Coplas.

1. Yo soy vn Sordo, señores, y de orejas tan cerrado, que por esso los Doctores, para que oyga me han ma[n]dado, que ande con dos habladores.

2. Otro Sordo mas cerrado soy; perdonen lo importuno, que por vno, y otro lado me ensordecio el ayre de vno que me pedia prestado.

1. Soy tiniente, y mi Doctor dize, que estaria mejor, y sanarà lo tiniente si me dieran derrepente vna plaça de Oydor.

2. Yo he gastado mi moneda para que vn Doctor me cure, y por remedio me queda, que bena puro, y procure oyr todo cuanto pueda. 1. Yo, porque ninguno trate de fruncir labio, ni ozico, soy Sordo a Natiuitate, $\mathrm{y}$ assi tendrà el villancico dos Sordos, y vn disparate.

Dialogo en disparate.

2. Abra Sordo las orejas, y cantemos nouedades.

1. Claro es, que las Nauidades son malas para las viejas.

2. El Niño haciendo pucheros esta entre la nieue elada.

1. El agua, ni aun saludada 
no la beuen los Cocheros.

2. Su modo de responder

es digno de fama, y nombre.

1. Ya lo entie $[n]$ do, Dios se hizo ho $[m]$ bre

y le han de hazer reponer.

2. Hable recio el Sordilon

para que entenderle pueda.

1. Tambie $[n]$ lo entie $[n]$ do, al de Vzeda

le lleuaron a Alarcon.

3. El mejor remedio que hallo

para oyr es, algodon.

1. Si la cantara vn capon

no fuera Missa del Gallo.

2. Entre rebaños de ouejas

naciò el Cordero Ioan.

1. Con el vino de Polan

doy vn baño a mis orejas.

2. Por redimir a los Tribos

Dios humanado se ve.

1. Dize, que el Niño anda a pie, no aura menester estriuos.

Vaya recio, \&.C.

\section{LECCION TERCERA.}

Tercero Villancico, en metafora

de vnos albañiles.

POr los passos luzidos graciosos

de aq[ue]lla luz clara q[ue] lexos se ve,

baylando los gremios a choros

se van acerca $[n]$ do al Portal de Bele $[n]$.

[...]

mira[ $n]$ do el Pesebre de sobados pies

al techo, que en glorias abaxo se viene

le pone $[n]$ festiuos puntales de Fe.

Coplas.

Señor, pues todos los gremios 
celebran vuestra venida, escuchad aquestos versos, que han venido por la China. Los Albañiles os hablan, no lo estrañeis, que en la villa gente es que puede ingeniosa hablar de texas arriba.

Que no los dexeis caer en la tentacion suplican, y tambien de los andamios, que es otra mala cayda. Esto os ruegan temerosos, que dizque esta Iglesia rica oy como de los caidos, y ser juros no querrian, $\mathrm{Y}$ aunque pueden murmurarlos por gente vana, y altiva, los hombres $\mathrm{q}[u e]$ en buenas obras se ocupan toda la vida.

En las pajas os contemplan cantando alabanças dignas, no pierden punto, que en todo tienen gran regla, y medida. $\mathrm{Y}$ aunque su fiesta por corta a ninguno causa embidia, Señor, no podeis negar que son hombres que edifican. Deuotos de vuestra Madre son tambien, si bien se mira, pues las obras que comiençan paran al Aue Maria.

Esto de Ioseph lo aprenden, que es de la virgen bendita tan deuoto suyo, que la guarda todos los dias. Parida està, pero como vn Carpintero la abriga, no le pueden faltar nunca çoquetes para torrijas. 
Labraros quieren el sitio, aunque no amenaza ruina; el ripio dèn los Poetas, y el Choro la canteria.

Albañiles seràn, \&.C.

\section{SEGVNDO NOCTVRNO.}

\section{LECCION QVARTA.}

Quarto Villancico. Ensaladilla.

Texto. Atencio $[n]$ y pu[ $n]$ to en boca, oygan, escuchen ate $[n]$ tos, que en noche tan mysteriosa se ha de cantar de Mysterio. Por hazer vna funcion vn Monazillo Manchego, al Niño cantò entonado a enterezas de sus quiebros.

\section{Estriuillo.}

Soy el Sacristán Perote,

Niño mio, no se alborote, que si ofreciendole estan el Cordero, miel, y el pan es justa razon se entienda, que siempre donde ay ofrenda, bolando va el Sacristan. Si todos le dan, Niño, tambien darle quiero, mi poquitico de Cordero, mi blandito de las faxas, mi ruidito de sonaxas, y los Pastores dirán: Los dineros del Sacristan cantando se vienen, cantando se van.

\section{Coplas.}


Niño, mire que le doy

de vna sabana vn pañal,

que hurtar para Iesu Christo

no es quitarlo del altar.

Este panal, si le come,

como vna miel le sabrà,

que el puchero es de Alcorcon,

y la miel de Colmenar.

Tome esta alcuça de azeite

con que alumbrarse podrà,

que vna lampara en vn Christo,

està bien en vn portal.

Tome el Alma que le doy,

que si la gloria la dà,

no me diràn, que anda en pena

el alma del Sacristan.

Si todos le dan, \&.C.

Texto. Repicando las campanas

dos Sacristanes vinieron,

aunque oy nace la Vida,

no viuirán de los muertos.

\section{Coplas.}

1. De Belen campanitas dindindinn, tocan al Alua, que don don don

2. Son parteras sin duda, dan, dan, dan, pues se adelantan, que don don don.

1. Ya enoblezen los cielos, din, din mucho a los hombres, que don don.

2. Es que muy de varato, dan dan, todos los dones, que dan don.

1. A merced de los muertos, din din, tu vida logras, que don don

2. Si ellos me hazen mercedes, dan dan yo les hago honras, que don don.

1. Oy entierro a la muerte, din din, le han celebrado, que don don.

2. Yo haré de aqui a ocho dias, dan dan el cabo de año, que don don. 
1. El Relox de la vida, din, din,

estâ en las pajas, que don don.

2. Assi ha dado en el mundo, dan dan,

tal campanada, que don, don.

Texto. Vn Sacristán Portugues,

a par de Deus caualeyro,

por apear ciertas dudas

propone sus argumentos.

Coplas. Dialogo.

Portug. O Menino de o ceo,

que a la terra baxo, faralalayla, faralalaylo.

Si o ceo es como terra,

si e terra o ceo, naon, faralay, \&c.

Castell. Porque la tier[r]a, y cielo

el amor los juntò, faralaylayla, faralaylaylo.

En vna criatura,

que cria su Criador, fara, \&.C.

Portug. Como posso xuntar,

sim [...] varom, fara \&.C.

vm varoum tudo obras,

que es milagro de Deos, fara, \&.C.

Castell. Que admira aya parido,

la Niña vn hombre oy, fara, .\&.C.

si ha siglos infinitos,

su Padre, le engendró, faral, \&.C.

Portug. O Pay Fillo a [...]

si ay en o mundo amor, faral, \&.C.

he si ay amor les prouo

de los dois procedion, faral, \&.C.

Estriuillo.

Castell. Los Portugueses callen,

que deste Niño Dios, faral, \&.C.

no alcançan los mysterios,

aunque reuelados son, faral, \&.C.

Biblioteca Nacional. Madrid (VE/88-18). Palau, 3676 24. "Serafines se despeñan". 
Métrica: versos de cabo roto en las Coplas. En general versos octosílabos, con rimas alternas, dobladas o derivativas. Una de las formas métricas de la Letrilla es el villancico. 


\section{VILLANCICOS}

Que se cantaron en la santa Yglesia cathedral de la muy noble, y muy leal Ciudad de Cadiz en los Maytines solemnissimos del Nacimiento de Iesu Christo Señor y Redentor nuestro este año de 1654. Siendo en ella Maestro de Capilla Blas Gomez Zaragoça. CON LICENCIA.

Impresso en Cadiz por Fernando Rey, año de mil y seiscientos y cinquenta y cuatro.

\section{SEGVNDO NOCTVRNO}

VILLANCICO III1.

1. Que nouedad es esta?

valgame Dios

y que sola lloraua el Alba,

y llora tambien ya el Sol.

2. Llorarà de frio,

y llorarà de amor.

1. No puede ser

que el sol es vn fuego;

no puede ser,

que amor es vn Dios.

2. Si puede ser,

que es Sol en pañales;

si puede ser,

que es Dios que nacio,

y Dios que nace niño,

y Sol que oculta ardor,

bien puede en vez de rayos

aljofares dar oy.

1. No puede no,

que aunq[ue] infante à nacido, es inmenso,

y aunq $[u e]$ se oculte, es vn fuego en rigor

2. Si puede si,

que aunque inmenso es mortal

por ser hombre,

$\mathrm{y}$ au $[n] \mathrm{q}[u e]$ es vn fuego pasible es en fin 
y assi naciendo llora,

ay, ay como llora.

ay, ay como nace

sujeto a morir.

\section{COPLAS.}

1. No admires entendimiento que el Sol llore en su Cenit, pues confiesas que la culpa de su llorar fue feliz.

No admires $\mathrm{q}[u e]$ vn Dios gigante

vierta lagrimas ansi

pues crees que sus finezas

le han traido a edad pueril.

2. Si admirarè aunque no dude lo que me enseñò el oir.

$\mathrm{q}[u e]$ vn Sol llora[n]do es prodigio, que admirarà a vn Serafin.

Si admirarè, que es milagro del mas admirable ardid, $\mathrm{q}[u e]$ llore vn tiempo quie $[n]$ haze eternamente gemir.

Pasible es en fin, y assi naciendo llora, \&.C.

1. El que es vida por esencia como para morir nace?

2. Amor lo haze, y a lo que el haze, paciencia.

1. El que lo sujeta todo como à de estarlo a la muerte?

2. Amor es fuerte, y lo ordena deste modo.

1. El que es infinito amor a que amor està obediente?

2. Al suyo ardiente, que no tiene superior, si bien aunque es tan Señor, que es su solio vn Cherubin. Passible es en fin, 
y assi naciendo llora, \&. C.

\section{VILLANCICO V}

\section{Gallego.}

Alegrense os çeos, teña prazer a terra pois nace vn Galeguiño honor de Compostela. Que para dar a vida era razon que fueira fillo de o pai Galego, y de mai Galega.

\section{COPLAS}

Depos de la comida de la muller primeira estaua morto o mundo, e preso en a cadena. Reynaua aquel dimoño que fizo la culebra, e por librarnos viño o Rey de o ceo, e terra. Chorando està nas pallas e la sua mai, que es bela le faze mil cantiñas con que suo llanto deija. Trazamosle a Galiza, pos e por liña recta fillo do pai Galego y de mai Galega.

Alegranse os ceos, \& CC.

\section{VILLANCICO V1.}

Aunq[ue] el fuego le abrasa de frio tiembla llora $[n]$ do el Dios niño amor, mas ay que le miro, 
$\mathrm{q}[u e]$ en graue deshecha

con cada suspiro

arroja vna flecha,

y en cada sollozo dispara vn harpo[n],

al cuerpo los tira, y dan en el alma,

$\mathrm{y}$ todos se meten en el coraçon.

\section{COPLA}

Aunque del amor la brasa

abrasa la humanidad

del alma, cuya deidad

gloria oculta, y gozos passa

como al cuerpo los escassa,

expuesto a la escarcha, y yelo

fuera de abrigo en el suelo,

llora del tiempo al rigor.

Mas ay que le miro, \&.C.

Biblioteca Nacional. Madrid. (VE/92-18-2) "Que riendose llorava".

En cuanto a la métrica, alternan los versos octosilábicos con versos de numerosas variantes, apareciendo pentasílabos de rítmo dactílico. 


\section{VIILLANCICOS}

AL NACIMIENTO DE

nuestro Señor Iesu Christo, que se cantaron la Noche Buena en la Santa Iglesia de

Toledo, en este año de 1656.

Siendo en ella Maestro de Capilla Thomas Micieces.

\section{PRIMERO NOCTVRNO.}

Villancico Primero.

VEnid a Belen Pastoras,

Venid, vereis a estas horas

Tiritando al fuego ardie $[n]$ nte,

Dà el Amor diente con diente,

$\mathrm{Y}$ al aluergue de vn pesebre

Rie triste, llora alegre

Con destemplanças sonoras:

Venid a Belen Pastoras.

\section{Coplas.}

EL gozo resucite

Con mayor alegria,

Pues acaba la muerte

Naciendo en braços del Amor la Vida.

Feliz aliento cobra

Oy del hombre la dicha,

Vn Pesebre le dà Cuna,

De toda su vida empleo,

Pues por vn Madero empieza,

Y acaba por vn Madero.

En el dos Brutos le assisten,

Tan vizarramente cuerdos,

Que de su aliento los humos

Los ponen sobre el Sol mesmo.

El Portal para este Rey,

Que es espejo afirma el techo,

Pues el Cielo en el se mira,

Y por el se mira el Cielo. 
Antes que alli se obstentasse

El Ilustre nacimiento,

Sin Templo paredes eran,

Mas ya paredes contemplo.

Tan altamente las pajas

Pensaron deste mysterio,

que no admiro que estèn huecas

Gozando el mayor concepto.

Al Portal, \&C.

\section{I1. NOCTVRNO}

\section{Villancico Quarto.}

BVele, buele, buele,

Buele el Serafin mas fino

$\mathrm{Al}$ anunciar la mañana,

En nubes de nieue, y grana,

La Luz que reparte el Sol,

Buele, y en tanto arrebol

Cada pluma Xirasol,

Tenga el Nido en el Crisol

Donde examinarse suele.

Buele, buele, buele.

$\mathrm{Si}$ al hombre glorias preuino

El Sol grande, y peregrino

Hijo del mayor caudal,

Que al mundo dà sin igual

Luces, que al Alua preuine.

Buele, buele, buele.

\section{Coplas.}

Buele el amor presuroso

A la region de vn pesebre,

Vera que el fuego se hiela,

Y que se abrasa la nieue.

Buele el pensamiento, y mire

en extremos diferentes

Vna vnion, que al hombre sube, 
Y à Dios abaxo le tiene.

Buele, buele, buele.

Buele el dolor, si es que busca

Centro, donde mas se cebe;

Pues hallarà la razon

Entre brutos descorteses.

Buele la piedad, y atienda,

Para vn barro delinquente

Dispuesta la encarnacion,

Porque sus quiebras se suelden.

Buele, buele, \&C.

Buele el apetito torpe,

$Y$ en vn esteril albergue,

En aparador pajizo

Hallarà el grano Celeste.

Buele el discurso, y al punto

Abata sus plumas leues,

Porque quanto mas volare,

Serà su buelo mas deuil.

Buele, buele, \&C.

Buele el Angel à la tierra,

Porque la gloria se pierde,

Si ya en los Cielos la busca,

Quando en el suelo la tiene.

Buele el hombre, pues con esto

Tomar tantas alas quiere,

Que por ser Dios tan humano, presumir de Dios pretende.

Buele, buele, buele.

Villancico quinto.

1.Oyga. 2.Diga.

1.Oygame vna letrilla

Con solfa nueua.

2.Cantemela despacio,

Porque la entienda.

1 . Vn villancico alegre

Pide la fiesta. 
2. Mas despacio le quiero.

1. Que linda flema.

Es para muy despacio

La noche buena.

2. Mas despacio le quiero,

Que es lo que intenta,

Vaya de Iacarilla

Graciosa, donosa,

Festiua, amorosa,

Que es lo que alegra.

Baya, baya, baya.

Iacara,

Que la noche lo pide.

Iacara,

Que la noche lo manda.

Metro piden alegre,

Diuinas alabanças,

Y humanese lo serio,

Al ver que Dios se humana.

Iacara, jacara.

Pues vaya norabuena,

Que aunque la noche es larga, Ay mucho que dezir,

En solo vna palabra.

\section{Coplas.}

Afuera, afuera tinieblas,

Que el Rayo de luz mas clara

Naciò llorando en Belen,

Antes de reir el Alua.

Afuera la noche obscura,

Y en sus mexillas de nacar,

De tantos hilos de perlas,

Cogeremos vna sarta.

Afuera no me lo impidan,

Porque es marauilla rara,

siendo todo el vna perla,

Que estè derramando tantas.

Afuera, que es cosa, y cosa, 
Diganme quien tal pensara,

Que lagrimas sean dulces,

Porque ay mançanas amargas.

Afuera, y pregunto à todos;

Si la frasis Castellana,

Que dize, el agua haze limpios,

Se dixo por aquesta agua?

Afuera, y digan, porque

Al hombre, que mas le ama,

Verle gemir, y llorar,

Le ha caido tan en gracia?

Afuera, y digan tambien,

Porque con belleza estraña,

La primera vez que llora,

Tiene vna cara de Pasqua?

Afuera, que và de enigma,

Porque serà cosa falsa,

Afirmar, que es criatura

Vn Niño como vnas platas.

Afuera, y veremos quien

Otra duda me desata,

Antes que hable, como puede

Ser este Niño Palabra:

Y afuera, de Dios pregunto

Dos cosas extraordinarias;

Es varro aqueste pesebre,

Diga[n]me, si este heno es pajas.

Oyga. 2. Diga, \&C.

Biblioteca Nacional. Madrid. (VE/88-22). "Venid a Belen Pastoras”. Palau, 367624.

Métrica: Versos de arte menor, octosílabos, pentasílabos, polirrítmicos, con rima a veces consonante y a veces asonante. En el estribillo, se facilita el canto de los oyentes. 
VILLANCICOS QVE SE

han de cantar en la Capilla Real de su Magestad la noche de los Reyes deste año de 1657.

VILLANCICO 1.

1. Para, para,

Para, para,

Que esta montaña es adonde

La marauilla se esconde,

Menos sabida, y mas rara,

2. Para, para,

Dize la tropa Real,

Que de vn farol Celestial

Siguiendo và la luz clara.

Para, para,

3.Que se ha de hallar el Tesoro,

Que dà quilates al oro,

En esta dichosa cumbre,

Coronada de la lumbre,

Mejor, que gira la Esfera.

Espera Pascual, espera,

Dexa los Reyes entrar,

A ver, y à lograr

Esta riqueza escondida,

De los siglos oluidada,

De los hombres ignorada,

Y del Cielo prometida.

ROMANCE.

En el monte de Belen,

Para cuya frente altiua

Guardò más benigno el Cielo

Las riquezas, y las dichas.

Fuente de cristal copioso

Amanece à la subida,

Que en auenidas de gracia 
Al mundo se precipita.

Verde Zarça la sucede,

Que es Rosa tambien la misma,

Que hallò libre de vn incendio,

Quien la juzgaua cenizas.

\section{VILLANCICO III.}

1. MEguelejo vener a Belén

2. Con quien?

1. Meguelejo vener conmego,

Que Moresco ser bon amego,

Y estar Moresco de bien.

2. Con quién?

1. Con los Reyes, è la Estrelilia,

Baylaremosle la folilia,

Para el Chequillo alegrar.

2. Ben estar,

Tocar, tocar.

Cantar, cantar.

1. Arrojome sus perlas el Nenio,

Por hazer a Moresco llorar,

Arrojomelas, y arrojeselas

E tornomelas a arrojar.

\section{COPLA 1.}

Estauase el Rey Chequelio

En el portal de Baylen,

Estar su Madre tambien,

Con la mula, y el baquilio:

Alegrarse Moresquilio

Sus lagrimas adorar.

Arrojomelas, \&C.

I1.

Llorar mucha perleria

El Chequilio Celestial,

Yo acallar con vn panal,

E datil de Berberia, 
E con passas de Almeria

Que ser bon para almorçar.

Arrojomelas, \&C.

II1.

Vener siguiendo la Estrelia

Con bota para el camino,

Con espuela para el vino,

Que el jambon ser buena espuelia,

La gloria se ver con elia,

E los Angeles cantar.

Arrojomelas, \&C.

\section{IV.}

Con los Reyes mis seniores

Reco vener, è contento,

Para ver el Nacimiento,

E ayudar a los pastores,

Que ser zagales mejores,

Los que mas traer que dar.

Arrojomelas, \&C.

V.

De los Reyes la quadrilia,

Los camelios corcobados

Traer de mirra cargados,

De incienso, è plata amarilia;

Sin tanto humo mi mochilia

Saber mejor caminar.

Arrojomelas, \&C.

V1.

Mi presente estar barata,

Que no ser Moresco Rey,

Traer colacion de Ley

Mucho alcuzcuz, è batata,

Que Moresco solo trata

Regalar, è no encensar.

Arrojomelas, \&C. 
VILLANCICO IV.

VEnan os Galegos,

Venan a baylar

Por la Nai garrida,

Estrela do mar.

Doncella fermosa

Como el Sol, y mas,

Que ha dado o Solciño

Polido, y galan,

Lo mas garridiño

Que pode mirar:

Mas ay, mas ay,

Correr, correr, andar, andar:

Mingo afurquillay.

Que se derruba o Ceo no portal.

COPLA. 1.

Venan os Galegos

Todos à baylar,

La noite que nace

Noso Mayoral,

Angeliños baxan

Por nos ayudar.

Mingo afurquillay, \&C.

I1.

$\mathrm{O}$ recien nacido

No pesebre està,

E à palla enriquece,

Solo con chorar,

Dos fontes de perlas

Por lo feno van.

Mingo afurquillay, \&C.

II1.

La sua Nay fermosa

Zagala sin par,

De su llanto quiere 
Fazer vn zartal

Para sua garganta

De puro cristal.

Mingo afurquillay, \&C.

IV.

A coller el grano,

Que en la parua esta,

Colanse os pastores

Dentro no portal,

Solo vn grano buscan,

E hallan muyto mas.

Mingo afurquillay, \&C.

V.

Hallan vn tesouro,

Qual no foi jamas,

En cuna de prata

Neno de cristal:

El he el Sol fermoso,

La Luna sua Nay.

Mingo afurquillay, \&C.

V1.

Asombrado Mingos

Foise a persinar,

Sin poder de espanto

Fazer la siñal:

Ya no soy gaiteiro,

Se oluido el tocar.

Mingo afurquillay, \&C

Biblioteca Nacional. Madrid (VE/91-17). "Para, Para".

Métrica: con formas litánicas, en Letanía, de solista y coro, similar al LLanto por Ignacio Sánchez Mejías de García Lorca: “a las cinco de la tarde,” (...). Rima consonante. 


\section{VILLANCICOS QVE SE CANTARON LA NOCHE BVENA \\ Este año de 1658. \\ EN LA SANTA IGLESIA DE TOLEDO, SIENDO MAESTRO DE CAPILLA \\ DELLA el Racionero Tomas Miciezes. \\ CON LICENCIA. \\ En Toledo. Por Francisco Calvo, Impressor del Rey N. S.}

\section{VILLANCICO V1.}

OYgan, y veràn venir

al Portal con sus porfias

a las dos Filosofias

de llorar, y de reir.

Escuchen, que vienen

la risa, y el llanto,

que mezcladas con el canto,

para que aya nouedad,

esta Nauidad,

entre otras que van entrando

al Portalico,

ha venido vn Villancico

riendo, y llorando.

1. Yo que soy la compuncion,

y al cuerdo Heraclito sigo,

viendo desnudo a mi Dios,

toda soy suspiros,

ay ay suspiros.

2.Yo à Democrito sigo,

que la esperança

viendo en Dios su remedio,

rie, rie, rie en el Alua,

toda soy carcajadas.

1. Yo he de llorar.

2.Yo he de reir.

1. Yo he de proseguir.

2.Vamos a la par.

1. y 2. Ay mi Dios desnudo,

ay hermoso Niño, 
que el frio os penetra.

2. Que en amor no ay frio.

1. Yo lloro.

2.Yo rio.

1.Yo siento el verle temblando.

2.Yo rio en verle tanchico.

3. Pues prosiga el Villancico

riendo, y llorando.

\section{Coplas.}

1. Yo lloro en ver que mi Dios se haze hombre por nuestro aliuio, $y$ venga a comprar del hombre desprecios por beneficios:

ay ay dios mio, toda soy suspiros.

2. Yo en verle hombre me alegro, $\mathrm{y}$ antes presumo,

que pues èl se haze hombre tendrà hartos triunfos, ay esperança, toda, toda soy carcajadas.

1. Yo lloro el verle tan pobre, que solo a verle han venido vnos humildes pastores, quando le arrojan los ricos. Ay ay Dios mio, \&C.

2. Essos pobres pastores son mi alegria porque solo con ellos haze Dios migas.ay Ay ay esperança, \&C.

1. Yo lloro el ver quando nace, a ser misterioso Trigo, que ha de morir en vn Palo despues de ser Pan de viuos.

Ay ay Dios, \&C.

2. Esso es mas alegria para nosotros, pues del Pan, y del Palo 
nos darà a todos.

Ay ay esperança, \&c.

1. Yo lloro el considerar

que a su grandeza atreuidos

han de coronar su frente

de agudos juncos marinos.

Ay ay Dios mio, \&C.

2. Essos juncos destruyen

las culpas mias,

pues con esso el pecado

queda en la espina.

Ay ay esperança, \&C.

1. Yo lloro que a sus contrarios,

vn Discipulo enemigo

le ha de vender por vn precio

mas baxo que su delito.

Ay ay Dios mio, \&C.

2. Si en la venta que hizo

fue tan barato,

tal barato merece

ser ahorcado.

Ay ay esperança, \&C.

NOCTVRNO II1.

VILLANCICO VI1.

VN Portugues, y vn Gallego

se trauaron de palabras

por Nauidad, y vno a otro

dixo el nombre de las Pascuas:

Oygan a entrambos

que se dan vaya.

Portug. Ficay là Galeguiño, q[ue] o Niño

naõ quere Galegos nel suo Portal,

ficay là, ficay là, que os Galeguiños

naon entran acà.

Ficay, ficay, ficay vos alà.

Gallego. Ficay vos, dize el Gallego, 
Portuguesiño ratiño,

que no està seguro ou Niño

de vos, se os entras acà,

ficay là,

ficay là, que los Portuguesiños

acà no han de entrar,

ficay, ficay, ficay vos alà.

\section{Coplas.}

Gallego. Calà, que cando Deus nace

o Galego señas dà,

que donday boy, mula è palla

es de Galiica vn casal.

Portug. Miray, si Galego fora

tembrara muito o Zagal,

mais si està ao frio, e naõ tembra,

Portugues es, craro està.

Gallego. Calà, que o fermoso Neno

non quer soberbios acà,

e por vassalos humildes

Rey de Galegos es ja.

Portug. Quando chora este Minino

Portugues falando està,

pois cando faze pucheiros,

craro es que nos dize ollay.

Gallego. Mentides Portugues vano

que fora de vn Santo que ay

que e o señor San Antonio,

nada ay boo en Portugal.

Portug. Por la pala de a forneira

me digais lo que pesais,

que por no os levar a as costas

non vos mato, naon por mais.

Gallego. Ficay là, que ay Galeguiño

que ogaño fo a pelear,

e de matar Portugueses

a espada con sebo tra1.

Portug. Ficay là, q[ue] en vos vencendo

si vos colho en Portugal 
solo por vna cebola

seis Galegos he de dar.

Ficay là, \&C.

\section{VILLANCICO VII1.}

1. Porque llorais Niño mio? mas ya la causa no ignoro, llorais mis ojos, sin duda porque no lloren mis ojos.

2. Por todas las almas llora, y quando dellas se quexa, para declarar sus ansias, dà suspiros por querellas. 1 y 2. Ay no lloreis Niño mio no, que en las clausulas de amor cessando la consonancia diuierte la suspension.

\section{Coplas.}

1. Suspended lagrimas tantas, para su repeticion, pues pueden con descansar bolver a correr mejor.

2. Proseguid con el solloço, si es del oido fauor, que bien sabeis que al sentido ofende la digression.

1. Suspended tan tierno llanto, que siendo tristeza en vos pensarà que es alegria, quien viere que estais de humor. Ay no lloreis Niño mio, \&C.

2. Proseguid la tempestad de vuestros ojos, Señor, basta vn sereno a la noche, que es rigor ponerla dos.

1. Suspended la lluuia hermosa, que causarà admiracion, 
viendo a la Aurora sin nubes,

que nazca llouiendo el Sol.

2. Mas llorad, y no cesseis,

que si sois diuina voz

para logar las cadencias,

es instrumento el dolor.

Ay no lloreis Niño mio no, \&C.

F I N.

Biblioteca Nacional. Madrid. (VE/88-24). "Porque Leyes de Dios".

Métrica: aparece repercusión de versos con repetición parcial de uno o varios versos octosílabos, con rima asonante. No podemos olvidarnos de que el zéjel equivale a "bailada" ni de que muy próximo al zéjel està el villancico. Rima asonante. 
VILLANCICOS QVE SE

han de cantar en la Capilla Real de su Magestad la Noche de Navidad deste año de

1660.

\section{VILLANCICO.}

1. Que musica, que harmonia

Abre con serenidad

De la noche a la mitad

Todas las puertas al dia?

2. La Celeste Gerarquia,

Que publica la Iornada

De la Paz mas deseada,

Que siglos veràn.

1.Escuhad, escuchad,

Como puebla $[n]$ los ayres velozes

Celestiales clarines, y vozes

De gloria, y de Paz.

2. Escuchad, escuchad,

Como alista[ $n]$ sus plumas y galas

Serafines, que baten las alas

A son, y a compàs.

1. Escuchad, escuchad,

Como cerca[n] en tornoglorioso

La carroza del sol mas hermoso,

Mas nueuo, y galan.

2. Escuchad, escuchad,

Que Sale su Magestad,

Y pàra en Belén,

Y nunca mas bien.

\section{ROMANCE}

A lo tosco de vn pesebre,

De cristal luciente mina,

Donde llora vn Sol elado,

Que entre sus pajas se abriga.

Llega el Rey, cuyos Imperios

Ningún espacio limita, 
Ni la tierra en Orizontes,

$\mathrm{Ni}$ los mares en orillas.

El seno de vna Donzella,

De gracias, y glorias rica,

Le siruiò en esta jornada

De carrroza cristalina.

En Belen quiere hazer Noche

Tan Buena con su venida,

Que esta sola lo es de quantas

Luzes embidian al dia.

Llega al Portalico, y entra

En su fabrica pagiza

Por la puerta del Oriente

Del cierço a la Galeria.

En este pequeño aluergue,

que jura de Corte Impirea.

Lo mas que el Cielo atesora

Quiere salir oy a vistas,

Aqui se ajustan las Pazes

De la oposicion reñida,

Que cerrado tuuo el cielo,

Y sus glorias escondidas.

Aqui esta lo más distante

Con hermandad tan vnida,

Que amigos ya Dios, y el ho $[\mathrm{m}]$ bre,

Son vna persona misma.

Que música, que harmonia, \&C.

\section{VILLANCICO I1.}

\section{INTRODVCCION.}

A las vozes que diò al ayre

Vno, y otro Serafín,

Paraninfos del Sol Niño,

Que en Belen quiso salir.

Despertò el egido todo,

Y con la nueua feliz,

Perdona al sueño el assombro, 
Y el alboroço el redil.

Que es Noche de Nauidad,

Dixo el Celestial Clarín,

De vn Puro Iazmin, que nace

Vestido de carmes1.

Los obligados del chiste,

Todo Bras, y todo Gil,

Preuienen sus chançonetas,

Para celebrarle ass 1 .

\section{ESTRIVILLO.}

Toquen, toquen el tamboril

Con repiques alegres sonoros,

Baylen juntos, y canten a coros

Zagalejos de mil en mil.

Toquen, toquen el tamboril,

$\mathrm{Y}$ al compàs de los mouimientos

Consona $[n]$ cias se lleuen, y ace $[n]$ tos,

Inquietudes del ayre sutil.

Toquen, toquen el tamboril.

Repiquen aqui,

Aqui, y en Belen,

Donde se bayla mas bien,

Donde se canta mejor,

Y à mi desnudico Amor,

Porque se entretenga, y calle;

Los Zagales de gracia ricos

Le canten los Villancicos,

Le baylen los Passacalles.

\section{COPLAS.}

\section{1.}

Entrò con grande opinion

Messe Bras al Portalico,

Y repartiò vn Villancico

De donayre, y deuocion:

Luego sacò del Zurron,

Las letras con mucho aliño,

Al Nacimiento del Niño 
En estilo Pastoril,

Toquen, toquen el tamboril.

I1.

Cantò vna Xacara Bras

Muy osco, y muy agouiado,

Celebrando vn sol elado,

Mas valiente que el que mas,

$\mathrm{Y}$ al bullicioso compàs

De la ayrosa guitarrilla,

Le baylò (que es marauilla)

Vn pasacalle gentil.

Toquen, toquen tamboril.

II1.

A ò Sol, que fica deitado

Cantò vn Portugues Anton

Con magoas do coraçon,

Saudades de namorado:

Y despues que huuo cantado,

Embraçando las sonajas,

A baylar se hizo rajas,

Y quedò como vn Brasil.

Toquen, toquen el tamboril.

IV.

Domingo lleuò al Portal

Vn Villancico Gallego,

Y a la Gayta baylò luego,

Que tocaua Anton Pascual:

Con propriedad el Zagal

Lo cantò, y baylò tan bien,

Como si fuera Belén

A las orillas del Sil.

Toquen, toquen el tamboril.

V.

Cantò Gil a la vihuela

Vn Villancico muy graue,

$Y$ con estilo suaue

Celebrò al Sol que se yela: 
Lo trauieso de la suela

Tanta grauedad no admite,

Y assi se buscò el desquite

En las cabriolas Gil.

Toquen, toquen el tamboril.

V1.

Ver à Pascual admirè,

Que vn Negrillo de manera

Cantò, como si viniera

de Angola, ò Santo Tomè:

Dixo acaso, cucambè,

Y dixolo tan buen hora,

Que lo ha baylado hasta aora

En Belen, y en el Redil.

Toquen, toquen el tamboril.

VI1.

A la Rosa mas Diuina,

Que viò el Mayo en su Vergel,

Cantò vn Morisco Miguel

Con propriedad peregrina:

Y como el papel le inclina

A danças Moriscas mas,

Baylò vna Zambra al compàs

De vn Africano Añafil.

Toquen, toquen el tamboril.

VII1.

Al son de claro arrebol,

Y a su Madre hermosa, y Pura,

Cantò con grande mesura,

Vn Villancico Bartol,

Y tras el Remifasol,

Repicò de linda gana

La Floreta Cortesana,

La Zapateta ciuil.

Toquen, toquen el tamboril. 
VILLANCICO III

GALLEGO.

Venhan os Galegos

A Belen a baylar,

A ò Neno fermoso,

Que no palleiro jaz:

Das ruas os legos,

Das praças os cegos,

Das Grejas os Cregos,

Que vinden, è van.

Vehan ver ò Neno

que no palleiro jaz.

\section{COPLAS.}

Venhan os Pastores,

Venhan ver ò día,

Que à noite mas fria

Lhe tira os rigores,

Tudo he prado he frores,

Que cheiran fermosas,

O caminho he rosas,

E Ceo ò Portal.

Das praças os cegos, \&C.

Venhan ver Nacido

El que fijo ò Ceo,

Con vestido alheo,

Anque vay hispido;

El Zagal frorido,

Sol de luz mais bela,

Filho de hua Estrela,

Que serea ò mar.

Das praças os cegos, \&C.

Venhan ver ò Neno

Deitado na palha,

Que muito trabalha,

Ainda que he Piqueno;

Por tirarle ò feno

A mula se chega, 
Se fora Galega,

Non fijera tal.

Das praças os cegos, \&C.

Venhan ver a Aurora,

Mais branca è mais pura,

Que na noite escura

De luz se milhora;

He nosa Siñora

A Virge Maria,

De quen nace ò dia,

Que à fijo sua Nay.

Das praças os cegos, \&C.

Para vir mais cedo,

Venhan polo atalho,

Poden sen trabalho,

Pois tudo he rasedo.

O tempo ten ledo,

Quen oge caminha,

Coa venteliña,

Suaue que fay.

Das praças os cegos, \&C.

Venhan dos Outeiros,

Venhan das malhadas,

Zagalas preçadas,

Moços pracenteyros;

Deigen os obreiros,

o seruiço, è gado,

Pois nos da ganado

O Ceo el cabdal.

Das praças os cegos,

Das ruas os legos,

Das Grejas os Cregos,

Que vinden, è van.

Venhan ver ò Neno,

Que no palheiro jaz.

VILLANCICO IV.

Ayres, 
Ayrezillos, ayres,

Que el rubio cabello

Del Niño mas bello

Quereis tremolar,

Parad, y mirad,

Si heris atreuidos

Los rizos perdidos,

Que burlan desayres,

Ayrezillos, ayres.

Si las hebras de oro

Del rico Tesoro

Moueis con desgayres,

Ayrecillos, ayres.

Si el hermoso pelo,

Donde puso el cielo

Gracias, y donayres,

Parad, y mirad,

Si trauiesos quereis jugar

Con el oro, que su melena.

En sortija, y en cadena

Presos aueis de quedar.

\section{ROMANCE}

En lo ardiente de vn pesebre,

Que doran rubios celages,

Quiso introducir el viento

Muchos elados desayres.

De la madeja más bella,

Que viò el Sol en sus plumages,

Hebra à hebra con su aliento

Hizo dorados bolantes.

Vandera de amor parece,

Toda glorias, toda pazes,

Que à inquietudes la tremola

La trauesura del ayre.

Atreuiòse el ayrecillo,

Muy preciado de intratable,

A burlarse con sus rizos,

Y siruieronle de carcel. 
Parece que se retira

Mal discreto, y bien cobarde.

Quando encuentra prisionero

En cada rizo vn Alcayde.

Ya està preso en la melena,

Y siendo prision tan facil,

No quiere de bien hallado

Solicitar alexarse.

No deue a las harmonias

El ayre serenidades,

Sino al oro, que en sortijas

Le detiene con su engarce.

Al cabello, vientecillos,

Cueste, ò no cueste llegarse,

Que es interès viuir presos

En cadenas tan suaues.

Ayres, ayrecillos, ayres.

Biblioteca Nacional. Madrid. (VE/88-57) 136-1. "Que música, que harmonia".

Métrica: un Romance, nos da la clave, en octosílabos. En este metro cantan los puebos hispánicos, copla, soleá, sevillana, etc. Rima consonante. 


\section{LETRAS}

DE LOS VILLANCICOS, QVE SE CANTARON EN LOS MAYTINES

del Nacimiento de Nuestro Señor Iesu Christo, en la Santa Iglesia Metropolitana de Sevilla.

\section{COMPVESTAS POR EL RACIONERO IVAN SANZ,} Maestro de Capilla de dicha Sancta Iglesia.

Año de 1661.

\section{VILLANCICO DE KALENDA.}

\section{Estrivillo}

1. AY, que se yela en el Cielo

la Antorcha mayor!

2. Ay, que dolor!

1. Ay, que el Farol mas brillante tiembla de temor!

2. Ay, que rigor!

3. Quien sus luzes desinaya?

1. Otro Sol.

3. Quien le yela en su Esfera?

2. Otro Sol.

3. Pues si tiembla, y se yela, baxe su esplendor a Belen, a ponerse al rayito del Sol.

2. Ay, que las Flores madrugan mas temprano oy!

Luminarias pone el Agua.

[...] Niño recién nacido trae a la redonda quantas alegrias se divisan, festividades se aclaman. Pero tal es el Chiquito, $\mathrm{y}$ a fè que si me lo pagan, he de pintar sus facciones, 
pues vienen pintiparadas.

Es el Pelo como vn Oro;

dixe mal, que mejor quadra

que el Oro es como su Pelo, como su Frente la Plata.

Los Ojos son dos Luzeros, que dan risa a la Mañana, vn Cupido en cada Niña, vn Rayo en cada Pestaña. Las Mexillas dos Iardines de Rosas de Nieve, y Grana, que al Agua, y Sol de sus Ojos se florecen, y se esmaltan.

Con su boca no ay mas Indias, ni todo el Reyno del Alva hizo alarde en sus Tesoros de mas Perlas, ni mas Ambar. Con su Garganta es Guinea la Nieve de Guadarrama, y con sus Manos Bayeta las Olandas que le fajan. Este es el Niño que adora vna Niña, que le guarda como Arca del Testamento, como Paloma del Arca.

\section{VILLANCICO IV.}

1. NIño que vienes a darme la Gloria que no merezco, si el bien que tienes me ofreces, y quieres el mal que tengo cante yo tus Glorias, llora tu mis Duelos. 2. Niño, que quieres librarme de las Penas que padezco, y por sacarme has rompido prisiones de tantos yerros, cante yo tus Glorias, 
llora tu mis Duelos.

1. Niño dichoso

2. Amante glorioso.

1. Que males padeces.

2. Que bienes ofreces.

1. Que llevas desvelos.

2. Que traes consuelos, si es mi dicha tu Passion,

y es tu Pena mi Desvelo,

y gustas de padecer

porque viua yo contento,

cante yo tus Glorias

llora tu mis Duelos.

\section{COPLAS}

HVmano Sol divino,

en quien, a fuer de estremos,

se oponen a luzirse

lo grande, y lo pequeño.

Hermoso Niño mio,

por quien se ven a vn tiempo

la Pena tan gloriosa,

y el llanto tan risueño.

Amante el mas sufrido,

Galan el mas atento,

en quien hallo lo humilde

luzidos desempeños.

Aunque de pobre choza

gustoso albergue te has hecho,

mas es que se conformen

las Pajas con tu Fuego.

El riesgo de tu vida

sin duda estàs sintiendo,

si ya no es que te quexas

de que se tarde el riesgo.

Mas el sabrà buscarte,

que para dar tormento,

ni la ocasión se duerme,

ni es pereçoso el Tiempo. 
VILLANCICO V.

VEnan os Galegos, venan a baylar, por la Nay garrida

Estrela do Mar:

Donzella fermosa

como o Sol, y mas, que ha dado o Solciño

polido, y galan,

lo mas garridiño

que poder mirar.

Mas ay, mas ay,

correr, correr, andar, andar,

Mingo, afurquillay,

que se derriba o Ceo no Portal.

COPLAS.

VEnan os Galegos

todos a baylar,

la Noite que nace

noso Mayoral.

Angeliños baxan

por nos ayudar,

Mingo, afurquillay,

que se derriba o Ceo no Portal.

$\mathrm{O}$ recien nqcido

no Pesebre estâ,

e a Palla enriquece

solo con chorar:

dos Fontes de Perlas

po lo feno ván,

Mingo, afurquillay, \&C.

La sua Nai fermosa,

Zagala sin par,

de su llanto quiere

fazer vn zartal

para sua garganta 
de puro Cristal,

Mingo, afurquillay, \&C.

A coller el Grano

que en la Parva està,

colanse os Pastores

dentro no Portal:

solo vn Grano buscan,

è hallan muyto mas,

Mingo, afurquillay, \&C.

Hallan vn Tesouro

qual no foy jamas,

en Cuna de Prata,

Neno de Christal:

el he el Sol fermoso,

la Luna sua Nay,

Mingo, afurquillay, \&C.

Assombrado Mingos

foisse a persinar,

sin poder de espanto

fazer la siñal:

Ya no soy Gaytero,

se olvido el tocar,

Mingo, afurquillay

que se derriba o Ceo no Portal.

Biblioteca Nacional. Madrid. (VE/1309) "Ay, que se yela en el Cielo".

Métrica: Versos de gaita gallega, típicos de la poesía Gallego-Portuguesa; las coplas castellanas casi siempre son de rima asonante. 
LETRAS

QVE SE CANTARON LA NOCHE BVENA

en la santa Iglesia de Toledo, hechas por D. Agustín

Moreto, y compuestas en Musica por el Racionero Tomas Micieces, Maestro de

Capilla della, este año de 1661.

Con licencia. En Toledo por Francisco Caluo, Impressor del Rey N. S.

\section{NOCTVRNO}

VILLANCICO 1.

ALbricias, hombres, albricias

que la Reina soberana

en vn Hijo ha dado al mundo

possessiones, y esperanças.

Albricias, albricias, y dicha tan alta

celebre la Ciudad con luminarias.

Y la Santa Iglesia,

pues interessa mas en esta fiesta,

haga una processio $[n]$ da $[n]$ do a Dios gracias

y a buelo toquen relox, y campanas,

dadandan din dan don dan.

Y todas las Capillas

repiquen sus campanillas,

dilin dilin dilin.

Y resuenen los organos todos,

y las chirimias,

y al Te Deum laudamus

acompañen relox, y campanas,

y campanillas,

organos, instrumentos, y chirimias.

Y cielo, y tierra con zelo

hagan dos coros sonoros,

mas no podràn ser dos coros,

que oy son vno tierra, y cielo.

Coplas.

Tierra. Gloria a Dios en las alturas.

Cielo. Paz en la tierra a los ho[m]bres. 
Tie. Que oy estè el cielo en la tierra.

Cie. Que oy el cielo es todo el orbe.

Tie. A la deue el cielo

lo que èl hasta oy no conoce,

que èl tiene a Dios poderoso,

pero no tiene a Dios pobre.

Cie. Mas deue al cielo la tierra,

que oy le ha trocado su no[m]bre,

pues porque el cielo à ella baxa,

la tierra es cielo esta noche.

Tie. La verdad nace en la tierra

Cie. El cielo es el que la coge.

Tie. La tierra es la que la goza.

Cie. Y el cielo el que lo dispone.

Tie. La tierra a Dios glorifica.

Cie. El le embia. Tie. Ella le acoge.

Cie. El le humilla. Tie. Ella le ensalça.

Cie. El le dà a Dios.

Tie. Ella le haze hombre.

Cie. Quanto la tierra contiene

todos del cielo son dones,

pues quanto le ofrece en culto

ha recibido en fauores.

Tie. Si el cielo tiene a Dios justo,

la tierra misera, y pobre,

le haze misericordioso,

que es su mas alto renombre.

Cie. El cielo da Rey al suelo.

Tie. La tierra Reina que le honre.

Cie. El haze a essa Reina Virgen.

Tie. Y Madre los pecadores.

Cie. A essa Reina el cielo cede.

Tie. Cielo es ella. Cie. Y èl mas noble.

Porque el mundo se alegre

llorando èl està

que le cuesta los ojos

su felicidad.

Nouedad,

dicha que es tan de todos 
todos celebrad,

organos, instrumentos,

oy han de bailar,

porque tenga esta noche

nouedad, nouedad, nouedad.

Tex. Tras ell entrò mas bizarro

el Escarraman de xaque,

que prouoca a lo valiente

vn Dios que tan hombre nace.

Coplas.

Ya esta metido en la trena,

Alma, tu querido Adan,

que los pecados del viejo

viene el nueuo a remediar.

Prendieronle sus clemencias

en casa de su piedad,

porque le acusò la culpa,

que el reo se hizo Fiscal.

Cogieronle apaciguando

vna pendencia mortal,

que se ahogò en vnas palabras

dichas sobre vino, y pan.

Por venir a caçar almas

sus yerros vino a caçar,

y cantaron su venida

las vozes que dio san Iuan.

Estriuillo.

Iuntos los bayles antiguos

llenaron todo el Portal,

y las castañetas

con el tras tras tras,

dieron fin a la fiesta

sonando a compas,

tras tras tras.

I1. NOCTVRNO. 
VILLANCICO IV.

VN buen Castellano viejo

de llana sinceridad,

y vn Cortesano muy culto

entraron en el Portal.

Celebrar pretenden al Niño,

oiganlos hablar,

porque en su competencia la noche

tenga nouedad.

Castellano. Iesu Christo Hijo de Dios,

nuestro Señor natural,

naciò para remediarnos

la noche de Nauidad.

Cortesano. Como hablais co $[n]$ tal baxeza,

adonde alternando estàn

eloquentes Paraninfos,

gloria a Dios, y al hombre paz?

Cast. Yo no sé de estos vocablos,

que nace Dios es verdad,

y en diziendo que Dios nace,

sobra todo lo demas.

Cor. Tan tosco lenguage empaña

las luzes de su Deidad.

Cast. Si està al yelo, dicha fuera

el poderle yo empañar.

Cor. Mas explica la elegancia

su grandeza sin igual.

Cast. Mejor es, pues Dios se humilla,

hablalle con humildad.

Estriuillo.

Todos. Y dize verdad.

Cor. No tal. Cast. Si tal,

$\mathrm{q}[u e]$ pues Dios es palabra, y se humilla,

ta $[n] \operatorname{bie}[n]$ mis palabras yo deuo humillar.

Cor. No tal. Cast. Si tal. Cor. No tal,

que Dios ha baxado a ser hombre

es para que suba el ho[ $m]$ bre a Deidad.

Todos. Mejor dicho està. 
Cast. No tal. Cor. Si està. Cast. No està, porque para que suba $[n]$ los hombres,

les dà Dios exe $[m]$ plo de $\mathrm{q}[u e] \mathrm{ha}[n]$ de baxar.

Todos. Mejor dicho està.

Coplas.

Cor. Niño de oro, que eloquencia

no os deuo yo al contemplar

transformado en plata el barro

de mi tosca humanidad?.

Todos. Dize verdad.

Cast. Dios no tomò oro ni plata,

sino la carne de Adan;

ni naciò en la Plateria,

sino en vn pobre Portal.

Todos. Mejor dicho està.

Cor. Que costoso a vuestros ojos

es quererme rescatar,

pues les cuesta tantas perlas

como derramando estàn!.

Todos. Dize verdad.

Cast. Para que son essas perlas,

sino dezir sin disfraz:

Dios llora claro como agua,

que es mas propio, y mueue mas?.

Todos. Mejor dicho està.

Cor. En vn Pesebre os ha puesto

Amor, que su trage os dà,

que el Amor con purpura es Rey,

y sin vestido es Deidad.

Todos. Dize verdad.

Cast. Para dezir la pobreza

de Dios, que es menester mas,

que dezir que està desnudo,

como es la misma verdad?

Todos. Mejor dicho està.

Cor. De la mies dorada el fruto

ya entre las pajas està,

y à vista del grano cessa 
toda el hambre del mortal.

Todos. Dize verdad.

Cast. Si Dios en la paja es trigo,

que nos viene a sustentar,

para que son mas rodeos,

que dezirlo pan por pan?

Todos. Mejor dicho està.

Cor. Quitaos allà, que a vn Dios sabio

le ofende baxeza tal.

Cast. Quitaos vos, que con la alteza

le negais la magestad.

Cor. Mas està Dios en mis versos,

que en vuestro estilo vozal.

Cast. Es verdad, porque son paja, y oy Dios en pajas està.

Todos. Y dize verdad, \&C.

\section{VILLANCICO V.}

Texto. El feruor de los Gallegos, por hazer mas fiesta al Niño, para esta noche su dança ha puesto en vn Villancico.

Con cumplida reuerencia dàn a la dança principio, que en la reuerencia son los Gallegos muy cumplidos. Precediendo su passeo, de dos en dos diuididos, en mudanças de villano mostraron noble cariño.

\section{Estriuillo.}

Gallegos. Meu Miniño folijay pois sois Pay de vosa May. Folijay, bello Miniño, pois sois Pay do Galeguiño. Que aunque sexa de Lamego, è voso fillo o Gallego. 
Folijay, pois sois parente

de vna tan guerreira gente.

Que emboluera a toda España

en magostos de castaña.

Meu Miniño, folijay,

pois fois Pay de vosa May.

Texto.Tras el villano bailaron la gaita,

y como propia mas diestros la baila $[n]$.

\section{Estriuillo.}

Gallegos. Ay meu Miniño,

si estais pobreciño,

indo a Castela vos tornareis rico.

ay ay ay.

Que con la gaita, e vosa May bella, engaytaremos a toda Castela.

ay ay ay.

Ay meu Miniño, faceivos Gayteiro,

e ganarèmos muyto diñeiro,

ay ay ay.

Con boy, e mula, e con casa pagiza, non negareis que naceis en Galiza, ay ay ay.

Daynos a mula, e o boy juntamente ansi vos fazan Oubispo de Ourense, ay ay ay.

Non quero a mula, q[ue] non e Galega, pois ao Miniño tan pouco se chega, ay ay ay.

Texto. Y mudando el son a la gaita, otra buelta dieron a la dança.

Galleg. Que dizis Galegos do Miniño?

2. Que è tan bello como pan de trigo.

3. De presente que quereis dallo?

4. Si me da o boy, lle darè vn qarto.

5. Zapatiños eu lle daria.

6. Para que los poña na pretiña.

7. Daille o coraço $[n], \mathrm{q}[u e]$ è o $\mathrm{q}[u e]$ mais preça.

8. De diñeiro abaxo qanto queira. 
Text. Y rematando con otra mudança, de quatro en quatro dàn fin a la dança. $\mathrm{Y}$ no es muy poco $\mathrm{q}[u e]$ bailen a quatro $\mathrm{q}[u e]$ ay en Galicia poquissimos quartos.

Gall. Miniño meu, vos sois Caualeiro, pois primo sois do mais nobre Galego.

Casa vos ten voso primo en $\mathrm{Sa}[n]$ tiago, que ha enriquecido despois q[ue] foi $\mathrm{Sa}[n]$ to.

Id para là, e serei lo Galego mais regalado que o Conde de Lemos. Pero cuiday non vos coman en casa, por $\mathrm{q}[u e]$ en $\mathrm{Sa}[n]$ tiago Pan de Angeles yanta $[n]$.

\section{V1. VILLANCICO}

Texto. OY con dança de espadas los Negros a Dios festejan para que sea la dança de espadas blancas y negras.

\section{Estriuillo.}

Guineo.1 Hi hi hi: Maltiniyo

\section{Siola.}

1.Damo la buelta.

2. Hi hi hi: Si siola, saltemo apliesa, que oy za la negla valiente, e pol aleglà la gente, puez nace el Tligo diuino hemo de haze ya el molino, ande la rueda al rededola, que polque haze la halina saluados sale mejola.

1. Hi hi hi, sube aliba Maltiniyo, que hemo de haze ya el castiyo, aliba aliba. Vamo tlepa $[n]$ do subiendo agala $[n]$ do, aliba aliba. 
2. A siola ya zamo en altura.

1. Da palmada Maltiniyo.

2. No caygamo del castiyo, que za lo suelo muy dura e muy blanda el colodriyo.

1. Y agola que hazelemo?

2. Vamo abaxo,

$\mathrm{q}[u e]$ essto tenemo lo neglo, y lo blanco, que por donde subimo baxamo.

1. Hi hi hi: Maltiniyo.

2. Siola, vamo con eya, pulque quando Dioso nace turo dà buelta.

\section{Coplas.}

Texto. Para la dança de espadas, por autorizar la fiesta, traen los negros las figuras, que mejor la blanca juegan. Saltò Dauid con la espada que a Goliat ganò en la guerra, que el gigante lo hizo juego, y èl ganò por vna piedra.

Guineo.2. Si al Niño que ha nacilo le conociela, no muliela el Gigante de mal de piedla.

1. Hi hi hi: Maltiniyo.

2. Siola: vamo con eya, que quando Dioso nace turu dà buelta.

Texto. Con su espada saltò Elias al cielo, donde se queda, que esta es la primer espada que se quedò siendo buena.

Guineo. 2. Boluelà con el Niño de otla venida, mas quando buelua fuego de Iesuncliza. 
1. Hi hi hi: Maltiniyo, \&C.

Texto. Saltò Iudich con la espada

que le quitò a la soberuia,

y excediò tanto a Holofernes,

que le lleuò la cabeça.

Guineo.2. No dirà Gallofernes

que lo inquietalon,

pues quedò el plimel sueño

descabeçado.

1. Hi hi hi: Maltiniyo, \&C.

Texto: $\mathrm{Co}[n]$ su espada el Rey Herodes

entrar en la dança intenta,

mas no pudo, que su espada

solo para niños era.

Guineo.2. No fue pala ece Niño,

polque Iusepo

mas que Elodes velando

supo dulmiendo.

1.Hi hi hi: Maltiniyo, \&C.

Texto. Con vna espada $\mathrm{q}[u e]$ hablaua, para que todos la oyeran,

saltò Pedro, y lo que dixo

no llegò mas que a vna oreja.

Guineo.2. Lo dueño de essa oleja

fue glan veyaco,

mas pol Dioso que agola

se la pegalon.

1. Hi hi hi, \&C.

Texto. Con su espada saltò Pablo,

ya conuertido a la Iglesia,

que no fue buena su espada

hasta que tuuo vna buelta.

Guineo. 2. Paulo fue a la manela

de lo tapiza,

que es mejol quando tiene

glande caida.

1. Hi hi hi, \&C.

Texto. En rueda entrò Catalina,

y saltò con tal destreza, 
que sin errarse la dança

se desbaratò la rueda.

Guineo.2. La cabeça de vn Reye

tiene a su planta,

con que tiene dos triunfos

de espada, y mala.

1. Hi hi hi, \&C.

\section{II1. NOCTVRNO.}

\section{VILLANCICO VI1.}

\section{Estriuillo.}

DIos mio, en que ha de parar vn tan contrario sentir, vos nacer, y yo morir, yo reir, y vos llorar?

\section{Coplas.}

Del viejo Adan por las culpas desnudo llorando està, entre vnas pajas el nueuo, y recien nacido Adan. Llora el daño de los hombres, que ignoran su enfermedad, pues lo que el hombre no siente, es lo que Dios siente mas. Para que lo reconozca, nace, y llora su bondad, que en lo grande del remedio se vè lo graue del mal.

Mas no basta, porque el hombre piensa que es remedio tal, no equidad en su justicia, sino excesso en su piedad. O buen Dios! ò culpa mia! pues es en mi ceguedad mi agradecimiento menos, por ser tu clemencia mas. 
Llora tu pues, y yo ria,

que esto serà menos mal,

pues en ti el mayor placer

es verme a mi sin pesar.

Bilbioteca Nacional. Madrid. (VE/88-26). "Albricias, Hombres, albricias".

Métrica: Villancicos, con coplas castellanas octosilábicas. Rima asonante. 


\section{VILLANCICOS \\ QVE SE CANTARON LA NOCHE DE NAVIDAD EN LA SANTA IGLESIA \\ CATHEDRAL DE HVESCA.}

Este Año de 1661.

Dedicados a los muy Ilustres Señores dean, y Cabildo de dicha Santa Iglesia. Siendo

Maestro de Capilla el Racionero

LVIS GARGALLO.

VILLANCICO 1.

Vengan todos los Poetas,

y prisa se den, alargue el paso;

que oy el campo de Belen

serà su monte Parnaso.

Ningún ingenio se escusa,

donde es Maria la Musa,

y el llanto de vn Inocente

es de Elicona la fuente.

Pues haga lugar, lugar, la gente,

que viene, que llega,

que entra el Amor,

vn ciego, que de repente

ninguno dize mejor.

Hagan lugar, que quiere el Amor

glosar

al Niño, fragante rosa,

y ha de acabar cada glosa

en vn romance vulgar.

Hagan lugar.

COPLAS.

EN esta noche dichosa,

que el Rey de los Cielos nace,

vn Sarao vistoso haze

la tierra con gala airosa.

La fiesta serà gustosa,

pues el hombre glorias da, 
el mundo se alegrarà,

y al son de sus esperanzas,

si es bailar hazer mudanzas,

ò que bien que bailarà.

O montañas de Iudea

dignas sois de presumir,

que al Cielo podeis subir,

si el a vos baxar dessea.

Si Dios con verde librea

renueua vuestra vegez,

justa serâ la altiuez;

pues oy sin tener recelo,

tambien salteais al Cielo

gigantes segunda vez.

El Deziembre en la frontera

del monte, que el Sol se beue,

con los volantes de nieue,

mostrò de paz su vandera.

Y porque la Primauera

ausente no se presuma,

sobre el Pesebre que suma

todo el sacro firmamento,

que entre los moços de silla

tomauan tabaco, y ellos

mas quisieran ceuadilla.

Iugando (aqui se hizo rajas

el Rey del Norte, y del Sur)

a los cientos en las pajas,

con vn Sacristan tahur,

que es natural de Barajas.

Ganòle muchos doblones

el Niño, sin poner leyes;

pues tenia entre otros dones,

consigo, y otros mirones

siempre catorze de Reyes.

El Sacristan se abrasaua,

y como era tagarote,

si el Niño se descuidaua,

le picaua, y repicaua, 
mas no le daua capote.

Conocio el Niño la flor

del Sacristan, y con traza

quiso echarle vna mordaza;

porque como era hablador,

no le dexaua hazer baza.

Buscò en el lance segundo

vn palo solo, y no malo,

porque con saber profundo,

diz q[ue] ha de ganar vn mundo,

en quedándose en vn palo.

Tres Principes, dizen, que,

le buscaron por trofeo,

y diuirtiose en su fe,

conque en tres manos arreo

vino el muchacho a ser pie.

El Sacristan le pidio

vn partido en las entradas,

y la mula que lo oyò,

el partido que le dio,

fue las bazas enpatadas.

Ganàrale la ventura,

y toda la plata franca:

mas no pudo esta criatura

(por vna negra figura)

hazer diez de carta blanca.

Diole vna quinta a lo crudo,

de espaldas, con linda resta,

el Sacristan que no es rudo,

y cogiole en vna sexta,

con que le dexò desnudo.

Quantos estauan delante,

viendole por varios modos,

que ganaua lo restante;

porque barato dè a todos,

aguardan, que se leuante.

Oygan, \&.C. 


\section{VILLANCICO VI1.}

ESte Sol, que nacio de la Luna,

que meciendole estan en la cuna

los Villanos, y Pastores,

oygan, miren con que amores,

miren con que aliño,

que arrullan al Niño,

y como se durmio

Niño ro ro ro.

\section{COPLAS}

DIxole Perote,

muy puesto de codos:

pues que duermen todos,

no nos alborote,

tome este capote,

si tiene fatiga;

y si no le abriga,

mire que nacio.

Niño ro ro ro.

Dixole Bartola:

si es de frio el llanto,

no madrugue tanto

por mi vida sola,

tanta tabahola,

y dormir tan poco,

guardate del coco,

que niños comio.

Niño ro ro ro.

Dixole Toribio,

el yerno de Bato:

presto paga el pato

por el hombre tibio:

no hallarâ otro aliuio

en el mundo loco,

ni le hallò tampoco

quien mas le buscò.

Niño ro ro ro.

Dixole Casquete. 
llore mas pasito, no levante el grito, quexese en falsete, yo soy vn pobrete, y en grandes fatigas, si almuerço vnas migas el frio volò.

Niño ro ro ro.

Dixo pero Bratos:

muy temprano llora, que aun le falta aora ver muchos ingratos, toparà vn Pilatos, y vn Herodes fiero, y con vn madero verà lo que obrò. Niño, \&.C.

Dixole Gil Santos, viendo en sus confines tantos Serafines, y Cherubes tantos: cessen ya los llantos, que entre tantas saluas, si el nacio en las maluas, el se lo buscò.

Niño \&.C.

Dixole Filena

con muy buen despacho: duermete muchacho, que es la noche buena: para casa agena muchas son las vozes, duermete, assi gozes, porque viua yo.

Niño, \&C.

Viendole Benito con buey, y con mula, mucho disimula, (dixo) lo infinito, 
en tanto conflito,

y rigores tales,

a padecer males,

oy lo començò.

Niño ro ro ro.

\section{VILLANCICO VII1.}

Negro.

HAgamole plaça a lo Reye Mago

turo lo neglo, é turo lo bra $[n] \mathrm{co}$,

que venimo en Cameya,

e buscamole por estreya,

$\operatorname{co}[n]$ oro, $\operatorname{co}[n]$ cienso, $\operatorname{co}[n]$ mirra diuina.,

Diosu chiquitin,

Diosu, que nace bonitu,

en paxia, è pesebricu,

como hijo de Gaìna.

Traemole a lo chiquitu

vna danza de neglitu,

y vno mono de Tulu,

con esto, y el gu gu gu,

y el gua gua gua,

y el gue gue gue

festejamole a su melce,

como a vno Niño Sesu.

1. Plimo, $\mathrm{q}[u e]$ yeuan lo Reye en done?

2. Yeuan cienso, chaculate,

oro, mirra, piñonate,

de Calicante turrone,

caixiña de canelone,

grana branca, è cururara,

panara Ingresa, cuchara,

è para hazer almendrara

guego mas branco que tu:

con esso, y el gu gu gu,

y el gua gua gua,

y el gue gue gue, 
festejamole a su melce,

como a vno Niño Sesu.

1. Plimo, $\mathrm{q}[u e]$ yeuan al tielno Infante.

2. Yeualmole piñona, nuesa, y almendra moldara,

aseituna, y alcapara,

camueza, y melacotona,

yeualemole valona,

y a Susepe le dalè

samarra de consejela,

si se la quiele ponè:

con esso, y el gu gu gu,

y el gua gua gua,

y el gue gue gue,

como a vno Niño Sesu,

festejemole a su melce.

1. Plimo, que yeuan a la parira?

2. A la Siola Malia

yeuamo con aleglia

bayalde para la cara,

manto de gloria con punta,

moño, è tanta cosa junta,

que para auer de yeuayo,

sa menester vn cauayo

tan glande como yo, é tu:

con esso, y el gu gu gu,

y el gua gua gua,

y el gue gue gue,

festejamole a su melce

como a vno Niño Sesu.

1. Plimo, que yeuan de cantulia?

2. No quede a vira instrumenta,

que no toque la peliona,

chilimigula, y baxona,

lo sacabucha, y culneta,

tocamole cubetiya,

sonagia, è cascabe,

y vna famosa cansiona

por el la sol fa mi re: 
con esto, y el gu gu gu,

y el gua gua gua,

y el gue gue gue,

como a vn Niño Sesu,

festejamole a su melce.

\section{LAVS DEO.}

Con licencia, en Huesca, por Iuan francisco de Larumbe, Impressor de la Vniuersidad. Año 1661.

Biblioteca Nacional. Madrid. (R. 3498/). "Vengan todos los Poetas".

Métrica: Villancico con coplas típicamente castellanas. Rima asonante. $8^{\mathrm{a}} 8 \mathrm{~b}$. Muchas aliteraciones en el canto de los negros. 


\section{VILLANCICOS QVE SE}

han de cantar en la Capilla Real de su Magestad la noche de Reyes deste año de 1662.

\section{VILLANCICO 1.}

PRONOSTICO.

Lleguen, llegue $[n]$ los ente $[n]$ didos

A los astros recien nacidos

En el Portal de Belen.

Lleguen, pues,

Los que pican curiosos,

$\mathrm{Y}$ a sus rayos luminosos

Consultan su parecer.

Lleguen, pues,

Si quieren hazer juizio,

Que en el cielo està propicio.

Quanto Planeta se vè.

Lleguen, pues,

Lleguen al Portal,

Y todo Zagal

Dichas verà sin rezelo

en su esfera celestial,

Porque el cielo del Portal

Es otro modo de cielo.

\section{ROMANCE}

Lleguen, lleguen los curiosos de obseruar los mouimientos A tanta errática Estrella.

A tanto fixo Lucero.

Lleguen a ver en la esfera

De vn Portal, que todo es cielo,

De venturas, y de glorias,

Iuizio que solo es cierto.

En lo corto de vn pesebre,

Y entre lo debil del heno,

Casa del Sol mas Diuino

Llega a adorarle el Sol mesmo. 
La exaltacion de sus rayos

Quando tan Niño le vemos,

De vna Virgen Madre suya

Es el purissimo seno.

Influyen serenidades

Dos Celestiales veneros

De diamantes bien llorados,

A tempestades del Cierço.

Mejora signos el año,

Despues que el Sol por Enero

Sus luzes brilla en el Toro,

Que le abriga con su aliento.

Vna Estrella pronostica

En su risa alegre,

$\mathrm{Y}$ a vna seña suya

A adorale vienen,

Orientales Indias

En Flotas de Reyes.

$\mathrm{Y}$ al ayre duerme,

El tonillo le canten de los valie $[n]$ tes

Tenganse todos, \&c.

\section{VILLANCICO IV.}

\section{GALLEGO.}

Anda Domingos,

Camine à gente,

Bertolo tanja,

E cante Llorente.

Polo camiño,

Que va à ò Portaliño,

Onde ò Solciño

Se dorme, è descansa.

Veña à Gayta,

Gayta de fole,

Gayta Galega,

Brando me sone,

Pois fuge à noite, 
Tocai alborada.

Solciño nouo deitado na palla

Quen vos ca $[n]$ tar boa ca $[n]$ tiña faga,

Deitado na palla,

Quen vos ta $[n]$ ger boa gaitiña ta $[n]$ ja.

\section{COPLAS.}

Solciño nouo de noite nacido,

El è sua Nay sian muito ben vidos.

Solciño nouo, que baixa do ceo,

Ele vira para ser noso Deus.

Solciño nouo, q[ue] chora, è q[ue] treme

Douos a Deus, $\mathrm{q}[u e]$ asi nace doe $[n]$ te.

Solciño nouo, Solciño garrido,

Quen me ora dera tiralle lo frio.

Solciño nouo do pelo dourado,

Sae mais cedo q[ue] ò ca[n]to do Galo.

Solciño nouo, $\mathrm{q}[u e]$ nace na palha,

Tuda la acende, mais non a derrama.

Solciño nouo, $\mathrm{q}[u e]$ he fillo da Lua,

Quanto folgara que se ele non puña.

Solciño nouo, $\mathrm{q}[u e]$ chora de amores,

Trae carabel, carabeles de frores.

Solciño nouo no leito descansa,

Que ainda non ten hua presa de palla.

Solciño nouo, $\mathrm{q}[u e]$ nace a deshora,

Vamolo ver na sua Pallota.

Solciño nouo Pastor das ouellas,

Ben para ela, milhor para elas.

Solciño nouo q[ue] chama seu gado,

Outros con siluos, mas ele chorando.

Solciño nouo, que quer darnos vida,

Tiñamos ollo quando ele veria.

Solciño nouo, que manda hua Estrella,

Que a Belen traça os Reis doutra terra.

Solciño nouo, que os Reis le saludan,

Beijanlle a mao, è fainlle mesura.

Solciño nouo, que pobre parece,

Tendo por seu todo o ouro Dorente. 
Anda Domingos,

Camine a gente, \& c.

\section{VILLANCICO V.}

1. Amigo Anton?

Tras, tras, tras.

2. Amigo Anton?

Tras, tras, tras,

2. Quien me busca, quien me llama?

Quie $[n]$ me inquieta, y alborota?

Que estoy malo de la gota,

$Y$ es fuerça guardar la cama

Quien tiene presos los pies.

1. Abrid, pues

Que el remedio vuestro es

Toda esta alegre noche bailar.

2. Lindo modo de curar

A quien mouerse no puede.

1. Esta noche todo sucede

Como podeis desear,

Que gotoso aueis de apostar

A baylar,

Y a çapatear

Ligero, y ossado.

2. Ya parece que estoy aliuiado

De solo oirte, Zagal,

Bartol, vamonos al Portal,

Que me coge me coge el mal.

COPLAS.

Leuantaos, Bartol aprisa,

Dadme luego vna camisa,

Que huela a Visperas y a Misa.

Irè de Pontifical.

Mas no quiero, no,

Que diràn que encamisado me coge el mal.

Dadme el jubon de las fiestas, 
Sin preguntas, ni respuestas:

No os pongais co[n]migo en sestas,

Que so Alcalde criminal.

Mas no quiero, no,

Que diran que enjubonado me

coge el mal.

Dadme el sayo ribeteado,

Que aunq[ue] no me le he probado,

Pues le hizo Anton Pintado,

No puede venirme mal.

Mas no quiero, no,

Que diran que ensayonado me

coge el mal.

Dadme aquellos calçones,

Que entre varias guarniciones,

Puso el sastre por botones

Mucha fruta garrafal.

Mas no quiero, no,

Que diran que encalçonado me coge el mal.

Esta vez, Bartol, te pierdes,

Dame las polynas verdes,

$\mathrm{Y}$ aunque dellas no te acuerdes,

Yo tengo buen memorial.

Mas no quiero, no,

Que diràn que empolaynado me

coge el mal.

Biblioteca Nacional.Madrid. ( R.34988-36). "Lleguen, lleguen los entendidos".

Métrica: villancico con Romance octosilábico, el verso separado por pausas versales, con encabalgamientos. Rima asonante. 
VILLANCICOS QVE SE CANTANRON EN LA SANTA YGLESIA APOSTOLICA Metropolitana de Granada, en los Maytines del Nacimiento de Nuestro Señor Iesu-Christo, este año de mil y seiscientos y sesenta y dos.

DEDICADOS

AL ILVSTRISSIMO Y REVERENDISSIMO

señor D. Joseph de Argaiz, Arçobispo de Granada, del Consejo de su Magestad, CON LICENCIA.

Impresso en Granada, En la Imprenta Real de Baltasar de Bolibar, en la calle de Abenamar.

Año de 1662.

VILLANCICO V1.

TERCERA PARTE.

A Dios vozes, y Elementos, Que en nueuo festejo se haze Ya quatro partes la tierra porque es persona de partes. Al Portal và por Europa A alegrar al Rey Infante, Galicia vna pobre tierra Que se anda por los Portales. Por el América Angola Tambien llega à festejearle, Que en esta noche los Negros No pueden quedarse in alvis. Los baylarines Gitanos Por el Africa, al instante Se partieron dando brincos, Porque baylan que se parten. Por el Asia fue Turquia, Mas con la nieue que cae Y con la turba de Moros Todo el Portal ya es turbante.

ESTRIVILLO.

Y cada vno hablando

En su propio lenguage 
La fiesta començaron Dios dela[n]te.

Gallego. Eu los Galeygos à pares

Vs dan Nino Celestial

Nuessa hortaliza nabal,

Da as coseytas à mares,

E con festas singolares

En que muyto amor se encerra.

Al Niño Deus qui naize na terra,

Fagale gaytiñas la geinte Galeiga

Ay, ay, ay, na geinte Galeyga,

$Y$ cada vno hablando

En su propio lenguaje, \&. C.

Negro. Lu Neglo tlaemo à lu Niña

Chiculata cum canela,

Polque no vale en la yela

Vn cacau lu gala piña;

Y polque al Niña le guiña

Tlaemo vn coco que az eya,

Zola eya (guache) za negla.

Y cada vno hablando, \&.C.

Morisco. Como el mo[n]do tener mal,

Bener Chequelio à xanarnos,

E como bene à corarnos

Tener mola en el bortal,

E asse el Moresco leal,

Xali, li li, li, Xa, la, la, la,

Hazer bonas festas al xonior Alà.

$Y$ cada vno hablando, \&.C.

Gitana. Dame la mano hermozura,

Que erez Hijo de buen Padre,

Y mil cozas por tu Madre

Parlarè a Dioz, y a ventura,

Y zi el premio ze azegura,

Te cantarà la Gitana:

Vaya, vaya,

Que ez la cara de roza, co[n] el aire $\mathrm{q}[u e]$ zopla

Roza zoplada.

Y cada vno hablando

En su propio lenguage 
Acabaron su fiesta Dios delante.

\section{VILLANCICO VII}

ZAgalejos de Belen

Baxad del monte, baxad,

Que Pasqual Perote os llama

Como vuestro Mayoral.

Sabed, que nacio esta noche

El bien contra nuestro mal,

Que de vna voz de los Cielos,

Gloria à Dios lo escuche en paz.

El Cielo, el ayre, y la tierra

Luz desta dicha nos dan,

Y aun hasta la noche obscura

Lo dize con claridad.

Venid à vn Portal, que lleno

De luziente variedad,

Por Alcázar soberano

Le tendreys mas que Portal.

\section{ESTRIVILLO.}

Al Portal, al Portal Zagalejos,

Venid presurosos, no os tardeis mas

$\mathrm{q}[u e]$ viniendo a ofrecerse à este Niño,

El mas diligente es el mas liberal,

Andar, as dar, correr, y saltar,

Porque solo las mudanças

Son buenas para baylar,

Andar, andar,

Venga Anton, y Vato,

Venga Gil, y Bras,

Trayendo al Portal

La bandurria Gil,

Bras el tamboril,

Anton el rabel

Vato el cascabel, 
Y yo el Mayoral.

Aunque aora a baylar os apremio,

Despues Zagalejos os è de premiar.

1. Iuntos ya con voz serena,

Pregunto al Recien Nacido,

Gil, vn Zagal mas leido

Que el Pastor de Noche Buena.

2. Si os a de costar tanto,

Señor, librarla,

Como traeys al mundo

La Ley de Gracia.

1. Bras, vn viejo descosido,

Dixo con gozos estraños,

Bestido de muchos años,

Y desnudo de vestido;

3. Como estays tan desnudo,

Que el frio es grande,

Y aunque soys Dios, mi Niño,

Se os vè la carne?

1. Dixo Anton el horobado

Al Niño con grande empeño,

Siendo vn hombre muy pequeño,

Con ser su cuerpo doblado.

4. Pues soy hombre pequeño,

Mi Dios, yo logre

El que sepa la gracia

De hazeros Hombre.

1. Vato, vn ciego Pastorcillo,

Dixo, haziendo al Niño luego

Grano de trigo, que vn ciego

Todo lo haze Lazarillo.

5. Muy blando soys Dios mío,

Mas vendra tiempo,

Que aun estando mas blanco

Sereys trigueño.

1. Bartolo haziendo la salva,

Dixo al ver tanto arrebol,

Y que se abrigaua el Sol

Entre los braços del Alva. 
6. En sus braços al Niño

Su Madre abriga,

Y le sirve de Marta

Siendo Maria.

\section{VILLANCICO VIII}

HAla, traz, los Gitanoz,

O que bien zaltan,

Hala,

Que el Gitanico ze lleua la gala,

$\mathrm{O}$ que bien brincan,

O que bien cantan,

$\mathrm{O}$ que bien baylan,

A landola, landola,

Hombre ez el que llora

Por vna mançana,

Traz, hala,

A la dina dana

a la dana dina,

Perzona Diuina,

Duina, y humana,

Que el Gitanico ze lleua la gala.

\section{COPLAS}

Dame acà eza mano

Carita de Pazqua,

Que ya ze que tienez

El Alma en la palma.

No en la mano guztaz

Que la Cruz te hagan

Porque te la pongan

Zobre laz espaldaz.

Para buen Paztor

El Amor te enzaya.

Por ezo te à puesto

$\mathrm{Al}$ yelo, y escarcha. 
Biblioteca Nacional. Madrid. (VE/92-21) "Los zagales y Serranas".

Métrica: Coplas castellanas, que recita una gitana, ceceando; versos heptasílabos, arte menor. Rima asonante. 
VILLANCICOS QVE SE HAN DE CANTAR

en la Capilla Real de su Magestad la Noche de Nauidad deste año de 1664.

Año de 1664

EN MADRID.

Por Ioseph Fernandez de Buendia.

\section{VILLANCICO V.}

Bien tus estremos conciertas,

Niño celestial, pues ya

La Puerta del Sol està,

Donde el Sol està por puertas.

1.

Marauillas celestiales

Se ven lucir vna a vna,

$\mathrm{Y}$ en estremos desiguales

Vn Niño Dios en la cuna,

Le abrigan dos animales:

Aluas sueltas de cristales,

De sus ojos siempre abiertas.

Bien tus estremos co[n]ciertas, \&C.

I1.

El que triunfo victorioso,

Siempre Dios del fuerte braço,

Oy Niño vierte amoroso,

De su Madre en el regazo,

Llanto de perlas glorioso:

$\mathrm{Y}$ a dilubio tan copioso

Quitò el amor las compuertas.

Bien tus estremos co[n]ciertas, \&C.

II1.

El Sol de noche se anida

En su Madre Hermosa, y Pura,

Porque tenga repetida

Todo el cielo la ventura,

Y todo el mundo la vida:

$\mathrm{Y}$ a la esfera mas lucida

sus glorias dexa desiertas.

Bien tus estremos co[n]ciertas, \&C. 
IV.

De aquel Orbe celestial

Por rumbos esclarecidos,

Viene Dios a este Portal,

Milagrosamente vnidos

Lo mortal, y lo inmortal:

En èl da fin nuestro mal,

Siendo nuestras dichas ciertas

Bien tus estremos co[n]ciertas, \&C.

\section{VILLANCICO V1.}

\section{ESTRIVILLO.}

Escuche todo Pastor,

Que canta la Xacarilla

Gilillo, que es en la Villa

Quien la Repica mejor:

Vaya de gusto, y primor,

Y sepan qué quando canta,

Los gorgeos, y garganta,

Si las tejolillas toca,

Apenas abre la boca,

Quando al cielo los leuanta.

\section{XACARA.}

Vn brauo, que a lo entendido

Campa, y triunfa entre valie $[n]$ tes.

A los hijos de Israel

Deste modo se la tiende

Yo soy vn Auenturero,

Que ha de venir con los Reyes

Por su casi Camarada,

Que puede selo vn Pariente.

Soy vno, q[ue] en nuestra Magia,

A lo sabio, y lo prudente,

Dicta en escuelas mayores

Los futuros contingentes.

Oygan, pues, lo que les digo, 
Y sabràn Vuessas mercedes

Algo, que en tiempos futuros

Han de ver que les sucede.

Estauan muy presumidos,

Y a fee de Señor que pueden,

Viendo que nace en su tierra

Vn Dios, aunque en vn Pesebre.

Y que quiso emparentar

Con la sangre de sus Reyes,

(Graue honor) perdone el Angel,

Que tanto el nuestro le excede.

Pues desde aqui a pocos años

Tanto auemos de excedeles,

Que a merced de nuestras armas

Han de estar, si viuir quieren.

Sobre esto ha de auer batallas

Entre vnos, y otros, de suerte,

Que su razon corra sangre

A mis tajos, y reueses.

El Imperio espiritual,

Que en Ierusalen pretende

Fundar el Principe Dios,

Veràn que passa a las gentes.

Poco les valdrà lo agudo

De sus argumentos fuertes,

Porque las glorias passadas,

Con el tiempo desvanecen.

Pero ya en mis juizios veo

Vn Campeon excelente,

Que con obras, y palabras

Paz a unos, y otros promete.

El Rey, que la trae del Cielo,

Perdona vidas valiente,

Y que a vna Palabra suya,

La tierra, y los cielos temen.

VIILLANCICO VI1.

GALLEGO. 


\section{INTRODVCCION.}

Vna tropa de Gallegos,

Muestra en festiuo solaz

Con presentes, y con bayles

Ser su fiesta tal Por-tal.

La gayta, y las castañetas

Preuenidas vienen ya,

Tal fineza Por-tal dicha,

Por-tal amor, tal solaz.

Alentados llegan todos,

$\mathrm{Y}$ ciertos que venceràn

Las cantiñas de Galicia,

Folias de Portugal.

Empeçauase la fiesta,

Y assi oìa resonar,

Leru leru con la gayta,

Las castañetas chàs chàs.

\section{ESTRIVILLO.}

Tocay dominguiño, tocay a compÀs,

Turururu, y andar, correr, y baylar.

Suene ò tamboril rurururu a co[ $m]$ pas;

Suene la gaytiña turururu, y andar.

Y la castañeta turururu a co[m]pas,

Que los Bartoliños queremos baylar,

Turururu, y andar,

Cruzando los ventos,

Los sones doblay,

Pois que çapatiños

De pao calçais,

Tamben castañetas

En los pes cheuais, Turururu à compàs.

\section{COPLAS}

Mi Nino, en as pallas

Que pracente estais,

$\mathrm{Y}$ es por que mas Cruzes

en ellas hachais.

Aquestas mançaes, 
Memorias de Adan,

Polo encarnadiño,

Las podeis tomar,

Aquesta cestiña

De os ouos tomay,

Y para vna Bula

Este medio real.

Dominguiño roscas

De centeo vos da,

Aunque en vuestros braços

La ve de cristal,

Tomay de sardiñas

Diez ducias no mais,

Pastillas Gallegas

De menjui con sal.

Estos çapatiños

Rusticos calçay,

Que el cravo passado

Busca el pie galan.

Vna çamarriña,

Forrada en sayal,

Que de Monterrey

Este è ò cambray.

A ò buey, y a la mula

Cebadiña train,

Porque al trigo dexen

La palla en que està.

Si en Galicia fora

O voso Natal,

De Madril ò Rey

Os fora a hospedar.

F I N.

Bilbioteca Nacional. Madrid. (VE/88-62). "Bien tus estremos conciertas". 141. (5) . Métrica: Versos de gaita gallega, rima asonante. Aparecen figuras retóricas como la homeotéleuton de origen latino, sonidos próximos a la rima. 


\section{VILLANCICOS QVE SE HAN DE CANTAR \\ en la Capilla Real de su Magestad la Noche de Reyes deste año de 1665. \\ EN MADRID, \\ por Ioseph Fernandez Buendia.}

VILLANCICO 1.

ESTRIVILLO.

1. Deste Niño, que todo es

dulçuras,

Y todo hermosuras,

Por Dios, por Amor, y por

Hijo del Alva.

Cantemos de alegria

Tonillos de gusto,

Saynetes de gracia.

2. Vaya, vaya,

Mas no, no,

De burlas no le canten,

Si acaso me le cantan,

Que gusta de las veras,

En medio de las gracias.

1. Que si, si, si,

Que cantenle de gracia,

2.Que no, no, no,

que burlas no las passa.

1. Pues cantenle vnas coplas

de veras, y agraciadas.

\section{ROMANCE.}

Pues co[n] la culpa hechos yelo,

Al fuego estamos, que nace,

Vaya de exemplo de vn Niño

Cargado de Nauidades.

Erase que sera vn Dios,

Allà en sus eternidades,

Siempre muy dentro de si, 
Que oy quiso salir de Madre.

Como ay Dios, te $[n]$ go por cierto

que Hijo, y Padre son iguales

que aunq[ue] es el Hijo mas $\mathrm{Ho}[m]$ bre

Por esso es mayor el Padre.

No se pudo penetrar

Como naciò de vna Madre,

Siendo Madre, y siendo Virgen

Pero pudo penetrarse.

Rico, Grande, y Poderoso,

Dizen los que dèl bien saben,

Que ha venido a nuestra tierra

Siendo assi que vino en carne.

Mayor (no obsta $[n]$ te) es q[ue] todo

Pues viniendo a visitarle

Tres Reyes, los rezibiò

En el Portal quando sale.

En vn Pesebre le hallaron,

Con vn disfraz tan notable,

Que llegar a conocerle,

Sin alguna Luz, no es facil.

Su Madre de si le aparta,

Y con ser dèl tan Amante,

No ha tenido mas dolor,

Que si tal no le apartase.

Profetas, y mas Profetas

Hablaron de su linage,

Pero agora ya sabremos

De que color es su sangre.

El viene contra el infierno

Tan fuerte, è incontrastable,

Que solamente vn Iudio

Ha de poder aguardarle.

VILLANCICO I1.

GALLEGO.

Outra bolteta 
Pero Fernández,

Outra bolteta,

Antes que vos vades;

Ay,

Toca o pandeyro,

Tange a gayta,

Vaya de bayle,

Sone a frauta;

Ay,

Repicay o tamboriño,

O cascabel, e a sonaja,

Vaya de vaya de vaya,

Vaya de gusto Pastor:

Que oje tirita[n]do madruga o Sol.

\section{COPLAS.}

1.

Ao son de ò Miño, è Mo[n]dego

Baylay, pois Deus nace acà,

Galego, que pouco và

De Galileo a Galego:

Desde ò casadiño a ò Crego

Mostran suas habilidades.

Outra bolteta

Antes que vos vades, \&C.

I1.

Solo vn Galego, cal nos,

Fazera lo que Deus faze,

Pois entre mula, y boy nace,

Como Galego, aunque Deos:

Baylemos de dos en dos,

Que outra cosa non fagades,

Outra bolteta

Antes que vos vades,\&C.

II1.

Si a Estrela q[ue] a os Reyes guia

Es de a nosa è prima hermana,

Como a parenta cercana,

Fagamos muyta alegria: 
E Compostela este dia

Ajuntarà os seus Abades,

Outra bolteta

Antes que vos vades, \&C.

IV.

Santiago sea con vos,

Como Patron Souberano,

Pois do Neno, è Primo hermano

E quijo pousar con nos:

Baylemos de dous en dous

Diante das Tres Magestades.

Outra bolteta

Antes que vos vades, \&C.

Biblioteca Nacional. Madrid. (VE/91-17) "Deste Niño, que todo es dulçuras" 142.(1) 388.(5.) .

Métrica: Tipo Letanías propias de los himnos de la Romania, versos octosílabos, rima consonante. 


\section{LETRAS DE LOS VILLANCICOS QVE SE AN DE CANTAR EN LA SANCTA Iglesia de Cordoba, en la Kalenda, Noche, y Dias de la Natiuidad de Iesu Christo Nuestro Señor, este año de mil y seiscientos y sesenta y cinco.}

\section{KALENDA.}

1. TOdo es tristezas la tierra, tinieblas por galas viste, y en desaliños y horrores acordando esta su origen.

2. Solo fatigan lamentos del ayre, Esferas sublimes, duplicandose suspiros a el eco que los repite.

3. Ay infelices! hasta qua $[n]$ do sera $[n]$ lagrimas tristes?

4. Desmayos, y esperanças se compiten, y la tardança aflige:

5. Digalo el sentimiento, Ay!

6. La pena lo publique, Ay!

7. Ya lo explican las vozes, Ay!

8. Ya los ecos lo diçen

3. Ay infelices! hasta qua $[n]$ do sera $[n]$ lagrimas tristes? Mas ya oste $[n]$ nten muda $[n]$ ça los Orbes, $\mathrm{q}[u e]$ son de la dicha anuncios felices:

2. Mas ya alegres el cielo, y la tierra de flores, y luzes belleça co[ $n]$ siguen 3. Las aues gorjean, las fuentes murmuran,

4. Los prados se adornan de hermosos matiçes;

5. Y a la luz,

6. A la voz,

7. Al adorno, atento el deseo del ho[ $m]$ bre, colije: 
que quiere naçer el Sol,

pues que el Aurora se rie.

8. Porque la esperança,

que en sombras viue,

â sus rayos logre

dichosos fines.

\section{COPLAS.}

De la campaña del Alua

a tanto prolijo eclipse,

sucede en luz admirable,

mucha lisonja apacible.

Hermoso,y claro el Oriente.

mirad Señor, que essa gloria

no cabe en la admiracion

Que quereis con tal fineza, que aun para mi es confusion proporcionadme la dicha que es mucho ya esse fauor. En tan desiguales fuerzas, como las que tengo yo si es gustosa la ventura es carga la obligacion.

Tiembla el respeto de veros, aunque se alegra el amor, $y$ entre el amor y el respeto no hallan la satisfacion.

Que importa para la cuenta que os tengo de dar Señor, que el amor os mire en mi si el respeto se mira en vos. Para miraros medroso, basta la veneracion, sin que al respeto se añada la culpa de ser deudor. En el mar de mi ventura calmen las dichas mi Dios, que si se busca la causa se va a pique la razon. 
Templaos mi Dios, \&.C.

VII1. VILLANCICO.

Niño callar y zufrir

es el sino padezer,

porque morir por nazer

es nazer para morir.

\section{COPLAS}

PAstorcico mira mi pena

no mires por ti

que el morir a vida me importa

$\mathrm{y}$ duelete de $\mathrm{m} 1$.

Si la risa naciendo llora

bien puedes reir,

pues aun tiempo la risa y llanto

en ti se ve vnir.

Mi dolor si iguala a tu pena,

sere muy feliz,

mas si lloras de amor, yo no,

si ries, yo s1.

Si lo ingrato detiene el llanto,

al verte zufrir,

al mirarte alegre la risa,

llora por salir.

Callar y zufrir, \&.C.

IX. VILLANCICO .

\section{GINEO.}

1. QVe tenemo, plimo Anton que tan deplissa venimo?

2. Siñol Plimo,

tenemo mucha ocasion,

y pol esso andamo tal.

3. Qual es, qual?

3. Tenemo aya en el Portal 
lo neglo vna plosesion,

ys ${ }^{8}$ Anton,

desta fiesta el mayoldomo.

4. Y sepa como

no tenemo que gaztá,

2. Y que ya eztâ

la Pastola a loz vmblales,

4. Y los Altales

no se acaban de pone,

2. Y no ay quien de

limozna para la fiesta:

mala fiezta

es coza pala alegla!

1. Vamo aya,

y vna danza tlazalemo.

3. Y a lo Niño aleglalemo,

3. Y a la gente entletendlemo,

3. Y halemo a todo lugar,

Tapalatà

tocamo Flasico,

lo tamborilico,

con la sonaxa,

haziendo el son

mientraz paza la plosession.

COPLAS.

1. Venga aplisa su melsé

a ayudal à Anton su plimo

que tan cansada venimo,

que no podemo tenè,

Altales emo de hazé

y aula vino y colassion

mientraz paza la Plosession.

2. Sepa vse que no es desuelo

esta Plosessiona santa,

porque los Angeles canta

vna gloria que es consuelo:

vamo saltando hasta el Sielo

${ }^{8}$ En el original $y s$, es decir 'y es'. 
sin que demo cozcorron

mientraz pasa la Plosession.

3. Vn Angel viene delante, como Alcalde de la cassa, vamo hasiendo plasa plasa, cantando polque no espante, y caminemo al instante, a Belen con deuosion mientraz pasa la Plosession. 4. Luego uiene la Pastola, con sun surron, y pellico $\mathrm{y}$ al son de lo rabelico dansanso, como siola que son como los de Angola alegles de culason, mientraz pasa la Plosession. 1. Luego viene la Capiya, de los Angelez, que ezpanta, con passo de guruganta, $\mathrm{y}$ vose que marauiya; dulse traera gargantiya, como es tiempa de turron mientraz paza la Plo[se]ssion.

2. En vn carro, cosa beya, viene con Dioso tliunfante, tamañito, aunqne es gigante, y es el carro vna Donseya yega al Pesebre y en eya hase Iglesia de vn Messon mientraz paza la Plosesison.

\section{VILLANCICOS PARA}

la Missa.

\section{VILLANCICO.}

Despertad paxarillos, que el Sol mas noble, desterrando tinieblas 
vence la noche,

alerta, alerta, alerta flores,

pues naceis con el Sol

decidle amores.

\section{COPLAS.}

No buela a quenta del tiempo

el mundo desde esta noche, pues trocados los efectos halla aplaudido el desorden. Ya por quenta de las luzes nueua infancia goçe el orbe, pues trueca a flores y galas, el Diziembre los rigores. A las señas de otro Oriente corrida la noche borre los horrores de sus yelos cediendo a luzes mas nobles. Ya se confunden los tiempos, los montes no se conocen, los efectos se desmienten, $\mathrm{y}$ antiguos fueros se rompen. Todo es prodigios el valle, todo admiracion el monte, que mucho si Dios humano pasible se desconoze.

\section{I1. VILLANCICO.}

AGrauios padeçe un Niño, que es prodigo de finezas, y de los hombres la gloria Zifrada tiene en sus penas A piedades y a cariños triumfar de lo humano intenta, venzerà, porque el ingrato contra si mesmo pelea. Si las armas son mis dichas, donde ha de hallar resistencia? 
que si es gloria el rendimiento,

es desgracia la defensa.

Con lo que padeçe hiere, que en la amorosa contienda

al dar al hombre la herida, se queda Dios con la ofensa.

No mata, solo ay prisiones,

como es de amor esta guerra,

y no estima beneficios,

quien resiste las cadenas.

Si es gloria lo que castiga,

que vendrà a ser lo que premia?

que sera lo que perdona

si es piedad lo que se venga?

\section{Estriuillo.}

SI a triunfar de ingratos

a el mundo llegas,

Niño como juntas

llantos y fuerças?

Si amante, buscando

la victoria, buelas

tente, que ya logras

tanto como intentas.

\section{II1. VILLANCICO.}

A mi Niño tierno

no le toque el Ayre,

porque es el donayre

de su Padre Eterno.

\section{COPLAS.}

Viento adulador,

que al amaneçer,

sueles ofrezer,

cariños y amor,

Si de tu fauor

al impulso leue, 
vieres que se atreve,

riguroso inuierno,

A mi Niño tierno, \&C.

Quando de Belen,

los campos corrieres

y en la escarcha vieres,

a mi dulze bien;

Flores le preuen

que aunque pobres llora

vestido atessora

del mas alto terno.

A mi Niño tierno

no le toque el ayre, \&.C.

Con Licencia, en Córdoba, en la Imprenta de Saluador de Cea, este año de 1665.

Biblioteca Nacional. Madrid. (VE/1308-38). "Todo es tristeças la tierra" 121(1).

Métrica: aparecen los versos como poemas monométricos, heptasilábicos, con rima consonante. 


\section{LETRAS DE LOS VILLANCICOS, QVE SE CANTARON EN LA Santa Iglesia Metropolitana de Sevilla, EN LOS MAYTINES DE LA EPIFANIA \\ de Nuestro Señor Iesu Christo. Este año de 1666. COMPVESTOS POR EL RACIONERO JVAN SANZ, Maestro de Capilla de dicha Santa Iglesia.}

VILLANCICO 1.

Estrivillo.

QVien es aquella gente, que corre, que para, que llega, que viene? Tres Reyes son, que ofrecen Aromas, Afectos, Tesoros de Oriente.

Quien es aquella gente, que siguen alegres

la Estrella luziente, que a el Sol que amanece es sombra no mas? Llega, pues, llega, y veràs lo que no han visto jamas tantos Siglos, y tantas Edades, que tales Magestades al mas bello Infante le ofrecen los Cetros, y Dones con ellos, tan sacros, tan grandes, tan raros, tan bellos, $\mathrm{q}[u e]$ aun el Oro no ha sido lo mas.

Romance.

EN vn Portal, que la Noche triste, sorda, obscura, elada, junto para hazerse Dìa 
Luzes, Rayos, Soles, y Albas.

Donde en rebaños el Yelo

cubre, viste, adorna, esmalta,

como en manadas vnido

$\mathrm{Ca}[\mathrm{m}]$ pos, Prados, Yervas, Plantas,

Por ver vn Sol que componen

Nieve, Rosa, Yelo, Nacar,

vna Belleza que vence

Muertes, Vidas, Gustos, Almas

de sus purissimos Soles,

conque la luz olvidaron

la que los conduxo entonces.

VILLANCICO VI1.

Estrivillo.

VEnid a ver, Zagales,

venid, vereis

la entrada mas grande,

que fuera de leyes,

buscando al Dios del Amor,

con alegria, y temor

de Orie $[n]$ te ha $[n]$ hecho tres Reyes.

Venid a ver vn Dios Niño,

Blanco, y bello como armiño,

sin riqueza poderoso,

en su talamo dichoso,

que lo dà la Aurora bella

para que sea adorado

de tres Reyes, que han llegado

que los guia buena Estrella.

\section{COPLAS}

TRes Reyes de Oriente viene $[n]$

a vna Magestad excelsa:

quien viò venir del Oriente

los que estavan en Tinieblas?

Alli el Cielo està cifrado, 
pues puso Maria bella

La Luna, su Hijo el Sol,

y los Reyes las Estrellas.

No vienen buscando Reynos,

ni tampoco sus riquezas,

porque solo vna palabra

querian con su licencia.

En lo corto de su Albergue

el Infante los hospeda,

que para el recebimiento

no le faltò a el Portal telas.

Aunque son tres Magestades,

con èl su poder no Reyna,

que no pueden hazer Grande

al que lo es de Cielo, y Tierra.

Desapareciò el Antorcha

a vista de la Sobervia,

$\mathrm{q}[u e]$ es bien quede a escuras quien

no camina via recta.

\section{VILLANCICO VII1.}

\section{Estrivillo.}

AY Gayterino, Gaytero,

Ay, turururu cantemos,

que lo Galeguiño

por lo Neno miño,

e por os Reyes luego,

ya que non estameñas

mil ra[y] as nos faremos.

Ay, turururu cantemos,

Y a os Reyes de Orense,

que chegan en Camelos

mil cosas les diremos.

Ay, turururu cantemos.

COPLAS.

Miño Neno, y el Rey Nergo 
forman en sus boas caras

a serena de à Noche,

a crara de a Mañana.

Aunque parece que os Reyes

sedientos por suo Ben andan,

no deben de estallo, pois

a Deus ofrezen as Iarras.

Al humildarse el Anciano

dizen por terra suas canas, que para suba el Ouro

bacha primero a Prata.

Por aumentar sua salude

besandole os pes (señalan)

ser Boticaros del Cielo,

pois vienen buscando Prantas.

De vellos rendir al Chico

mais que valen treinta casas,

està el Dia, è aun a Noche

alerge como hua Pasqua.

En a Corte de vn Hirodes

causaron con sua passada,

hua Mosica de Chicos

con mil passos de galganta.

Qué ben en burlarle hizieron

mirando en sua cara mala,

que no estavan suas pleguntas

en la Dotrina Cristiana!

No en valde al velle acupado

en verter sangre tamaña,

dirian sin despedirse:

a Deus con à colorada.

\section{VILLANCICO IX.}

Estrivillo.

AY Amor,

Ay del Amor, del Amor,

con que estàn tres Magestades, 
que con finas humildades

solicitan su favor:

ay del Amor, del Amor.

COPLAS.

1. HErmosa Estrella luzida

a los tres Reyes se ostenta.

2. No es sino el Amor, que inte $[n]$ ta

ser Iman de tanta Vida.

1. Cada Corona ofrecida

adquiere alli mas valor:

Ay Amor, \&C.

1. A el Amor van a buscar

tres Monarcas desde Oriente.

2. Si el Amor es Fuego ardiente,

en Oriente se ha de hallar.

1. Vn Niño les ha de dar

a sus deseos primor:

Ay Amor, \&C.

1. Como en amar son valientes

aun del tiempo dàn querellas.

2. Y aun por esso con Estrellas

madrugan tan diligentes:

no miran inconvenientes,

porque es mucho su fervor:

Ay Amor, \&c.

1. Su Purpura mas campea

siendo de sus pues alfombra.

2. Esso es porque a su sombra

grana de polvo se vea:

Bien en este amor se emplea

porque no es Dios de rigor:

Ay amor, \&C.

FIN.

Impressos en Sevilla, por Juan Gomez de Blas, su Impressor mayor.

Año de 1666. 
Biblioteca Nacional. Madrid.(VE/1309). "Quien es aquella gente" (375.(1) . Métrica: versos octosilábicos, romanceados. Coplas castellanas. Arte menor. 


\section{VILLANCICOS QVE SE HAN DE CANTAR \\ en la Capilla Real de su Magestad, la Noche de Nauidad deste año de 1667. \\ EN MADRID, \\ por Ioseph Fernandez de Buendia.}

VILLANCICO II1.

\section{Estriuillo.}

Vaya Xacara, vaya,

vaya, que es nueua,

vaya, pues que tenemos

la Noche Buena.

Esta Xacara escuchen,

que es de vn Valiente,

a quien siempre ha temido

la misma muerte.

De valiente ha campado

por muchos siglos,

y oy se vè que està haziendo

cosas de Niño.

No se espanten que llore,

ni sienta el yelo,

si su Padre le tuuo

siempre en el seno.

Contra el hombre ha viuido

tan enojado,

que es milagro del Cielo

verle oy humano.

Vaya Xacara, vaya,

vaya que es nueua,

vaya, pues que tenemos,

la Noche Buena.

\section{Xacara.}

Oygan todos a vn valiente,

que en vn Portal esta echando

verbos por que no le digan, 
que es hombre $\mathrm{q}[u e]$ habla de alto.

Manuel de la Cruz se llama,

nombre tan ilustre, y claro

que es el arbol de su sangre,

timbre goza soberano.

Rescostado en vnas pajas

lo haze gala de su garbo

porque sobre lo pagizo,

salga mas bien lo encarnado.

Siendo tan pobre en el mundo,

dizen al verle campando,

que es de la vida penosa,

y que viue de milagro.

A los alientos de vn Buey

deue del frio el reparo,

que desde su Nacimiento

le viene el ser alentado

Contra el rigor de los yelos, parece que està enojado,

pues de coraje vn valiente

solo puede estar temblando.

Todo el poder del infierno,

teme la espada en su brazo,

y le llaman matasiete,

hasta los mismos pecados.

Buscando viene vn valiente,

Adan de todos llamado,

el primero que en el mundo

tomò la hoja en las manos.

Por comer de vna mançana,

sobre alcançarla de un arbol,

cierto dia se matò

con todo el genero humano.

Gustar pretendio aquel fruto,

y le saliò tan amargo,

que le dio braua culebra,

Lucifer con el engaño.

Sabiendo aquesta pendencia,

nuestro Manuel, que es bizarro, 
sacarlos del riesgo quiere,

aunque muera por saluarlos.

Sucederà que en vn Huerto

se verà muy fatigado,

si aquí tirita en las pajas,

alli le veràn sudando.

Defenderale vn alfanje,

contra vno que llamana Malco,

a quien se sabe de oidas,

que vna oreja le cortaron.

$\mathrm{Al}$ verle tan atreuido,

Manuel le puso la mano,

y al mirarle sin oreja,

se la pegaua al mas zayno.

Todo jaspeado de heridas

saldrà de vn lance apretado,

porque seràn contra èl

mas de cinco mil, y tantos.

En fin perderà la vida

en vn monte, que este Brauo

para nacer, y morir

tuuo su cama de campo.

VILLANCICO IV.

Estriuillo.

Gallego.

Zumbe a gayta,

Toribio ò cego,

porque folije

todo Galego,

ay folixay, folixay, folixemos, ay folixay, folixay os Galegos.

Zumbe a gayta,

rebente ò demo,

pois ha nacido

ò Fillo de Deus,

ay folixai, folixay, folixemos, 
ay folixay, folixay os Galegos.

\section{COPLAS.}

A ò Neno que està ò Portal, fincan rodilla os Galegos, que ainda mais Excelencia ten que ò conde de Lemus. Zumbe a gayta, rebente o demo, pois ha nacido ò Fillo de Deus. Vna Mula ten, y vn Boy, he si fora en Ribadeo, solo con ò boy, è a Mula, fora mais rico que ò Crego. Zumbe a gayta, \&C.

Desnudiño entre huas pallas, has sopiñas vay comendo, que assi crian suas mais os fillos en Mondañedo. Zumbe a gayta, \&C.

A casiña donde mora esta mais crara que ò ceo he folixan Angeliños, que serà vna groria velos. Zumbe a gayta, \&C.

Cantando van as cantiñas, he volando por ò vento, que non fora mais que ver, si folixaran Galegos. Zumbe a gayta, \&C.

Entre as pallas que nace, està ò Neno moy trigueño dà color que he en Lugo ò Diuino Sacramento. Zumbe a gayta \&C.

Polo error do primer home vene a saluar os Galegos, he ferido de tres Crauos, 
passara a Cruz de Ferro.

Zumbe a gayta, \&C.

\section{VILLANCICO V.}

\section{Estriuillo.}

Pasqual hagamornos rajas

con celebar al Señor,

que al incendio de su amor,

brasas se bueluen las pajas.

Pasqual, es justa razon,

que a nuestro Dios celebremos,

pues por serlo le tenemos

natural obligacion:

enciendase el coraçon,

al ardor de aquellas pajas,

Pasqual hagamo[no]s rajas, \&C.

A tan grande Magestad, como a la tierra ha venido,

es poco ningún sentido

para su celebridad,

con su Fé, y tu caridad,

veras que bien le agassajas.

Pasqual hagamonos rajas, \&C.

Si las riquezas del suelo

por festejo le ofrecieres,

si a ti mismo no te dieres,

saldrà vano tu desvelo,

que sin ellas, Sol, Luna, y Cielo

son de su gloria migajas,

Pasqual hagamonos rajas, \&C.

El alma le has de ofrecer,

si le quieres obligar,

porque esta viene a buscar,

y por ella a padecer,

si esto hizieres, has de ver,

que en su gusto te auentajas.

Pasqual hagam[o]nos rajas. \&C. 
El alma se ha suspendido

con tan rara admiracion,

pues en ella el coraçon

no se halla de perdido,

mirando vn Dios escondido,

entre mantillas, y fajas,

Pasqual hagamonos rajas \&.C.

Por tan inmensos fauores,

aya gustos, y contentos,

y junten los instrumentos

las Pastoras, y Pastores,

muestren todos sus primores,

al pandero, y las sonajas.

Pasqual hagamonos rajas. \&C.

\section{VILLANCICO V1.}

\section{Estriuillo.}

Plaza, plaza,

que también la Plaçuela

viene de gracia.

1. Entre.

2. No entre.

1. Vaya.

2. No vaya.

1. Andar, andar.

2. Parar, parar

y por ser Plaçuela Real, proponga las razones,

que tiene para entrar.

COPLAS.

1. La Plaçuela de Palacio pide licencia de entrar, por mostrar en adorarle su mucha capacidad.

2. Quedese afuera, que avrà quien diga, 
que sin estar culpada la meten en la Capilla.

1. La primer razon que tengo, porque le deuo adorar,

es por $\mathrm{q}[u e]$ me han hecho grande, y tengo titulo ya.

2. Que le importa ser grande si reconoce,

que otros años lo ha sido, y quedado

a Buenas Noches

1. Todos saben que he seruido muchissimos años ha, y que aunque he seruido bien, siempre me han pagado mal.

2. De lo bien que ha seruido, ya està pagada, pues por lo que ha seruido en la Corte le han dado plaza.

1. Yo harè que mejore el sitio, de tal manera el Portal, que su ser ruin se ensanche, por mirarse tan capaz.

2. No quiere essos ensanches, como discreto,

porque teme le saquen a Plaça muchos defectos.

1. Pues por correr Mançanares. entrò dos años avrà yo por dexarme correr, lo merezco mucho mas.

2. Que importa, si de modo correr se dexa, que de puro o corrida, esta humilde como la tierra.

1.Campo espacio a su aplauso le podrè a lo menos dar, ya que el rio no lo hizo, 
porque le faltò caudal.

2. Su entrada se traia, gentil historia,

si no enfadara a quantos la vieran,

por espacio

$\mathrm{Si}$ el rio elado de frio,

se entrò al Sol a calentar,

yo estoy con frio, y mojado,

que es doblada enfermedad.

2. Alegue otras razones,

que hagan al caso,

porque lo que han propuesto

hasta aora

es todo barro.

Biblioteca Nacional. Madrid. (VE/88-64). "Vaya Xacara, vaya" 467(5).

Métrica: Villancico con jácara, típica de los bailes, cañas, versos octosílabos. Rima consonante. 
VILLANCICOS QVE SE CANTARON EN LA SANTA IGLESIA

Catedral de Málaga, en los Maytines del Nacimiento de Christo S. N. este año de 1667.

Compuestos por Don Alonso Torizes, Racionero, y Maestro de Capilla de dicha Santa

Iglesia.

DEDICADOS.

Al Ilustris. y Reverendis. S. D. Fr. Alonso de Santo Tomas, del Consejo de su

Magestad, y Obispo de Malaga.

\section{ILMO. SR.}

LA cortedad deste trabajo recibe calidad de el objeto siendo alabanças de Dios con que se haze digno de la atención de VS Ilust. y me da confiança para llegar a sus pies a lograr la continuacion del amparo que siempre he devido a VS. Ilust. cuya vida guarde Dios en la mayor grandeza.

V, L. P. de VS. Ilustris. su criado afectissimo

D. Alonso Torizes

\section{VILLANCICO}

Estribillo.

1. RAyos disparados son

los suspiros de mi Amado.

2. Perlas a roja lis son

los suspiros de mi Amado.

1. Rayos son, $\mathrm{q}[u e]$ no son perlas.

2. Perlas son, $\mathrm{q}[u e]$ no son rayos.

Mas si en rayos y perlas à disparado,

Alma cuydado,

si no estimas las perlas,

teme los rayos.

\section{Coplas}

Bucaros de claueles

que se inundan de perlas

por boca de vn Infante

despeñan dulce nectar. 
Lagrimas, y suspiros

dizen lo que le cuesta

satisfazer del hombre

a la justicia deudas.

Impetus mas ardientes

entre lo elado templa,

que son de amor incendios,

$\mathrm{y}$ de su amor son etnas.

Provido persuade

que en su amorosa escuela

solo experiencias de obras

acreditan finezas.

Atomos de sus luzes

a la nieve despeñan,

corrida de lo activo

de vn Sol que tanto quema.

Angeles a porfía

de luz el ayre pueblan,

cantando al cielo Gloria,

y Paz en la tierra.

\section{VILLANCICO IV.}

Gallego.

1. BArtolo.

2. Que mandades?

1. Mingos escuita.

3. Que me mandades?

1. Benan Galegos.

Todos. Que nos mandades

dicey, dicey?

1. Eu bu lo direy

Si me escuitais ben,

Vin Angeliños q[ue] andava $[n]$ bola $[n]$ do,

e por el ayre la Gloria canta[n]do.

Todos. Dicey, dicey.

1. Eu bu lu direy.

A vn Portaliño cheguey 
en bonora

e vna miNina mirey

como Aurora.

Vin au miNino

deitado o palleyro,

e que era Deus me dizo

o Crego.

2. Norabona beña

Miño deos Ceos,

beña norabona

para noso remedio.

1. Mi[n]gos,

pois que nos nace

la paz en la terra

tange gaytiña,

y vaya de festa.

Gayta.

Mingos,

pois a gaytiña a todos alegra,

por miño amor tocà otra bolteta.

Coplas.

Nun Portaliño miNino deitado

chega miNina de o bra $[n]$ co tre $[n]$ çado

y aunque a neve de o Ceo caia,

no le quitava tuda que tracia,

por $\mathrm{q}[u е]$ a noyte deitava chubeiros,

$\mathrm{q}[u e]$ os apañava de nosos agueiros,

y estas cosiñas, e outras como estas

eu las direi si la gayta sona.

Todos. Sone a gaytiña, e vaya de festa.

Huns angeliños no ve $[n]$ to $\mathrm{ca}[n] \mathrm{ta}[n]$ do

chaman Pastores $\mathrm{q}[u e]$ van tiritando

afeçoados a meu Zagaliño,

cada vn le leva su regaliño,

cal o cordeiro le tira da ovella

cal o q[ue] pousa no ventre a parella.

Vn Pastorciño chego de radeiro

cõs Galeguiños q[ue] viña $[n]$ de oteiro 
vendo q[ue $]$ o Niño chorava de frio

tira de en riba o gaban desu[...]io,

chega por cima de as dos dos alimañas

e se le deu coas suas entrañas.

y estas cosiñas \&C.

Toudos camiña $[n]$, nos vamos aora

ver o $\mathrm{q}[u e]$ tanto na terra enamora

e nos çurrones le vemos cu $[m]$ plido

lo que tuver cada vn escollido.

Para lle dar a mi Niño de rousa

y a su May q[ue] mi Nina fermosa.

\section{SEGVNDO NOCTVRNO}

\section{VILLANCICO V.}

Oy parte un hermoso Niño

de la Redencion al puerto,

nadie pierda la ocasion,

que es un viage del cielo.

\section{Estribillo.}

\section{Barquerito nuevo}

que la barca engolfas,

$\mathrm{y}$ al ayre tus plumas

buelan viento en popa

mira mis ansias,

oye mis quexas,

que me anego

me anego

si tu me dexas.

\section{Coplas.}

Pielagos de tierno llanto

tus ojos, tus ojos forman

que para nacer el Sol,

llora tambien el Aurora.

Ola, ola

echa el barco en el agua

de mis congojas. 
Barco se frague el pesebre,

golfo tu llanto componga,

que si aguardas como Niño,

mas como tierno enamora.

Barquero, Barquero,

que van por las aguas

mis remos.

Navega hàzia mi remedio,

que aun $\mathrm{q}[u e]$ la barca remontas,

no te alexarán tus alas

si te alcançaron mis olas

Ola \&C.

Biblioteca Nacional. Madrid. R. 34980-1.”Rayos disparados son”..(326.3) .

Métrica: rima asonante, versos octosílabos. "Ola, Ola", versos bisílabos, utilizados en el siglo de Oro, aparecen en la rima en eco y en ovillejos. 
VILLANCICOS QVE SE HAN DE CANTAR

la noche Buena en el Conuento Real de nuestra Señora de la Merced Cal.çada, Redempción de Cautiuos.

PVESTOS EN MVSICA POR EL

Padre Fray Iuan Romero, Maestro de Capilla del dicho Conuento.

EN MADRID.

Por Ioseph Fernandez de Buendia, año 1668.

VILLANCICO VII

Gallego.

Ao Sonciño, que bayla Gila

Tange a gaita.

Ay como suena, masa y como bayla.

E tan [...] a meu Neno le arrulla

Que me [...] gayta.

\section{COPLAS}

Ao sonciño bayla Gilera,

que lle faze Mingo Garrido,

Festejando al Deus que ha nacido

Na metad de o boy, e a muleta,

E Llourente dis chançoneta,

Por que sea grande a sua folgança.

Ay como suena, \&C.

En o portaliño grorioso

Nace Deus de frio chorando,

E sua Nay lle està calentando

No seu regaciño amoroso,

Mais o vento sopra $\mathrm{f}[$ uri]oso

Para le adormir con a elada .

Ay como suena, \&C.

Vn rio caudal es meu Neno,

Que de sua Nay ha salido,

Que sin que se sinta ruido

$O$ pesebre inunda sereno,

O que manso vay por lo feno,

Para enriquezer con sua prata. 
Ay como suena, \&C.

Nace de vna Nena mais pura

Que de o Sol o rubios cabellos,

Pois vestirse suele con ellos,

Para darles mais fermosura.

Es de palma la sua estatura,

Quel Diuino fruto nos guarda.

Ay como suena, \&C.

Tembrando de frio al Chicorro,

Si le veiran a miña terra

Con os Pastorciños da Serra,

Fora muito cedo Chamorro,

Ei brando lle deran aforro

Para cobijar a la sua cama.

Ay como suena, \&C.

De byalar non cesse Gileta,

Non da gayta pare [o] sonciño,

En tanto que no Pesebriño

El Deus de Galizia se deita

Porque a bolteta sea perfeita,

Faça na sua [...].

Ay como suena \&.C.

F I N.

Biblioteca Nacional. Madrid (V/E 77-33).

Métrica: versos de gaita gallega, octosílabos, ¡Ay como suena!. 


\section{VILLANCICOS QVE SE HAN DE CANTAR \\ en la Capilla Real de su Magestad la Noche de Reyes deste año de 1669. \\ EN MADRID, \\ Por Ioseph Fernandez de Buendia.}

\section{INTRODVCION.}

A festejar al Rey Niño

Vienen los Negros, y Negras,

Que son hijos de la noche,

Y buscan la Noche Buena.

Oy haze con los Pastores

Muy malas migas Guinea,

Porque a los Negros lo blanco

De los dientes no les entra.

Los Reyes Magos arrastran,

En lacayos ricas telas,

Y los del Rey Melchor viste

Cabos negros la librea.

Mas cerca de Dios se hallaron

Los Negros, segun las señas,

Porque en lo tostado dizen,

Que vieron al Sol mas cerca.

ESTRIVILLO.

NEGRO.

1. Antoniyo zi vemo tre Reya,

Doz brancos, y vn tinto, zelà

Noche Buena.

2. Plimo, Plimo, q[ue] vamo a la fezta,

Que zamo en la Noche de la

Nacimenta.

1.Que zi, zi, zi,

2. Que no, no, no,

Que de noche no nace lo Sol. 
1. Que zi, zi, zi, porq[ue] Dioza ha nazilo pol mi, Y pol vida tuya.

Que cantemo la Leluya,

A Iezuza, Malia, y Iuzé,

Gulumpé, gulumpé, gulumpé,

$\mathrm{q}[u e]$ a turu lo diabla ze dà Lucifé

De zaber la Nacimenta,

Y que vienen por la Orienta

Tre Reyas en dromedaria,

La Guinea, y la Canaria,

Pical, pical,

Anton zi vamo al Poltal,

Pol Xetafe caminal,

$\mathrm{Y}$ veremo la legua negla.

\section{COPLAS}

Tre Reya van con lacaya

De la branca, y la Guinea,

Con curulada liblea,

Que palece papagaya.

A Belen van con cauaya,

Y aunque la branca curriò,

Antez la negla llegò,

Que pica maz la pimenta,

Antoniyo, zi vemo tre Reya,

Doz brancos, y vn tinto zela Noche Buena.

Zi turo lo Rey ze nombla

Retlato de Dioz nacida.

Lo neglo ez maz palecida,

Polque ez de Dioza vna zombla.

Retlato de neglo azombla

En turo lu retlatado,

Polque Apelez, y el Tiznado

Zon Pintola de Guinea.

Antoniyo, zi vemo tre Reya, \&C.

Cun ezpada, y la maliya

Herodaz pol Nacimenta,

Mata tura la inocenta. 
A la branca, y la neguiya,

Da a turu Niño papiya,

Y Dioza riya zu cepada

Que zi Herodas tray colada,

Tizona yeua ò Rey Negla.

Antoniyo, zi vemo tre Reya, \&C.

Iuzé tiene a Reye en Luna,

Y eztà dulmiendo en la zuela,

Que en caza del Calpintela

A Dioza falta vna cuna.

Armohadiya de culuna

Zobre colchona pajiza,

Polque duelma lezuncliza,

Cantama a la mu lo bueya,

Antoniyo, zi vemo tre Reya, \&C.

Anton a turu Negliyo

De Belen noz echalan,

Que ez Belen caza de Pan,

Y zamo lo tizonziyo.

Al Niño Rey, que ez Plimiyo,

Por Angola le oflezcamo

Zeis negliyos, y aleglamo,

Que fuela de telciopela,

Antoniyo, zi vemo tre Reya, \&C.

Melece sel Rey de Angola

Tan helmoso Rapaciyo,

Que ez como plata el Chiquiyo,

Y de barro ze enamola.

Dezpidamo de Ziola,

Que ze và Negla, y plezumo,

Que za la ida del humo,

Zin andal pol chimenea,

Antoniyo, zi vemo tre Reya,

Doz branchos, y un tinta zelà Noche Buena.

VILLANCICO VI1.

GALLEGO. 


\section{INTRODVCION.}

Vna Procession de gaytas Al Portal tocando vienen, $\mathrm{Y}$ en venir vnas tras otras, Que son Gallegos parecen. Gallegos son, que en la cara Dizen la tierra que tienen, Porque todos los Domingos traen vnas caras de Viernes.

Los zapatos en la cinta

Caminan por el Diziembre, Que los Gallegos estiman En lo que pisan la nieue. Los primeros que llegaron, Fueron Toribio, y Llorente, Y en el Portalillo baylan

Dios delante, muy alegres.

\section{ESTRIVILLO.}

1. Toquen has gaytas Toribio, é

Llorente,

Que los Domingos por festa se tenen.

2. Tocay os Galegos,

E canten os Cregos.

3. Cantay Galeguiño,

Que nace Deus Niño.

1. Tocay a Cordeyro.

2. Non queyro.

3. Si Queyro,

Que Deus pode ser Obispo Dorense,

Toquen has gaytas Toribio, é Llorente, Que los domingos por festa se tenen.

1. Al Niño cantay,

2. A Deus folijay.

2. Su Madre, por bela,

Es Reyna en Castela,

En cuna pajiza,

Deus nace en Galicia,

Ay folyjay, folijay a Cordeyro. 
1. Non queyro.

2. Si queyro,

Que Deus é Galego, pois nace entre bueyes,

Toquen has gaytas Toribio, é Llorente,

Que los Domingos por Festa se tenen.

\section{COPLAS.}

Tanjeme al Cordeyro

Diuino, y Humayno,

Baylara el villayno,

Por el Caualeyro,

Dançaré ligeyro,

A Deus verdadeyro,

Que nace en pesebre,

Toquen ahas gaytas Toribio, é Llorente,

Que los Domingos por Festa se tenen.

Folijay en coro,

A o Rey garridiño;

Que viste de armiño,

Y es Deus el aforro.

Diò al home socorro,

Y de esclauo es horro,

Pois quitò la esse,

Toquen has gaytas, \&C.

Non cayga al fazer

Boltas Galeguiño,

Que llora Deus Niño,

Si nos vey caer.

Deus queire nacer,

que Adain por comer

Maytò sus parentes,

Toquen has gaytas, \&C.

A ò Reyna discreta,

Que ò Rey Niño guarda,

Tocay la Gallarda,

Por Españoleyta.

Tocay castañeyta,

Daré zapateyta

A ò Reyna, y a ò Reye, 
Toquen has gaytas, \&C.

Pois de festa estoy,

Si el pandeyro sacas,

Baylarey has vacas,

Aunque peyse al boy,

Que day boltas oy,

Y tembrando voy

De sus perendengues,

Toquen has gaytas, \&C.

F I N.

Biblioteca Nacional. Madrid. V/E. 91-18. "A festejar al Rey Niño" 3. hojas.

Métrica: a veces en los villancicos aparecen rítmos similares a una Nana. Versos de gaita gallega. Rima consonante. 


\section{LETRAS DE LOS VILLANCICOS QVE SE CANTARON EN LA SANTA YGLESIA de córdoba, en la Kalenda, Noche, y Dias de la Natiuidad de N. Señor Iesu Christo, este Año de 1669.}

\section{KALENDA.}

1. POr que el temor no te asombre Hombre, Hombre, vn Dios por tu consuelo suelo, Suelo busca, y deja el Cielo, yelo, yelo es tu culpa, incendio su renombre, nombre.

2. Nombre apacible!

3. Amor incomparable!

2. Que dicha!

3. Que fortuna!

2. Que fineza!

3. La Noche huye cobarde, arde

2. Arde en luzes la tierra yerra,

4. Yerra asustado el Bruto,

5. Incendios son las Selvas,

1. Y sonoros Clarines del Bosque con vozes suaves, aves,

2. Alegres, y parleras,

3. Publican en su Salva, Alva, que ya amanece risueña.

4. Los rudos troncos secos ecos, Repiten de Clarines,

5. Y alados Serafines, fines, de esperanças, y penas, 1. Y anunciando à los Hombres sus dichas, de vozes, y luzes, el ayre pueblan.

2. Para que conozcan por estas señas, el dia deseado, que ya se llega.

\section{COPLAS}

YA los Montes de Belen misteriosamente truecan a influencias soberanas el ceño inculto, en agradable esfera, 
para q[ue] conozcan por estas señas

el dia deseado, que ya se llega.

La negra frente à la cumbre,

corona de luz rodea,

y el Valle confuso estraña

examinada à Rayos la maleça.

Para que conozcan \& C.

Alegres los Arroyuelos

musica sonora alternan,

siendo risa lo que antes

rumor triste en Christal que se despeña.

Para que conozcan \&.C.

El mas culto retiro,

de la Campaña desierta,

pueblan Angeles, si nunca

se concediò a señal de humana huella.

Para que se conozcan $\& C$.

En confussion agradable

la Nieve, y Flores se mezclan,

y en Primavera dudosa

florece $[n]$ Copos, y Iazmines nieba $[n]$

Para que conozcan \& $\mathrm{C}$.

Cielo, Tierra, Montes, Valles,

Aves, Fuentes, Riscos, Fieras,

en indicios de alegria,

previenen a los hombres dichas nuebas.

Para que conozcan \& $\mathrm{C}$.

\section{VILLANCICO.}

1. Venid à ver prodigios

Pastores, en Belen

que en el à media Noche

vereis amanecer.

2. Dezidnos Zagales,

como puede ser?

1. En nuestras palabras,

no puede caber,

ni en tierra, ni en Cielo, 
ni en todo el desvelo

de humano poder.

2. Dezidnoslo pues,

1. Que, No, No, No,

que no puede ser,

pues solo la admiracion ,

lo puede dar à entender.

2. Dezidlo pues, que nosotros

lo admiraremos tambien.

1. Escuchad Pastores,

2. Vaya pues,

1. Honras y sabores,

3. Vaya pues.

1. Que a los pecadores,

4. Vaya pues,

1. Quiere Dios hazer,

5. Vaya pues,

1. Y admirense,

Que solo la admiracion,

lo puede dar à entender.

\section{COPLAS.}

Fuimos à ver esta Noche

vna Parida en Belen,

Iesus, y que bello Niño,

Madre de Dios, que muger.

Admirense,

Que solo la admiracion,

lo puede dar à entender.

Con los dos estava vn Viejo,

$\mathrm{y}$ eran juntos todos tres

vn pasmo, vn Cielo, vna Gloria,

Iesus, Maria, y Ioseph.

Admirense \&C.

Vna voz nos llebó à verlos,

y segun cantô despues

no es posible, fuese otro,

que el Archangel San Gabriel.

Admìrense \&C. 
La noche estava muy fria, y al yr corriendo tras el, en tanto calor entramos, que nos vino Dios à ver. Admirense \& $\mathrm{C}$.

A remdiar biene el mundo que tan perdido se be, y el remedio que a de darnos poder de Dios, y qual es! Admirense \&C.

\section{I1. VILLANCICO.}

\section{Estrivillo.}

Si os aflige el tiempo rigido

Señor, y la Noche es aspera, Vaya de jubilos, cesen las lagrimas, que si hazen las glorias los Angeles publicas de vn Dios sin macula, Pastores solicitos, dóciles, rusticos, en festejos logran Politica Clasica.

\section{COPLAS.}

EN el albergue mas infimo se hospeda entre pajas Palidas. el que es del Eterno Oraculo vnica dadiva.

Humilde yaze, y sin credito expuesto à la Nieue candida, vertie $[n]$ do en hermosos ordenes, líquidas lagrimas.

Al suelo baxa no timido, dexando Esferas diafanas à ser de vn elado Paramo funebre lastima.

A el hombre busca solicito, $\mathrm{y}$ afectos poniendo en practica, 
le ofrece al rigor de vn emulo, victima tragica.

De Amor en ardiente pielago alienta su llama calida, hasta que derrame prodigo purpura cardena.

Vaya de jubilos \&C.

\section{II1.VILLANCICO}

\section{GALLEGO.}

LEru, Leru, Leru, veña a ver o Fillo de Deus, Ferrol, Coruña, Ribadaiva, y Lemos, ay beñan muy preisto poys Angeliños, y os Pastorciños, à ó Portaliño veñen à vello. Leru, Leru, Leru, \&

\section{COPLAS.}

1. En suo sembrante Diviño me diz, ò Infante, que nace, que con os Galegos faze muito lindo Galegiño.

2. Querenle por suo cariño as moças de Ribadeo.

Leru, Leru, Leru, \&C.

3. Veña a Orense, é Compostela, Vila Franca, é Monte Rey, à ver ó noviño Rey, que à nacido de vna Estrela.

4. Dichosos seran en vela y al garridiño Galego, Leru, leru, Leru, \&.C. 
Biblioteca Nacional. Madrid. (V/E 127-61). "Porque el temor no te asombre".

Métrica: variedad de metros, fundamentalmente versos octosílabos. Rima en eco: suaves / aves.

Pausa versal. Versos de cabo roto, con las terminaciones de los versos truncadas. Coplas mixtas, romances con estribillo. Rima asonante. 


\section{VILLANCICOS QVE SE HAN DE CANTAR \\ en la Capilla Real de su Magestad la Noche de Nauidad desde año de 1670. \\ EN MADRID, \\ Por Ioseph Fernandez de Buendia.}

VILLANCICO II1.

INTRODVCCION.

Gallego.

Vn Castellano, y Gallego,

De genios tan diferentes,

Que vno està siempre llorando

Y otro està riendo siempre,

Cada vno con su tema

Se entraron hasta el pesebre,

Y cantaron a su modo

Diziendo de aquesta suerte.

\section{ESTRIVILLO.}

Escuyta, Bartolo,

Llorente, escuyta.

Cast. Dezid, que quereis?

Gal. Ya voslo diràn:

Mirad o meu Neno,

Branco que no ay mais.

Cast. Dezid, que quereis?

Gal. Ya voslo diràn:

Miray como chora,

$\mathrm{Y}$ repite ay.

Cast. Al son de su llanto

Mejor es llorar.

Gal. Mellor es reir

Para lo alegrar.

Cast. Yo quiero gemir.

Gal. Eu quero cantar.

\section{COPLAS.}

Cast. No canteis, que llora. 
Gal. Pois chora, cantay.

Cast. Que estoruais su llanto.

Gal. Seu llanto estoruà.

Cast. Al son de su llanto

Mejor es llorar.

Gal. Millor es reir

para lo alegrar.

Cast. Yo gusto del llanto,

Porque dizen mal

Lagr[i]mas ${ }^{9}$ de Dios,

$\mathrm{Y}$ risas de acà:

Yo quiero gemir.

Gal. Eu quero reir,

Que si el Neno chora,

Por gusto me fa,

Eu por recompensa

Le deuo alegrar.

Cast.Yo quiero gemir.

Gal. Eu quero reir.

Cast. Dexale que llore.

Gal. Non quero deixar.

Cast. LLorad mas mi Niño.

Gal. Meu Neno, no mais.

Cast. Al son de su llanto

Mejor es llorar.

Gal. Millor es reir

Para lo alegrar.

Cast. Verted essas perlas,

Que en ellas estàn

Mi satisfacion,

Y vuestra amistad:

Yo quiero gemir.

Gal. Eu quero reir,

Que si satisface,

Y amistad me dà,

Deuo por amego

Quitalle el pesay.

${ }^{9}$ En el original, Lagrmias. 
Cast. Yo quiero gemir.

Gal. Eu quero cantar.

Cast. Al son de su llanto

Mejor es llorar.

Gal. Millor es reir, \&C.

\section{VILLANCICO IV.}

\section{ESTRIVILLO.}

\section{XACARA.}

Ela, ela,

Que viene, que llega

La jacara nueua

De gusto, y de risa,

De garbo, y de porte,

Que llega matante,

Que viene de Corte,

Que es de un valiente la historia,

Que auiendo nacido apenas,

Por ver la noche tan cruda,

Dio con todo el cielo en tierra.

Que viene, que llega

La Xacara nueua

Ela, ela.

\section{XACARA.}

Allà và la xacarilla

De aquel Valenton del hampa,

Que con el tiempo por crudo

Quiso salir a campaña.

El que en las eternidades

Allà en si mismo se estaua,

Hasta que huuo vna discordia

No sè sobre que mançana.

Trató de venir al mundo,

Y empeñando su Palabra,

Con solo su altento echó

Vn Angel por la ventana. 
Llegò a Nazaret, y al punto

Con vna Donzella habla;

Turbòse, y tambien la Niña

Se turbò, pero con gracia.

Dixola el Angel: de parte

Del muy Alto es mi embáxa,

A que obedeciò diziendo:

Yo Reyna? No sino Esclaua.

Baxó luego a hazerse hombre,

Y preuenido de gala,

Con vn vestido encarnado,

Dispuso el hazer la entrada.

Retiròse nueue meses,

$\mathrm{Y}$ en la noche mas elada

Del erizado Diziembre

Hizo vna salida estraña.

Echa[ $n]$ do vn cuerpo de Christo,

Todo el infierno temblaua

Por ver que a la media noche

Saltó sin romper el Alva.

Vn Portal fue la palestra,

$Y$ en vnas humildes pajas

Diò con todo el cielo en tierra,

Solo por una villana.

$\mathrm{Al}$ alboroto llegaron

Pastores de la comarca,

Que algun Angel fue sin duda

Quien estas cosas guiaua.

Vieron en vn Portalillo

Temblando al frio, y la escarcha

Vn Niño, y naciendo apenas

Le miran hombre en sustancia.

Publicaronse las pazes,

Mirando al Niño, que estaua

En los braços del Aurora,

Que el Arco de Paz señala. 
Biblioteca Nacional. Madrid. (V/E 88-66 (I). "Vn castellano, y Gallego". Métrica: polirritmia, varios tipos de métrica, rima asonante, parcial. 


\section{LETRAS DE LOS VILLANCICOS DE NAVIDAD, que se han de cnatar en la Santa Iglesia de Toledo Primada de las Españas, este año de 1670.}

\section{VILLANCICO V. \\ Romance.}

SV yelo esgrime la noche, el Sol fulmina su ardor, que lo abrasa, aqui del yelo, que lo yela, aqui del Sol. Con la mas villana sombra lucha el mas noble arrebol, que ciega, aqui de su luz, que alumbra, aqui de su horror. Contra amor que arroja perlas, de yelo el desden se armò, que llora, aqui del desden, que ofende, aqui del amor. Del hombre y Dios hazer compuesto amor quiere en dulce vnion, que lo eleua, aqui del hombre, que lo humilla, aqui de Dios.

\section{Estriuillo.}

Despertad, Zagalexos, cantad al amor: pero no canteis, llorar es mejor, que al compas de su llanto llora la Aurora, y suspira el Sol.

$$
\text { Coplas. }
$$

Elado Sol en llamas, nieue abrasada en yelos, fuego que estàs temblando, cristal que estàs ardiendo. En braços del Alua 
te aliuien del tiempo

rigores tan duros,

alagos tan tiernos.

Mucho dizes callando,

quando callas sintiendo;

quien viò en palabra muda

silencio tan parlero!

Si mudo te explicas,

mirando te entiendo,

que escuchan los ojos,

quando habla el silencio.

Oy es de tu fineza

mi ingratitud el premio,

pues fueras menos fino,

a ser yo mas atento.

Que suelen finezas

nacer de desprecios,

y en medio de agrauios,

amor es estremo.

\section{VILLANCICO VI.}

\section{Estriuillo.}

Ao sonciño que baila Gila,

tange a gaita,

ay como suena,

mas ay como baila,

è tan dolce a meu Neno le arrulla,

que me le engaita,

ay como suena,

mas ay como baila.

\section{Coplas.}

Ao sonciño baila Gileta,

que lle face Mingo Garrido,

festejando a Deus que ha nacido

na mitad de o boy, e a muleta,

è Llorente diz chançoneta, 
por que sea grande a folgança,

ay como suena, \&C.

En o Portaliño glorioso

nace Deus de frio chorando,

è sua Nai le està calentando

no seu regaciño amoroso,

mais o vento sopra furioso

para se dormir con la elada,

ay como suena, \&c.

Vn rio caudal es meu Neno,

que de sua Nai ha salido,

que sin que se sinta ruido,

o pesebre inunda sereno,

o que manso vai por lo feno

para enriquecer con sua prata,

ay como suena, \&c.

Nace de vna Nena mais pura,

que de o Sol os rubios cabelos, pois vestirse suele con elos

para darlles mais fermosura, es de palma su estatura,

que diuiño fuito nos garda, ay como suena, \&c.

Tembrando de frio el Chicorro, si lle viran en miña terra, con os pastorciñós da serra fora muito cedo chamorro, e brando lle deran aforro para cubijar la sua cama, ay como suena, \&c.

De bailar non cese Gileta, nen da gaita pare o sonciño en tanto que no pesebriño el Deus de Galiza se deita, porque a bolta sexa perfeita na sua vida faza mudança, ay como suena, mas ay como baila, \&c. 


\section{VILLANCICO VII}

\section{Romance.}

A Hazer concierto viene entre hombre, y Angel Dios, mas el concierto todo parò en oposicion. Quedò vaco el lugar primero de su amor, $\mathrm{y}$ acariciando a entrambos diò zelos a los dos.

Teme el hombre, que el Angel elija por mejor, el Angel porque al hombre le inclina la passion. Publicose el concurso, $\mathrm{y}$ el cielo despachò vozes con muchos rayos, rayos con mucha voz.

\section{Estriuillo.}

Al Edicto que el cielo pub[1]ica ${ }^{10}$ Vengan, señores, y aunq $[u e]$ muchos opuestos se miren, lleguen conformes:

y veràn que oy vn Principe viene desde su Corte,

a premiar a los que en sus afanes saben ser hombres:

oygan las vozes que dan los cielos, que estas son de la gloria a $\mathrm{q}[u e]$ aspiran los dulces ecos:

corran belozes, buelen atentos, venga $[n]$, y lleguen al sacro alvergue, que vn Principe enriquece, y llena de clemencia, y sin dexar del puesto la eminencia,

${ }^{10}$ En el original, pubiica. 
oy humano se ofrece,

y a cada qual darà lo que merece.

Coplas.

De los cielos oy se llama

a la tierra a vn alto empleo

tan superior, que està a todos

si le logran, de los cielos.

Oy se llama

a vn alto empleo,

que està a todos

de los cielos.

Muchos vienen al Edicto,

por conseguir deste emepeño

el lauro a que se comboca

lo mejor del vniuerso.

A sus vozes, auisados

los Pastores, concurrieron,

que en la Iglesia, los Pastores

en todo son los primeros.

Auisados

concurrieron

los Pastores

los primeros.

Lleguen, pues, que todo es gloria

quanto se oe en este Templo,

$\mathrm{y}$ admirense, pues son pazes,

no oposicion, los encuentros.

Todo es gloria

en este Templo,

pues son pazes

los encuentros.

A premiar viene vn Dios hombre, sus meritos desde el cielo,

tan a tiempo, que aunque tarde, es cierto que lega a tiempo.

Vn Dios hombre

desde el cielo,

aunque tarde, 
llega a tiempo.

Ciñe lo grande, aunque puede

ostentarse como dueño,

y aunque es Deidad, muy humano

con los suyos, viene el Verbo.

Aunque puede,

como dueño,

muy humano,

viene el Verbo.

Tengan cuenta, que lo firme

de la ciencia de su Reino

son las obras, pues que al justo,

segun ellas, darà el premio.

que lo firme

de su Reino,

es que al justo

darà el premio.

A ceñirse todos cor[r]an

este laurel con aliento,

que aunque dizen que vno solo,

quien merece lleua el puesto.

Todos corran

con aliento,

que vno solo

lleua el puesto.

Mayor serà quien se mira

en si mismo con desprecio,

pues sabe el que mas alcança,

que sube mas por lo menos.

Quien se mira

con desprecio

mas alcança

por lo menos.

Al Edicto, \&C.

Biblioteca Nacional. Madrid. V/E 661-1. R. 34982. "Entre el llanto y la risa".

Métrica: romance, octosílabos, variedad polimétrica y polirritmia. Coplas castellanas. Arte menor.

Rima en general asonante, parcial. 


\section{LETRAS DE LOS VILLANCICOS QUE SE CANTARON EN LOS MAYTINES \\ del Nacimiento de Christo S. N. en la S. Iglesia Catedral de Malaga, este año de 1671. PVESTOS EN MUSICA}

Por Don Alonso Torizes, Racionero, y Maestro de Capilla de dicha S. Iglesia.

\section{K A L E N D A.}

1. HOmbres q[ue $]$ muere la noche, que eternidades presume.

2. No muere, que sus candores, el Alva aun no los descubre.

3. No es candor el que brilla el Oriente, que ilustra los valles, y dora las cumbres?

4. No es horror el que influye el Ocaso, que el vago elemento del ayre discurre?

5. Sombras parecen,

6. No son sino luzes.

7. Prodigio raro.

8. Portento ilustre con luzes que ya brillan, con rayos que ya lucen, las sombras se equivocan la noche se confunde.

1. Señas son de vn Sol que nace, sin Ocaso que le turbe, pues la esfera de la noche en dia se restituye, para que vençan, para que triunfen sufridas esperanças, que ya se cumplen.

Todos. Llegue el Sol deseado, lleguen sus luzes, pues de la noche al dia nos restituye.

$\mathrm{Ho}[m]$ bres de aquesta escuela salgan con entendimiento, 
que en alta filosofia,

no es el nacer el tenerlo.

Hombres que sepan de lides, $\mathrm{y}$ en mas heroicos alientos,

publiquen a fuego, y sangre

batalla contra si mesmos.

Hombres que esforçados rinda,

y que arrebaten violentos,

a precio de sus fatigas,

todo el Reyno de los cielos.

Mas oy ya se dan de valde,

pues a los suspiros tiernos

de vn Niño, su mayor gloria

se ha[ $n]$ inclinado ellos mesmos.

\section{VILLANCICO VI.}

\section{Gallego.}

Pois ha nacido

o Fillo de Deus,

tange Pedro

Tange a Gaitiña

de festa, e contento,

pois ha nacido

o Fillo de Deus.

\section{COPLAS.}

Veñan Galeguiños,

ao Portal entreimos

a adorarme vn Nino,

toudos placenteiros.

Magestad tan bela,

en fermoso geisto,

no la ten, par dicas,

o Conde de Lemos.

Aun mellor que o miño

de sus ollos beyo

as perlas garridas, 
sembrar toudo o feno.

La fermosa Nena, mais pura que o ceo, que el Sol se cobija de los seus cabelos.

En seu regaziño

poune eu Nino belo, e calmava a vista, como en craro espeijo. Recebid meu Nino eusos dois cordeiros, pois soys semeyança de la sua paz de elos. Catro camuesiñas tamben os trayemos, que para vos dar non somos Galegos. De veros tembrar, ao rigor de o tempo, van os Galeguiños toudos muy azedos. Pois ha nacido, \&C.

\section{VILLANCICO VII.}

A batalla mi desden a Dios llama en vn Portal, Dios se humilla bien al mal y el se rinde mal al bien.

\section{COPLAS.}

Si los dedenes sentis del hombre, no ay para què, pues si del gusto no son, del credito avran de ser. Arder entre las ofensas, sin templarse, esso es querer, porque amar a quien obliga, aun mas que fineza es ley. 
Siempre del amor que es fino corona el desprecio fue, porque gozar sin batalla es possession sin laurel. Si añade glorias el triunfo, amad, Señor, no lloreis, que tendreis mas que gozar, aviendo mas que vencer.

\section{VILANCICO VIII.}

\section{Negro.}

HA zo Anton, ha zo Anton, no respondemo?

Ha zo plimo.

2. Que tenemo?

1. Como venimo tan glave?

2. Ya no zabe que samo Alcalde de este año?

y no me amaño

a parlal como çolia?

2. Bueno ezà pol vila mia.

Y de ezà la Alcaldia que tiene vuesamelsè?

2. Tenemola de ponè el camino de Belè turo limpio, y turo yano, como palma de la mano, que podamo en el baylal 1. No diga tal, que ha de ser con glavedad Alcalde de lo moleno.

1. Como no? Agola velemo como se misca el polvico.

\section{Toca Flasico}

lo tamborlico, y repica de valde, que vaylamo el Siñol Alcalde. 


\section{COPLAS}

1. Saran glave desde ayè, que a pleguntal no atlevemo, porlque neglo no quelemo enojal a su melsè: diga si puede sabè lo que quielo pleguntal, pero si se ha de enojal, Anton cayarà su pico.

Toca Flasico, \&C.

2. Bien podemo en mi conciencia, pleguntal lo que quisiere, y si con repelto fuere, dalemo lo Alcalde audiencia: no plegunte impeltinencia, nimucho, puez q[ue] le ezcucho, quezto de pleguntal mucho se queda pala lo rico.

Toca Flasico, \&C.

Biblioteca Nacional. Madrid. R.34980-2. "Hombres que muere la noche". Métrica: versos octosílabos, propios del villancico. Rima asonante, romanceada. 


\section{LETRAS DE LOS VILLANCICOS, QVE SE CANTARON EN LOS MAYTINES DEL NACIMIENTO DE N. S. IESU CHRISTO, EN LA SANTA IGLESIA METROPOLITANA DESTA CIVDAD DE SEVILLA, ESTE AÑO DE M.DC. LXXI. Compuestos por el Racionero Iuan Sanz, Maestro de Capilla de dicha Santa Iglesia. IMPRESSOS EN SEVILLA. \\ Por IVAN FRANCISCO DE BLAS, su Impressor mayor.}

VILLANCICO VI.

Gallego.

1. AY tangei à gaytiña.

2. Ay tangei, è cantai,

3. Ay leru leru à compàs, ay tangei, è bailar:

Ay leru leru à compàs, Ay tocai frautiña, bailay à gaytiña, è à castanetiña, alto Galegos chegai à bailar. Ay leru leru à compàs, è dad cabrioliñas:

Ay leru leru à compàs.

\section{COPLAS.}

VEnan Galeguiños, venan à bailar, a noite que nace noso Mayoral. Ay leru leru à com[p]ás ${ }^{11}$. $\mathrm{O}$ recien nacido, no pesebre està, à palla enriqueze solo con chorar. Ay leru leru à compàs.

\footnotetext{
${ }^{11}$ En el original, comoás.
} 
La sua Nay fermosa,

Zagala sin par,

de su llanto quiere

facer vn zartal.

Ay leru leru à compàs

A coller el grano,

que en su parva està,

colanse os Pastores

dentro no Portal.

Ay leru leru à compàs.

Hallan vn Tesouro

qual no foy jamas,

en cuna de prata

neno de cristal.

Ay leru leru à compàs.

Assombrado Mingos,

foise à persinar,

sin poder de espanto

fazer la sinal,

Ay leru leru à compàs.

\section{VILLANCICO VII.}

\section{Estrivillo.}

NVeva celestial,

y tal:

que tuvo fin nuestro mal,

y yà nuestro mal es bien,

que mas bien,

que vèr en Belen

la gloria, y el bien

en forma mortal.

\section{COPLAS}

LOs estremos mas distantes

de Dios, y hombre veràn,

que el amor los ha juntado,

y està noche naceràn. 
Solo Persona Divina

se pudo à tanto empeñar,

$\mathrm{q}[u e]$ siendo Dios se haga hombre,

y muera siendo inmortal.

Ser humano el ser Divino,

vistiendo humano sayal,

y en este trage necer,

le vereis en vn Portal.

El Cielo tendrâ sus glorias,

la tierra tendrà su paz,

y sus hazañas los hombres

à vozes publicaràn.

Nueva celestial, \&C.

\section{VILLANCICO.}

\section{Estrivillo.}

1. A Belen, Zagales, que à nacido el Sol.

2. Quedito, que llora.

3. Pasito, $\mathrm{q}[u e]$ rie humanado Dios.

1. No, no, le recuerden, no,

que en los braços del Alva

descansa el Amor.

2. Ay que dolor:

Recibid Niño hermoso

mi coraçon,

$\mathrm{q}[u e]$ à mi me duele, y os adora à vos.

3. Ay que dolor.

2. Ay que plazer.

1. Pues adoro à vn Dios Niño, dexenme,

$\mathrm{q}[$ ue $]$ llora $[n]$ do mi mal, co $[n]$ sigo mi bie $[n]$.

Dexenme, dexenme.

\section{COPLAS.}

SI Dios por librarme

del perpetuo Angel,

su llanto me lima 
yerros que labrè.

Dexenme, \&C.

Si Dios por no herirme,

siendo recto Iuez,

humano convierte

el rayo en laurel. Dexe[n]me, \&C.

Si Dios es tan fino,

que sabiendo, que

se nace à morir,

muere por nacer.

Dexenme, \&C.

Si Christo, que es Piedra,

la Piedra Iman es,

que me lleva el hierro

por verme sin èl.

Dexenme, \&c.

Si el arroyo helado

que dormir le vè,

por no hazerle ruydo.

no quiere correr.

Dexenme, \&c.

Biblioteca Nacional. Madrid. (R. $83 \mathrm{n}^{0}$ ). " Anegado en sus dolores”.

Métrica: villancicos polimétricos, coplas castellanas. Rima asonante. Coplas en gallego, reiterativas,

"Venan Galeguiños...", como si se tratase de una letanía continua. Hay polimetría, propia del Siglo de Oro. 


\section{VILLANCICOS QVE SE HAN DE CANTAR \\ en la Capilla Real de su Magestad la Noche de Nauidad deste año de 1672. \\ EN MADRID. \\ Por Ioseph Fernandez de Buendia.}

VILLANCICO V.

PORTVGVES.

ESTRIVILLO.

Le, le por la minha Fè;

le, le que vos he de amar;

le, le que vos he de querer;

le, le que naon posso mais.

\section{COPLAS}

Minino fermoso,

para que chorais?

ollai que essas perlas

es muito caudal.

Le, le por la minha Fè, \&C.

O tempo os aflige, siendo o frio tal, que solo o amor sofrirle podrà. O poder do Sceptro do Reyno Eternal, està en vossas manos, $\mathrm{y}$ ahinda està mais.

Senhor, he possible que tiranisar podesse hua culpa tanta Magestad?

Mais que marauilla, que a ofensa mortal obrigàra a Deus 
a tanto penar?

Que estraña finesa

os debemos ya,

pois en carne humana

nos mostrais amar!

Todo me derritu

por congratular

tanto Sol fermoso,

que arde sin quemar.

Pois naceis ao mundo,

a otro Rey le dad,

de tantos Imperios

el goze con paz.

Y a la Rainha Mae,

pois es vossa ollai,

con ollos, y afeitos

de vossa piedad.

Le, le por la minha Fè. \&C.

\section{VILLANCICO VI.}

\section{ESTRIVILLO.}

Gil, y Bràs mancomunados, del Niño han de censurar, que no solo el murmurar se hizo para los estrados.

\section{COPLAS.}

Gil. Tu tambie $[n]$, Bràs, has venido al Nacimiento Sagrado del Hijo de Dios, que es Ho[m]bre aunque le ves tan Muchacho?

$B r$. Este es el Hijo de Dios?

Gil, pues yo estaua juzgando, que el Hijo de Dios lo era el Santo Christo del Pardo.

Gil. No ves su bendita Madre como le està contemplando? 
aunque le huuiera parido

no pudiera amarle tanto.

La mula, y el buey estàn

cerca del pesebre echados;

que es muy propio de las bestias

el estar acomodados.

Tres Reyes desde el Oriente

han de venir a adorarlo,

porque esto del adorar

solo se entiende en Palacio.

Vna Estrella de los Cielos

tendrà estrella en alumbrarlos,

que es luz muy acomodada,

por no andar despauilando.

Dandoles vista a los ciegos

los ha de hazer de su vando,

siendo vna gente, que antes

no le pudo ver pintado.

Los coxos celebraràn

sus marauillas de passo,

porque en sanando, corriendo

se le iràn con los milagros.

Quando sane endemoniadas,

dudarè, a quien ha librado,

si al diablo de las mugeres,

ò a las mugeres del diablo?

Yo pienso pedirle al Niño

por merced, que me haga Santo;

pero en Iglesia en que no aya

Sacristan que ande con palos.

Yo pienso pedirle el Cielo,

que es lugar acomodado,

porque para la salud

es bueno viuir en alto.

\section{VILLANCICO VII.}

GALLEGO. 


\section{INTRODVCION.}

Esta noche los Gallegos, festejando al Niño Rey, en mudanças de villano mostraron su noble Fè. Con el çapato en la cinta, por no tropezar con èl, van muy calçados de barba, y muy lampiños de pies. Al Niño, cierto Gallego le pidiò prestado el buey, porque ya lo dado es dado, y lo prestado tambien.

Bostezando con el hambre, llegan cantando a Belèn, la boca de par en par, y la bolsa pez con pez.

\section{ESTRIVILLO.}

Pues esta noite à nacido o Cordeiro, $\mathrm{zu}[\mathrm{m}]$ be a gayta, retu $[\mathrm{m}]$ be o pandeiro. Tocay Galeguiños, tocay a gaytiña, que oy ha nacido, o Rey de Galicia. Ay Toribiño, chegay, è no temas $\mathrm{q}[u e]$ hasta la mula de o Rey es Galega. Oranday de bulla, di gira, é de trulla; tocay la flautiña, tocay, que retiña a la Paridiña, que tein en la palla ao Rey Celestial. Tocay Galeguiños, ay, ay, ay, Baylay Toribiño [áo] ${ }^{12}$ Rey, que es vn Niño

\footnotetext{
${ }^{12}$ En el original, $o$ à.
} 
mais branco, è rubiño

que o Sol Oriental.

Tocay Galeguiños,

ay, ay, ay.

Correy, paray, è bolteay,

tocay è cantay,

è andese a gayta por el Portal.

COPLAS.

Para librainos del yeyrro,

quey nos puso vna maliza,

Deus ha nacido en Galiza

poi buscair la Cruz del Feyrro.

En lo desnudiño,

que es Galeguiño

non poide negar;

tocay, è cantay, \&C.

Os galeguiños ao Rey, è a su May,

De May, è Doncela el parto

ha nacido o Niño Rey,

è si queire darme o buey

eu teño de dairle vn carto.

E yo farè harto,

que por su pobreyza,

en toda Galeyza

vn carto no ay;

tocay, é cantay, \&C.

Traballo al pey de la seyrra

le mando, è si ha de payssar

hambre, è sed, para ayunar,

es famosa nosa teyrra.

La neue se afeyrra,

è chuzos arroyja,

poilo que hyzo Adan;

tocay, è cantay, \&C.

Cantay todos a la bela

Soberayna, è Virgen pura,

que eyta Nauidad el Cura

nos dixo que eira Doncela. 
Reyna de Castela

es por garridiña,

por blanca, è rubiña

del mundo seray;

tocay, è cantay, \&C.

$\mathrm{Eu}$ Niño que chora graue,

con Maria por mi ben,

paray regalairse ben

fa los pucheyros con Ave.

Su May es la Naue

que os Celos agota,

è tray esta Flota

el Armada Real,

tocay, è cantay, \&C.

Ao Niño que tembla chebe

vn neglo, aunque say borron,

queis gusto dair o carbon

haziendo tempo de neiue.

Amante se mueiue

a paigar escote,

que tray o Chicote

pegaydo o pañal;

tocay, é cantay, \&C.

Toribiño dayndo voyzes,

a lo Rey recien nacido

le ha day do noyzes, è ha sido

mas el roydo que las noyzes.

La mula day coyzes,

que in so mal sentir,

veindolos partir

los queiso cascar.

Tocay, è cantay

os Galeguiños ao Rey, è a su May.

FIN. 
Biblioteca Nacional. Madrid. (V/E 88-67). "Le, le por la minha Fè”. Versos polimétricos, octosílabos, aunque a veces aparecen con 6 sílabas, otras con 4 sílabas; tetrámetro, tipo "Pange Lingua gloriosi”, documentado en todo el dominio románico. Versos hipermétricos, con rima asonante. 


\section{LETRAS DE LOS VILLANCICOS QUE SE CANTARON EN LOS Maytines del Nacimiento de NUESTRO SEÑOR JESU-CHRISTO, en la Santa Iglesia Metropolitana de Sevilla. \\ CO MPVESTOS \\ POR EL RACIONERO \\ IVAN SANZ, MAESTRO DE CAPILLA \\ DE DICHA S. IGLESIA. \\ EN SEUILLA, por la Viuda de Nicolás Rodriguez. \\ Este presente año de 1672.}

\section{COPLAS.}

Poys nace tan fidalgo,

è quere en todo serlo, porque ningun le poña en su Nobreza preyto, Ay él.

Chorando en vnas pallas; mas co sus liños velos, aynda chorando, é dizen: Rinde el alma co elos. Ay él.

Porque estos Judios ainda que nace entre elos, que no teñe arroña, é todo Cavaleyro. Ay el, \&C.

Poys en nosa mallada fica lo badoneyro, que o Fillo de o Conde nau yà merece serlo. Ay él, \&C.

\section{XII}

Ay daquela vanda, ou desta Fálame una Santiaguesa. 


\section{COPLAS}

Ay, daquela ou desta vanda, Falame una galegada.

Ay, si fermosa e sua Nay, En os coes ten seu Pay.

Ay garridiño he u Garzone, Mais que o fillo do conde.

Ay, jaze en o portal o miniño

Con a mula e o vecerriño.

Ay, cavodoneyro o chaman, Vamos a la sua mallada, Ay fermoso e garridiño, Jaze en un Pesebriño. Ay fermosura agrazada, Trillando vay a palla. Ay, paridiña he a donzella, E a Nay como una estrela. Ay veñe a la nosa teirra, en a noite pracenteira.

Ay inda que en ateirra nace, Angeles dos ceos o apracen. Ay fican dos seus pucheiros Os homens pracenteiros. Ay, mais que os de Compostela $\mathrm{Y}$ a sua parentela.

Ay, fermosura tamaña, Mal grado foy que praña. Ay, seus olhos son tan belos, Que las almas rinde co elos. Ay, està muy pracenteiro Todo o mundo enteiro. Ay, pela nossa campiña Tangei sedo a gaitiña. Ay, tangelde o pandeiro Que ele se farà galego Ay, si he sua Nay tanbela Solo pode ser galega. Ay, daquela vanda, etc. 


\section{VILLANCICO VI.}

Negro.

\section{A Zeñora Flanciquiya?}

2. Què me manda buezanze?

1. Que tlayga su guitarriya, y acompañe mi rabé.

2. Pala qué? pala què? Pala què?

1. Escucheme plima, que yo lo dilè.

2. Digalo plimo con zolfa mi re, yo lo dilé.

2. Paleseme ben.

3. Turo Neglo hasemo fiesta à tan Sobelano Reye,

y vestiros de dansanta le baylamo el zulambeque.

2. Paleseme ben el tequereteque; ay que reteque, mas ay $\mathrm{q}[u e]$ reteque.

3. Vaya plima de zulambeque.

4. Y turo Neglo cantémo el reteq[ue];

2. Ay que tequereteque, vaya plima de zulambeque.

\section{COPLAS.}

AL Reye que và en Carosa, fiesta hasemo que le alegla, polque sepa que lo Negla samo Vasalla bliosa, que echando de la gloliosa, baylamo hasiendono rajas, y con pandela, y zonajas hasemo mil sonsonete, teque, teque, reteque, reteque. Disflasado turo plimo con la capirota larga, y vestiros le botar ga en mosiganga salimo, $\mathrm{y}$ tanta invension fingimo, 
que nueztro plimo Antolin

sale hasiendo el Matachin,

yevando ensendido vn cuete,

teque, teque, reteque, reteque,

vaya plima de zulambeque.

Pol donde lo Reye ván

pala ha ser mucha entlemesa,

con bonete en la cabesa,

y camison de ruàn,

se vistiò de Saclistan

vn Neglo de Monicongo,

y al Rey quitó el bonete,

teque, teque, reteque, teque,

vaya plima de zulambeque.

Dando imbidias à lo branco,

palesiendo al Molo Muza,

salimo con caperusa

mucho Neglo puesto en zanco;

luego saltamo de un tlanco

con cavayito, y con lansa,

corriendo hisimo la dansa

del toriyo que arremete,

teque, teque, reteque, reteque,

vaya plima de zulambeque.

\section{VILLANCICO VI.}

\section{Estrivillo.}

EN las pajas del Portal,

los Zagales de Belen

llegan à coger el bien

en vn grano celestial.

COPLAS.

1. GLoria es ver à Dios nacido, y verle nacer tambien, pues llueve en sus ojos oy lo que he de coger despues. 
2. Pues si esso es,

digo, que huyendo del mal,

llegan à coger el bien

en vn grano celestial.

1. Perlas sus lagrimas son, porque quiere padecer:

$\mathrm{y}$ aquestas perlas de amor oro serán otra vez.

2. Pues si esso es, dudar no puede el mortal, llegan à coger el bien en vn grano celestial.

1. Finezas de su aficion obstenta en su desnudez; pero es facil que mi error lo vista de lo cruel.

2. Pues si esso es, los que obran con fee cabal llegan à coger el bien en vn grano celestial.

1. Luzes brilla como el Sol contra la noche cruel, pues assi quiere mostrar que nos viene Dios à ver. 2. Pues si esso es, todos en misterio tal llegan à coger el bien en vn grano celestial. 1. En sus penas el favor venturoso el mundo vé; porque en ellas la cizaña de vn yerro se ha de perder.

1. Pues si esso es, no es el dezir desigual, llegan à coger el bien en vn grano celestial.

1. Sus ansias logra mejor si las cultiva la Fè, que son tesoro escondido 
en el campo de su ser.

2. Pues si esso es, todos hallando caudal, llegan à coger el bien en vn grano celestial.

\section{VILLANCICO VIII.}

\section{Gallego.}

POys en nosa terra,

o meNino de Osseos ${ }^{13}$, chorando en las pallas esta noyte tenemos; venid, venid, Gallegos, que en el Portaliño con o vaqueriño mas blanco que armiño, faze pucheyros; ay êl se farà Galego. Dexad o mi Nino cobodoneyro, que xima, que praña, que fique ao sereno; ay él se farà Galego.

Biblioteca Nacional. Madrid. (V/E.1309). " Poys nace tan fidalgo".

Métrica: con versos hipermétricos, octosilábicos, incluso una cuarteta preciosa. La estructura es típicamente rítmica, propia del verso español. A veces hay repeticiones en los villancicos ad libitum. Hay poemas estróficos de cuatro versos, muy usados en la literatura española.

\footnotetext{
${ }^{13}$ Es decir, de os Seos 'de los Cielos'.
} 


\section{LETRAS DE LOS VILLANCICOS DE NAVIDAD,}

que se han de cantar en la Santa Iglesia de Toledo Primada de las Españas, este año

de 1672.

\section{VILLANCICO I.}

\section{Estriuillo.}

1. TOdo es tristezas la tierra,

tinieblas por galas viste,

y en desaliños, y horrores

acordando està su origen.

2. Solo fatigan lamentos

del ayre esferas sublimes,

duplicandose suspiros

al eco que los repite.

3. Ay infelizes!

hasta quando sera $[n]$ lagrimas tristes?

4. Desmayos, y esperanças se co[m]pite $[n]$, que la promessa alienta,

y la tardança aflige.

5. Digalo el sentimiento:

ay.

6. La pena lo publique:

ay.

7. Ya lo explican las vozes:

ay.

Ya los ecos lo dizen:

ay.

3. Ay infelizes!

hasta qua $[n]$ do seràn lagrimas tristes?

1. Mas ya ostenta $[n]$ muda $[n]$ ças los orbes,

$\mathrm{q}[u e]$ son de la dicha anuncios felizes.

2. Mas ya alegres el cielo, y la tierra, de flores, y luzes belleza co[n]sigue $[n]$.

3. Las aues gorgean,

las fuentes se rien. 
4. Los prados se adornan de hermosos matizes.

5. Y a la luz.

6. A la voz.

7. Al adorno atento el deseo

del hombre colige,

que quiere nacer el Sol,

pues que la Aurora se rie;

porque la esperança

que en sombras viue,

à sus rayos logre

dichosos fines.

\section{Coplas.}

De la campaña del Alva, a tanto prolijo eclipse sucede en luz admirable mucha lisonja apacible.

Hermoso, y claro el Oriente molestas sombras corrige, con nueuas luzes que ostenta, con nueuos rayos que esgrime. $\mathrm{Y}$ todos coligen, que quiere nacer el Sol, pues que la Aurora se rie. Muy presto vereis tratable, aun lo que es inaccesible, toda vna deidad humana, toda vna grandeza humilde. El portento mas estraño que labrò amor, donde assiste mucho mas allà de aquello que la admiracion concibe. $\mathrm{Y}$ todos coligen, \&C. Vereis como la esperança, que de sus ansias resiste la pena, solo vn instante muchos siglos le redime. Mortales, ya llegò el tiempo 
en que à los llantos se siguen

placeres; y a tanta noche,

un dia que se eternice.

$\mathrm{Y}$ todos coligen

que quiere nacer el Sol,

pues que la Aurora se rie.

\section{VILLANCICO II.}

\section{Estriuillo.}

1. QVe se viene à la tierra el Cielo tenganle,

tenganle no se estrelle en el suelo.

2. A qué baxa di?

ò lo dirè yo:

Es embidia?

1. No.

2. Es aplauso?

1. $\mathrm{Si}$,

que de embidia, y de aplauso

bien puede venir,

pues sin hazerse guerra,

en agasajos lidian,

$\mathrm{y}$ assi quando le embidian,

mejores ru $[m]$ bos si siguen en la tierra

ell Sol, Luna, y Estrellas,

y las luzes mas bellas

ansiosas de luzir co[ $n]$ mas primores

de la esfera de vn establo

baxan a me $[n]$ digar los respla $[n]$ dores,

con mas ligero buelo;

que se viene à la tierra el Cielo,

tenganle no se estrelle en el suelo.

\section{Coplas.}

1. De vn Niño recien nacido,

Artifice de los Cielos,

por darle la bienvenida, 
buscan el Cielo en el suelo.

2. Hazen muy bien los Astros, que en su presencia

tendrà el mas desgraciado

feliz Estrella.

1. En competencia sagrada, turba hermosa de Luzeros, por luzir con mas ardores vienen à templar sus yelos. 2. Mal podràn las Estrellas, quando dos Soles no han templado sus rayos con mas ardores.

1. El Sol por Rey de los dias le viene à rendir el feudo, $y$ en su rendimiento labra mas seguros rendimientos. 2. A la Luna se queden sus resplandores, y los dias se vayan a buenas noches.

1. La Luna intenta su aplauso, con mas fundado derecho, pues que Dios nace en su noche, y de otra Luna Hijo bello.

2. Retirese la Luna con sus menguantes, porque este Dios no gusta de los mudables.

1. Espiritus celestiales los Principes de su Imperio, viendo à su Dios en la tierra, dexan por la tierra el cielo.

2. Bien los Angeles vienen à festejarle, pues es su rostro bello, mas que de vn Angel.

1. Los de su Corte le siguen, con trage a su gusto atentos, 
y si el ser hombres no alcançan,

solicitan parecerlo.

2. Oy la tierra se llame

Corte del Cielo,

pues donde el Rey assiste

dize el proberuio.

\section{VILLANCICO III.}

Estribillo. Gallego.

TOcay Dominguiños,

tocay à compàs.

turururu, y andar,

correr, y baylar,

suene ò tamboril,

turururu à compàs;

suene la gaitiña,

turururu, y andar,

y la castañeta,

turururu à compàs,

que los Bartoliños

queremos bailar,

cruzando los ventos

los sones doblay,

turururu à compàs,

tamben castañetas

è nos pes chebais

pois que zapatiños

de pao calçais

turururu, y andar,

turururu à compàs.

Coplas.

Mi Nino en as pallas,

que pracente estais,

y es porque mas Cruzes

en elas achais.

Aquestas mançanas, 
memorias de Adan,

por lo encarnadiño

las podeis tomar.

Aquesta cestiña

de houos tomay,

y para vna Bula

este medio Real.

Dominguiño, roscas

de centeo vos dà,

aunque en vuesos braços

las vè de cristal.

Tomay de sardiñas

diez ducias no mais,

pastillas Galegas

de menjui con sal.

Estos zapatiños

rusticos calçay,

que el crauo passado

busca el pie galan.

Vna zamarriña

forrada en sayal,

que de monte Rey,

este e o cambray.

Ao boy, y a la mula

ceuadiña train,

porque el trigo dexen

la palla en que està.

Si en Galicia fora

o voso natal,

de Madrid ò Rey

os fora a hospedar.

Correr, \&C.

VILLANCICO IV.

Introducion.

SIlencio, silencio pido, mudos hablen mis afectos, 
pues la palabra mayor

se explica con el silencio.

Dè vozes mi voz al ayre,

y al compàs de mis acentos

la palabra explique,

pues es la voz el instrumento.

\section{Estriuillo.}

Pues rompase el silencio,

resuene la palabra

por todo el vniuerso,

y en acorde, festiuo,

sonoro, acento,

suene la palabra

por todo el vniuerso;

suene la palabra,

y veràn del poder los portentos;

suene la palabra,

y verán del amor los estremos;

suene la palabra,

y veràn del amor los afectos;

suene la palabra,

y veràn la fineza en su empeño;

suene la palabra,

por todo el vniuerso,

$\mathrm{y}$ veràn los prodigios

deste misterio.

\section{Coplas.}

Pasmada la admiracion, vera como ciñe a vn tiempo

lo eterno solo vn instante, solo vn espacio lo inmenso.

En vn delicado Infante, entre temblores, $\mathrm{y}$ afectos verà como arde la nieue, como se yela el incendio.

Tan amante, que ninguno dirà a su fineza atento, 
que le viò tibio al cariño,

ni desmayado al desprecio.

Muy Niño, pero muy Hombre, aunque se verà en su pecho triunfar el amor temblando, temblar el amor venciendo.

Hombres, ya ha llegado el dia en que vn Dios vereis al yelo, muy pobre para ser suyo, muy rico para ser vuestro.

\section{VILLANCICO V.}

\section{Coplas.}

EL Sol de justicia dormidico està en Belen, adonde se quiso ocultar; despiertenle ya no sepa dormir quien viene a alumbrar.

Si nace a morir, y muriendo està de amores, y amor le hizo humanar; despiertenle ya, no sepa dormir quien viene a penar. Si es el llanto empleo de su tierna edad, y sus perlas precio de mi libertad; despiertenle ya, no sepa dormir quien viene a llorar. Si nace à ser Rey, y avràn de lleuar sus ombros el peso 
de su potestad;

despiertenle ya,

no sepa dormir

quien nace a Reinar.

Si es del hombre amante,

$\mathrm{y}$ viene a mostrar

que sus oluidos

con zelos està;

despiertenle ya,

no sepa dormir

quien sabe zelar.

\section{Estriuillo.}

Mas no le despierten,

no, no, no,

que dormido le mira mi afecto

con menos temor,

con mas fino amor,

$\mathrm{y}$ mira mi fè

con nueuo primor,

que aunque duerme mi Niño

en las pajas,

no se duerme en las pajas su amor.

\section{VILLANCICO VI.}

Estriuillo. Negro.

1. TOca la frauta siolo Matia,

tocalebè,

que me cayo de risa.

2. Que ay de nueua?

$\mathrm{q}[u e]$ ay de nueua, digalo vosa melce,

que londiosa Siquitiya

ha nasiro ya en Belè;

plimo Blasico toca,

tocale bé,

y sie, y sie.

yo solito quelo 
tocar lo mortelo,

sonar lo pandelo,

cantar al Cordelo,

y sie, y sie,

y sie, que plimo neglo,

al Siquitiyo aleglalemo,

mil cositas le tlaemo,

y a la glolia cantalemo,

y sie, que le le le,

al sonsoneciyo del zambacate.

Coplas.

De Guinea salimo,

pol que sa noso plimo,

y a buscaya venimo,

que la vira nos dè;

ay ay, que le le,

al sonsoneciyo del zambacatè.

Si besamo la mano

selemo coltesano,

y si agola viyano,

cauayera dempuè.

Ay, ay, \&C.

De contenta me rio

quando yora de frio

polque za Chiquiyo

do lo Neglo lo vè.

Ay, ay, \&c.

Biblioteca Nacional. Madrid. (V/E88-37)."Todo es tristeza en la tierra"..

Métrica: a veces parece una "nana". "No le despierten, no, no, no". En las Coplas de los Negros, rima consonante. Polimetría, con versos octosilábicos y heptasílabos. 
VILLANCICOS QVE SE HAN DE CANTAR

en la Capilla Real de su Magestad la Noche de Nauidad deste año de 1673.

\section{VILLANCICO I.}

\section{ESTRIVILLO.}

PRodigio, prodigio,

Milagro, portento,

Que dos Soles ay,

El vno en la tierra,

Y el otro en el Cielo:

Y qual haze excesso?

El de la tierra consigue el trofeo.

Por què?

Yo lo dirè:

Diga, que es milagro,

Oyga, que es portento,

Que el del Cielo en la tierra se forma,

Y el de la tierra se forma en el Cielo,

Conque tenemos

Dos Soles lucientes,

El vno en la Esfera,

Y el otro es el Verbo,

Y sin competir, compitiendo,

Cada qual de sus gracias

Forma vn concepto.

\section{COPLAS.}

NAce el sol, para q[ue] el hombre

Goze en radiante reflexos

Con sus luzes la alegria,

Con sus rayos el aliento.

Nace Dios, y apenas nace,

Quando en diuinos efectos,

Al hombre amante ilumina

De tantos borrones negros.

Y sin competir, compitiendo, 
Cada qual de sus gracias

Forma vn concepto.

\section{VILLANCICO VII.}

\section{GALLEGO.}

\section{INTRODVCCION.}

EN el Portal los Gallegos

Hizieron su rancho aparte,

Porque siempre son amigos

De dormir en los Portales.

Domingo andaua buscando

Para dar principio a vn Bayle,

Castañuelas, y la Mula

Le diò tres, ò quatro pares.

Quando dixo vna Gallega

Sin zapatos, y con guantes,

Con vn rostro de vn demonio,

Y con vna voz de un Angel.

\section{ESTRIVILLO.}

Que bulirè, bulirè, buliria,

Que bulirè con Rey de Galicia.

Ay Galeguiña,

Tocay la gaytiña,

Poiqueis garridiña

De o Reye la May,

Ay folijay, folijay, folijay,

Ay Galeguiño,

Quitay zapatiño,

Non desperteis con ò ruido à meu Niño,

Quedito Gayterio,

Que dorme o Cordeiro,

Ya o Reyna la queyro

Dezir la cantiña.

Que bulirè, bulirè, buliria,

Que bulirè con o Rey de Galicia?

Quedito cantay, 
Pasito baylay.

Ay folijay, folijay queditiño,

Non desperteis con ò ruido à meu Niño.

COPLAS.

1. Alegres los Galeguiños

Prencipio ao bayliño dain.

2. Y o Santo que is Carpinteyro

Los queire echar el compais.

3. Delante de o Rey Domiño

Sacar vos queiro a baylar.

Si sacareis, poi que vos

Lo fais todo poi sacar.

$\mathrm{Be}[n]$ pode entrair todo o $\mathrm{mu}[n]$ do

Ao bayliño de o Portal.

$\mathrm{Si}$, poique cando Deus naice,

Todo o mundo bolta day.

Quedito cantay,

Pasito baylay.

Ay folijay, folijay queditiño,

Non desperteis con o ruido a meu Niño.

O Rey poy blanco, è rubiño

Parece ù Sol Aleman.

Par Deus, quey merece ser

Reyna de Ospaña su May.

1. Sen duda el vento Galego

Oy se ha entradu a folijay.

2. E pensa quei toca gaytas,

Pois todo se và en soplar.

1. Domiño, las caras cheua

$\mathrm{O}$ fero vento que fay.

2. Domiña, si te cheuara

La tuya, que dicha mais?

Quedito cantay,

Pasito baylay, \&C.

1. Miray, que en lo Portaliño

O Rey en pallas estay.

2. Si chora Deus por el home,

Quein ha visto tail Portal? 
1. Domingo baylay con boy.

2. Non queiro, que in boltear

De Domingo a Dominguiño

Poca diferencia vay.

1. Fazendo glan coltesia

Fun domingo ao bayle day.

2. E con muyta reuerenza

Chamo ao Rey Paternidad.

Quedito cantay,

Pasito baylay.

Ay folijay, folijay queditiño,

Non desperteis con ò ruido meu Niño.

F I N.

Biblioteca Nacional. Madrid. (R.34988 ${ }^{51}$ )Barbieri. "Prodigio, prodigio".

Metríca: versos octosílabos, propios del villancico,;en la Romania, el octosílabo suele ser polirrítmico, mezclando versos trocaicos con otros dactílicos. Gran polimetría y variedad de rima, unas veces consonante, otras asonante. 


\section{VILLANCICOS QVE SE CANTARON EN LA REAL CAPILLA DE GRANADA, EN LA SOLEMNE FIESTA DE EL NACIMIENTO DE CHRISTO SEÑOR NVESTRO ESTE AÑO DE 1673 \\ DEDICADOS \\ A LOS SEÑORES CAPELLAN MAYOR, Y CAPELLANES DE DICHA REAL CAPILLA}

VILLANCICO V.

Estriuillo.

Atended,

à las vozes de vn Niño

que en acentos suave explicò

y en ternuras de llanto gustoso,

$\mathrm{q}[u e]$ le enciende en su pecho amoroso

[...] indigno,

atended,

ay, como llora,

atended a las voces de vn Niño,

que en acentos sonoros explico.

Atended,

ay, que fineças,

ay, que suspiros,

atended a las vozes de vn Niño

que en acentos sonoros explico.

COPLAS.

Què dirè de vn Niño amante,

que hablò siempre, y benigno

hasta mi recuerdo sabe

sacarle de [...].

Dirè que Dios llora amante,

sin ser pretexto en lo [...],

para estorvo a lo piadoso,

la raçon de lo ofendido.

Dire, que entre las distancias

de lo [...], y lo esquiuo, 
me retiran sus fineças,

y le acercan mis desvios.

Dirè, que el llanto en sus ojos

Diçe, que en su pecho vino,

que no oluida mis memorias

quien me acuerda mis olvidos.

Dirè, que el llanto derrite

al fuego de los suspiros,

y que a vna piedad que es cera,

sabe ser bronce vn delito.

Dirè, que como la culpa,

hiço [...] mi alvedrio,

no oye las voces del llanto

de tantos yerros al ruydo.

Dirè, que aún en lo quexoso,

me disfraça lo rendido,

se le ve el semblante al ruego,

de la quexa entre los visos.

\section{VILLANCICO VII.}

Introduccion

Al tiempo que los Pastores

al Sol vienen a adorar,

a festejar a la Luna

los Moros van al Portal.

Estriuillo.

Gaçul, Zellun Mohen,

jamalá, jamalá,

ea apressi correndo

venid al Portal.

con Verxeo, Macla y xonior Alá.

estàs bona $[\ldots]$

Iay, jay, jay, Jatembay.

E todos cantar.

Iay, jay, jay, jatembay.

E venir contentos 
con sonoros instrumentos, de xarpa, è çambomba para le tocar.

Bono me leja, bono estar, è presser el primo del xonior San Iuan, tocarle el Çarcol, con mucho premor, è darles tambem el çalamelec.

Tod. E todos juntos, dançar, è cantar, Iatembay, jay, jay, jay, jalà malá. Bono me leja, bono estar.

\section{COPLAS.}

Yo te adorar el premero, xonior Dios que soy Himere, ya no traer mas vonete, que querer traer lo obrero, el mal bejo del Arriero, vaya mulasa rascar.

Baylar, e dançar, choque chaque, fuerte estar. Mahomelia estar berracho, è ya no ser mas su amego, que Iesus estar con mego, que ser Dios, è ser mochacho, andar tu, que bon despacho, en el inferno te dar, Baylar, \&C.

Vergen Sagrada Maria, ya tu sola estar mi Luna, no adorar otra ninguna, como hazer allà en Turquia, ser tu esclauo yo querria, mas que no en Argel Reynar, Baylar, \&.C.

Reyes que vienen de Arabia 
à adorar al Nenio de oro,

cada qual trae vn tesoro,

que al Demonio causar rabia,

tu Mahoma estar en Bavia,

quando a tanta luz cegar,

Baylar, \&.C.

Yo traer para su Alteza,

vn alfange Abencerraxe,

para que a Herodes le raxe,

el metad de la cabeza,

cortar como vna cereça,

si a mi braço le fiar,

Baylar, \&C.

No ser ya Moro mezquino,

ni a Mahoma hazer el buz,

passa higo, y alcucuz,

trocar por torrezno, è vino,

con dos botas de camino,

desde ey mas querer andar,

Baylar, \&.C.

Quedar con Dios e contigo,

xonior Nenio, è Vergxen belia

que venir con bona estrella?

è querer [...] consigo;

Mahoma estar mi enemigo,

è Iesus mi amigo estár,

Baylar, \&.C.

\section{VILLANCICO VII.}

3. Nocturno. Estriuillo.

A los cultos que à Dios le co[n]sagra $[n]$,

las aues sonoras,

digan la dicha,

canten la gloria,

y la fiesta de verle nacido,

escuchense alegres

publiquenlo todas. 


\section{COPLAS.}

En buen hora tierno Infante, llegais desterrando sombras, tan milagro, que se ha visto, el Sol sin faltar la Aurora.

Dueño sois de voluntades, y para que se conozca, en señal de possession, venis derramanado aljofar. Honrad las humildes pajas, y serà la luz que arrojan, todo lo pagizo vn Cielo, y lo encarnado vna gloria. No emboce clavel tan [...], la hermosura que atesora, que al soplo que el Zierço ha dado, le han descubierto sus ojas.

Biblioteca Nacional. Madrid. (R $34987^{31(2}$ ). "Atended".

Métrica: típica del villancico, versos octosílabos, polimétricos, a veces son heptasílabos. La rima es asonantada. 


\section{VILLANCICOS QVE SE HAN DE CANTAR EN LA SANTA IGLESIA METROPOLITANA DE \\ Granada, la noche del Nacimiento de Nuestro Señor Iesu Christo este Año de mil seyscientos y setenta y tres.}

\section{E D I C A T O R I A}

AL ILMO. SR. D. FR. FRANCISCO DE ROSYS Y MENDOZA, dignísimo Arçobispo de Granada, Predicador de su Magestad, y de su Consejo, \&.C.

$$
\text { ILL.MO. SR. }
$$

Aviendome mandado los Señores Dean y Cabildo desta Santa Iglesia q[ue] governare la Música della, haziendo oficio de Maestro de Capilla en el interin que se prouee el Magisterio, aunq[ue] no me tocaua por mi antiguedad obedeci ciegame $[n]$ te, procurando con mi desuelo desempeñarme de obligación tanta, y hallandose estos Señores, no deseruidos de mi puntualidad, y cuidado, tuuiero $[n]$ por bien, el $\mathrm{q}[u e]$ assimismo corriesse por èl la disposicio[ $n]$ de los Villancicos, y fiesta del Nacimiento, a cuyos preceptos he dado muy gustoso cumplimiento, deseando $\mathrm{q}[u e]$ a todos parezcan bien, y nadie tenga aliento a censurarlos, solo por lo que tienen de influencia mia, para librarlos de esta calumnia, propuse saliesen defendidos con la protección de V. S. ILL. ma. a quien se los dedico, y consagro con el rendimiento mayor que puedo, y deuo; pues patrocinados, y amparados con tan ILL.mo. Principe, y Señor correran con feliz fortuna, para que todo redunde en mayor culto de Dios nacido Hombre, que celebramos, y guarde a V. S. ILL.ma. y dè muchos años de vida, como lo desseamos sus Capellanes, y ha menester esta su Esposa, de cuyas manos aguarda su total hermosura.

ILL.mo. Sr.

Capellán de V. S. ILL.ma Q. S. M. B.

El R. ro Francisco Blanco.

\section{VILLANCICO.}

Triunfantes coros silencio, Quedo

Que descansa vna passion, Passo que se ha suspendido el Cielo, Oygan Y se ha dormido el valor. 
$\mathrm{Al}$ son sonecito $\mathrm{q}[u e]$ le haze el amor.

Quedito coros celestes, Quedo

Que amor al labio atajo, Passo

Pues oy duerme la palabra, Oygan

$Y$ se halla el Verbo sin voz.

$\mathrm{Al}$ son sonecito $\mathrm{q}[u e]$ le haze el amor.

Quedito q[ue] vn Niño duerme, Quedo.

Sueño que es tan Superior, Passo.

Que el secreto de su Padre, Oygan.

Con dormir le descubriò.

$\mathrm{Al}$ son sonecito $\mathrm{q}[u e]$ le haze el amor.

Quedo $\mathrm{q}[u e]$ ay prodigio en luzes, Quedo

Si entre la nieue esta el Sol, Passo.

Pues quando estàn mas elados, Oygan

Mas viuos sus rayos son.

$\mathrm{Al}$ son sonecito $\mathrm{q}[u e]$ le haze el amor.

Alma quedo, que el dormido, Quedo.

Buscando tu coraçon, Passo

Por no hallar la puerta abierta Oygan.

En el Portal se quedò.

$\mathrm{Al}$ son sonecito $\mathrm{q}[u e]$ le haze el amor.

Si a redimir vas los censos Quedo

De aquel primer pecador, Passo

Pues tales tributos quitas, Oygan.

No descanses Niño, no.

$\mathrm{Al}$ son sonecito $\mathrm{q}[u e]$ te haze el amor.

\section{Estriuillo.}

Serafines que dais en el Trono

El punto mas alto,

Con mas dulçe voz,

Quedito, pasito, silencio,

Que se duerme el Sol

En braços del Alva

$\mathrm{Al}$ pecho mayor,

$\mathrm{Y}$ al son sonecito

Que le haze el amor. 
VII. VILLANCICO GALLEGO.

TOdos os Galegos,

Que à Belen ven, è van,

Da igreja os cregos

Das ruas os legos,

Das prazas os cegos

Que ven, è que van.

Ay como baylaran.

Ao solciño louro

Que nos trae tesouro,

Nas madejas de ouro,

Que na palla està.

Ay como baylaran.

A sua may fermosa,

Pura e fresca Rosa,

Que pariò graciosa

No tosco Portal.

Ay como baylaran.

Baylarà ligeyro

Ao son do pandeyro,

O noso Barbeyro,

Con, o Sacristán.

Ay como baylaran.

E nos tamben imos à Belen

A ver noso ven por los ayudar,

Andar, Andar,

Que o son me retiña,

De la frautiña,

De la gaitiña, lo corpo todo.

Tangueme Bartolo,

$\mathrm{Y}$ veras como trisco no polvo.

\section{COPLAS.}

TAngeme frautiña

De Pasqual Llorente,

Que entre toda a gente

Mas bein la retiña,

Darey vna boltiña,

Por la vida miña, 
Por que nie non riña,

O solciño nouo.

Tangeme Bartolo, \&. C.

Tangeme pabana

Por lo cabaleyro,

Baylare ligeyro,

Poys que Deus se humana.

E de boa gana

Darà na bentana,

Con cabeça sana

Si brinca Maroto.

Tangeme Bartolo, \&.C.

Tangeme villano,

Por la çarabanda,

Pois me neno anda,

Sendo Deus tan llano,

Que me da sua mano,

Y rico, y vfano,

Direy, y omegano,

Perdendome todo.

Tangeme Bartolo, \&. C.

Tangeme o sonciño,

Que a baylar combide,

Poys que Deus se mide,

Con o polvo miño,

$\mathrm{Y}$ es tanto el cariño

Que tien de ser niño,

Que viste de armiño,

$Y$ es Deus el afforro.

Tangeme Bartolo, \&. C.

Por la Españoleta

Tageme Canario,

E qual camapanario,

Darey hua bolteta,

E nadie se meta

En fazerme treta,

Por uqe na gambeta

Me rompa los ollos.

Tangeme Bartolo, \&. c. 
Tangeme Rugeyro,

Por las miñas Bacas,

Que las teño fracas

Desque di en ligeiro,

Y al Deus verdadeiro,

Que naze Cordeiro,

Por todo el oteyro,

Le brincarey solo.

Tangeme Bartolo,

$\mathrm{Y}$ veras como trisco no polvo.

VIII. VILLANCICO. GITANO.

A La gala del Niño,

Baylad, Gitanoz,

Y coronen zuz araz

Florez, y ramoz.

Cantad primorez,

Y coronen zuz cienez

Rozaz, y florez.

Del claro Iordan,

Laz frezcaz riberaz,

De Belen loz bozquez,

De Iudà laz celvaz,

À ofrezerle vengan

Zuz ricos donez,

Y coronen zuz cienez

Rozaz, y florez,

Cruzar, y baylar.

Ala, ala, y maz ala,

Con el ayre que corre.

Ala, ala, y maz ala.

Puez tambien zuz cruzadoz

Hazen laz pajaz.

Baylar, y cruzar.

Y en la gira Gitana feztiua.

Ala, y maz ala.

Cruzar y baylar. 
Biblioteca Nacional. Madrid.(R.34987 n ${ }^{\circ}$ 8. "Triunfantes coros silencio".

Versos de cabo roto en el V1. Villancico, con rima doblada en eco: Triunfantes coros silencio Quedo, Passo, Etc. Las rimas dobladas también las usò Lope de Vega en otras temáticas. Ejemplo: "dichoso aquel que en un comprado Prado" 


\section{LETRAS DE LOS VILLANCICOS, QVE SE CANTARON EN LOS MAYTINES de la Natividad de Nuestro Señor Iesu Christo. \\ EN LA COLEGIAL DE SEÑOR SAN \\ Salvador de Sevilla. \\ COMPVESTOS POR MIGUEL OSS[O]RIO, \\ Maestro de Capilla de dicha Iglesia. \\ Impressos en Sevilla, por Iuan Francisco de Blas, Impressor mayor de dicha Ciudad. \\ Año de 1674.}

K A L E N D A.

VILLANCICO PRIMERO.

Coro. AY, ay, mi Dios,

quando de tanta noche

desterrarà las tinieblas el Sol?

Tierra, piedad, piedad,

Cielos, favo[r], favor.

1. Aténded a mis ecos mortales, aplicad el oìdo à mi voz, poque ya para vuestras dole $[n]$ cias vengo anunciando el remedio mayor.

Coro. Quien llama? quien piadoso

del sueño nos despierta?

y quien con tiernas vozes

rompe tan duras quexas?.

3. La Tierra.

2. El Viento.

3. No sino el Agua.

4. No sino el Fuego.

Tod. Porque à Dios le anunciamos

los Elementos.

1. La tierra,

pues Flor de sus entrañas

le brota la mas vella.

2. El Ayre,

pues donde el Austro biene

con soplos admirables.

3. El Agua, 
pues en hermosa pluvia

del Cielo se desata.

4. El Fuego,

pues como Sol ardiente

inflama tanto yelo.

Coro. Si como todos biene,

cesse el empeño,

no parezca discordia

lo que es Misterio.

Todos. Y en señales de gozo, repitan nuestros ecos:

Venga en ora buena

la Flor de la Tierra;

el Agua del Cielo,

el soplo del Ayre,

la llama del fuego.

\section{COPLAS.}

Suspendanse los suspiros, quedese todo en silencio, porque escuche la dolencia solo la voz del remedio.

Ay mi Dios, que cada instante le miramos siglo inmenso, que serà la eternidad si assi nos parece el tiempo? Llegad, y de nuestras ansias llegue tambien el consuelo, que es propio de la Deidad el no retardar el premio. Aliviad nuestra esperança del incomparable peso, reprimase ya la pena a vista del instrumento. Y si [...] al sollozo nos advertis, llegad presto, que no es facil respirar si se dilata el aliento. 


\section{VILLANCICO II.}

ENamorado Dios,

que venciendo impossibles,

quieres acreditarte,

de que solo tu amor a sido firme.

Si has de morir de Amante,

como de Amante vives?

\section{COPLAS.}

Bien tu fineza prueba

ser tu Amor mas sublime,

pues corre las distancia

$\mathrm{q}[u e]$ ay do $[n]$ de impasible a lo pàsible:

Si has de morir de Amante,

como de Amante vives?

El Imperio dexaste,

y en vn Portal assistes,

exponiendo a dos brutos

lo que dessean ver los Seraphines:

Si has de morir de Amante,

como de Amante vives?

La ingratitud humana

hasta llorar te rinde,

no tanto por tu ofensa

quanto porq[ue] del hombre te divide:

Si has de morir de Amante

como de Amante vives?

Mas que en estar con brutos

estar con èl hiziste,

que vn racional ingrato,

con la mayor brutalidad compite:

Si has de morir de Amante

como de Amante vives?

\section{VILLANCICO III.}

Gallego. 
ZVmba à gayta

Toribio ò cego,

porque folixe

todo Galego.

Folixay, folixay, folixemos,

folixay, folixay os Galegos.

Zumbe a gayta,

rebente ò Demo,

pois à nacido

ò Fillo de Deus.

Folixay, folixay, folixemos,

folixay, folixay os Galegos.

\section{COPLAS.}

Ao Neno questà ò Portal fincan rodilla os Galegos, que ainda mais excelença ten que o Conde de Lemos.

Folixay, folixay os Galegos.

Vna mula ten, y un boy,

è si fora en Ribadeo,

solo con ò boy è a mula

fora mas rico que ò Crego.

Folixay, \&C.

Desnudiño entre uas pallas

as sopiñas vay comendo,

que assi crian uas mais

os fillos en Mondoñedo.

Folixay, \&C.

A Casiña donde mora està mais crara que ò Ceo, è folixan Galeguiños, que serà vna groria velos. Folixay, \&C.

Entre as pallas que nace està o Neno muy trigueño, dà color que tein en Lugo ò diviño Sacramento.

Folixay, \&C. 
Por lo error do primer home, vene à salvar os Galegos, è ferido de tres Cravos passarà a Cruz de ferro, Folixay, \&C.

\section{VILLANCICO IV.}

Quedito quedo Pastor pisa con tie $[n]$ to la mas bella flor, suspende el aliento, reprime la voz, que duerme mi niño, que duerme mi Dios, quedito, quedo Pastor.

\section{COPLAS.}

Como dormis Niño mio que se quexara el amor, viendo que todo su Imperio el de seuydo le vsurpò. Sueño, y amor no ha[ $n]$ podido estar en segura vnion, poco le deve el cuydado al que amante se durmio. No està bien con su fineza quien al ocio la entregò, y en que mas se desvela es la fuerza mayor.

Pero bien hazeis dormid porque esse no es sueño en vos, sino recoger la vista para doblar la atencion. No están los ojos dormidos quando vela el coraçon, que es abrirlos al cuydado cerrarlos al exterior.

Quando los ojos cerrais mas despierto os miro yo, 
que jamas para dormir

los ojos cierra el Leon.

Quedito, quedo pastor.

\section{VILLANCICO V.}

Niño mio que lloras tambie[ $n]$

busca $[n]$ do mi gloria penando mi mal, ay ay ay.

Que con cada perla $\mathrm{q}[u e]$ viertes niño mio la vida me das,

ay ay ay.

No dexes no

mi Sol mi dueño, y mi amor de llorar,

ay ay ay.

Que si lo perdido me lloras

assi me mexoras,

para ganar vn inmenso caudal,

no dexes no,

mi sol mi dueño, y mi amor de llorar.

\section{COPLAS.}

Amante de mis ojos

que assi tan liberal,

de humano te has vestido

por darme libertad.

A redimirme ${ }^{14}$ bienes

empeño que te dà,

su mucho que sentir,

no menos que pe[n]ar.

Si en tu llanto consiste

que se pierda mi mal,

quien duda que mi bien

està en que llores mas.

En todo quanto penas

alivio mi pesar,

que es tu tormento gloria,

\footnotetext{
${ }^{14}$ En el original, Arredimirme.
} 
y tu batalla paz.

Las lagrimas que viertes

parecen vn Christal,

y son vn fuego vivo

que me llega abrasar.

De tu lecho lo digan

las pajas pues estàn

ardiendose de gozo

de verte a ti llorar.

\section{VILLANCICO VI.}

1. Zagalexos del lugar

yo soy el Alcalde

que salgo a rondar ${ }^{15}$.

2. Y que pretende el Alcalde,

1. Rondar esta noche

las plazas, y calles.

Tod. Nadie se esconda

que el Alcalde Perote

sale de ronda.

1. Tenganse a la josticia

no passe nadie,

sin que diga primero

quien va al Alcalde.

COPLAS.

1. Toda tonada se tenga que so Perote el Alcalde, que vo de ronda prendie $[n]$ do quantos tonos encontrare.

Mando pues q[ue] en los Maitines

tonads nuevas se canten,

porq $[u e]$ algunas se hazen viejas

por las muchas Navidades.

Tod. Tenganse à la josticia no passe nadie,

${ }^{15}$ En el original, arrondar. 
sin que diga primero

quien va al Alcalde.

2. Las folias muy rasgadas

de cas de vn Barbero salen.

1. Pues si tan rasgadas bienen

vayanse en casa de vn Sastre.

Fol. To. Porque esta desnudito en las pajas, mi Niño temblando q[ue] es todo vn Sol.

3. Porque siendo chiquito Cordero, vn Cordellate en el mundo no h[a]llò.

1. Ha de la Rondda,

2. Que dize el Alcalde?

1.Que essa tonada vieja

vaya à la carcel.

Tod. Porque se enfada[?]

1. Porque quiero ${ }^{16}$ folias,

mas no rasgadas.

2. Este es el Señor Canario,

que pretendiente, y danza $[n]$ te

a puro hazer reverencias

las suelas gastadas trae.

Tod. No lloreis chiquitico

rufayfa,

que si Herodes lo sabe

mataros ha.

1. Buen Canario tenemos

vaya a la carcel.

3. Tanto rigor suspenda

Señor Alcalde.

Biblioteca Nacional. Madrid. (V/E. 79 n ${ }^{\circ}$ 5.) “Ay, ay, mi Dios”.

Rima asonante, versificación octosilábica, arromanzada. Juegos de palabras con muchas figuras retóricas que dan vida al villancico. Versos heptasilábicos, que dan mucha rapidez al verso. Redondillas octosilábicas propias de la forma clásica del villancico, con cuarteta octosilábica. Nos encontramos con variedades métricas.

\footnotetext{
${ }^{16}$ En el original, Porque que quiero.
} 


\section{VILLANCICOS QVE SE HAN DE CANTAR}

en los Maytines de los Reyes, en la Santa Iglesia Angelica, y Apostolica del PILAR, Metropolitana, y primera Cathedral de Zaragoça, de este año de 1674.

Siendo Maestro de Capilla Diego de Càseda.

\section{VILLANCICO PRIMERO.}

NAue que a Belen caminas

con fanal de Estrella errante

dando la esperança velas

de los suspiros al ayre,

buen viaje, buen viaje:

Conduze en pielago vndoso,

al Puerto tres Magestades,

donde con valas de nieue,

salua el granizo les haze.

Amaina, amaina las velas:

Ha del Mar, ha de la Naue.

Quien dà vozes?

Pirata,

que hecho un Herodes oy sale,

en Corso para dar caza

a tres Galeras Reales.

Y que busca?

Su Tesoro.

No va aqui, adelante passe.

Si passa, serà a cuchillo,

a quantos van en la Naue.

No temen su azero Reyes,

que solo corta en Infantes:

al arma, al arma, al arma,

la Artilleria disparen,

Estrellas son sus tiros,

con poluora de Rayos celestiales:

al arma, al arma, guerra,

suenen los Clarines, y Trompetas,

yà se embisten,

yà combaten, 
que se anega!

ay Iesvs,

mas libròla de esse Infante,

la planta, laurel, y Puerto,

de Rayos, y tempestades.

Vitoria, venciò su Estrella, vitoria,

yà buelue a Oriente triunfante,

tremolando de Encarnado

sus vanderolas al ayre,

y de acordes instrumentos,

dizen acentos suaues,

buen viaje, buen viaje.

COPLAS.

Del Oriente Si caminas,

con Estrella Rica Naue,

para volar Ayres lleuas

en tus ansias De salvarte.

Si caminas rica Naue,

ayres lleuas de saluarte.

A la esfera De vn Sol noble,

co[n] voz muda Va a enseñarte,

en sus plantas Puerto frio

de tu Estrella Luz errante.

VILLANCICO QVINTO.

ESTRIVILLO.

1. Moroso, y Gentil Labrador,

que expuesto a las furias del Sol, y el rocio,

[...] pajas me ofreces el pan de flor,

[No] serà mucho Labrador mio,

[...] està en tu amor el ardor del Estio,

[...] en mi despego de Inuierno el rigor,

[...] cojas el fruto sudando al calor,

$[\ldots]$ siembras el $\mathrm{Ca}[m]$ po temblando de frio.

COPLAS. 
Labrador de los Cielos, que en dura esteril tierra, Diuino siembras glorias Por flores te produze, espinas que te ofendan, que el Campo del desden, es fertil de Asperezas. Hallan tus Perlas finas, Conchas en su dureza, que ingratitudes labra, el que finezas siembra. La escarcha de essos Campos, que de tus Soles riegan, congelados ardores, en liquidas Centellas, Que milagro! es dar flores, si llueuen Primaueras, que mucho! aborte luzes, si se fecunda a Estrellas.

Tu Madre es de Oro Espiga, y de gracia tan nueua, que estando fuera el Grano, queda la Espiga llena. Es tierra, que el Arado, no se atreuiò a romperla. que a tierra tan fecunda, jamas el hierro llega. Por fruto tres Monarcas de la Arabia te feudan, quanto precioso nace, y Aromatico engendra, Belen a tu labranza, Mula, y Buey te presenta, que yugo tan suaue, a un los Brutos desean.

VILLANCICO SEXTO.

INTRODVCCION. 
OYgan la Letra presente, hecha de Letras passadas, que por ser Letra de letras, al Rey de Reyes se canta. En el Portal esta noche, Prouincias de Lenguas varias, por hazer plato a los Reyes componen vna ensalada. En el Verbo que ha nacido, diran las lenguas su gracia, que para todas las lenguas, es nacida la Palabra.

Salgan, salgan,

Las Naciones lenguas [...] hagan.

Salgan, salgan, el Morisco, y Portugues, la Gaytilla, la Gallarda: el Negrillo, y el Francès, los Herreros de Vizcaya. Salgan, salgan, suene en todas las lenguas la Palabra.

Lleguen, lleguen, $\mathrm{y}$ con primor decente, lo antiguo se renueue, y al cabo de los años mil, uuelvan las Letras por dò solian ir.

\section{COPLAS.}

Por ayrosa en los passeos, tocò la Gallarda a España, que entre todas las Naciones, la Española es la Gallarda.

Mi bien està llorando en vn Portal, y aunque llora mi bien, llora mi mal, mi oluido siente mas, que es mas desde[n], auerle yo ofendido, sin querer.

Fue vn Portugues, y hablò poco, que por ser corta la estancia, apenas huuo lugar, 
como tan inchado entraua.

Pois Mi Rey sous mi Nino, eu vos he de ser fiel,

fincarè a vosas prantas,

naon me leuantarè,

le, le, le, por miña fè.

Porque aya perro en la fiesta, vn Morisco entrò en la danza,

y ha de auer, si baila el Moro, en el Portal braua zambra.

Cantar todo Torquilio, morisquilia tonada, pues nacer Rey chiquilio, extar paja Granada.

Baylà, Morisca, baylà, que èxta extàr Noche buena, por el hejo de Alá.

Vn Francès que vio temblando al Rey desnudo en las pajas, pretendiò para mantillas, de passo leuarse a [...] Pero esta vez lleuó [...] que por vn arco brincaua, y le han de hazer de la tierra, saltar por el Rey de España 5. Hàla, hàla, salta per lu Roe de Fransa:

6. No quere saltá.

5. A lo pleisant, falta per le vel Enfant, qui en li presepe ha nasqui, e una Vierge li a embrulli, como il Profete li pàrla:

6. Si quere saltà.

5. Tuque le violì, tuque flandubela, faremole festì, tucando le Rabè, a le vel Enfant, 
è Roes dè Belè.

1. Su Gaita lleuò Galicia, porque es su pobreza tanta, que apenas tiene que dar, lo que monta vn sus de Gaita.

7. Tange la Gaita, retumbe ò pandeiro, tange la Gaita aò fillo de Deus, tange la Gaita Mingo. tange la Gaita a ò Nino, tangela, que de Gaita està el dia. tangela, que ò sonciño me engaita.

1. Aunque cargada de hierros, no hablò en Vazquence Vizcaya, que lo obscuro, y lo cerrado, destierra noche tan clara.

8. En la fragua se templan los hierros, que el yunque recibe con mudo dolor, y a compàs concertados los golpes, labra $[n]$ do los hierros, la Gracia haze el so[n].

1. Los Negros van a Maria, Arca del diluuio Santa, que oy viendo nazer el Arco. bueluen los Cuerbos al Arca.

9. Cantemo al recien naziro, que pur lu Neglo ha veniro, cantemo a la Virgen veya, que ez la que nuz diò la Estreya, cun que campa lu Negriyo, canten luz Negloz al Branco Chiquiyo, $\mathrm{q}[u e]$ al Neglo, y al Branco co[n]uira el toniyo.

\section{VILLANCICO SEPTIMO.}

\section{INTRODVCCION.}

Enfermò Adan, y sus hijos

para su caìda, yà

hallaron hecha la cama,

en aquella enfermedad. 
De la Inocencia caìmos, porque su malicia Adan, como eramos Inocentes, nos la pudo alli pegar.

Viòle caìdo en la cama, de vn achaque tan mortal, y baxa Dios, porq[ue] el hombre oy se pueda levantar.

1. Quien es Medico? 2. Christo.

1. Pues para visitar, no le faltarà todo, que yà tiene la mula en el Portal.

2. La sortija le falta.

1. Christo es piedra, que està por la vnion engastada, en el anillo de la humanidad. 2.Como, si no tiene barba, se hán de fiar de vn Rapaz?

1. Quiere enmendar esse abuso, que ha crecido con la edad, y el Niño al cumplir doze años, vna consulta tendrà, que los mas graues Dotores las barbas se han de pelar. 3. A la visita enfermos, Venid, que empieza ya, del general achaque, la cura vniuersal: Informen los suspiros, salga a la boca el mal, que el Niño por los ayres cura la enfermedad.

\section{ESTRIVILLO.}

4. Ay, ay, ay, socorro, piedad, que muere $[n]$ los ho[m]bres por culpa de $\operatorname{Ada}[n]$. Ay, ay, ay.

3. Aliento enfermos mios, los ayes alegrad, 
y pues que yà el aliuio,

viene nacido al mal,

el ay del mal no suene,

donde remedio ay.

\section{COPLAS.}

1. Enfermò de la cabeça,

el Mundo todo, en Adan,

y como naciò de vn Arbol,

echò raìzes el mal.

2. Que trabaje Adan, y sude,

le fue vn Angel a ordenar,

que aunque de su mal no cure,

de su sudor viuirà.

3. Essa sudor, no puede

sanar al hombre,

mas sanarà en vn Huerto,

de otras sudores.

1. A la opilacion de Eva, su ser algun color dà;

porque ser del barro antojo,

disculpa su enfermedad.

2. Vna Lança de vn Costado, su remedio sacarà, que la opilacion de el barro, el azero ha de curar.

3. Su hierro a Dios encarna, miren si es barro,

pues color dà a sus quiebras;

con encarnarlo.

1. Pidiendo vna gota de agua,

el rico Auariento està,

y haze nouedad, que a vn rico,

gota le pueda faltar.

2. Pretende sanar, y quiere,

que Lazaro vaya allà,

que hasta en el Infierno vn rico, mira su comodidad.

3. A su sed no ay remedio, 
no le dan gota.

Rico que guarda tanto, guarde la boca.

1. Pedro con grande dolor, bañandose en llanto està, sanarà, que nadie al baño, con tanta fè ha de llegar.

2. Sus quejas seràn ventosas, que el fuego señalarán, sus lagrimas las sangrias, quando su afecto el cordial. 3 . Viertan agua sus ojos, que el mal de Pedro, con hazerse dos fuentes, tendrà remedio.

1. A Pablo ver las Estrellas, le hizo vn golpe, y si al rodar, enfermò de la caìda, luego se leuantarà.

2. Hazele Dios instrumento, para otros muchos sanar, que si es medicina el agua, San Pablo el vaso serà.

3. Es medicina a muchos, sanar San Pablo, que el Dotor de las gentes, serà llamado.

1. Iudas de su salud, tanto llegò yà a desesperar, que por bien poco dinero, al Medico venderà.

1. Lleuò vnguento Madalena, que tan mala vino a estar, que tuuo para la Vncion preuenido el Olio yà.

3. Iudas vendiò el remedio, pues que se ahorque, Madalena se cure, pues lleua el bote. 


\section{Con el Niño se visitan}

Reyes, y no es de admirar, que si empieza con Estrella, visitas le sobraràn.

2. Piden remedio a sus plantas, que no ay duda que sabran, siendo Magos, la virtud que en aquellas plantas ay. 3. Aunque cura de gracia dones le ofrecen, porque de su visita pagado quede.

\section{VILLANCICO OCTAVO.}

\section{ESTRIVILLO.}

PAsito, silencio, quedito la voz, que duerme el amor; y al Sol Infante le arrulla vn Aue, con tan soberano primor, que no es bien le despierte el rumor: y pues al mundo le viene nacido, es justo le arrulle con suspension, al Sol dormido, pasi[u]o amor, no le despierte la voz.

\section{COPLAS}

Vengan a ver vn Portal, pieza que el Diziembre hizo, a poder de copos blanca, siendo morada de Christo. Vengan a ver con quartana oy al Leon de los Iudios, que del hombre el accidente le pudo pegar el frio.

Vengan a ver que a vn ingrato, Dios hazerle cura quiso, 
cargando en su ingratitud, la pension del beneficio.

Vengan a ver vn Infante, que con misterio diuino, aunque nace por Deziembre, por San Iuan tendrà el Baptismo;

Vengan veràn, que en la nieve,

oy que de Madre ha salido, conservando su limpieza, se hizo barro el Armiño.

Vengan veràn que su Madre, con ser su amor excesiuo, sabiendo que a morir nace, dolor no tuuo al parirlo.

Biblioteca Nacional. Madrid.( V/E 1303-5). "Nave que a Belen caminas".

En el Villancico Primero nos encontramos con versos de cabo roto, rima asonante, versificación octosilábica, propia del villancico y del romance. 


\section{VILLANCICOS QVE SE HAN DE CANTAR EN LA CAPILLA REAL DE SV MAGESTAD}

la Noche de Reyes deste año de 1675.

\section{VILLANCICO PRIMERO.}

\section{ESTRIVILLO.}

1.TRes Aues con melodia,

Al Niño Dios, Sol Diuino,

Hazen la salua, que à vn Trino

Reducen oy su armonia.

2. Buenos dias, Zagales, buenos dias,

Que ya es alvor;

Pues tres Aues saludan al Sol,

Que à vn Pesebre haze Oriente pagizo

De su encarnado arrebol.

3. Ay Dios, que gran dicha;

Què musica tan Diuina!

Pues por gozarla, los Cielos

De sus exes se desquician.

4. Buenos dias, Zagales, buenos dias.

\section{COPLAS.}

Oy tres Estrangeros Reyes,

Que Astrologos de su dicha

Con rasgos de oro, en la Esfera

La pudieron ver escrita.

Siendo del azul Volumen,

Que escriuiò Pluma Diuina,

Vn caracter cada Estrella,

Y cada Rayo vna cifra.

De donde el Sol nace, a donde

Otro Sol nace, caminan;

Iornada de Sol a Sol,

Que les durò treze dias.

No errado Adalid sus huellas,

Si errante Estrella, encamina: 
Quien viò para ver el Sol

Dar luz quien dél la mendiga?

Entran del Portal humilde

A la desierta ruina,

De su Deidad pobre Cielo,

Tosco Oriente de su dia.

$\mathrm{Y}$ al ver la Luz entre el yelo,

Dudò, confusa su vista,

Si el Sol al yelo se elaua,

O si el yelo al Sol se ardia.

Flechas tira, y para ser

Dios de Amor, como lo pinta,

Si le desdize lo ciego

Lo desnudo le acredita.

Ven la Diuina Amaltea,

Que al Niño Iobe ofrecia,

Pechos, que vassallo el ampo

Le pagò, por ser mas limpia.

Quando el blanco nectar bebe,

Pasmada la Astrologia

De los Reyes, en vn Cielo

Dos Vias Lacteas admira.

A sus pies llegan, y humildes

Rinden la Corona altiua,

Porque de aquel Sol la planta

A los tres de Laurel sirua.

En tres enigmas le ofrecen,

Myrra, que mortal lo afirma;

Incienso, que Dios lo aclama;

Y Oro, que Rey lo apellida.

\section{VILLANCICO II.}

\section{GALLEGO.}

\section{ESTRIVILLO.}

1. Sali da Ribera, branquiña Fror,

Sali da Ribera darcha ò Sol.

2. Branquiña Fror, tan galana, 
Sali da Ribera de mañana.

3. Branquiña Fror, tan garrida,

Sali da Ribera por el dia;

Veredes no fraldillo del Alva,

O Zagal, que tres Reyes agarda.

4. Chegaos logo aos Galeguiños,

Que ao Portal vàn alegriños

A catar as Magestades.

1. E si vos vades. 2. Erguios cedo.

3. Que deste penedo

Se deixan ver camiñar.

4. Alegremonos, alegrar,

Que èl es ja, è nos ora imos al Portal.

COPLAS.

Vna Zagaliña,

Branca como fror,

$\mathrm{Na}$ ribeira deixa

Seu gado ao çurron.

Porque dos Galegos

Camiñaua en pos

A catar os Reyes,

Que de Orente son.

En vn Portaliño

el Alua catoù.

En que seu regazo

A pousaua o Sol.

Entre tuda a gente

Tres de eles achou

Vestidos de prata

Con seu relumbron.

Os dos eran brancos,

Vn vello, outro non,

Otro tiña o rostro

Do preto color.

Ao Neno se chegan,

Con muita razon,

Beijando na terra

Palla que deitò. 
Tres cousas lle deron, A mia fè boas son,

Porque o relucente

Oro pareceò.

O Neno lles bolve

Seus ollos de amor,

Que valen mais eles, Que tudos tres son.

Co esto fujiron,

E chegamos nos,

A dalle en vontade

Noso coraçon.

Vn branco cordeiro

Domingos lle deò,

E vindo que es outro,

Ao punto valò.

A su May, Bartolo

Vn panal dexoù,

E sonriendo ela,

Seu Ceo mostrò.

Nos tudos queidamos

Con dobre aficion,

E a nosa Ribeira

Camiñamos oy.

1. Sali da ribeira, \&C.

\section{VILLANCICO III.}

\section{ESTRIVILLO.}

Hagan la salva,

Con ecos los clarines,

Con rumores las caxas.

Hagan la salva,

Los paxaros sonoros

Con dulces consonancias,

Que vienen de marcha

A vn Portal humilde

Heroycos Monarcas, 
A ver a vn Rey Niño,

Que en braços del Alva,

Qual Sol amanece

Brilla $[n]$ te en las Esferas de su gracia.

\section{COPLAS.}

Niño hermoso de Perlas,

Que hazes del llanto voz,

No hagas con tus finezas

Mi ingratitud mayor.

Quiero hablarte de veras,

Y no acierta el amor,

Perdonarà el respeto

Culpas de la aficion.

Como vienes tan solo

A nuestra Redempcion,

Parece que has nacido

A la merced de Dios.

Si la piedad se viene

A coronarte oy,

Despues harà la injuria

Lo que oy la deuocion.

Vna estrella a tres Reyes

Trae de agena Region:

Quien vio que vna Estrella

Se explique todo el Sol?

Què tumbado esta Herodes

porque tu nombre oyò!

Que al nacer la Iusticia,

Se turba la ambicion.

Viue, y Reyna en las almas

Que es el Reynar mejor.

Lo demas es imperio.

Mas no jurisdicion.

Hagan la salva, \&C.

VILLANCICO IV.

INTRODVCION 
NEGRO.

1. Los Negrillos, que en la Plaza

Regozijaron a todos,

Oy al Portal se han venido

Iuzgando que el buey es toro.

2. En ademanes Guineos,

Esguinces de Monicongo,

La noche, en vez de Goajaca,

Sirve su placer en Cocos.

1. Lu Nengliya de Panamà

Venimo a tureà,

$\mathrm{Zi}$ len guzta a sun Magestà.

Todos. Hu, hi, hu, ha.

Zalga lun buey enziya [...].

1. Plimo Anton?

2. Mano Flasico?

3. Labe vozanzè el fuzico,

Y palezcamo pelzona,

Cun plumiya, y cun banlona.

Tod. Hu, hi, hu, ha.

4. Barantolo con zu lança

Tamben quele entlal en dança,

$\mathrm{Y}$ ha de hsel glande matança

Zi el turiya queda ezà.

Biblioteca Nacional. Madrid. V/E 91-21. "Tres aves con melodía".

Versos octosílabos, rima consonante, en el villancico Negro. Versificación polimétrica en otras partes del villancico primero. Se trata de vna poesía para ser cantada, adaptada a la música. 
LETRAS DE LOS VILLANCICOS QUE SE CANTARON EN LA

Santa Iglesia Metropolitana, y Patriarchal de Sevilla, en los Maytines de los Reyes.

Este año de 1675.

EN SEVILLA.

Por la Viuda de Nicolas Rodriguez de Abrego.

VILLANCICO VIII. GALLEGO.

Estrivillo.

AY meu mancebiño,

pois que chorando està,

querolle alegrar

$\operatorname{co}[n]$ toda la tropa dos meos baqueriños:

Ay, ay, ay,

querolle alegrar,

tocay, tocay,

Domingui, Domingui, Dominguiño,

tocay a gaytiña, y el tamboriliño,

porque soy Toribi, Toribi, Toribiño;

Ay que queiro baylar

al tuo sonecillo,

queirole cantar,

vnas coplas al Niño,

$\operatorname{co}[n]$ toda la tropa dos meus baqueriños,

porque soy Toribi, Toribi, Toribiño.

COPLAS.

SI naciera en la Coruña

fuera mais ben acullido,

en espigas de centeno,

que no enas pallas do trigo.

Ay que queiro, \&C.

Al pesebre de Caleça

con vna mula le miro,

alla la diera la Estufa

con sus seis el Arçobispo.

Ay que queiro, \&C. 
Pero oy los Reyes do Orente

a Belen dis que han venido,

y les traxen maytos Dones, por verle tan pobreciño.

Ay que queiro, \&C.

De os tres vn Rey es Negro,

de quein ha dicho Dumingos,

que bein quexera tener

la suerte que ele a tenido

Ay que queiro, \&C.

Ninguno dellos es cierto

que en Galicia fue nacido,

que ha ser Gallego, qualquiera

viniera aca descalçiño.

Ay que queiro, \&C.

Pues peregrinos os Reyes,

a adoraros han venido.

idos vos a Santiago

que a fe que sois Peregrino,

Ay que queiro, \&C.

La serena de la noite

nos descubre el regocijo,

y al Portal de Gran Señor,

en la tropa de Coritos

Ay que queiro, \&C.

Os Gallegos carpinteros,

os faran muchos banquillos,

para comer y sentarse,

porque ay hayos como pinos.

Ay que queiro, \&C.

VILLANCICO IX.

Estrivillo.

DUeño que llorando penas

os tiene el amor,

no lloreis mas, no, no,

que essas perlas que al Alva enamoran,

al hombre mejoran si os causan dolor, 
no lloreis mas no, no, no;

Mas pues la aficion,

que al hombre mostrais,

con tanta razon

os hizo humanar,

sentid, sufrid, y llorad,

que en pena tan repetida,

essas lagrimas mi Dios,

si os causan dolor a vos,

a mi me daràn la vida.

COPLAS.

SIntiendo mi ingratitud,

por mi llorando està Dios,

solicitando disculpas

su pena las culpas de mi perdicion.

Aprisionado en los yerros,

que mi delito labrô,

por darme mi libertad,

esclavo se mira temblando al rigor.

Siendo su valor inmenso,

por lo mas vil se humanó,

compensando su cariño

la falta del precio, con su estimacion.

siendo mi culpa infinita,

a su piedad motivó

hazer el pago excesivo

pues de tantas perlas por satisfacion.

Reverente sacrificio

el Oriente le ofreciò,

rindiendole en tres Coronas

debidas ofrendas a tanto Señor.

Con justa razon se quexa

de mi duro coraçon,

quando a vna gentilidad

conduce a sus plâtas la Fee y el Amor.

F I N. 
Biblioteca Nacional. Madrid.V./E. 83, n ${ }^{\circ}$ 5. "Ay meu mancebiño”. .

Versos polimétricos desde el principio con similitud paralelística propia de la poesía gallegoportuguesa, donde pervive el apego al paralelismo retardando la adhesión a las nuevas técnicas de versificación. Gran resistencia a abandonar la técnica del paralelismo. 


\title{
LETRAS DE LOS VILLANCICOS QVE SE CANTARON EN LA SANTA IGLESIA METROPOLITANA, Y PATRIARCHAL DE SEVILLA, Este Año de M.DC. LXX.V. \\ EN LOS MAITINES DEL NACIMIENTO DE N. REDEMPTOR IESVCHRISTO. COMPVESTOS POR EL RACIONERO ALONSO XV AREZ, Maestro de Capilla de dicha Santa Iglesia.
}

\author{
KALENDA. \\ VILLANCICO I. \\ Estrivillo.
}

SOldados de esta Milicia, oy es el dia en que es fuerça, ya que no ganar el Mundo, à lo menos darle guerra. Llegad, Soldados, al muro, echad à pique sus fuerças, si no es $\mathrm{q}[\mathrm{u}] \mathrm{e}$ rendidos quieren el dar las plazas por nuestras, 1. A del muro terrenal, à Soldado, à Centinela, Quien es quien lleno de errores con tanto estruendo le altera?

La Minerva despreciada, la Vanidad mas sobervia.

2. Pues què pretende nos diga, si es de paz, ò si es de guerra?

1. Que el pecado le rindais con voluntad las potencias. 2. Haganse afuera, villanos, que ay vn Dios que nos defienda. Otro Coro. A del castillo del Orbe.

1. A de su fabrica excelsa.

2. Que voz suspende mi oido? quien es quien passa, quien llega? 1. La Hermosura disfraçada con toda la Omnipotencia. 
2. Pues què pretende nos diga, con armonia tan nueva?

1. Vengo à rescatar cautivos, salgo solo à esta defensa

2. Pues à embestir, que ya està el enemigo à la puerta.

Toquen los clarines, suenen las trompetas, al arma, al arma, al arma, guerra, guerra, guerra, que contra los Vicios la Virtud pelea.

Coplas.

1. Vanidad me llamo.

2. Y yo la Prudencia.

1. Aqueste es mi centro.

2. Fuera, fuera, fuera, que son perniciosos humos de la tierra.

1. Yo soy el Furor.

2. Yo Iusticia recta.

1. Donde vás, Señora?

2. A tierra, à tierra, à tierra, porque està perdida, de traiciones llena.

1. Fortaleza soy.

2. Y yo la Flaqueza.

1. Diga que pretende?

2. Fuerça, fuerça, fuerça, porque son mis lazos la Red barredera.

1. Yo soy el Pecado.

2. Yo la Virtud mesma.

1. Què quereis de mi?

2. Muera, muera, muera, porque ya ha encarnado para que perezca.

Todos. Victoria, victoria, victoria, 
que ha quedado por Dios

la fortaleza.

Vencidos quedan

de la Virtud los Vicios

en la contienda.

Y despues de la guerra

al ayre se tremolan

de paz los esta $[n]$ dartes, y va[ $[n]$ deras.

\section{VILLANCICO II.}

\section{Estrivillo.}

FAvonios lisonjeros,

Zefiros bullidores,

no sopleis inquirietando Luzeros,

no desperteis de su sueño à las flores:

quedito, pasito,

parad, tened,

que se duerme mi Niño de perlas,

no me le desperteis.

\section{Coplas.}

Vientecillos lisonjeros,

cesse el aliento vizarro,

q[ue] la hermosura del Niño no es barro, para obligarla a que haga pucheros.

Si serenidades bellas

pretendeis entre arreboles,

no les corrais la cortina à sus Soles,

que los hareis que lluevan Estrellas.

No encienda ayrado Aquilon

à quien està en pobres fajas,

no se diga, que à humo de pajas

obra el chiquito nuestra Rede $[\mathrm{m}]$ pcion.

Airecillos, no sopleis,

ò soplad con mas aliño,

no sea $\mathrm{q}[u e]$ poniendo la mira en el Niño

al Rey Herodes el soplo le deis. 


\section{VILLANCICO III.}

Estrivillo.

VN Portugues, y vn Gallego

se travaron de palabras

por Navidad, y vno a otro

dixo el nombre de las Pascuas.

Todos. Oigan à entrambos,

que se dàn vaya.

Port. Ficay la Galeguiño, que o Niño

naõ quere Galegos nel suo Portal:

Ficay la ficay la, que os Galeguiños

naõ entran aca,

ficayvos alá.

Gallego. Ficay vos, dize el Gallego,

Portuguesiño ratiño,

que no està seguro o Niño

de vos, se os entrais aca.

Ficay la, Ficay la,

que los Portuguesiños

acà no han de entrar.

Ficay, ficay vos alà.

\section{Coplas.}

Gall. Calà, que cando Deus nace

o Galego sañas dà,

que donde ay boy, mula, e palla,

es de Galicia vn casal.

Port. Miray, si Galego fora,

tembrara muito ò Zagal,

mais si està ao frio, è naõ tembra,

Portugues es, craro està.

Gal. Calà, que o fermoso Neno

non quer sobervios acà,

e por vassallos humildes

Rey de Galegos es ja.

Port. Quando chora este Miniño 
Portugues falando està, pois quando face pucheros craro es que nos dize ollay. Gal. Mentides, Portugues vano, que fora de vn Santo que ay, que he o señor San Antonio, na[d]a ay boo en Portugal.

Port. Por la pala de a forneira me digais lo que pesais, que por no os levar a costas non vos mato, naõ por mais.

Gal. Ficay la, que ay Galeguiño que cando à las feiras và, a trueque de çapatiños os Portugueses le dan.

Port. Ficay la, que en vos vencendo si vos colho en Portugal, solo por vna cebola cen Galegos he de dar.

\section{SEGUNDO NOTVRNO.}

VILLANCICO IV.

Estrivillo.

DVlces Avecillas,

que veis nacido el Sol,

acalladle con cantos alegres,

pues veis que llora de amor

Gemid mi gozo,

su dolor,

pues de su llanto procede

la dicha del hombre,

y contento mayor.

\section{Coplas.}

Mirando al Sol madrugado

las Aves en dulce voz,

la bienvenida le davan

vna à vna ; y dos à dos. 
De sus rayos suspendidas, para alabarle mejor, con el afecto le dizen lo que con las vozes no. Lucid, y llorad à vn tiempo, pues naciendo como el Sol, mas fecunda hareis la tierra con la lluvia, y el calor.

\section{VILLANCICO V.}

\section{Introducion.}

VN Pastor, que en valentias es mas crudo q[ue] el Diziembre, dixo a Dios, viendole humano, con tonillo, y sonsonete.

\section{Estrivillo.}

1. Oy gigante Niño temanle, que del Cielo viene terrible guerrero, poderoso, y fuerte.

2. Tengase.

1. Al frio no tiemble, y pues nace la vida.

2. Muerase.

1. Que se muera la muerte, siendo el fuego mismo,

oygame, que la teirra enciende.

2. Ay Iesus, como abrasan los yelos.

1. Pleguete, como quema la nieve.

Mireme, no llore, ni se quexe, y pues nace la vida.

2. Muerase.

1. Que se muera la muerte.

Coplas.

Amante de vn mundo amargo

oy dulces lagrimas vierte, 
y auque no tiene la culpa,

pues èl se lo quiso, cuestele.

No desperdicie las perlas

con que la tierra enriquece,

que si le texen corona

seràn las espinas fertiles.

Bien aya, Zagal hermoso,

quien à los suyos parece,

venciò serpientes su Madre,

$y$ èl es en la cuna vn Hercules.

Herodes, Medico insano,

que de la salud se ofende,

manda que tome el azero,

guardese Niño del Recipe.

Para adquirir el renombre

de piadoso, y de valiente,

levantar puede al caido,

solo que diga, dueleme.

Quando la oveja perdida

à su rebaño bolviere,

echese la carga al ombro,

y sile pesare, pesele.

$\mathrm{Y}$ al fin, si truxeren dones,

al visitarle tres Reyes,

recibalos, que es gran cosa,

que dexen algo los huespedes.

\section{VILLANCICO VI.}

\section{Introducion.}

POrque muy crudo el Diziembre quiere preciarse de guapo,

lo festivo desta noche

darle vaya ha procurado.

\section{Estrivillo.}

Va de vexamen, vaya,

lleve el Diziembre, lleve, 
pues, $\mathrm{s}[\ldots]$ do conjura su nieve,

lleve, lleve.

Pues del Sol la artilleria

echando ya rayos viene,

burlando burlandillo la nieve.

Y pues la noche es tan fria,

con la vaya en calor entre,

lleve burlandi, burlandillo la nieve.

\section{Coplas.}

Si preciandose de crudo

el invierno con porfia,

à vn Niño Dios desafia

por verle que està desnudo,

pues con enojo sañudo

rigores contra vn Sol mueve,

lleve burlandi, burlandillo la nieve.

Si porque mira en el Prado,

que el mas osado arroyuelo

se queda al verle hecho vn yelo,

y de colera pasmado,

quiere de su escarcha armado,

que el Sol sus desdenes prueve,

lleve burlandi, \&C.

No por sus locas rencillas

vea el Pastor entre quexas,

si por tierra las ovejas,

por el cielo las cabrillas:

y si à tantas maravillas

se opone su furia aleve,

lleve burlandi, \&C.

Mas si de pagar no trata

los cristales que codicia,

mandarà el Sol de justicia

que los restituya en plata:

y si su frialdad ingrata

rizos Moncayos conviene,

lleve burlandi, burlandillo la nieve. 
Biblioteca Nacional. Madrid. V/E n ${ }^{\circ}$ 5. "Soldados de esta Milicia".

Rima asonantada, con una letanía en las coplas, propia del verso románico, con hipermetría e hipometría, mezcla de arte mayor y arte menor. A veces aparece el tipo de métrica propio de la Romania y muy característico de la poesía gallego-portuguesa de carácter popular. Ejemplo:

"Meu maridiño foise por probe,

deixou vn fillo, topou dezanove"

"Tanto bailè con el ama del cura,

tanto bailè que me dio calentura"

Paraíso ${ }^{17}$, cree que existe un sustrato germánico de nuestra cultura, sobre todo la cultura visigótica (siglos V y VIII, desde el 418 al 711), que nos hace comprender la importancia del acento en el Latín vulgar hablado en la Península. El canto y el baile, fijan los tiempos fuertes en cada frase melódica.

${ }^{17}$ Isabel Paraíso: LA MÉTRICA ESPAÑOLA EN EL CONTEXTO ROMÁNICO. Arco/Libros, S. L.Madrid, 2002 , p. 37. 
VILLANCICOS QVE SE HAN DE CANTAR EN LA CAPILLA REAL DE SV

MAGESTAD LA

Noche de Reyes deste año de 1676.

VILLANCICO PRIMERO.

ESTRIVILLO.

ATencion, silencio,

Que los Reyes entran,

Trayendo por guia,

Si Estrella en el cielo,

Al Sol en la tierra;

Y porque se sepa,

Al Sol de Iusticia sus dones franquean:

Para que?

Yo lo dirè:

Digame el assumpto;

Oygame el contexto,

Que en el Cielo alumbra vna Estrella,

Y el Sol a la tierra le dà lucimiento;

Luego diremos,

Que el Sol en Iudea,

La Estrella en Oriente,

Con vn fin nacieron:

Y que alumbrando, y luciendo,

Le dàn a la tierra

La vida, y ser nueuo.

COPLAS.

NAcio el Sol, y con sus rayos

Dorò todo el Vniuerso,

$\mathrm{Y}$ a expensas de lo radiante

Se vistiò de luz el Cielo.

Naciò la Estrella, y cobrando

Luz de luz, fue su ardimiento

El fin de vna profecia,

Que tres Reyes entendieron; 
Y que alumbrando, y luciendo,

Le dàn a la tierra

La vida, y ser nueuo.

El Sol de Iusticia, Christo,

Con sus dorados incendios

Viuificò a los mortales,

Para que cobren aliento.

La Estrella dio inclinaciones,

y sin forçar, influyendo

Atractiua , como imàn

Lleuò tras si tres afectos;

$\mathrm{Y}$ assi alumbrando, y luciendo, \&C.

Al Rey, Sol, vienen buscando,

Por solo de dos Imperios,

Ofreciendo en holocausto

Breues instantes del tiempo.

Auisados por los Sabios

De Ierusalen, salieron,

Y por la luz de la Estrella,

Con los rayos del Sol diero[n];

Porque alumbrando, y luciendo, \&C.

Procediendo con amor

Le adoraron, y ofrecieron

Tres dones, que solo a Dios

Los Reyes darle pudieron.

Conocieron en su Madre

Mejor Estrella, pues vieron,

Que el efecto de vn Dios Hombre,

Fue de virginal efecto;

Y que alumbrando, y luciendo, \&C.

VILLANCICO VI.

\section{GALLEGO.}

\section{ESTRIVILLO.}

1. PEruquin, peruqin, al Portal,

Por aqui, por alli a baylar.

2. Turibin, Turibin, tocay 
El sonsoneciño,

Que mas garridiño

Le bote el compàs.

Tod. Ay ay, ay.

3. Sone la gaytiña,

Ay, ay, ay.

4. Girando, crozando.

Tod. Ay, ay, ay,

1. Con la reboltiña.

4. La castañetiña.

Tod. Ay con el quey, con el ay.

1. Repita lo son.

2. Y diga el solaz.

1. En los pes como campañetiñas.

2. Me pica, y repica.

1. El sonsoñeziño.

2. Sin ser Sacristan.

Tod. Con el quey, con el ay.

1. Pues mira o pracer.

2. Vna Estrela sumiller.

1. Con abrasado arrebol.

2. Correr la cortina al Sol, $\mathrm{y}$ tres por tres,

Los Reyes al Niño Rey

Fincados le dàn.

Tod. Ay, quey, quey,

Con el quey, con el ay.

1. Y no fazen mas.

2. Que chegar, y besar.

Tod. Ay, quey, quey,

Con el quey, con el ay.

\section{COPLAS.}

LOs tres Reyes pracenteiros

Buscando vienen a vn Rey,

Porque con èl ajostada

Tenen la conta de tres;

Ay, quey, quey,

Como se toman la mano, 
Porque o Niño les dà el pe;

Ay, quey, quey.

Ferodes con suas preguntas,

Muchachos los quiso hazer,

Que vn necio preguntador

Cuchillo de todos es;

Ay, quey, quey, quey,

Non son de mi Catecismo,

As preguntas de su Ley,

Ay quey, quey, quey.

En camellos sus jornadas

Gostosos vieron fazer,

Que no se vsauan entonces

Las Muletas de Aranjuez;

Ay, quey, quey quey,

Que es ligereza de Almagro

Correr por solo correr;

Ay, quey, quey, quey.

En vna casa palliza

Fallan a o bello crabel,

Sin duda de algun Galego

Casa Solariega fue,

Ay, quey, quey, quey.

Por darme pan en la palla,

$\mathrm{O}$ trigo quiso nacer;

Ay, quey, quey, quey.

Erguido en braço del Alua

A mi Sol fermoso ven;

Porque a la luz desta Aurora

Solo quiso amanecer:

Ay, quey, quey, quey.

Entre gorgeos de rayos

Brillante le ven mecer;

Ay, quey, quey, quey.

Representando el anciano,

Ternuras chega a ofrecer,

$\mathrm{Y}$ en este passo la barba

Fizo famoso papel:

Ay, quey, quey, quey: 
Mas en la fiesta de ò Corpus

La joya al Niño le dèn:

Ay, quey, quey, quey.

Baltasar en el incienso

Lo fidalgo diò a entender;

Porque siempre el buen olor

Descubre la nobre prez,

Ay, quey, quey, quey.

El menjui de los Galegos

Tociño, y sardiñas ser,

Ay, quey, quey, quey.

El Rey prieto de azabache

Figas se quisiera hazer;

Porque de ollo los Iudios,

No fieran al Agnus Dei,

Ay, quey, quey, quey.

$\mathrm{Si}$ fora negro el bermello

Nunca le fora a vender:

Ay, quey, quey, quey.

\section{VILLANCICO VII.}

\section{INTRODVCCION.}

EL Alcalde de Belen

Con los zagales del Pueblo,

De quantos puso a la sombra,

Preuiene al Sol vn festejo.

Al Portal, en mogiganga

Llegan locos de contento,

$\mathrm{Y}$ con el brindis venian

Algo tiznados los negros.

\section{ESTRIVILLO.}

TOdo el mundo se alegre, vie $[n]$ do,

Que la tierra se ha buelto Cielo;

Ay que vaya, que vaya, vaya,

Celebremos al Nino, que todo es gracia.

1. Que si mira 
2. Que si rie.

3. Que si 1lora. 4. Que si canta;

Ay que vaya, que vaya, vaya;

Atención, porque empieza la mogiganga.

\section{COPLAS.}

1. DE parte de Vizcainos,

Ioangaycoa, yo te ruego,

Iuras a Dios, quites culpas,

Y no nos quites el hierro.

2. Ser de soancho paysana

Mula señora,

Que los dos nos calçamos

en vna horma.

Tod. Ay que vaya, que vaya, vaya,

Festejemos al Niño, q[ue] todo es gracias.

1. Pues naceis Portuguesiño

Naon fagais tembrar al yelo,

Que estoy de verus tembrar,

Vatu a Christo que rebentu.

2. El fidalgo finchado

Nos da las coplas,

Que pare a la musa,

Que a todos sopla.

Tod. Ay, que vaya, que vaya, \&C.

1. Ziolo, auqnue negra zamo,

Branco la neue me ha hecho,

Polvo a pezal de refran,

Ay titnula zoble neglo.

2. Quando el engro estornuda

La mula brinca,

Por pensar que le toma

La ceuadilla.

Tod. Ay que vaya, que vaya, $\& \mathrm{C}$.

1. Yo Siñor, vengu a amolar

Cuchillos para inocentos,

E cun vna muela masco

A España todu el dineru.

2. Con el Frances tendremos 
La Noche Buena,

Si con queso, y con vino

Dà en ratonera.

Tod. Ay, que vaya, que vaya, vaya,

Festejemos al Niño, que todo es gracias.

1. Galeguiño, meu Señor,

Os presenta oviños frescus,

Que vos los tengo guardados

Desde el otro nacimento.

2. Los Gallegos los huebos

Mucho los gastan;

Pero nunca los quieren

Passar por auga.

Todo. Ay, que vaya, que vaya, vaya,

Festejemos al Niño,

Que todo es gracias.

F I N.

Biblioteca Nacional. Madrid. (V/E 91-22), 163. “Atención, silencio”.

Son varias lenguas en el villancico, pero todas del mundo románico: versos de gaita gallega. Rima asonante, versos octosílabos. 


\title{
VILLANCICOS QVE SE HAN DE CANTAR EN EL REAL CONVENTO DE LA ENCARNACIÓN \\ LA NOCHE DE NAVIDAD \\ Año 1676. \\ PVESTOS EN MVSICA \\ Por el Licenciado D. Matias ruiz, Maestro de Capilla.
}

\author{
VILLANCICO II \\ INTRODVCCIÓN \\ Vn Portuges, y vn Gallego \\ se trabaron de palabras \\ por Nauidad, y vno a otro \\ dixo el nombre de las Pascuas.
}

ESTRIVILLO.

Portu. Ficay la, Galegiño, q[ue] ô Nino naon quere galegos nel su Portal, ficay la, que os Galeguiños naon entran acà.

Ficaybos alà.

Galle. Ficaybos dize el Gallego,

Portugesiño ratiño,

que no està seguro ô Nino

de vos, se os entrais acà.

Ficay la, que los Portugesiños

acà no han de entrar.

Por. Ay, qui morro por ver ô Zagal.

Gal. Ay, que me lleuan sus ollos alá.

Ficay la.

Ficaybos alá.

\section{COPLAS.}

Gall. Calà, que cando Deus nace

ô Galego señas dà,

que donde ay boy, mula ê palla 
es de Galicia vn casal.

Port. Miray, si Galego fora

tembrara muyto ô Zagal,

mas si està ao frio, ê naon tembra

Portuges es, craro està!

Gall. Calà, que ô fermoso Neno

non quer sobervios acà,

ê por vassalos humildes

Rey de Galegos es ya.

Por. Quando chora este mi Nino

Portuges falando està,

pois quando face pucheiros

craro es que nos dize ollay.

Gall. Mentides, Portugues vano,

que fora de vn Santo que ay,

que he o Señor San Antonio,

nada ay boô en Portugal.

Por. Por la pala de a forneyra

me digais lo que pesais,

que por no os lebar a costas

non vos mato, naon por mais.

Gall. Ficay la, que ay Galegiño

que cando a las feyras và

a trueque de zapatiños

os Portugeses le dàn.

Por. Ficay la, que en vos vencendo, si vos collo en Portugal,

solo por vna sebola

cen Galegos he de dar.

\section{VILLANCICO III}

Al Zagal que nos ha nacido,

que arde de amores,

y tiembla de frio,

presentadle galas

Pastores,

ofrecedle rosas,

y flores. 


\section{COPLAS}

1. Yo le ofrezco vna Guirnalda, que del rubi, y esmeralda, de los claveles tegi, que lo verde y carmesi es Corona de las flores: presentadle galas Pastores.

2. Yo le doy vna Azuzena, que de granos de oro llena su rostro, y pelo retrata, que son de oro, y la plata firmes y puros colores, ofrecedle rosas, y flores.

3. Yo le presento vn vestido de lirios todo tegido al Zagal enamorado, que es empressa lo morado de todos los amadores, presentadle galas Pastores.

4. Yo le presento vna Rosa, que lastima siendo hermosa, porque despues de humanado se precia de lo encarnado aunque le cueste dolores, ofrecedle rosas, y flores.

5. Yo le presento vn Iacinto, en que le retrato, y pinto, por ser piedra, y por ser flor firmeza, olor, y color, essencia, y flor de las flores: presentadle galas

Pastores.

6. Yo le presento vn Iazmin de la Corte de vn Iardin, que en breue tierno candor 
aun no ha descollado flor,

y ya es ambar de las flores

ofrecedle rosas,

y flores.

Biblioteca Nacional. Madrid. (V/E 91-50) “Al venir lo Divino".

Versos polimétricos, propios de una ensalada de lenguas característica del Renacimiento. Rima asonantada. A veces es rima abrazada, propia de la literatura castellana. 
VILLANCICOS QVE SE HAN DE CANTAR EN EL REAL

Convento de la Encarnación, la noche de los Santos Reyes, este año de 1676.

PRIMERO NOTURNO.

ESTRIVILLO.

PRIMER VILLANCICO.

Aves, celebrad al sol que nos nace,

y con solfa de Estrellas

Entona vn Angel:

Canten,

Al Cielo la gloria:

Canten,

Al hombre las pazes:

Canten,

La dicha a la tierra:

Canten,

La luz a los ayres:

Canten,

La capilla sonora de las Aves.

\section{COPLAS:}

En la selva de Belén

La Capilla de las Aves,

Sobre facistol de nieve

Cantaron al Sol que nace.

Vn Ruyseñor muy preciado

De retorico del valle,

Començô a templar el pecho

A vn organo de cristales.

Vn Xilguero, que a colores

Es de los vientos plumaje;

En la mano del Sol Niño

Fue ramillete bolante.

Vn Pelicano cantaua

A vna lyra de corales;

Y gustò Dios de la letra, 
Porque empezaua con sangre.

Vna Tortola amorosa,

Siendo de Maria imagen,

Busca al Niño, porque tenga

Quien le arrulle, y quien le cante.

Vn cisne, paxaro docto,

como musico mas graue,

Conociendo que se muere,

Le canta a Dios cuando nace.

\section{VILLANCICO.}

INTRODVCCION.

Por los montes de Belen

los Reyes de caza vàn,

pues del amanecer,

aunque nacido el Sol ya,

[...] suena la Monteria

[...] Belen, y es de admirar

[...] ver que haga tanto ruido

[...] donde nace la Paz.

\section{ESTRIVILLO.}

Al monte, al llano, a la selva, Que baxa yà su Alteza.

Ataja à la culpa fiera:

Al monte, al llano, a la selva,

Que pues baxa ser humano

En el llano hallarse es llano;

Pues de Dios es la llaneza:

Al monte, al llano, a la selva.

Divino Caçador,

Desnudo dios de amor,

Dispara,

Tira, tira,

A la culpa fiera:

Al monte, al llano, a la selva.

\section{COPLAS}


1. A un Portal oy a caça

Sale el Rey Niño,

Que este Rey no và al Pardo

Sino al Pagizo.

2. Desnudo anda,

Y faltandole telas

Busca la caça.

1. Como siembra rigores

El llano dexa,

Porque le muestra el monte

Mas aspereza.

2. Corriendo el monte

Siembran flores sus plantas,

Y espinas cojen.

1. Aunque espinas sus plantas

Con gusto pisa,

Mucho mas su cabeza

Se les inclina.

2. Viles se llamen,

Aunque tienen sus puntas

Tan buena Sangre.

1. Aquel tigre manchado

Flechas dispara,

$\mathrm{Y}$ a la fiera las tira,

pero a êl le encarnan.

2. Dios de este Tigre

Por quitarle las manchas

Su piel se viste.

1. Oy que en vn lazo el Verbo

Se vne a lo humano,

Para cojer la fiera

La arma esse lazo.

2. La red le tienda,

Que si es bravo, oy es tiempo

Ya de tendella.

1. Corre el Niño a la fiera

Que al viento imita;

Ella và sin verguença,

Pero corrida. 
2. Fuerça es la alcançe,

Pues aun mas que sus plantas

Corre su sangre.

1. De vna Cruz, por la senda,

Và cuesta arriba,

Y essa subida, ô cuesta,

cuesta su vida.

2. Del ombro pende,

Peligrosa su vida,

Que està pendiente.

1. Son tres Clavos sus flechas,

Y ellos le hieren;

Si son yerros,què mucho

Que en nada acierten?

2. Và a castigarlos;

Pero essos mismos yerros

Le atan las manos.

1. Con temor de las fieras

Los Reyes cazan,

Que la sombra esta noche

La hizo cerrada.

2. La Luz de vn Astro,

De essa boca de lobo

Pudo escaparlos.

VILLANCICO III.

INTRODVCCION.

De la Noche buena, dizen

Sus Catolicos devotos,

Que no son cuerdos, los que

No se alegran como locos.

Con este intento a la fiesta

Vienen los dos mas notorios;

Que es el vno Linajudo,

Y Predicador el otro.

Oyganlos, y nadie de ellos

Diga mal, porque a si propio 
Se agrauiarà, el que hable mal Del que es pariente de todos.

Aora salga el Rector,

Que entre locos, no es impropio, Que el que ha de ser el postrero Salga el primero de todos.

\section{ESTRIVILLO}

Atencion a los locos,

Que esta noche son ellos

Los mas devotos;

Pues si nace de amor la alegria,

Mas amor tiene

quien tiene mas gozo.

\section{COPLAS}

Pred. Hermanos, oy nace Dios:

In saecula saeculorum,

Pax vobis.

Que esta noche ha de tener

Paz los bobos.

Linaj. Los bobos eran de Coria, Y son mis parientes propios;

Hijos por parte de Abuelo

Del Mariscal, y del otro

Que casô en Nabal Carnero,

Sobrino de los Redondos;

Que son primos por tres partes, Y los quemaron a todos.

Todos. Victor, Victor

Los locos,

Pred. Nace Dios en vn Pesebre;

Nascit in paxis paxorum;

Los pajes andan a pie,

Dios nace del mesmo modo;

Nace a redimir el mundo,

Alma Christiana, abre el ojo;

Porque. Iudica me Deus,

Los Iudios maliciosos 
No creyeron, que aunque el Niño

Estaua desnudo, y roto,

Ellos estauan en cueros;

Doctissimi Villalobos.

Linaj. Los Villalobos, son primos

Por parte de Iuan Palomo,

Mi tio, mi tio, mi tio;

Porque tambien con los Roxos,

La Abuela de Villaseca;

La que era prima del Sordo,

Con el pariente de Olias,

Sobrino de Mari Alonso,

Que casô con el Aguelo

De segundo Matrimonio.

Todos. Victor, Victor,

Los locos.

Pred. Auia vna mula, y vn Buey

En vn portal; Memento homo,

La Mula era muy honrada;

Aqui vereis lo que noto,

Bobis arantibus terram:

Y la Mula cantô vn tono,

Que sabía muy bien solfa;

Como dize cierto Docto,

Y se prueba con el texto

Fa-mularum, fa-mulorum.

Linaj. La Mula tambien es tia,

Que era de Almagro

Nieta de Mari Machon,

Fue prima por quatro modos,

Y la Mula del Doctor,

Que muriô de comer bollos,

Fue tambien mi prima hermana;

Porque mi abuelo el de Tornos,

Tuuo por parte de madre,

Quinze nietos, Machos todos.

Todos. Victor, Victor

Los locos.

Pred. En la noche de los Reyes: 
Regis magis, grande elogio,

Que los Reyes eran Magros;

Porque no venian gordos;

Vna Estrella los guiaua,

Y los dexô bolver solos:

Tornatilis committatus;

Vên aqui el sucesso propio.

Linaj. Tambien la Estrella es mi prima

Por el tio de Logroño

Y Luzia de la Luna,

Madre de Bernardo el Tonto,

Sobrino de Iuan Luzero;

Porque los Luzeros todos,

Son sobrinos de su tio,

Y del Ama que es lo propio.

Todos. Victor, Victor, \&c.

\section{NOTVRNO.}

\section{VILLANCICO.}

\section{INTRODVCCION.}

Al Sacristan de Belen,

Por los Reyes preguntò

Vn Pastor, que de misterios

No sabe mas que vn Pastor.

La Noche Buena passaron

Preguntandose los dos:

Atencion, porque la letra

consiste en la responsion.

\section{ESTRIVILLO.}

1. Atencion,

Que la razon de dudar

No dexa de ser razon.

Atencion.

Pastor. Dime, Sacristan.

Sacristan. Quê dizes Pastor?

Pastor. quien son estos tres 
De vario color?

Sacristan. Sabios son que siguen

De vn Astro la voz.

Pastor. Sabios son, y Reyes:

Pues aqui de Dios;

Como son tan ricos,

Los que sabios son?

Sacristan. Porque oy vea el mundo

Lo que nunca viô.

1. Atencion,

Que dudar para saber

Mas que yerro es discrecion.

2. Atencion,

Que la razon de dudar

No dexa de ser razon.

Atencion.

\section{COPLAS.}

Pastor. Por quê en Enero los Reyes

Buscan al Sol que naciô?

Sacristan. Porq[ue] en Iulio, ni en Agosto

Nadie và a buscar el Sol.

Pastor. Por quê van en Dormedarios

Los Reyes y en coches no?

Sacristan. Por no aguardar a vn choche,

Irse a pie fuera mejor.

1. Atención

Que la razon de dudar

No dexa de Ser razon.

Pastor. Por quê llora el Sol humano

Quando a los tres Reyes viô?

Sacristan. Derrama perlas, y luzes

Porque llueua, y haga Sol.

Pastor. Dizen, que naciô a las doze

Y el Relox ninguno oyô?

Sacristan. Si le oyeran, si naciera,

En la calle de el Relox.

I Atencion,

Que la razon de dudar 
No dexa de ser razon.

Pastor. Por quê quiso Dios nacer

Siendo absoluto Señor?

Sacristan. Porque nos ha de salvar,

$\mathrm{O}$ vêr para que naciô.

Pastor. Por quê Dios a los Pastores

Don de ciencia non les diô?

Sacristan. Porque los $\mathrm{q}[u e]$ son pastores,

No han menester tener Don.

Atencion, \&c.

Pastor. Todos le juran por Rey,

Desde el pequeño, al mayor?

Sacristan. Y oy dia los Carreteros

Le juran que es bendicion.

Pastor. Por quê ofrece al Niño Rey

Seis Negros el Rey Melchor?

Sacristan. Porque en el tie $[m]$ po de nieues

Es gran regalo el carbon.

Atencion, \&c.

Pastor. Por la Encarnacion el Rey

Vino a remediarnos oy?

Sacristan. Quando viene hazer mercedes

Viene por la Encarnacion.

Biblioteca Nacional. Madrid. R.34989 R. ${ }^{14}$ 162. 1 Barbieri "Aves, celebrad al Sol que nos nace". Versos en latín "macarrónico", cuando ya no se hablaba latín. Las coplas son una constante reivindicación, se contestan unas rimas a otras. Rima asonante, polimetría en la versficación, aunque predomina el octosílabo, propio del villancico. 
VILLANCICOS, QVE SE HAN DE CANTAR

en los Maytines de los Reyes, en la Santa Iglesia Angelica, y Apostolica del Pilar, Metropolitana, y Primera Cathedral de Çaragoça, este Año de M.DC.LXXVI.

Siendo Maestro de Capilla Diego de Cáseda.

VILLANCICO PRIMERO.

\section{INTRODVCCION.}

Reyes Doctos,

Nobles Magos,

En quien pone,

En quien $[\ldots]$,

El mando Ley a las luzes,

La ciencia luz a las Leyes.

Donde a [...],

Donde a aciertos

En lo humano,

En lo celeste,

Logra el poder lo que sabe,

Muestra el saber lo que puede.

\section{ESTRIVILLO.}

Oid, atended,

reparad, advertid,

que lengua de rayos?

que llama de $[\ldots]$ ?

rompiendo los vientos

su curso veloz,

os habla su luz

y alumbra su voz,

Que serà, responded a mi duda,

que en lengua, que es muda

acierte el Luzero

silencio parlero.

Que será? que si fin disimule,

y que no articule

la voz sin reparto 
viniendo a hablar claro

Que será? No es novedad,

[...] aunque hablar con claridad

a los Reyes tanto importe.

no tiene voz en la Corte

la lengua de la verdad.

No es novedad.

\section{COPLAS}

Con vago dosel de luzes

en mudo trono de horrores

presso imperioso vn [...]

los silencios de la noche.

De tan misteriosos rayos

a tres sabias anteriores

en poca luz se descifra

mucha verdad, que se esconde

No solo a su vista alumbra

pero ilustra sin errores,

que aun mas alla de los ojos

tiene la luz su Orizonte.

Su resplandor por los ojos

enciende sus coraçones,

que son vidrieras del Alma

que hazen las luzes ardores

[...] descubre con luzes,

[...] eloquencia del Norte,

declararse sin palabras,

quando acusa sin-razones.

Como es Luz, que enseña a Reyes, es muda, porque se oponen

a la ignorancia las luzes,

pero al decoro las vozes.

Vna palabra, y por cifras

les dize, que si los que oyen

son muy sabios, la razon

tiene el riesgo en las razones

Mostrarle enigma a los Sabios

es de empeñar ardid Noble, 
a que sigan los afectos

lo que huye a las discrecciones.

Llegan a Ierusalen,

y si alli el Astro se esconde,

retirarse en obediencia,

no es desluzirse en temores.

En Belen si, que templando

su desaire en tantos Soles

Se resiste sus peligros

supo hazer veneraciones.

VILLANCICO SEPTIMO.

\section{INTRODVCCION.}

Oy Cielo, y prado batallan,

luz a luz, y flor a flor,

si este $[\ldots]$ sus hojas,

sus rayos aquel se armò.

Campaña ofrece su duelo,

Belen, palenque de amor,

y en los ojos de vn Infante,

se les ha partido el Sol.

\section{ESTRIVILLO.}

O que choque de Esferas, y Mayos,

ò que encuentro de flores, y rayos

ò que bien

tiñen Lucero, y Clavel

ò que Lid

tienen Estrella, y Iazmin;

ya embisten y lidian,

por tiros previenen

Ambares que exalan,

atomos que encienden.

$\mathrm{O}$ que ardiente choque!

yà a faltar les viene,

polvora que arrojan,

purpuras que vienen, 
Pero en solo vn Infante el amor

Luz del Cielo, y del campo flor, por socorro les ha dado

polvora en sus incendios,

atomos en sus rayos,

ambares en su aliento,

purpura en sus labios.

O que choque de Esferas, y Mayos;

ò que encuentro de Flores, y Rayos.

\section{COPLAS.}

Desafian las flores inclitas,

Luces, y Astros,

en el rostro de vn bello Principe

que les dà Campo.

Aun la flor, que es mas roxa, palida

fue a sus mexillas,

y la luz mas gigante tremula

quedò a sus Niñas.

En sus ojos Luzeros Diáfanos

lidian valientes;

pero estàn azuzenas candidas

haziendo frente.

Dio tal golpe vna Estrella fulgida, que al Clavel fino, de su labio en dos roxos Nacares dexò partido.

A tal golpe las flores timidas, color perdieron;

pero luego en su boca de ambares cobran aliento.

Como Rayos pelean agiles

las luzes todas,

mas presumen las flores celebres

ser de la hoja.

$\mathrm{Si}$ en sus ojos Estrellas nitidas

sus triunfos hallan,

en sus manos jazmines providos, buscan la Palma. 
Si la Luz de dos Soles atomos

tira encendidos,

el clavel de vna boca purpura

que es mejor Tiro.

Con flores de luzes emulas

la guerra es viva,

con la Rosa en sangrientos limites,

mas encendida.

Las luzes en claros circulos,

que dà vn cometa,

[...] socorro su curso rapido

con buena Estrella.

[...] la guerra tragica,

pues para el triunfo,

a las flores Inciensos Arabes,

crecen los humos.

Pero a flores, y luzes Arbitro,

fue el bello Infante,

con los dos Arcos Divinos indices, de eternas Pazes.

VILLANCICO VIII.

ESTRIVILLO.

Al Niño, que llora

Monarcas llegad,

y con vuestro llanto

el suyo enjugad,

aires de suspiros

le serenaràn,

pues llora mi Cielo,

porque no llorais,

de Oriente venid,

Monarcas llegad.

COPLAS.

Del yelo està mi Dueño

al mal 
expuesto por la ofensa,

que vio

en cuya recompensa

quedó

al verse en tal empeño

mortal,

que aunque es en mi alivio

su gloria el penar.

$$
\begin{aligned}
& \text { al mal } \\
& \text { que vió } \\
& \text { quedò } \\
& \text { mortal }
\end{aligned}
$$

Compitiendo nos vemos los dos,

yelo, y fuego se allentan

aqui,

que por lucir intentan,

en mi

juntar sus dos estremos, $y$ en Nos,

pues hallo en contienda de desden, y amor,

$$
\begin{aligned}
& \text { los dos } \\
& \text { aqui } \\
& \text { en mi, } \\
& \text { y en Dios. }
\end{aligned}
$$

Alli miro al Divino

Amor

perlas entre arreboles

llorar,

formando de dos Soles

un mar,

pielago cristalino

de ardor,

por abrasar yelos

del hombre, intentò

$$
\begin{aligned}
& \text { Amor } \\
& \text { llorar } \\
& \text { vn mar }
\end{aligned}
$$


de ardor.

En Arabia vn errante

farol,

de que ay mejor Oriente

que allà,

a su engañada gente

luz dà,

siendo embidia vn Infante

del Sol,

con fe menos ciega

la Arabia siguiò

$$
\begin{aligned}
& \text { farol } \\
& \text { que està } \\
& \text { luz dà } \\
& \text { del Sol, }
\end{aligned}
$$

Sus coronas qusieron

postrar

tres Reyes adorando

a vn Rey.

y del Cielo abrazando

la Ley,

su Estrella conocieron

de amar,

que solo pudiera

a tanta humildad,

$$
\begin{aligned}
& \text { postar } \\
& \text { a vn Rey } \\
& \text { la Ley } \\
& \text { de amar. }
\end{aligned}
$$

Biblioteca Nacional. Madrid.V/E. 1303-6. "Reyes Doctos".

Métrica: gran polimetría, infinidad de figuras retóricas, con luces, flores, imágenes, comparaciones y letanías, propias del mundo románico. Rima asonante. 


\section{VILLANCICOS QVE SE HAN DE CANTAR EN LA CAPILLA REAL DE SV MAGESTAD}

la Noche Buena deste año de 1677.

\section{VILLANCICO V.}

\section{GALLEGO.}

Introduccion.

Pues que todas las Naciones

Oy en el Portal se hallan,

Los Gallegos esta Noche

Han dispuesto entrar en dança.

\section{ESTRIVILLO.}

Zumbe, y retumbe

La gayta, Domiños,

Que o Baylarei

Mientras chora mi Nino,

Vallasme Deus!

Quein tuuera ò capote

Para abrigar

Aò garrido Chicote!.

Ay quein tuuera

Vnas boas polaynas

Para ponerle

En sus fermosas Patas!

Si el Boy me deran,

Dariale logo

Vna Monteyra,

Que $[\ldots]$

Y porque conozca

Que en todo soy larga

Deme la Mula

Darele dous cartos.

Zumbe, y retumbe la gayta, Domiños.

Que [...] baylarei mientras chora mi Nino. 


\section{COPLAS}

Eu le presento!

Do[...]s mantequiñas,

Para que à Nay

Lle fagan Tourrijas.

Tod. Toca, Domiños, con son pracenteyro,

Zumbe à gayta, retumbe ò pandeyro.

Eu de [...],

Vna peza he de darle,

Pois que sabemos,

Que oy [...] Carne.

Tod. Toca, Domiños, \&c.

Dous çapatiños

de palo le traygo,

Para que ò Mundo

Meta en vn çapato.

Tod. Toca Domiños, \&C.

Vna cestiña

Le traygo de huevus,

Que como nieua

Todos vienen frescus.

Tod.Toca, Domiños, \&c.

Traygo vna Cabra

Por grande regalu,

Que soy Cabrito

Mais ha de dez anos

Tod. Toca Domiños, \&C.

Vnos corales

Le traygo por dixe,

$Y$ èl con las maos,

E pes los recibe.

Todos. Toca Domiños, \&C.

Para que mate

Con ela ao demo,

Doyle vna espada,

Que es toda de fierro.

Todos.Toca Domiños; \&C.

Como à Pastor

Le traygo vn cachorro, 
Para que garde

As ouellas del lobo.

Todos. Toca Domiños, \&C.

Vn corderiño

Sin mancha le traygo

Que es a su Nay

Moy pintiparado.

Todos. Toca Domiños, \&C.

Vna caldeira

Lle traygo relimpia,

por que con homes

Faga boas migas.

Todos. Toca Domiños, \&C.

Eu vn cochillo

Le traygo afilado,

Para que à Herodes

Lle rompa os cascos.

Todos. Toca Domiños, \&C.

Yo so Alcalde,

E le doy esta vara,

Para que à todos

Iosticia nos faga.

Toca Domiños con son pracenteyro,

Zumbe a gayta, retumbe ò pandeyro.

VILLANCICO VI.

\section{ESTRIVILLO.}

Pues es flor del campo

El que nace oy,

Con nueuos colores,

Con vozes de olores

Saluden la Flor,

Que es justo, pues nace

La Flor de las flores.

COPLAS.

El Alva colora 
Su nueuo esplendor,

Que siempre es la Flor

Parto de la Aurora.

Mas ay como llora

De ver la Flor entre la nieue fria

Que tambien tiene llanto el alegria.

El Clauel fragante,

Purpura vestido,

Es de flor Cupido,

De la flor Amante,

No solo constante

Le copia como Rey enamorado,

Pero tambien le imita en lo Encarnado.

Con fragante aliento

Retrata discreta

La azul Violeta

$\mathrm{Al}$ conocimiento,

$\mathrm{Y}$ el Entendimiento

En breue Flor imite mucha llama.

Porque quie $[n]$ mas conoce, es quie $[n]$ mas ama.

Candida belleza

Al Lirio matize,

Pues su candor dize

Amor con pureza,

Que bien su fineza

En los blancos albores assegura

Con candido matiz de nieue pura.

Contempla constante,

Al nacer el Sol

El vago arrebol,

Girasol Gigante,

Contempla $[n]$ do su ardor, su ardor mejora;

Mas quien sigue la Luz, la Luz adora.

La Purpura hermosa,

La fragancia grata

La gracia retrata

En suaue Rosa,

Luego oy misteriosa

Es justo q[ue] su imperio pregone, 
Que Purpura vista, y oro le corone.

\section{VILLANCICO VII.}

\section{INTRODVCCION.}

1. Al Rey Niño, que en pobre hospedage

Ha puesto su Corte,

A cantarle, à adorarle, y à verle

Oy vàn las Naciones.

\section{ESTRIVILLO.}

2. Entren, por que tengamos

Buena la Noche.

1. Canten.

2. No canten.

3. Vengan

4. No vengan,

No hagan el Portal Sala de Competencias.

1. Yo soy Casstellano.

2. Pues yo soy Manchego.

3. Yo soy vn Gallego.

4. Yo soy vn Indiano.

1. Entren todos, pues viene Dios tan humano.

2. Oy la Mancha no entre,

Entre Vizcaya,

Que donde està MARIA

No ha de auer Mancha.

1. Canten.

2. No canten.

3. Vengan.

4. No vengan.

No hagan del Portal Sala de Competencias.

\section{COPLAS.}

Viendo en el Portal vn Negro,

Que estaua la Noche Buena

Mas neuada que sus dientes

$Y$ mas que su casa negra,

Le dixo canta $[n]$ do tonada Guinea. 
Neg. A lo Reyes tlaemo

Lo Neglo flota,

Que el Genelal Pimienta

Viene de Angola.

Biblioteca Nacional. Madrid. (V/E 88-71). "Pues que todas las Naciones".171. 1 Barbieri.

Métrica: comparaciones amorosas con Mongibelo, rima asonante, gran variedad métrica, propia del Barroco. Aparecen el verso endecasílabo galaico antiguo, con acentos en quinta y décima. Ej. "Zumbe a gayta, retumbe o pandeyro". 


\section{VILLANCICOS QVE SE HAN DE CANTAR EN EL REAL CONVENTO DE SAN FELIPE \\ la noche del Nacimiento de Nuestro Señor Iesu-Christo de este año de 1679. SIENDO MAESTRO DE CAPILLA \\ el P. Fr. Iuan Baptista.}

\section{VILLANCICO VI.}

\section{ESTRIVILLO.}

1. A Siolo mandiga de Chungulungue.

3. Qui manda busamilce.

1. Escucheme, y lo vela lo que yo le pleguntale.

2. Yo lon dile.

1. Pues digame, como và tan afanada, vestira di culurada, çagayera en la rocina? digalo pue.

2. No mi ditinga, que vamo de plisa, porque zamo plegolela, y quelemo plegonà. 1. Pues digalo pue, que todos le escuchalan.

2. Atended todos que Negla plegonala: Manda Flacico de Congo, Pliol de la Conslandia, que tura la Negleria venga moleno Cliziana, de Flansia, e le tola Espana, a festejar Nacimenta en el Portal de Belen, que ha naciro Siolo Manue. Todos. Gulumbe, gulumbe, 
mas ay que contentu,

mas ay que plaze,

2. Escuhal,

que la mascala vene ya,

y tocan el tamboril,

tilin, tin, tin, tin,

$\tan , \tan , \tan$,

cun el atabal.

COPLAS.

1. Ya vene la trulla Angona, cun turo Corregidor, y lus Neglo se espantor debel tucal a vna mona.

2. Con la mazcariya ampona, que palecia cucliya, y lu Neglo que la viya de medu empeçò a tucal, tin, tin, tin, cun el tamboril, $\tan , \tan$, ta, cun el atabal.

1. Moleno cun Flasiquiya, và delante muy galan, cun capa de curduban, y calçon de trompetiya.

2. Yeva la gora amariya, con plumage de malcolta, y vna sotana muy culta, que palece vn Escolar, tin, \&C.

1. Vene Antohio bizarra, cayaiera en vn bayena, cun buton de verengena, y tucando vnan guitarra.

2. Taly detlas vnan mudarra, con rabeye, y manduriya, $y$ al tucal la panderiya con eyo empeçò a baylal, tin, \&C.

1. A la Flansesa el vestiro, 
que es aola nueua mola,

và Pascualiyo de Angola

el del fusico turciro.

2. Quiso sel muy conociro

pues yebaua ali vna tlanca

pala engañal a la blanca,

y alçalla mano, y cascal.

tin. \&C.

1. Turos de acabaya, y pe, como zan gente ligela

yegalon de vna carrela

hasta el portal de Bele.

2. Tu cabalo neglo ve,

con sonajas, chas, chas, che,

canta mandinga, vsie,

$\mathrm{y}$ dan en esto inurar.

Tin, \&C.

1. Mandingà de Zangungue

yeva vn moyo de ciboya,

y en la cabeça vnan joya

con moscas, y cascabe.

2. Yeva colcoba tambe, con los caicanos metia, y lu Neglo que la via de risa no pulo hablal tin, \&C.

\section{VILLANCICO VII.}

Gallego, y Asturiano.

INTRODVCION.

Descalços, y con su Gayta

los Gallegos muy gustosos,

vie $[n]$ do q[ue] el Niño està en carnes

en cueros los pies traen todos.

Para ayudar al festejo.

và vn Asturiano famoso,

que en qualquiera cosa ponen 
los Asturianos ombro.

\section{ESTRIVILLO}

Galegui Galeguiños, andair, andair

tocai o Gaitiña

e todois bailair,

porque ò Niño de perlas,

se poda aleigrar.

Ast. El Ninu garridu,

di dunde serà?

Gall. Serà Galeguiño.

Ast. Pois nace ò Portal

como Curitu no sexa

sexa do foire, beña do beña.

Gall. Domiñus, por q[ue] non queires

que ù Nino Curitu sea?

Ast. Purque nun tener cugote

yo, ni non quiero le teña.

Gall. Ser Galeguiño sein duda

a escollido

pois vemos que nace

tan pobreciño,

tanxe à Gaita, è vaya vn solciño,

porque se alegre en as pallas mi Niñu.

Ast. Das Montañas traigo

mantiyas aù Chicu,

porque no se perdan

atadas ò chincu.

Gall. Eu lleuò a sua Mai

tortillas de millo,

porque aun es mellor

que la escanda, è o trigo,

tanxe a Gaita, è vaya vn solciño

porque se alegre en as pallas mi Niñu.

\section{COPLAS.}

Gall. Desde miña terra

veño descalciño, 
que en Galiza no se vsa entre neue traer zapatiños.

Ast. Os Gaiegus nunca

traen os botiños

que aunque gastan ò cuero en zapatus

xamais se le han vistu.

Gall. Tocai Galeguiños

que os Curitos non bailan con Gayta

si no es con el cinchu.

$\mathrm{Ga}$. Nino, que en as pallas

os teinen ao frio,

si en Galiza nacerais bus deira[ $n]$

millor portaliño.

Ast. Caien os Gayegos,

que por Xesu Christu,

sein Asturias nacera, estuvera

millor acoxido.

$G a$. Tocai Galeguiños,

$\mathrm{q}[u e]$ en Galiza mas vale ha palla

que todos vs Coritus.

Ga. Cestiña os Galegos

os damos de oviños,

que traemos desde miña terra

os mas escollidos.

Ast. Esportiya traigu

con mi regalitu,

$\mathrm{q}[u e]$ la cesta nois bona en o parto

si no es daspartiñu,

Gall. Tocai Galeguiños,

$\mathrm{q}[u e]$ hasta aqui os Coritos queire[ $n]$

traer esportillo.

Gall. Entre ò Boi, è a Mula

nace ò Garridiño,

porq[ue] siempre en Galiza entre pallas

nacen os meninos.

Ast. No es lo qui barruntan,

que Ioseph muy vibu,

no is Galego aunq[ue] en pajas le vedes

por Christu les dixu. 
GAll.- Tocai Galeguiños, porque tembra ò Boi, è a Mula de ver ò Corito.

Gall. Sombreiro de palla le traigu al Chiquito; muito y espigaido le a poisto, que si es grano de trigo. Ast. Viendo tanta paya el bueye, muy tristu, sin zapatos comiòse ò Galego de dous bocaditus.

Gall. Tocai Galeguiños, $\mathrm{q}[u e]$ os Coritos si llegan aò palla faranse ò mesmo.

Gall. Tocai ò pandeiro a meo polidiño, tanxe, $\operatorname{ta}[n]$ xe Domiño, pois leba Galiza oi el vitor. Ast. El pandeiro queiren tocar au Chiquitu, quandu solo vs Galegus entenden de Gayta, è Perriyu.

Gall. Tocai Galeguiños, $\mathrm{q}[u e]$ pandeiros non faltan avendo tantos Coritos.

Galegui Galeguiños, \& C.

\section{VILLANCICO IX.}

para la Missa.

\section{ESTRVBILLO.}

1. Quien serà, el que nace entre luzes? el autor de la Gracia, a quien todos oy buscan en los braços del Alva. Quien serà, el que en vn pesebre, 
al yelo, y la escarcha, de pobres mantillas

aun desnudo se halla?

Quien serà,

el que entre dos brutos

nace entre vnas pajas,

donde los Pastores

Cordero le aclaman?

Quien será

tan grande Monarca?

2. Quien puede ser,

el clavel, que encarnado se mira,

nacer de vna rosa, que Azucena es?

3. Quien puede ser,

el q[ue] baxa del Cielo a la tierra,

$\mathrm{y}$ en vn pobre alvergue oy

quiso nacer?

4. Quien puede ser,

el que a incendios de amor,

con sus rayos,

desluze a la culpa su fiera altiuez?

5. Quien puede ser,

el que llora la culpa del hombre?

mas aunque es tan Niño la viene a vencer:

Quien puede ser

tan grande Monarca?

Quien puede ser?

\section{COPLAS.}

El que en pobre alvergue,

al yelo, y la escarcha

nace entre dos brutos

quando Sabio se halla.

Quien será

tan grande Monarca?

El que del Imperio

a la tierra baxa,

porque el hombre vea

cumple su palabra. 
El que en vn pesebre

su hospedage guarda,

con tan pobre abrigo,

que solo es de pajas.

El que vn portalejo

tiene por estancia,

tan pobre, que solo,

es pena, y no es casa.

El que en trage humilde

oy su amor disfraça,

porque logre el hombre

lo que mal le paga.

El que entre pastores,

Cordero le aclaman,

donde a ser validos

a los hombres llama.

El que yà a su Madre,

que es Luna sin mancha,

ensalçò a Divina

tan Divina Gracia.

El que como Sol,

en braços del Alva,

al reir la Aurora

las perlas derrama.

Quien será

tan grande Monarca?

F I N.

Biblioteca Nacional. Madrid. (V/E 150-23) “A Siolo mandiga”. Palau 367521.

Métrica: villancico en varias lenguas, ensalada de lenguas, redondillas, versos octosílabos, con rima asonante. Figuras retóricas como reír la Aurora o perlas por lágrimas; metáforas. 


\section{VILLANCICOS QUE SE CANTARON EN LA CATHEDRAL DE CÁDIZ EN LOS MAYTINES DEL NACIMIENTO DE IESU CRHISTO... ESTE AÑO DE 1656. SIENDO EN ELLA MAESTRE DE CAPILLA EL PADRE FRAY FRANCISCO LOSADA. IMPRESO EN CÁDIZ POR FERNANDO REY.}

CONTIENE VILLANCICO DE KALENDA. 1.

NOCTURNO. VILLANCICO PRIMERO.

VILLANCICO PRIMERO.

\section{La Nave Santa María}

llegò al puerto la primera, y como es Nave y es Ave: por aires y por agua buela:

Su gran Tesoro, no ay donde quepa, pues llena el mundo quedando llena.

3. Todavia flota esta Nave guiò al puerto sin tormenta. y fue del mar esta dicha, porque del mMar es Estrella; no viò las olas del Mar inquietas sola esta Nave, que es sola entre ellas. 4. El Galeón San Ioseph tuvo de vnas borrascas sospecha; mas por dormirse el Piloto se librò soñando della: no huvo en el mundo dicha como esta, pues fue soñada sin ser incierta.

5. El Galeon San Salvador haziendo agua la puerto llega: mas tan lleno de tesoro, que entrò derramando perlas: agua và haciendo para la tierra. y con agua mas agua la halla mas seca. 6. Todas la deudas del mundo viene a pagar su riqueza, que haziendo se nuestro hermano hizo suyas nuestras deudas quando quien pague con tal fineza, gran mal seria que aya quien deva. 
7. El Galeón San Gabriel

de alegria el aire llena,

que por Navio de aviso

toda la Gloria se lleva:

en las alturas den Gloria eterna

à Dios, y al hombre paz en la tierra.

VILLANCICO I1.

ESTRIVILLO.

1. ZAgalejos, venid, y morad los divinos estremos.

que incluye vn Portal.

2. Zagalejos, venid à entender

los humanos estremos,

que encierra Belen.

3. Escuchaz, Zagalejos, la voz

q`estremos ${ }^{\wedge}$ publica, $q^{\wedge}$ se juntan oy.

4. Zagalejos, llegad, y Advertid,

los estremos q`ofrece la noche feliz.

1. Ved entre tablas, la Luz,

2. Essos son los estremos, ser Cuna, y ser Cruz.

3. Venid, corred, esperad, esso son los estremos.

correr y parar,

Zagalejos, llegad y advertid

los estremos que ofrece

la noche feliz.

COPLAS.

Ya Humanado, ya Divino, tiene Niño, tiene Eterno,

entre pajas, entre estrellas

tiempo poco mucho tiempo.

Todos. Vienenestremos.

Su principio no hallarlo,

su fin no averlo.

Su edad sin tiempo. Véd. \&C.

En el cielo y en la tierra

habitante ò estrangero, 
el descanso, la fatiga,

es su patria y su destierro.

Véd los estremos, \&C.

levantarse la nieve,

ceñirse el fuego,

y en la ya media noche

el Sol entero. Ved. \&C.

Desde lexos conocido,

y desde cerca encubierto,

de vnos Reyes por lo mas,

de vnos brutos por lo menos.

Véd \&C.

A esta parte cayados,

à essotra, cetros,

Mula con los humildes,

Buey con alientos, Véd. \&C.

Triste nace, alegre muere,

ya tiritando, ya ardiendo,

áz dentro , y azia fuera,

entre llamas, y entre yelos. Véd.\&C.

$\mathrm{Y}$ se cansan esquivos,

con suspiro, y llanto,

el agua y fuego. Véd. \&C.

VILLANCICO II1. GALLEGO

ESTRIVILLO.

Canta e bayla Domingo Man-

gueiro (A3 que)

que eu queiro ser ò tamborileiro.

Miña Comadre, miñz viziña,

escoitame esta cantiña,

Vena todos os Galegos

vean ao fillo de Deus

nace muito pequeniño,

nace muito tamañiño,

nace muito garridiño,

nace qual Fillo de Deus.

Fay o Gaiteiro, è canta,

è bayla Domingo Mangueiro.

COPLAS. 
1. Nun pesebre està o Miniño, o que os Reis aventalla, en unha pouquiña palla, naceu como Galeguiño, no so he o garridiño, salto e brinco de pracer, porque Desu nos veu a ver en corpo manso Cordeiro. E canta è bayla. \&.C.

2. Logo que nacido soy

Deuz como home chorava, è morto se imaginava, porque està con Deus o Boy, como a Mula non se doy, o boy a mira de corno, è a Mula de retorno, lle bolve à anca mohina. Miña comadre. \&.C.

3. Vamos homes sin receos; llevomosle de mel favos e pra Mula do centeo: vêres Angeles de oceo. dar no ayre cabriolas, baylando con castañolas è San Miguel o primeiro. E canta e baila. \&.C.

4. si fazer queredes gentes o Fillo de Deus regalo, a sua My podres dalo, que o Miniño no ten dentes: leite levai en presentes à Virgen que o manten, porque sostento non ten mais ca úa Corderiña, Miña comadre. \&.c.

5. Vendo os demos qeu son vaos, jà cobarde a Luzifer, despreciaron seu poder, è andoveron à paos, 
como vinieron as maos,

Mahomaà vn tizón arranca,

è Barrabas vn lareiro.

E canta, è baila, \&. C.

6. Todos Pranetas con danças

acudieron a Belen ,

e a Lua bailou ben

que sabe boas mudanças

Libra con suas balanças

a noite bailou en peso,

y o Miniño vendo esso

o celebrou con risiña.

Miña comadre. \&-C.

SEGVNDO NOCVRNO.

VILLANCICO IV.

ESTRIBILLO.

Venid a ver os prodigios,

Pastores en Belen (que)

que en el a media noche

vereis amanecer.

Que dizes Llorente?

Que has visto Ginés?

En nuestras palabras

no puede caber,

ni en tierra ni en cielo

ni en todo el desvelo

de humano poder.

Dezisnoslo pues.

que no, no, no, no,

que no puede ser

pues solo la admiracion

lo puede dar à entender.

Dezidlo pues, que nosotros

lo admiraremos tambien.

Escuchad Pastores. Vaya pues,

honras y favores. Vaya pues.

que a los pecadores Vaya pues.

quiere Dios hazer. Vaya pues.

$\mathrm{Y}$ admirense. 
que solo la admiracion

lo puede dar a entender.

COPLAS.

Fuimos aver esta noche

vna parida en Belen:

IESVS, y què bello Niño!

Madre de Dios, que Muger!

Con los dos estava vn Viejo,

$y$ eran juntos todos tres,

vn pasmo, vna admiracion.

IESVS, MARIA, Y IOSEPH.

Vna voz nos llevo a verlo,

que segun cantò despues,

no es posible sino que era

el mismo Angel San Gabriel.

La noche estava muy fria

y al< ir corriendo tras él,

en tanto calor entramos

que nos vino Dios a ver.

Entramos allà y diximos

viendo vna Mula y vn Buey

y tal Niño en vn Pesebre:

Verbum Caro Factum est.

A remediar viene al mundo,

que tan perdido se vè,

y el remdio que ha de darnos,

Poder de Dios y qual es!

Hombre a Dios vivmos y ay hombre

que lo niegue mas no sè,

que delante de nosotros

no lo diga en buena Fè.

En carne mortal le vimos,

mas hermoso que vn Clavel,

muy bello estarà en el Cielo,

pero no tiene que ver.

Mundo, Belen es tu gloria,

Belen es todo tu ser,

Belen te trae el remedio,

valgate Dios por Belen. 


\section{VILLANCICO V.}

1. Coraçon que buelas cantando

y ansioso caminas

en busca de vn Dios,

como algre cantas y buelas.

buelas y cantas, llorando tu error:

2. Mas si buelas por ver entre nieve

temblando al Amor.

3. Canta, canta y celebra tu dicha

llora y llora, y publica el dolor. (que)

Biblioteca Nacional. Madrid. V/E 92-18 3“"La nave Santa María” (22-1) Cátedral de Cádiz en 1656. ( 354-4) 1633 en la Iglesia de Sevilla.

Métrica: Versos octosílabos, rima asonante, comparaciones metafóricas de gran belleza, "Más hermoso que vn clavel".Alternancia entre heptasílabos y octosílabos, propios del villancico. 


\section{VILLANCICOS QVE SE CANTARON EN EL REAL CONVENTO DE LAS}

DESCALZAS LA NOCHE DE NAVIDAD DESTE AÑO DE M.DC.LXXIX.

V. VILLANCICO.

\section{Estriuillo.}

Mi Niño, esse temblado

Aliento de tu dolor,

Que se anima en vn rigor,

Escuchese aqui mudado:

Pues en mi Fe assegurado

De vna encendida terneza

Vn no terminado ardor,

Que en incendios de amor Acrisole mi fineza.

\section{COPLAS}

Tierno amor, pues es tu llanto

Disfrazado fuego en perlas, Llora mas, porque la llama,

Que se aviva en las ternezas

Acrisole mi fineza.

Tierno amor, pues tus gemidos Enamoran con la quexa,

Gime mas, porque mi pecho Al sentir tan dulces penas Acrisole mi fineza.

Tierno amor, pues lo que sientes

Enamorado me dexa,

Siente mas, porque el desmayo, Que al escucharte me cuestas Acrisole mi fineza.

Tierno amor, pues lo que abrasas, Enciende quanto me yela, Arde mas, porque el incendio en que mis ansias se engendran Acrisole mi fineza. 
VILLANCICO VI.

\section{INTRODVCION.}

Vnos Gallegos Cantores,

Y Pintores por mas señas,

A Belen vienen alegres

A desterrar la Serena.

De las broches de sus vozes,

Al Rey Niño le presentan

Vn Retrato parecido

A la entrada de la Reyna.

Pues Apeles celestial

En las pajas se recrea,

A las tablas del Pesebre

otra tabla le presentan.

\section{Estriuillo.}

1. Toribiño à cantar.

2. Dominguiño à pintar.

1. Que el Niño fermoso

2. Espera donoso

El lien[ç]o gracioso,

El quadro brioso

Del bello jardin,

que alegre, y Reyal,

A vn pobre Portal.

Vaya de gaytiña,

Y de tonadiña.

Por aqui.

Por alli.

Tirun, tiruron, tan, tin,

Galegos,

Tirun, tiruron, tan tin.

Vereis entre muytas frores

La mas bella Fror de Lis.

Galegos. 
Sopre, ò gayteyro,

Muyto, muyto, muyto,

Con el ayre $\mathrm{q}[u e]$ vene de Burgos,

tirun, tiruron, $\tan$ tin,

Vereis entre muytas frores

La mas bella Fror de Lis.

1. Vamos ao Portal,

Cantemos la entrada

Que està aparellada

al Palacio Real.

Ay, que andar, andar,

Para hazer chichones

Tudesquiños ay.

2. Ay muyto que ver,

Ventanas, pinturas,

Y muytas figuras,

Sin la mia moller.

Ay, que arder, arder

Cohetes os Galegos

Corren busca pes.

3. En silla volante

La Reyna agraciada

Irà bien sentada

$\mathrm{Co}[n]$ su Guarda-Infante.

Ay, que grande, grande

Dicha es, que nos dè

Otros doze Pares.

4. O Palio en suas Aras

Dize à su hermosura,

Ninguna pintura

Chega con mil varas.

Ay, que craras, craras

As luzes mas bellas

Son del Sol, y el Alva.

5. Arcos por despojos

Se rinden Gigantes,

Pois los mas brillantes

Los cheva en sus ojos.

Ay, que solos, solos 
De los coraçones

Son nuesos adornos.

6. En las Damas fallo

Suos artes fermosos

Ser muytos ayrosos

Homes de à cavallo.

Ay, que garbo, garbo,

Del sol en la puerta

Mudaran cavallos.

7. Hurracas por señas

Con los longos cuellos

Mulas en camellos

Semejan las Dueñas.

Ay, que fuera, afuera,

Grullas son que vienen

Con la Primaveyra.

8. Fidalgos Señores,

Tudos de buen talle,

Faran otra calle

de los Bordadores.

Ay, que corren, corre

Por ellas as telas

Con os Regidores.

9. Como dos mil Mayos,

De oro, y prata en frores

Tendran por Señores

A muytos Lacayos.

Ay, que passo, passo,

Estos son Alexos

De escalera aballo.

10. Saldran muy locidos

Todos en sus puestos,

Con tan ricos gestos

Como sus vestidos.

Ay, que digo, digo,

Que alegre es la dança

De los cavallitos.

11. Hallarà aliñada,

Por mas alegria, 
A la plateria

Muy bien empredada.

Ay, que garda, garda,

El Señor San Iorge

mate las arañas.

12. El Rey por remate,

Con muyto despacio,

Le tendrà en Palacio

Feyto el chocolate.

Ay, que agarde, agarde,

Mas acà ay possada

De la Reyna Madre.

13. A vos, segun leyes,

Mi Niño fermoso

Vos toca gracioso

La entrada de Reyes.

Ay, que dexen, dexen

Las alegoriñas

Para el otro Iueues.

VII. VILLANCICO.

INTRODVCION.

Dos Angeles en Belen

Cantan la gloria que admiran;

Y si es tan dulçe cantada

Como serà posseìda?

Oyendo las consonancias

De Solfa tan peregrina,

Vinieron de oposicion

Los Maestros de Capilla.

\section{Estriuillo.}

Atencion,

Que empieza la oposicion.

Dos Angeles sonoros à Ioseph cantan,

Porq[ue $]$ no falte el Duo del Patriarca.

Digan los Musicos 
De Solfas praticas,

Porque dos Angeles

Enseñan clausulas.

Ay, $\mathrm{q}[u e]$ vaya de gusto, de fiesta vaya,

Y vera $[n]$ los Maestros q[ue] pasa[n] plaça.

Atencion,

Que en empieça la oposicion.

\section{COPLAS.}

1. Vn Maesto Montañes

Entrò poniendo vn motete,

Y la mula echò en falsete

Los compases con los pies;

Y la mula se la pega,

Porque la mula Gallega

Puso en las falsas el son.

Atencion,

Que empieça la oposicion.

2. Vn Maestro vino a escuras

Con mucha re mi fa sol la,

Cantando vn tono de Angola,

$\mathrm{Y}$ fue de negras figuras:

Gloria à Dios en las alturas

Lo puso en Solfa bien rara,

Pero se le viò en la cara,

Que iba la letra en borron.

Atencion, \&C.

3. Quiso cantar bemolado

Vn Maestro de vna Villa

Cogiò el compas la mulilla,

Y le puso de quadrado:

De la Guarda entrò vn Soldado,

Diziendo; soris, señores,

Solfeando à los Pastores

Vno, y otro coscorron.

Atencion, \&C.

Vn Maestro del Oriente

Hizo de compas mayor

Vn tono para vn tenor, 
Y fue del tenor siguiente:

La mula con el torrente

Reir hiciera à vn difunto,

Porque à cada contrapunto

Hazia respiracion.

Atencion, \&C.

5. Vn Maestro por demas

Puso tonos à vn gilguero,

Y à Ioseph por carpintero

Pidiò que echase el compàs:

Viendo el buey cantar a Bras,

Le hizo gemir la armonia,

Con el tono de alegria

Se puso à lamentacion.

Atencion, \&C.

6. Otro, que à Belen madruga,

Dixo levantando el grito,

Para la huída a Egipto.

Al Niño le doy la fuga:

Porque Herodes apechuga

Con los Niños, y à mi ver,

Aunque à Dios desea ver,

Lleva muy mala intencion.

Atencion, \&C.

7. Otro de Vizcaya fue,

$\mathrm{Y}$ à la mula en canto llano

La quiso enseñar la mano,

Y la mula alargò el pie:

Dos passos tirò, con que

Del pesebre en el teatro

Le enseñò vn tono de à quatro,

Pues dos pares quatro son.

Atencion, \&C.

8. El postrero en tonos graves

Puso à Dios vn tono rico,

Y acabado el Villancico,

Dixo: Aì te quedan las claves:

Dos tiempos tirò suaves.

El Buey, oyendo las vozes, 
Y la mula con las cozes

Les llevava el fabordon.

Atencion, \&C.

Biblioteca Nacional. Madrid. (V/E 83-44). "Zagalejos, venid".

Métrica: versos hipermétricos, hiperbolización del lenguaje. Versos octosílabos. Rima asonante, similar a la del romance. 


\section{VILLANCICOS QVE SE HAN DE CANTAR EN EL REAL CONVENTO DE LA ENCARNACION LA NOCHE DE NAVIDAD DESTE AÑO M.DC.LXX. IX.}

\section{PRIMERO NOCTVRNO.}

KALENDA.

\section{VILLANCICO.}

1. Entre los densos horrores

De este Caos repetido,

Que por la ausencia del Sol, Dexa al Orbe mal distinto,

2. Ya corre la cortina

El Alva a los zafiros,

Que empañaron vapores

De vn aliento atrevido.

1. Huye la sombra cobarde,

$\mathrm{Y}$ en desorden fugitiuo,

Cobra la luz vencedora

Quanto la vsurpò el Abismo,

2. En medio del silencio

Vozea en puros visos

Nueva Aurora de perlas

Vn Concepto Divino:

\section{Estriuillo.}

Y con saluas alegres,

Los paxarillos

$\mathrm{Su}$ venida saludan,

Con regocijos;

Diziendo acordes,

Repitiendo vnidos:

Norabuena venga

La Rosa, la Palma, la Fuente, la Estrella;

Sea bien venida

La Naue, La Nube, el Cedro, la Oliua; 
Sea bien llegada

La Flor, la Azucena, la Luna sin mancha:

$\mathrm{Y}$ en confusion sonora

De vozes, è instrumentos,

Alhaguen los vientos

Acordes acentos,

Con salvas festiuas,

Clarines, y chirimias,

Aplaudiendo en las Esferas

Del Cielo, y la Tierra,

La Rosa, la Plama, la Fuente, la Estrella,

La Naue, la Nube, el Cedro, la Oliua,

La Luna sin mancha, La Flor, la Azucena,

Sea bien llegada,

Sea bien venida,

Norabuena venga.

\section{COPLAS.}

Ya la Sagrada Rosa

De su Claustro de nacar

En vn rubi animado

Nos dà todo el Tesoro de la Gracia.

2. $\mathrm{Y}$ en dulce salua,

A pesar del Diziembre,

Los prados se matiza $[n]$ de fragancias.

1. Ya la Palma fecunda,

Iris de la campaña,

Su dulce Fruto ofrece,

Vandera verde $\mathrm{q}[u e]$ la paz señala.

2. $\mathrm{Y}$ en dulce salva,

A pesar del Diziembre,

Las pla $[n]$ tas y los tro $[n]$ cos visten galas.

1. Ya la risueña Fuente

De su raudal desata

En lagrimas preciosas,

Las mas costosas Perlas, que viò el Alva.

2. Y en dulce salva,

A pesar del Diziembre,

Con risas de cristal le feudan 
1. Ya la brillante Estrella

Anuncia la mañana,

Dorando con sus luzes

El Orizonte, que esmaltò la escarcha.

2. Y en dulce salva,

A pesar del Diziembre,

El dia cuenta alegre edades largas.

1. Ya la Naue ligera,

De riquezas cargada,

En Belèn toma Puerto,

Libre de los peligros de la Playa.

2. $\mathrm{Y}$ en dulce salva,

A pesar del Diziembre,

Espumas riza, en muestra de bonança.

1. Ya la fecunda Nube

El rocio derrama,

Porque produzca fertil

La Tierra el Saluador, que el Orbe aclama.

2. $\mathrm{Y}$ en dulce salva,

A pesar del Diziembre,

Mas brilla el Sol, con nubes que le empañan.

\section{VILLANCICO.}

\section{Introduccion.}

Oygan, que porque se alegre

Oy el Amor que ha nacido,

En Portuguès le ofrecemos

Vn Valiente Villancico.

Lo temeron de la Noche,

Parece, le ha confundido,

Con el ceño encapotado,

El afecto derretido.

Viendo a mi Niño que tiembla,

A los rigores del frio;

Almivarando el acento,

Dize en el alcorçado estilo:

Estriuilllo 
1. Con quien falo, Minino?

Ha tamaño?

Ha Brinquiño?

Ha miña Alma?

Ha Crauel?

Digu, non choreis;

Que imprica contradizaon

Chorar, è ser Portugueis.

2. Si è fineza, penar,

Si è vountade, morrer;

Si è ternura, sentir;

Si è cariño, sofrer:

Pero non choreis,

Que imprica contradizaon

Chorar, è ser Portugueis.

\section{COPLAS.}

Quein vos dà cuitas, Minino,

Quando à vosso lado teeis

Vn home, que a tudo ò mundo

Mouerà de vn puntape?

Ha Tamaño?

Ha Brinquiño?

Ha miña-Alma?

Ha Crauel?

Naon choreis;

Que imprica contradizaon

Chorar, è ser Portugueis.

Si el ayre os faze tembrar,

Bein me pode agradecer,

Que fuxe, proque si naon,

Eu le fizera correr:

Ha Tamaño, \&c.

Con el embozo de à Noyte

Salir à rondar podeis,

Fazei estouques de as pallas;

E de ò pesebre broqueis:

Ha Tamaño, \&c.

Si à matar vn Serpentao 
Vinis, dezidme vos dèl;

Que as serpes, para conmigu,

Saon como guindas en mel:

Ha Tamañu, \&c.

Para ostentar meu valor,

Naon sè, par Deus, que fazer;

Quereis, que prante en Lisboa

Tudo ò Portal de Belem?

Ha Tamaño, \&c.

O Boy de mirarme tembra;

Si naon fora menester,

Xa con el Touro de ò Ceo

Le hovera embiado à pacer:

Ha Tamaño, \&c.

Por ser à Mula mohiña,

Naon la presumo ofender,

Que os mohiños, è os valentes

Grande parentesco tein,

Ha Tamaño, \&c

Aunque rebento de forte,

Magoado me teneis;

Si naon fora pundonor,

Chorara con vous tambein:

Ha Tamaño, \&c.

\section{VILLANCICO}

XACARA.

Estriuillo.

1. Ala, ola, vaya, ea,

Si ha de auer Xacarilla,

Vamos con ella.

2. Vaya, ea, ola, ala,

Empezemosla luego

La Xacaranda,

1. Ala,

Diganos de què trata?

1. Ola, 
Es de vn Niño la historia.

2. Vaya,

El tonillo del hampa.

1. Ea,

Que esta Noche es la Buena.

2. Ala, ola, vaya, ea,

1. Atencion, que la Xacara empieza.

2. Pero quedo, quedito, pasito, tengan,

Que de saber nos falta,

$\mathrm{Si}$ acaso es nueua.

1. Oyganla con atencion,

$\mathrm{Y}$ veràn, que và compuesta

De los refranes comunes,

Que usan los de la heria.

2. Ala, ola, vaya, ea,

Atencion, que la Xacara empieza.

COPLAS.

1. Vamos, digu, es para oy?

2. A que guardan? linda flema?

3. Brava Xacara por Dios!

4. Al caso, y vamos con ellla

1. A la Salud; ya me entienden!

2. Somos bobos? buena es essa!

3. Del que se haze Criatura.

4. Y ha dado con todo en tierra;

1. En la mismissima Noche.

2. Mas Rubio, que las candelas

3. Naciò el Xixo de Maria.

4. Es posible! que me cuenta?

1. Por la saluacion de mi alma.

2. Que es valiente por mas señas.

3. Aora acaba de nacer.

4. Todo el mundo le respeta.

1. En vn Pesebre la tiende.

2. Ay es humo de Pajuelas.

3. $\mathrm{Y}$ està entre dos Animales.

4. No si no fueran dos bestias. 
1. Voto al Sol, que es vn perdido!

2. Ya lo vèn, pues vierte perlas.

3. Oygan, oygan lo que ensartan!

4. En fin, lo que vale, cuesta.

1. Vna dança de Negrillos,

2. Y otra de Gitanas entra.

3. Pues essotra, que bien bayla!

4. Ello estamos para fiestas.

1. Madre de Dios, que de cosas

2. Los Pastores le presentan!

3. Gallinas, no sino huevos.

4. Vn pavo, miel sobre ojuelas.

1. El Cierço à mi Niño sopla.

2. El Portal, què linda pieza!

3. El Buey, què bravo Bonete!

4. La Mula castaña enxerta.

1. Los Angeles volaverum.

2. El ayre de vozes pueblan.

3. Gloria parece? Que dizen.

4. Lo que me suena, me suena.

1. Para quando son los rayos?

2, Nadie en las pajas se duerma.

3. El Sol tirita de frio.

4. Buen animo, que ya tiembla.

1. Dexelo, no ay que cansarnos.

2. Bien està de essa manera.

3. Buenas noches, Amo mio.

4. A Dios, Señora Doncella.

SEGVNDO NOCTVRNO.

IV. VILLANCICO

Introduccion.

Por diuertir à los Reyes,

Los Zagales representan

Del viage las jornadas,

con todas sus apariencias. 


\section{Estriuillo.}

1. Vaya de fiesta,

Puede ser, que à los Reyes

Los entretenga.

2. Vengan alegres,

Canten los Españoles,

Con los Franceses.

1. Dime, Pasqual,

Azia donde està el Zagal,

Que Tierno, Amoroso,

Gracioso, y Hermoso,

Haze Palacio el Portal?

2. Andar, Andar,

Porque và caminando la Casa Real.

1. Andar, andar.

2. Aguarda, Cochero,

Que passa vn Archero

A dar palo fiero.

1. Y trae el vestido

de vnguento amarillo,

Con que al que hiere, le puede curar.

2. Andar, andar,

porque và caminando la Casa Real.

\section{Coplas.}

Por el camino mas ancho

Parten Cielos Rey, y Reyna,

Porque no es siempre el camino

De los cielos senda estrecha.

Y la Aurora, que sigue

Al Sol del Austria,

Merece ser, por Linda,

Reyna de España.

Vn Labrador, que en su vida

Viò carroza, dixo, al verla:

La carroza es vn milagro,

Pues no cae, quando rueda.

Viendo en coche à la Reyna,

Dixo el Rey luego: 
Este coche que traygo,

Lleua dos Cielos.

Vna Labradora dixo:

Puesto que el Rey, y la Reyna

Por la Nauidad caminan,

El Nacimiento desean.

Segun tienen Estrella,

Muy presto el cielo

Ha de dar à los Reyes

Vn Nacimiento.

En sus mulas con gualdrapas

Ivan passando las Dueñas,

Y vn Pastor dixo: En el mundo

Nadie passa como ellas.

Estas Pascuas las Dueñas

No es bien que falten,

Porque llevan à cuestas

Las Nauidades.

Biblioteca Nacional. Madrid. (V/E 91-53). "Entre los densos horrores".

Métrica: versos octosílabos. En la literatura de cordel se entremezclan sucesos populares con el tema navideño; de ahí que aparezcan Jjcaras, o se inicie vn villancico con "Oygan en breve ensalada". Rima asonante. 


\section{VILLANCICOS QVE SE HAN DE CANTAR EN LA REAL CAPILLA DE LAS DESCALZAS LA NOCHE DE NAVIDAD ESTE AÑO DE 1680. PVESTOS EN MVSICA}

Por el Licenciado Don Alonso Torizes, Maestro de Capilla.

\section{NOCTVRNO.}

VILLANCICO VII.

\section{Estriuillo.}

Atended,

A las vozes de vn Niño,

Que en ace $[n]$ tos sonoros explico,

$\mathrm{Y}$ en ternuras de llanto gustoso,

Que le enciende en su pecho amoroso.

Mi amor indigno.

Atended.

Ay, como gime!

Ay, como llora!

Atended à las vozes de vn Niño,

Que en acentos sonoros explico.

Atended.

Ay, que finezas!

Ay, que suspiros!

Atended à las vozes de vn Niño,

Que en acentos sonoros explico.

\section{COPLAS.}

Que dirè de vn Niño amante, Que sabio siempre, y Benigno, Hasta mi remedio sabe

Sacarle de mi delito.

Dirè, que Dios llora amante,

Sin ser pretexto en lo fino,

Para estorbo à lo piadoso,

La razon de lo ofendido.

Dirè, que entre las distancias

De lo amoroso, y lo esquivo 
Me retiran sus finezas,

Y le acercan mis desvios.

Dirè, que el llanto en sus ojos

Dize, que en su pecho vivo;

Que no olvida mis memorias

Quien me acuerda mis olvidos.

Dirè, que el llanto derrite

Al fuego de los suspiros,

Y que à vna piedad, que es cera

Sabe ser bronce vn delito.

Dirè, que como la culpa

Hizo esclavo mi albedrio,

No oye las vozes del llanto

De tantos yerros al ruido.

Dirè, que aunque en lo quexoso

Me disfraça lo rendido,

Se le vè el semblante al ruego

De la quexa entre los visos.

\section{VILLANCICO VIII.}

\section{Gallego.}

\section{Introducion.}

Enfadado de la gayta,

Con que siempre al Nacimie $[n]$ to,

Para divertir la noche,

Han traido los Gallegos;

Vn Gallego Baylador

Quiere con los instrumentos,

Que son compàs de sus pies,

Cantar, y baylar à vn tiempo.

\section{Estriuillo.}

Tuturutu, y andar, tuturutu, y andemos.

Que sin à gaitiña baylarà ò Galego

Aò compas de os instrumentos,

Ay, ay, ay, que me folgo.

Que me fino, me collumpio, me recreyo, 
Aò compas de os instrumentos,

Que sin à gaytiña, baylarà ò Galego.

\section{COPLAS.}

A cantiña nova,

Que el Abad ha feito

Para fin de á dança,

Escuitad meu Neno.

Tuturutu, \&C.

Mallestad tan bela,

E fermouso giesto,

No le ten pardicas

O Conde de Lemus;

Tutururtu, \&C.

A un mellor que ò Miño

De sus ollos veyo

As perlas garridas

Sembrar todo o feno;

Tuturutu, \&C.

Su garrida Mai,

Mais Pura è que ò Ceo,

Que ò sol se cobixa

De los suos cabelos;

Tuturutu, \&C.

Tan riquiña à miro,

Que en sus baços ternos

Tene mais que vale

A Terra, è os Ceos;

Tuturutu, \&C.

En su regaciño

Poune ò Nino belo,

E calmava à vista

Como en crairo Espeijo;

Tuturutu, \&C.

Os perros Iodios

No veren à verlo,

Fasta que le veyan

En à Cruz de ferro.

$\mathrm{Tu}$, turutu, \&C. 
Ya à buscarle andan,

Llastima le tengo,

Mas en sua culpa

Ternan ò escarmiento.

Tu, tururu, \&c.

Recebid meu Nino

Eussos dos Cordeiros,

Pois sois semellança

De la sua paz de elos.

$\mathrm{Tu}$, tururu, \&C.

Catro camuessiñas

Tamben os trayemos.

Que para vos dar

Non somos Galegos.

tu, turutu, \&C.

De veros tembrar

Ao rigor de o tempo

Van os Galeguiños

Toudos muito acedos.

$\mathrm{Tu}$, tururu \&c.

VILLANCICO IX.

Introducion.

Dos Maestros al Portal

Llegan con distintas letras,

El vno todo de burlas,

$\mathrm{Y}$ el otro todo de veras.

Vno à su Capilla apunta

Tonadillas de la tierra,

$\mathrm{Y}$ el otro muy mesurado

Solo canta letras viejas.

\section{Estriuillo.}

Vaya de gusto, vaya de fiesta,

Celebremos el parto

De nuestra Reyna.

El Gigante salga, 
Llegue la Chamberga,

Los Bisbises hablen,

$\mathrm{Y}$ otros tonos vengan,

Que tonillos vulgares

Son los que alegran

Vaya de gusto,

Vaya de fiesta,

Celebrèmos el parto

De nuestra Reyna.

\section{COPLAS}

1. Dulce Dios, bien humanado,

Que has llegado

A ser nuestro regozijo,

Puesto que por ti se dixo:

Aquesta es la Noche buena.

Vaya la tonadilla

De la Chamberga.

Que pues quiso ser Niño

Dios humanado,

Oy le alegren los tonos

De los muchachos.

Ay, Cielos,

Que se alegra con ellos,

Que hermosos

Vierten luces sus ojos,

En donde

Amanecen dos Soles.

Y puesto,

Que se alegra con ella,

Vaya tonadilla

De la Chamberga.

2. No es sino llanto hermoso

El que sus ojos brillan,

Mar, que à su Cielo llega,

Para que yo le diga,

Gigante cristalino,

Que al Cielo se oponia

El Mar en blancas torres 
De espumas fugitivas.

3. Si es llanto el de sus ojos,

Llora para lavarme,

Y el ayre en sus suspiros

Me acuerda, que le cante.

Andar, andar, que es ayre,

$\mathrm{Y}$ andar, que es ayre,

Pues que con sus suspiros

Cessan mis males.

$\mathrm{Y}$ andar, andar, que es viento,

$\mathrm{Y}$ andar que es viento;

Gozese ya la tierra,

Pues llora el Cielo.

$\mathrm{Y}$ andar que es ayre,

$\mathrm{Y}$ andar que es ayre;

Pues con sus suspiros:

Cessan mis males.

4. No dès vozes, pues miras

Que su divino ceño

Se ofende de que turbes

Aquel blando sossiego;

Aora que la noche

Con el horror, y el sueño.

Los ojos al dormido,

$\mathrm{Y}$ al desvelado roba los afectos.

5. Como ha de dormir el Sol,

Si està tan cerca el Aurora,

$Y$ es señal de que amanecen

En sus braços nuestras glorias?

Entre luzes divinas

Bis, bis, sarmiento si sis,

De jazmines, y rosas,

Le texieron guirnaldas,

Bis, bis, sarmiento si, sis,

De que se corona.

Miren la gracia,

Oygan la gloria,

Que entre luzes divinas,

Bis, bis, sarmiento si, sis, 
De que se corona.

6. Es verdad, que no descansa,

Porque para lecho busca

Mi coraçon, mas si es piedra

Sirva al pesebre de cuna,

Ya que aquete peñasco,

Cuya esmeralda bruta,

Pedazo desasido

Del venenosos mo[n]te de la Luna.

7. No ay coraçon que resista

La fuerça de sus imanes,

$\mathrm{Y}$ al verle robar las almas,

Dizen por èl en el valle.

Dize mi madre,

Que à robar coraçones

Salgo à la calle,

Boli, bolitero,

Bolitero, boli,

Boli, bolitranca,

Bolitero, boli.

Y es mi amor tanto,

Que me pierdo, y en ellos

Nunca le hallo.

8. Vaya el bayle, que del Niño,

$\mathrm{Y}$ de la Madre en obsequio,

A pesar de mi mesura

He de dançar el torneo.

Reverencia os haze el alma

Reyna de mi pensamiento,

Por ser Deidad de su Altar,

Por imagen de su Templo.

Vaya de gusto, vaya de fiesta, \&C.

Biblioteca Nacional. Madrid. (V/E 83-45) "Atended".

Métrica: versos octosílabos y heptasílábicos, rima asonante. Polimetría. 
VILLANCICOS QVE SE HAN DE CANTAR EN LA CAPILLA DE SV MAGESTAD

LA

Noche Buena deste año de 1680.

VILLANCICO PRIMERO.

ESTRIVILLO.

DEl Amor que nace

Retratan su imperio,

Con dulce armonia,

Los quatro Elementos:

Del Ayre, del Agua, La Tierra, y el Fuego:

Escuchen compasses,

Del Fuego, del Agua, La Tierra, y el Ayre:

Escuchen acordes,

Escuchen iguales,

Escuchen sonoros,

Escuchen suaues,

Iazmines, centellas, penachos, cristales.

\section{COPLAS.}

1. DIbugen laços conformes

Las flores.

2. Imiten Lyras sonoras

Las ondas.

3. Retraten selvas confusas

Las plumas.

4. Derramen lumbres doradas

Las llamas.

$\mathrm{Y}$ al amor que nace

Le siruan de arpones,

Las llamas, las plumas, las ondas, las flores.

1. Obstenten galas ayrosas

Las rosas.

2. Desaten risas alegres

Las fuentes.

3. Destricen rizos volantes 
Las aues.

4. Argenten Orbes azules

Las luzes.

$\mathrm{Y}$ al Amor que nace

Tributen lisonjas,

3. Las luzes, las aues, las fuentes, las rosas.

1. Enciendan Signos plateados

Los rayos.

2. Coloren lineas sutiles

Los Iris.

3. Conciban perlas lustrosas

Las conchas.

4. Coronen prados floridos

Los lirios.

$\mathrm{Y}$ al amor que nace

Le doren el Arco

Los lirios, las conchas, los Iris, los rayos.

1. Dilaten copias pintadas

Las plantas.

2.Serenen playas brillantes

Los mares.

3. Granicen copos perenes

Las nieues.

4. Aumenten luzes serenas

Los Etnas

$\mathrm{Y}$ al amor que nace

Den feudo à su aljaua

Los Etnas, las nieues, los mares, las plantas.

\section{VILLANCICO II.}

\section{INTRODVCCION}

A La tierra baxa humilde

El Amor enamorado,

Que desde el mas alto seno

Desciende al seno mas baxo.

Como fino, y como amante,

A buscar el hombre ingrato 
Desde su Solio Diuino,

Obediente baxa Humano.

Y por imitar sus passos,

Tanto mi amor và subiendo

Quanto mi Dios và baxando.

Albricias, Pastores,

Que alegra los campos,

Y el ayre, respiran,

Con dulces alagos.

Las Auras, Los Notos, Los Cierços, los Austros.

Albricias, Pastores,

Que alegra los campos,

Con yelos, con luzes, con nieues, con rayos.

Mirad que es Diuino,

Sabed que es Humano,

Y mueue suaue

Las Auras, Los Notos, \&C.

Amadle, Pastores;

Que Dios se ha humillado:

Mirad que le adoro,

Sabed que le amo;

Pues por imitar sus passos

Tanto mi amor và subiendo.

Quanto mi Dios và baxando.

\section{COPLAS.}

1. DEl Cielo, gloriosa,

Desciende a la tierra

La Paz, que destierra

La saña horrorosa

De la antigua guerra:

Porque reynando la paz en el mundo

Batalle el abismo en su centro profundo.

2. El Verbo amoroso

Oy baxa humanado,

Y diuinizado,

Al hombre, piadoso

Le borra el pecado:

Porq[ue $]$ le tiene su amor reducido 
Al trage grossero que viste rendido.

3. El barro se eleua,

De nueuo amasado,

Que Adan le renueua,

Por verle quebrado

De la antigua Eua,

Y al ensalçarle co $[n]$ Real marauilla

Adan, poderoso, obediente se humilla.

4. Como Niño llora,

Vertiendo las perlas,

Y el Sol, al verterlas,

Dexando su Aurora,

Se arroja a beberlas:

Porque recoge la luz, y la llama

en sacros sudores, que humilde derrama.

5. Las luzes mas puras,

Con puros albores,

Dan vida a las Flores

$\mathrm{Y}$ a las Criaturas

Desterrando horrores;

Porq[ue] la Aurora sus luzes desprende

Y el Sol de Iusticia a la tierra desciende.

6. Colmada de frutos,

La tierra escabrosa,

Ya rinde tributos,

$\mathrm{Y}$ aun los fieros brutos

Paz gozan dichosa;

Pues les preuiene en el campo la fruta,

La yerba en el prado, sossiego en la gruta.

7. Las luzes del dia

Desata la Aurora,

El Sol se mejora,

Y a tanta alegria

El abismo llora;

Pues el bostezo, con voz de gemido,

Soberuio le forma en su centro abatido.

8. La nube, que ofrece

El Verbo fecundo, 
El ayre esclarece,

La tierra enriquece,

Y dà gloria al mundo

Porque la nuebe, $\mathrm{q}[u e]$ sombras destierra

Nos llueue oy el Iusto, y fecu[n]da la tierra.

\section{VILLANCICO III.}

\section{GITANAS.}

\section{ESTRIVILLO.}

Ezcuchen alegrez,

Feztiuaz Gitanaz,

Que al Niño dezpiertan

Con dulzes zonajaz,

Y haziendoze rajaz,

Dando çapatetaz

Con el chaz, chaz, chaz

De laz caztañetaz.

Con belloz primorez,

De ayrozaz mudanzaz,

Al Niño dezpiertan

Con dulzez zonajaz.

Ala, ola,

Albaule briozaz;

Ola, ala,

Al bayle gallardaz;

Ala, ola,

Al bayle donozaz;

Ola, ala,

Al bayle bizarraz;

Ala, ola,

Ola, ala,

Dezpierten azentoz,

Despierten zonajaz

Al Niño, que hermozo,

Ze duerme, ze duerme, ze duerme en laz pajaz.

\section{COPLAS}


1. AZentos vnidoz

Loz zonez concierten,

Del Niño dezpierten

Loz ojoz dormidoz:

Zuz rayoz luzidoz

Arpònez zon rojoz;

Dezcubran zuz ojoz

Zuz flechaz doradaz,

Ola, briozaz,

Ala, gallardaz,

Ola, donozaz,

Ala, bizarraz,

Dezpierten azentoz,

Despierten zonajaz,

Al Niño, que hermozo

Ze duer[m]e, ze duerme, ze duerme en laz pajaz.

2. Auiuen doz Zieloz

Dormidaz Eztrellaz,

Luzientez centellaz

Enziendan loz yeloz:

Amor con dezveloz

El zueño zacuda;

Puez duerme, zin duda

Que zin zeloz ama.

Ola, \&C.

3. Zoñando, que llora,

Gimiendo ze advierte,

Laz perlaz que vierte,

Con rayoz laz dora:

Luzeroz zu Aurora

Recoge al vertelaz,

Arponez laz perlaz,

Con entre peztañaz.

Ola \&c.

4. Amantez enzayoz

En zueñoz compone,

hechizoz dizpone,

Con dulzez dezmayoz:

Quien mira zuz rayoz 
Le quiere infinito;

El ez Gitanico,

Que roba laz almaz

Ola, \&C.

\section{VILLANCICO IV.}

\section{ESTRIVILLO.}

HErmoso Niño, que al yelo

Lagrimas tiernas llorais,

No lloreis, que derramais

Todo el tesoro del Cielo.

\section{COPLAS.}

De la inclemencia al rigor

Vuestro amor quiso nacer,

Sin duda, para encender

Mi yelo con tanto ardor:

Mal correspondido amor,

De esse ardiente Mongibelo,

Pues tan amante desvelo,

Con el agua no templais;

No lloreis, que derramais

Todo el tesoro del Cielo.

Essas perlas que verteis,

Hijas son de vuestro Amor,

Que no las vierte el dolor,

Pues llorais, porque quereis:

Si del hombre ingrato veis,

Que las mira sin anhelo,

Y siendo de amor ançuelo,

No aitiende a que lo buscais;

No lloreis, que derramais

Todo el tesoro [del] Cielo.

Esse tesoro Diuino,

En tantas Diuinas Perlas,

Solo por querer verterlas

Fue el trage de Peregrino, 
Pues que no atiende a lo fino:

Viendo la gloria en el suelo,

Sin duda mas crudo yelo

En su coraçon hallais;

No lloreis, que derramais

Todo el tesoro del Cielo.

Si no atiende la rudeza

Esse precio Soberano,

Es verter perlas en vano,

Pues no atiende a tal fineza:

Viendo ta cruda fiereza

Como tan ardiente el buelo,

Si echando el humano velo,

El Ser Diuino ocultais;

No lloreis, que derramais

Todo el tesoro del Cielo.

\section{VILLANCICO V.}

\section{ESTRIVILLO.}

Venid, Pastores, siguiendome a mi

Vereis en la tierra el Eterno Zafir;

Venid, que ya yo le vi:

El Sol, que amanece,

Con rayos de oro,

El rico tesoro,

Que al hombre se ofrece,

Clauel, que florece,

Mejor que vn Abril:

Venid, Pastores, siguie $[n]$ dome a mi,

Que ya yo le vi.

Cordero Sagrado,

Cupido abrasado,

Amor peregrino,

Rocio Diuino,

Que llora por mi:

Venid, pastores, siguie[ $n]$ dome a mi,

Que ya yo le vi. 


\section{COPLAS.}

YA la Sagrada Aurora,

Con resplandores,

Matizando las flores,

Los campos dora;

A quien ofrece

La nieue rica plata $\mathrm{q}[u e]$ los guarnece.

Diuino Sol madruga,

De vna Alva hermosa,

Y con luz amorosa

Su llanto enjuga;

Y haze a porfia

El tropel de sus rayos la noche dia.

Clara nube, fecunda,

Llueue el rocio,

Que en el Diziembre frio

La tierra inunda;

Y sus cristales

Serenidad prometen a los mortales.

Como nace Cordero,

De sus fauores,

La gloria los Pastores

Logran primero;

Venid Zagales,

Que jamàs avreis visto Corderos tales.

La vara mysteriosa

De Iesè ha dado

Vn Clauel encarnado

De Virgen Rosa;

Aprenderàn fragancias todas las flores.

De vna Concha Diuina,

Nacar sagrado,

Oy la Perla ha mostrado

Mas peregrina;

Venid à verla,

Que no tiene el Oriente tan rica perla.

Del Cierço en los rigores

Se vè Cupido,

Dios del Amor, herido 
De sus amores;

Y tanta herida

Durarà hasta $\mathrm{q}[u e]$ amante pierda la vida.

Amoroso desvelo

Tanto le inflama,

Que del pecho la llama

No templa el yelo;

Y no te assombre,

Que del hombre el cariño le vista de Hombre.

La discordia, y la guerra

Vnidas quedan,

Pues los Cielos conceden

Paz a la tierra;

Los Serafines

De la dicha del mundo son los Clarines.

El Clauel encendido

Brilla neuado,

Que haze al Diziembre elado

Mayo florido;

Por cuyo fruto,

Como à su Rey los meses le dèn tributo.

VILLANCICO VI.

NEGRO.

ESTRIVILLO.

1. LO Branco se aparte,

Que entramo en Beleya

Flazico, y Tomeya,

La Flò de Guinea.

2. Afuela lo Branco,

Que vamo corriendo

Tomeyo, y Flazico,

La flò de lo Neglo:

Corramo,

Corramo,

Plimero que el Branco:

Corramo, 
Cantemo,

Toniyos alegles;

Al Niño Sesu;

$\mathrm{Cu}$ curùca;

Yeguemo,

Cantemo,

$\mathrm{Y}$ al sone baylemo,

Ligelo, y bolteado:

Cucurùcu, zarandi, zaranda $[n]$ do;

Cucurùcu, zala $[m]$ beque baylamo;

Cucurùcu, po lo Diozo nasido

Cucurùcu, por lo neglo pecado

Cucurùcu, zarandi, zaranda $[n]$ do;

Cucurùcu, zala $[m]$ be que baylamo.

\section{COPLAS.}

1. TVro Neglo, mi Flazico,

Baylamo en la Nacimenta.

2. Turo Plimo està contenta,

Aunque estamo con fozico.

1. Por esso samo bonico,

Mas q[ue] Branco, en die $[n]$ ta, y ojoz;

2. Dexemo del Branco enojoz

Mientra lo Neglo cantamo:

Cucurùcu, zarandi, zaranda[ $n]$ do;

Cucurùcu, zara $[m]$ beque baylamo

Cucurùcu, por lo Diozo nacido

Cucurùcu, pò lo neglo pecado.

1. Tocando rabeye apriza,

Crusado hagamo, y baylemo;

Samo Christiana, y hasemo;

Crusado por Iesuncliza;

Al Chiquitiyo le dà riza,

Que andemo en pie como gruya.

2. Y Siolo Iosè le arruya,

Mientras Lo Neglo cantamo:

Cucurùcu, \&C.

1. A Siola vn dezenalio

De Neglos aleglan locos; 
Samos Rosalio de cocos

De la Virgen del Rosalio:

Misteliosa necessalio,

Polque baylemo con cuenta.

2. Rese el Blanco, que se aflenta,

Mientra lo Neglo cantamo:

Cucurùcu, \&C.

1. Amor quema corasona

De turo Neglo que passa.

2. Fasilmente nos ablasa

El que nos hiso calbona.

1. Acabemo con chacona,

Que es talde, y està youiendo:

2. Y el Chiquiyo sa dulmiendo,

Mientra lo Neglo cantamo:

Cucurùcu, \&C.

\section{XACARA}

\section{ESTRIVILLO.}

EScuchen, reparen, admiren, atiendan;

Miren, sepan, oygan, la Xacara, nueua,

De gracia, de fiesta, de gusto, y de garbo:

Vaya, venga, siga, vamos;

Vaya, con sonoros, festivos aplausos;

Venga, con acentos alegres, y blandos;

Siga, con estilos, sutiles, y claros;

Vamos, con acordes afectos mezclados,

Texiendo las vozes que forman los lazos,

Acordes sonoros, suaues, templados.

\section{COPLAS.}

1. Naciò en Belen vn Valiente, Que es Diuino.

2. Pero es Guapo, Que en lo Diuino compone

Lo valiente.

3. Con lo humano, 
Y si llora, es por las quiebras

De vna hechura.

4. Y es de vn barro,

Que con Encarnacion quiere

Remediarle.

5. Y es milagro,

Que esto hiziesse, porque estaua

Muy seuero.

6. Y era el caso,

Que tuuo en el Paraiso

Vn disgusto.

7. Y enojado,

Desembaynò alli el azero

Contra vn hombre.

8. Porque ossado,

Sin respeto de su espada

Llegò al pomo

9. $Y$ vn mançano,

Fue la raiz, y el origen

Desta culpa.

10.Y otro Arbol,

Hizo que el hombre bolviesse

A su gracia.

11. Y el agrauio

De su Padre satisfizo

Nuestro Xaque.

12. Derramando,

Con vn valor infinito

Mucha sangre:

Lindo laço!

Tod.Vaya, siga, Corra, buele,

Acorde, sonoro, suaue, te $[\mathrm{m}]$ plado

1. Naciò, repito, en la cuna

De vn pesebre.

2. Ya vn establo,

Iuntò de la Ley las Tablas

Siempre fixas.

3. Con tres clauos,

Que el amor forja en la fragua 
De su incendio,

4. Cuyos rayos,

Los disfraza con el yelo

Del Diziembre.

5. Y es en vano;

Pues ser Dios Niño, lo dize

Lo desnudo.

6. Cuyo arco,

Es el Iris, que esta noche

Se descubre.

7. Disparando,

En vez de duros arpones

Tiernas pajas.

8. Triunfo raro!

Porque es al herir sus flechas

Lo mas fuerte,

9. Lo mas blando;

$\mathrm{Y}$ es que el golpe es la ternura

Con que llora.

10. $\mathrm{Y}$ en su llanto,

Consiste todo el hechizo

De sus ojos.

11. Que bendados,

Por ser de Amor, estuuieron

Otra noche.

Tod. Lindo laço! Vaya, siga, \&C.

1. En fin, por Crudo le llaman

Mata siete.

2. Los pecados

Assi lo dizen, muriendo

Quando èl nace.

3. Y en su aplauso,

La gloria le cantan vozes

De Querubes.

4. Que gritando,

A media noche despiertan

Los Pastores.

5. Y adoraron

Vn Dios, que muestra piadoso 
Ser de cera.

6. Por ser Agnus,

Que guarnecido de paja

Se viò entonces.

7. Y a los campos

Excedia de la nieue

Su blancura.

8. Por ser parto

Del Alva, de quien el Niño

Es Luzero,

9. Y esso es claro,

Siendo de su Madre bella

El Espejo.

10. No empañado,

Por no tener, ni el abrigo

De las fajas.

11. Demostrando,

Que para todo nacia

Desembuelto,

Lindo laço!

Vaya, siga, \&C:

F I N.

Biblioteca Nacional. Madrid. ( V/E) 52-7. "Del Amor que nace".

Métrica. Estos villancicos son una letanía de alabanzas al Niño Dios, con versificación polimétrica y muy variada, con encabalgamientos y figuras retóricas con valores semànticos y estructurales con paralelismo de sinonímico. 


\section{VILLANCICOS, QVE SE HAN DE CANTAR EN LA CAPILLA REAL A SV Magestad la Noche de Reyes deste año de 1680.}

VILLANCICO PRIMERO.

$$
\text { ESTRIVILLO. }
$$

QVè se mouiessen tres Reyes

A buscar vn nuevo Rey,

No mas de porque vna Estrella

Se le diesse a conocer:

No ay mas fè.

Y que siendo Señorias

De justicia todos tres,

El Conductor Celestial

Los tratasse de merced:

No fue desden.

Quien lo duda, quien?

Si a la luz del mismo Luzero

Se puede ver.

Atender, atender,

Que quien sabe humillarse,

Quanto mas Sabio,

Mientras menos se entona

Sube mas alto.

Esse es el contrapunto

Mas soberano,

Que en la acorde armonia

De Sol, y Estrellas,

Quanto mas se obscurecen,

Y humillan

Luzen, y brillan

Con mayor fuerça.

Essa es la ciencia,

De lograr en el Sol-La-Re-compensa.

\section{COPLAS.}

VN dia a tantos de Enero, 
Que si no fue Gran Maestre

Del Nacimiento en el Orden,

Es sin duda que fue Treze.

Tres Monarcas a vn Dios Niño

A adorarle dende Oriente,

Conducidos de vna Estrella,

Como rayos diz que vienen.

Es verdad que en el camino

Huuo sus inconuenientes;

Pero quando vna fineza

Se librò de quien azeche?

La embidia por diuertirlos,

Al hombre quiere que jueguen,

Mas esta vez la malilla

No hizo baza con los Reyes.

Faltòles alli la Estrella,

Mas no les negò la suerte

Que como eran todos Magos

A fè que se las entienden.

Ya se despiden, ya parten,

Y por que mas presto lleguen

En la carrera les pone

La misma Luz que les mueue.

Azia Belèn se encaminan,

Y hallando en vn pobre albergue

Toda la gloria abreuiada,

$\mathrm{El}$ indulto no fue Breue.

Alli, abriendo sus tesoros,

Los rinden, y no se niegue,

Para ir a la ligera,

Que ofrecieron Gentilmente.

Oro, Incienso, y Myrra, fueron

Los Dones, segun se entiende;

Pero lo futuro, dizen

Que es lo mas de este Presente.

Què se mouiessen tres Reyes

A buscar vn nueuo Rey,

No mas de porque vna Estrella,

Se le diesse à conocer!. 
No ay mas Fè, \&C.

\section{VILLANCICO II.}

Negro.

1. Plimo Antona, plimo Antona.

2. Que quelemo? que mandamo?

1. Que corramo, $\mathrm{q}[u e]$ volemo, $\mathrm{q}[u e]$ sigamo

A la Estleya, q[ue] vemo en Angola:

Gulungus, gulungus,

Que me alumbla vna Lus:

Gulungu, gulungueyo,

Que me alumbla vn Luselo:

Gulungu, gulungueya,

Que me alumbla vna Estleya:

Gulungu, gulungola

Que me alumbla vna Antolcha:

Gulungu, corramo,

Gulungu, volemo,

Gulungu, sigamo,

Gulungu, gulungola

A la Estleya, q[ue] vemo en Angola.

\section{COPLAS.}

1. Plimo Antona, que es aqueyo

Que tanto luse en Angola?

2. Sà vna Estleya, mas bliyanta,

Que la dienta de tu boca.

1. Donde corre tan apliza

que paleze exalacion?

2. A Belè, donde es lo Diozo

El Sol que nase de Aulola:

Gulungu, lo Neglo,

Gulungu, corramo,

Gulungu, volemo,

Gulungu, sigamo,

Gulungu, gulungugola,

Que quando el Sol nase 
Mas colen las somblas.

1. En sus centeyas se ablasa

Tura la gente de Etiopia.

2. Eya es blaselo de plata, y lo Neglo la calbona.

1. Con calboncito, y blaselo

Le haremo al Niño vnas zopas.

2. Y le haremo chocolata

Con su bollita maymona:

Gulungu, lo Neglo, \&C.

1. Dichosa Estleya, tres Reyas

Guia à lo Diozo que adolan.

2. Plimo, como yeban olo,

Su Estleya sà muy dichosa.

1. A la Siola Malia

Tambe los Reyas se postlan.

2. Y el Neglo resa, y la oflese

De Cocos vna Colona.

Todos. Gulungu, lo Neglo,

Gulungu, corramo,

Gulungu, volemo,

Gulungu, sigamo,

Gulungu, gulungola,

Que quando el Sol nase

Mas colen las somblas.

\section{VILLANCICO III.}

Gallego.

\section{INTRODVCCION}

Como en Galicia se dixo,

Que a pagar el Verbo baxa,

Los gallegos acudieron

A Belèn por ver la paga.

\section{ESTRIVILLO.}

Tanxe à gayta,

Vaya de festa; 
Ay Deus de miña alma!

Que o Neno se alegra.

\section{COPLAS.}

EV soy Domingo Araujo,

Que con à gayta, y à perra

Veño à ser aquesta Pascua

El domingo de sua festa.

Por tocar ào Neno Rey

Viñe desde a Pontevedra,

Con çapatiños en cinta,

E descalço de pe, è perna.

Todos. Tanxe a gayta,

Vaya de festa:

Ay Deus de miña alma!

Que o Neno se alegra.

Tanxe, que veñe a dança

De os Galegos, y as Galegas,

Folixando uas gaytiñas,

Y tocando as castañetas.

Tanxe, que bayla Locia

Con Bartolumè Filgueyra,

Ambos gordos, con que o bayle,

Ten pandeyro, y ten pandeyra.

Todos. Tanxe a gayta, \&C.

Tanxe à Neno garridiño,

Que entre as pallas se deita,

Y parece vn faz de trigo

Por o tempo de a siega,

Tanxe, è gardate de a mula,

Que si alguno se le chega,

Sole estirarse de patas,

E recollerse de orellas.

Todos. Tanxe a gayta, \&C.

Tanxe por o Rey Diuiño,

Que es Rey de a xente Galega,

Con que darà a sus contrairos

Vn Santiago en touda guerra.

Tanxe ainda mais folixones, 
Por la Dona nosa Reyna,

Tan fermosa, que seus ollos

Seràn de os Reyes a Estrela.

Todos. Tanxe a gayta.

Vaya de festa:

Ay Deus de miña alma!

Que o Neno se alegra.

VILLANCICO IV.

ESTRIVILLO.

OYgan la Xacarilla,

Oygan,

La Xacarilla Señores,

Oygan,

Que lleua primores,

Que a tres Reyes en Belen

Quiere dar el parabien,

Y al Sol que los ha traido,

Con el Dios recien nacido,

Que es el rayo entre Valientes,

Oygan,

Cosas eminentes,

Que se deuen admirar;

A escuchar.

XACARA.

EN la noche mas elada

del erizado Diziembre,

Echando vn cuerpo de Christo

Llegò a Belen vn Valiente.

Cubierto de polvo, y barro

Se reclinò en vn Pesebre,

Para remediar el mundo,

Aunque en las pajas se duerme.

Aunque llegò disfrazado,

No se ignora a lo que viene,

Pues se sabe que ha venido 
Solo a indultar vna muerte.

Por ver el tiempo tan crudo

Se fue aquel pajizo albergue,

Para que vean que es hombre,

Que nadie teme, ni debe.

Que aunque se nos haze Niño,

Bien pueden todos temerle,

Porque es la ira de Dios

Con aquellos que le ofenden.

Por venir como vn Cordero

A todos la Paz ofrece;

Y para el que no la busca

Por Christo $\mathrm{q}[u e]$ es vn Leon fuerte.

Corriò luego la palabra,

Y vn Astro resplandeciente

Informò, que es luz del Cielo

La que ha de hablar co[n] los Reyes.

Siguen la marcha al instante,

Porque fuera el detenerse,

qua $[n]$ do haze el cielo vn prodigio,

Mirarle, mas no entenderle.

Venciendo dificultades

Llegan al Portal, y advierten,

Que si perdieron la Estrella,

Fue porque el Sol amanece.

Rindieron adoraciones,

Ya tantas luzes se encienden,

Pues vieron al Sol, y al Alva

Cara a cara, y frente a frente.

Quedaron con tanta luz,

Siendo Sabios, mas prudentes,

Pues salieron de ser ciegos

Viendo la Verdad patente.

Sirvieron al Niño Rey

En todo lo que se ofrece;

Pues si vinieron Gentiles,

Como vnos Santos se buelven.

Oygan la Xacarilla, \&C. 


\section{VILLANCICO V.}

Gitanas.

\section{INTRODVCCION.}

SIguiendo vienen la Estrella,

Que guia a los tres Monarcas.

Alegremente festiuas,

En vn bayle de Gitanas.

\section{ESTRIVILLO.}

GItanillaz briozaz,

Pulidaz, rizueñaz,

Baylemoz alegrez,

Festiuaz, contentaz,

Al zonzonezito de la zonajuela:

Ola, vaya, ea.

1. Aplaudan mudanzaz

Gloriozaz fiermezaz

De doz Florez Reales,

Clauel, y Azuzena.

Todos. Ola, vaya, ea.

2. Aqueze ez mi Rey.

3. Aqueza ez mi Reyna.

1. Què cara de Roza!

2. Què cara de Perlaz!

Todos. Ola, vaya, ea:

Y puez noz hallamoz

En zu Real prezencia,

Baylemoz alegrez,

Feztiuaz, contentaz

Alzonzonezito de la zonajuela.

Ola, vay, ea.

\section{COPLAS.}

GAlan de miz ojoz

Ezcucha a Laureta,

Que quiere dezirte

La ventura buena. 
Todos. Ola, vaya, ea.

Zabe que te quiere

Vna linda Hembra,

Que por zu hermozura

Mereze ser Reyna.

Todos. Ola, vaya, ea.

Dizen que vn viage

Haz hecho por ella,

En esto no dudo,

Puez camino lleua.

Todos. Ola, vaya, ea.

En vn Lugarzito

Dizen que la encuentraz,

Que a Quintana-Palla

Mucho ze zemeja.

Todos, Ola, vaya, ea.

Resp. Gitanillaz briozaz,

Pulidaz, rizueñaz,

Baylemoz alegrez,

Feztiuaz contentaz

Al zonzonezito de la zonajuela.

Permanentez Pazez

Tuz Reynoz ezperan,

Puez noz traez el Iriz

En tu Ezpoza bella.

Biblioteca Nacional. Madrid. (V/C. ${ }^{0}$ 91-25). "Que se moviessen tres Reyes".

Métrica: polimetria, versos heptasilábicos que alternan con endecasílabos. Imitación fónica, aliteración de la sonajuela. Rima consonante. 


\section{VILLANCICOS QVE SE HAN DE CANTAR \\ EN EL REAL CONVENTO DE LA ENCARNACIÓN LA NOCHE DE LOS SANTOS REYES DESTE AÑO M.DC.LXXX.}

\section{PRIMERO NOCTVRNO}

\section{VILLANCICO}

\section{Estriuillo}

1. No perdamos de vista la Estrella, Vamos con ella,

2. Ay como corre!

3. Ay como buela!

4. Ay como passa veloz, y ligera

Transparentes Zafiros,

Cristalinas Esferas!

1. Tres Monarcas, que siguen

Sus luzes bellas,

Aunque Errante la admiran,

Fixa la esperan.

2. Què linda Estrella!

3. Què hermosa, y bella!

1. Pero dexenla, dexenla andar, Que ella pararà,

2. Adonde, Zagal?

3. En Belèn, en vn Portal, Que alverga vn Infante Sol

En braços de vna Doncella.

Todos. No perdamos de vista la Estrella, Vamos con ella.

\section{COPLAS}

Vn Astro flamante induce

Tres Magestades Excelsas

A adorar vn Rey, que yaze

Del tiempo à las inclemencias.

Marauilla nueua,

Que los Discretos logren 
Tener Estrella!

En vn Portal derribado

Le hallaron porque aduirtera $[n]$

Que a reparar ha venido

$\mathrm{Y}$ assi entre ruinas se alverga.

Rara providencia,

Que apenas nace, quando

Nace a-penas!

Aunque le vèn tan humilde,

Reconocen su grandeza;

Que los Sabios se pagan

De exteriores apariencias,

Bien lo manifiestan,

Pues Diuino le adoran

En tal miseria.

Quando à sus Plantas las ponen,

Mas sus Coronas eleuan,

Que sublima el sacrificio

Lo rendido de la ofrenda,

Discrecion ostentan,

Hazer el culto sombra

De la fineza.

Mortal, y Diuino a vn tiempo

Le adoran, y le contemplan;

Porq[ue] el ser hombre admirassen;

Quando como Dios le vieran,

Que la Providencia

Saca luz, que ilumina,

De ardor que ciega.

Al punto que el Don ofrecen,

Su viage feliz aprestan,

Que desluze el beneficio

Quien aguarda recompensa.

Quanto mas se alexan

De la dicha que huyen,

Estàn mas cerca.

\section{VILLANCICO}


Estriuillo.

1. Gitanaz alegrez,

Trigüeñaz, bizarraz,

Ligeraz ce apreztan,

Pulidaz enfaldan,

$\mathrm{Y}$ al bayle preuienen

Graciozaz mudançaz

Ola, ala.

2. Que nace la perla

Del Mar de la Gracià,

Ola, pulidaz, ola,

Ala, graciozaz, ala,

Que llegan de Oriente

Trez Zabios Monarcaz,

Y vna Eztrella dize

$\mathrm{Zu}$ ventura clara

Ola, ala.

1. Laz tocaz bolantez,

Que el ayre embaraçan,

En rizos zutilez,

Cean alaz,

Ola, ala.

2. Laz Bueltaz garbozaz,

Pompa de laz zayaz,

Nuevoz lazoz formen,

Y dezhagan,

Ola, ala;

Que nace la Perla

Del Mar de la Gracia.

\section{COPLAS}

1. La Perla Precioza,

Que alli ce repara,

Gitanaz, trigüeñaz,

Graciozaz, pulidaz,

Me ha dado en el alma

2. Ola. 3. Ala,

Que baxa à la Tierra

A cozaz muy altaz, 
Ola, ala.

1. El fuego que encierra,

Arroja en la ezcarcha,

Bizarraz, garbozaz,

Preciozaz, rizueñas,

Que ez fuerte la llama,

2. Ola. 3. Ala.

Y el Amor que la enciende,

Con rayoz lo apaga,

Ola, ala.

4. Gitanaz, trigueñaz,

graciozaz, pulidaz

Rizueñas, preciozaz,

Garbozaz, bizarraz,

Que nace la Perla

Del Mar de la Gracia.

1. De precio la zuben

Gloriaz, que la cantan,

Amadaz, prendidaz,

Alegrez, jovialez,

Maz yo la comprara.

2. Ola. 3. Ala.

A zer mio el Cielo,

Que luzez le cambia,

Ola, ala.

1. No conciente igualez

$\mathrm{Zu}$ ezquicita gracia,

Honradaz bellezaz,

Prodigioz zutilez,

$\mathrm{Ni}$ a laz artracadaz,

Ola, 3. Ala,

Que lleua en zarcilloz

La Reyna de Ezpaña,

Ola, ala.

4. Amadaz, prendidaz, 
Alegrez, jouialez,

Zutilez prodigioz,

Bellezaz honradaz,

Que nace la Perla

Del Mar de la Gracia.

1. Al Zol de ci mizma,

La Concha de Nacar,

Prendadaz, atentaz,

Cortezez, queridaz,

Oztenta la gala.

2. Ola. 3. Ala,

Y abre laz bellezaz;

Que el mundo aguardaua,

Ola, ala.

1. El heno algodonez,

El pecebre caxa,

Ingrataz, ezquivaz,

Crueles, ceveraz,

Las luzes le guardan.

Ola. 3. Ala,

Para joya rica

De vna Cruz Zagrada;

Ola. ala.

4. Prendidaz,

Atentaz,

Cortezez,

Queridaz,

Ceveraz,

Cruelez,

Esquivaz,

Ingrataz,

Que nace la Perla

Del Mar de la Gracia.

\section{VILLANCICO}

Introduccion.

Escuchen todos atentos 
Lo festivo de las danças,

Que los Lugares hizieron,

Por donde los Reyes passan.

La vna fue à lo Morisco,

Otra à vso de Vizcaya,

Huvo Gallegos, Franceses,

Y Negrillos, y Gitanas.

\section{ESTRIVILLO.}

1. Escuchen, escuchen,

$\mathrm{Y}$ ande la dança,

Con sonajas, panderos, violines, y flautas;

2. Ande la dança,

Que à los Reyes, que vàn de camino,

El melon de la Estrella serà su posada.

1. Ande la dança,

Que a los Reyes caminan, haganles salva Festiuos aplausos, alegres mudanças

Ande la dança,

1. Toca el pandero.

2. Tañe la flauta.

3. Suenen violines.

4. Zumben las gaytas.

Tod. Ande la dança,

Con gaytas, violines, panderos, y flautas,

1. Ande la dança,

Con el chichirichi de alegres sonajas,

2. Ande la dança,

$\mathrm{Y}$ vnidos à vn tiempo,

Suenen à pausas

Castañetas, panderos, violines, y gaytas,

Con el chichirichi de alegres sonajas.

COPLAS.

Text. Las Gitanas à los Reyes

Dezian, quando baylauan,

Que la Estrella parecia

Flor de Lis en lo dorada:

Ande la dança, 
Gitan. Flor de liz parece

La Eztrella maz clara,

Que dezde zu Oriente

Alumbra hazta Ezpaña:

Ande la dança,

Con el chichirichi de alegres sonajas.

Text. Los Moriscos en vn bayle

Ladrauan, en esta dança

Perros $\mathrm{q}[u e]$ à vn Rei hazen fiestas,

Por su Señor le declaran:

Ande la dança.

Moris. Cantar, Moresquilio,

Y estar buena zambra,

Ser nuestros Xoniores

Reyes de Granada:

Ande la dança, \&C.

Text. En la dança Vizcaina,

Las canciones anunciauan

A los triunfos de los Reyes

En Vitoria muchas palmas:

Ande la dança.

Vizc. Reyes, que Estrella

Traes à Vizcaya

De San Iuan de Luz,

Muy vendràs clara:

Ande la dança, \&C.

Text. Los Negrillos, del Rey Bla $[n]$ co,

Que era la çestrella, cantauan,

Vnos bellos ojos negros

De vna Reyna que adoraua:

Ande la dança.

Neg. Rey Branca su Eztreya

Viò en luza brillanta

De vnoz ojoz negloz,

Do eztà al Zol al Alva:

Ande la dança. \&C.

Text. Sin la gayta, los Gallegos

Baylaron al son de flauta:

Porque esta vez no tuvieron 
Los pobres vn sus de gayta:

Ande la dança.

Galleg. A Estrella, que allumbra

Aò mundo tan crara,

Pois è Peregrina,

A Santiago vaya:

Ande, \&c.

Text. Los Franceses, que la Estrella

Vieron de luz coronada,

A la Francesa cantaron,

Y a la Española baylauan:

Ande la dança.\&C.

Franc. Estrello, que os Roes,

Alumbra en la Fransa,

Estrello pares

De ò Roe de Espagna:

Ande la dança,

Con el chichirichi de alegres sonajas,

Biblioteca Nacional. Madrid (V/E 91-78) Palau, 367752. "No perdamos de vista la Estrella".

Métrica: se trata de una ensalada de Lenguas, característica del Renacimiento, en donde abunda la polimetría, con versos octosilábicos y rima asonante. 
VILLANCICOS, QVE SE HAN DE CANTAR

la Noche Buena de Nauidad, en el Real Convento de Nuestra Señora de la Merced, Redempción de Cautiuos de esta Corte, este Año de 1680.

SIENDO MAESTRO DE CAPILLA

de dicho Convento el Padre Fray Domingo Ortiz de Zarate.

EN MADRID. Año De 1680.

TERCERO NOCTVRNO.

VILLANCICO VII.

\section{Estriuillo.}

MI Niño, aquesse temblado

Aliento de tu dolor,

Que se anima en vn rigor,

Escuchese aqui mudado.

Pues en mi fè assegurado,

De vna encendida terneza,

De vn no terminado ardor,

Que en incendios del amor

Acrisole mi fineza.

\section{COPLAS.}

TIerno amor, pues es tu llanto

Disfraçado fuego en perlas,

Llora mas; porque la llama

Que se auiua en las terneças,

Acrisole mi fineza.

Tierno amor, pues tus gemidos

Enamoran con la queja;

Gime mas, porque mi pecho

Al sentir tan dulces penas,

Acrisole mi fineza.

Tierno amor, pues lo que sientes

Enamorado me dexa;

Siente mas, porque el desmayo

Que al escucharte me cuestas,

Acrisole mi fineza. 
Tierno amor, pues lo que abrasas,

Enciende cuanto me yela;

Arde mas, porque el incendio,

En que mis ansias se engendran,

Acrisole mi fineza.

Mi Niño esse temblado, \&c.

\section{VILLANCICO VIII.}

GALLEGO.

\section{Estriuillo}

TOcay Dominguiño,

Tocay à compàs,

Turururu, y andar,

Correr, y baylar,

Correr, correr, correr, y bailar.

Sone ò tamboril

Sone la gaytiña,

Y la casta[ñ $]$ eta $^{18}$,

Andar, andar,

Que los Bartoliños

Queremos baylar.

Cruzando los ventos,

Los sones doblay,

Turururu, à compàs,

Pues que çapatiños

De pao calçais.

Tamben castañetas

En os pes cheuais.

Turururu, y andar,

Correr, y baylar.

\section{COPLAS.}

MI Niño en as pallas,

Que prazente estais,

$\mathrm{Y}$ es porque mas cruces

En ellas achais. 
Aquestas mançanas,

Memorias de Adan,

Por lo encarnadiño

Las podeis tomar.

Aquesta cestiña

De houos tomay,

Y para vna Bulda

Este mediu real.

Dominguiño, roscas

De zenteo vos dà ${ }^{19}$,

Aunque en vuestros brazos.

Las vê de cristal.

Tomay de sardiñas

Diez ducias no mais

Pastillas Galegas

De menjuy, con sal.

Estos zapatiños

Rusticos, calçay,

Que el crauo passado

Busca el pie galan.

Vna zamarriña

Forrada en sayal,

Que de Monte-Rey

Este he o Cambray.

Aô boy, è à mula

Ceuadiña train,

Porque al trigo dexen

La palla en que està.

$\mathrm{Si}$ en Galicia fora,

$\mathrm{O}$ voso natal

De Madrid, ô Rey

Os fora à hospedar.

Tocay Dominguiño, \&c.

F I N.

\footnotetext{
${ }^{18}$ En el original, castaneta.

${ }^{19}$ En el original, De zenteo ò vos dà.
} 
Biblioteca Nacional. Madrid. (V/E 129-9) "MI Niño, aquesse temblado".

Métrica: los villancicos se escribían para ser cantados; por ello solía ocurrir que la adaptación de las letras a la música previamente establecida exigía variaciones. En este villancico hay polimetría, versos de paralelismo libre, versos octosílabos con rima asonante. El sistema métrico latino gravita enormemente sobre la cultura occidental y sobre todo en el Renacimiento. Abundan los diminutivos en gallego ("Vna zamarriña"), impregnando de afectividad el texto. 
VILLANCICOS, QVE SE HAN DE CANTAR LA NOCHE

de los Reyes, en el_Real Convento de Nuestra Señora de la Merced, Redempción de Cautivos, desta Corte, este año de 1680.

PVESTOS EN MVSICA

Por el Padre Fray Iuan Romero, Maestro de Capilla de dicho Convento.

Año 1680

VILLANCICO VI.

Gallego, Asturiano, y Maragato

Introduccion.

VN Gallego, y Corito,

Y vn Maragato (no es nada)

A la Aldea de Belen,

Partieron de camarada.

Para diuertir al Niño,

Hizieron vna ensayalada,

De Coplas y Villancicos,

Con diferentes tonadas.

Atencion al Galleg[u]illo ${ }^{20}$,

Que es linda, y nueva tonada,

Del Maestro de Capilla,

Herrador de Ponferrada.

1. Salga el Gallego.

Todos. Salga.

2. A diuertir al Niño.

Todos. Salga, salga,

3. A cantar su tonada.

Todos. Salga, salga,

Y repitan los Organos todos,

Y los Músicos à dos Coros,

Canten oy mil alabanças;

Acompañen chirimias,

Repiquense las campanas,

Arda la nieve en incendios,

\footnotetext{
${ }^{20}$ En el original, Gallegillo.
} 
Saque el Sol sus luminarias,

1. Que salga el Gallego, digo, otra vez digo que,

Todos. Salga, salga, salga.

\section{COPLAS}

VEn benidu seya la fror dal Deya,

O fillo de Mariya, que naciô en Iudea,

E sobrin de Isabela,

Primito de Ian, Aradan, dan, dan,

O doybos à Deus, mi Nino galan,

Que y aradan, y aradan, que y aradan, dan, dan,

En essas paliñas donde bos fincades,

A besà bosas maos, bin tres Magestades,

Con muytos presentes, que lis bos daràn,

Que yaradan \&C.

Sodes razimiño, muyto sazonado,

Y de os Iudiyos seredes cortado,

E pro cinco bocas vos exprimieran,

Que y aradan, \&C.

Ay, arriba, arriba, mis lagrimiñas santas,

Do à Deus, has perliñas tan ben empregadas,

Pois que as chaurades pros fillos de Adan,

Que y aradan, \&C.

Aunque Grano terno seredes trillado,

Y de la farina, vn pan regalado,

Mos darà ena Egresia, noso Capellan.

Que y aradan, \&c.

A lo arribaruca, yora en San Vicente,

Dara $[n]$ mos à Deus, en opà como leyte;

Beña todo ome à comer de opan,

Que y aradan, \&C.

1. Tenga vze seor Gallego,

Descanse la gayta vn rato

Cante como Maragato,

Vnos Coplones de Ciego,

Por el tono del sayago.

Maragato. 
VEncerril de los campos, Madre,

No se quijo dar al Condestable.

Al mi Niño recien nacido,

Yo li endono este bestido,

Con zaragueles azules,

Que los huuo Peranzules,

En la erencia de so Padre,

Vencerril, \&C.

Del Infante Don Pelayo,

Bos presento aqueste sayo;

Y tambièn essa casaca,

De la Infanta Doña Orraca,

Que tiene mil Nauidades,

Vencerril, \&C.

Recebir Señor Diuino,

Essa botija de vino,

De la Duca mi Señora

De la viña, que es aora,

Del Duco de mi Lugare,

Vencerril, \&C.

Mi moger Mari Camacha,

Bos embiba aquessa faja,

Recebilda Virgen bella,

Mas firmosa que vna Estrella,

Hija, y Esposa del Padre,

Vencerril de los campos, Madre.

No se quiso dar al Condestable.

1. No hable mas en Maragato:

$\mathrm{Y}$ cante aora en Corito,

De buen gusto, algun tonito,

Mientras duerme el Niño vn rato.

Corito. Plazeme, que ye razon.

Toniyu ha de cantar;

Porque enfetu tangu miedo.

1. Pues contad la Procession

Que haze la ciudad de Oviedo,

En la Santa Nauidad.

Corito. Vos dezes muncha verdad.

1. Pues comenza. 
Corito. Ya escomienzo.

SE queredes saber lla folganzia,

Que allà en Oviedo fazen al Natal,

Escucha Iuan Noriega vn raticu,

Que abes de plasmabos de tal ñobedad: Ay, ay, ay.

Vn Domingu sali de miou casa,

Tan zedo, que apenas se bia mio llugar,

$\mathrm{Cu}, \mathrm{cu}, \mathrm{cu}$, me cantaron los Gallos,

Quando yo entrê por ella Zuydad; Ay, ay, ay.

Pintarebos oy lla Prouzezion,

Que yo eña miou bida ñon bi otra que tal:

Nin tampoco el buruyon de gente,

Que polla mio alma, pensê rebentar: Ay, \&C.

Por Tarasca iba Iuan Ferreyra,

Con sos castanueles queren deperal,

Y amarrada con vna tomiza,

Leyuaua vn baqueru, que era de sayal: Ay, \&C.

Adelantri iben llos pendones,

Vnos de teliya, y otros de fustan,

De color de sangre de ñarizes,

Mas quantu ralin, que debieron questar: $\mathrm{Ay}, \& \mathrm{C}$.

Mas de zientu y mil, sobenta cruzes,

Todos en ringlera, y en filera ban,

Cada Cruz, leybaua so manguiya,

E cada manguiya leyba vn Sancristan.

Flayres foron, ya Flayres pasoren,

Ya Frayres tornoren, ya Frayres que vàn

Lla mitad, echô peila man dreyta,

Y pella man riesga, iba otra mitad: Ay, \&C.

Aqui tengo perder el juiziu,

Ay mio Iuan ñoriega, si lo he de falar,

Vi vnos omes tan lluengos, tan llargos,

Que ziertu, que à el Cielu querian lleygar: Ay, \&C:

Lluego foron vños Cantorciyos,

Con sos pelliciques, que eren de Ruan,

Mas garrides, fermoses, y blanques,

Mijor que la nieve, y el diente del Can: Ay, \&C.

Lluego foren todos 1los Canoregos,

Ainda con muyta de so grauedad; 
Lles camisas lleyban sobre el sayu.

Con vnos bonetes de quatro esquinal: Ay, \&C.

Tan ben foron ellos Rugidores,

Con zapatos nuevos, de altu calcañal,

Con sus zirios ardiendo en es manos,

Que vên me parez baldrin a mediu Ral: Ay, \&C.

Esta Rolda, que aqui bos refieru,

Como los Gallegos que vàn à segar,

Vnos tres, vnos, ya otros tres otros,

Cantando les coses à la Igresia vàn: $\mathrm{Ay}, \& \mathrm{C}$.

Alli estàben pintados tres Reyis,

En vn paramentu, que auia en el Altar,

Vnu yera San Melchor, el Negru,

Y el otri Gaspar, y el otri Baltesar: Ay, \&C.

Llos ginoyos en tierra fincaron,

Delantre del fiyu del Padre Eternal,

Besucaronye plantes, y manes,

Y alli lle ofrecieron muyta cantidad: Ay, \&C.

\section{TERCERO NOCTVRNO}

\section{VILLANCICO VII.}

\section{Estriuillo}

XAcara, que la pide el aplauso,

Xacara, que la noche la lleua,

Xacara, que se canta à los Reyes,

Xacara, que entra la buena Estrella,

Que và à rendirse a vn valiente,

Que apenas recien nacido,

Viene por vida del mundo,

Echando vn cuerpo de Christo.

Afuera, afuera, afuera,

Que la digo cantando,

Porque se entienda.

XACARA.

EN el Meson de la Luna.

Que ofrece posada al Sol, 
Del Cielo de vna Doncella;

En tierra vn Luzero diô.

A ser galan de las almas,

El Verbo al hielo naciô,

Que lo tomô con fineza;

Pero con poco calor.

Los tres Reyes de Arabia,

$\mathrm{Al}$ vêr este valenton,

Se turbaron; pero el Negro,

Le viô sin mudar color.

De tres dones que le ofrecen,

Mas al Oro se inclinò;

Que el que es valiente, es amigo,

De vêr cosas de valor.

Meciôse en cuna de nieve,

Que no es nuevo en su aficion,

Dexarse lleuar de el agua,

El espiritu de Dios.

A matar viene à la muerte,

Pecado, de que el amor

Le diò vna herida mortal,

Y fue, porque le encarnô.

Que no se cayga el Portal,

Es vn milagro de Dios,

Bien puede el Iayan hazer

Cuenta, que ha nacido oy.

El nacer en la Campaña,

Es prueba de su valor,

Y esperarle cuerpo, à cuerpo,

Es cosa de confession.

El sangriento azero esgrime

Herodes, que en su region,

Con tener mala conciencia,

Deseaua vêr à Dios.

Hasta nacer Iuan, y el Verbo,

El tirano enmudeciò;

$\mathrm{Y}$ es, porque no eran nacidos,

La palabra, ni la voz.

Contra el Señor,ensangrienta 
La espada, porque ignorô,

Que no se mueve la hoja,

Sin voluntad de el Señor.

$Y$ en fin el Cielo dispuso

Que burlasen de el traìdor,

Con el Rey Niño, los Reyes.

Buena Pasqua les dê Dios.

Biblioteca Nacional. Madrid (U. C $C^{\mathrm{a}}$ 83-45) VE/ 128-66 "VN Gallego, y Corito". .

Métrica: existe una gran variedad métrica en este villancico, debido a que hay un predominio del asturiano, con influencia occidental en los diptongos. El endecasílabo galaico antiguo con acento en quinta y en décima aparece en la poesía gallego-portuguesa y en el Modernismo. La rima en general es asonante. 


\section{LETRAS DE LOS VILANCICOS QVE SE CANTARON EN LA SANTA Iglesia Metropolitana, y Patriarchal de Sevilla. \\ En los Maytines del Nacimiento de Nuestro Redemptor Jesu Christo. \\ ESTE AÑ DE MD.CL.XXX.}

\section{VILLANCICO VII.}

Introduccion.

Los que vivis en el mundo,

llegad que Dios humanado

viene a curar los achaques,

que os pega vn mundo tan malo.

\section{Estrivillo.}

1. Venga el mundo, que quieren residenciarlo.

Tod. Vamos andando, porq $[u e]$ el mundo se vaya enme $[n]$ dando.

3. Vamos corriendo, porque el mu[ $n]$ do comienza de nuevo.

Venga el mundo, que el niño

le estâ aguardando.

busca el mundo, y le tiene

Dios en la mano.

Quie $[n]$ es el mundo q[ue] a gustos $\operatorname{co}[n]$ vida y el conocerle nos cuesta la vida?

1. El hombre, es el mundo, por quien viene el Verbo, porque el hombre es mundo pequeño.

2. Pues Dios â nacido por ver redimido

al hombre, que á sido por quien se á humanado.

1. Si Dios con mi pena de llanto se llena pues es noche buena, espantemos los males cantando. 
Tod. Vamos andando, porque

el mundo se va registrando.

\section{COPLAS.}

1. Yo Rey mio soy vn Sordo.

con tan terrible Sordera,

que como si fuera chirlo

me coge de oreja a oreja.

2. Oyga el Vervo que es palabra,

1. no oygo palabra ni media.

2. pues oyrâ el dia del juizio

si le han de hablar con trompeta,

en oir a Dios se meta,

porque al alma le estâ hablando.

Tod. Vamos andando, porque

el mundo se va registrando.

2. Astrologo soy, y siempre

que me sacan mentiroso,

respondo, que alguna vez

se ha dè errar el reportorio.

2. Los Astrologos no pueden

ver al Niño de sus ojos,

que hasta las mismas estrellas

levantan los testimonios:

Astrologos son demonios,

que en el cielo quieren mando, \&C.

Yo señor soy vn soldado.

2. Lo que ay de Olanda $[n]$ nos diga.

1. Yo no se lo que ay de Olanda,

porque non tengo camisa,

al Ave Maria vengo

huiendo de la milicia.

2. Las gallinas se recogen

siempre, á las Ave Marias:

no se meta en valentias

que al yelo esta vn Leon temblando.

Tod. Vamos andando, \&C.

4. Yo soy labrador, y tiemblo

mucho mas que el niño al año, 
porque Dios tiembla en diziembre

y yo tiemblo Abril, y Mayo.

2. Ya en Christo a nacido el trigo.

Muy chiquito esta, temamos.

que valga a treinta dineros

alla por el tiempo santo.

2. No encarezca el trigo tanto

que en Belen anda rodando

vamos andando $\& \mathrm{C}$.

5. Hipocrita soy señor

y gusto de que me vean

muy palido, y es que traigo

opilada la conciencia.

2. Sirba á Dios derechamente

y no tuerça la caueça

porq[ue] santos de tramoya

son vuenos para comedia.

Y si Dios no lo remedia

se ira al infierno rezando,

vamos andando.

porq[ue] el mundo se và registrá[n]do.

\section{VILLANCICO VII}

\section{Estrivillo}

1. Como podre celebrarte

mi recien nacido Dios.

2. Cantando, temblando

porque tierra soy

temblando de frio

estas siendo sol

$\mathrm{y}$ al berte temblando

tambien tiemblo yo.

\section{COPLAS.}

1. Tie $[m]$ blas mi amado Iesvs

que as querido siendo Dios

ser hombre porque de tierra 
ve $[n]$ ga a ser esse te $[m]$ blor

$\mathrm{y}$ al verte temblando

tambien tiemblo yo.

Tie $[m]$ blas, y al mundo estremeces

sin que sea admiracio[ $n]$

el que tiembre la flaqueza

vie $[n]$ do te $[m]$ blar al Valor

$\mathrm{y}$ al verte temblando

tambien tiemblo yo.

3. Tiemblas, y entonces predicas

avnq[ue] palabra sin voz

que para auissos, temblores

voces, y palabras son.

$\mathrm{Y}$ al verte temblando $\& \mathrm{C}$.

4. Tiemblas llora $[n]$ do, y quebra $[n]$ tas

ávn las piedras de dolor

$\mathrm{y}$ ay racionales que tienen

mas de piedra el corazon.

$\mathrm{Y}$ al verte temblando \&c.

5. Tiemblas con ser inocente

si tu tiemblas que are yo?

que el temblar es del culpado

del q[ue] esta sin culpa no.

$\mathrm{Y}$ al verte temblando $\& \mathrm{C}$.

6. Tiemblas, piadoso, y naciendo

me previenes desde oy

para el dia en que juzgando

sea tu piedad rigor

$\mathrm{y}$ al verte temblando

tambien tiemblo yo.

\section{VILLANCICO IX}

Gallego.

Estrivillo

Zumbe retumbe

la gaita domiños 
que o bailarei

mientras chora mi nino

vallasme Deus

quien tuuiera, ó capote

para abrigar

âo garrido chicote

ay quien tuuera

vnas boas polaynas

para ponerle

en sus fermosas patas

si el Boy me deran

dariale logo

vna monteira

que non ten caforros

y porque conozca

que en todo soy largo,

deme la Mula,

darale dous cartos:

zumbe retumbe la gaita

Domiños

que o bailarei mientras

chora mi nino.

\section{COPLAS}

1. Eu le presento

dos mantequiñas

para qeu a May

lle fagan tourrijas.

Tod. Toca Domiños con son pracenteiro:

zumbe a gaita, retumbe o pandeyro.

2. Vna cestiña

le traigo de huevus,

que como nieva

todos vienen frescus.

Tod. Toca Domiños \&C.

3. Como a Pastor

le trago vn cachorro,

para que garde

as ovellas del lobo. 
Tod. Toca Domiños, \&C.

4. Traigo vna cabra

por grande regalu,

que soy cabrito

mas ay de diez anos,

Tod. Toca Domiños, \&C.

5. Vna caldeira

lo traigo relimpia,

porque con homes

faga boas migas.

Tod. Toca Domiños, \&C.

6. Yo so Alcalde

e le doy esta vara

para que a todos

josticia nos faga.

Tod. Tocay Domiños con son pracenteyro:

zumbe a gaita retumbe o pandeiro.

\section{LAVS DEO}

Con licencia en Sevilla por Iuan Francisco de Blas, su Impressor mayor.

Biblioteca Nacional. Madrid. (VE. 83-10) "Los que vivis en el mundo".

Métrica: polimetria, muy variada, con versos heptasílabos, rima asonante y a veces muy libre. Todo nos hace evocar canto y baile, propio del sustrato germánico. 


\section{VILLANCICOS, QVE SE CANTARON LA NOCHE DE NAVIDAD EN LA SANTA IGLESIA CATHEDRAL DE VALLADOLID ESTE AÑO DE 1680. DEDICADOS A LOS MVY ILUSTRES SEÑORES DEAN, CABILDO DE DICHA SANTA IGLESIA. \\ SIENDO RACIONERO, Y MAESTRO DE CAPILLA EL LICENCIADO MIGVEL GOMEZ CAMARGO}

VILLANCICO VIII. Gallego.

ESTRIVILLO.

1. Todos os galegos que à Belen ben è van dai Grexa os Cregos, das Ruas os Legos, das Prazas os cegos, que ben, è que van: Ay, ay, ay, como vaylaràn.

2. Ao Solciño louro, que nos trae Tesouro, nas madexas de Ouro, que en pallas estan: Ay, ay ay como vaylaràn.

3. A sua mai fermosa, pura, y fresca Rosa, que pariò Gloriosa no tosco Zaguan.

Ay, ay, ay, como vaylaràn.

4. Vaylarà ligero ao son del pandeyro

ò noso Barbeyro con ò Sacristan:

Ay como baylaràn.

5. E nos tamben imos à Belen à ver noso Ben, po los axudar andar, andar.

Que ò son me retiña de la frautiña, de la gaytiña lo corpo todo tanxeme Bartolo, è veràs como trisco lo poluo:

\section{COPLAS.}

2. Tanxeme à frautiña de Pascual Llorente, que entre tuda xente [...] ben la retiña 
darei ua boltiña

por la vida miña,

porque no me riña

ô Solciño nouo:

Tanxeme Bartolo,

ê veràs que assi trisco lo poluo.

Tanxeme pauana por lo Caualeyro

Vaylarey ligero, pois que Deus se humana,

è de boa gana darà en à bentana

con cabeça sana: si brinca maroto:

Tanxeme Bartolo, \&C.

3. Tanxeme villano po la zarabanda,

Pois meu Neno anda sendo Deus tan llano

que me da la mano: y rico, y vfano

direi yo me gano, perdendome todo,

Tanxeme Bartolo, è veràs, $\& \mathrm{C}$.

4. Tanxeme ô sonciño

que à vaylar conuide,

pois que Deus se mide

con ò poluo miño,

y es tanto el cariño

que tein de ser Niño

que viste de Armiño

y es Deus el aforro:

Tanxeme Bartolo, è veràs $\& C$.

5. Por la españoleta

tanxeme canario

è qual campanario

darei hua volteta,

è nadie se meta

en facerme treta,

porque $[. .$.$] gaueta$

me rompa os ollos:

Tanxeme Bartolo, è veràs, \&C.

6. Tanxeme ô rugeyro

por las muchas vacas

que las teño fracas,

disque di en ligeyro,

y al Deus verdadeyro 
que nace Cordeyro

por todo el oteyro

le brincarey solo:

Tanxeme Bartolo,

ê veràs como trisco lo poluo.

F I N.

Valladolid: Por la Viuda de Iuan Antolin de Lago. Año 1680.

Biblioteca Nacional. Madrid (V/E 150-31) 603-1. Palau 367694. "Todos os galegos que à Belen". Métrica: versos heptasílabos, con rima consonante, polirrímicos. 
LETRAS DE LOS VILLANCICOS QVE SE CANTARON EN LA

Sancta Iglesia de Cordoba, en la Kalenda, Noche, y Dias, de la Natiuidad de N. Señor

Iesu Christo, este año de mil seiscientos y ochenta.

III. NOCTVRNO. VILLANCICO VII.

ESTRIVILLO.

HAgan salua los Hombres

al Alba bella

que con el Sol en brazos

sombras de[...]erra

Y con vozes alegres publiquen,

Y cante $[n]$ la gloria de dicha tan nueba.

COPLAS.

DIos te Salue Reyna, y Madre

de misericordia llena

pues eres vida y dulçura

seràs la esperança nuestra.

Dios te salue a ti llamamos

lo[s] desterrados de Eua

hijos, que solo pedimos

que tu piedad nos atienda.

Tambien a ti suspiramos

gimiendo para que tengan

aliuio nuestros suspiros,

y remedio nuestras penas.

Llorando en aqueste valle

de lagrimas nos alienta

ver que el Sol recien nacido

tan de tu mano le tengas.

Ea pues, Señora, ya

siendo tu abogada nuestra

serâ euidente el fauor,

pues son nuestras culpas ciertas.

Buelue à nosotros tus ojos

misericordiosos, ea 
exersitese en piedades

quien saue hazer finezas

$Y$ pues es fruto bendito

de tu Vientre à IESVS muestra

como luz, que nos alumbre

como sol que nos encienda.

Despues de aqueste destierro

á de ser por que se vea

que siendo Niño entre paxas

tendrà muy linda presencia.

O clemente, o piadosa

o dulce Virgen perfecta

MARIA Madre de dios

por todos nosotros ruega

Para que seamos dignos

de aquellas dulzes promessas

de Christo que [en] vn Pesebre

promete la vida eterna.

\section{VILLANCICO.}

\section{ESTRIVILLO}

NIño hermoso si lloras y penas

pagas mi deuda

mas quando la pagas

mas me la aumentas:

mas ay que mis rigores

malogran tus fauores

pues el quejarte

explica bien lo ingrato de mis desayres.

\section{COPLAS.}

A Los suspiros de vn Niño

da tiernos ecos el ayre

mas ay mi Dios que tu buscas

los ecos en otra parte.

De mi coraçon los quieres

pero suspiras en balde 
pues siendo pena te niego

los ecos, que penas hazen.

Viendo que no te responde

del tierno llanto te vales

que el agua ablanda vna piedra

$y$ es $[. .$.$] pues es diamante.$

Quando diamante rehile

Cordero por el te hazes

mas es diamante tan bruto

que no le labra tu sangre.

Mi Dios que has de hazer conmigo

si mi dureza es tan grande

que ni lloro quando mueres

ni te abrigo quando nazes.

IX. VILLANCICO GALLEGO.

\section{INTRODVCION.}

ESta noche los Gallegos

festejando al Niño Rey

en mudanzas de Villano

mostraron su noble feè.

Con el zapato en la cinta

por no tropezar con el

van, muy calzados de barba

y muy lampiños de pies.

Bosteçando con la hambre

llegan cantando a Belen

la boca de par en par

$\mathrm{y}$ al bolsa pez con pez.

\section{ESTRIVILLO.}

1. POis esta noyte à nacido ò cordeiro zumbe à Gayta

retumbe ò Pandeyro.

Tocay Galegiños

tocay à Gaytiña

que oy á nacido ó Rey en Galicia. 
2. Ay Toribiño chegay è nou temas

$\mathrm{q}[u e]$ hasta la mesa de ò Rey es Galega

3. Tocay Galegiños

ay, ay, ay

tocay è cantay

è andese á Gayta

por el Purtal.

\section{COPLAS.}

PAra librarmus del fierru

que nos puso vna maliza

Deus à nacido en Galiza

por buscar la Cruz do Ferru.

En lo desnudiño

que es Galegiño

non pode negar

tocay è cantay

è andese á Gayta

por el Purtal.

De á May è doncela el partu

á nacido o Niño Rey

è si queire darme ò Boey

eu teño de darle vn carto

è yo farey harto

que por tu prubeza

en toda Galei[ç] $\mathrm{a}^{21}$

vn carto no ay.

Tocay è cantay \&C.

Cantay todus à la vela

Soberana è Virgen pura

que eista Nauidad, o Cura

mos diju que eira donçela

Reyna de Castela

espurgarridiña

por blanca è rubiña

do mundo seray.

Tocay \& C.

O Niño que chora grabe

${ }^{21}$ En el original, Galeica, por Galicia. 
con MARIA por meu ben

para regalarse ben

fay os pucheiros con Aue

su May es la Naue

que os Celos agota

è trai esta frora

ó armada Real.

Tocay \& C.

Aò Nino que tembro cheue

vn Negro aunque foy borron

que è gusto dar o carbón.

facendo tempu de Neue

amante se moebe

a pagar escoyte

que trae ò Chicote

pegadu ò pañal.

Tocay \&C.

Toribiño dandu voices

a su Rey recin nacido

le à dadu voiçes è â sido

mas ò roido que as noiçes

la Mula day coiçes

que in so mal sentir

veindolos partir

as quisu cascairar.

Tocay \& $\mathrm{C}$.

VILLANCICOS PARA LOS DIAS DE PASQVA.

ESTRIVILLO.

AL Sol que la Aurora

Infante nos da

venid y adorad

Astros, Flores, Aues, Fuentes

plantas, luzes adorad

al Sol que la Aurora

Infante nos da.

Y todos vnidos en lazo inmortal 
Astros brillantes

Flores fragantes

Aues canoras

Fuentes sonoras

Plantas amenas

Luzes serenas

Astros, Flores, Aues, y Fuentes

venid y adorad

al Sol que la Aurora Infante nos da.

COPLAS.

AStros que en açul volumen

brillantes le transformais

por que sus obras se lean

en el Zafiro inmortal

Astros brillantes venid, y adorad.

Flores que à este Sol Infante,

fragantes ambares dais

porque es el humo oloroso

de la adoracion señal

Flores fragantes venid y adorad.

Aues que à la pura Aurora

canoras la salua dais

porque en sus brazos el Sol

eterno dia nos da

Aues canoras venid y adorad.

Fuentes que en dulces mormureos

sonoras solemniçais

aquella fuente de gracia

que nos da de gracia el mar

Fuentes sonoras venid y adorad.

Plantas que en suaues verdores

amenas pronosticais

la esperanza de que acaba

de otra planta lo mortal

Plantas amenas venid y adorad.

Luzes, que adorando el cielo

serenas manifestais

de la passada tormenta 
el yris bello de paz

luçes serenas, venid y adorad.

LAVS DEO.

En Córdoba por el L. Francisco Antonio de Cea y Paniagua Presbytero.

Biblioteca Nacional. Madrid. (V/E)1308-42. (65-1 Kalenda.) "Hagan salua los Hombres". Métrica: las primeras coplas son de tipo similar a la antífona ("Salve Regina") y dentro de este tipo de poesía litúrgica se incluye el tropo y el motete. En general la rima es asonante. 


\section{VILLANCICOS QVE SE HAN DE CANTAR A SV MAGESTAD EN LA CAPILLA REAL, LA NOCHE DE REYES DE ESTE AÑO DE 1681.}

VILLANCICO III.

ESTRIVILLO

EN GALLEGO.

EScuyten atentos

Oa gayta Galega,

Que o Niño y ao[s] Reyes

A vn tempo festexa:

Escuyten.

1. Ay como suena, ya o Niño le alegra.

2. Ay como suena, ya o[s] Reyes celebra.

3. Ay como suena, y a o Celo se acerca.

4. Ay como suena, y a tudus cuntenta.

Ay como suena, mas ay como suena,

El tum turum tum de a gayta Galega.

\section{COPLAS.}

1. Ay como suena,

Que o Niño que nace

Oa gayta le aprace

De a gente Galega.

2. Ay como suena,

Que estay descalciño,

Como vn Galegiño

Que vene a la sega.

3. Ay como suena,

Que dorme ao sereno

En pallas, y feno

A vso de a terra.

4. Ay como suena,

Que o boy le acaricia,

Y como en Galicia

La cama estay cerca:

Ay como suena, mas ay como suena 
El tum turum tum de a gayta Galega.

1. Ay como suena,

Que o Niño meu centro,

Es Deus por adentro,

$\mathrm{Y}$ ù demo rebenta.

2. Ay como suena,

Que a edad se dispense

Y Obispo de Orense

Mis oxos le vean.

3. Ay como suena,

Que Obispo le fagu,

Sea de Santiagu,

Que tene mais renta.

4. Ay como suena,

Que o Niño le demus

Ser Conde de Lemus

Por mais Excelença.

Ay como suena, mas ay como suena,

$\mathrm{El}$ tu $[m]$ turum tum de a gayta Galega.

1. Ay como suena,

Que aprausos preuenen,

Pois tres Reyes venen

$\mathrm{Y}$ os guia ùa Estrela.

2. Ay como suena,

Que siguen ù Astro

$\mathrm{Y}$ os pes de alabastro

Ao Niño le besan,

3. Ay como suena,

Que o Niño que adoyro

Ofrecen en Oyro

Diuina riqueza.

4. Ay como suena,

Que o Rey afumado

Incensu le ha dado,

Que tray de Guinea.

Ay como suena, mas ay como suena,

El tum tuum tum de a gayta Galega. 
VILLANCICO IV.

ESTRIVILLO.

COraçones, que ardeis en la llama, Que enciende vn arpon,

Pues Amor, que dispara las flechas, Es fuego, y es Dios,

Adorad al Amor.

\section{COPLAS.}

1. Coraçones, que en tres pechos

Consagrais vn coraçon,

Pues Amor hizo de vn Astro

Ardiente flecha veloz,

Adorad al Amor.

2. Coraçones, que abrasados

Venerais blanco esplendor,

Pues amor forma de vn signo

Flamante Celeste arpon,

Adorad al Amor.

3. Coraçones, que en incendios,

Suspirais, tierno dolor,

Pues Amor llora en Estrellas

La dulce llama del Sol,

Adorad al Amor.

4. Coraçones, que en gemidos

Explicais penas mejor,

Pues Amor dize en sollozos

Lo que no puede la voz,

Adorad al Amor.

5. Coraçones, que en silencios

Escondeis fuego interior,

Pues Amor cubre de escarchas

La ardiente flecha veloz,

Adorad al Amor.

6. Coraçones, que en suspiros

Encendeis elado ardor,

Pues Amor tie $[\mathrm{m}]$ bla entre yelos,

Que imitan vuestra passion, 
Adorad al Amor.

7. Coraçones, que en alagos

Padeceis dulce rigor,

Pues Amor flecha vnas pajas,

Por herir con blando arpon,

Adorad al Amor.

8. Coraçones, que en finezas

Mereceis alto fauor,

Pues Amor muestra en ternuras,

Del querer fino, el blason,

Adorad al Amor.

9. Coraçones, que en afectos

engendrais nieue, y calor,

Pues Amor junta en congojas

De vn Etna, y nieue la vnion,

Adorad al Amor.

Biblioteca Nacional. Madrid. (V/E 91-26) "Escuyten atentos".

Métrica: versos de gaita gallega. No deja de ser un tipo similar en el rítmo a la muiñeira. Rima asonante, versos octosilábicos, propios del villancico. Hipermetría. 
VILLANCICOS, QVE SE HAN DE CANTAR

la noche de los reyes, en el real convento de nuestra señora de la merced, redempcion de cautivos de esta corte, este año de 1681.

SIENDO MAESTRO DE CAPILLA

de dicho convento el padre fray domingo ortiz de zarate.

EN MADRID. Año de 1681

\section{VILLANCICO V.}

\section{Estriuillo}

AL Portal curiosos,

Que ay mucho $\mathrm{q}[u e]$ ver en vn pensamie $[n]$ to.

Al Portal discretos,

Que el Misterio que en èl se celebra,

Publican los ecos.

Al Portal donde està

A todas luzes la gloria

De Tierra, y de Cielo;

Y pues viene el concepto nacido,

Cuydado al concepto,

Que ay mucho que ver en vn pensamiento.

\section{COPLAS}

Señores, quien es el Mundo,

Que no conoce à su Dueño,

Añadiendo de Cautiuo

Este eslabon à sus yerros?

Como es Argel la tierra,

Que el hombre habita,

Nadie estrañe que venga

Quien le redima.

Esclauo misero yaze,

En infame cautiuerio,

Y de el rescate, vno mismo

Es el Redemptor, y el precio.

Bien à su diligencia,

Puede fiarse

A la Merced aciertos, 
En el rescate.

Entre horrores tenebrosos,

El sol amanezca Regio,

Que à la luna despossea

De tanta noche de Imperio.

De la Luna el concepto,

Si no le apura.

El ingenio, es preciso

Quede à la Luna.

Nazca en buen hora, y humille

De aquel Tiranico Reyno

El vano soberuio erguido,

Sañudo erizado Cetro.

$\mathrm{Si}$ al nacer, es la muerte

Correlatiua,

Solo este Niño nace

Para dar vida.

Nazca, para dar salud,

A quien cautivo, y enfermo

Tiene aprisionada el Alma,

Y tiene doliente el Cuerpo.

Que le cure, y redima,

Tengan por cierto,

Vn Hijo de la Virgen

De los Remedios.

Nazca, y vnido, se explique

En tan Sacro Nacimiento,

Al concepto de nacer,

De redimir el concepto.

Y porque hasta el discurso

Tenga Misterio,

No se oluide el curioso

De el Euangelio.

Al Portal, \&C.

VILLANCICO VI. Gallego.

\section{Estriuillo}


TOdos os Galegos,

Que a Belên ven, ê vàn,

De Egrejas, os Cregos,

Das Ruas, os Legos,

Das Praças, os Cegos, que venen, que vàn,

Ay como bailaràn:

Bailaràn ligeiro

A son de ô pandeiro,

Con noso Barbeiro,

Con noso Sacristan:

Ay como bailaràn

A sua May fermosa,

Pura fresca rosa,

Que pariô gloriosa,

No tosco saguan:

Ay como bailaràn.

Andar, andar,

Correr, y bailar,

Que ô son me reitina

De la gaitiña,

Lo corpo todo,

Tange, me Bartolo,

$Y$ veràs, que assi trisco no poluo.

\section{COPLAS}

TAngeme Rugeiro,

Por las miñas bacas,

Que las teño fracas

Desque di en ligero.

Y al Dios verdadeiro,

Que nace Cordeiro,

Por todo el Otero

Le brincarei solo.

Tangueme Bartolo,

Y veràs, que assi trisco no poluo.

Por Españoleta

Tangueme ò Canario,

E qual campanario, 
Darei ua bolteta.

E nadie se meta

En fazerme treta,

Porque en la gambeta

Me entorte algun ollo.

Tangueme, \&C.

Tangueme à pavana,

Por la sua May bela,

que es May, ê Doncela,

$E$ fror da mañana.

Bailarê de gana,

Con Minga Romana,

Pois es nosa hermana,

Que assi yo me folgo.

Tangueme, \&C.

Tangueme ô Villano,

Que à bailar conbide,

Pues que Deus se mide,

Siendo Deus tan llano.

Que me dà la mano,

Que rico, y vfano

Dà Reyno me gano,

Perdendome todo.

Tangueme, \&C.

Tangueme à gayardas,

Que ê son de lo bueino,

Mijor que ô Rugeiro,

Mijor que as bacas.

Miñas alpargatas

Se fagan migajas,

Por ô Nenu, que en pajas

Tremiendo està todo.

Tangueme, \&C.

Tangueme as folias

De noso Barbero,

Aô son de ô pandeiro,

$\mathrm{Y}$ de as frautiyas.

Y las chirimias,

E mais panderiyas, 
E mais sonagiyas

De ò cascabel gordo.

Tangueme, \& c.

A compàs me tangue,

Que sun muy Mayestro,

Que ò Pastor de ô destro,

Tamben solfa sabe.

E muito suaue,

Ninguno sa alabe,

Que todo ô sabe

Qui el lo sabe todo.

Tangueme, \&C.

Tangueme ô gran Duque,

Que he ô son garridu,

Pro ô Deus que ha nacidu,

Que à miña alma cruge.

Todo Oteiro ruge,

Rugida que cruge,

$\mathrm{Y}$ el de mote fuge,

Y el Infierno todo.

Tangueme, \&C.

Biblioteca Nacional. Madrid (U. C . 128-67). "Al Portal curiosos".

Métrica: como se trata de ensalada de lenguas, hay varios metros, en especial el octosílabo con rima romanceada. Hipermetria. Versos de gaita gallega, propios de la literatura gallego-portuguesa de tipo popular. 


\section{LETRAS DE LOS VILLANCICOS QVE SE CANTARON LA NOCHE LA NOCHE DE NAVIDAD, EN LA SANTA IGLESIA CATHEDRAL DE LÉRIDA, ESTE \\ Año de 1681, \\ SIENDO MAESTRO DE CAPILLA EL RACIONERO \\ Iuan Barter. \\ DEDICADOS A LOS MVY ILVSTRES SEÑORES DEAN \\ y Cabildo de dicha Santa Iglesia.}

VILLANCICO VI.

EN GALLEGO.

ESTRIVILLO.

Escuyten atentos

oa gayta Galega,

que ao Niño, y ao[s] Reyes ${ }^{22}$

a un tempo festexa:

Escuyten.

1. Ay como suena,

y ao Niño le alegra.

2. Ay como suena

y ao[s] $]^{23}$ Reyes celebra.

3. Ay como suena

$\mathrm{y}$ ao Celo se acerca.

4. Ay como suena.

y a tudus contenta.

Ay como suena, mas ay como suena

el tum turum tum

de a gayta Galega.

\section{COPLAS}

1. Ay como suena, que ò Niño que nace, ò a Gayta le aprace de a gente Galega.

2. Ay como suena, que estay descalciño,

\footnotetext{
${ }^{22}$ En el original, ao Reyes.
}

${ }^{23}$ En el original, ao Reyes. 
como vn Galeguiño

que vene a la Sega.

3. Ay como suena

que a dorme ao sereno

en pallas, y feno

a vso de a terra.

4. Ay como suena

que ò Boy le acaricia,

y como en Galicia

la cama estay cerca.

Ay como suena, mas ay

como suena,

el tum turum tum

de a Gayta Galega.

1. Ay como suena,

$\mathrm{q}[u e]$ ò Niño meu centro

es Deu por adentro,

$\mathrm{y}$ ù Demo rebenta.

2. Ay como suena,

que a edad se dispense

y Obispo de Orense

mis ojos le vean.

3. Ay como suena,

que Obispo le fagu,

sea de Santiagu,

que tene mays renta.

4. Ay como suena,

que ò Niño le demus

ser Conde de Lemus .

por mais Excelença.

Ay como suena, mas ay

como suena,

el tum turum tum

de a Gayta Galega.

1. Ay como suena,

que aprausos prevene,

pois tres Reyes venen

y os guia ua Estrela.

2. Ay como suena, 
que siguen ù Astro,

y os pes de Alabastro

ao Niño le besan.

3. Ay como suena,

$\mathrm{q}[u e]$ o Niño que adoyro,

ofrecen en oyro

divina Riqueza.

4. Ay como suena,

que o Rey afumado,

incenso le ha dado,

que trai de Guineya.

Ay como suena, mas ay

como suena,

el tum turum tum

de a Gayta Galega.

\section{TERCER NOCTVRNO}

\section{VILLANCICO VII}

\section{INTRODVCCION}

1. El Sacristan, y, el Barbero

cantan en Belen motetes,

vno en Latines los dize,

y otro en Romance los buelve.

2. En infusion de Folias,

el Barbero dixo alegre,

valgame a doña Guitarra,

abogada del buen temple.

\section{ESTRIVILLO.}

1. Oygan latines del Sacris solemnis.

2. Y oygan al Barbero

que los interprete.

Sacrist. La materia parvam,

colacion faciebis.

Barb. Si yo rapo barbas,

tu rapas molletes.

Coro. Lindis mentis. 
Sacrist. Cum magis iratus

Herodes videbis.

Barb. Si Herodes rabiò,

que rabie, y rebiente.

Coro. Lindis mentis.

Sacrist. Lavabo mis manos

inter inocentes.

Barb. Pues que me faltava

a mi, si pudiesse

hazerles las barbas

a los inocentes.

Coro. Lindi mentis.

Sacrist. Vaya de fiesta Domine,

pues de Dios somos huespedes.

Barb. Aunque empeñe los bartulos,

le pienso dar vn Recipe.

1. Oygan latines del Sacris solemnis

2. Y oyga $[n]$ al Barbero $\mathrm{q}[u e]$ los interprete.

\section{COPLAS.}

Sacr. Quando el Niño està llorando

tace, tace, amicus, mens

Barb. Para que quiero yo tazas,

quando Dios haze pucheros?

Todos. Lindo, lindo, bueno, bueno.

Sacr. Rapaverunt en Belen

las barbas, oy, los Barberos.

Barb. Y tambien los Sacristanes,

donde ay cera, rapaverunt.

Todos. Lindo, \&.C.

Sacrist. De Torrente en via viber,

puramente amicus meus.

Barb. Para llegar a cazalla

vino de Torrente es bueno.

Coro. Lindo, \&C.

Sacrist. Iunto al Pesebre la Mula .

es mascula, mas que genus.

Barb. Si no la echan vn bocado

que mucho $\mathrm{q}[u e]$ masque el freno? 
Todos. Lindo, \&.C.

Sacrist. A vn Negro le mira el Buey,

et pescabis vultum meum.

Barb. Y huyendo del Buey, le dize,

con esse hueso a otro perro.

Todos. Lindo, \&. C.

Sacrist. Si Domino non cantabis,

non habebis partem mecum.

Barb. Pues soy yo Gallego acaso

para renegar de Meco?

Todos. Lindo, \&. C.

Sacrist. En el Portal la Mulilla

in Latine morietur.

Barb. Las Mulas de los Doctores

no se espantan de los muertos.

Todos. Lindo, \&.C.

Biblioteca Nacional. Madrid. R. $34985{ }^{14}$ Barbieri. "Escuyten atentos".

Métrica: gran variedad de metros, especialmente octosílabos, con rima asonante. 


\section{LETRAS DE LOS VILLANCICOS QVE SE CANTARON EN LA SANTA Iglesia Metropolitana, y Patriarchal de Sevilla. \\ En los Maytines de los Santos Reyes. ESTE AÑO DE MD.C.LXXXI.}

\section{VILLANCICO V}

\section{Introducion.}

Del dia al primer albor los vezinos de Belen van a dar el parabien al nacido Redemptor, y alas calçando en fervor entraron en el Portal, vn Tiple que era Zagal, y vn Baxo que era Pastor.

\section{Estrivillo.}

Atencion que porfian quien canta mejor:

Atencion que su pleyto le meten a vozes, de Tiples, y Baxos en dulce cancio[n]. Tip. Aqui de las Aves que canta $[n]$ suaves. baxo. Aqui de los vientos que suenan violentos.

tiple. Aqui de las selvas, los ecos frondosos.

baxo. Aqui de los montes, los ecos ruidosos.

tiple. Aqui de las fuentes el blando ruido.

baxo. Aqui de los mares el rondo sonido.

tiple. Aqui de los Tiples.

baxo. Aqui de los Baxos.

Tod. Ya te escuchamos. 
tiple. Pues todos acordes dezid, que â Dios Hombre.

baxo. Pues todos vnidos dezid, que a Dios Niño.

tiple. Mejor le celebran.

baxo. Mejor le han loado.

tiple. Los Tiples.

baxo. Los Baxos.

tiple. En Selvas.

baxo. En Vientos.

tiple. En Aves.

baxo. En Montes.

tiple. En Fuentes.

baxo. En Mares.

todo. En selvas, en vientos, en aves

en montes, en fuentes, en mares.

\section{COPLAS}

tiple. Al Niño Dios que se humilla

darle diges mi fee trata,

y assi mi voz que es de plata,

le ofrezco por campanilla.

2. Deste dige en la ofrenda

se ve en la Missa,

porque al Santus le tocan

las campanillas.

baxo. Mi campana aunq[ue] es de yerro

suena como nadie sabe,

pues puede mi voz suave

servir al Buey de zenzerro.

tiple. Gilguerillo lisonjero,

trinando ace $[n]$ tos velozes,

sabrà el Niño con mis vozes

gorgearse como vn Gilguero.

2. Gilguerillo encarnado

nace el inmenso,

y oy el nido compone

de pajas, y heno.

baxo. Yo con mi voz de carraca 
cantando entre aquestas peñas

le enseñare como ay dueñas

a parlar mas que vna hurraca.

tiple. Ofreciendo a vn Dios humano

vno, y otro gorgorito

sera mì voz pajarito

que el Niño tenga en la mano.

2. Pajarito, y Dios hombre

todo es del caso

que assi pintan a vn Niño

quando es milagro.

baxo. Porque humano duerma el Verbo

a ofrecerle me hacomodo ${ }^{24}$

tiernos arrullos, al modo

[...].

\section{VILLANCICO VI.}

Gallego.

Estrivillo.

Tuturutu Gaitero,

tuturutu tuiron,

que $\sin$ a gaitiña

vaileremos oy:

facendo o son,

con as sonagiñas,

con as castanetiñas,

con as tejoliñas;

con as campanetiñas:

Tuturutu Gaitero,

tuturutu tuiron,

que sin a gaitiña

vaileremos oy.

\section{COPLAS.}

1. En cama palliza,

miro a meu Señor, 
que va que de istrelas,

es el seu gergon;

Tuturutu Gaitero

tuturutu tuiron,

magamosla la palla,

non la seguen non,

Tuturutu Gaitero,

tuturutu tuiron,

facendo o son,

que sin a gaitiña

vailaremos oy.

2. De la neve o vento,

por ser tegeidor

le face al Portal

rico pavellon;

Tuturutu Gaitero,

tuturutu tuiron,

de brucato azul

le tiene millor,

Tuturutu Gaitero,

tuturutu tuiron,

facendo o son,

que sin a gaitiña

vaileremos oy.

3. Por vosos validos

Corderiño sois,

e de oir as quexas,

moriendome estoy:

Tuturutu Gaitero,

tuturutu tuiron,

ay de as ovejiñas,

que no os ten amor,

Tuturutu Gaitero,

tuturutu tuiron,

facendo o son,

que sin a gaitiña

vailaremos oy.

\footnotetext{
${ }^{24}$ En el original, me ha comodo.
} 
4. Por $\mathrm{q}[u e]$ fror nacedes,

que es finura en vos

queiren os Judios

cortarvos en fror:

Tuturutu Gaitero,

tuturutu tuiron;

o quien revanara

tanto narigon:

Tutururu Gaitero,

tuturutu tuiron,

facendo o son,

que sin a gaitiña

vailaremos oy.

Biblioteca Nacional. Madrid. (V/E.1189) 172. 1, Palau. "Del dia al primer albor".

Métrica: versos en gallego de gaita gallega, con ritmo de muiñeira, invitando al canto y al baile, como sucedía en la lírica gallego-portuguesa. Versos octosílabos. rima asonante. 


\section{VILLANCICOS QVE SE HAN DE CANTAR EN LOS MAYTINES DE LOS REYES, EN LA SANTA IGLESIA METROPOLITANA}

Cesar -Augustana, en su Santo, Angelico, y Apostolico Templo de el PILAR, este Año de M.DC.LXXXI.

Siendo Maestro de Capilla DIEGO de CASEDA.

En Çaragoça, por los herederos de AGVSTIN VERGES. En la Calle de la Cuchilleria.

\section{VILLANCICO IV. \\ INTRODVCION.}

ROmpiendo al tiempo las leyes

vestidas con mil primores,

celebrar quieren las flores

la Fiesta de los tres Reyes.

ESTRIVILLO.

Vaya de aliño, vaya de ensayo,

$\mathrm{q}[u e]$ esta Noche el Enero se ha buelto Mayo:

Miren que espera

la Primavera,

sin que amenaze

la escarcha que haze,

pues del Sol que nos nace,

al mas benigno Rayo,

todo el Enero se convierte en Mayo.

\section{COPLAS.}

Reyna del Iardin, con guarda

de Espinas, saliò la Rosa,

y al Niño Rey le ofreciò

de Espinas vna Corona.

De Dios Hombre la Rosa

gala sacando,

su buen gusto le imita

en lo encarnado.

Muy candida la Açucena

fragante Estrella lo adora,

y al ver la Madre de el Niño 
su candidez pura assombra.

Inclinò la cabeça

de muy corrida,

y anda sin ser hipocrita

cuelli-torcida.

Mirando por todas partes

alli vn Clavel se desoja

y jurando Rey al Niño

de su Purpura le adorna.

El Clavel por los labios

de el Niño assoma,

y su Carmin le vino

a pedir de boca.

Muy preciado de Real

entrò vn Jazmin con su Aroma,

y por verlo gateando

despreciaron su Persona.

Arrimando al Pesebre

trepò hasta el Cielo;

porque tiene, aunque humilde

lindos alientos.

Entrò haziendo los Alcaldes

la Vara de Iesè hermosa,

que en los agrados de Dios

puede medirse con todas.

Si esta Flor tiene Vara

serà muy rica,

y tendrà los Aromas

muy de Iusticia.

Al son de mil campanillas

entrò vna Flor muy zelosa,

$y$ de vèr vn Hombre Dios

muchas maravillas forma.

De esta Flor se guardaron

las flores cuerdas,

porque tiene gran fama

de enredadera.

Con visos de mal Francès

cardeno vn Lirio se postra, 
y de su Passional Niño

le pronostica memorias.

Por su aspecto le elige

para Prelado,

y por esso vestido

và de morado.

Amante de si el Narcisso

entrar se quiso de gorra,

mas con Dios no tiene entrada,

el que de si se enamora.

Al Narcisso por vano

le despidieron,

y a buscarse fue triste

la flor del verro.

\section{VILLANCICO V.}

\section{ESTRIVILLO.}

Diafana, La Region mas luciente, Rafagas, Esparciendo dexaron,

Nacares, Que del frio se encienden,

Victimas, Que su fuego han elado, si en la noche mas rigida

de las luzes preambulo:

Timida, A sus glorias se encoge,

Aspera, El retiro ha buscado, y en sus Carambanos,

Aspera, y Timida,

ofrece en su Trafago,

Nacares, Vidimas,

quando en el ayre, Canticos,

la Esfera inquietan, Diafanas

en los accentos, Musicos,

de sus sonoras Rafagas.

\section{COPLAS.}

Nitidos, Oy los Astros madrugan,

Tremulos, En su obscuro letargo, 
Palidos, En sustos les aviva,

Paramos, Del sueño en sus espacios, pues descubren mirandolos,

Nítidos, Tremulos, Palidos, Paramos.

Quando los Astros

con la luz no le dexan,

vida al Letargo,

Rigido, Es el Sol apacible,

Candido, Favorece en sus rayos,

Miseros, Que del frio se encogen,

Asperos, Que su luz abrasaron,

Pues vne sin escandalo.

Rigido, Candido, Misero, Asperos,

Quando los Rayos

con su incendido conducen

los que cegaron,

Purpuras, Al Oriente presentan,

Arabes, Conducen holocaustos,

Delficos, A esplendores divinos,

Talamos, Que han vnido lo humano, pues se hallan en su Valago,

Purpuras, Arabes, Delficos, Talamos,

Quando el Milagro

del Oirente señala

los holocaustos.

Lagrimas, De la Aurora despojos,

Liquidas, El Tesoro mostraron,

Termino, De los ojos no visto,

Animo, Descubierto del llanto

pues quedan en su transito

Lagrimas, Liquidas, Termino, Animo

Quando elevado

trae el Alva por Estrella

lo que fue llanto.

VILLANCICO VI.

ESTRIVILLO. 
OYd, esperad, mirad, y atended, en presentes al Niño Rey, a las fieras de tres en tres, que seis Profetas le vàn a ofrecer. Oìd, esperad, atended, de Sanson, de Ionàs, de David, oìd la Vallena, el Gigante, las zorras, oìd, oìd, esperad, de Moyses, de Balan, y Eliseo, los Osos, la Burra, y Bezerro:

Esperad, atended, en presentes al Niño Rey, a las fieras de tres en tres.

\section{COPLAS.}

David. David atado con onda, truxo al Gigante Golias, que aunq[ue] hizo frente a la piedra, con el castigo hizo iga.

Sanson. Sanson presentò a la hermosa lumbre, que entre pajas mira, con la lumbre y con las pajas, vnas Zorras encendidas.

Ionàs. Ionàs truxo vna Ballena, al que es Puerto de la vida: no digo bien, que a Ionàs la Vallena le traìa.

Todos. Que linda Trinca, la Vallena, las Zorras, Golias, 1. Si el gigante aqui busca tan alta empressa, para andar por los pies de este Niño, el Gigante no tiene Cabeça. 2. No profanen las Zorras este sagrado, que es vn $\mathrm{Te}[m]$ plo con fruto, y co[n] flores, y ellas buscan Hermitas con ramos.

3. La Vallena, aunque justos los talles haze, 
para estar junto a vn Niño tan bello, la Vallena no tiene buen talle.

Los 3. Ved los caminos.

1. El Gigante por tierra ha venido

2. La Vallena ha venido por agua.

3. Y las Zorras vinieron por vino.

Todos. Ved los caminos.

Eliseo, El Profeta de Vetel,

truxo xon su calva lisa,

vnos Osos enseñança,

de vnos Niños sin doctrina.

Moyses, Moyses ofreciò vn Bezerro, por quien las Aras mas dignas

tributa aqui adoracion;

lo que alla fue Idolatria.

Balan, Balan vna Burra que habla, le diò al Niño, que no chista, que habla la simpleça, quando calla la sabiduria.

Todos. Que linda zumba, el Bezerro, los Osos, la Burra.

1. Son opuestos los Osos contra los Calvos, que a los Osos de su terciopelo, estos les llevan vn tercïopelado.

2. El Bezerro se vaya, que oy el Cordero, en desierto portal, representa, la Columna y Manà del desierto.

3. La Borrica no adore solo la planta, que le dà en sus trofeos al Niño el Domingo de Ramos la Palma. Los Tres, Ved lo que biscan,

1. El Bezerro del Buey las dos puntas,

2. Vn bocado de Mula los Osos,

3. $Y$ vn mendrugo de paja la Burra.

Los tres, Ved lo que buscan. 
VILLANCICO VII.

ESTRIVILLO.

VEnid apriessa Zagales

a la Comedia de amor, que en Belen representa

del mundo el Autor.

Venid a la comedia,

que en vna Cruz pondràn

el Titulo de ella.

Venid a la Comedia,

que oy echan los Angeles la Loa

bolando por el ayre en apariencias,

y yà la tierra, y Cielo

por Musica conciertan,

que sean oy los Angeles los Tiples,

el hombre el baxo,

y Dios el alto sea.

Venid a la Comedia,

que oy que de Dios la piedad

paga del hombre la deuda,

de Dios la Iusticia assiste

para cobrar a la puerta:

Venid a la Comedia.

COPLAS.

En Oriente sonando

Clarin de plata,

con Estrella empeçaron tres Reyes

vna jornada.

A Belen se encaminan

los tres, y es llano,

si es a Dios la jornada, que seràn

buenos sus passos.

Galan haze, y del alma, siente desdenes

Dios Niño, y que es sin duda de todos

quien mejor siente. 
Apuntando a los Reyes

el pie les dava,

y en vez de versos flechas, sus ojos

les apuntavan.

Tan gracioso el Rey Negro

fue, que imaginan

si se avrà revestido, por ser pez

oy de Escamillas.

De MARIA la gracia

Flor pura, y vella,

todos oyen con gusto, que es Rosa

quien representa.

Aunque otras vezes hizo

papel de zelos,

el Santo IOSEPH haze las barbas

oy como vn Viejo.

Haze Alcalde con Vara,

que el tierno Infante,

le importò contra Herodes, oy tener

el Padre Alcalde.

Aunque suela de Herodes

traza ingeniosa,

esta vez con el Niño, le sale

mal su tramoya.

El Toreador, oy quieren

que entremès sea,

y el Buey que era Iudio, fue el Toro

de la manteta.

Sin papel a la Mula

oy han dexado,

porque han visto que es bestia, y no mas

que de su establo.

De esta comedia ha sido

Belen teatro,

donde vè todo el mundo, que su bien

yà està entablado. 
Biblioteca Nacional. Madrid. (V/E.1189-15) "Rompiendo al tiempo las leyes".

Métrica: polimetría, rima en general asonante y a veces libre. Versos octosílabos, y aparece el endecasílabo "antiguo" de gaita gallega, con acentos en quinta y décima. 


\section{VILLANCICOS QVE SE HAN DE CANTAR EN LA REAL CAPILLA DE LA ENCARNACION, LA NOCHE DE NAVIDAD DESTE AÑO DE MDCLXXXII. PVESTOS EN MVSICA POR EL LIC. DON FRANCISCO SANZ, MAESTRO}

De dicha Real Capilla.

\section{VILLANCICO VIII.}

\section{Introduccion}

DOs Gallegos de buen tomo Oy à Belèn han llegado.

Mas no les dieron posada, con tener tan buenos quartos. Lleuan guantes de poluillo En sus pies de vara en ancho, Que esta gente siempre trae Los zapatos en las manos.

Con Bato, y Bràs, que los siguen, En vn Portalejo entraron: $\mathrm{Y}$ vieron el Cielo abierto Con hallar solo vn Establo. Luego que el Infante vieron, Con tal primor festejaron, Que con cantar solo à vno, Tambien cantauan à quatro.

\section{Estriuillo}

AL Meu Garridiño,

Mais branco, que armiño,

Minino, minina dos ollos do Pay,

Ay como le arrulla,

Le canta, y le mece

Le aduerme, y le acalla

La sua bella Nay.

Tod. Vamos todos à adoralle, A ofrecelle, y festexalle, Que aunque de cuitas ò Valle Le teña en vn Pesebriño, 
Por miña fee, que e mi Deus

o Minino;

Por miña vida, que e Fillo do Pay.

1. Ay como le arrulla,

Le canta, y le mece,

Le aduerme, y le acalla

La sua bella Nay.

1. Dime, Menga, tu què ofreces?

2. Yo huas nuezes, que si e Pan,

Ao Minino le veràn

Con vn pan como huas nuezes.

Tod. Calcaras para

Presentiño tal,

$Y$ què buena pro

Que à Minino farà!

2. Y tu, Catuxiña bella,

Què le ofreces Cortesana?

1. Eu le levo hua Mançana,

Porque èl se morre por ella.

Tod. Què linda, è què buena

Es à Mançaniña

De la nossa terra!

3. Tu Bràs, que leuas tamben?

4. Vn Cordeiro e mi rescate,

Que aquesto del cordellate

Con el frio dize ben.

1. Y vos, Bato, dezid, què

Ao Minino heis de leuar.

3. Eu non teño mais que dar

Si no es que el allento dè.

Tod. O què lindo en bona feè!

3. Pois que el empeño me acosa,

Y non teño que dar nada,

Vaya pois hua tonada

A vsança da terra nossa.

\section{Tonada}

1. COn la cantiña

De nossa terra 
Fagase raxas

A xente Galega.

1. Pois que non teño

Mais que ofrecer,

Boltiñas à pares

Eu queiro facer.

Tod. O què lixeira!

Con la cantiña, \&C.

COPLAS

COn lo Encarnado

Meu Chocotiño,

Ay como campa,

En o campo paxizo.

Aunque a tela

Puso sua Nay,

Elloro que encubre

Lle deu seu Pay.

Tod. O què pulidu!

Con lo Encarnado, \&C.

2. Dènle, si chora,

Branco alimento,

Que a vn Rey se acalla,

Si lle dàn o peyto.

Pero Minina

La sua Nay

O candido nectar

Do Ceo lle trae.

Tod. O què portento!

Dènle, si chora, \&C.

3. E o Portaliño

Preta alimaña,

Fogo de Deus

En a Mula castaña.

Pois castañera

La Muliña e,

O son para o bayle

Nos quere fazer.

Tod. Ay que acompaña, 
E o portaliño, \&C.

4. Quiso o Toriño

Tanto à Minguiña,

Que la sua cabeça

Lla deu para silla.

E yo admirado,

Quedo de la ver

Señora oy de silla.

Y descalça ayer.

Tod. Porque es garridiña,

Quiso o Toriño, \&C.

5. Quitòle as bragas

A Antón Pintado,

Con que quedò

Meu Toriño bragado.

Mais o Minino

Non lle faz mal,

Que tein o baqueyro

Por su delantal.

Tod. Ola coydado,

Quitòle as bragas, \&C.

6. Si en musiquiña

Son boas falsas,

Entre a Mula

En nossa tonada.

Aunque o Touro

E muy bozal,

Os puntos que coxe,

Os abre en canal.

Tod. No guarda pausa,

Si en musiquiña, \&c.

7. Diz quein entende

Desta mateyra,

Que sua cantiña

Es todo carreras.

Si vay picado,

Fogo en èl,

Que enristra corcheas,

Que no ay mas que ver. 
Tod. Què ben solfea!

Diz quein entende, $\& C$.

8. Vitor Minino,

Vitor mea terra,

Leuese o vitor

A xente Galega.

Si la cantiña

Gusto vos dà,

A muy Boas Noytes

Todos vos quedad.

Tod. Que fin dà a festa

Vitor Minino, \&C.

F I N.

Biblioteca Nacional. Madrid (V/E.91-56) "Dos Gallegos de buen tomo".

Métrica: polimetria. Rima asonante, a veces el verso es libre, el poeta se desliza a través de la inspiración e irrumpe con un cantarcillo popular ajeno al poeta y sigue la mudanza propia de los Cancioneros. 


\section{VILLANCICOS QVE SE CANTARON EN LA CAPILLA REAL DE LAS SEÑORAS DESCALZAS, LA NOCHE DE NAVIDAD DE 1682 Y LA DE LOS SANTOS REYES DE 1683.}

\section{VILLANCICO I.}

\section{Estriuillo.}

HA del Monte?

Ha del Valle?

Pastores los de Belen,

Mirad, que en vuestras Campañas

Oy vn prodigio se veè;

Que es Cristal, y esparce Rayos, Que es Fuego, y Nieue tambien; Que es Flor, y nace en Diziembre, Que es Deidad, y humano es, Que es Niño, siendo Gigante, Y està humilde, siendo Rey.

Venid, pues yà, que este Enigma Pastores descifrareis, Ayudando vuestra voz Nuestras vozes, que han de ser Clarines del Orbe todo, Diziendo vna, y otra vez: Venid al Enigma, Pastores, Venid, Corred al prodigio, Zagales, corred, $Y$ vereis, que el Enigma es vn Niño, Que oy ha nacido en Belen.

\section{COPLAS.}

Yo digo, que el Niño es Nieue

En su hermosa candidez;

Pero lo que es el ser Sol,

De justicia lo ha de ser;

Pues en el se vee

De Diuina Aurora

Luzir, y nacer. 
Yo asseguro, que es Deidad,

Viendo tanta luz en èl,

Aunque muestra el ser humano

Padeciendo en el nacer:

Pues en êl se vee,

Naciendo à morir,

Penar al nacer.

Yo, que es Gigante, no dudo

En el valor, y el poder;

Mas se conoce que es Niño,

En que siente al padecer:

Pues en el se vee,

Del frio, y del riesgo,

Llorar, y temer.

Yo digo, que el Niño es flor,

Porque es Diuino Clauel,

Cuya purpura ha enseñado,

Que à mas de ser Flor, es Rey,

Pues en èl se vee

Triunfante, y feliz

Reynar, y nacer.

VILLANCICO II.

INTRODVCION.

LLeguen todos esta noche

à la Corte de Belen,

y veràn dar parabienes

al recien nacido Rey.

De diferentes Naciones

le buscan alli, porque

solo aqui las diferencias

le pueden parecer bien.

Como en varias lenguas hablan

con quien los ha de entender,

esta noche al Portal hazen

vna Torre de de Babel.

Estrivillo. 
Varios Sugetos le buscan, $\mathrm{y}$ andan en buscarle bien, y quando el Palacio encuentran, luego en el Portal le vèn.

Entren y nadie se admire viendo que ay bestias con èl, que es pension de los Palacios dar à tales de comer Ola, Gitanos

Pastores, y Negros venid à Belen, que à este Rey obedecen los Orbes, y Cielos tambien.

Ola, y ola que al verlo desnudo, y pobre, y siendo tan bestia el Buey, le quiere dar vn coleto, aunque le cueste la piel. Ola, y ola, que entren aprissa lleguen à ver, que naciò para todos su Alteza por hazernos merced.

Ola, y ola, que.

\section{COPLAS.}

Vn sencillo Vizcayno

besando à la Mula el pie,

dezia, juras à Dios,

quiero conocer à vsted.

Ola, y ola, que.

Entrò vn Domine Manchego, y viendo à vn Negro despues, diò en dezir, hagamos migas, que yà no falta sarten. Ola, y ola, que. Mas tierno que vna xalea, feito de manteca, è mel, deretido al Sol, que fà, 
dixo al Niño vn Portuguès.

Le, le, por la miña fe, que vos he de amar.

è vos he de querer;

le, le, por la miña fe.

A vn ciego de nacimiento

dixo la Pastora Inès:

Oye vsted, yo me conte $[n]$ to

solo, con que mire vsted.

Ola, y ola, que.

Rodeado de muchachos

vn Tutili Mundi fue,

y en nombrando al Rey Herodes,

ninguno quedò con èl.

Ola, y ola, que:

Vn Montañes dixo al Niño,

si cauallos quiere el Rey,

yo le ofrezco seis castaños,

que plantados tengo diez.

Ola, \&C.

Vn Filósofo admirado,

dixo, hablando con el Buey,

no he visto mayor bonete

en la Escuela de Belen!

Ola, \&C.

Pidiò vn Medico la Mula,

y no se la diò Ioseph,

porque no sirva al morir,

la que ha servido al nacer.

Ola, \&C.

Vn culto, que entrò al Portal,

sin conocerle se fue,

porque hablaua tan obscuro,

que no le pudieron ver.

Ola, \&C.

Entrò vn Letrado muy feo,

salvo mejor parecer

y dixo: El Rey, que ha nacido

nos darà la mejor Ley. 
Ola, \&C.

Como diziendo: Aqui ay Parto,

y Olandas son menester,

al hilo de media noche,

se entrò vn hilo Portuguès.

Ola, \&C.

Ioseph, que estaua en su oficio,

aunque no era Ginouès,

andaua buscando traza

de dar vn assiento al Rey.

Ola, \&C.

\section{VILLANCICO III.}

INTRODVCION .

A Belen con regozijo, van à ver al Niño Amor

muchos sugetos à pares, $\mathrm{y}$ algunos de dos en dos.

Como han visto, que ha nacido el mas celebre Doctor, van à buscar su remedio, como por amor de Dios.

Sus tachas malas, è buenas alegres celebran oy.

y se saliò cada vno del mismo modo que entrò.

Estriuillo.

Afuera, afuera, plaça, plaça, que à Belen esta noche vienen con gracia, vn Doctor, y vn valiente con vn Barbero, y con vn Vizcayno viene vn Gallego: Entren, no entren, tenganse adentro, 
que viene vn coxo,

y vn vandolero

à alegrar el Dios Niño

con gran contento,

vaya de gusto, de fiesta vaya,

que esta noche es de fiesta,

mañana es Pasqua.

\section{COPLAS.}

1. Vn Gallego entrò, y tenia

por sobrenombre calçones,

el Buey se encarò con èl,

y le quitò el sobrenombre:

Si Domingo se llama,

el Buey le dixo,

allà và esse recado,

feo Dominguillo.

2. Entrò vn Vandolero fuerte,

y en su defensa traìa

vna charpa de Doctores,

en lugar de carabinas:

Quando el valiente quiera

matar à vn hombre,

si vn Doctor le dispara,

Dios le perdone.

3. Vn Coxo, Don Cortesias, baylando con su muleta, entrò, y aqueste entre todos vino con mas reverencia: Vaya fuera al instante, porque es bien claro, que si viene Coxuelo, sin duda es Diablo.

4. Buscando el Portal venia, con grandes ansias vn Tuerto, y aqueste fue Peregrino;

pues vino al Portal derecho:

Para Dios son los Tuertos

de mucho agrado, 
pues por buscarle siempre

vàn desojados.

5. Llorando à Dios sus pecados, vn recien casado vino,

que en ser casado traìa

insignia de arrepentido:

De Dios Niño el casado

sacò gran premio,

porque dixo este es Martyr,

vayase al Cielo.

6. Vn Vizcayno, y la Mula, vna question porfiavan, y vno muy sabiondo dixo, que la Mula no iba errada:

Y en pago del apoyo

le diò la Mula,

acertando al Vyzcayno,

con la erradura.

7. Con vna cierta Zagala, vn Valenton tuuo vn tope, desafilòla, y la dixo,

que al campo salga, si es hombre:

Con aquese Valiente

nadie se meta,

porque à fè, que es mas ho $[m]$ bre, que no su Abuela.

8. Al Niño dixo vn Barbero:

Señor, socorre à este pobre, que està perdido mi oficio con la baxa de vigotes:

Essa baxa, su oficio

ha ocasionado,

pues los mas, con sus hierros

tiene abrasados.

9. Mirando al Buey, y la Mula, dixo vn Pastor Inocente, que eran bellos animales, no quitando lo presente:

Y del dicho vn Mulato, 
solo, picòse,

porque solo se pica,

quien ajos come.

10. Los postreros que vinieron,

fueron Moros, y Gitanos,

y aunque vinieron oy juntos

son como Perros, y Gatos,

es cosa clara,

pues araña el Gitano,

y el Moro rabia.

11. Viendose ahogados de gente,

barrieron todo el Portal,

el Buey con los de delante,

la Mula con los de atràs:

Por remate de Fiesta,

no estuuo malo,

pues lleuò cada vno

su sepan quantos.

Biblioteca Nacional. Madrid (V.E $79 \mathrm{n}^{05}$ ). "Ha del Monte? “.

Métrica: polimetria, a veces como si se tratara de una melodía litánica. En el siglo XVII aparecen

formas métricas de letrilla o de romance con estribillo. Son las dos formas del villancico cuando encierra el deseo de satirizar, ya que la sátira cansa menos. 


\section{LETRAS DE LOS VILLANCICOS QVE SE HAN DE CANTAR EN LOS MAITINES del Nacimiento de N. S. Iesu Christo en la Santa Iglesia de Toledo, Primada de las Españas \\ Este Año de 1682.}

Siendo en ella Racionero, y Maestro de Capilla Don Pedro de Ardavaz.

\section{Noct. VILLANCICO I. Introducion.}

ARma, arma, Guerra, guer[r]a,

$\mathrm{q}[u e]$ tyranizado del mundo el dominio, que en duras prisiones la naturaleza

la culpa la tiene, y a fuerça de Armas, à redimirla la Gracia se apresta; y à su Conquista vn Principe viene en la Naue mas pura, y mas vella, y en el Puerto de Santa Maria, Diuino, y Humano su Amor toma tierra.

Estriuillo.

Al arma, al arma, que puesta en defensa, la culpa se alista, y el orbe se altera. Ha de la saña del tiempo, ha de las furias inquietas del ayre, que à nuestras Costas Principe estrangero llega, arma, guerra. Ha del sueño, ha del silencio, ha de la quietud serena; hazed salva à vuestro Rey, montes, prados, valles, selvas, al arma, al arma, que la gracia, y la culpa se dan la batalla: toca la marcha, toca la marcha, à embestir, suene en el viento el rumor de las espadas; à ellos, a ellos, arma, arma, el Pifano suene, resuenen las Caxas, la culpa vencida haze retirada; 
à recoger, a recoger, puesto $\mathrm{q}[u e]$ la gracia

alegre, y festiua la Victoria canta.

COPLAS

Aloxado està en Belen

aquel Caudillo que intenta

por la libertad del mundo,

perder la vida en la empressa.

$Y$ entre dos vagages,

à las inclemencias

del frio, y del hielo,

vn Portal le alverga.

Ya vna herida peligrosa

la Circuncision les cuesta,

muchos riesgos le amenazan,

quando tan sangriento empieça.

$\mathrm{Y}$ aun dizen que a Egypto,

que huya serà fuerça,

que anda el Enemigo

pujante, y muy cerca.

General lo diga Herodes,

que con las Armas opuestas

ha degolladole vn Tercio

de la Infanteria tierna.

Mas si àl acaudilla

à la culpa, es fuerça

sus primeras iras

pruebe la inocencia.

Tres Reyes, como auxiliares, manda alistar, a vna Estrella

de cuya voz las Espias

contrarias oy se desmientan.

Vsando el sabido

ardid en la guerra

de fingir temores,

por lograr proezas

Ya sus victoriosas Armas

siente la culpa, pues ciega,

mas que la Cruz de su espada, 
la espada de su Cruz tiembla.

Que mucho si es arma

la Cruz tan seuera,

que en Dios que la ciñe,

su filo ensangrienta.

Del mas hondo Calaboço

ha de romper las cadenas,

y la voz de su Victoria

sonarà en toda la tierra.

Lleuando en despojos

quando al Padre buelva,

de libres Esclauos,

legiones inmensas.

$\mathrm{Al}$ arma, \&C.

\section{VILLANCICO II.}

\section{Introducion.}

DEspues que la Noche buena dos guapos de Andaluzia se holgaron à puros tragos, porque aguados no lo estilan: A consultar ciertas dudas, que en sus conciencias tenian sobre el Nacimiento, en busca de vn Fraile Lego caminan.

\section{Estriu.}

Guap. 1. Vaya pues de disputa, Vaya Leg. Digan todas sus dudas, Digan.

Guap. 2. Oigan pues la consulta, Oigan.

Leg. Pidan por essas vocas, Pidan.

Guap. 1. Deo gracias, Padre de llalma, su Tauernidad mos diga, sabe Tología? Lego. Assi supiera yo dezir Missa.

Guap.2. Es el caso, que esse mandria de mi camarada, afirma 
cien cosas denfecultosas, que no estàn en la Cartilla.

Guap. 1. Su Tauernidad persona

tan leída, y escreuida, mos darà lengua?. Lego. Bien puedo, que la tengo muy cumplida mas primero han de dezirme sai traen las conciencias limpias.

Guap. 2. Ellas bien regadas vienen, no sè si estaràn barridas.

Tod. Pues vaya, pues oigo, pues mire, pues diga.

\section{COPLAS.}

Guap. 1. Por què en tierra de Christianos no naciò Dios, si queria possada esta noche, aviendo tantas buenas en Seuilla? Leg. A estudiar voy la duda con toda prissa, que en la bodega tengo mi Libreria.

Guap. 2. Tiene razon mi compadre, que fue gran vellaqueria, y lo que en Belen hizieron, no lo hizieran en Turquia.

Leg. Los Pastores suplieron sus demasias, que con Dios Niño hizieron muy buenas migas.

Guap.1. Por què en ibierno, y de noche pario la Virgen Maria el Niño, siendo al contrario en Santa Isabel su Prima? Leg. Porque como el Sol era lo que nacìa, quando ay Sol, es lo mesmo noche, que dia.

Guap.2. Si es Fuente de Vida Dios, 
$\mathrm{y}$ nace en Belen, queria

saber yo como en Madrid

anda otra agua de la Vida?

Leg. De las cosas del agua

nada me diga,

pues la conozco solo,

para servirla.

Guap. 1. Boto al gijo, Padre mio,

que esto me huele à mentira,

que yo no he visto buenagua,

si no es el agua Bendita.

Leg. Que de la Vida es agua,

todos afirman,

si no del que la toma,

del que la embia.

Guap. 2. Y a nuestro Portal bolviendo,

su Tauernidad mos diga

si eran el Buey, y la Mula

marido, y muger por dicha.

Leg. Sobre si eran casados

no ay cosa escrita;

mas si el Buey no lo era,

lo parecia.

Vaya pues \&C.

VILLANCICO III. Introducion.

1. DOmingo da Veiga,

vamos al Portal.

2. Pues que Toribiño,

ay que ver alà?

1. Que pariò la Virxen

vn velu Zagal.

2. Y es essa la Virxen

de la Soledad?

1. Hombre, si.

2. En mi vida

avia oìdu tal.

1. Comu de essas cosas 
si viues verais.

2. Hombre non me engañes, dime la verdad.

1. Verais al Chiquitu, su Madre inda mais,

el vno reir,

y el otro llurar;

y por alegrarle

con algun solaz,

vamos los Galegus;

pois vamos en paz.

Ay $\mathrm{q}[u e]$ bien suena, mas ay $\mathrm{q}[u e]$ bien suena

la tonadiña da Gaita Galega;

con el adufe, pandero, y sonajas,

los Galeguiños hagamonos raxas

ante el Chiquillo $\mathrm{q}[u e]$ nace en las pajas,

que està llorando, por ver si le alegra

la tonadiña da gaita Galega:

Tenga cuidado cada Galeguiño

de ir preuenido, para dar al Niño

vna embaxada con vn regaliño,

$\mathrm{q}[u e]$ esse es el modo con $\mathrm{q}[u e]$ mejor suena

la tonadiña da Gaita Galega.

\section{COPLAS.}

1. Yo, Niño mio, porq[ue] estos Pastores con frores, y natas serviros intentan, dos jamonciños os traigo galegos, regalo $\mathrm{q}[u e]$ honra, y mais aprouecha.

Ay q[ue] bien suena, mais ay $\mathrm{q}[u e]$ bien suena la tonadiña da gaita Galega.

2. Yo para hazeros pañales vs traigo de lie $[n] c ̧ u$ texiga en mia casa esta peza que por traeros regalo del vso, del vso le traigo, y ta $[m]$ bie $[n]$ de la rueca Ay como suena, \&C.

3. De Riabadavia esta bota de vino llena traia, mas non està llena, $\mathrm{q}[u e]$ en el camiñu, el dimoño es vellaco, 
yo pecador, y mamemè la media.

Ay como suena, \&C.

4. Yo de sardiñas vos traigo vha carga

que el mismo Reye podia comerlas,

mas si estuvieren vn tanto saladas,

ya teneis bota, cuidado con ela.

Ay como suena, \&C.

5. Lo que le pidu, Señor, assi viua,

es que mos libre à la gente galega

del fiero Herodes persigue Inoce $[n]$ tes

$\mathrm{q}[u e]$ ay tantos de ellus en la miña terra.

Ay como suena, \&C.

6. Pero si diere en querer degolarnos,

hazed, Señor, $\mathrm{q}[u e]$ nos pongan guriyas,

$\mathrm{q}[u e]$ las guriyas $\mathrm{ta}[\mathrm{m}]$ bien mos deguellan.

Ay como suena, \&C.

7. Y à la Señora Maria su Madre,

$\mathrm{q}[u e]$ en su piadosa memoria mos te $[n] \mathrm{ga}$;

y si mudare à Egypto su ropa,

que nus avise vendremos por ela.

Ay como suena, \&C.

8. Y co[n] aquesto, Dios mio, nos vamos,

si es q[ue] nos dais para hazerlo licencia,

que bolveremos, si Dios es servido,

al veraniño que es tiempo da siega

Ay como suena, \&.C.

VILLANCICO III. Estriuillo.

AL llanto mas tierno,

que el Alva engendrò,

al dulce gemido,

a la tierna voz,

Aves, suspension,

flores, suspension,

fuentes, suspensión,

Aves, flores, y fuentes,

en acorde vnion,

con el Alva imiten 
el llanto del Sol

\section{Recitatiuo.}

Esse llanto, Señor, que desatado de la prision del pecho, al hielo de mi culpa conjelado, y al dulce ardor de vuestro amor deshecho, en liquidos raudales mi coraçon anegan sus cristales. Mas ay piadoso Cielo, que Amor recien nacido temblando està del hielo, del hielo de mi olvido; no augmente su desvelo mi pecho endurecido: antes en dolor tanto, eco sea mi llanto de su llanto. Y tu lobrega impia noche fria, que en vez de luzes vellas, con querellas sepulcro dàs al dia, en raudales desata tus estrellas, rompa el Zafiro su candor brillante, $y$ en dulces metros la venida cante del Sol resplandeciente, sea su voz aurora de su Oriente. Mas ay que si llorando nace su Luz hermosa, todos deben llorar con eco blando: y essa Campaña de jazmín, y rosa, que en dulce melodia de Paxaros preuino su armonia, su dulçura entonada, en Cromaticos blandos desmayada, en suaue concento equivoque la musica en lamento; los suspiros seràn los Sustenidos, y seràn los Trinados los gemidos, 
repitiendo, y cantando:

selvas llorad, q[ue] nace Amor llora[ $n]$ do.

Mas si fue del nacer pension precisa

en los que nacen á morir viuiendo,

el llanto, sea en vos risa,

ya que naceis à ser Vida muriendo;

y solo en mal tan fuerte

llore yo, $\mathrm{q}[u e]$ he nacido à daros muerte

con penetrante herida,

mas no vos q[ue] naceis a darme vida.

Aves, fuentes, y flores,

ved que llora de amor el Dios de amores:

pero de que me espanto,

si el idioma de Amor es solo el 1la[n]to.

\section{VILLANCICO V. Introducion.}

VNa Tonadilla nueua,

airosa, rica, Indiana,

al Portal llega festiua

de Lima muy bien limada.

Atiendanla, que es donosa,

veràn por lo sazonada,

que del otro mundo vienen

las Tonadillas con alma.

\section{Estriuillo.}

Oigan, escuchen,

que suena, que encanta,

y al Niño celebra

con gusto, y con gala;

que si es como vn Oro,

tambien la Tonada

oy viene de Indias,

y es como vna Plata.

Mire, mire,

que retumba, tumba la Cara,

que se quema el Sol queridito

de mi lindo Amor; 
para lo Enamorado,

querido Muchacho:

Cataña, Regalo,

la Ruda;

vès que vn Liston encarnado

de mi lindo Amor

de mi coraçon.

\section{COPLAS}

Mi Niño en vn Pesebre

la Cuna encuentra

entre dos animales,

Iesvs que pena!

Mire, mire, \&C.

Obediente vna Mula,

y vn Buey contemplo,

por estàr junto al Grano,

que estàn contentos.

Mire, mire.

Los Pastores alegres,

felizes llegan

à mirar como el Cielo

ha dado en tierra,

Mire, mire \&C.

Viendo al Niño que llora,

juzgan discretos,

como Carne ha tomado,

que haze pucheros.

Mire, mire \&C.

Antes que le adoraran,

primero encuentran

con Maria, y tuvieron

muy buena Estrella.

Tiritando en la paja

viendole han dicho,

fuego de Dios en ella,

que lindo abrigo!

Mire, mire, \&C.

Quando à sus pies humildes 
se hallan postrados,

no se han visto Pastores

mas ensalçados?

Mire, mire \&C.

Le adoraron sintiendo

como està pobre,

para aver de ofrecerle,

no tener dones.

Mire, mire \&C.

Bolvieronse, y el gozo

que recibieron,

como en Dios le buscaron,

no lo perdieron.

Mire, mire \&C.

Biblioteca Nacional. Madrid (VE.128- 68- (229. 2). Palau 337760. "Arma, arma, guerra, guerra”. Métrica: versos octosílabos, rima asonante. Polimetría propia del Barroco. 


\section{VILLANCICOS QVE SE CANTARON EN LA CAPILLA REAL DE LAS SEÑORAS DESCALZAS LA NOCHE DE NAVIDAD DE 1682 Y LA DE LOS SANTOS REYES DE 1683.}

\section{VILLANCICO VI.}

\section{Gallego.}

\section{INTRODVCION.}

1. Oyes Rampriega.

2. Que quieres Turibio?

1. Hombre, que à Belen te vengas cunmigo.

2. Pus que ay en Belen?

1. En vn portaliño

Iose està, la Virgen, tres Reyes, y el Chicu.

2. Do al diabro si fuere.

1. Pues por que non imus?

2. Porque donde ay Reyes, ay muchos perigros: suelen ir aquellos hombres amarillos, de calças muy largos, de bragas muy chicos, y de vna palada matan vn Corito. 1. Si dones lleuamos, entrar serà fixu.

\section{Estriuillo.}

Vamos los Galeguiños, vamos à ver el Niñu, y aunque Reyes non semos, dones tambien lleuemos para que le alegremos, vamos a ver al Niñu, tocanos tu Rampriega, 
el tono que en la Siega

con la Gaita Galega

suena con tanto aliñu,

vamos à ver el Niñu.

\section{COPLAS.}

1. Si los Reyes por Reyes

tan guapos han venidu,

nosotros aunque astrosos

semos fidalgos limpios:

vamos à ver el Niñu.

2. Si ellos por autorencia

Camellus train, yo digu,

que no faltan Camellus

entre los que venimus:

vamos, $\& \mathrm{C}$.

3. Si ellos papando moscas tras la Estrella han venidu, nosotros tras la Gaita vamos papando vino: vamos \&c.

4. Si ellus porque Coronas tran, vienen tan garridus, el Cura en miña terra tiene tambien ò mismo: vamos $\&$ C.

5. Si ellos con Negros campan, no semos aqui armiñus, que solo nos exceden en vn palmo de hozicu: vamos, \&C.

6. Si ellos à Dios traen oro, acà se le pedimos,

ellus piensan que es probe, pero yo sè que es ricu:

vamos \&C.

7. Si ellos le train incienso, mas regalo es el mio, porque quando ellos humo, 
le traigo yo churizos:

vamos, \&C.

8. Ellos de mirra amarga

le train vn botecillu,

cierto que es vn regalo,

que en mi vida le he visto:

vamos, \&c.

9. Pero yo de manteca

le traygo sesi bollitos,

que para hazer papilla,

es cosa de prodigio:

vamos, \&C.

10. Yo vn xamoncillo traygo

de los màs bacuriños,

que en Belen aurà pocos,

que es tierra de Iudios:

vamos, \&C.

11. Y assi los nuestros dones, que le han de ser afirmo, si no tan misteriosos, inda mais de seruicio: vamos, \&C.

12. Y aunque yo reconozco son sus dones Diuinos, que echen en el puchero todo lo que han traìdo: vamos, \&C.

\section{VILLANCICO VII.}

\section{XACARA.}

\section{Estriuillo.}

VAya vna Xacara nueua, de gusto, donayre, y garbo, que al buen ayre, y al Diziembre, ha de ser dos vezes pasmo; oyganme con atencion el tono y letra a lo guapo. 
1. Oyganme,

2. Digalo.

1. Mirenlo

2. Cantelo

1. La historia de vn cierto amigo de muy valiente preciado, $y$ vna noche en vn Portal, le vimos estar temblando. Prestenme el oìdo vn poco, les bolverè decontado con los reditos del gusto, si me escuchan mejorado. Vaya vna Xacara nueua, que ha de ser dos vezes pasmo; bueno, lindo, brauo.

\section{COPLAS.}

Amante de vn Mundo amargo, oy dulzes lagrimas vierte, y aunque no tiene la culpa, pues èl se lo quiso, questele. No desperdicie las perlas con que la tierra enriqueze; que si le texen Corona, seràn ssu Espinas fertiles. Bien aya, Zagal hermoso, quien à los suyos parece, venciò Serpientes su Madre; y èl es en la cuna vn Hercules. Herodes, Medico insano, que de la salud se ofende, manda que tome el azero; guardese el Niño del recipe. Para adquirir rel renombre de piadoso, y de valiente, leuantar puede al caido, solo con que diga, dueleme. Quando la obeja perdida à su rebaño bolviere, 
echese la carga al ombro,

y si le pesàre, pesele.

$\mathrm{Y}$ al fin, si truxeren dones

al visitarle los Reyes

al Valiente tres Coronas,

dexen algo los huespedes.

Siguiendo la voz de vn Astro

tres sabios de Arabia vienen,

lleguen al Portal que entonces

les dirà la Estrella hetele.

El diablo està que rebienta

[...] ver que el mundo remedie;

mas que rabie, que nosotros

nos reìmos de sus pleguetes.

[...] Rediles, y Cabañas

[...] ofrecen varios presentes,

los Zajales corderitos,

y las Gitanillas treuedes:

Danças, y vayles al Niño

los Pastores le preuienen;

todo es regozijo, y fiesta,

pues Dios ha nacido huelguense.

Victor el Niño, y su Madre,

victor los Reyes mil vezes,

$\mathrm{y}$ victor la xacarila,

aqui se remata, dexese.

Biblioteca Nacional. Madrid. VE/ 79-1 -205. "Oyes Rampriega".

Métrica: polimetría, versos octosílabos propios del villancico. Pasajes decriptivos en lengua gallega, comparaciones, imitación de una lengua que no se domina. Rima asonante. 


\section{VILLANCICOS QVE SE CANTARON EN LA IGLESIA MAYOR, COLEGIAL INSIGNE DE SANTA MARIA DE CALATAYVD, LA NOCHE DE NAVIDAD, DE ESTE ANNO DE M.DC.LXXXIII. \\ SIENDO MAESTRO DE CAPILLA MANVEL CASSAXVS. DEDICADOS A SV MVY ILLVSTRE CABILDO.}

\section{SEGVNDO NOCTVRNO.}

VILLANCICO IIII.

Estrivillo.

SAbiendo Menga, que Dios en todas partes està, a todas partes acude, por ver a Dios, y ninguno lo dude, que es como todas, amiga de andar; $y$ antes que en Belen con los Reyes le adore, a todo correr de vno en otro lugar, rodeando le busca, y hallarle pretende por aqui, por alli, por acà, por allà.

\section{COPLAS.}

Menga, que seguir desea la ley de su natural, por andar, como muger, se fue a Belen por andar. Por aqui, por alli, por acà, por alla. Dizen, que està de su Aldea Belen dos leguas no mas, que cerca està de bolverse, si dizen, que cerca està. 
Si repara, que en Belen poco que mirar avrà, que mirar, ay a Dios hombre, mire si ay mas que mirar. En ser, de andar tan amiga, no ay yerro, y si acaso le ay, a dorar viene su yerro, con ir a Dios adorar. Viendo, que Dios con su llanto laba la mancha de Adan, alabar la piedad quiere, de quien le viene a lauar. Algunos diges le ofrece, por si el Niño Celestial, en jugar su mal divierte, y haze su llanto enjugar. No le lleva otros presentes, aunque quisiera al Zagal lleuar de todo, que Menga es fina a todo llevar. Menga, y los Reyes, sus pechos al Niño en tributo dàn, lo demas es lo de menos, si es el oro lo de-mas.

\section{VILLANCICO V.}

\section{Introduccion.}

COmo es tan fria la noche vailando van los Gallegos, por si haçe al son de la Gaita, alguna mudanza el tiempo. Que esten de Gayta, no es estraño. que es la Gayta sie $[m]$ pre en ellos, de su Musica, y su gozo, la causa, y el Instrumento.

\section{ESTRIVILLO.}


Galegos baylarines Folijay,

folijay cantando ay, ay,

dicendo do son de à Gayta,

que ò fillo de Deus Santo

parece Galeguiño de Santiago

pois veñe de sua terra sin çapatus

folijay cantando,

$\mathrm{q}[u e]$ veñe a lasegado, ò trigo sagrado

folijay cantando,

que antes que, ò trigo

a palla à segado,

folijay Galegos

folijay cantando,

$\mathrm{q}[$ ue $]$ para, ò Corpus segara os granos,

folijay, \&C.

dicendo ào son de à Gayta,

que ò fillo de Deus Santo

parece Galeguiño de Santiago

pois veñe de sua terra sin çapatus.

COPLAS.

Nino fermoso,

pois sois pobreciño

colled as perlas,

$\mathrm{y}$ os tornareis rico.

Zumbe, è retumbe

à gayta Domiños,

que eu vaylarey

mentras chora mi Nino.

Chorai meu Nino,

que de vosas perlas,

ricos zartales

faran as Galegas.

Zumbe, è retumbe, \&C.

Con Galeguiños

teneis pairentesco,

pois voso primo

Santiago, è Galego.

Zumbe, è retumbe, \&C. 
Como nas pallas

as perlas deirrama,

se van mios ollos

deitras de à palla.

Biblioteca Nacional. Madrid (V/E 1308-5) "Sabiendo Menga, que Dios".

Métrica: versos de gaita gallega, "Zumbe, è retumbe, \&.C. Versos de arte menor, con rima asonante. Ensalada de lenguas, propia de los Cancioneros y del Renacimiento. 


\section{VILLANCICOS QVE SE HAN DE CANTAR EN LA REAL CAPILLA DE SV MAGESTAD \\ LA NOCHE DE NAVIDAD \\ DESTE AÑO DE 1683.}

\section{VILLANCICO VI.}

\section{ESTRIVILLO.}

EN la ca $[m]$ paña espaciosa del ayre

Dos instrumentos aplauden al Dios

De los exercitos Emperador;

$\mathrm{Y}$ en acorde vnion

Rompen el agua, cruzan el viento,

Suavizan la tierra, $\operatorname{co}[n]$ blando rumor

La voz del Clarin,

El son del Tambor;

Oygan à los dos,

Que en salva sonora,

Con voz que enamora,

Saludan la Aurora

De quien nace el Sol.

$\mathrm{Y}$ en acorde vnion,

Si esfuerça el Clarin,

Anima el Tambor;

Ya se oye la lid

Del Clarin;

Ya se escuha el son

Del Tambor;

Y en el lidiar,

$\mathrm{Y}$ al competir

Haze mas festin

El tin tin, tiririn

Del dulze Clarin,

Es festin mejor

El tan, taran tan, tambalan.

COPLAS. 
EL Tambor publica humilde

Que al nacer el Niño Amor

El hombre trasciende

Por transformacion

En alas amantes

A ser como Dios;

$\mathrm{Y}$ en su aclamacion

Resuena en la tierra

El tan, taran, tan, tambalan

Del suave Tambor.

El Clarin que oye la Musica

De vn ardiente Serafin

Entona armonioso

Con metro sutil

Canciones suabes

Al Sabio Eloyn:

$\mathrm{Y}$ con mas festin

Resuena en el Cielo

El tin, tin, tiririn

Del dulze Clarin.

El Tambor festivo canta

Que al nacer el Criador

a la criatura

Rompiò la prision

Del yerro atrevido

Que ingrata labrò.

$Y$ con mas primor

Se escucha en el centro

El tan, taran, tan, tambalan

Del suave Tambor.

El Clarin repite armonico

Que vn robusto Rey feliz

Nos diò la Esforzada

Gloriosa Iudith,

Que hollò de Holofernes

La altiva cerviz:

Y en aplausos mil

Saviza los ayres

El tin, tin, tiririn 
Del dulze Clarin.

El Tambor ruidoso explica,

Que al nacer la Paz, naciò

El Fuerte Guerrero

Que el buelo cortó

Al siempre enemigo

Sobervio Aquilon:

Y con blanda voz

Sus glorias venera

El tan, taran, tan, tanbalan

Del suave Tambor.

El Clarin dize, que al Barbaro

Mahometano ha de rendir

El Sol que amanece,

Pisando en la lid

$\mathrm{Su}$ altivo Turbante

Su Luna infeliz:

$\mathrm{Y}$ al verle abatir

Asusta el Oriente

El tin, tin, tiririn,

Del dulze Clarin.

El Tambor publica triunfos

De este Heroyco Emperador, Que viene del Austro

A dar mas blason

A la Austria, en quien Reyna

$\mathrm{La} \mathrm{Fe}$, y el valor;

$\mathrm{Y}$ en gloria mayor

Repite su Imperio

El tan, taran, tan, tambalan.

Del suabe Tambor.

El Clarin dize, que al Perfido,

Nuestra España ha de oprimir,

Y Australes Pendones

Verà en su Confin

Belen en quien tuvo

Segundo Zafir,

Pues deste Adalid

Al Turco estremece 
El tin, tin, tiririn

Del Dulze Clarin.

\section{VILLANCICO VII.}

GALLEGO.

\section{INTRODVCION.}

DEscalços vnos Gallegos

Entre nieve à Dios se acercan

Al modo que allà Moyses

Se acercava entre vna hoguera.

Con Los çapatos en cinta

Vienen desde Pontevedra,

Y lo que de pies gastaron

Se lo han ahorrado de suelas.

Viendo que la tierra al Niño

Le trata con inclemencia,

Cantando al son de la Gayta,

Le dizen desta manera.

\section{ESTRIVILLO.}

HAy Niño meu

Si te proba la terra

Chegate acà

Con la xente Galega,

Chégate acà,

Y oyrais como suena

$\mathrm{V}$ fabordon de a gaitiña que alegra,

Chegate acà,

Dareyte manteca,

Chegate acà,

Dareite tuciño,

Chegate acà,

Dareite turrejas,

Chegate acà,

Y oyrais como suena

$\mathrm{V}$ fabordon de a gaitiña que alegra.

Retumbe à gaitiña 
Que ào Niño festeja,

Retumbe, que o Niño

Durmido se queyda,

Retumbe a gayitiña

Fazendole festa:

Retumbe diziendo

Aò Niño en suas Penas

Hay Niño meu

Si te proba la terra,

Chegate acà

Con la xente Galega,

Chegate acà,

Y oyrais como suena

$\mathrm{V}$ fabordo $[n]$ de a gaitiña que alegra.

\section{COPLAS.}

O Fillo de Deus

Que nayce en Xudea,

Con moytos rigores

Le proba la terra.

$\mathrm{O}$ Seno de ù Pae

Yam no le caienta,

Y eladu de frio

Chorando se queyxa.

Vas lagrimas suas,

Pareceyn Estrelas

Que caen sobre ò mundo

De ò Celo que tembra.

Aò mundo reparten

Con muyta riqueza,

Santiagu uas conchas,

Y ò Niño uas perlas.

Hay Niño meu

Si te proba la terra

Chegate acà

Con la xente Galega,

Chegate acà,

Y oyrais como suena

$\mathrm{V}$ fabordo $[n]$ de à gaytiña que alegra. 
Suos Llantos os causa

El furto de ua breva,

Que foy golosina

De la primer fembra.

Entunces ua serpe

Non temia Eua,

$\mathrm{Y}$ aora de as ratas

Se espantan as Euas:

$\mathrm{O}$ à serpe maldita

A tudos infeita,

Y hasta os Galegos

Morden la culebra.

O Niñu por estu

Padece as tristezas,

Y solu Galicia

Diverte suas penas.

Hay Niño meu, \&C.

Vas pallas, y feno

Va cama le cercan,

Como si ò Niño

Galego nacera.

De ò trigu que naze

Vas pallas son señas,

$\mathrm{Y}$ foy terra virgen

A donde se sembra.

O grano Divinu!

Ya esperu que crezca,

Porque para o Corpus

Tengamos ua sega.

Cubertu de à neue

$\mathrm{Si}$ ascarcha non cesa

No habray en Galicia

Queyn teña cosecha.

Hay Niño meu.\&C.

\section{LAVS DEO}

Biblioteca Nacional. Madrid, V/E. 130115. "EN la ca[m]paña espaciosa del ayre". 
Métrica: muy variada, ensalada de lenguas, ríma interna y en la mayoría de los casos asonante, propia del villancico y del romance. 


\section{VILLANCICOS QVE SE CANTARON EN LA S. IGLESIA CATEDRAL de la ciudad de Malaga, en los Maytines del Nacimiento de Christo Señor nuestro, este año de 1683 \\ Puestos en Musica por Don Alonso Torizes, Racionero, y Maestro de Capilla de dicha Santa Iglesia.}

VILLANCICO VIII. Gallego

Estribillo

EV bulirê, bulirê, buliria, eu bulirê por ò Rei de Galiza.

Ay Mariquiña, tocai â cantiña. Ay, ay, ay, folixai, folixai aprissiña, que ù bulirei, bulirê buliria, que ù bulirê por ò Rey de Galiza.

\section{COPLAS}

1. O Soleciño que ardente tirita, ê a Luna que ispeijo se mira, por miña fe $\mathrm{q}[u e]$ me chevan la vida. 2. A bela faz co as lluzes diviñas, touda de frores, ê campo, ê miña, por miña fe, \&C.

3. En suos ollos valentes se lidan, ha acendo fronte azuçeñas limpas. por miña fe, \&C.

4. Son suas cellas, ê hermousas meu xilas arcous que as pazes de o mundo confirman, por miña fe, \&C.

5. Roixos crabeles sua boca refiña[ $n]$ pois en os lasbios ay boa partida, por miña fe, \&C.

6. Teine sua boca de dentes a piña en caida vño de o ceo as indas, por miña fe, \&C. 
7. Duos armiños saon porlo pollidas porque a ñeve suas maos retiña, por miña fe, \&C.

8. Nace en a palla dourada a Espiga e para ô Corpus la sega se aprica, por miña fe, \&C.

9. Si a co $[m]$ praceirle o homo se incliña de sua terra arroixe as espiñas.

Eu bulirê. \&C.

L A V S D E O.

En Málaga, por Mateo Lopez Hidalgo, Impressor de su Ilustrissima.

Biblioteca Nacional. Madrid (V/E. 91-14). "EV bulirê, bulirê, buliria" 329-1 Palau, 367527. Métrica: Versos de gaita gallega. 


\section{VILLANCICOS QVE SE HAN DE CANTAR EN LA REAL CAPILLA DE LAS SEÑORAS DESCALZAS, LA NOCHE DE NAVIDAD ESTE AÑO DE 1683. Y LA NOCHE DE REYES DE 1684. \\ SIENDO MAESTRO DE DICHA REAL CAPILLA \\ EL LICENCIADO DON MATIAS IVAN VEANA. \\ EN MADRID: Por Antonio de Zafra, Criado de su Magestad.}

XACARA.

VILLANCICO IX.

ESTRIVILLO.

ELa, ola, mas vaya ela,

Que va de xacarilla,

Vamos, y venga:

Ela, ola, mas ela,

Vaya.

Si es la xacarandilla, caranda,

Ela.

Diganos como empieça,

Vaya.

Mire que ya nos cansa,

Ola.

Es xacara, ò historia?

Vaya:

Diga, pues, de que trata?

Ela, ola, mas vaya ela;

Acabemos con ella,

Vaya.

Que es de vn guapo del hampa.

Ela.

Que và de xacarilla

Muy de la heria:

Ola, ela, mas vaya,

Que es la primera noche

Que sale a plaza:

Ola, mas vaya, ela,

Ninguno me replique, 
Quedito, tenga:

Oyganla, pues que la empiezo,

Con las mismisimas señas

Que trae el comun estilo

De los abate que truena:

Ela, ola, mas vaya ela,

Que es de vn Niño la Historia

De Noche-Buena.

COPLAS.

ES para oy seor compadre?

Vamos aprisa, aya flema:

Bravo ru $[m]$ bo; que me place:

Erase, pues, lo que se era.

Famosa xacara diga,

Ya me entie $[n] \operatorname{de}[n]$, buena es essa;

Somos, ò no somos, ala:

Al caso, y vamos con ella.

Erase, pues, ò que lindo,

En vna noche morena,

Bla $[n]$ ca, y muy bla $[n]$ ca, en la misma

Del mismo modo que quenta.

Naciò el Xijo de Dios, pues,

De Maria por mas señas:

Es posible lo que hablo,

Valiente, y Niño de Perlas.

Por vida de, bueno es esso,

Aora, y muy aora, en la mesma

Al fresco ha nacido, y llora:

No sino el Alva, y Estrellas.

Y el Mundo todo le teme,

Muy de respeto: en pajuelas,

No se duerme, es vn perdido,

Entre animales: son bestias.

Boto al Sol, que en vn Portal,

En Belèn, ya se me acuerda,

La tiende mejor que dize,

Ni mas, ni menos, atiendan,

Que de amor, echando Bervos 
baxo del Cielo à la Tierra.

Oyganme, pues, que derrama

Aljofar menudo: es buena,

Tanto q[ue] el sol: todo es luzes,

$Y$ valen mas lo que cuestan:

En fin como xablo en bulla,

Los Pastores le presentan

Xijo de Dios que de cosas!

No ay mas gusto, brava fiesta,

Rosquillas, como vnas flores:

Pabos, como vnas almendras:

Mantequillas, como vn ambar,

Gallinas, no sino yemas:

Huevos frescos, y muy frescos:

Empanadillas Inglessas

El Zefiro, le retoza;

El Portal, Sala de Audiencia:

El Buey, le calienta al Niño;

La Mula, en todo se ceba:

No es tonto, es bravo bonete;

No es maliciosa, es Gallega;

Los Angeles tienen alas,

Bolaberum, y ya empiezan:

El Gloria diezen, no es mucho,

Cantan, pues, en las Esferas:

Para quando es el sentido,

Lo que me gusta me alegra.

Madre de Dios, y que frio!

Ya naciò el Sol, como yela:

No me escuchan: no se canse,

Dexelo de essa manera:

Amor mio, Santas Pasquas,

Buenas noches: à Dios Reyna.

\section{VILLANCICO X.}

De La Adoracion.

ESTRIVILLO. 
$A L$ vèr que Dios llora

De amor por el Hombre:

Los Riscos, los Balles,

Los Prados, las Flores,

Le adoran, le ofrecen,

Le rinden conformes.

Los Riscos,

Los candidos Narcisos,

Los Balles,

Los líquidos Cristales

Los Prados,

Odoríficos nardos,

Las Flores,

Ambares en olores.

Le adoran,

Con purpura las rosas.

Le ofrecen,

El Murize en claveles.

Le rinden,

Placidos carmesies.

Conformes,

Bellissimos colores.

En suabe suspension, dizen

acordes,

Que llora el Dios de amores por

el Hombre;

El que causa tu llanto se está

inmobil.

COPLAS.

LOs candidos Narcisos

Que fragantes descogen

La nieve de sus hojas,

Y el oro $\mathrm{q}[u e]$ atesora $[n]$ sus primores,

Cultos le ofrecen

En gratas oblaciones;

Y el que causa su llanto

Se està inmobil.

Los liquidos cristales 
Que en raudales velozes,

La esmeralda enriquecen

Con perlas $\mathrm{q}[u e]$ producen qua $[n]$ do corren,

Cultos le ofrece $[n], \& C$.

Los inclitos aromas

Del nardo le componen,

Al mas diuino Apolo

Presagios mas felizes de su no $[m]$ bre:

Cultos le ofrecen, \&c.

Los ambares Sabeos,

Que en matices, y olores,

Claveles, y jazmines

Sacrificios inspira $[n]$ a sus Soles:

Cultos le ofrecen, \&C.

La purpura en las rosas

Enciende sus botones,

Siendo pensil la cuna

De la flor mas fragante de las flores:

Cultos le ofrecen, \&C.

El Murize encarnado

Dedica esmaltes nobles

A la deidad $\mathrm{q}[u e]$ adora

Por Rey mas soberano de los Soles:

Cultos le ofrecen, \&C.

Los placidos rubies

Anuncio son, y vozes,

Ecos que amor embia

Herido co[n] la pena $\mathrm{q}[u e]$ los ro $[m]$ pe:

Cultos le ofrecen, \&C.

Los vnicos matices

Esmaltan sus colores

Con variedad hermosa,

$\mathrm{Y}$ en adorarle siempre estàn conformes:

Cultos le ofrecen

En gratas oblaciones,

Y el que causa su llanto

Se està inmobil. 
Biblioteca Nacional. Madrid. (V.E.79-5) “Ela, ola, mas vaya ela”.210-8.

Métrica: versos octosilábicos, rima asonante, polimetría. ¿Hasta qué punto se bailaban las piezas? Los villancicos tenían un componente escénico, eran una representación y se vendían por toda la ciudad como un cantar de ciego. 


\section{LETRAS DE LOS VILLANCICOS, QVE SE HAN DE CANTAR EN LOS \\ MAYTINES de la Natiuidad de N. Señor Iesu Christo, en la insigne Colegial de N. \\ Señor S. Salvador de Seuilla, este año de 1685. \\ Siendo Maestro de Capilla de dicha Colegial el Lic. D. Miguel Matheo de Dallo y Lana. \\ En Seuilla, por Tomás López de Haro, en las siete Rebueltas.}

\section{VILLANCICO VIII.}

Gallego. Estriuillo.

Eu bulirè, bulirè, buliria, eu bulirè por ó Rey de Galiza.

Ay Mariquiña, tocai a gaitiña,

ay, ay, ay,

folijay folijay aprisiña,

$\mathrm{q}[u e]$ eu bulirè por ò Rey de Galiza.

Coplas.

O Soleciño que ardente tirita,

è a Luna bela $\mathrm{q}[u e]$ ispeijo se mira,

por miña fè $\mathrm{q}[u e]$ me cheban la vida.

A bela faz co [...] Diuiñas,

touda de frores, è [...]:

[...] \&C.

del Sol, y [...] se $[\ldots]$

pues al co[n]ter $[\ldots]$ azuceñas limpas

rie el Alua, y c.

Ay Diuino [...] hermosas mexillas

que a su $[\ldots]$ de o mu[ $n]$ do co[n]firman:

Yo oyjos craueles sua boca resiña,

pois en los labios ay boa partida:

por miña fe, \&C.

Tiene sua boca de dentes a piña,

en cada vño de o ceo as indas:

por miha fè, \&C.

Suos armiños saon por lo pollydas,

porque a ñeue suas maos retiña 
por miña fè, \&C.

[...]

[...]

è para o Corpus la sega se [...]

por miña fe, \&C.

$\mathrm{Si}$ a compraceirle o homo se incliña

de sua terra arroixe as espiñas:

por miña fe, \&C.

Estriuillo.

1. POrque derramais perlas

dulcissimo amor?

2. Porque en vn portalillo me veo

temblando de frio un $\mathrm{Sa}[n]$ Saluador

1. Para enjugar las lagrimas tiernas

dale Templu, y casa Christieno a tu Dios.

\section{COPLAS.}

LLorais de veros sin Templo?

Llorad mi Niño, y mi Dios;

pero no, que en vn portal

estais en San Saluador.

Si en vn Portal derribado

sin adorno, y sin primor,

allà en Belen os hallasteis,

del mismo modo estais oy.

Aqui si, que se celebra

con debida proporcion

vuestro dichoso natal

como ello mismo passò.

Pero como tu Christiano

consientes assi a tu amor, quando por ti su Deidad

los altos cielos dexò?

No sin Templo Niño mio,

no sin Templo, no Señor,

que desde oy los caudales

de Seuilla vuestros son.

Maria en vn portalejo! 
y Ioseph sin obrador

Iesus sin Templo, y sossiegan!

pobre de ti pecador.

F I N.

Biblioteca Nacional. Madrid. (VC.88). "Eu bulirè, bulirè, buliria".

Métrica: muy variada, versos heptasilábos y octosílabos. Rima asonante. 


\section{LETRAS DE LOS VILLANCICOS, QUE SE CANTARON EN LA SANTA Iglesia Metropolitana, y Patriarchal de Seuilla, en los Maytines de la Venida de los Santos Reyes, este año de 1685.}

\section{VILLANCICO I.}

\section{Introducion.}

LA Naturaleza humana, aun tiernamente lamenta con triste voz, desabrigos, que á Dios causa la inclemencia. De tres Purpuras esmalta Obsequios, que reuerencia en el de tres Magestades que se postran à vna Alteza: $Y$ en el lamento que exclama todo su yerro compendia, con que á la atencion preuinen oy segunda vez sus quexas.

\section{Estriuillo.}

Oíd montes, valles, selvas, oíd como se quexa.

1. Ven, ven, esperado Bien, llega, llega desseada Prenda, que la Naturaleza, triste, cautiua, sola y presa, gime, llora, suspira, y pena. Todos. Oid como se quexa. 1. Ven, que te aguarda, ven, que te espera en la lobréga noche de sus penas la misera infeliz Naturaleza.

Su voz ha penetrado las esferas, pues rompiendo las nieblas, $\mathrm{co}[\mathrm{m}]$ padecida el Alba bierte perlas. Pues bueluase alegria la tristeza, 
y en salvas festiuas,

alegres, risueñas,

mares, Cielos, vientos, selvas,

serenen, alumbren, gorgeen, florezcan,

del agua, del fuego, del ayre, y la tierra,

perlas, luces, aues, fieras,

$\mathrm{y}$ vniendo sus primores,

sus estruendos publiquen à los Orbes,

que ya llega

el desseado bien que el Orbe espera.

Coplas.

YA de la noche triste

huyeron las tinieblas,

restituyendo al dia

las luces viuas de las sombras muertas:

Demosle la norabuena

á la Naturaleza,

montes, valles, troncos, fieras,

pues tanto bien alcança,

$\mathrm{q}[u e]$ vé ya posseida su esperança.

Yà de Sabà encaminan

hasta Belen las huellas

Magestades sus Cetros

a ser alfombra del que el Orbe impera.

Demosle la norabuena

à la Naturaleza,

Signos, Astros, Rayos, Etnas,

pues arde en pecho que ama

de luz Estrella, que á mejor los llama.

Ya cada qual vn Fenix

buscando vida eterna,

de sus afectos haze,

Pyra no de holocausto, sino hoguera.

Demosle la norabuena

à la Naturaleza.

vozes, ansias, llantos, penas,

pues vemos adorada

la q[ue $]$ esta[ $n]$ do abatida en Dios se hallò ensalçada. 
Ya fecunda en el oro,

similitudes Regias,

el que anciano à sus plantas

dora con su esplendor las canas que platèa.

Demosle la norabuena

á la Naturaleza,

hombres, aves, fuentes, selvas,

pues queda enriquecida

la que alvergò su ser en el Portal que anida.

Ya Sacerdote grande

en el Incîenso alienta

los humos de que hombre

victima en sacrificio serà ofre $[n]$ da.

Demosle la norabuena

á la Naturaleza,

plantas, flores, riscos, peñas,

de que antigua dolencia

viene cuerda à sanarnos la innocencia.

Ya de mortal la Myrra

le simboliza apenas

quando en tiernos sollozos

por albricias derrama finas perlas.

Demosle la norabuena

à la Natrualeza,

Orbes, mares, Cielo, tierra,

pues tres coronas hallan

la paz de quantas lidias nos contrallan.

Ya en sfin su planta hermosa

les fabricò diadema,

que de blason ilustra

mucho mas que las sienes, la potencia.

Demosle la norabuena

à la Naturaleza,

rio, fuentes, Auras, lenguas,

pues del Cielo atesora

valor inmenso que en su seno mora.

\section{VILLANCICO II.}


Estriuillo.

Al Niño de Belen, adoremosle.

1. Que es Nieue.

2. Fuego.

3. Rayo.

Todos. En traxe de clauel.

Adoremosle,

Nieue, fuego, rayo, Rey.

Adoremosle

como Dios,

como Sol,

como Rey.

Al Niño de Belen

adoresmosle,

ques es nieue, fuego, rayo.

en trage de clauel.

Coplas.

1. Al que es flor de las Estrellas, y en purpura candidez, ostenta brillantes hojas vn neuado rosicler.

Adoremosle, que es nieue, fuego, rayo en trage de clauel.

2. Al que es fuego de las flores, cuyo esplendor al nacer, fragrancia de luz exala de la llama en la niñez. Adoremosle, \&c.

3. Al que es rayo de hermosura florido, y brillante, y que relampagos de jazmines fulmina al amanecer. Adoremosle, \&c.

4. Al que es nieue, Dios misterio admirado de la Fè.

quando iluminar le mira 
al tiempo que florecer.

Adoremosle, \&C.

5. Al que es fuego, sol del mundo,

y tan de las flores es,

que es su mayor diligencia

lucir primero que arder.

Adoremosle, \&C.

6. Al que es rayo, Rey, è indicio

de quan hermsoo ha de ser,

Monarca de los jardines,

pues que nace Rayo Rey.

Adoremosle, \&C.

\section{VILLANCICO III.}

\section{Estrivillo.}

Galegos baylarines

folixay cantando, ay,

decendo no son de a gayta,

que ò fillo de Deo Santo,

parece Galeguiño de Santiago,

pues vene de sua terra

sin zapaytos.

Ay, ay, folixay Galegos,

folixay cantando,

que para o Corpos

segaray os granos.

Ay, ay, folixay Galegos,

folixay cantando,

que antes que ò trigo, ò palla

ha segado, ay, ay.

folixay $\& \mathrm{C}$.

Que venen à la sega

de ó Trigo Sagrado,

ay, ay, folixay cantando,

que venen os Reyes

ó Trigo buscando;

folixay, \&c. 
Galegos baylarines,

folixay cantando,

dezendo ao son de a gayta,

que ò Fillo de Deo Santo,

parece Galeguiño de Santiago,

pues vene de sua terra

sin zapaytos.

\section{Coplas.}

1. A suo Fillo ó Pay Eterno

por ó mundo lo ha embiado

desnudiño como andan

en Mondego los muchachos.

A segar vene as mieses

de Trigo mais soberano,

y para ó Corpus ó tempo

de a sazon agardando ${ }^{25}$.

Parece Galeguiño de Santiago,

pues vene de sua terra

sin zapaytos.

2. A hoz que trae, es ó ferro, que o fizo primer pecado, y esta noite en uas pallas si ben sega estay probando, De ò Diuino Sacramento nos promete ô Pan Sagrado, $\mathrm{y}$ en primicias de as espigas a rubia palla mostrando.

Parece Galeguiño \&c.

3. Con las pallas las has Cruzes forma con su misma mano. descubriendo, que en à sega sudarâ sangre ò Costado: Conque en Lugo os Galegos le verán Sacramentado ao mismo que en ò pesebre ao demo a morte dando. Parece, \&c.

${ }^{25}$ En el original, de asazona agardando. 
4. Lo suo Pay que es muyto rico

à Mula, y ò Boy le ha dado,

con que seray poderoso

mais que ó Cura de Betanços.

Ainda con Boy, y ha Mula

Pode, si compray arado,

ser mas que ó Conde de Lemus

el que de frio temblando,

Parece Galeguiño, \&C.

Biblioteca Nacional. Madrid (V.E. 1309, $\mathrm{n}^{0}$ 43) "La Naturaleza humana" 212-1. ; 426-1.

Métrica: versos octosílabos, rima asonante, romanceada. Polimetría. 


\section{VILLANCICOS QVE SE CANTARON EN LA REAL CAPILLA DE LAS \\ SEÑORAS DESCALZAS LA NOCHE DE NAVIDAD. ESTE AÑO DE 1685. Y LA \\ NOCHE DE REYES DE 1686. \\ SIENDO MAESTRO DE DICHA REAL CAPILLA EL LICENC. DON MATIAS \\ IVAN VEANA. \\ EN MADRID: Por Antonio De Zafra, Criado De Su Magestad.}

VILLANCICO SEVUNDO.

Gallego.

INTRODVCION.

COmo por las Navidades

se cumple del año vn tercio,

al de los Reyes concurren

oy en Belèn los Gallegos.

Nevadas las cargas llegan

que traen al Niño, y sabiendo

que ay oro, vienen vaylando

por el dinerillo fresco.

ESTRIVILLO.

1. A Martin Llopez?

2. Què quiereis, Piedro.

1. Pois ay, paga al oxo

vaylemos cuntentos:

2. Comu nos lu paguen,

Pardeus vayleremus.

1. Cata qual chegan

los Reyes àò Neno.

2. Ya non me diràs, porquei traen Camellus?

1. No ay moçus forçadus por los outrus Reños?

2. Pois ea, vaylemos, que à do nos estamus non serviràn elos.

Todos. Zumbe, y retumbe 
à gaytiña, mancebos:

ay que folgança ${ }^{26}$

ay que contento!

que dizen que todo

ò pagarà ò Neno.

1. A Martin LLopez?

2. Que quiereis Piedro.

1. pois ay paga al oxo vaylemos contentos.

Tod. Zumbe, y retumbe à gaytiña, mançebos.

\section{COPLAS}

1. A Martin Llopez?

2. Que quiereis, Piedro.

1. Non veis à Dona

fermosa de ò Neno,

como le apaña

chegandole àò peito:

2. Ela, pardiobre,

mas bela es que ò Ceo;

pero non paga,

me dizen, ni à ò Demo.

1. Què faze ari

aquel Santo Viello,

con la su vara

en la maon sospenso?

2. Chamanlo todus

Pay de meu Neno;

mais eu cuido ainda

que es Fillo de Deus.

Tod. Ay que folgança!

ay que contento!

zumbe, y retumbe

à gaytiña, mancebos.

1. A Martin Llopez?

Que quiereis, Piedro.

Non veis que chegan

${ }^{26}$ En el original, flolgança. 
os Reyes Seveyros

faziendo ào Chico

el suo acatamiento.

Eles son homes

honrados al menos,

zedo besucan,

ya endonan primeiro.

Cata vn canoso

que ante todos elos

de prata parecen

as barbas, è ò pelo.

E si le endona

de su galsopeto

vnus drobrones

cumo vnus arneiros.

Tod. Ay que folganç $[a], \& C$.

1. A Martin Llopez?

Que quiereis, Piedro.

2. Esti segundo

de lindu perxeñu,

que chevarai,

que parece vnguentos?

2. Non sei que diga

entre estu, y aquelo,

vnto por vnto

al dourado me atengo.

1. Aunque lle endonan

as cousas ao Neno,

sua Nay Garrida

os và recollendo.

2. Ni el oro toma

ò Chicote enfeito;

tal non fizera,

si èl fora Galego.

Todos. Ay que folganç $[a], \& \mathrm{C}$.

1. A Martin Llopez?

2. Que quiereis Piedro.

1. Cata que aina

chega ò Rey preto; 
que amigu suyo

era ò Tintoreiro.

2. Deus me perdone, que en solu verlo, floxome el zinchu, que à risa rebento, 1. Traele vnas gomas con que nosos Cregos à los Santiños

lles dàn zahumerios.

2. En nosa terra se fazen de aquestos os Santiaguiños que al collo traemos. Ay que folganç $[a], \& \mathrm{C}$. 1. A Martin LLopez?

2. Que quiereis, Piedro, 1. Non veis à Mula que engreida se ha puesto, porque la chegan à maon por ò zerro?

1. Guardate de ela, non bolva el redeyro, que es Galeguiña, è darà mil pernexos. 1. Que tene ò Boy que parece està ledo, è con las suas maons escarba en ò feno?

2. Tene xaquéca ò Voy, que por esso xunto as orellas con parches le vemos. Ay que folg[ança $], \& C$.

1. A Martin Llopez!

2. Que quiereis, Piedro;

1. Pois que mercedes fay ò Rey Neno, dalo vn membrete 
contra os Camellus.

2. Eles nos quitan

que nos gañemos,

y tanto medran

sin duda por eisso.

1. Mais que dez homes

carga vno de elos;

y assi nos falan

con tanto pizcoezo.

2. Ora, señores,

pois xa se vàn hiendo,

digan, quien paga

que nos nos folguemos!

Ay que folgança!

ay que contento!

zumbe, y retumbe

à gaytiña, mancebos.

\section{VILLANCICO TERCERO.}

\section{INTRODVCION.}

EL Cazador de los Astros

en el Bosque Celestial,

Astrologo, y Cazador

en mentir, y no acertar.

Siguiendo viene à los Reyes

hasta llegar al Portal,

y no entra dentro, porque

no puede vèr la verdad.

Contentos los Zagalejos

le vienen à preguntar

cosas futuras, en tanto

que al Niño presentes dan.

ESTRIVILLO.

OYgan, atiendan, escuchen, veràn

que el gran Cazador

se empieza à emboscar; 
y aunque yerre el tiro,

es muy insigne en el disparar.

1. Dexenle tirar

que este Cazador,

como los demàs,

que à los Astros tiran,

amaga, y no dà.

Oygan, atiend[an], \&C.

2. Dexenle tirar

que el Divino amor,

expuesto al rigor,

su blanco serà.

3. No le acertarà,

que vn Pronostico, nunca

diò en la verdad.

4. Sì le acertarà,

que este Niño, oy de todos

se dexa dàr.

Oygan, atiend[an], \&C.

\section{COPLAS.}

Poeta soy de la Inclusa, y quisiera aberiguar,

aunque Apolo hijo me llama, adonde esta mi Solar.

Resp. En la Casa de la Luna

ay vn quarto principal,

donde todos los Poetas

tienen su antiguo desban.

1. Vze hà errado el tiro.

2. Como he de acertar,

si finjo que ay quarto,

donde no le ay.

Yo soy vn valiente, y tengo

que reñir, antes de entrar

en Maytines dos pendencias;

como me sucederá?

Resp. Digo, que todo este año, por ser tropico, es fatal 
para el que sale à reñir, y mas si acaso le dàn.

1. Vze ha errado el tiro.

2. Como he de acertar, si vze es de los guapos que oy corriendo estàn? Yo soy tan puntual en todo, que he llegado à reparar, que nada estas Coplas dizen de Reyes, ni Navidad.

Resp. Sabe vsted que el Nacimiento mas pulido, y mas cabal, se compone de figuras: entre vsted, que aun faltan mas.

1. Vze ha errado el tiro.

2. Como he de acertar, si vze, aunque tan necio, sabe reparar.

Señor, yo soy vn Gallego que al Niño traygo vn panal, y solo quiero saber si me le querrà pagar?

Resp. Cerca del Signo de Virgen essa miel viendole se està, mas siendo Gallego, Martyr por no darla vste serà.

1. Vze ha errado el tiro.

2. Como he de acertar, si vze con la miel la viene à pegar.

1. Yo soy Vieja, y por el siglo que tengo, que por San Iuan sali à oìr, si quinta vez me bolveria a casar?

Resp. Vzed con su parecer, sin duda se casarà; y haziendose Dueña, ò suegra tendrà vna vida inmortal, 1. Vze ha errado el tiro. 
2. Como he de acertar, si vna Vieja, solo muere por matar.

1. Yo soy vn Soldado raso, como el trage lo dirà, y he soñado, con ser lerdo, que soy Vivo, y Capitan?

Resp. Marte en su Signo me dize, que puede vsted despertar, porque come mucha hembra de su Paxaro Marcial.

1. Vze ha errado el tiro.

2. Como he de acertar, si vzed en las guerras solo vive en paz.

1. Yo soy desdichado, y vengo siguiendo el Astro Real, que dizen ser buena Estrella, y essa es la que ando à buscar?

Resp. Si es desdichado en su Estrella procurela dominar, que la Estrella, que es de vn Rey, no se hizo para vn Zagal.

Biblioteca Nacional. Madrid. (VE. 79 n. 5) "COmo por las Navidades".

Métrica. Algunos villancicos aluden a comedias populares, y por eso empiezan: "Oygan". Mucha polimetría, en la que pueden aparecer mojigangas, bailables, jácaras etc. Versificación octosilábica, con rima asonante. Al músico le importaba poco el esquema métrico literario. 
VILLANCICOS QVE SE CANTARON EN LA

Iglesia Mayor, Colegial Insigne de Santa Maria de Calatayud, la Noche de Navidad, este Año 1686.

SIENDO MAESTRO DE CAPILLA DON

Francisco Piquer.

DEDICADOS A SV MVY ILVSTRE CABILDO.

VILLANCICO VI.

ESTRIVILLO.

NAdie grite, callen todos,

que ni alentar no se puede:

à là lo lo lo Niño mio,

à la turù ru ru, que yà duerme.

Arrulando estàn al Niño

su Santa Madre, y Iosephe:

à la lo lo lo Niño mio,

à la turu ru ru, que yà duerme.

COPLAS.

1. EStando mi Dios dormido, vnos Pastores se sienten,

vino Bato, vino Gil,

Pasqual vino, y bino tienen.

A la lo lo lo

bino tienen,

à la turu ru ru,

que yà duerme.

2. Vàn llegando los Pastores

quando yà el Alva amanece, de corderos traen los dones, y son lobos dos que tienen.

A la lo lo lo

los que tienen,

à la turu ru ru,

que yà duerme.

3. Llegò Bato a despertarlo, 
y Buelve corrido al verle, que al resgistrar el Pastor, estos Zorros huyen siempre.

A la lo lo lo huyen siempre,

à la turu ru ru, que yà duerme.

4. Mas atrevido Pasqual con el Toro se entretiene, y como lo viò hecho vn cuero, estuvo con èl de suerte.

A la lo lo lo con èl de suerte, à la turu ru ru, que yà duerme.

5. Quiso Gil probar fortuna, y àzia la Mula se viene, y como lo viò tan manso, le diò paja en su pesebre.

A la lo lo lo en su pesebre, à la turu ru ru, que yà duerme.

6. Despertòse el Niño Dios, y los Corderos le ofrecen, se assomaron a mirarlo, y yà assomados se buelven. A la lo lo lo se buelven, à la turu ru ru, que yà duerme.

III. NOCTVRNO.

VILLANCICO VI1.

\section{ESTRIVILLO.}

AY Zagal,

que a rayos, que a luzes, 
que el Cielo nos dà:

miro lo que ciega

para mirar mas.

Ay Zagal,

que fuego, que nieve,

que Cielo, y Pesebre

mezclados estàn.

Ay Zagal,

que a explendores que esparce

este Sol que nace,

del yelo, a pesar,

miro lo que ciega

para mirar mas.

\section{COPLAS.}

DEsde la cumbre de vn Monte Anton saluda el Portal, que coronado de luzes es del Sol espejo yà.

Dichoso centro le dize, de la Divina piedad, donde el inmortal poder nace para ser mortal.

Sagrado Alcazar del Cielo, que para nuestro bien da, señas en humildes pajas de la mayor Magestad. Paraìso de la vida, pues quien nos lo viene a dar, nace de vna Virgen Rosa, pronta al bien, intacta al mal. Mortales, buscad la dicha, pues en vn Pesebre està, el mas precioso Diamante para el rescate de Adan. De la Aurora mas Divina nace el Sol mas Celestial, albricias, que yà la Noche jurisducion no tendrà. 
VILLANCICO VIII.

INTRODVCCION.

DEscalços vnos Gallegos,

entre nieve, a Dios se acercan,

al modo que allà Moyses

se acercava ente vna hoguera.

Con los zapatos en cinta

vienen desde Pontebedra,

y lo que de pies gastaron

se lo han ahorrado de suelas.

Viendo que la tierra al Niño

le trata con inclemencia,

cantando al son de la gayta,

le dizen de esta manera.

ESTRIVILLO.

HAY Niño meu,

si te proba la terra,

chegate acà

con la gente Galega:

Chegate acà,

y oyràs como suena,

ù fabordon de a gaytiña $\mathrm{q}[u e]$ alegra:

Chégate acà,

dareite as Sopiñas:

Chegate acà,

dareite Manteca:

Chegate acà,

dareite Tuciño:

Chegate acà,

dareite Turrexas:

Chegate acà,

y oyras como suena,

ù fabordon de a gaytiña q[ue] alegra.

Retumbe a gaytiña

que ao Niño festeja; 
Retumbe, que ò Niño

durmido se queyda;

Retumbe a gaytiña

facendole festa:

Ay Niño meu,

si te proba la terra:

Chegate acà,

con la gente Galega:

Chegate acà,

y oyràs como suena,

$\mathrm{u}$ fabordon de a gaytiña $\mathrm{q}[u e]$ alegra.

\section{COPLAS}

O Fillo de Deus, que nayce en Iudea, con moytos rigores

le proba la terra.

O Seno de ù Pae, yam no le calenta, y eladu de frio chorando se queyxa.

Bas lagrimas suas parecein estrelas, que caen sobre ò Mundo, de ò Celo que tembra.

Ho Mundo reparten con muyta riqueza, Santiagu vas Conchas, y ò Niño vas Perlas.

Ay Niño meu, si te proba la terra:

Chegate acà, con la gente Galega, Chégate acà, y oyrais como suena, ù fabordon de a gaytiña $\mathrm{q}[u e]$ alegra. Suos llantos os causa el furto de va breva, que foy golosina 
de la primer fembra.

Entunces va Serpe

non temia Eba,

$y$ à era de eas raras

se espantan asevas.

$\mathrm{O}$ à Serpe maldita

à tudos infeyta,

y hasta os Galegos

mordeu la Culebra.

O Niñu, por estu

padéce has tristezas,

y solu Galicia

diverte suas penas.

Ay Niñu meu, \&C.

Vas pallas, y feno

và Cama le cercan,

como si ò Niño

Galego nacera.

De o trigu que nace

vas pallas son señas,

$\mathrm{y}$ foy terra virgen

à donde se sembra.

O grano Divinu,

yà esperu que crezca,

porque para ò Corpus,

tengamos va sega.

Cubertu de à neve

si ascarcha non cessa,

no habray en Galicia

quein teña cosecha.

Ay Niñu meu,

si te proba la terra, $\&$ C.

F I N.

Biblioteca Nacional. Madrid (VE. 49-6) "Nadie grite, callen todos".

Métrica: polimetría, versos octosílabos, baile, coplas en diálogo propio de los villancicos del siglo XVII. La mayoría son romances con estribillo y éste puede tener hasta treinta versos. 
LETRAS DE LOS VILLANCICOS QUE SE HAN DE CANTAR LA NOCHE DE Navidad, en la Santa Iglesia Cathedral de Lerida, este Año de 1686.

SIENDO MAESTRO DE CAPILLA EL

Racionero Miguel Ambiela.

DEDICALOS A LOS MVY ILVSTRES

Señores Dean, y Cabildo de esta Santa Iglesia.

En Lerida: por IAYME MAGAILON.

VILLANCICO III.

INTRODVCCION.

El Alcalde de Belen

con los Zagales del Pueblo

para celebrar la Noche

previene al Sol vn festejo.

Al Portal en Mogiganga

vienen locos de contento,

$\mathrm{y}$ con el brindis venian

algo tiznados los Negros.

ESTRIVILLO.

Ay que vaya, que vaya, vaya,

festejemos al Niño

que todo es Gracias.

Francès. Monsiuris, festejai

la gala de Iesv,

si ma tornato a Francha,

non tornameremo a pliu.

Nan turu ru ru, nan turu ru,

le nantan tu.

Tod. Ay que vaya, que vaya, vaya

Atencion, porque empieza

la Mogiganga.

Español. Yo soy Castellano

Portuguès. Non faleis primero

que yo soy Portugueis,

è non faltarà vento. 
Francés. Que yo soy Monsiur.

Gallego. Que yo soy Gallego

Vizcayno. Yo eres Vizcayno.

Neglo. Aqui zamo Neglo,

con cala de Pasca.

Tod. Ay que vaya, que vaya, vaya, atencion, porque empieza

la Migiganga.

\section{COPLAS.}

Francés. Yo siñur, vengo a amolar cuchillos para Inocentos, è con vna muela mascu a Espagne tuti el dineyru.

1. Con el Francès tendrèmos la Noche Buena, si con queso, y con vino dan en ratoneras.

Vizcay. De parte de Vizcainos Iuan Gaicoa, yo te ruego, juras a Dios quitas culpas, y no nos quites el yerro.

1. Al oir quitar yerros le diò la Mula vnos quantos aciertos con la herradura.

Gallego. Galeguiño, meu Señor, os presentu gobus frescus, que vus lus teño guardadus desde el otru nacimientu. Los Gallegos los huebos nunca los gastan, pero nunca los quieren passar por agua.

Negro. Ziolo, aunque Negro zamo, branco la neve me ha hecho, porque a pesar del reflan ay tintula sobre neglo.

1. Quando el Negro estornuda, 
la Mula brinca,

por pensar que se toma

la cevadilla.

Portuguès. Pois que sois Portuguesiño, non me esteis tembra[ $n]$ du al hielu,

que estoy de verus tembrando

batu a Christu que rebentu.

El Fidalgo finchado

nos dà la copla

que parece a la musa

que a todos sopla.

\section{TERCERO NOCTVRNO}

\section{VILLANCICO I}

\section{INTRODVCCION.}

Descalzos vnos Gallegos

entre nieve a Dios se acercan,

al modo que allà Moysses

se acercava entre vna hoguera.

Con los zapatos en cinta

vienen desde Pontevedra,

y lo que de pies gastaron,

se lo ha $[n]$ ahorrado de suelas.

Viendo que la tierra al Niño

lo trata con inclemencia,

cantando al son de la Gayta,

le dizen desta manera.

\section{ESTRIVILLO.}

1. Ay Niñu meu, si te prova la terra, chegate acà con la gente Galega.

2. Chegate acà, y oirais como suena

$\mathrm{v}$ fabordon de a gaitiña que alegra.

1. Chegate acà, dareyte sopiñas

2. Chegate aca, dareite manteca.

1. Chegate acà, dareite tuzino.

1. Chegate acà dareite turrejas 
Tod. Chegate, y oyrays como suena $\mathrm{v}$ fabordon de a gaytiña que alegra.

Tod. Retumbe a gaytiña

que o Niñu festeja, retumbe, que o Niño dormido se queyda.

Ay Niñu meu, si te proba la terra, chegate con la gente Galega.

\section{COPLAS.}

O Fillo de Deus

que nayce en Xudea

con muitos rigores

le proba la terra,

O Seno de v Pae

yam no le calenta,

yelado de frio

chorando se queja.

Vas Lagrimas suas

parecein Estrelas,

que caen sobre o Mundo

de o Celo que tembra.

Ao mundo reparten

con muyta riqueza,

Santiago vas Conchas

y ao Niño vas perlas.

Ay Niñu meu

si te proba la terra,

chégate acà

con la xente Galega,

chegate acà e oyrays como suena

$\mathrm{v}$ fabordon de a gaytiña que alegra.

Suos llantos los causa

el furto de la breba,

que foy golosina

de la primer fembra.

Entonces hua serpe

non temia Eva,

$\mathrm{y}$ ahora de as ratas 
se espantan as Evas.

$\mathrm{O}$ a serpe maldita

a todos infeita

y hasta os Galegos

mordeu la culebra.

O Niñu por essu

padeze as tristezas,

y solu Galicia

divierte suas penas:

Ay Niñu meu, \&C.

3. Vas pallas, y feno

va Cama le cercan

como si o Niño

Galego Nacera.

De o Trigu que nace

vas pallas son señas

que foy Terra Virgen

a donde se sembra.

O granu Divinu

yà espero que crezca,

porque para o Corpus

tengamos va Sega.

Cubertu de a neve

si as[carcha $]^{27}$ non cesa

no abray en Galicia

queyn teña cosecha.

Ay Niñu meu, \&.C.

\section{VILLANCICO VLTIMO}

\section{INTRODVCCION.}

\section{A Belen con los Pastores}

vienen vn Sordo, y vn Tonto,

ensartando necedades,

como cuentas de abolorio.

Desatinos dize el Necio,

y disparates el Sordo,

${ }^{27}$ En el original, ascharca. 
pues ni vno se entiende a si,

ni el Sordo le entiende al otro.

Atencion, que ha de haver Fiesta,

que en noche de tanto gozo,

sin Villancico de chanza,

se haze mudo el Auditorio.

\section{ESTRIVILLO.}

1. Ha señor Sordo?

2. Que dize el Tonto?

1. No escucha, no oye?

2. Ya escucho, ya oigo.

1. Sepa que es este Niño

hombre como nosotros.

2. Dize bien, que este frio

no lo haze por Agosto.

1. Que no digo esso.

2. Ya escucho, ya oygo.

1. El Buey le pide al Verbo

le haga del Cielo el toro.

2. Con azucar, y huebos

se hazen muy buenos bollos,

1. Que no digo esso.

2. Ya escucho, ya oygo.

Tod. Pues al Tonto escuchen, escuchen al Sordo.

\section{COPLAS.}

Esta Noche los Pastores

vienen al Niño a adorar,

como si fuera esta Noche

la mañana de San Iuan.

Que gran desatino.

Esta es necedad?

No lo es dezir, que el Rey Niño,

teniendo vna Eternidad.

Dios es Dios, que cumple años

por Pasqua de Navidad?.

Que no digo esso. 
Buelvase a explicar.

Digo que està desnudo

el Verbo Humanado

y se andan los Pastores

con sus zamarros.

Ya lo he entendido,

es verdad que de Francia

fue el Rey Pepino.

Tan comedido es el Niño

con los que a adorarle van,

[...] en la antesala,

[...] en el Portal.

Que gran desatino.

Esta es necedad?

No lo se dezir, que el Pesebre,

donde el Niño Dios està,

estando escarchado todo

parecia mazapan?

Que no digo esso.

Buelvase a explicar.

Digo, que al que catarro

diere esta Noche

se le apliquen dos Pajes

por lamedores.

Ya entiendo aora,

que el gran Turco no cumple

con la Parroquia.

Los Pastores al Dios Niño

dones le dan a la par,

porque saben ofrecer

antes de saber rezar.

Que gran desatino,

Esta es necedad?.

No lo se dezir, que al instante

que el Niño empezò a llorar,

fue el Alcalde de Berdu

sus pucheros a embargar?

Que no digo esso,

Buelvase a explicar. 
Digo pues, que si Herodes

bolviera al Mundo

a buscar Inocentes,

no hallara ni vno,

Esso es sin duda,

lo mejor de las Pavas

son las pechugas.

Alli huvo vn Buey, y vna Mula

$\mathrm{y}$ desde entonces aca,

me he llegado a persuadir,

que bestias dichosas ay:

Que gran desatino

Esta es necedad?

No lo se dezir, que Belen,

siendo en Iudea vn Lugar

es como Pueblos en Francia.

Aldea de Portugal.

Que no digo esso

Buelvase a explicar.

Digo que Adan fue el hombre

mas feliz que huvo,

pues que siendo casado

suegra no tuvo.

Ya yo sabia,

que al punto que el Sol sale

luego es de dia.

Entre las demas Pastoras

vino vna Negra vozal

a ofrecer al Niño higas

de azabache natural.

Que gran desatino,

Esta es necedad?.

No lo es dezir, que a Belen,

por ser la Casa de Pan,

quisieron los de Belbis

tener por suyo el lugar.

Que no digo esso,

Buelvase a explicar. 
Biblioteca Nacional. Madrid. (R. 34985 n. 15). "El Alcalde de Belen".

Métrica: aparecen versos octosílabos, heptasílabos, estribillo, refrán, copla. Son muy vaiadas las composiciones adaptadas para la representación escénica. 


\author{
LETRAS DE LOS VILLANCICOS, QUE SE HAN DE CANTAR \\ en los Solemnes Maytines del Nacimiento de N. Señor Jesu Christo, en la Santa \\ Metropolitana , y Patriarchal Iglesia de Sevilla, este Año de 1686. \\ COMPVESTOS POR D. DIEGO IOSEPH DE SALAZAR, \\ Racionero, y Maestro de Capilla de dicha S. Iglesia. \\ En Sevilla, por Juan Francisco de Blas, Impressor Mayor \\ de dicha Ciudad.
}

VILLANCICO III.

Introducion.

Vn Astrologo, y vn Sastre.

1. A El oír que Dios era nacido,

y vestido encarnado traìa,

vn Astrologo, y vn Sastre

vàn à Belen sin juizio, $y$ medida.

2. Entraron en el Pesebre,

y sin pensar en tal dicha,

el Astrologo viò el Cielo,

El Sastre la Corte Empirea.

3. En Dialogo el Baticinio

el Astrologo principia,

porque el Arte Liberal

sigue à la especulatiua.

Estrivillo.

Atienda $[n]$, repare $[n]$, publique $[n]$, repitan,

en claros conceptos,

en vozes distintas,

de vn Dios humanado

la accion peregrina.

COPLAS.

1. Ast. ESte refulgente Sol expuesto à riesgos se mira, pues en el signo de Tauro

halla su suerte caìda. 
S. 2. Con resolucion amante à mortal derrota aspira, vniendo à su sempiterna la debil tela que anima.

A. 3. Contra el celestial influxo la oposicion es ruyna; y assi con nacer de Virgen de padecer no se libra.

$S .4$. Aunque ceñido le observen los Astros, no predominan, que à su humildad darà ensanchas, la vara de su justicia.

A. 5. Vndoso golfo el Portal, mar escarcha se divisa, y en Piscis no le halla Herodes, quando el Centro aquario habita. S. 6. Huya de tal Carnicero, que poco fiel solicita el entrar alta la hoja, solo por lograr la sissa.

A. 7. Cordero Benigno obstenta, noble de su Fè diuissa y Sagitario de amor, ya Leo sus flechas vibra.

S. 8. No obstante todo su esfuerço, ojalà la suerte mia, para que à Egipto camine, dispusiera su ropilla.

A. 9. Rey severo, à tres Monarcas, con rece los examina, y en Cancer Vero inmutado muchas gargantas derriba.

S. 10. La Estrella que los conduze, Norte feliz los inclina, y el rumbo que surcan cierto, sin aguja le caminan.

A. 11. En el regazo del Alva, abrassado Signo miran, que en mas que tiernos abrazos, 
dulces libraba caricias.

S.12. De su costoso viaje

llegan al Ave Maria,

y lograron su tarea

con hechura tan Divina.

A. 13. El erizado Diziembre

rizos penachos fabrica,

$\mathrm{y}$ de su disforme Aspecto

sus puntas à el aire gira.

S. 14. Los Pastorcillos previenen

poco incendio à tanta briza,

y la sencillés sincera

rodea la candelilla.

A.15. Voraz enemigo intenta, de escorpion lengua nosciva que la misma vida muera, $y$ en Aries su fin consiga.

$S .16$. Antes que tal execute mal de sastre le persiga, y de su exercito todo vea sus mangas perdidas.

\section{NOCTVRNO.}

\section{VILLANCICO IV.}

ESTRIVILLO.

Seguidillas.

OYgan las seguidillas, que por ser nuevas,

Ay, ay, ay, de vn Dios q[ue] ha nacido, que, que, que, ver en ellas.

Oygan, miren, atiendan, que, que, que, lo que canto, ay, ay, si me atienden con gusto, que, que, tendràn buen rato.

Miren, oygan señores,

que, que, que aqueste Niño, 
ya, ya, ya redime comperlas, que, que, nuestro delito.

Oy el mundo se alegre, no, no, no tenga miedo si, si, si de tantos pesares, ya, ya, ya hallò el remedio.

\section{COPLAS.}

ATencion, $\mathrm{q}[u e]$ à vn Señor Poderoso escriuo con miedo;

que es muy propio de humildes vassallos hablar con respecto.

Por librar al humano linage de carne se viste;

ò gran Dios! siendo Rey sois esclauo, quedando yo libre; al rigor del Invierno erizado naceis sin abrigo: pero sois tan amante, que al yelo resiste lo fino.

Vn Pesebre es Sitial Soberano de vuestra grandeza, y el que en Cielos, y tierra no cabe, humano se estrecha.

A Joseph Patriarcha Diuino consuela, y aflixe, el miraros desnudo, y miraros con rostro apacible.

Vuestra Madre devota os contempla tan llena de gozo, que quisiera erigiros del pecho Palacios, y Tronos.

De sencillos Pastores se pueblan las Selvas, y Valles, y por veros tambien Serafines habitan el ayre.

O Señor! amparad las Columnas que fixan la Iglesia; y contra infieles, vuestra fe santa, 
regid sus vanderas.

VILLANCICO V.

Estrivillo.

Gallego.

AY si chorais,

meo Galeguiño nobre;

ay si chorais,

ay, ay, ay meo Galeguiño nobre;

non choreis de pena,

choray de amores.

COPLAS.

1. POis chorando as culpas miñas,

bolveis vosas lagrimiñas,

mar de algofar, y perlinas,

ao Portal humilde, y pobre.

Non choreis de pena,

choray de amores.

2. Quen vos fizo assi chorar

sendo vos ome de amar,

fillo de pay mas si amar,

vos fay chorar por os omes.

Non choreis de pena,

choray de amores

Biblioteca Nacional. Madrid. V.E 1309. n 46. (432-3.) "A el oir que Dios era nacido”.

Métrica: polimetria, versos octosílabos, versos de gaita gallega. Rima asonante, romanceada. 
VILLANCICOS QVE SE CANTARON EN EL REAL

Convento de la Encarnación la noche de Reyes, este año de 1687

\section{PRIMERO NOCTVRNO \\ VILLANCICO PRIMERO \\ INTRODVCION}

EN las Vivezas del Sol,

el ayre sagrados fuegos,

sin nuve repite vn Astro

toda su luz es misterios,

De claridades se viste

el mas sutil Elemento

Cometa que tanto brilla,

mucho despierta del sueño

vamos a rendirle aromas

en mas humildes obsequios.

\section{ESTRIVILLO}

VEngan, vamos,

que la luz nos habla,

que la estrella alumbra,

que nos guia el astro.

Farol,

que tanto brillas galan,

detèn el paso

del aye rayo fulgor,

que luces peynas.

1. Que siguiendo el guiar sin embidias,

2. Que mira $[n]$ do el luzir sin engaños

3. Que advirtiendo el correr sin estorvos,

1. Corremos. 2.venimos. 3. llegamos

ha de los sobervios muros

que a Ierusalem la cercan?

donde a tropas de Luzeros,

el aviso de vna estrella

nos llama, nos trae, nos guia, nos entra, 
à donde este Rey que ha nacido se esconde?

4. Quien? quien?

Los tres. El Rey de los Iudios:

4. Quien grandezas atropella

Quien, que yo solo soy el Rey

mas el pecho en latidos,

quien?

Turbado, en congojas,

quien?

las ansias engaños se ven

con el alma, pues ya

mas no acierto,

Los tres. Confusa,m y turbada

està Ierusalem,

4. Id, y preguntad

del Niño nuevo Rey,

y lo que viereis antes,

despues me lo direis:

vamos,

que la esfera del ayre se ilustra:

vamos

$\mathrm{q}[u e]$ otra vez aparece $[n]$ los rayos

vamos, vamos, vamos.

\section{COPLAS.}

1. Salve, Humanado prodigio,

2. Dulce Infante,

3. Niño tierno,

à cuya deydad prostramos

Coronas, Dones, y Cetros.

1. Admite. 2. Recibe 3. y goza

la Mirra, el Oro, è Incienso,

pues adoramos rendidos

Hombre, y Rey,

y Dios excelso,

y à tanta Magestad.

y tal grandeza,

reberencien los Cielos, y la tierra. 
VILLANCICO SEPTIMO

\section{ESTRIVILLO}

1. Peregrino, que el valle discures, el paso suspende, y escucha mis vozes Ital. Yo no inte $[n]$ do de questa parola, que sò vn Italiano, maña macarrone.

2. Zagales, Pastores ${ }^{28}$, venid à Belen, que esta Noche Buena con el Italiano serà Buena Noche.

Ita. Andàte, via que vollo der al mio Padrone, qui al fredo tirita è pianche de amore.

2. Atended, Zagales, escuchad Pastores

los dulces afectos de sus suspe $[n]$ siones Ita. Ay mio core!

Regazo Divino, Pulito Bambion, laxate el tremore, ay mio core!

1. Vaya de alegria $\mathrm{q}[u e]$ lo pide la Gracia oy de justicia: y en tanta fiesta solo quiere el co[n]tento, la Tara $[n]$ tela, Ita. Questo, è cosa bruta, sentite vna arieta, que à tuti el Signiori le indone alegrezas.

Tonada. Cum le Ancheli, è i pecorari cantè ancor, o mi Amor Armelino!

Peregrino

fra la neve

${ }^{28}$ En el original, Pastastores. 
que te mueve,

pura fior,

cun li, \&C.

COPLAS DEL ITALIANO

REveriscole, mio Padrone,

Regi Famosi,

è ttuti pien,

con fineza, è alegreza,

claro hiorno, bona note

son per me,

Reveriscole, mio Padrone,

Regi Famosi,

è tuti pien,

2. Desde Napoli, con mia Vibola

yo à venuto,

per cantar,

e sonar

al Bambino picolino,

per si dona li quatrini

dopo à say.

Desde, \&C.

3. O que afabile pia $[n]$ che de amore

sopra il cavaño!

mio Signor,

bon Pastor,

lli crudeli Pecorile,

impietosi son lli cause

de tal rigor.

O que, \&c.

4. Con el Chimbalo vollo cantare,

per gradire

que lli Re,

qui son tre

portan oro da il Tesoro

de la Arabia al Poberelo

di Belen.

Cum el Chim, \&c.

5. Mi gargatile à il sole Trino 
con dolche voze

donarò,

perque no

me la fece Re Crudele,

que à inocenti

escannatò.

Mi gargatile, \&c.

6. Tre Magnifichi Cavalieri, molto voltieri,

se abaten qua,

qual dirà,

qui al potente lli Sapienti,

son quiamati à ossanare

la povertà.

Tre Magnifichi Cava. \&.C.

7. Terminamole pur bene mio,

qui sun difeso

de cantar,

que laudar

tu Grandeza, tu Beleza,

ancor lli Ancheli solo poseno

en la Eternità.

Termi. \&c.

\section{VILLANCICO VIII}

\section{INTRODVCION}

Pues Asturiano ha de aver, tambièn la Noche de Reyes su buena Estrella le guie, y empieze quando quisiere.

\section{ESTRIVILLO.}

Ast. Digu you,

pus me mandang que empiezi

à trabaxar, siendu Noite de Reyses:

Non me diràn,

quien me paga de vstedes? 
1. Si Dios te lo paga,

Martin, què mas quieres?

Ast. Pus Dious buenas noites

lle dè à sus mercedes.

2. Aguarda, y repara

que es Noche de Reyes,

donde el humo buela,

porque el oro ruede.

Ast. Si Dious toma el oru,

què haràn lus pobretes?

1. En esso ay Mysterio:

No vès que le ofrecen

tres Sabios en culto

de vn Dios que à vèr vienen:

Ast. Convengu cun essu;

mais lu que hazer pueden,

es, que à Dious lo ofrezcan,

è you me lu rieve.

2. Discreto Zagal,

esta noche vienes?

Ast. O! O! En esti punto

so vn Aristòteles,

peru vaya de gustu.

Tod. Vaya.

Ast. Que en la Noite de tantus praceres

ei de cantar, purque el Chicu se alegre;

mais votu à mi,

que non sei por do me eche.

1. El Birlimbon

repetirnos puedes.

Ast. Hartu Birlimbadus

estàn mis oyentes.

Ton. Ora escuhen Zangales,

que?

Vna tonada

que me hallè en Mançanares;

que?

xuntico al agua.

Ven pur la hiedra 
para enramar la choza;

que?

que al Chicu alverga.

Ola, è mais ola

champitel merecia;

que?

veleta, y vola;

que?

veleta, y vola.

\section{COPLAS}

A servir à los Reyses,

que

oy me acomodu,

que en efeto son nobres

que

y endonan oru.

Tre son pur ciertu,

par Dious, el chicu carga

con vn buen terciu.

Presentes traen

que siempre se regala

por Navidades.

En Camerus se vienen

sus Señoriyas,

(dome à Dious) $\mathrm{q}[u e]$ aya bestias

cun tanta dicha

quedense afuera,

pus tienen vn piscuezo

de bara, y media:

ò Reyes Santus!

que hasta en esta quisisteis

parecer llargus.

El Rey Viexu ora riega

y es que lus viexus

en irle à ver al Chicu

son los primeiros.

Esti trae Oru

que en el pelo de prata 
se la cunozeo.

Tanto oxo abierto

de ver el metal rubio

el Buey marieru.

Ora pranta el Rey Ioven,

al pie del Chicu

vna cousa que amarga,

Cuerpu de Christu.

Non se acurdava,

que en donar se vsa[ $n]$ dulces

pur estas Pasquas.

Mais non se espantein,

$\mathrm{q}[u e]$ à quien $\mathrm{da}[n]$ nunca escoxe

dize el Refrane.

Ora va el Morenitu,

cun el non fablo,

pus de ser tieni traza

home atufado.

Desti Rey Negru

deben de ser vasallus

lus Carbuneiros,

y à esti le plugò

el traer el incienzu,

pues muestra fumu.

Si en mi terra nacieras

Chicu donosu,

todu quantu ay te deran

menus el oru.

Derante oviellas

para que las guardaras,

ou para verlas,

estu ye fixu,

que ari todus son nobres;

mais non partidus

Biblioteca Nacional. Madrid. (R. 34989, n.19) 172. 1. "En las vivezas del Sol". Métrica: polimetría, versos octosílabos y de gaita gallega. Rima asonante. 


\section{VILLANCICOS QVE SE HAN DE CANTAR EN LA REAL CAPILLA DE SV MAGESTAD, LA NOCHE DE NAVIDAD DE ESTE AÑO DE M.DC.LXXXVIII.}

VILLANCICO VII.

Gallego.

ESTRIVILLO.

AY:

Venhan os Galegos

A Belèn à baylar:

Ay.

Veñan ver ò Neno,

Que no palheyro jaz:

Ay.

Das Ruas os Legos,

Das Praças os Cegos,

Das Grejas os Cregos, Que vinden, è vàn, A Belèn a baylar, Aò Neno fermoso,

Que no palheyro jaz.

\section{COPLAS.}

1. VEñan os Pastores, Venan ver ò Dia, Que a noyte mas fria Lhe tira os rigores, Todo ò Prado he flores, Que cheyran fermosas, O camiño he Rosas, E he Celo, ò Portal: Das Ruas os Legos, Das Praças os Cegos, Que vinden, è van. Venan ver o Neno, 
que no pa[1]heyro ${ }^{29}$ jaz.

2. Veñan ver nacido

El que fijò ò Celo,

Con vestido alleo,

Anque vay vistido:

El Zagal florido,

Sol de Luz mais vella,

Fillo de hua Estrella,

Que serca ò Mar.

Das Ruas os Legos \&C.

3. Veñan ver ò Neno

Deytado na palla,

Que muyto traballa,

Ainda, que he piqueno,

Por tirarle o feno,

A mula se chega.

Se fora Galega,

Non figera tal.

Das Ruas os Legos, \&C.

4. Veñan ver à Aurora,

Mais branca, è mais Pura,

Que na noyte escura,

De luz se milhora,

He nosa Sinora,

A Virge Maria,

De quien nace ò Dia,

Que a fijò sua nay.

DAs Ruas os Legos, \&C.

5. Para vir mais cedo,

Veñan polo atallo,

Poden sen traballo,

Pois todo era sedo,

O tempo ten ledo,

Que en oge camiña,

Coà vente liña

Suave que fay.

Das Ruas os Legos, \&c.

${ }^{29}$ En el original, pa heyro. 
6. Veñan dos oteyros,

Veñan das malladas,

Zagalas preçadas,

Moços prazenteyros,

Deyjen os abreiros,

O servicio e gado,

Pois nos da ganado,

O çeo el caudal.

Das Ruas os Legos, \&C.

F I N.

Biblioteca Nacional. Madrid. (V. C ${ }^{\text {a. } 88-79) ~ 136 . ~ 3 . ~ " A Y: ~ V e n h a n ~ o s ~ G a l e g o s " . ~}$

Métrica: rima asonante, formas romanceadas. Polimetría. 


\section{VILLANCICOS QVE SE HAN DE CANTAR \\ EN EL REAL CONVENTO DE LA ENCARNACION \\ EN LOS MAYTINES DE LOS SANTOS REYES \\ DE ESTE AÑO DE 1688.}

EN MADRID: Por Antonio de Zafra, Criado de su Magestad.

\section{VILLANCICO SEPTIMO.}

ESTRIVILLO

ESte Carreterillo

oygan mis Reyes,

que a servirle, si gustan,

rodando viene:

2. Ala, digo,

ruede, y mas ruede,

pues assi se lo quiere.

1. Como mi ganadillo

mis deseos son,

en Belèn me ha cogido

el Carro de Amor.

Pero que mas fuerte,

que dicha mayor,

que ser Carreti Carretero

del Sol!

Ala digo,

vamos andando,

que est noche del Cielo

nos viene el Carro,

Ala digo, cuidado, atencion

con el Carreterillo del Sol.

Oygan mis Reyes,

que a servirlos, si gustan,

rodando viene.

\section{COPLAS}

COnducia yo mi ganadillo,

del valle à la cumbre, con passo veloz: 
Ay amor! amor,

por llegar à Belèn con Estrellas,

siguiendo las huellas

de vn Real esquadron:

Ala digo, cuidado atencion,

que soy Carreti Carretero del Sol.

Deseava aliviar la fatiga

$\mathrm{q}[u e]$ de mi tarea el ca[n]sancio causò:

Ay amor! amor;

y en lugar de posada, hallò el alma

desvelos, que en calma

sintiò el coraçon,

Ala digo, \&c.

Al Pesebre llevava el ganado,

y vi q[ue] le ocupa (o válgame Dios!)

Ay amor! amor,

como el Sol, vn Infante desnudo

de aquel Nacarrudo,

la Perla mejor:

Ala, digo, \&c.

Serafines, Luzeros, y Pajas,

mezclados poblavan la inculta mansion.

Ay amor! amor:

Sabios Reyes, y simples Pastores

en lazo de amores

oy forman vnion:

Ala, digo, \&c.

Viendo el Buey, me acorde de aquel Carro

que vn Angel tirava; vn Aguila, y vn Leon.

Ay amor! Amor,

y por mas que su gloria zelebre

en este Pesebre vi gloria mayor:

Ala digo, \&c.

Vna Estrella pendiente del ayre,

fue sacra divisa de aquel Real Meson.

Ay amor! Amor,

do $[n]$ de Reyes se alberga $[n]$ dichosos,

sin perder gloriosos

de su pundonor: 
Ala, digo, \&c.

Vna Huespeda hermosa en su Estancia

limpieza ostentado, pureza, y honor:

Ay amor! amor,

agradable recibe en su Espacio,

ya Choza, ò Palacio,

al Rey, y al Pastor,

Ala, digo \&c.

\section{VILLANCICO OCTAVO}

Gallego.

ESTRIVILLO.

VOtai os zapatiños,

Galegos, è Galegas,

è descalciños todos

fagamos cuchupetas;

Tras, tras, tras,

con la tantarrañuela.

1. Tanyei ò Tamborino,

pois brava Xente chega,

cabeiças coronadas,

qual Cregos de mi terra;

Tras, tras, tras,

con la tantarrañuela.

2. Las grandes Alimañas

cargadas ora entran,

vn bulto tran al lombo

mayor que vna caldeira:

Tras, tras, \&c.

3. O Neno Garridiño, plañendo estai de pena, acercate Dominga, pois ves que verte perlas, Tras, tras, \&c.

4. Vailemos, y cantemos, è demos mil boltetas, que os Nobles Cavaleiros 
nos pagaràn la Festa.

Tras, tras, tras,

con la tantarrañuela.

Ora bono vay, andar;

Galegos, è Galegas

votai os zapatiños,

fagamos cuchupetas,

Tras, tras, tras,

con la tantarrañuela.

\section{COPLAS}

AO Reyeciño novo,

lo traen de lexas tierras

los viellos Reyes, cousas

que valen mais que pesan

Aquel de barva longa,

con ò ropón de seida

por Deus, le endona aquelo

con que afuman la Igreja.

El otru le trae Mirra:

yo non sey lo que deyxa,

mais non lo probaria,

inda que vn ral me deran.

A esti otru, yo me atengo,

que endona con largueça

vnos teixazos de oro,

mais grandes que rodelas.

Ora bono vay andar,

Galegos, y Galegas

fagamos cuchupetas:

Tras, tras, tras,

con la tantarrañuela.

Eu teño que endonarle

vn tarro de manteyca

mas doneme la mula,

si quier probar de ela.

Eu traigole vnos obos

sin craras, è sin hiemas,

para que Herodes tire 
por las carrestollendas.

Eu Chamome Toribia,

è si ele ò boy me dera

fariamos por certo

los dos boa pareixa.

Eu le suprico à Neno

Camelos non consienta,

pois mais que oito Galegos

carga vna de estas bestias.

Ora bono vay andar,

A sua Nai garrida

non sey que me le dera:

darele boas Pasquas;

que me darà por elas?

Cara como los Reyes

las Patiñas le beisan;

mais si eles le regalan,

que faigan como queiran.

Los dos son xente branca

el otro azabachea

pois ào Neno enriquezen,

que boa Pasqua teñan.

Pois que se vàn aina,

passen por miña terra,

veràn mil nacimentos

entre palalas, è bestias.

F I N.

Biblioteca Nacional. Madrid. (V.E. 91-73). " ESte Carreterillo".

Métrica: polimetria, ensalada de lenguas romances, rima asonante. 
VILANCICOS QVE SE HAN DE CANTAR EN EL REAL CONVENTO DE LA

ENCARNACION EN LOS MAYTINES DE NAVIDAD DE ESTE AÑO DE 1688.

EN MADRID: Por Antonio de Zafra, Criado de su Magestad.

\section{VILLANCICO V}

\section{ESTRIVILLO:}

1. Ola ahò? hà del Exido.

2. Norabuena vengais Anton

à alegrar à mi Niño que llora,

con el tamborilillo, y la voz

norabuena vengais Anton.

1. Pues que hazeis fuertes Zagales!

vaylad, que yo os harè el son;

que tamborili, borila, borilero,

tamborili, borilero soy.

2. Vaya de gusto, de chança, y primor.

Ay, que Cordero

Ay, que Zagala,

Ay, que tiririta

Ay, que se abrasa.

Ande la Loza, corra la chança

buele el contero, viva la gracia,

pues es Noche Buena el dia me[j]or:

1. Que Tamborili, borila, borilero, tamborili, borilero soy.

Ola, dexeme que cante,

porque el dimuño se espante,

y se alegre mi Señor.

que tamborili, borila, borilero,

tamborili, borilero soy.

\section{COPLAS}

POr Diobre, que està la noche

que es para alabar à Dios,

vna Virgen, como ay Cielo, 
con vn Niño, como ay Sol,

Vn Pesebre, como vn Templo,

Vn Portal, como vn Salon,

vn Buey que parece vn Toro,

vna Mula, como dos.

Que linda invencion,

que tamborili, borila, borilero

tamborili, borilero soy.

2. Al Niño à pedirle vamos, mil cosas que justas son, que temgamos buenas Pasquas, y nos libre del Dotor,

à las dueñas las empalen que frian todo soplon, que los miserables presten y los ricos dèn por Dios: que linda invención, \&c.

3. Cada qual le pida aquello que le estuviere mejor, yo ser rico, hazte necio, yo ser viejo, Sant Anton, yo ser bueno, santa cosa, yo vivir, para esso yo, salud, y gracia deseo, y diràn que es bobo Anton: que linda invencion, \&c.

4. Y que traen que presentarle al Zagal que nace oy?

yo vna obeja, guarda el lovo; yo vn cayado, buen pastor, yo vn bodigo, buena masa, yo vn Mastin, que no sois vos, yo traygo que darle gracias; este es pobre, y tiene dòn: que linda invencion, \&c.

5. Pues oy todo haze mudanzas, vaylad, y pedid el son; las folias: no ay barbero, el gran Duque: sois ramplon; 
la mariona: castañeras;

saltaren: pesado sois,

la zarabanda se vayle,

paredetas es mejor;

que linda invencion, \&c.

6. A la Madre del Chicote,

diganle algo, que es razon:

es Estrella, como ay dia,

Azuzena, linda flor,

Parayso, sin manzana,

Rosa es, Iesvs que olor!

es Fuente del Buen Sucesso,

Belèn la Puerta del Sol;

que linda invencion, \&c.

7. En fin, que quisierais ser

para alegrar al Señor?

yo Poeta: calabazas,

yo Soldado: paz: ay oy:

yo Valiente: brava maula,

Yo Clarin; mas sois tambor;

que el Niño me salve quiero,

vea para que naciò,

que linda invencion, \&c.

\section{VILLAN[CI]CO VI.}

\section{Introducion}

VN Gallego, Pastorzillo,

su gaita estrenar dispone,

porque al fin todo lo bueno

se hizo para aquesta Noche.

\section{ESTRIVILLO}

TEño de alegrar à meu Chicote,

$\operatorname{co}[n]$ mi gaytiña noba aquesta Noite

ay, ay, ay,

que zumbe la gaytiña, sin cesar,

ea Galegiños à vaylar; 
andar, zumbar, brincar, saltar,

ay, ay, ay,

que ò meo Garridiño,

$\left[\mathrm{si}^{30}\right.$ nace pobreziño,

Galegiño serà,

ay, ay, ay,

que zumbe la gaytiña, sin cesar:

àò son de mi gaytiña

farei mil gorgoritas,

como las paxaritas

de ò Sol al despertar;

ay, ay, ay,

ora bravo, lindo, bono, vay,

andar, zumbar, brincar, saltar,

è todos à cumpàs,

diremos è montones;

teño de alegrar à meu Chicote,

con la gaytiña nova aquiesta Noite;

\section{COPLAS}

NOso Señor me vala!

que ò Fillo de à Zagala

non cesa de chorar,

catay, que verte perlas;

Galegos, à cogerlas,

que muito nos valdràn.

E yo con mi gaytiña

farei mil gorgoritas,

como las paxaritas

de ò Sol al despertar.

2. Pascoal, el de Betanzos,

traerale vnos garbanzos,

para le reygalar,

que ò Crego dixo vn dia,

que certa golosiña

àò Neno à tierra tray,

è yo como mi, \&c.

3. Anton de Rebolledo,

${ }^{30}$ En el original, is. 
de ò pan de Mondoñedo

traerale vn bon candeal,

que ò Neno que està en palla,

espiga è serenada,

que ò Hebreo trillarà;

è yo con mi, \&c.

4. Endonele Palayo

aquel pallizo sayo

con que foy Mayoral,

que ò Neno està desnudo,

è fay vn zierzo crudo,

como por Nanvidà:

è yo con mi \&c.

5. Martin, el de Coruña, traeralo sin que gruña

vn xilguerin zerdal,

pois Deus fai boas migas

àò Demo malas figas

su bon olor darà,

è yo con, \&c.

6. Marina, la de Lugo

le endonarà vn besugo

qual la nata frescal,

que oy chama los Pastores,

dempois los Pescadores

ò Neno chamarà

è yo con, \&c.

7. Gines, el de Monforte

vn galo, e sus consortes

àò Chico traerà,

que ò Neno de meus ollos

como galiña à os pollos

nos quiere cobijar;

è yo con, \&c.

8. En fin, Galegos nobres

donayle los corazones,

fazenda è canto ay;

mais non los zapatiños

que en voos Galegiños 
del zinto han de colgar,

è yo con mi, \&c.

\section{NOCTVRNO.}

VILLANCICO VII.

ESTRI[VI]LLO.

FUentes de la Corte,

venid al Portal,

que con vozes de Perlas os llama

la Estrella del Mar:

Uenid, corred, volad;

Venid

en alas de christal,

Fuentes de Madrid,

Corred,

en Circulos de aljofar

Fuentes à Belèn;

Uolad

Ueloces, y risueñas

Fuentes al Portal,

y en azentos de liquida plata

al Sol saludad.

Cada qual tributando en su nombre

con voz misteriosa, dulze claridad;

Uenid Fuentes de Madrid

corred Fuentes à Belèn,

volad Fuentes al Portal,

pues rompiendo los grillos del hielo,

el Sol que amanece os dà libertad.

venid, corred, volad.

\section{COPLAS}

OY la Fuente del Ave Maria

vertiendo alegria

de su origen claro,

la primera Dios Niño os odora

que es Fuente, y Aurora 
del Sol Verbum Caro.

Buen sucesso ostentando en su Oriente

la mas Pura Fuente

con gracia difusa

de la Puerta del Sol en Raudales

tiene sus Cristales

la Victoria, Inclusa.

Santa Cruz, con su fuente celebre

dichoso el Pesebre

en que te reclinas,

que si vn Arbol le induxo à este empeño,

bien es que otro Leño

repare las ruinas.

Bien de San Salvador en la Fuente

nos muestras corriente

la gracia, y justicia,

pues de Adàm, el villano atributo

restauras [...] Fruto

de noble primicia.

Si Domingo al Señor le retrata

su Fuente de Plata,

te copia Narciso;

pues los Angeles que alli te assisten,

gloriosos se visten

de luz à tu viso.

Sean Fuente de los Relatores

humildes Pastores,

y Excelsos Querubes,

que si la Trinidad es tu origen,

baxando à vna Virgen,

desciendes, y subes.

Ostentado Salud tu hermosura,

la Fuente del Cura

seràs de mis males;

pues si Adàn me dexò desauziado

ya tu al No-Viziado

confortas, y vales.

En la Fuente del Humulladero

te adoro, y venero, 
en fin, Niño mio,

formen, pues, oy mis ojos corrientes

con las otras Fuentes

de dolor vn Rio.

Biblioteca Nacional. Madrid.(R.34989 n ${ }^{0}$ 5) (50. 6. ) "Ola, aho? hà del Exido". Métrica: muy variada, cuartetas, versos octosílabos. Rima asonante. 
LYRA POETICA DE VICENTE SANCHEZ, NATURAL DE LA IMPERIAL CIVDAD DE ZARAGOZA.

OBRAS POSTHVMAS, QUE SACA A LVZ VN AFICIONADO AL AVTOR. DEDICADAS A LA ILVSTRISSIMA SEÑORA DOÑA VRSVLA DE ARAGON, HIJA DEL EXCELENTISSIMO SEÑOR DVQUE DE VILLAHERMOSA, Y RELIGIOSA EN EL REAL MONASTERIO DE SANTA INÉS. CON LICENCIA: EN ZARAGOÇA, POR MANVEL ROMAN, IMPRESSOR DE LA VNIVERSIDAD, AÑO M.D.C.L.XXXVIII.

LIRA POETICA

COPLAS.

En Oriente sonando

clarin de plata,

con Estrella empezaron

tres Reyes,

vna JORNADA.

A Belen se encaminan

los tres, y es llano,

si es a Dios la jornada,

seràn...

buenos sus PASSOS.

Galan haze, y el alma

siente desdenes

Dios Niño, y que es, no ay duda

de todos,

quien mejor SIENTE.

Apuntando a los Reyes,

el pie les dava,

y en vez de versos, flechas

sus ojos

les APVNTAVAN.

Tan gracioso el Rey Negro

fue que imaginan,

si se havrà revestido

por ser Pez, 
oy de ESCAMILLAS.

De MARIA la Gracia,

flor Pura, y Bella,

todos oyen con gusto,

que es ROSA,

quien representa.

Aunque otras vezes hizo

papel de zelos,

el Santo Joseph haze

las barbas,

oy como vn VIEJO.

de Alcalde con vara,

que el tierno Infante

le amparò contra Herodes

oy tener,

oy tener el Padre ALCALDE.

Aunque fue la de Herodes

traza ingeniosa,

esta vez con los Reyes

le sale

mal su TRAMOYA.

El toreador, oy quieren,

que entremes sea,

y el Buey, que era Judio,

fue el Toro

de la MANTETA.

Sin papel à la Mula

oy han dexado,

porque han visto que es bestia,

y no mas,

que de su ESTABLO.

Venid apriesa Zagales, \&C.

VILLANCICO III.

Vena todo Galegiño

que adoiran con yelo tal,

en dos Brancos, è vn Negriño

à meu Niño garridiño 
esta noite en el Portal.

Venid si quereis folgaros,

eas prantas de o Niño Santas, veredes tres Homes raros,

que asemeijan herbolaros,

pois venen buscando prantas.

De la terra Galleguiña,

homes votad a Belen,

tocareis vosa gaitiña,

eu cantare vna cantiña

que à meu Niño sone ben.

ESTRIVILLO.

GAleguiños à Belen venid,

tocando à gaita, y ò tamboril!

\section{COPLAS}

GAleguiños de a Montaña

venid a ver Deus Home,

que Galeguiño de nome

no a feito mayor fazaña

con fermosura tamaña

del Eneiro faze Abril:

A Belen venid

tocando a gaita, y ò tamboril.

En [...] de sua Mai

chegad vos a ser prestiño

chorando en pallas ò Niño

tan grande como suo Pai,

perlas que en sus ollos ay

mas valen que o Potosi.

A Belen venid, \&C.

En Camelos dando trancos

os treis Reyes venen dreitos, è les han passado leitos,

que son como a neve brancos, mas non salen muito francos, que el ouro deixan aqui.

A Belen venid, \&C. 
De Orente jornada larga

vene cargados Camelos,

mas a o Niño quedan elos?

pois se tornan con a carga,

Outro, Incenso, è Mirra amarga

a suas prantas ve rendir,

A Belen venid, \&C.

Biblioteca Nacional. Madrid. (R.2633). "En Oriente sonando".

Métrica: polimetría propia de los villancicos y del "Periodo Nacional”, rima asonante. 


\section{VILLANCICOS QVE SE HAN DE CANTAR EN}

los Maytines de los Reyes, en la $\mathrm{Sa}[n]$ ta Iglesia Metropolitana Cesaraugustana, en su

Santo, Angelico, y Apostolico Templo del Pilar este año de 1688

Siendo Maestro de Capilla D. Diego de Cassedà, y Zaldibar.

\section{VILLANCICO VII.}

\section{INTRODVCION.}

VN Sacristan, que en beleta

a la mayor Torre passa,

y que por badajo es deudo,

que les toca a las Campanas,

sus Campanas hizo lenguas,

porque hasta esta noche clara,

en que nace, y campa todo,

no suena, ni campa nada.

\section{ESTRIVILLO.}

Albiricias, y nueva tan alta

haga ruido en el Oriente,

para que dè en el Orbe $\mathrm{Ca}[\mathrm{m}]$ panada,

y de su Madre en la Iglesia,

que es la que mas interessa,

en las glorias del hijo soberanas,

abuelo toquen Relox, y Campanas,

Dan, Dan, Dan,

y todas las Capillas

repiquen sus Campanillas,

dilin, dilin,

y resuenen los Organos todos

y las Chirimias,

y a los acentos sonoros

acompañen Relox, y Campanas, y Campanillas,

Organos, Instrumentos, y Chirimias,

y Cielo y tierra con zelo,

hagan dos Coros sonoros, 
mas no podràn ser dos Coros, que oy son vno tierra, y Cielo.

\section{COPLAS.}

1. La Campana de la Ley, le tocò a Adan, y se quiebra. 2. No se quebrarà si Adan lo que le tocava hiziera. 1. Eva la quebrò primero por hablar con la Culebra.

2. El quebrarse essa Campana lo hizo el yerro de la le[n]gua. 1. El son que al quebrarse hizo, a ofender la Deidad llega.

2. Como a Dios fue a quien tocava, le sonò muy mal su quiebra. 1. Saliò el emtal mas precioso con que aquel yerro se suelda 2. Mas fue sin romper la Mina, que ella sie $[\mathrm{m}]$ pre quedò entera. 1. A esta Campana de molde, vino el si de vna Donzella.

2. Tocando el Ave Maria el eco en su vientre suena. 1. En ella el Oro del Cielo se vniò al cobre de la tierra. 2. De essos metales la liga, la hizo mas sonora, y bella. 1. Verla colgada en los braços de su Madre, a quien no eleva 2. Es la Torre de David, Y por esso alli se cuelga. 1. Campana es, $\mathrm{q}[u e]$ a Reyes llama, y el Astro es de fuego lengua.

2. Les tocava sermon por ser, la palabra de Dios ella.

VILLANCICO VIII. 


\section{INTRODVCION.}

DOs Gallegos de buen [...]

oy a Belen han llegado,

mas no les dieron possada

con tener tan buenos quartos,

llevan guantes de polvillo

en sus pies de vara en ancho,

que esta gente siempre trahe

los zapatos en las manos:

Luego que la Infante vieron

con tal primor festejaron,

que con cantar solo a vno,

tambien cantavan a quatro.

\section{ESTRIVILLO.}

Al meu garridiño,

mas branco que armiño

mi Nino, mi Nina dos ollos do Pay

ay como le arrulla,

le canta, y le meze,

le duerme, le acalla

la sua bella nay.

Tod. Vamos todos adorralle, a ofrecelle, y festejalle, que aunque de Cuitas, ò Valle

le teña en vn Pesebriño

por miña fè que e mi Deus o mi Nino

por miña vida, que e fillo do Pay.

1. Dime Menga, tu que ofreces,

2. Yo huas nuezes que [...]

ao mi Nino le veràn,

con vn pan, como huas nuezes.

1. Cascaras para presentiño tal, y que buena pro que a mi Nino farà.

2. Y tu Catuxiña bella que le ofrezes Cortesana.

1. Eu le lebo hua Manzana, porque èl se muere por ella.

1. Y vos Vato dezid que levais. 
2. Eu non teño mais que dar si no es que el $[. .$.$] .$

Tod. O que lindo en bona Fe.

3. Pois que el empeño me acosa, y non teño que dar nada, vaya pois hua tonada.

a usanza de terra nossa.

1. Con la cantiña da nossa terra fagase tajas a gente Gallega.

1. Pois que non teño mais que ofrecer voltiñas a pares eu quiero fazer.

Tod. O que ligera con la Cantiña, \&C.

\section{COPLAS.}

1. Con lo encarnado meu Chocotiño ay como campa en o campo pagizo, aunque a tela puso sua nay elloro que encubre lle deu su Pay.

Tod. O que pulido con lo encarnado,\&c.

2. Denle si chora branco alimento, que a vn Rey se acalla, si le da[n] o peyto, pero mi Nina la sua nay ò candido nectar Do ceo lle trae.

Tod. O que portento, denle si chora, \&c.

3. E o portaliño preta alimaña, fogo de Deus [...] mula castaña, pois [...] muliña è o son para o bayle nos quere fazer.

Tod. Ay que acompaña [...] Portaliño, \&c.

4. Quiso O torino tanto a Minguiña, que la sua cabeza la deu para silla, e yo admirado quedo de la ver, señora oy de Silla, y descalça ayer. Todos. Porque es garridiña quiso [...], \&c.

5. Quitòle as bragas Anton pintado, 
con que o meu Torino bragado,

mais ao mi Nino no lle faz mal,

que teiño baquero por su delantal.

Tod. Ola cuidado,

quitole as bragas, \&c.

6. Si en musiquiña son boas falsas

entre a Mula en noa tonada,

aunque ò Touro e muy bozal

os puntos que coge os habre en canal.

Todos. No aguarda pausa

si en musiquiña, \&c.

7. Diz que intende desta mateira,

que sua cantiña es todo carreras,

si bay picado fogo en èl,

$\mathrm{q}[u e]$ en ristra corcheas, $\mathrm{q}[u e]$ no ay mas $\mathrm{q}[u e]$ ver.

Todos. Que bien solfea,

diz que entiende, \&c.

8. Vitor mi Nino, vitor mea terra

levese ò vitor a gente galega,

si la cantiña gusto vos dà

a muy boas noites todos bos quedad.

Todos. Que fin dà a festa

vitor mi Nino, \&c.

Con licencia: En Zaragoça, Por Domingo Gascon. En la Calle de la Cuchilleria. Año 1688.

Biblioteca Nacional. Madrid. (VE. 1303-11) (631-1). "VN Sacristan, que en beleta".

Métrica: polimetría, rima asonante, ensalada de lenguas, sátira. 
LETRAS DE LOS VILLANCICOS, QVE SE

han de cantar la Noche de Navidad, en la S. Iglesia Catedral de Lerida, este año de 1688.

SIENDO MAESTRO DE CAPILLA EL

Racionero Miguel Ambiela.

DEDICADOS A LOS MVY ILUSTRES

Señores Dean, y Cabildo de dicha S. Iglesia.

En Lerida: Por Iayme Magallon, Impressor de la Ciudad, y Real Vniversidad.

TERCER NOCTVRNO.

VILLANCICO I.

ESTRIVILLO.

GALLEGO.

AL meu Garridiño,

mas branco que armiño,

mi Nino, minina dos ollos do Pay;

ay como le arrulla,

le canta, y le meze,

le duerme, le acalla

la sua bella Nay.

Tod. Vamos todos a adoralle;

a ofrecelle, y festejalle;

que aunque de cuytas, ò valle

le teña en vn Pesebriño,

por miña Fè, q[ue] e mi Deus, o mi Nino,

por miña vida que e Fillo de O pay.

1. Dime, Menga, tu que ofreces?

2. Yo huas nuezes, que [...] pan,

ao mi Nino le veràn

con vn pan con huas nuezes,

1. Cascaras, para presentiño tal,

y que buena pro que a mi Nino farà.

2. Y tu Catuxiña bella,

que le ofreces, Cortesana?

1. Eu le levo hua Manzana, 
porque se morre por ella.

1. Y vos Vato, dezid, que ao mi Nino heys de levar?

2. Eu non teño mais que dar, Si no es que el allento dè.

Tod. O que lindo en bona fee.

3. Poys que el empeño me acosa, y non teño que dar nada, vaya poys vna tonada a vsanza de terra nosa.

1. Con la cantiña de nosa terra fagase rajas a gente Galega.

2. Poys non teño mays que ofrezer, voltiñas a pares eu quero fazer.

Tod. O que ligera; con la cantiña da nosa terra fagase rajas a gente Galega.

\section{COPLAS.}

1. Con lo Encarnado, meu Chocotiño ay como campa en o campo paxizo, aunque a tela puso sua Nay ell oro que encubre lle Deu su Pay. Tod. O que pulido! con lo Encarnado meu Chocotiño. 2. Denle, si chora branco alimento, $\mathrm{q}[u e]$ vn Rey se acalla si le dan o peyto pero, mi Nina, la sua Bella Nay o Candido Nectar de o Ceo lle trae.

Tod. O que portento, denle si chora, \&.c.

3. E o Portaliño preta alimaña:

Fogo de Deus en a mula castaña:

poys castañuera la mulina he, ao son para o vayle nos quere fazer.

Tod. Ay que acompaña e o Portaliño, \&c.

4. Quiso o touriño tanto a Minguiña, que la sua cabeza la dou por ella; 
e yo admirado quedo de la ver,

Señora oy de silla, y descalza ayer.

Tod. Porque es Garridiña,

quiso a toriño, \&.c.

5. Quitòle as bragas a Anton Pintado

$\operatorname{co}[n]$ que quedou meu toriño bragado

mays ao mi Nino no le faz mal,

que teyno Baquero por su delantal.

Tod. Ola, cuydado,

quitòle as bragas, \&.c.

6. Si en musiquiña son voas falsas,

entre a mula en [...] tonada:

aunque o touro e muy bozal,

os puntos que coge los hace canal.

Tod. No aguarda pausa.

si en musiquiña son voas falsas, \&.c.

7. Diz que intende desta mateyra,

que a sua cantiña es todo carreras:

si vay picado, fogo en él,

$\mathrm{q}[u e]$ enrristra corcheas, $\mathrm{q}[u e]$ no ay mas que ver.

Tod. Que bien solfea,

diz que intende desta mateyra. \&. C.

8. Vitor meu Nino, vitor mea Terra,

levese o vitor a gente Galega:

Si la cantiña gusto vos dà,

a muy boas noytes todos vos queda[d].

Tod. Que [...] a festa,

vitor meu Nino, vitor mea terra.

\section{VILLANCICO VLTIMO.}

GITANA.

AY de mi! ay de mi!

que donozito, y que lindo le vi:

Ezcucha Zagala,

que a fe de Gitana

era el Niño azi:

Ay de mi! ay de mi! 
que donozito, y que lindo le vi.

\section{COPLAS.}

Zu carita de Pazcua

como vn Zol era,

y harà, a quien no le ame,

ver laz Eztrellaz.

Zuz ojicos de Zielo

perlaz llovian:

quien fuera niña delloz,

para zer rica!

Tiritava de frio

entre la ezcarcha:

quando toda de amorez

yo me abrazava.

Verle hazer pucheritoz,

ez donozura:

pucheritoz que ablandan

entrañaz crudaz.

Como durava tanto

noche tan larga:

dixe: el Zol ze ha dormido

entre laz pajaz.

Contemplava el buen Viejo

zu Prenda Rica:

y de gusto la baba

ze le cahia:

$\mathrm{Zu}$ poquito de bayle

huvo con gayta:

porque diz viene el Niño

ha hazer mudanzaz.

Tuvo el Niño Cruzadoz

con linda Grazia:

la Zeñora Maria

vna Gallarda.

Noz partimoz, diziendo,

con reverenziaz,

Buenaz Nochez, Zeñorez, y Noche Buena. 
F I N.

Biblioteca Nacional. Madrid. (R.34985 ${ }^{-16}$ ) (117-9). "AL meu Garridiño".

Métrica: polimetría, versos octosílabos, con variedades en heptasílabo. Rima asonante. 


\section{LETRAS DE LOS VILLANCICOS QVE SE HAN DE CANTAR EN LA INSIGNE COLEGIAL}

de N. Señor San Saluador en los Maitines de la Natiuidad de nuestro Señor Iesu

Christo. Este año de 1689.

PRIMERO NOCTVRNO.

\section{VILLANCICO}

de Kalenda.

Estriuillo.

1. MOntañas de Iudea, cuyas pagizas choças, si de nieue se calçan, de yelo se coronan.

Todos. Quien las mo[n]tañas nos alborota?

1. Pastores destos campos, que guardas oy os nombra[n] de candidos vellones manadas numerosas.

Todos. Quien los Pastores nos alborota?

1. Corred, notareis prodigios que aquesta noche se logra $[n]$.

2. Llegad, vereis la grandeza abreuiada en parte corta.

Todos. Vamos a ver el prodigio Pastores.

Vamos a ver la grandeza, y primores.

1. Corred, corred, corred $\mathrm{q}[u e]$ en Belen ay mucho $\mathrm{q}[u e]$ ver.

Todos. Andar, andar, andar, que el prodigio està en vn portal, suene, Pastores, festiua alegria. $\mathrm{q}[u e]$ a verse Dios humanado, sin duda que conuenia. 
Todos. Llegue, Pastores, en ta $[n]$ to consuelo, si gloria por las alturas,

la paz hasta el mismo suelo.

Coplas.

TAnta fineza, Dios mio, como mostrais oy nacie $[n]$ do, ò es hazer el amor gala, ò lo poderoso empeño.

Quien medirà la distancia que juntais en vn supuesto? hombre, y Dios qua $[n]$ to desdize, como enlaza carne y Verbo. Mucho ha podido mi culpa, pues os ha traido al suelo, ò vuestra piedad es mucha, ò encubris lo justiciero. Vos Señor de los señores os veis tiritando al yelo, como dize Dios, y frio? como lo humano, y eterno Si por viuir con los hombres hazeis la pena contento, ò estas son vuestras delicias ò en la injuria hallais co[n]suelo. Vos mi Niño reclinado en vn pesebre en el heno, quien juntò Rey, y pobreza? quien el establo, y el cielo?

VILLANCICO II

ESTRIBILLO.

SIlguerillo sonoro no estès suspenso, quando por escucharte solo me pierdo, No des plumas al ayre, abate el buelo, 
que solo quiero

que cante tu voz suaue,

que en las pajas cabe

de vn Dios el poder inme $[n]$ so

Ay que me eleuo,

que tiernos ecos!

no escuses cantarme

tan dulces quiebros,

ni dexar de tus vozes

tales acentos.

COPLAS.

1. COmo tan mal paga el ho[m]bre, procura el Diuino Verbo,

por cobrar siquiera en pajas

oy echarse sobre el heno.

2. Muy dissimulado viene,

y el vestido le està estrecho,

mas en abrirle vn costado

consiste todo el remedio.

3. Tan cuerdamente se viste,

y es su trage tan honesto,

que solos dos passamanos

se los echaron por hierro.

4. Mas por lo ama $[n]$ te prete $[n]$ de

vestir vestir colores diuersos,

sobre carne de donzella,

color pagizo se ha puesto.

5. Galan sale como el Sol, y no es prodigio pequeño, de que sin romper el Alua

le salga el Sol al Misterio.

\section{VILLANCICO}

Gallego. Estriuillo.

AY ay veñan, y bailen,

$y$ dèn mil boltetas, 
ay veñan primero

la gente Galega.

Ay veñan los homes

do peito brioso,

ay faganle festas

al niño fermoso.

Ay al pai, y a su mai

ay muito celebren,

que son peregriños

de muy boa gente.

Coplas.

MIo señor, eu soy Domingos

que de la gente Galega

veño a veros: soy Alcalde

ò mellor dà miña terra.

Teños dos boes, dous bacas, e mais de catorze ouellas, aqui teño este cordeiro, perdoay $\mathrm{q}[u e]$ no ay terneira.

Sois muito belo, y fermoso

Minino, y es muito bella

vosa may, y la bendiçaon

de ò $[\mathrm{s}] \operatorname{ceos}^{31}$ os cubra, y os veña.

De veros tembrar do frio

todo meo corpo ya tambra

dexay aquesta chociña,

vindevos a nosa aldea.

Dareivos rosquiñas brancas

de o millo, y mas de ma[n]teca,

boos nabos apadiños,

è boas sardiñas frescas.

Por esta muliña fraca,

$\mathrm{q}[u e]$ en los peis ten poca força,

otra mellor os darey,

en manos, è peis Galega.

\footnotetext{
${ }^{31}$ En el original, de òceos.
} 
SEGVNDO NOCTVRNO.

IV. VILLANCICO.

Estriuillo.

Vozes, ayres, hojas, quedo, no respireis, no, no,

que mi amante querido, de amores rendido, dormido quedò.

No respireis, no,

quedito llegad,

y sus luzes, sus rayos

atentos mirad.

Coplas.

VOzes, pues que no podeis tanta ventura explicar, sea el silencio la voz, y retorica el callar.

Ayres, pues mirais dormida tan Diuina Magestad, amantes de su hermosura, deponed la crueldad.

Hojas, si es que hazeros le[ $n]$ guas con el bullicio aspirais, suspe $[n]$ ded vuestra inquietud, $\mathrm{y}$ ved que durmiendo està.

Mas ay que ama $[n]$ te, y dormido implica contrariedad, y es solo su suspension para boluer a penar.

Como es possible dormir quie $[n]$ siempre velando està? si no es que ta $[m]$ bien disfrace con el sueño su deidad.

\section{VILLANCICO V.}

Estriuillo. 
DOrmidito en las pajas

le tengo a mi bien,

ayresillos parad, tened,

no me lo recordeis,

que no no, tened,

que descansa mi amante,

no me le desveleis, tened,

no me le recordeis,

que no no, tened,

que sossiega mi Niño,

no me le fatigueis, tened,

quedito soplad,

pasito corred,

que aunque llora, y suspira

se duerme tal vez.

Coplas.

YA se ha quedado dormido

entre las flores mi bien,

ayrezillos bulliciosos

parad, no me le inquieteis,

quedito soplad, pasito corred,

que aunque llora, y suspira,

se duerme tal vez.

Mas ay que llorando està,

mal aya el pecado amen,

$\mathrm{q}[u e]$ a tal estremo ha llegado,

que a Dios hize padecer.

Quedito, \&C.

Pero parece que duerme,

ayrezillos detened, detened

vuestra ruidosa inquietud,

porque sossiegue mi bien.

Quedito, \&C.

Mas ay dolor tan igual,

ni fatiga tan cruel,

que qua $[n]$ do juzgo q[ue] duerme

buelue a llorar otra vez?

Quedito, \&C. 
Biblioteca Nacional. Madrid. (C 79-109) 451-1 "Montañas de Iudea".

Métrica: versificación octosilábica propia del villancico. Ensalada de Lenguas propia de los Cancioneros, en especial del Cancionero de Palacio. Rima asonante. 
VILLANCICOS, QVE SE HAN DE CANTAR

en los Maytines de los Reyes en la Santa Iglesia Metropolitana Cesaraugustana en su

Santo, Angelico, y Apostolico templo de el PILAR

este año de 1691.

SIENDO MAESTRO DE CAPILLA D.

Diego de Casseda, y Zaldibar.

\section{VILLANCICO OCTAVO.}

GALLEGO.

Introduccion.

COntra los pobres Negrillos

los Gallegos vaya dan,

porque en blanco no se queden

en esta noche Real.

Quanto les saben les dizen,

y es cosa bien singular,

que aunque la verdad les digan

nunca en el blanco daràn.

\section{ESTRIVILLO.}

Vamus à Belen Turibinu,

Vamus à Belen à ver al Niñu,

1. Ven à ver à May de orrostro hermoso

2. Ven à ver o biello de su Esposo,

3. Ven à ver à Mula con reposo,

que diz, que es Gallega su poquiño.

Vamus à Belen, \&c.

Vamus cantaremus à gaytiña

à lus Negrus vna tunadilla,

para divertir al alma miña,

$\mathrm{q}[u e]$ està con o frio tembra[n]diño.

Vamus à Belen tur[ibiñu], \&C.

Oygan à los Gallegos,

$\mathrm{q}[u e]$ à dar vaya han venido à los negro[s], 
$\mathrm{y}$ tanto les dizen, que he recelado de vergüença se passan à colorados. Oygan pues que ya dizen festivos Vamus à Belen, \&c.

\section{COPLAS.}

Bes lu Chiquillu de à Celo abajao, que oy à Belen aveis amanesiru, bein se conoce que sois Sol hermoso pois de las sombras estais assitiru. Vamus à Belen Turubiñu, Vamus à Belen à ver al Niñu.

Bien se conoce, que friu, y tembrandu estais recrinado en o pesebriñu, pois, ò lo cause el friu, ò los Negrus mais estonuro, que con romadizu. Vamus, \&c.

Y pois de friu vos miru tembrandu faced Vos enciendan qual q[uer] braseriñu, que con aquestos señores Morenus ay à Dios gracias carbo[n], y maisciscu. Vamus, \&c.

Dizque humànarus Señor por el ho[ $m]$ bre, es q[ue] su hermano vos faga el cariñu, pero o Señor de los hombres morenus non sois hermanu, q[ue] basta ser primu. Vamus, \&c.

En la mi terra se cria azabache de que se facen los Santiaguiños, mais en la terra de questos morenus el azabache debe ser vivu.

Vamus, \&c.

Lo que me espanta de dichos Fidalgus, es que en vn dia de tal regoziño, den à entender, que se ven desgustados, porq[ue] se estàn con vn palmo de ozicu. Vamus, \&c.

Au buen Chiquillu de la miña vida, $\mathrm{q}[u e]$ non sois Vos como estotrus Chiquillus 
pois à poder espa $[n]$ taros el coco

todos son cocos, que espantan los Niñus.

Vamus, \&c.

Pero enojados no quiero dexarlos

antes me tenen con todo cariñu,

y como juren que no han de tiznarme

yo quieru darles à manu de amigus.

Con licencia: En Zaragoça Por Domingo Gascon. En el Callizo de la Imprenta, à la Cuchilleria. Año 1691.

Biblioteca Nacional. (VE. 129. 39) ( 635. 1) "Contra los pobres Negrillos".

Métrica: polimetría, versos octosílabos, ensalada de lenguas románicas. Rima asonante. 


\section{VILLANCICOS, QVE SE HAN DE CANTAR LA NOCHE DE NAVIDAD EN LA REAL CAPILLA DE LAS SEÑORAS DESCALZAS ESTE AÑO DE 1691. Impressos en Madrid: POR MELCHOR ALVAREZ.}

VILLANCICO III.

INTRODVCCION.

ESta noche los Gallegos

festejando al Niño Rey,

en mudanças Pastoriles

mostraron su noble fee,

Con el zapato en la cinta,

por no tropezar con èl,

van muy calçados de barba,

y muy lampiños de pies.

Al Niño, cierto Gallego,

le pidiò prestados el buey,

porque yà lo dado es dado,

y lo prestado tambien.

Bostezando con el hambre

llegan cantando à Belèn,

la boca de par en par,

y la bolsa pez con pez.

\section{Estrivillo.}

Pues esta noyte ha nacido ò Cordeyro

$\mathrm{zu}[\mathrm{m}]$ be à gayta, è retu $[m]$ be ò $\mathrm{pa}[n]$ deyro:

Tocay Galeguiños,

tocay à gaytiña,

que oy ha nacido

ò Rey de Galiza:

Ay Toribiño, chegay, è no temas,

$\mathrm{q}[u e]$ hasta la mula de ò Rey es Galega

oranday de bulla,

de gira, y de trulla,

tocay à flautiña,

tocay que retiña 
à la paridiña

$\mathrm{q}[u e]$ tein en la palla ò Rey Celestial:

tocay Galeguiños, tocay,

ay, ay, ay:

Baylay Toribiño

àò Rey que es vn Niño,

mais branco, è Rubiño

que ò Sol Oriental:

tocay Galeguiños,

tocay à gaytiña,

que oy ha nacido ò Rey de Galiza

\section{COPLAS.}

Meu rapaziño quein sois yo no dudo

Fillo de Mai tan fermosa, è polida.

quein pode ser sino Fillo de Deus

pois ha nacido en vna Ave Maria?

tocay Galeguiños tocay à gaytiña,

pois ha nacido ò Rey de Galiza.

Que sois Galeguiño meu Neno yo creygo,

pois señas da vosa May garridiña,

è lo asseguran los que vos atienden,

con boy, è mula, è con Casa pagiza:

Tocay, \&c.

Que sois el mismo que està en la Hostia mos dize el Cura, è lo que me admira verus entero, tan sanu, è garridu, è que vos coumen en todas as Missas.

Tocay, \&c.

Disque à este mundo venis à traballos, y que las penas son vosa coumida, si non comer nen beber vos regala, meu Siñor idos al punto à Galiza:

Tocay, \&c.

Si à ser remedio de ò Mundo veniste, è con la paz quereis darnos la vida, no aya Doutores, tampoco Lletrados, aya diñeru, è no aya Boticas:

Tocay, \&c. 
Danos toziño, è pan abundante, vinu sin agua, medida sen sisa, que el chiculate al preizo que corre para Galegos no es boa coumida:

Tocay, \&c.

Mais si tomar chiculate queredes gardaibos Niño de los llamejicaras, que por tomarle, è que nada lles queste; à todas horas se van à vesita:

Tocay, \&c.

Yà con aquesto meu Niño me parto, è pois que tanto gustais que vos pidan, facednos Santos, è danus el Cielu, porque este Mundo està cousa perdida:

Tocay, \&c.

\section{NOCTVRNO II.}

\section{VILLANCICO IV.}

\section{INTRODVCCION.}

\section{Estrivillo.}

AY amor, quien tuviera, capaz el alma, para el que oy Peregrino busca posada! Què pena, què ansia, ay que por mis amores al mundo baxa, y aunque amor le abrasa, oy desnudo padece yelos, y escarchas! Què pena, què ansia, que la tierra que pisan sus tiernas plantas: yà merece el renombre de tierra Santa.

Ay, que nadie le acoge, 
nadie le ampara!

ay amor quien tuviera

capaz el alma,

para el que oy Peregrino

busca posada!

\section{COPLAS.}

Galan Peregrino,

que à tierras estrañas

oy vienes dexando

tu Padre, y tu Patria.

Si buscas posada,

no llores, aguarda,

que mi pecho te ofrece

su humilde estancia.

Què buscas en esta

cruel tierra ingrata,

que con sus espinas

tu frente amenaça?

Si buscas posada,

no llores aguarda,

que hospedarte entre rosas

quisiera el alma.

Quien de Peregrino

al trage te humana,

que aun siendo tan pobre

le tienes por gala?

Si buscas posada,

no llores aguarda,

que ninguna es mas pobre,

que mi morada.

La hermosa esclavina

sin duda te labra

la que fue Señora

llamandose Esclava.

Si buscas posada,

no llores aguarda,

que sus braços blasonan

de eterno alcaçar. 
Quien el bordoncillo

te ha dado, que enlaça,

ser Cetro en la mano,

y oprobio en la espalda.

Si buscas posada,

no llores aguarda,

que el pesebre se dora

de humildes pajas.

$\mathrm{Y}$ en fin Peregrino

de piedades tantas,

cuya gracia es norte

de nuestras desgracias.

Si buscas posada,

no llores aguarda,

que si el mundo la niega,

mi amor la guarda.

Biblioteca Nacional. Madrid. (R. 34988, - 10) "Esta noche los Gallegos".

Métrica: versificación muy variada. Rima asonante. 


\title{
VILLANCICOS QVE SE HAN DE CANTAR EN EL REAL CONVENTO DE LA ENCARNACION EN LOS MAYTINES DE NAUIDAD \\ ESTE AÑO DE 1691.
}

EN MADRID: Por Antonio de Zafra, Criado de su Magestad.

\author{
VILLANCICO V. \\ Introducion \\ VNa danza de Galegos, \\ contentos, como la Pascua, \\ vienen à Belèn baylando, \\ y preguntando: Quien paga? \\ Al Portal gustosos llegan, \\ que han sabido allà en su Patria, \\ ser el Niño como vn Oro, \\ su Madre como la Plata. \\ Estrivillo \\ 1. EA Galegos de boa pujanza, \\ Lebante $[n]$ àò Ceo ò polvo las patas, \\ $\mathrm{Zu}[m]$ be, $\operatorname{retu}[m]$ be la gaitina, Pasquala, \\ Tuturutu, birindi, birindayna, \\ 2. Que ta $[n]$ to queires àò Neno, Domiños? \\ 1. Mais que os zapatos que traygo en el chinchu. \\ 3. Cata que Nay tan fermosa le abriga. \\ 1. Si el Boy me dera, inda fora mais linda. \\ 2. Pidele à Mula, que es nosa paisana. \\ 1. En nosa terra Galegas ay fartas. \\ Zumbe, retumbe, \&c. \\ Tuturutu, \&c. \\ 3. Que le daràs en baylando àò Chicote? \\ 1. Que le ei de dar? darele boas noytes \\ 2. Quierole yo endonar meus zapatus. \\ 1. Los que èl pornà, so[n] de cravo passado. \\ 3. Los Angeliños la gloria le cantan. \\ 1. Sempre en las Festas os mosicos anda $[n]$. \\ Zumbe, retumbe, \&c.
}




\section{COPLAS}

MEu Domingon, responde.

Preguntame Pasquala.

Dime, que es cousa, y cousa,

vna Paloma Branca,

tein por Fillo vn Cordeiro,

que de Hombre tiene traza?

Esta Paloma, es Ave,

y Maria se llama,

Filla del Padre nostro,

y de la Salve Hirmana.

O valasme la Virxen!

Noso Siñor mos vala;

En vna noite obscura,

que por lo negro espanta

palabra non se veia,

y se vio la palabra.

Essu de creer es facil, que es vna cosa crara, cantan los Angeliños, è non teinen garganta. O valasme, \&c.

Si ò Sol està deytado enzima de las pallas, como no las enziende, como no las abrasa.

Porque ò Sol garridiño que entre la neve campa, los corazoines queima, la ropa deixa sana.

Comu los Pastorciños, vienen con sus zamarras, y tiritando ò Neno desnudito se halla! Porque à la nosa terra, viene con prisa tanta, que sin duda en ò Ceo, sei le quedò la Capa. Siendo su Pay tan rico, 
tein de Galego traza,

pois à su Fillo embia,

por el mundo sin branca.

No està muy pobreziño,

pois que perlas derrama,

à por sua Nay se dize,

que tiene muy buen Arca.

Todos le traen presentes,

Nos non le damos nada,

mais esso importa poco,

ser Galegiños basta.

Si và à dezir verdade,

nosa franqueza es tanta

que antes que darle vn carto,

dariale yo el alma.

Si por O chicotico

fazemos esta danza,

al fin de lo Baylado,

quein nos darà la paga?

Non fagas quema de essu,

si non sírvele, y calla,

pois es canto nos deue,

en suma vn sus de Gaita.

En Metadora de la tempestad

deste presente año

\section{VILLANCICO VI}

\section{Introducion}

Las Campanas de Belèn, tocando estàn à nublado,

Jesvs, y que tempestad,

el Cielo se viene abaxo.

Los Pastores al Portal

se recogen assustados;

que al vèr empañar el Sol,

à escuras se queda [e]l campo. 
ESTRIVILLO.

TOquen à nublado,

Toquen sin cessar:

din, don, dan,

Ay, Ay, Ay,

Cielos piedad:

Astros favor,

Que se vè à la inclemencia

El Grano mejor,

Din, dan, don,

Que en dilubios de perlas,

Se anega el Sol.

Din, dan, don,

Que lastima! que orror! q[ue] confusion!

Din, dan, don,

Que truenos! que relampagos!

Que rayos.

Que me anego, me ahogo,

Me abraso;

Ay ay, ay: din, dirin, din, dan, dan.

Din, din, dàn.

Tente Nublado,

Que el Trigo, està en el campo:

Tente, detente,

No mates à la gente:

Pastores repetid, dezid, clamad,

Cielos favor, Astros piedad:

Din, dirin, din: dan, dan,

Din, din, dan.

Mas ya rompiendo el Sol,

La densa obscuridad,

Todo es serenidad,

Que coronando el Cielo

Iris de paz,

Todo es sosiego, Gloria y Claridad:

\section{COPLAS}

1. Zagales, mil norabuenas, pardiobre podemos dàr, 
à la Virgen de Belèn,

y al Niño que en braços trae.

2. Ella, à la he, mos librò,

de vna juerte tempestad,

deve de ser esta Virxen,

Madre de Dios, voto à San.

3. Tantissimos de milagros

ha ${ }^{32}$ hecho, haze, y hará,

que esto de hazer maravillas, no quiere mas que empezar.

4. Pus las campanas à ñublo se tocaron sin cessar,

que repiquen à milagro,

par diobre razon serà.

Los 4. Din, dirin, din, dandan, dan, din, dan,

que lo que fue tormenta,

es ya serenidad.

1. Enojado estava el Cielo

con nosotros Gil Pasqual;

y esto es cierto como ay Sol, pues nos vimos a pedicar.

2. Vna piedra de dos libras

dià à mi suegra, y voto à tal, que està buena, con que tengo suegra de nunca acabar.

3. Yo para hazer vnas migas

estava tostando el pan

$\mathrm{y}$ es que por lo que tronare, siempre es bueno el almorzar.

4. A esse tiempo en mi Cabaña empezaba yo à roncar, $\mathrm{q}[u e]$ en comiendo, duermo vn poco; y en cenando, duermo mas:

din, din, \&c.

1. A vn Calbo le diò en la bola vna piedra garrafal,

${ }^{32}$ En el original, han. 
y sin tocarle en vn pelo,

al punto empezò à chillar.

2. Vn Dotor iba en la mula,

y vn trueno la hizo espantar:

si dura, mata al Dotor:

si mata, dura el curar,

3. Vn Poeta iba ideando

Coplas para Navidad,

y diò tan gran resvalòn,

que no parò hasta San Juan.

4. Como a càntaros llovia,

dixo entre sì el Sacristan:

campanitas haze el agua,

voy a punto à repicar,

din, \&c.

1. Ya escampa y llovian rayos

de hermosura en el Portal,

y es que el Agnus de Inocencio,

serenò la tempestad.

2. A dàr mil gracias à Dios muchos Zagalejos vàn, y el Sol les diria entonces, buenas noches, claro està.

3. En avenida de perlas, venia de mar à mar,

vn golpe de luz tan grande,

que la noche hizo estrellar.

4. En fin, despues del nublado,

el Sol saliò mas galàn;

vino el dia, huyò la noche,

con que quedamos en paz.

din, dirin, \&c.

Biblioteca Nacional. Madrid. (34989-7) (255-5) "Vna danza de Galegos".

Métrica: polimetría, versos osctosílabos y rima asonante. Ensaladilla de lenguas románicas. 
LETRAS DE LOS VILLANCICOS QVE SE CANTARON EN LA PARROQVIAL Iglesia de Señora Santa Ana de Triana.

EN LOS MAYTINES, Y OCTAVA DE LA PVRISSIMA

Concepcion de Maria Santissima Nuestra Señora.

Cantados por la Capilla de el señor San Miguel de esta Ciudad De Sevilla, Año de 1691.

PVESTOS EN METRO MVSICO,

POR DON GABRIEL GARCIA DE MENDOZA,

Maestro de dicha Capilla.

VILLANCICO DE KALENDA.

ESTRIVILLO.

1. Siglos.

2. Tiempos.

1. Horas.

1. 2. Instantes, y hedades.

Todos. Oid, que ya el clarin sonoro rompe el ayre;

y a su dulce co $[m]$ pàs el armonia se escucha de las aves

à la Aurora saludan,

cuyo ser admirable

es Concebida luz,

que de la sombra errante,

ni en tiempos, ni en siglos,

en horas, ni edades

tocò los horrores,

pues se previno en ella

lo flamante.

Por hedades,

por siglos,

por tiempos,

por horas, y por instantes:

COPLAS.

1. Vencedora de las sombras

brillante la Aurora sale, 
que de su horroroso seño

tuvo la excepcion mas grande.

Cho.2. Si, porque nadie dude,

que en todo instante

del poder de Dios tuvo

forma con $\mathrm{q}[u e]$ del riesgo se escapasse.

2. Con su lucida hermosura

las esperanças renacen,

hallando ya para el dia

misteriosas las señales.

Cho.3. Si, que es muy evidente,

que el Sol su amante,

para su intacto olimpo

quiso en la eternidad $\mathrm{q}[u e]$ se animasse.

1. El asseo de su planta

invidia es de los cristales,

manifestando al moverse,

quanto ha llegado à apurarse.

Cho.2. Si, que al bella la Luna

llegò a calçarse,

y logrò en este empleo

toda vna plenitud de lo brilla $[n]$ te.

PRIMERO NOCTVRNO.

\section{VILLANCICO I.}

Al El Icaro de la Gloria,

$\mathrm{q}[u e]$ à vna eternidad de penas

cayò derribando luzes

para quedarse en tinieblas.

Va vn bexamen, pues, sus triunfos

se han convertido en afrentas,

lleve siquiera cordel,

quien nos diò a todos cadena.

Erase vna hermosa Niña

deste cautiverio essenta

coronada de victorias,

aun antes que huviesse guerras. 
Pidela el comun tributo

siendo singular belleza,

ya de ser Dios tan su deudo

que la eximio desta deuda.

Vengo, dixo, de por vidas,

ya de conocer la bestia,

que al Rey he de dar el pecho,

y no puedo ser pechera.

No se acuerda con Miguel

como le fue en la refriega,

pues si esto pudo vn Arcangel,

què esperava de su Reyna?

De oy que mas, el lucero à escuras

no querrà, entablar pende $[n]$ cias

con Niña, q[ue] aun es Dios mismo

Niño de teta con ella.

\section{Estrivillo.}

Querubin despeñado, sufra el bexamen

que postran altivezes

las humildades,

sufralo, y calle,

que si Madre del Verbo

le adora el Angel,

no temen riesgos de Hija,

triunfos de Madre.

\section{VILLANCICO II.}

\section{Introduccion.}

1. Cosa es bien rara,

$\mathrm{q}[u e]$ de alvores el Alva fabrique

la Purpura Sacra.

2. No es cosa rara,

si el Monarca pacifico obstenta

vestirse del Alva.

1. Si es cosa rara, 
$\mathrm{q}[u e]$ la Purpura dize en los Reyes,

la sangre mas alta.

2. No es cosa rara,

que lo candido dize, y publica,

purezas del alma.

Estrivillo.

1. 2. No aya argumentos,

no aya palabras,

$\mathrm{y}$ vniformes al triu[ $n]$ fo mas alto,

cantemos la gala,

no aya argumentos,

no aya palabras.

\section{COPLAS}

Vestida el Alva del Sol

sale à recebir bizarra

triunfos, que contra $1 \mathrm{a}[\mathrm{s}]$ sombras $^{33}$

aun antes de su luz cortò la fama.

Salva le hazen las aves,

tierra, viento, fuego, y agua,

y en tanta salva sonora

solo la dulçura de Maria es salva.

Esta Emperatriz triunfante,

esta Margarita intacta

concebida, pura, y limpia

en vn instante fue, y esta es la gracia.

En aquel càos profundo

era aquesta Reyna Infanta,

la benjamin mas preciosa,

y en la Divina mente muy me $[n]$ tada.

Tanto llegò à merecer

aquesta Ester Soberana,

que la Justicia Divina

con los hijos de Adan se muestra humana.

\section{VILLANCICO III.}

\footnotetext{
${ }^{33}$ En el original, la sombras.
} 
1. A La Domingos venid à folgar,

2. Ay Thoribiño à gayta tocay.

3. A la garridiña,

que a la Cerpentiña

le diò con su pranta vn golpe mortal.

Tod. Festivos decid, co[n]tentos ca[ $n]$ tai

que se ha concebido

para ser de Deus Mai,

andar andar, correr folixai.

E naon pare o son de a gayta,

y contentiños bailai,

andar andar, correr folixai.

\section{COPLAS.}

1. Galeguiña se nos mostra

la Niña de Deus Mai,

pois que con tanta limpeza

se concibe sin igual.

Todos. Andar andar, \&c.

2. Craro està que es Galeguiña,

pois naon se quiso calçar

para pisar nosos campos

os sapatiños de Adan.

Andar.

3. Disen que es valente muyto

sen tener sombras jamàs,

que amaneciò Deus en ela

porque apuradiña està. Andar.

1. Quiso atrevida à su pranta

uà Serpente chegar,

mais dexóle sen peleixo

tan maliciosa maldad. Andar.

2. Hisole con à frutiña

vn coco, mais en verdad;

con golosiña no era

$\mathrm{q}[u e]$ naon la quiso probar. Andar.

3. Mostrò muy grande poder

para tener libertad,

mas que muito si foy sempre

à filla de ò Eterno Pai. Andar. 
1. Os Galegos le hasen festa, y con folganças le dàn prasemes, y parabienes todos juntos à la par. Andar.

2. Dexemos o pan de o millo porque con esta veldad, aunque cuitadiños somos comeremos branco pan. Andar.

3. Naon pare o son de a gaita, soplai Domingos tocai, y el tamboriño Llorente naon sese de repicar.

Andar, andar, correr folixai.

SEGVNDO NOCTURNO.

XACARA.

VILLANCICO I.

Estrivillo.

1. VAya de Xacara, vaya.

Tod. Vaya.

1. Llevo la antigua Serpiente.

Todos. Lleve.

1. No à lo del diablo sea sordo, porq[ue] importa $\mathrm{q}[u e]$ oyga, y lleve; y pues de lo que oy le diga qualquier pobre penitente nunca bien puede pesarle llebarà mal que le pese, vaya de Xacara, vaya, lleve, vaya, vaya, y lleve.

\section{COPLAS.}

1. Oyga esse bravo del tizo, que astuto mas que valiente campava en el mundo solo, porque aconsejò vna muerte.

Digamos como fue aquello 
de caer, tomando adrede

la mañana para nunca,

y la noche para siemrpe.

Que huvo allà quando la imbidia

le cegò viendo patentes,

para su culpa, y sus males

nuestra gracia, y nuestros bienes.

Que leña hizo en aquel monte

donde èl, y sus feligreses

juzgaron subir las sillas,

y cayeron à escabeles.

Diga, el toston del abismo, que lucero inobediente

conserva sobervio el humo

de alquitranado pebete.

Sabe que es la lama hermosa

que oy en vn instante prende

para èl, seculum perignem,

y para nosotros, Requiem?

Sabe, que para reparo

de sus tajos, y reveses

tienen, Redemptoris mater

los exules fili eve.

Sabe, que esta tierna Niña

es aquella muger fuerte,

cuyo acendrado coturno

le ha de raxar el casquete.

Sabe, que este privilegio

la Redempcion le concede

por consequencia en que tuvo

probado el antecedente.

Pues si lo sabe, no calle,

sino publique, confiesse,

engrandezca, adore, alabe,

y si esto no haze, rebiente.

VILLANCICO II.

Estrivillo. 
1. TEmplense las Angelicas citaras, y oygase, $\mathrm{q}[u e]$ en sus metricas clausulas termino, la dulcissima musica pone à las lagrimas.

Cantese, que Maria Santissima vnica, se $\operatorname{co}[n]$ cive sin macula, vnanse, nuestras metricas musicas con las Seraficas.

\section{COPLAS.}

Dios que es el Maestro vnico, de la Capilla, extatica de su eterna Theorica, vn punto fisico pone oy en practica.

Aunque puso lo armonico, en vna sex qui altera, todo le saliò dìsono, menos la minima, $\mathrm{q}[u e]$ oy haze maxima.

A su compàs beatifico no la bolviò en la $\operatorname{tr}[\mathrm{a}] \mathrm{xica}^{34}$ fuga del primer musico, porque su credito fue sie $[\mathrm{m}]$ pre dadiva.

De las harpas profeticas, con armonia enfatica, passò hasta la Apostolica, esta voz inclita, que oy suena pàrbula. Puso el Supremo Artifice en la armonia orgànica deste natural termino, la gracia implicita, pero no tacita. Y pues nuestros hipervoles no pueden celebrarla, canten sus Panegiricos vozes Angelicas, $\mathrm{q}[u e]$ son sus aulicas.

Biblioteca Nacional. Madrid. (VE.1309. -71) "Siglos, Tiempos".

\footnotetext{
${ }^{34}$ En el original, trrxica.
} 
Métrica: polimetría, versos octosílabos, propios de villancico y del romance. Rima asonante. 


\section{LETRAS DE LOS VILLANCICOS, QVE SE HAN DE CANTAR EN LOS SOLEMNES MAYTINES DEL NACIMIENTO DE}

N. Señor JesuChristo, en la Santa, Metropolitana, y Patriarcal Iglesia de esta Ciudad de Sevilla, este año de 1692.

COMPVESTOS POR DON DIEGO JOSEPH DE SALAZAR, Racionero, y Maestro de Capilla de dicha S. Iglesia.

VILLANCICO SEXTO.

Estrivillo.

Gallego.

AY, veñan os G[a]legos ${ }^{35}$,

veñan à baylar, ay,

veñan ver ao Neno,

que en o palleiro jaz:

Ay, das ruas os legos,

das prazas os cegos,

das Grejas os Cregos,

que vinden, è vàn.

Ay, viñan os Galegos,

veñan à baylar, ay.

veñan ver ao Neno,

que en o palleiro jaz.

\section{COPLAS.}

1. VEñan ver ò Neno deitado en à palla, que muito traballa, ainda que he piqueno por tirarle ò feno,

a Mula se chega, se fora Galega non figera tal.

Das ruas os legos, \&c.

2. Veñan ver à Aurora, 
mais branca, è mais pura que en à noite escura de luz se millora: he nosa Señora à Virgen Maria, de quen nace ò dia, que à fixo suà nai. Das ruas os legos, \&c. 3. Para viir mais cedo veñan por lo atallo, poden sen traballo, pois todo era sedo: ò tempo ten ledo, que en oge camiña coà ventaliña suaue que fai. Das ruas os legos, \&c.

4. Veñan dos oteiros, veñan das malladas, Zagalas prezadas, mozos pracenteiros: deixen os obreiros, ò servicio e gado, pois nos dà ganado, ò Ceo el caudal.

Das ruas os legos, \&c.

\section{TERCERO NOCTVRNO}

VILLANCICO SEPTIMO.

Introduccion.

1. MAno à mano dos Poetas

à Belen vienen corriendo, à hazerle al Niño vnas Coplas à su Santo Nacimiento.

2. El vno es muy presumido

\footnotetext{
${ }^{35}$ En el original, Golegos.
} 
de que haze cultos sus versos,

y el otro en estilo baxo

solo explica sus conceptos.

3. Atencion, que echan entrambos

de repente, y considero,

que al ver lo Diuino humano

han de hablar de los Cielos.

\section{Estrivillo.}

Chiton que ya empiezan,

quedito, silencio,

que la Noche buena

con ellos tendremos:

quedito, silencio,

à el oìr que ingeniosos, $\mathrm{y}$ amantes

cada vno en su estilo

explica su afecto:

quedito, silencio,

que la Noche buena

con ellos tendremos:

quedito, silencio, silencio.

\section{COPLAS.}

1. A El ver nacer entre pajas en el erizado Ibierno

à el gran Dios de las Alturas, por essos trigos echemos.

2. Echemos mas reverentes, con devocion empezemos adorando, Verbum caro, tantum ergo Sacramentum.

1. Gima a el verle la Serpiente, que à Adan le diò su veneno, y à este fulgurante Astro rinda su indomito cuello.

2. Gima viendo, que ha venido à destruir el infierno, y que ha querido ser Hijo por ser solo Padre nuestro. 
1. Todo el Cielo en sus dos Soles mira mi atencion, y en ellos

liquidas hermosas perlas amante quaxa su incendio.

2. Que las derrama por todos es constante, y segun creo, por el hombre se verà hecho vn Jesus Nazareno.

1. Ro[m]pa, pues, vuestra presencia la cadena, cuyo yerro, eslabonado Provincias cautivo haze el vniverso.

2. Esso intenta, y el tamaño es muy hombre para ello, conque esta noche nos viene como nacido el consuelo.

1. Desterrad con vuestas luzes el lugubre trage negro, que en la noche de la culpa vistiò nuestro ingrato pecho. 2. Si lo harà, que sabe mucho, y tiene poder inmenso, y para vecerlo todo, que se haze chiquito entie $[n]$ do.

\section{VILLANCICO OCTAUO.}

\section{Estrivillo.}

QUè es esto Niño hermoso?

Niño admirable?

Uos sois el Dios terrible, vos el Rey gra $[n]$ de, y sois el que naciendo pequeño Infante mis tibiezas, mis culpas, llorando os traen à que os cueste sollozos, buscar mis ayes.

\section{COPLAS.}

1. QUè es esto mi Dios, quien pudo imaginar que obstentaseis en la ternura de Niño 
la gran robustes de amante?

$\mathrm{Y}$ à q[ue $]$ os cueste sollozos, buscar mis ayes?

2. Què es esto Señor, quien mueve

vuestra piedad inefable

à sacar de enfermo al hombre

dexando morir al Angel?

Y à q[ue $]$ os cueste sollozos, buscar mis ayes?

3. Mas que dudo, si obligado

estais, proque vuestra imagen

borrada otra vez se pinte

à nacer su semejante.

Y à q[ue $]$ os cueste sollozos, buscar mis ayes?

4. Què dudo, si en testimonio

de vuestro amor entrañable

à ser mi vida, y sustento

naceis hecho Carne, y Sangre?

$\mathrm{Y}$ à q[ue $]$ os cueste sollozos, buscar mis ayes?

Biblioteca Nacional. Madrid. (VE. 1301) (479-1). “Ay, veñan os Galegos”.

Métrica: aparecen frases de Latín cultual, versos octosílabos, rima asonantada. 


\section{LETRAS DE LOS VILLANCICOS QVE SE HAN DE CANTAR LA NOCHE de Nauidad en la Iglesia Colegial de nuestro Señor San Saluador de Seuilla este año de}

1692.

PRIMERO NOCTVRNO.

\section{VILLANCICO I.}

Kalenda.

\section{Estriuillo.}

PVes gloria en el Cielo,

y paz en la tierra,

publica para gozo el Serafin

Pastrores aclamad,

Querubes aplaudid,

y albricias alternando mil a mil,

à coros repetid,

que en Angeles, y hombres

diferenciado assi,

la tierra serà Cielo,

como el Diziembre Abril.

A coros repetid,

que eterno Sol brillante

de nueuo Oriente le vera salir,

a todos à vna voz

festiuos prorrumpid:

Venid, Señor, venid

à ser la noche buena

el dia mas feliz:

Venid, Señor, venid, \&c.

\section{Coplas.}

QVando de alados Querubes

se puebla todo el confin,

quiere ser teatro el ayre

de mas luzes q[ue] estrellas viô el zafir.

A coros repetid,

que eterno Sol brillante, 
de nueuo Oriente se vera salir.

2. Desde la esfera Celeste

en Belen veran luzir

noche que dar pudo al dia

embidias mas que aplausos tenga en si.

A coros repetid, \&c.

3. Todo el Portal ve asso $[m]$ bros

y las plantas produzir

contra el orden natural

flores, porque el Diziembre

fuesse Abril.

A coros repetid, \&c.

4. Las Aues desde su alvergue

en armonia sutil

sera todo agradecer

parabienes, que el Alua vé aplaudir.

A coros repetid, \&c.

5. Los ho $[m]$ bres co $[n]$ alboroços

agradecidos alli

festejaron el contento

de la felicidad del conseguir

A coros repetid, \&c.

\section{VILLANCICO II.}

Estriuillo.

VN Papagayo traen los Pastores

para festejo del Niño Dios hombre;

oygan $\mathrm{q}[u e]$ habla, oyga $[n] \mathrm{q}[u e]$ canta

y haze sus passos tambien de garganta.

Tiene misterio, $\mathrm{q}[u e]$ en este caso

arguye à hombres con ser Papagayo.

Noten su acento, oygan sus vozes,

mas que palabras pronuncia razones

Vn Papagayo trae $[n]$ los Pastores.

Coplas.

1. COmo estàs Loro? 
2. Como cautivo de amor prodigioso, pues vn Infante

Viene a la tierra del seno del Padre, oy le hemos visto, que para el mundo le viene nacido.

1. Dime, quien passa?

2. En esto ay mucho que hablar, y sus traças passan mentiras, hombres, y casas labrò la malicia, que no componen sin priuilegios del Rey Dios y hombre.

1. Que ay Cotorrero?

2. Ay mucho malo, aunque ay mucho bueno, malas ausencias, la Caridad no ha passado de Illescas; todo es embidia por los establos la Sabiduria

1. Canta vn poquito.

2. Si [...] por el Niño Diuino que siendo incendio, oy ha venido a nacer en el yelo, y entre animales, que estos abundan en todas las partes.

1. Dime tus gracias:

2. Preso, y cautiuo, y ociosas las alas; hablo muy claro, mas sin perder el respeto al recato, peyno mi pluma, pero en mi jaula no embidio ninguna.

1. Como te ha ido?

2. Siruo a mi Dios, ya mi Rey en mi oficio, y esto no basta, pues los Zagales me suelen dar baya, que por su antojo, ellos quisiera $[n]$ hablarselo todo. 
1. Di, que mas sabes?

2. Sé defenderme de los animales, que por mi pico,

ni vña, ni diente se vè en mi distrito,

que en todo caso

es natural el derecho al amparo.

1. No eres muy bobo.

2. Aunque animal ya no es tie $[m]$ po de tontos,

soy enseñado,

$\mathrm{y}$ al experiencia es maestra

en los casos.

y en esta jania

adoro a Dios, pues tambien

tengo alma.

\section{VILLANCICO III.}

\section{Estriuillo.}

AY mi Nino que chora

por meu bein meu mal,

le, le le, todos festexaid,

le ,le le, que sen belo chorar

que naun de Castela,

que he de Portugal;

po aqui por ali,

por aca, por ala,

deu lindu amor finezas lembrai,

le, le, le, que naun poso mais.

\section{Coplas.}

QVanto mais mi Nino chore, mas valente pode ser, porq[ue] ainda masi sente muito quein tein muito que querer è non pode ser que chore de amor sin ser Portugueis;

le, le, le, por aqui por alli, 
por acà, por alà,

dou mi lindu amor finezas

lembrai;

le, le, le que non posso mais.

Chora triste, è magoado,

porque naon tein $\mathrm{q}[u e]$ vencer,

que en vendo a meu Nino o mundo,

se le ha ficado a seus pes.

E naon pode ser, \&c.

Tener brando o coraçon,

e ser fiño Portugueis

que fanfarron Castexao

de pedra coraçaon tein.

E naon pode ser, \&c.

E tembrar inda è valor,

e naon se debe entender

que en valentes è tembrar

lo que en galiñas temer.

E naon pode ser, \&c.

El amor naceo en Lisboa,

que ainda està en Belen,

como es Deus en todo te $[m]$ po,

face semper seu querer.

E naon poder ser, \&c.

SEGVNDO NOCTURNO.

VILLANCICO IV.

Introducion.

EL Saluador de los ho[ $m]$ bres

oy en vn Portal se obste[ $n]$ ta

como pobre siendo Rey,

pidiendo el que dà riquezas.

Y como el pecho del hombre

tan auaro considera,

pide llorando, porque

con su llanto se enternezca. 


\section{Estriuillo.}

AY quien le dè a Dios por Dios?

aura alguna alma $\mathrm{q}[u e]$ atienda

al gran dolor con que pido,

pues $\mathrm{q}[u e]$ lagrimas me cuesta?

Limosna mortales

al que de su alteza,

por ser vuestro hermano,

baxò a esta pobreza:

Con llanto os la pido,

limosna, que de ella

tendreis de mi Padre

mayor recompensa.

Y el vltimo dia,

despues de la cuenta,

oireis de mi boca

dezir con terneza:

hambre tuue, y de comer me disteis,

tuue sed y bebi el agua vuestra,

me vestisteis esta $[n]$ do desnudo

y esta $[n]$ do sin casa me hicisteis Iglesia,

venid de mi Padre

benditos, y sea

por temporal obra

vuestra dicha eterna.

Coplas.

LLoro por $\mathrm{q}[u e]$ ho $[m]$ bres ingratos

vie$[n]$ do que baxé a la tierra

por saluarlos a vn Portal,

$\mathrm{q}[u e]$ esté en vn Portal co[n]sie[ $[n] \tan$.

Ya Niño mio

Seuilla espera

ver puesta en forma

sacra materia.

Lloro porque vine al mundo

llenando de mis riquezas

al hombre, y para mi casa

aun las primicias me niega. 
Para tu casa

dorada mezcla

darà el mas duro

si tu le riegas.

Lloro viendo que no ay ho[ $[\mathrm{m}]$ bre

que altiuo, y vano no tenga

puesta su piedra en lo alto,

y no la tenga en mi Iglesia.

O Dios inmenso!

que nuestras deudas,

por mal pagadas

cobras en piedras.

Lloro, pues siendo mi Madre

fue $[n]$ te de aguas de cleme $[n]$ cia,

entre el tener Templo, ó no,

entre dos aguas se queda.

Cesse tu llanto,

que ya se esperan

de ardientes pechos

nobles ofrendas.

VILLANCICO V.

Estriuillo.

NIño tu fineza adoro,

y de esso lloro

pero como el llanto es mio,

de esso me rio.

Coplas.

COmo miro tu pobreza

en lo vmilde de vn Portal

y que mi bien, y mi mal

ocasiona tal fineza,

no es en mi amor estrañeza

el dezir por tu decoro,

Niño tu fineza adoro,

y de esso lloro. 
Lloro, pero sin violencia, sintiendo verte sentir, y mirando que a morir vienes con esta experiencia: intento hazer resistencia del llanto con que porfio: pero como el llanto es mio, de esso me rio.

De mi culpa, y de tu pena yo solo tengo la culpa, pero merece disculpa culpa de dicha tan buena: mas si de disculpa agena fuere culpa que no ignoro, Niño tu fineza adoro, y de esso lloro.

Qua $[n]$ do entre la escarcha, y yelo te contemplo reclinado, me duelo de mi pecado, y de tus penas me duelo: buscote en el desconsuelo por templar mi desvario, pero como el llanto es mio, de esto me rio.

Biblioteca Nacional. Madrid. (249-1. ). "Pves gloria en el Cielo".

Métrica: polimetría con versos octosílabos, propia de los villancicos. Rima asoannte y rima a veces consonante. 


\section{VILLANCICOS QVE SE HAN DE CANTAR EN LA REAL CAPILLA DE SV MAGESTAD LA NOCHE DE NAVIDAD, ESTE AÑO DE M.DC.XCIII.}

VILLANCICO III.

\section{INTRODVCION.}

ATADAS vozes à solfa

De vna Italiana Sonata,

Que pulsa en el clavicordio

La mano mas Soberana.

Sirven al Niño en cadencias,

Que dos vezes son esclavas

Del precepto, y de la solfa,

Que à este estrivillo se enlaza.

\section{ESTRIVILLO.}

1. PVES se duerme el Dios Niño.

2. Pues las flechas desca $[n]$ san.

3. Pues las plumas no buela $[n]$.

Pues depone la aljava,

Mientras duerme, le sirva de arrullo

la dulce sonata.

Con los coros, las lyras, las vozes, las arpas.

Y la cuna meciendo con tierna armonia,

De metros canoros, y cuerdas templadas, Respiren ternuras de arrullos sonoros, las arpas, las voces, las lyras, los coros,

\section{COPLAS.}

SI tu duermes, ò Dios Niño,

Que yo dexe de adorarte,

No, no, no lo sueñes,

Que serà mi Dios jamàs

Pues quererte siempre mas,

Te promete mi cariño,

Mientras velo, duerme tu,

Lograràs en mi afan 
Las lisonjas de la cuna;

Que el amor mecer sabrà, Mas servirte sin amarte;

No lo sueñes, ò bien mio!

No, no, no lo sueñes,

Que serà mi Dios jamàs.

SI tu sueñas, ò mi vida!

Que yo quiera no velarte:

No, no, no lo sueñes,

Que serà mi Dios jamàs.

SI tu sueñas, ò mi vida

que yo quiera no velarte

No, no, no lo sueñes

Que serà mi Dios jamàs.

Pues tus ojos flechan mas

Disparando luz dormida,

Mientras dulce duermes tu,

Lograràs en mi afan

Los arrullos de la cuna.

Que el amor mecer sabrà,

Mas flecharme sin quererte,

No lo sueñes; ò bien mio!

No, no, no lo sueñes,

Que serà mi Dios jamàs.

\section{VILLANCICO IV.}

ESTRIVILLO.

GILGVERILLO canoro, no cantes

Que duerme el Amor.

2. Gilguerillo no dexes el canto

Que no duerme Amor.

3. Gilguerillo, gorgeos suspende,

Que duerme el Amor.

4. Gilguerillo prosigue los quiebros

Que no duerme Amor.

Los dos. Si duerme el Amor.

Otros dos. No duerme el Amor. 
Si, si, si,

No, no, no.

1. Si duerme templando los ojos

Las Luzes del Sol,

Si, si, si,

No, no, no,

4. No duerme pues arde su pecho

con tierna passion,

No, no, no,

$\mathrm{Si}$, si, si.

3. Si duerme, pues dora los rayos

Suspenso arrebol.

Si, si, si,

No, no, no.

4. No duerme, pues sienten las almas

La flecha veloz.

4. No duerme, que el arco

Mi pecho abrasò,

Causando las pajas

Incendio mayor.

No, no, no,

No duerme el amor,

Si, si, si,

No, no, no.

Pues digan cadencias,

Vniendo la voz,

Si duerme el amor,

No duerme el amor,

Velando ternuras

De su coraçon.

Si, si, si,

No, no, no.

\section{COPLAS.}

SI duerme quien sueña

Del hombre el perdon.

Haziendo dormido

Que no vee su error.

Si, si, si, 
Si duerme el amor.

No duerme, pues llora

Con tierna passion,

La culpa del hombre,

De que es Redemptor.

En la humana porcion sonando empeños.

De venzer de Luzbel el frenesi,

Gozosa la Deydad, quedò Encarnada,

(A tanto triunfo) por poder morir.

Naciendo Dios passible,

Assi pudo teñir,

Blasones de su Sangre,

En roja Cruz feliz.

Sonando en la Deidad los resplandores.

Con que al barro de Adan se quiso vnir,

Dios Hombre ennobleciò la tosa estirpe.

Naciendo para ser fuerte adalid.

A costa de sus venas,

Al que era barro vil,

Ofrece renovarle,

Con lustres de carmin.

Resuene acorde lid, \&c.

En la humana porcion, sonando acentos

Del triunfo, de que sombra fue David,

Se inflama la Deidad, y en la campaña,

Trocò à vm Pesebre el Solio de Zafir.

Naciendo entre Pastores,

En sombras se viò alli,

La honda, que al Gigante

Sobervio ha de rendir.

Sonando en la Deidad, que la Corona

Mas esmaltan las Penas, que el Rubi

El Hombre Dios, dorò con rubias pajas

El penoso Laurel que ha de ceñir.

Laureles son las pajas,

Mostrando que es assi,

Quien labra la Corona,

La Frente, y no el Ofir.

Resuene acorde lid, \&c. 
VILLANCICO II.

GALLEGO.

INTRODVCION.

MVy devotos por descalços

A Belen vàn los Gallegos,

$Y$ al Niño, assi con la gayta

Le festejavan, diziendo:

\section{ESTRIVILLO.}

TVCA Gayteru, tuca Gayteru,

Que ò Niño se rie de noso festejo.

Tuca Gayteru, tuca Gayteru,

Resone, resone, ò à gayta resone,

Que baylan Pastores;

Resone, resone, resone, ò a gayta,

Que baylan Zagalas,

Rebulla ò sonido, rebulla, rebulla,

Que sona ò [à] gayta mas ben que bandurrias.

Rebulla, rebulla,

Resone, resone,

Retumbe, repique,

Que sona ò à gayta mejor que violines;

Gayteru resone,

Resone Gayteru,

Non cesse ò bollicio,

De acordes acentos;

Toca Gayteru, toca Gayteru,

Que ò Niño se rìe de noso festeju.

COPLAS.

\section{TUCA Gayteru,}

Que alegran à ò Niño

Los dolces acentos;

Y ào son de à gaytiña,

Se paran os Cielus.

2. Tuca Gayteru, 
Que nosas canciones

Imitan os buelos,

De os Angeliños,

Que corren ò ventu.

3. Tuca Gayteru,

Que os Serafiñes

Que bolan ligeros,

Parece que baylan,

$\mathrm{O}$ as alas vatendu.

4. Tuca Gayteru,

Que os Cherubiñes

cantandu dixerum,

Que o Niño que nace,

es Fillo de Deus.

[...]. Tuca Gayteru, tuca Gayteru,

Que mas es ò Niño,

Que o Conde de Lemus,

Tuca Gayteru, tuca Gayteru.

4. Tuca Gayteru,

Que ò Cura de Lugo

Nos dixo en ò Templo,

Que ò Niño vn Tesoyro

Gardava encuberto.

2. Tuca Gayteru,

Que à su Mayordomu,

Despois le veremus,

$\mathrm{Y}$ pode pagarnos,

$\mathrm{Y}$ ricos fazernos.

3. Tuca Gayteru,

Que si ay Maordomus,

Yo verlos non quiero,

Que nunca es possibre

Sacarles dineru.

4. Tuca Gayteru,

Que no es de essus hombres

Que su Tesoreiru,

Tamben dixo el Cura

Que lo era San Pedru.

4. Tuca gayteru, tuca Gayteru, \&c. 
1. Tuca Gayteru,

Que sendu tan ricu

De ò Niño fiemus,

Nos pague, ò trabaju

De estarle servendu.

2. Tuca Gayteru,

Que ò cura dezia,

Que en todus, de certu,

Segun os trabajus,

Serian os premius.

Bilbioteca Nacional. Madrid. (VE.88-82-1). "Atadas vozes a Solfa.".

Métrica: muy variada, rima asonante, ensalada de lenguas. Endecasílabo antiguo procedente de la cultura popular gallego-portuguesa. 


\section{LETRAS DE LOS VILLANCICOS QVE SE CANTARON EN LOS SOLEMNES MAITINES DE NVESTRA SEÑORA DE LA CONCEPCION, EN LA INSIGNE \\ IGLESIA COLEGIAL DE NVESTRO SEÑOR SAN SALVADOR DE SEVILLA. COMPVESTOS POR DON SALVADOR GARCIA. \\ Maestro de Capilla de dicha Iglesia. \\ Este año de 1693.}

VILLANCICO TERCERO.

CHANZA.

ESTRIVILLO.

EN la fiesta alegre, la, lai, la, de la Concepcion, la lai la, la li lailon, que tamborili borilero soy: la lai la, la la li lailon, atiendan, escuchen, que traygo vn buen son que cantar en postigos, y en puertas de aquesta Ciudad vn Misterio de Dios, la lai la, la la li lailon, que tamborili, q[ue] tamborili boriloro soi.

\section{COPLAS.}

En la Puerta del Ossario, con singular prevencion de la costilla de Adan el yerro nunca heredò, la lai la, la la li lailon, que tamborile borilero soy. Juro à Dios, que fue Maria muy clara en su Concepcion, pues la Trinidad la tuvo, siempre en la Puerta del Sol, la lai la, \&C.

De Cordova, al fin la puerta, palma, y corona le diò, 
con los aplausos de vn Rey, junto con Virgines dos, lai la la, \&c.

De Macarena en la Puerta para su preservacion, tiene en vn grande Hospital, toda la Sangre de Dios, lai la la, \&c.

La Puerta de la Barquerta zozobrar nunca la viò, porque es Nave que la rige, Piloto el Divino Amor, la lai, \&c.

En la Puerta de San Juan, dize vna Aguila veloz, que todo el Sol la ha vestido, y La Luna la calçó, lai la la, \&c.

Allà en la Puerta Real, por decreto superior, la Merced preservativa, le diò feliz redempcion, lai la, \&c.

En la Puerta de Triana, para conservar la voz de sus purezas, el zelo, todo el Populo juntò lai la, \&c.

La Puerta del Arenal, defendiendo su explendor, de mar à mar, vna calle toda de armas la llenò, lai la, \&c.

Hizola muy preservada la Caridad del Seño, del Postigo del azeyte, y el Postigo del Carbon, lai la, \&C.

En la Puerta de Xerez, 
para glorioso blason

hallò la Sabiduria,

en el Colegio Mayor,

lai la, \&c.

En la Puerta del Socorro

con grande veneracion,

con solo vn Dominus tecum

tuvo el anuncio mejor,

lai la, \&c.

En la Puerta de Carmona,

Via Sacra descubrió,

y con vn persignum Crucis

dexò vencido al Dragon.

SEGVNDO NOCTVRNO

\section{VILLANCICO QVARTO.}

\section{Estrivillo.}

Niña, llena de Gracia,

oye, atiende,

que pretendo pintarte,

mucho parece!

mas el zelo con arte,

devoto siempre,

sin tocar en las sombras,

pintarte puede.

\section{COPLAS.}

Lo hermoso de tu cabello, bello el primor que le emprende, prende, y en hermosa mata, ata Estrellas à tus sienes.

$\mathrm{Si}$ en ser tu frente espaciosa, ossa el Sol lo que se adquiere, quiere tu luz que lo ampara, para quemas, el se afrente.

Sus cejas, que amor dispuso, puso en arco, que si quieren, 
hieren la invidia con flechas, hechas à vencer Serpiente.

Tienes por dulces despojos, ojos, que la luz que obtienen, tienen por Gracia prevista, vista la que los prefiere.

Tu Boca de si prendada, dada al bien que en ti previene, biene à ser en tal empressa, essa de tus gracias breve.

No hallò en tu barba, ni apoyo, hoyo, ni en lo que contiene, tiene la vista hecha à cosa, cosa alguna en que tropiece. Y pues contra la desgracia, gracia tienes evidente, dente el lauro por consuelo, suelo, y Cielo te celebren.

Biblioteca Nacional. Madrid. (V.C $\left.{ }^{a} \cdot 92-39\right)$. "En la fiesta alegre la, lai, la”.

Métrica: versos octosialbos, rima asonante, a veces de forma litànica, bien en letanías o en romance. 
LETRAS DE LOS VILLANCICOS QVE SE CANTARON EN LA INSIGNE

Iglesia Colegial de Señor San Saluador de Seuilla en los Solemnes Maitines del

Nacimiento de nuestro Redentor Iesu Christo. En este año de 1693.

Siendo Maestro de Capilla de dicha Colegial el Licenciado Don Saluador Garcia.

PRIMERO NOCTVRNO.

VILLANCICO I.

de Kalenda.

Estriuillo.

AVezillas $\mathrm{q}[u e]$ al vie $[n]$ to girais,

con buelo veloz atencio[ $n]$,

suspension,

suspended, auezillas, la pluma, y la voz,

oireis deste Niño en coros suaues

milagros de amor.

Atencion,

y los cielos celebre $[n]$ sus glorias

con dulce primor,

y festiua le cante la gala

nuestra deuocion.

suspension, suspension.

Coplas.

A Las glorias de vn Rey niño

que en pajas le puso amor,

atencion,

en Belen haze $[n]$ Fiestas Reales

humano, y Diuino del cielo

esquadron.

Suspension, suspension.

Los Pastores, que auisados

se ciegan al explendor,

atencion,

admirados dixeron al verle,

por Dios que estas luzes son

luzes del Sol. 
Atencion, suspension.

De Celestes Hierarquias

dulce resuena la voz,

[a]tencion ${ }^{36}$,

e ilustra[n]do la esfera de rayos

es cada buelo del alma prisio[ $n]$.

Atencion, suspension.

Vna Rosa, que a fragrancias

es Rosa de Iericò,

atencion,

al Infante entre fajas humildes

le abriga, y en telas de su coraçon.

Atencion, suspension.

\section{VILLANCICO II.}

\section{Coplas.}

PRocurad q[ue] duerma el Niño, Señora, en los braços vuestros, que es el pesebre muy duro y vuestro Hijo muy tierno. Procurad que dexe vn poco de llorar tan tristes duelos, pues sabeis que los q[ue] siente no son suyos, sino nuestros.

Dadle para reclinarse essos virginales pechos, que para que Dios descanse no ay otros como los vuestros. Si ha de hazer Cielo el Pesebre mejor sois vos para Cielo, pues lo so[n] vuestras entrañas, donde se encarnò esse Verbo. No le negueis vuestros braços hasta que los suyos tiernos, de ser puestos en la Cruz se aya llegado el tiempo.

\footnotetext{
${ }^{36}$ En el original, etencion.
} 
Pues que baxan à adorarle

los Angeles hasta el suelo.

sed vos, Señora, el Altar

en que adoren tal Cordero.

Estriuillo.

PVes del agua que bierten

sus ojos bellos,

tiene gloria la tierra,

y el Cielo zelos.

\section{VILLANCICO III.}

Chança Gallega.

Estriuillo.

A Bailar Galegos, Galegos à bailar, que ya veis nacido noso mayoral, repica ò pandeiro, è veni à bailar, que à gaita Galega toca Anton Pascoal, à boltechar Domiño, Domiño à boltechar àò son de à gaita $\mathrm{q}[u e]$ toca Anton Pascoal.

Coplas.

1. ALegraos, que ò Ceo

està en lo Portal

lleno de Angeliños

que veñen a bailar.

A boltechar Domiño,

Domiño à boltechar

àò son de à gaita

que toca Anton Pascoal.

2. En lo chocorrotiyo

tan fermoso estay,

que roba as vidas

solo con mirar.

A boltechar Domiños, \&c.

3. Sua cara es de prata, sua boca coral, 
é tein dos luzeriños

para nos alumbrar.

A boltechar Domiños, \&c.

4. V Sol resplandece

en la sua faz,

è sua Mai fermosa

eis otra que tal.

A boltechar Domiño, \&c.

5. Es tan fermosiño,

que posse apostar

à serlo con Deus,

é naun perderai.

A boltechar Domiños, \&c.

6. Aunque es pobreziño,

es de alto solar,

pois por su Pai vein

de la Trinidad.

A boltechar Domiños, \&c.

7. Chorando de frio

en lo feno estay,

e à palla enriqueze

solo con chorar.

A boltechar Domiños, \&c.

8. Naom choreis Minino,

porque ballen mais

essos pucheriños,

que este meo gaban.

A boltechar, \&c.

Biblioteca Nacional. Madrid. (V.E. 79-5) (489-1). "Avezillas q[ue] al vie[ $n]$ to girais".

Métrica: versos octosílabos y hexasílabos y rima romanceada. 
LETRAS DE LOS VILLANCICOS, QVE CANTARON EN SVS BAYLES LOS

Niños Seyses de la Santa, Metropolitana, y Patriarcal Iglesia de Sevilla, este año de 1693, en la solemnissima fiesta, y octava del SS. Sacramento.

ESCRIVIALAS

DEDICANDOLAS A LAS DOS SOBERANAS MAGESTADES DE

N. Señor Jesu Christo Sacramentado, y de Maria Santissima su digna Madre, su indigno Esclavo

DON ALONSO MARTIN BRAONES.

\begin{abstract}
DEDICATORIA
A la Magestad de Jesu Christo Sacramentado.

Voluntarie sacrificabo tibi, et confisebor nomini tuo Domine quoniam bonum est.

Quoniam ex omni tribulatione cripuisti me, Ps. 53.
\end{abstract}

1. COn el alma, y corazon,

ò Jesus Sacramentado,

te amo, porque me has librado

de toda tribulacion;

Gracias te dà mi atencion,

que te adora, Dios propicio;

y por tan gran beneficio

de alabança, eternamente,

te darè, Señor clemente,

voluntario Sacrificio.

2. Lo que oy de ti escrivo, y canto

te ofrezco, puesto à essos pies,

quando, porque bueno es,

confiesso à tu nombre Santo;

Admitelo al ver mi llanto;

que de ti piedad espera;

y tu Deidad verdadera

me libre, ampare, y assista

quando à mi el espiritu embista

la tribulacion postrera. 
A MARIA SSMA. MADRE DE DIOS, Y REYNA DE LOS ANGELES.

Ave gratia plena, Dominus tecum, benedicta tu in mulieribus. Luc.1.

1. MI voz, Sagrada Azuzena,

al Pan de Angeles alabe,

saludando tu luz: Ave

Maria de gracia llena.

2. A tu alabança me obligo,

y del Pan viuo al honor,

porque eres con el Señor,

porque el Señor es contigo.

3. Canto, que bendita eres

y que exaltò de tu Alteza

el Pan Sacro la grandeza

entre todas las mugeres.

4. Recebid mi humilde escrito,

que pongo à essos pies postrado,

tu, y de tu vientre Sagrado

Iesus el fruto bendito.

5. Santa Maria, que oy ores

pide quie $[n]$ su amor te entriega;

Madre de Dios, ora, ruega

por nosotros pecadores.

6. Que veamos la eterna Luz

pide aora, Muger fuerte,

$y$ en la hora de nuestra muerte.

Assi sea. Amen Iesus.

IESVS, MARIA, Y JOSEPH.

VILLANCICO PRIMERO.

Estrivillo.

EN la Mesa del Pan inefable,

al comer el Divino alimento;

vn afecto en amores se abrasa,

en temores se pasma otro afecto.

COPLAS. 
1. El amor que el Pan de vida

Divino enciende en mi pecho;

entre yelo afectuoso

arde afectuoso fuego.

2. El temor que al recebirle

ocupa todo mi aliento

entre ardores condensado,

viue condensado yelo.

3. Amar à vn Dios tan amante es del amor digno empeño;

porque à su obsequio amoroso

se debe amoroso obsequio.

4. Reverenciar lo Divino

es del temor noble empleo;

que en respetos Soberanos

es Soberano el respeto.

5. Alma, del Pan consagrado

no te prive el justo miedo;

llega al que temes amando,

y come al que amas temiendo.

6. Arde, y teme, pasma, y ama, pues que te dà el Pan del Cielo, fuego que al yelo mitigue,

y yelo que temple al fuego.

\section{BAYLE.}

1. Cada vez que recibo

el Celeste alimento

vn Diuino contento

en el alma percibo;

Y luego me apercibo

à mayores favores.

Ay,

que me abraso de amores

por este Pan de flores.

2. Quando al Pan consagrado

acercarme deseo,

como indigno me veo

voy con passo turbado; 
Y al comerle pasmado

tiembla humilde el rezelo.

Ay,

que en temores me yelo

por este Pan del Cielo.

3. Tanto al alma le inflama

este Pan de la vida,

que se abrasa encendida

en tan Divina llama;

Amando à quien la ama

con tan nobles primores.

Ay,

que me abraso de amores

por este Pan de flores.

4. Como veo que guarda

aqueste Pan bendido

al que es Dios infinito

el alma se acobarda:

$\mathrm{Y}$ aunque en amores arda

và con timido buelo.

Ay,

que en temores me yelo

por este Pan del Cielo.

5. Este Sol tan hermoso,

que luzido portento

se dà en gran Sacramento

es vn Dios Poderoso;

Que retira amoroso

su luz, y resp[1]andores.

Ay,

que me abraso de amores

por este Pan de flores.

6. Aunque Dios tan propicio

con su Pan me alimenta,

mi temor se acrecienta

con tan gran beneficio;

Pues tremendo el juyzio

comer teme el desvelo.

Ay, 
que en temores me yelo

por este Pan del Cielo.

\section{VILLANCICO SEGUNDO.}

\section{Estrivillo.}

EN el Pan de flores

quien dirà si es

Jesus nuestro amante

Jazmin, ò Clavel!

\section{COPLAS}

1. Es Jazmin, que en cinco hojas cinco Llagas tiene, en que los que arroyos de corales, son golfos de rosicler.

2. Es Clavel, pues Flor intacta le diò el encarnado ser; aunque vna crueldad le hizo que disciplinado estè.

3. Es Jazmin, que a su fragra $[n]$ cia correr las almas se vèn; y albo excede de la nieve la hermosura, y candidez. 4. Es Clavel, pues de carmines le hizo la embidia el laurel, y de purpura el vestido por ser de las Flores Rey.

5. Es Jazmin, pues exaltado de la tierra à padecer; fixo estuvo, y arrimado de la Cruz à la pared.

6. Es Clavel, pues que tres clavos en las manos, y los pies

Clavel le hizieron, abriendo fuentes quatro à nuestra sed.

BAYLE

1. A este Jazmin blanco, 
y roxo Clavel,

que en el Pan de Flores

se llega à atender:

que, que, que, que

festivo, devoto, y amante

yo le cantarè

que, que, que, que

en la lira templada,

sonora, y alegre

que toca la Fè.

2. A este fertil grano, que pudieron ver

Nazareth sembrado

nacido Belen:

que, que, que, que.

3. A esta hermosa Espiga,

que quiso nacer

en la Virgen Tierra

de vn Sacro Vergel:

que, que, que, que.

4. A este Pan Divino

con quien sombra fue

el del Sacrificio

de Melchisedech.

que, que, que, que.

5. A este Sacramento,

que ostentacion es

de Sabiduria,

Amor, y Poder:

que, que, que, que.

6. A este Sol inmenso,

cuyo rosicler

se vè por resquicios

se vè por resquicios

de blanco cancel:

que, que, que, que.

VILLANCICO TERCERO. 


\section{Estrivillo.}

Math. 22. Luc. 14. Apoc. 19.

Hvmildes venid, obedientes llegad;

venid à la Mesa del Rey de los Reyes,

llegad à comer el Divino manjar;

venid que os combida la Real Magestad.

Venid, llegad.

\section{COPLAS}

1. Venid à la Cena grande, que el alto Rey Celestial haze poderoso, en muestras de su liberalidad. Venid, llegad,

2. Llegad à la Sacra Mesa, puesta en la Solemnidad de las bodas de su Hijo, à quien quiere le assistais, Venid, llegad.

3. Venid pobres, o llegad ciegos donde os administraràn el que de los elegidos es Pan sobre sustancial. Venid, llegad.

4. Llegad debiles tullidos comereis aquel Manà, compendio de los deleytes, cifra de la suavidad.

Venid, llegad.

5. Venid hambrientos, que viuo vn Cordero os saciarà, que los dignos le comen gozan de vida inmortal. Venid, llegad.

6. Llegad, que los Poderosos se han embiado à escusar, y de ellos Varon ninguno esta Cena gustarà. 
Venid, llegad.

7. Venid à suplir su falta de que por disculpas dàn la Esposa, las cinco iuntas, y la comprada heredad. Venid, llegad.

8. Llegad, mas vestid primero, pues preuenidos estàn, para que llegueis decentes ropages de caridad.

Venid, Llegad.

9. Venid, que à nadie exceptua de fauor tan singular; mas ay de aquel, que el Rey viere sin el vestido nupcial.

Venid, llegad.

10. Llegad a llenar las bodas,

En cuyo combite Real, siendo muchos los llamados, pocos electos estàn.

Venid, llegad,

\section{BAYLE}

1. Chegad os meus Galeguiños àò Sacra Mesa dà Altar, que aqui si hambrientos fincaseis Pain Diviño os fartarà.

Ay, y hagavos muy buen proveito. Ay.

2. Chegad, que es ò Pain do trigo que en Belen en v o Portal vimos embolto entre pallas à noite dà Nauidad.

Ay, y hagavos muy buen proveito. Ay.

3. Chegad, que es à Eucharistis, que para nos consoar à Galegos cuitadiños endona Deus noso Pai. 
Ay,

$\mathrm{y}$ hagavos muy buen proveito, Ay.

4. Chegad, e à istu Pain de frores

do fillo de Deus està,

ào son dà gaita Galega

con cantiñas celebrad.

Ay,

y hagavos muy buen proveito. Ay.

LAVS DEO, ET LAVS MARIAE.

Biblioteca Nacional. Madrid. (VE.1309-80). "Con el alma, y corazón”. Métrica: versos octosílabos, rima asonante. 


\section{VILLANCICOS QVE SE HAN DE CANTAR EN EL REAL CONVENTO DE LA ENCARNACIÓN, EN LOS MAYTINES DE LOS SANTOS REYES. DE ESTE AÑO DE 1694.}

EN Madrid: Por Antonio de Zafra, Criado de su Magestad.

NOCTVRNO III

VILLANCICO VII

ESTRIVILLO

Passito, silencio, quedito la voz,

Que duerme el Amor,

Y al Sol Infante,

Le arrulla vn Ave,

Con tan soberano primor,

Que no es bie $[n]$ le dispierte el rumor;

Y pues al mundo le viene nazido,

Es justo le arrulle con suipension,

Al Sol dormido,

Pasito Amor.

No le despierte la voz.

\section{COPLAS}

1. VEngan à vèr vn Portal.

Pieza que el Diziembre hilò,

A poder de copos blanca,

Siendo morada en rigor;

Al Sol dormido,

Pasito Amor

No le despierte la voz.

2. Vengan à vèr con quartana,

Oy de Iudea al Leon,

Que del hombre al accidente

El frio se le pegò:

Al Corderito

Dirè mejor,

Lleno de plata el vellon.

3. Vengan à vèr como al hombre, 
Cura quiso hazerle Dios, Cargando del Beneficio

En su ingratitud pension:

Al Pastorzico

Que rubricò

Mi yelo con su calor.

4. Vengan à vèr vn Infante,

Que en la campaña està oy,

Esperando èl solo à tres,

Y los rinde su valor:

El que tirita

Siendo su ardor,

De quien zentella es el Sol.

5. Vengan à vèr que en la nieve,

Oy que de madre saliò,

Candido Arminio en el Varro

Su limpieza conseròó:

Pura Azuzena

Se despojò,

Para vestir su candòr.

6. Vengan à vèr vna Estrella

de tan hermoso explendor,

Que à vista del Sol, y el Alva,

Es su luz mas, y mejor:

Buele con alas

De resplandor,

Siendo Clarin del amor.

7. Vengan à vèr vn Dios Hombre,

Que el azento equibocò,

Pues es Dios por la palabra,

Quando es Niño por la voz:

Como se quexa,

Valgame Dios!

Quien le aliviara el dolor.

8. Vengan à vèr los tres Reyes,

Cuya sabia adoracion,

Dà principio al siglo de oro

Quando el del hierro acabò:

Que dulzemente, 
La humillacion,

Su Magestad les laureò.

Biblioteca Nacional. Madrid. (R.35155-26) (276-7) "Pasito, Silencio, quedito la voz". Métrica: polimetría, versos octosílabos, con rima asonantada.. 
LETRAS DE LOS VILLANCICOS QVE SE HAN DE CANTAR EN LA CAPILLA

DE SU MAGESTAD DESTA CIUDAD DE GRANADA, EN LOS MAYTINES DEL NACIMIENTO DE NUESTRO SEÑOR JESU CHRISTO ESTE AÑO DE 1694.

DEDICADOS AL LICENCIADO D.FRANCISCO DE BLAS Y SANDOVAL, PREBENDADO DE LA S. IGLESIA CATHEDRAL DE DICHA CIUDAD. PVESTOS EN MÚSICA POR ALONSO DE BLAS Y SANDOVAL, MAESTRO DE DICHA REAL CAPILLA.

NOCTVRNO II.

VILLANCICO IV.

Estrivillo.

QUe contradicion divina

admiro Señor,

que sabio, que amante

vnis en el medio

de vuestro esscesivo amor.

2. No puede ser, no,

porque fuera consiguiente

aun mayor implicacion

de que se hallase en estremos

contrarios la perfeccion.

3. No puede ser, no,

que la vuestra siendo summa

excluye la implicacion.

COPLAS.

Si es dueño de la Ley que impuso

sin superior respecto, para que

por borrar otra ley, que vos pusisteis

intentais sujetaros a la ley?

Si negacion de luz son las tinieblas,

como tan disfraçadas en vos se vè

vna substancia eterna luz de luz

en substancia mortal que sombra fue?

Si es el arder principio del luzir

de amor como os precisa el fuego a que 
divinas luzes ocultando sea

en no luzir efecto del arder?

Si es el primer aliento conseque $[n]$ cia

el aliento final como naceis

a respirar con humildad de Siervo

para espirar con Magestad el Rey?

Siendo la condicion tan desiguales

los dos alientos para que escogeis

si vn leño para cuna en que nacer.

si no admite el Oriente de la vida

la trsiteza menor no serà bien,

que confundido con el gozo el $1 \mathrm{la}[n]$ to

se equivoquen la pena y el plazer.

\section{VILLANCICO V.}

\section{Introducion}

Un Portugués, y vn Gallego,

un Francés y vn Asturiano

al portal llegan tan cierto,

como dos y dos son quatro.

LLamànse Pierres Dumiñu,

Lançarote, y Santiago,

quatro nombres que aun apenas

se ven en el Kalendario.

\section{Estrivillo.}

1.Vamus Llançarote

vamus al purtal

du està el Rey è la Reyna,

è el viexu. $2 \mathrm{E}$ inda mais

Os anxos e à groria,

qui cantan à cumpais

tan ben, como si ovieran

nacidu in Portugal

3. Non puedi caminar,

si Dumingu non tuca

lu gaitu, è à li pair, 
pudimus tudus quatru

cantar, è caminar

4. Eu tocare mais piensu

qui estamus acà.

2. Cantemus o minino.

4. Eu tucare, catay

ào son da miña gaita

tunadas de solaz.

4. Eu tucarè, mais piensu

qui estamus acà.

2. Cantemus ào minino,

4. Eu tucarè, cantay

ào son de miña gaita,

tunadas de solaz.

3. Qui eu miña gaita, faralela,

fara la tuna farala,

cantaremus todus, faralela,

vno en pos, otro luego farala.

\section{COPLAS.}

Cantò el Portugués primero,

$y$ haciendo vna reverencia,

dixo (y esto tan finchado,

que si le pican rebienta:)

Ollay minino, minhalma,

meus ollos que chego a ver

in vos ò primer fidalgo

qui non foira Portuguéis.

Passitiño zè, quedi

y paracumbè y paracumbè.

Ay cumbè, ay le le le.

Ay minino que mata de amores

Cantò luego el asturiano,

y aun quiso llevar la fiesta

él solo, porque esta gente

solo vive quando lleva.

La serena de la noche,

la clara de la mañana

bien venidu al mundo sea 
el tamañu que aun no mama.

La serena, \&c.

È ya su madre bendita,

que lla Virgen se riamaba.

La Serena, \&c.

Cantò el Francés, que ocultaba

su correon con cautela,

temiendo que el buey del cuero

le sacasse las correas.

Monsieur Ninu, si viniere

aquel Roy di bercebu

Herodis péra truncarti,

assipui le direi tu.

Monsieur de la Rochela,

puique me matai vu

fiend tan bon foldat

en la guerra, como vu.

Lanturulu lanturulu,

Cantò el Gallego, y venia

sin çapatos, pero diestra

un par le prestò la mula,

mucho fue siendo Gallega.

Pobreciñu estais chicorru,

eu discalzu, cusa es certa,

qui non tenemus los dos,

nos, nin vos, blanca nin media.

veni vos, blanca nin media.

Veni vos cumuñu

de aqui à Cumpustela,

qui eu cù la gaita, è vos cù la perra.

gañaremus dineiru como terra.

Biblioteca Nacional. Madrid. (R.34987 N²32) Coplas. "QUe contradicion divina" .

Métrica: polimetria, versificación variada con predominio del verso octosílabo propio del villancico y del romance. Rima asonante. 


\section{VILANCICOS, QVE SE CANTARON LA NOCHE DE NAVIDAD, EN LA SANTA \\ Iglesia Cathedral de Valladolid, este año de 1694. \\ Siendo Racionero, y Maestro de Capilla el Licenciado D. Ioseph Martinez de Arçe.}

\section{KALENDA.}

\section{Estrivillo.}

1. DELICIOSAS auras,

Inspirad suaves,

En la rica flota,

que del puerto sale.

Buen viage.

2. Procelosos vientos

Enlutad el ayre,

No toquen sus quillas

La dorada marge.

Mal pasage.

1. Cielos, piedad, que ya contrario el viento,

Duro contrasta cada leño fragil,

Amaynad el velamen:

Al timon, à la gabia, à la entena,

Al farol, à la ancla, al cable.

2. No ay piedad, no ay favor, no ay esperança,

Zozobre $[n]$, gima[ $n]$, llore $[n]$, sienta $[n]$, clame $[n]$.

1. La Capitana hermosa, se và à pique.

3. No la temais, felizes naufragantes.

Que es la Estrella del Mar quien os conduce,

Y lleva al Sol por norte nu[ $n]$ ca erra $[n]$ te.

1 . Buen viage, buen viage.

2. Mal passage, mal passage.

3. Mas $\mathrm{q}[u e]$ apacible viento nos inspira?

4. Cessaron ya las duras tempestades.

1. A tierra, passageros venturosos.

2. Al puerto, viadores naufragantes.

Salva, dulzes clarines,

Las piezas se disparen,

Pues el Alba mas bella, 
En parabienes buelve nuestros ayes.

Vnos. Ya da fondo en Bele[ $n]$ la rica flota.

Otros. Gloria à los Cielos, y à la tierra pazes.

\section{COPLAS.}

1. Nave de el Sol cargada,

Capitana flamante,

Que del mundo el remedio

En tu tessoro trahès.

Ya la salva te hazen

El ruydo de los bronces sonoros

El estruendo voreal de los [...].

2. En hora buena surques

Los procelosos mares,

Que los grandes peligros,

Mayor el triunpho hazen.

Ya la salva te hazen

Los ecos numerosos de la esfera,

Las vozes q[ue] del Cielo son plumages.

3. Llega, feliz, al puerto,

Sin que el temor te assalte,

Que à tu norte obececen,

Los vientos, y los mares.

Ya la salva te hazen,

La muda artilleria de los Signos,

A influxos apacibles Celestiales.

\section{SEGVNDO NOCTVRNO.}

\section{VILLANCICO IV.}

\section{Introducion.}

1. Vna dança de Gallegos,

Contentos como la Pasqua,

Vienen à Belen baylando,

Y preguntando, quien paga?

2. Al Portal, gustosos llegan,

Que han sabido allà en su patria,

Ser el Niño como vn oro. 
Su Madre, como plata.

Estrivillo.

1. Ea, Galeguiños, Galeguiños

De boa pujança,

Levante $[n]$ àò Ceo ò polvo las patas.

Zumbe, retumbe la gayta, Pasquala,

Tu turun, virindi, virindayna.

2. Que ta[n]to queires àò Neno, Domiños

1. Mais que os zapatos que traigo en el cinchu.

3. Cata que Nay $\operatorname{ta}[n]$ fermosa le abriga.

1. Si el Boy me dera, inda fora mais linda.

2. Pidele à mula, $\mathrm{q}[u e]$ es nossa paysana.

1. En nossa terra galegas ay fartas.

Zumbe, \&c.

3. Que le daràs en baylando àò Chicote?

1. Que le ey de dar? darele boas noytes.

2. Quierole yo endonar meus zapatos.

1. Los q[ue] él pornà, so[n] de cravo passado.

3. Los Angeliños la Groria le cantan.

1. Sempre en as festas os mosicos anda[n].

Zumbe, \&c.

\section{COPLAS.}

2. Meu Domingon, responde.

1. Preguntame, Pasquala.

2. Dime: que es cousa, y cousa.

Vna Paloma branca,

Tein por fillo vn Cordeiro,

Que de Hombre tein traza?

1. Essa Paloma, es Ave,

Y Maria se llama,

Filla del Padre nostro,

Y de la Salve hirmana.

2. O vallasme la Virgen!

1. Nosso Siñor mos valla!

3. En vna noyte oscura,

Que por lo negro espanta,

Palabra non se veia, 
Y se vio la Palabra.

1. Essu de creer es facil, Que es vna cousa crara, Cantan los Angeliños, $\mathrm{E}$ non tein garganta.

3. O vallasme, \&c.

4. Si ò Sol està deytado

Encima de las pallas, como no las encende?

Como no las abrassa?

1. Porque ò Sol garridiño, Que entre la neve campa, Los corazones queima, La ropa deixa sana.

4. O vallasme, \&c.

5. Comu los Pastorciños

Vienen con sus zamarras, Y tiritando ò Neno,

Desnudito se halla?

1. Porque à la nossa terra, Vino con prissa tanta,

Que sin duda en ò Ceo

Se le quedò la capa.

5. O vallasme, \&c.

6. Siendo su Pai tan rico,

Tein de galego traza,

Pois à su Fillo embia

Por el mundo sin branca.

1. No està muy pobreciño, Pois que perlas derrama, E por sua Nay se dize, Que tiene muy buen arca. 6. O vallasme, \&c.

7. Todos le traen presentes, Nos non le damos nada, Mais esso importa poco, Ser Galeguiños basta. 1. Si và à dezir verdade, Nossa franqueza es tanta, 
que antes que darle vn carto,

Dariale yo el alma.

7. O vallasme, \&c.

8. Si por ò Chicotico

Fazemos esta dança,

Al fin de lo baylado,

Quein nos darà la paga?

1. Non fagas cuenta de essu,

Si non sirvele, y calla,

Pois es canto nos deve,

En suma, vn sus de gayta.

8. O vallasme, \&c.

VILLANCICO V.

\section{Introducion.}

Oy que el mayor de los Reyes

Llega del mundo à las puertas,

A todos sus pretendientes,

Ha resuelto dar audiencia.

Atended; porque oy à todos,

Los memoriales decreta,

Y à su Portal, privilegios

Concede de covachuela.

\section{Estrivillo.}

Venid, mortales, venid à la Audiencia,

Que oy haze mercedes vn Rey en la tierra,

Y de sus decretos nadie se reserva.

Venid, mortales, venid, \&c.

Venid, pues consiste

El que logro tengan

Vuestros memoriales,

En que hechos bien vengan.

Venid, mortales, \&c.

$\mathrm{Y}$ oy que sus mayores

Validos le cercan,

Ioseph, y Maria, 
La gracia està cierta.

Venid, mortales, venid à la Audiencia,

$\mathrm{Y}$ pues no ay en el mundo quien no pretenda.

Venid, \&c.

\section{COPLAS.}

1. Adan, Señor, que goza,

Por labrador, indultos de nobleza,

Oy se halla presso, y pobre,

Forjando de su hierro su cadena;

Pide vna espera.

Pues el mundo obligado

Tiene à sus deudas.

2. Atended al decreto que lleva.

3. En el Limbo, por carcel,

Quedesse aora,

Que oy del Cielo ha llegado

La mejor flota.

1. Moyses, que en vn Monte,

Cursò de Leyes la mejor Escuela,

Hallandose con Vara,

La toga pide, que Feliz espera:

Porque en èl vean,

Que en vuestras Leyes solo

$\mathrm{Su}$ ascenso encierra.

2. Atended al decreto que lleva.

3. Por Alcalde de Corte

$\mathrm{Su}$ vara queda,

Que vnas vezes es vara,

Y otras culebra.

1. Salomon, Señor, pide,

Del Consejo de Estado plaza entera,

Pues solo para esto,

Vuestro amor le adornò de tantas ciencias. 
Biblioteca Nacional. Madrid (V. E. 150-.35) 98 (1); 607 (1). "DELICIOSAS auras". Contiene Villancico de Kalenda y se cantò en la Iglesia Metropolitana de Granada y en la Santa Iglesia Catedral de Valladolid.

Métrica: polimetría, con figuras retóricas preciosas ("O Sol deitado"). Versos heptasílabos y octosilábicos, muy combinados. A veces se contestan como si se tratara de vn Salterio y melismas, ya que la música religiosa se acompañaba de poesia y canto. Con melismas. Se jugaba con esta figura melódica sobre una vocal y el pueblo (o bien un coro entrenado ) contestaba en estribillo. Aunque tenemos que añadir que los villancicos eran similares a los cantos de ciego, colgados de una melodía adaptada a las letras del villancico, o viceversa. 


\section{LETRAS QVE SE HAN DE CANTAR EN LOS MAYTINES DE NAVIDAD EN LA IGLESIA DE LOS CLÉRIGOS REGLARES ,ESTE AÑO DE 1695. \\ SIENDO MAESTRO DE CAPILLA EL \\ Licenciado Don Pedro Martinez Orgambide. \\ EN MADRID: POR ANTONIO GONZALEZ DE REYES.}

\section{TERCER NOCTVRNO.}

VILLANCICO VIII.

\section{Estriuillo.}

FUego, fuego,

que Amor respira incendios:

Agua, agua,

que Amor alienta llamas;

y en el Ayre, y la Tierra,

todo es centellas,

siendo las pajas

centellas, bolcanes, incendios, y llamas;

porque Amor, que tirita en le yelo,

esse es quien respira,

esse es quien alienta

amantes Mongibelos.

Ay, que me abraso!

Ay, que me anego!

y en olas de llamas,

bolcanes, è incendios,

el riesgo de abrazarme solicito,

quando veo nace

del Amor el riesgo:

fuego, agua, agua, fuego.

\section{COPLAS}

OY todo el Mundo se abrasa.

porq[ue] siendo el Amor fuego,

à sus rayos, à sus flechas,

à sus harpones, è incendios, 
quema, abrasa,

enciende, y arde

el pecho, la paja,

el ayre, y el yelo.

Quema con rayos la paja,

con flechas abrasa el pecho,

con incendios arde el ayre

de harpones enciende el yelo.

De Adan el sudor se ofrece

por agua, pero Amor ciego,

à sus luzes, à sus llamas,

à sus ardores, y afectos,

muda, alumbra,

forma, y logra

el zelo, el agua,

el rigor, y el premio.

Logra con llamas el agua,

con luzes alumbra el zelo,

de afectos el rigor muda,

forma de ardores el premio.

Noè diluvios presenta;

no se apaga, pues el Cielo,

à suspiros, à sollozos,

à sus penas, y tormentos,

tiene, prende,

trueca, y haze,

ecos, rayos,

ondas, vientos.

De sus penas prende rayos,

de suspiros haze vientos,

de tormentos tiene ondas,

de sollozos trueca ecos.

Moyses, y la Magdalena,

Jeremias, y San Pedro,

à sus golpes, à sus llantos,

à su dolor, à su afecto,

causan, dizen,

rinden, postran

fuego, culpas, 
penas, yerros.

Con golpes rinden las peñas, con llantos causan el fuego, con su afecto postran culpas, con dolor dizen sus yerros.

\section{VILLANCICO VIII}

\section{Introduccion.}

VN portuguès, $\mathrm{y}$ vn Gallego

oy al Portal han venido,

vno tan harto de nabos,

como el otro de tocino.

Estrivillo. Escuchenlos todos,

prevengan el oìdo;

porque empieçan sus gracias gustosas,

de su amor indicios.

Port. Què vos falo Toribio da Parra?

Gall.Què me manda señur Dun Dumingu?

Port. Naõ ollais amante

al Cravel pulido,

as cuyas peistañas

desfilan armiños?

Gall. You la olla quieru,

que me acomodu

à tumar quantu quierang

aunque sea oru.

Todos. Escuhenlos todos, \&c.

Port. Naõ ollais? qui falo?

Patife, qui digo?

naõ falais ainda?

naõ escuteis Minino,

que sois garridino, polidino;

è naõ choreis,

porque à vosso lado

teis vn Portugueis:

falad, pois, Galego,

naõ seyais catisu. 
Gall. Heu estoy acupadu, è non fablo al Chicu; que si non me pagan, non serè Turibio.

Port. Callai. Gall.Ya non callu?

Port. Pois fale .Gall. Pus digu.

Todos. Prevengan el oìdu, \&c.

\section{COPLAS}

Port. Dezid, Galego, por què Chora feito Cupidiño, quando para aqueste peyto frechas das pallas fizu? Gall. Purque lus Kalendarius diz comeremus la cebada, y la paja pur pocu preciu. Port. Aora Herodes despatarra en Belèn os Mininos; si ficaran alà en Galicia, naõ tuviera $[n]$ este peligru.

Gall. Seniur, aquestu es fixu; purque en la tierra, solo ao zumbo da gayta los chicus sueltang. Port. El Boy en lu alentado Portuguès me ha parecidu; porque tanta tanta finchazaõ naõ es de pobre Galeguiño. Gall. Si Portuguès pareice, pur lo marieru, inda el pullinu era de mi Concellu.

Port. Por què, Gallego, naõ danças, quando por mi Pequinino, o coraçaõ e vs ollos todo en seu fogo derritu? Gall.You non quero fulgança pus lus çapatus 
se rompen, è lus dedos

se quedang sanus.

Port. O Galo de la Passion,

ollando ao Namoradito,

dize cantara quando

lo ollarà, ya feito trigo.

Gall. Non cantarà el Gallu,

si ay Portugueises,

purque alà del Calvariu,

diz que lus teme.

Port. Eu voy para Coimbra,

porque eu Recein nacido

lu de dey confites de Oporto,

brancos, dulses, pulidiñus.

Gall. You voy, que de vs Madriles

tengu vna carta,

en que para Silleru,

diz que me llamang.

F $\quad$ I N.

Biblioteca Nacional. Madrid. (V.E. 150-46) "Fuego, fuego".

Métrica: con mucha polimetria se presentan estos villancicos. Hay una ensalada de lenguas entre portugueses y gallegos. Versos octosilábicos, alternando con heptasílabos, propio de la estructura del villancico. Rima asonante, con versificación muy variada, polimétrica, propia del Siglo de Oro. 


\title{
LETRAS DE LOS VILLANCICOS QVE SE HAN DE CANTAR EN LOS SOLEMNES MAITINES
}

de N. Señora de la Concepcion, en la Insigne Iglesia Colegial de N. Señor San Salvador de la Ciudad de Sevilla. En este año de 1695. SIENDO MAESTRO DE DICHA IGLESIA D. SALVADOR GARCIA Y MENDOZA.

Con licencia, impresso en Seuilla por Iuan de Ossuna.

\author{
VILLANCICO III. \\ Gallega. \\ OLlai Galeguiños, \\ venid a la festa \\ de la Concepcion \\ de vna Minina Bela. \\ 2. Llegai pois alegres: \\ $\mathrm{v}$ seos y terra \\ festiñan a gracia \\ de la sua Reyna. \\ Mais si os Galeguiños, \\ naon saltan, y trepan, \\ ni o pobro se rie, \\ nis os cregos gorgean. \\ Ollai que vos digo, \\ bulli vas castañuelas, \\ bulli o as çapatas, \\ e a gaita Galega. \\ 2. Fincà por sua gracia \\ va Rosa tan bela, \\ que a culpa fuyendo \\ và de sua pureza. \\ Ollai que vos digo, \&c. \\ 3. Dis que foi Maria \\ de a gracia feita, \\ de Deus, y que es Luna \\ sin sombra, ni mengua.
}


Ollai que vos digo, \&c.

4. Pois ya a nubecita que Elias Profeta

vido allà en o ceo, es groria en la tierra.

Ollai que vos digo, \&c.

5. Ya aquesta Minina

quebrantou a testa

con su pie fermoso

a astuta culebra.

Ollai que vos digo, \&c.

6. Ya o Alva nos viño,

e as aves risueñas

fazen gorgoriños,

que espiritu alegran.

Ollai que vos digo, \&c.

SEGVNDO NOCTVRNO.

VILLANCICO IV.

Estrivillo.

A De la tierra que hermosa

en su fecundo Teatro

luze, viste, cria, pule

los montes, las selvas,

los riscos y prados;

venid, y festivos,

coronad de apalusos

de la Concepcion

el triunfo mas alto.

Venid, pues su Aurora

con luzientes rayos

es luz de los montes,

de selvas, de riscos,

de cumbres, y prados.

COPLAS.

1. ROmpa la nieve fria 
del Cielo los candores,

y en suaves resplandores

bañe el candido dia,

dando del Alva señas

los montes, los riscos,

los valles, y peñas.

2. De su deidad hermosa

produzen luzes bellas

multiplicando estrellas

su Concepcion gloriosa,

pues en su gracia encierra

los mares, los vientos,

la luz, y la tierra.

3. Oy que el Alva mejora

matizes, y arreboles,

iluminando soles

en la luz de su Aurora,

saludenla eloquentes

los troncos, las seluas,

arroyos y fuentes.

Biblioteca Nacional. Madrid. (V.E. 92-41) "Ollai Galeguiños".

Métrica: polimetria, versos octosílabos propios del villancico y del romance, en arte menor. Rima asonante. El verso en gallego es similar a una muiñeira, en heptasílabos, con rima asonante. 


\section{LETRAS DE LOS VILLANCICOS, QVE SE CANTARON EN LOS MAYTINES del Nacimiento de N. Señor IesuChristo, en la Santa, Metropolitana, y Patriarcal, Iglesia desta Ciudad de Sevilla. COMPVESTOS POR DON DIEGO JOSEPH \\ de Salazar, Racionero, y Maestro de Capilla de dicha Santa Iglesia.}

Año 1695.

En Sevilla, por JVAN FRANCISCO DE BLAS, Impressor mayor de dicha Ciudad.

PRIMERO NOCTVRNO, VILLANCICO PRIMERO DE KALENDA.

Estrivillo.

CLarin, que rompe los ayres, equivocado en su acento, que dulce para la vida! para la muerte, qué estruendo. Todos. Al arma, al arma, al arma, que assalta el rigor.

2. Choro. Què dolor!

Todos. Guerra, guerra, guerra.

2. Que ya en assombros la tierra se turba, se desmaya, y se lamenta, y á morir se condena.

2. Coro. Qué pena!

2. Confusion de mortales, el viento suena.

Todos. Al valle, al monte, al risco.

1. Que los cielos disparan rayos Divinos.

Todos. Fuego, fuego, fuego.

4. Que se abrasan en llamas los elementos.

Tod. Y á sus luzes los Orbes clama[n] victoria,

2. Qué gloria!

1. Coro. Siendo amor quien combate la desventura.

2. Coro. Qué ventura!

Todos. Muera la muerte, muera.

2. Coro. Viua la vida, viua.

2. Que por dicha le viene toda la dicha.

3. Siendo Nuncio Celeste de oy el Aurora.

1. Coro. Que ay vn Sol esta noche 
contra sus sombras.

Todos. Nadie se assombre, que esta es gracia que tiene fortuna de hombres.

\section{COPLAS}

1. Al aplauso de vna dicha alegres se vén conformes de las Esferas los ecos de la Montaña las vozes. Nadie se assombre, que esta es gracia que tiene fortuna de hombres.

2. Nuncios de la Paz publican nuevas, que fueron entonces de los mas puros desseos las esperanças mejores. Nadie se assombre, \&c.

3. Alva de vn Alva previenen á vn Sol que ardiente dispone perdido por dar sus luzes, que dos Alvas le pregonen. Nadie se assombre, \&c.

4. De lo obscuro las tinieblas su fineza reconocen, que amor para ser bien visto, hará de las sombras, Soles. Nadie se assombre, \&c.

5. A media noche sus rayos brillaron tales, que estorven ser Corte del medio dia, si rasgo de media noche. Nadie se assombre, \&c.

6. Ambos Orbes, centinelas aguardan sus resplandores, con el nombre las Estrellas, mas co[n] la gracia los hombres. Nadie se assombre, \&c. 


\section{VILLANCICO SEGVNDO.}

\section{GALLEGO.}

Estrivillo.

Todos. VEñan os Galegos, veñan á baylar.

4. Por la May garrida

Estrela de ó mar.

Todos. Veñan, \&c.

3. Donzela fermosa, como ò Sol, é mais.

Todos. Veñan, \&c.

4. Que ha dado Solziño, polido, é galan.

Todos. Veñan, \&c.

3. Lo mais garridiño, que poden mirar.

Todos. Veñan, \&c.

Todos. Mas ay, correi, andai, Mingo aforquillai, que se derriba ó Ceo no Portal.

\section{COPLAS.}

1. Ueñan os Galegos todos á baylar la noyte, que nace noso Mayoral: Angeliños baxan por nos ayudar. Todos. Mingo aforquillai, que se derriba ó Ceo no Portal.

2. $\mathrm{O}$ recein nacedo, que ò Ceo nos da, la palla enriqueze solo con chorar: dos fontes de perlas por lo feno vain. Todos. Mingo, \&c. 
3. A coller el grano,

que en na parva está, colanse os Pastores

dentro no Portal:

solo vn grano buscan

fallan muito mais.

Todos. Mingo, \&c.

4. Fallan vn tesoyro, qoal non foy jamas en cuna de prata, rico, é sin igual: ele he Sol fermoso, la Luna sua May. Todos. Mingo, \&c. 5. Assombrado Mingo foyse á persinar, sen poder de espainto fazer la siñal:

y á noso Gaytero se olvidó el tocar.

Todos. Mingo, \&c.

\section{VILLANCICO TERCERO.}

\section{Estrivillo.}

PAstores del Valle

Oid mis acentos, que amor ha nacido en brazos del hielo: Ya luze la escarcha, ya tiembla el incendio, ya ha dado el Diziembre el fruto mas bello:

Que hiela abrasando, que tiembla luziendo, mesclando a un tiempo de vn Dios lo terrible, de vn Niño lo tierno. 
Pastores del Ualle, \&c.

\section{COPLAS.}

1. Dios humano, Niño Dio

qué á prodigios, qué á portentos,

sin dexar de ser lo mas,

te humillaste á ser lo menos!

2. Amor de Dios, de hombre amor, qué á solloços, qué á tormentos, sin olvidar lo impassible,

passible tu amor te ha hecho!.

3. Luz Divina, humana luz, qué á explendores, que á reflexos sin apagar lo Divino,

estás á lo humano ardiendo!

4. Flor Divina, humana flor, qué en fraga $[n]$ cias, qué en alientos, sin olvidar lo inmortal quieres florecer muriendo! 5. Niño tierno, grande Niño, qué suave, qué tremendo, sin dexar de ser Gigante, has querido ser pequeño!

6. Llama ardiente, suave llama, qué en templanças, que en incendios, sin que dexes de abrasar, sueles halagar ardiendo!.

7. Oye mi amor, mi voz oye, qué con llantos, que con ruegos, sin ser dignos por si mismos, por si tu amor los ha hecho!

SEGVNDO NOCTVRNO.

\section{VILLANCICO QVARTO.}

Estrivillo.

1. AVezillas, cantad.

2. Paxarillos, llorad. 
1. De amor al Oriente mejor.

2. De dolor al Ocaso del Sol.

1. y 2. Los suspiros de vn tierno dolor.

Llorad, gemid.

1. Gorgeando con dulce primor.

2. Alternando el sonoro rumor.

1. Con requiebros, y afectos de amor.

$Y$ finezas de mil en mil.

1. y 2. Cantad, reid.

\section{COPLAS.}

Parleras Avezillas

la risa reprimid,

que es viendo muerto al Sol,

especie de traycion el no sentir.

1. y 2. Llorad, gemid.

2. Harpados Ruyseñores, lisonja de Abril,

cantad, que otro Sol nace

en brazos el Aurora mas feliz.

1. y 2. Gorgead, reid.

3. La noche, de sus sombras

negro viste el mongil,

porque la luz que falta,

su mucha obscuridad pueda advertir.

1. y 2. Llorad, gemid.

4. No ay que temer las sombras, pues nos dexò de si, otro Sol encendido,

el que ya alumbra en Orbes de Zafir.

1. y 2. Gorgead, reid.

\section{UILLANCICO QUINTO.}

\section{GITANAS.}

Estrivillo.

1. GItanicaz vienen,

Gitanicaz ván 
á adorar al Niño,

y a ver el Portal.

2. O que hermozaz que zalen

todaz á baylar.

Todos. Chaz, chaz, chaz.

3. Como suena $[n]$ laz caztañetillaz

que repican las Gitanillaz,

y en dulce armonia

laz hazen hablar.

Todos. Chaz, chaz, chaz.

1. Y á la Madre del Niño graciozo

morenica del Zol maz hermozo

la gala le cantan, la gloria le dán.

Todos. Chaz, chaz, chaz.

1. Que baylan ayrozaz.

Todos. Chaz, chaz, chaz.

2. Que cruzan briozaz,

Todos. Chaz, chaz, chaz.

3. Que cantan graziozaz.

Todos. chaz, chaz, chaz.

à zon, y á compaz.

2. Chaz, chaz, chaz.

Gitanicaz, \&c.

\section{COPLAS.}

1. Gitanico hermoso,

Niño Celestial,

Hijo del Aurora,

que tu Zol noz dá.

Todos. Chaz, chaz, chaz.

Gitanicaz vienen,

Gitanicaz ván.

2. Zi noz daz limozna,

te diremoz ya

la buena ventura,

que es nuestra no maz. Chaz. \&c.

3. Danoz eza mano

rica, y liberal,

que ez hazerle agravio 
quererla faxar. Chaz, \&c.

4. En zu palma vemoz

ramaz de coral,

floridaz de penaz,

que triunfoz zerán. Chaz, \&c.

5. Larga vida tienez,

que te ha de durar

maz allá del tiempo

vna eternidad. Chaz, \&c.

6. De enamoradico

tienez el mirar,

y de mani roto

vna gran zeñal. Chaz, \&c.

7. Ay Dioz lo que vemoz,

mejor ez callar,

las tiernas zeñalez,

que á loz ojoz daz. Chaz, \&c.

8. No lo oyga tu Madre,

que lo llorará

en noche que ez todo

feztejoz, y paz. Chaz, \&c.

9. A Dioz Gitanico,

puez nuestro erez ya,

que por no canzarte

no dezimoz maz. Chaz, \&c.

Biblioteca Nacional. Madrid.(V.E. 83 -5) (506-1) "Clarín, que rompe los ayres".

Métrica: versos polimétricos entre octosílabos, heptasílabos y pentasílabos. Rima asonante. 


\section{VILLANCICOS QVE SE HAN DE CANTAR EN LA REAL CAPILLA DE SV MAGESTAD, LA NOCHE DE NAVIDAD DE ESTE AÑO DE M.DC.XCVI.}

\section{VILLANCICO V.}

\section{INTRODVCION.}

VN Theologo Pastor,

Que ha sabido los Misterios,

No por los libros del $\mathrm{Mu}[n] \mathrm{do}$,

Sino por arte del Cielo.

Dize al Pueblo de Belèn

Lo que le han dicho primero

Del Niño, que vino al Mundo,

Siendo lo mas, à ser menos.

\section{ESTRIVILLO.}

VAya diziendo,

Qué con gusto, con gracia, y placer,

Todos atentos,

Los milagros de todos los dias

En vno sabremos:

Silencio, silencio,

Que de amor maravillas,

En tantos secretos,

Mas lo saben humildes, que discretos.

Vaya diziendo.

\section{COPLAS}

Past. ENtrè en el Portal, y vi

Vna Señora, y vn Viejo,

Ella alentava esperanças,

El conciliava respetos:

Padre del Niño lo llaman,

Y tiene el Padre en el Cielo;

Pero han dicho que los ojos

Se rindan à los Misterios.

Todos. Pues como es esso?

Past. Hanmelo dicho, 
1. Mas yo no lo entiendo.

2. De frio temblando està

Vn Niño mas que vn Luzero,

Los ojos vivos, y claros,

Que vela, y està durmiendo,

Todo el Sol tiene en las pajas,

Y le maltratan los yelos,

$\mathrm{Y}$ el frio nunca se apaga

con tanta hoguera de fuego.

Todos. Pues como es esso?

Past. Hanmelo dicho,

Mas yo no lo entiendo.

3. Las manos tiene ceñidas

Con vnos paños grosseros,

Y dizen, que no le ciñe

$\mathrm{Su}$ poder todo lo inmenso.

Dizen que el Cielo, y el Mundo

Son fabrica de sus dedos,

Yo no le he visto las manos,

Y porfian que las veo.

Todos. Pues como es esso?

Past. Hanmelo dicho,

Mas yo no lo entiendo.

4. Reclinado en vn pesebre

Pobremente està compuesto,

Y de vn Señor Rey de Reyes.

Me dizen que es heredero.

Todos los bienes del mundo

Entre sus manos le han puesto,

Y sin estar empeñado

No tiene para vn puchero.

Todos. Pues como es esso?

Past. Hanmelo dicho,

Mas yo no lo entiendo.

5. Aora dizen que ha venido

Al mundo para consuelo;

Y esta[n]do siempre con todos,

Dizen, que viene de nuevo.

Aora està, y estuvo antes, 
Aora empieza, y es Eterno,

Y con dos naturalezas,

Dize $[n]$ que queda compuesto,

Todos. Pues como es esso?

Past. Hanmelo dicho,

Mas yo no lo entiendo.

6. Dizen que es la misma Vida,

Y que vive por sì mesmo,

Pero que se ha de morir

Porque quiere, y porque quiero.

Dànos la vida, y se muere,

Pero que vence muriendo,

Y la muerte que le mata

Es de su braço el trofeo.

Todos. Pues como es esso?

Past. Hanmelo dicho,

Mas yo no lo entiendo.

7. Dizen que todo lo sabe

Con soberano talento,

Y que pregunta à los Sabios,

Para enseñarnos con esso:

No ay cosa que no conozca,

$\mathrm{Y}$ aun secretos del secreto,

Y con otra ciencia dizen,

Que todo lo irà apre $[n]$ diendo.

Todos. Pues como es esso'

Past. Hanmelo dicho,

Mas yo no lo entiendo.

Biblioteca Nacional. Madrid. (R.34988-29) (300-5). "Vn theologo Pastor".

Métrica: veros polimétricos y muy variados. El villancico es similar a una canción con versificación variada, nos recuerda las canciones trovadorescas. Rima asonante. 
VILLANCICOS QVE SE HAN DE CANTAR LA NOCHE

de los Santos Reyes, en el Convento del Real Orden de nuestra Señora de la Merced, Redención de Cautivos de esta Corte, el Año de mil seiscientos noventa y siete. PVESTOS EN MVSICA POR EL PADRE FRAY

Domingo Ortiz de Zarate, Maestro de Capilla de dicho Convento.

\section{VILLANCICO VI}

$$
\text { ESTRIVILLO. }
$$

GAlegos baylarines

Festexay cantando

Ay, ay, ay.

Decendo ao son de à Gayta

Que ò Fillo de Deus Santo

Parece Galeguiño de Santiago.

Pues vene de sua terra sin zapaytos.

Festexay Galegos:

Festexay cantando.

2. Que vene à la Sega

De ò trigo Sagrado.

Festexay Galegos, \&c.

3. Que antes, que ò trigo

$\mathrm{O}$ à palla à segado.

Festexay, \&c.

4. Que para ò Corpus

Segaray os granos.

Festexay. \&c.

1. Que venen os Reyes

O trigo buscando.

Festexay Galegos,

Festexay cantando

Decendo àò son de à Gayta:

Que ò Fillo de Deus Santo

Pareyce Galeguiño de Santiago.

Pues vene de sua terra sin zapaytos.

COPLAS. 
A Suo Fillo ò Pay Eterno

Por ò Mundo lo ha inviado,

Desnudiño como andan

En Mondego os Muchachos.

A segar vene as Messes

De ò trigo mays soberano;

Y para ò Corpus ò tempo

De à fazon à agardado ${ }^{37}$.

Tod. Pareyce Galeguiño de Santiago,

Pues vene de sua terra sin zapaytos.

2. A oz que trae es de ò ferro,

Que ò fizo primer pecado,

Y esta Noyte en huas pallas

Sin ben sega estay probando,

De ò Divino Sacramento

Nos promete ò pan Sagrado.

$\mathrm{Y}$ en primicias de as espigas

As rubias pallas mostrando.

Tod. Pareyce Galeguiño de San-Tiago.

3. Con as palluelas as Cruzes

Forma con su misma mao.

Descubrindo, que en à Sega

Sudar à Sangre, ò costado.

Con que en Lugo os Galegos

Le veràn Sacramentado

Aò mismo, que en ò pesebre

$\mathrm{Al}$ Demo à morte dado ${ }^{38}$.

Tod. Pareyce Galeguiño de San-Tiago, \&c.

4. Lo suo Pay, que es moyto rico

A Mula, y ò Boy le ha dado:

Con quey seray poderoso

Mays, que ò Cura de Betanços.

Ainda con Boy, y à Mula

Pode, si compray arado,

Ser mays, que ò Conde de Lemus

El que de friu tembrando.

Pareyce Galeguiño de San-Tiago

${ }^{37}$ En el original, agardando.

${ }^{38}$ En el original, dando. 
Pois vene de sua terra sin zapaytos.

NOCTVRNO. III.

\section{VILLANCICO VII.}

ESTRIVILLO.

SAlgan, Salgan los Reyes:

A quando aguardan?

Si les empeña el Niño

A la jornada.

Tod. Salgan.

1. Salgan ya, pues la Estrella Maria

Con su luz les alumbra, les mueve, y les guia.

Tod. Salgan, Salgan, y buelvan con bien.

Salgan.

2. Esso no.

1. Esso si.

Que aunque el Niño consigo

Con gran Fè tienen,

En los brazos del Alva

Mejor parece.

Tod. Pues vayan, pues corran,

Pues buelen, pues partan

A ofrecer con sus dones Augustos

Los Regios tesoros que emule la Arabia.

Salgan, Salgan.

Suenen los Clarines;

Prevenganse las Guardas.

Que la Estrella en Carroza de luzes,

Penetrando los vie $[n]$ tos, las sendas señala.

Salgan, Salgan.

\section{COPLAS.}

Enfermaron nuestros Reyes,

Y à luzes casi Eclipsadas

Benigna sucediò Estrella,

Que los bolviò al cuerpo el alma.

Algunos han juzgado 
Por cosa clara,

Que es Maria la Estrellla;

No sino el Alva.

La Estrella les muestra al Niño,

Porque à ver al Niño vayan,

Que està mejor con su Madre,

Que entre Reales almohadas.

Aunque el Niño en los Reyes

Tenga tal mano

Pero tiene en Maria

Mejores brazos.

Negros andan con los Reyes,

Que son, entre gente blanca,

Negros de nuestros pecados,

Que vàn à buscar la gracia.

Estos Negros pecados,

Que se interponen

Dizen, que han muerto à muchos:

Dios lo perdone.

Nuestros Reyes tienen suerte,

Pues en la Corte su estancia,

Virgen, Niño, y Belèn tienen.

Aora su Estrella les valga.

De Belèn a la Virgen

Con humos vayan,

Que no vàn nuestros Reyes

A humo de pajas.

Dones à vn Dios Hombre ofrezcan,

Que siendo de Hombres es causa,

Que entre humos de su grandeza

Se mezcle la Myrra amarga.

No se envidie à los Reyes,

Pues se halla, en suma,

En la mayor grandeza

Mas amargura.

$\mathrm{Si}$ algun oro le ofrecieren

Serà el mas puro, que se halla,

Pues nunca, como oy, se han visto

Las cosas mas apuradas. 
Dando el Niño à Maria,

Dan mil tesoros,

Pues el Niño que buelven

Es como vn oro.

Biblioteca Nacional. Madrid. (VE. 128-75) (303-1) "GAlegos baylarines".

Métrica: polimetría, similar a la canción de ciego. Pero en el villancico gallego aparece el endecasílabo "antiguo" de gaita gallega" propio de una romería. Rima asonante. 
LETRAS DE LOS VILLANCICOS, QVE SE CANTARON EN LA

Santa, Metropolitana, y Patriarcal Iglesia, de esta Ciudad de Sevilla, En los solemnes

Maytines de la Venida de los Santos Reyes.

Compuestos, por Don Diego de Salazar, Racionero, y Maestro de Capilla de dicha Santa

Iglesia.

1697.

\section{VILLANCICO IIII.}

Introduccion.

1. HA Josepeleo. 2. Que dezer.

1. Ha Joaneteleo. 2. Que querer.

1. Ha Perequeleo. 4. Que dezer.

1. Ha Baltasareleo. 5. Que mandar.

1. Que pues tanto Morezquilio

con los Reyes al chiquillo

le vener el pie à besar,

andar, yo tamben andar

he quererle festejar he boltear

he sober por la maroma

aunque le pese á Mahoma.

2. Morezco tener, tener.

que comenzar à sober

he para sober mejor

confesemos al Senior,

que nació en Belen.

A 4. Amoen.

1. He del perro Zancarron

renegar de corazon

para no caer.

A 4. Amoen.

1. He creer en el chiquilio, que estar en le portalilio he ser Dios tamben.

A 4. Amoen.

Estrivillo. 
O Que ben

que Morezco sober

sin bayben, ne tropezon,

tuca, tuca, y hazer el son,

Li, li, li, li, li, li, li,

tucar por aqui,

la, la, la, y la,

tucar por aca,

y alegremos lo Morezquilio

bolteando en el Portalilio

por los Reyes de Sabá.

La, la, la, y la, li, li. \&c.

\section{COPLAS.}

1. ALto Morezquilio, vamos en el nombre del Senior, que quanto creer mejor, tanto mejor bolteamos: de Mahoma renegamos á todo bon renegar, que el chiquilio Dios estar, y el otro ser mala cuca: Tuca, tuca, \&c.

2. Pues dios ser camino, y luz, he ayudar al que creer, quero empezar à sober con la señial de la Cruz: He de harriero Marfuz, no tener Morezco miedo, mas antes dezer el Credo, para no quebrar la nuca: Tuca, tuca, \&c.

3. Para comer bon Jamon, bon cosa es Crestiano ser, y si Moro no comer, por que adorar Zancarron? A Alá, que le diò el sazon dar gracias con reverencia, que sin cargo de conciencia 
poder ir a la bayuca:

Tuca, tuca, \&C.

4. Del Alcoran renegar,

he de todos sus encantos,

que tener muy pocos Santos

que poder encomendar:

Valgame el Senior sin par,

recien nacido en Belen,

he Santiago tamben

el que los Moros machuca;

Tuca, tuca, \&c.

VILLANCICO V.

ESTRIVILLO.

1. PAra dezir calidades de Amor, que en pajas ceñido,

esconde su ardor,

hablar es mejor.

2. Para dezir calidades de Amor,

callar es mejor,

que el silencio eloquente,

con voz reverente,

explica callando su noble fervor:

callar es mejor.

1. Hablar es mejor,

que la voz generosa,

con Alma gloriosa,

explica de el pecho Sagrada Passion.

2. Callar es mejor.

1. Hablar es mejor:

que la voz. 2. El silencio,

Los 2. Son lenguas Sagradas

de grandes misterios de Amor.

1. Hablar es mejor.

2. Callar es mejor.

COPLAS. 
1. EL amor, que es viuo fuego, vino en polvo disfrazado, y quanto mas recatado domina mas el sosiego: Es lince en trage de ciego. pues con la flecha encendida, dando en el pecho la herida, haze eloquente el dolor: Luego el mismo dezir es callarlo mejor.

2. Aunque es Niño en la estatura, es en las fuerças Gigante, no ay Muralla de Diamante que resista á su hermosura: Pero esconde su luz pura haziendo con noble imperio, en cada passo vn misterio, que calle, y diga el fervor: Luego el mismo callar es dezirlo mejor.

2. Entre pajas escondido recata su noble hoguera, y todo el Mundo se ardiera, si no se huviera ceñido: Mas quiere ser conocido del Mundo por poderoso, que el venir tan misterioso no es retirar el valor: Luego el mismo dezir es callarlo mejor.

4. Viene à vencer desarmado, y con silencio profundo sabe rendir todo el Mundo sin que le cueste vn cuydado: Todo el Oriente arrastrado siguiendo candida huella, viene á la luz de vna Estrella rico del Ayre vapor:

Luego el mismo callar 
es dezirlo mejor.

Biblioteca Nacional. Madrid (V.E. 83-5) (527-4) “Ha Josepeleo . Que dezer”.

Métrica: versos octosílabos y heptasílabos, aliteración en “li, li, li, li”. Rima asonante. 
LETRAS DE LOS VILLANCICOS QVE SE HAN DE CANTAR EN LA INSIGNE, Y SANTA

Iglesia Colegial de N. Señor San Salvador de Sevilla, en los solemnes Maytines de la Concepcion de N. Señora la Virgen Maria, Concebida sin pecado Original en el primer instante de su ser. Este año de 1697.

SIENDO MAESTRO DE CAPILLA DE DICHA IGLESIA D. SALVADOR

Garcia y Mendoça.

Impreso en Sevilla en este año 1697.

\section{SEGUNDO NOCTVRNO}

VILLANCICO IV.

Estriuillo.

MVera la noche,

huyan las sombras tiranas,

acaben los horrores,

cessen ya las borrascas,

pues nueuo dia, pues hermosa llama

pues durable explendor,

pues felice bonança

amanece se anima,

se enciende, se halla

en las misteriosas luzes,

$\mathrm{q}[u e]$ oy se concibe $[n]$ en la mejor Alua,

en cuyo esmerado ser

contra la comun desgracia,

ni a vn instante se vieron,

noches, so $[m]$ bras, horrores, ni borrascas.

Coplas.

COncibese Maria,

y en su ser a la esperança

nueuo dia le amanece

co[ $n]$ prevenidas luzes de la gracia,

y assi nu[ $n]$ ca la noche le vio la cara.

1. Para la mas luzida

se encendiò Divina llama, 
dandole espirito inmenso

actiuiad q[ue] la conserue intacta.

2. Y assi soplo tirano nunca la apaga.

1. Feliz haze la Luna

quando de explendor la calça,

dandole el sacro poder

a su admirable duracio $[n]$ consta $[n]$ cia.

2. Y assi es de los horrores sie $[m]$ pre ignorada.

1. Para èl comun aliuio

assegura la bonança,

pues en la Sabiduria

toda tranquilidad tiene librada.

2. Y por esso fue esse $[n]$ ta de la borrasca.

\section{VILLANCICO QVINTO.}

Introducion.

LAs tres gracias a Maria

gracias le vienen a hazer,

porque conocen que es ella

la gracia de su vergel,

Estriuillo.

Pues mirar, escuchar, atender, que las gracias este dia

diràn gracias a Maria,

y se las daràn mas bien.

Pues mirar, escuchar, atender.

1. Yo alego por Talia,

2. Yo Eufrosina serè.

3. Yo Aglaya, que a sus luzes

le rinda el parabien.

Pues mirar, escuchar, atender.

\section{Coplas.}

1. LA gracia soy florida, que la vida encontrè en la flor de Jese, cuyo fruto es la vida 
Flor blanca de Etiopia.

$\mathrm{q}[u e]$ sin original del Cielo es copia:

2. La gracia soy risueña,

que me gozo este dia

en ver como Maria

vn llanto desempeña,

pues el vè que ella pisa,

solo por ella se ha trocado en risa.

3. La gracia soy brillante, que acompaño este dia

como siempre Maria

en su primero instante,

en q[ue] se viò tan bella,

$\mathrm{q}[u e]$ a su lado aun el Sol fue opaca estrella

1. Fue su taller el Cielo,

cuya noble eficacia

la fabricò con gracia,

la adornò con desvelo,

Flor bella, y agraciada,

quanto mas cerca el Sol, menos ajada.

2. Entre albores esta Alua

festiua se aparece,

$\mathrm{y}$ al punto que amanece

el sol le haze salua,

en gracia se mejora,

pues la crió su Sol para su Aurora.

3. De sus luzes el Cielo

se retoca admirado,

y en su luz ha tomado

para su luz modelo,

que al Cielo en que se espacia,

fue notorio exceder su mucha gracia.

\section{VILANCICO SEXTO.}

Gallega.

Estriuillo.

1. HAla Domingos venid a folgar. 
2. Ay Toriuiño a gaita ${ }^{39}$ tocad.

3. A la Garridiña, que a la Serpentiña

le diò con su pranta vn golpe mortal

festiuos decid, contentos cantay,

$\mathrm{q}[u e]$ se à co[n]cebido para ser de Deus Mai

andar, andar, correr, folijai,

e naon para o son de a gaita,

e contentiños bailai.

Andar, andar, correr, folijai.

Coplas.

1. GAleguiña se nos mostra

la Nina de Deus Mai,

pois que con tanta limpesa

se concibe sin igual.

2. Claro està que es Galeguiña.

pois naon se quiso calçar

para pisar nosos campos,

los çapatiños de Adan.

3. Dizen que es valente muito, sen tener sombras jamas,

que amanecio Deus en ela

porque apuradiña estay.

Andar, andar, correy, folixai.

1. Quiso atreuida a su pranta

vna Serpente chegar;

mais dexôle sin peleijo

tan malicosa maldad.

2. Hizole con la frutiña

vn $[\ldots]$ mais $[\ldots]$

$[\ldots]$

que naon la quiso probar.

3. Mostró muy grande poder

para tener libertad,

mais que muito, si foy sempre

la filla de Eterno Pai.

Andar, andar correr, folixai.

1. Os Galegos le hazen festas,

\footnotetext{
${ }^{39}$ En el original, gaiita.
} 
y con folganças le dán

prasemes, y parabienes

todos juntos a la par.

2. Dexemos o pan de o millo,

porque con esta beldad,

aunque cuitadiños somos

comeremos branco pan.

Andar, andar, corrrer, folixad.

Biblioteca Nacional. Madrid.(VE. 92-43) (518-4). "Muera la noche".

Métrica: hipermetría, con rimas asonantadas sobre versos variados, endecasílabos, octosílabos, pentasílabos y cuartetas. 


\section{LETRAS DE LOS VILLANCICOS, QVE SE CANTARON EN LA SANTA, METROPOLITANA, Y PATRIARCAL IGLESIA, DESTA CIVDAD DE SEVILLA, EN LOS MAYTINES SOLEMNES DEL NACIMIENTO DE N. S. JESV-CHRISTO, COMPVESTOS POR DON DIEGO IOSEPH DE SALAZAR, Racionero, y Maestro de Capilla de dicha S. Iglesia.}

Año 1697.

\section{TERCERO NOCTVRNO.}

VILLANCICO VII.

\section{Estrivillo.}

1. NAce el Sol de justicia Diuino venciendo las sombras, y al formar felizmente los triunfos, rendido se postra.

2. Quien a visto venir a hazer guerra buscando victorias, sin mas armas que verse desnuda su Deidad heroica.

Los dos. Entre vn Buey, y vna Mula dispone su posada corta, donde a rayos, y a piensos la paja està peligrosa.

O, summa pobreza!

Deidad generosa, que de las humildades fabricas tus glorias; de esse corto Alvergue, de essa Esfera corta ilumina la tierra con Luzes, fertiliza la selva con Rosas, nace, viue, triunfa, reyna, manda, vence, rinde, postra: y arbitro de Cielo, y Tierra, conozcan que por ti logran la Tierra la Paz, y el Cielo la Gloria. 


\section{COPLAS.}

1. Nace, viue, pues viues, y naces

venciendo las sombras,

transformando en hermosas Estancias

las mas horrosas:

y pues a tu mano

deben la victoria

los rayos que triunfan

de la noche vmbrosa:

Nace, viue, triunfa, reyna.

manda, vence, rinde, postra.

2. Triunfa, reyna, pues todos los triunfos

tu brazo los forma,

para dar los Laureles Sagrados

con que te coronas,

que amante, y rendido

al alma la adornas

de todos los triunfos,

que felize logras:

Nace, \&c.

3. Manda, vence, pues vences, y mandas;

que el mundo conozca

por la ciega verdad de la Fè

tus luzes hermosas:

mudando los ritos,

pues las ceremonias

muestran realidades,

lo que fueron sombras:

Manda, vence, triunfa, reyna.

Nace, \&c.

4. Rinde, postra, pues para rendirse

vendran tres Coronas,

cuyas victimas son el indicio

de rendirse todas:

pues aun las humildes

Pastoriles Chozas

seràn las primeras,

que el culto dispongan:

Nace, viue, triunfa, reyna, 
Nace, viue, rinde, postra.

VILLANCICO VIII.

\section{Estrivillo.}

NO me tengais, Pastores,

cayga, ò no cayga,

dexad llegad mis ojos

donde mis ansias:

Dexadme vèr vn Niño,

que es la Palabra

del Señor Poderoso

de las Batallas:

$\mathrm{Y}$ aunque llora, tirita, y padece

reclinado en vn duro Pesebre,

su Amor descansa,

solo porque mi culpa

le hizo la cama:

$\mathrm{Y}$ assi dexadme,

que he de acercarme,

a que cada pajita, paja, pajuela,

que es su fuego chispa,

mi yelo encienda:

$\mathrm{Y}$ assi dexadme,

que he de acercarme,

porq $[u e]$ en cada pajita, pajuela, paja,

que el viento se me lleua,

me lleua el alma.

\section{Coplas.}

1. Quien es, Pastores, dezidme, este hermoso Niño, que ama

nuestra vil naturaleza,

pobre, y fea, sobre ingrata?

2. Qué Amor, qué Cupido es este

sin carcax, sin venda, ni alas,

y para heridas de fuego

son sus ojos flechas de agua? 
3. Què Amante es este, que siendo Hijo del mayor Monarca, le enamora la grossera terquedad de vna villana? 4. Què Peregrino es aqueste, que desde la Tierra Santa viene, y tan mal le reciben, que dos Brutos le agassajan? 5. Que Cautivo de su misma bondad es este, que para romper nuestra vil cadena, viene sugeto a arrastarla? 6. Què Pastor Cordero es este, que porque borrò la marca de su ganado vna culpa. trae su sangre a señalarla? 7. Mas no me digais, Pastores, quien es, pues sè que le llaman Manuel Iesus, que su nombre, y Salvador, que es su gracia. 8. Pero sabed, que al mirarle desnudo al frio, y la escarcha. serà de raiz infecta corazon que no se arranca.

\section{VILLANCICO IX.}

\section{Introduccion.}

Descalços vnos Gallegos entre nieve a Dios se acercan al modo que allà Moyses se acercaba entre vna hoguera: viendo que la tierra al Niño le trata con inclemencia, cantando al son de la gayta, le dizen desta manera.

\section{Estrivillo.}


HAy Niño meu

si te proba la terra

chegate acá

con la xente Galega:

Chegate acá

y oyrais como suena

ú favordon de a gaytiña que alegra:

Chegate acà

dareyte as sopiñas:

Chegate acà

dareyte manteca:

Chegate acà:

dareyte tuciño:

Chegate acá

dareyte turrejas:

Chegate acá

y oireis como suena

ú favordon de a gaytiña que alegra.

\section{COPLAS.}

O Fillo de Deus,

que nayce en Xudea,

con muytos rigores

le proba la terra,

O seno de ú Pae

yam no le calenta,

y eladu de frio

chorando se queyja.

Vas lagrimas suas

pareceyn Estrelas,

que caen sobre ò mundo

de ó Celo que tembra.

Aò mundo reparten

con muyta riqueza,

Santiagu uas conchas,

y ò Niño úas perlas:

Hay Niño meu

si te proba la terra

chegate acá 
con la xente Galega:

Chegate acá

y oireis somo suena

ú favordon de a gaytiña que alegra.

Suos llantos os causa

el furto de úa breva,

que foy golocina

de la primer fembra.

Entunces úa Serpe

non temia Eva,

$\mathrm{y}$ aora de as ratas

se espantan as Evas.

$\mathrm{O}$ a Serpe maldita

a tudos infeyta,

y hasta os Galegos

mordeu la Culebra.

O Niñu por estu

padece as tristezas,

y solu Galicia

diverte suas penas:

Hay Niño meu, \&c.

Vas pallas, y feno

úa cama le cercan,

como si ò Niño

Galego nacera.

De ò trigo que nace

úas pallas son señas

y foy terra Virgen

a donde se sembra.

O granu Diuinu,

ya esperu que crezca,

porque para ò Corpus

tengamus ùa sega.

Cubertu de a neve,

si ascarcha non cessa,

no habray en Galicia

quein teña cosecha:

Hay Niñu meo, \&c. 
L A V S D E O.

CON LICENCIA.

En Sevilla, por Iuan Francisco de Blas, Impressor Mayor de dicha Ciudad, Año de 1697.

Biblioteca Nacional. Madrid. (V.E.83-5) (520-1. ). "Nace el Sol de justicia Diuino".

Métrica: similar a la de una nana, "chégate acá", versos de gaita gallega, de romería.Hipermetria. 


\title{
VILLANCICOS QVE SE HAN DE CANTAR EN LA REAL CAPILLA DE LA ENCARNACION EN LOS MAYTINES DE LOS SANTOS REYES, EN ESTE AÑO DE 1698.
}

EN MADRID: Por Antonio de Zafra, Criado de su Magestad.

\author{
VILLANCICO V . \\ INTRODVCION. \\ POr facer festa àò Minino \\ Trusca, trus le, le, le \\ os Fidalgos Portugueses. \\ como en fro[...] ]a de Brasil, \\ trusca trus, le, le, le, \\ traen os Reyes de Oriente \\ com à musica mimosa, \\ trusta, trus, le, le, le. \\ De sua destreza queren \\ manifestar de seu peyto, \\ trusca, trus, le, le, le, \\ as reventenzas ferventes.

\section{ESTRIUILLO.}

PIquinino fermoso miraime, por ende, que morro, que fino pour vèr vossos beins.

Nome de Iesv, $\mathrm{q}[u e]$ si os traen os Reis el Ouro, è la Myrra, $\mathrm{e}[\mathrm{u}]^{40}$ os trayo ainda mayores riquezes; porque os Porto Orballo de à miña Fede,.

Nome de Iesv,

Que boo, que rico, mimoso precente que à Myrra è amarga,

\footnotetext{
${ }^{40}$ En el original, $e n$.
} 


\begin{abstract}
ò Ouro fenece,
è solo saon firmes

nosos Portugueses;

que boo, que rico

mimoso presente.
\end{abstract}

\title{
COPLAS.
}

1. Como tein atrevimento

vn Iumento

desatento

de estarse à vista de vn Rey,

è qua $[n]$ do os Reys concurren,

naon escurren,

nem discurren

de andar fora de Belèn?

Ficay para là

que eu le botarey.

2. Como ò boy à corname $[n]$ ta

naon aventa

è se contenta

com estar de Neno àos pes?

parece Boy Castellaon

Don Fulaon,

è Don Zutaon,

tudo è palla, è naon fazer.

Ficay, \&c.

1. Si en Belèn de Portugal,

ò Portal

taon principal

estivesse, eu iurarei

naon entrassen animais

com os quais

si os estais,

naon vos podem tenor Ley.

Ficay, \&c.

2. Muyto cuydo que Castela

Churumbela,

è zumbarela,

por humildade escolleis, 
pois $\operatorname{co}[n]$ brutos tan rendidos, encollidos

mortecidos,

sendo Deus tratais nacer.

Ficay, \&c.

1. Si queredes ir Lisboa

cosa boa

de gran loa,

mais servidu ficareis;

porque là tudo è grandeza

esclareza,

è riqueza,

dos Fidalgos de mais prèz.

Ficay, \&c.

2. Boos Reys vos han venido

Rey pulido,

bein nacido,

da Rinha de rosiclèr,

mais outro Rey farsantaòn

patifaòn,

vergantaòn,

vos quere facer morrer.

Ficay, \&c.

1. A Estrella que os conduce,

è reduze,

quando luze,

àos Reys $\mathrm{q}[u e]$ vos venen vèr,

os prometo, que è bien rara

mais ficàra,

inda crara,

sendo do ceo Portuguès.

Ficay, \&c.

2. Recebid nossas vontades

soledades,

è saudades,

que indò nos dexareis,

e si no tomais por garda

à espingarda,

è alabarda, 
rudo ò inferno nao $[n]$ te $[m]$ breis.

Ficay, \&c.

1. Herodes è vn espactallo,

si emforçallo,

espabentallo,

con nossos ollos quereis

ele matarà Inocentes

naon vallentes

com os dentes,

tudo me lo yantarey.

Ficay, \&c.

Biblioteca Nacional. Madrid. (34989-26) (123-5). "Por facer festa àò Minino".

Métrica: versos heptasílabos y pentasílabos, rima consonante. Hipermetria. Aparece el odio a Castilla: "Vingarse de Castela". 


\section{LETRAS DE LOS VILLANCICOS QVE SE HAN DE CANTAR EN LOS solemnes Maytines del Nacimiento de N. Señor Iesu Christo, en la Insigne Iglesia Colegial de N. Señor San Salvador de Sevilla. En este año de 1699. SIENDO EN ELLA MAESTRO DE CAPILLA Don Salvador Garcia y Mendoça.}

\section{SEGVNDO NOCTVRNO.}

\section{VILLANCICO QVARTO.}

Estrivillo.

AY que dolor q[ue $]$ padece el Dios de amor, socorro Cielos, $\mathrm{q}[u e]$ entre yelos està temblando el ardor.

\section{Coplas.}

1. SEñor que humildad es esta siendo Rey, y siendo Dios? como ho[ $m]$ bre, y como vassallo en vn Portal naceis oy.

2. Si es cierto que sois Giga[ $n]$ te, que assi David lo aclamo, por que de la pequeñez hazeis oy obstentacion? 3. Por que al rigoroso Invierno permitis juridicion? por que tiritais de frio, siendo de Iusticia Sol. 4. Por q[ue] en vn Portal humilde escogeis habitacion, quando todos essos Cielos no son capazes de vos?

5. Mas si hazeis estas finezas con amorosa passion por el hombre mas ingrato, el suspirar es razon. 
VILLANCICO QUINTO.

Estrivillo.

ATencion, atencion Pasqual, veremos en el Portal llegar infinitas gentes de Provincias diferentes, y como fueren llegando los iremos conociendo en el son que fuere haziendo, cada qual de su nacion.

Atencion, atencion, que por mas admiracion de ver Dios hombre nacido. los $\mathrm{q}[u e] \mathrm{ha}[n]$ de ser, son, y ha[ $n]$ sido, todos han de ser [...] atencion.

\section{Coplas.}

1. AL Villano se lo dàn entre paja el blanco Pan, al Villano pobre y rico este manso Corderito, lo cubre con su pellico las desnudeces de Adan. Al Villano mas grossero, Dios, $\mathrm{q}[u e]$ es grano verdadero, se le mete en el granero, porque como sin afan.

2. Monsiur lugar sonete, porque me plure, bu, estant $\mathrm{u}[n]$ vallant home qui ne puve entre plu la turu ru ru le dize de las batalles qui au Monde aves venu vus les autes tre gràndes por te bu, leben car la turu tu tu tu. 
3. Chora ò Sol, la Aurora rie, perlas corren de mar a mar, que si ela rie, lo Nino chora, namoreme ó seu chorar.

$\mathrm{O}$ meNino enamorado, chorando de amor està,

e la sua Mai o chega ao peito

e a cantiñas le fas calar.

4. Tu le tienes Niño vestido de tu Padre, juras tal no tengo, que pusome la Madre, pusome la risa de Auroras quando sales, aunque con vestido le vengo de mi Padre. Iuras tal no tengo, que pusome la Madre.

5. Pois que Deus nos dà bona noite, pois que Deus nos dà boas Pasquas.

Mingo que te falta, sone toda a noite a gaita, porq[ue] Deus nos dà boa noite, como te no $[n]$ alegras Mingote ${ }^{41}$ pois que Deus nos da noite franca, como te no $[n]$ brincas, e saltas Mingo que te falta? sone toda a noite a gaita. 6. Aqui sa mi Dios veldadelo; aqui quiele lo neglo molil santelo, aqui sa neglo de antaño, que quiele sel helmitaño, polque tiene desengaño de lo mundo pasa delo, aqui hala la santa vila, pues lo siglo dame en rostlo, con cantimplola en Agosto i calentalo en Enelo.

Biblioteca Nacional. Madrid. (V.E. 83-5) (214-1). "Ay que dolor padece el Dios de amor”. Métrica: polimetría con rima asonante. 
${ }^{41}$ En el original, mingote. 


\section{LETRAS DE LOS VILLANCICOS QVE SE CANTARON EN LOS SOLEMNES MAITINES}

de la Inmaculada Concepcion de N. Señora, concebida en gracia desde su instante primero; en la Insigne Iglesia Colegial de nuestro Señor San Salvador de la Ciudad de Sevilla. En este año de 1699.

COMPVESTOS POR DON SALVADOR GARCIA, Maestro de Capilla de dicha Colegial.

Con licencia, impresso en Sevilla por Iuan de Ossuna, año de 1699.

TERCERO VILLANCICO.

Gallego.

Estrivillo.

A Mea Zagaliña,

que tan garridiña

a la serpentiña

su pranta la frente le pudo quebrar.

Todos os Galegos, è Galeguiñas

le veñan a cantar,

ay ay, ay, vaya de boltiña,

$\mathrm{y}$ aò son de la gaitiña

naon paren de bailar.

Ay ay ay.

Coplas.

1. POis que sa concibida

tan pura, y tan luzida,

de Deus sin enollos

la niña de suos ollos,

e sen comun refrega

nos mostra que Galega

es ela sin igual. Ay ay ay.

Vaya de boltiña,

y ao son de a gaitiña

naon pareis de bailar.

Ay ay ay.

2. Pois que a vincido vela 
da serpe la cautela,

e con su pranta pura

ao mundo le assegura

felice la esperança,

cando la sorte alcança

ser de Deus la mai. Ay ay ay.

Vaya de boltiña, \&c.

3. Pois limpia Zagaleja

la celebra esta Igreja

Galega sen trafago, donde vn buen Santiago

de su alabança cura,

pois cando ela se apura,

el culto ele le da. Ay ay ay.

Vaya de boltiña, \&c.

4. Pois q[ue] de Adan os tratos

naon tein, e sen çapatos

vene de Compostela,

e tuda es vna estrela,

a quein por su fortuna

chapines dà la Luna,

y el Sol su claridad.

Ay ay ay.

Vaya de boltiña, \&c.

5. Pois tudo mal desterra

a ser de Salvaterra,

y es vn Iardin cerrado

a donde nunca ha entrado

del aspid el veneno,

y de la gracia lleno

su limpio ser estay.

Ay ay ay.

Vaya de boltiña, \&c.

6. Pois es Cipres copado

a donde nunca ha entrado

de culpa la polilla,

y a la infernal trampilla

de o demo con pisalla

la dexa de agalla, 
y ela se queda en paz.

Ay ay ay.

Vaya de boltiña, \&c.

\section{NOCTVRNO.}

\section{VILLANCICO QVARTO.}

\section{Estrivillo.}

VNa Niña valiente

triunfa briosa

de vn dragon atrevido

con gracia heroica.

Miren que bella

vean que hermosa, oy triunfa de la culpa

con gracia heroica.

\section{Coplas.}

1. ESta Niña q[ue] oy se co[n]cibe Reyna, Virgen, Madre, Esposa, oy el mu[n]do en acentos suaves llama, quiere, busca, logra.

2. En mirando la culpa su talle teme, gime, tiembla, llora $\mathrm{q}[u e]$ vna Niña $\mathrm{ta}[n]$ tierna la traiga presa, atada, muerta, en so $[m]$ bras.

3. Es la Estrella del mar, que se mira Luna, Puerta, Sol, Aurora, es tambien la paz desseada, Arco, Cedro, Mirra, Aroma.

4. Es del Huerto Concluso la palma, Poço, Zarça, Vid, Paloma, y del Verbo Divino encarnado. Casa, Lirio, Oliva, Pompa.

5. Los espiritus bellos le canta[ $n]$ Himnos, Triunfos, Lauros, Glorias, porque el espejo del Padre la miran Fue $[n]$ te, Te $[m]$ plo, Escala, y Rosa. 
Biblioteca Nacional. Madrid. (V.E. 92-45). "A Mea Zagaliñá”.

Métrica: gran variedad de polirrítmia, versos octosílabos. Aparecen formas letànicas en las alabanzas a la Santísima Virgen. Polimetría. Rima asonante. 
LETRAS DE LOS VILLANCICOS QVE SE CANTARON EN LOS

Maytines de la Inmaculada Concepcion de N. Señora la Virgen MARIA Concebida sin culpa Original desde el primero instante de su Concepcion Santissima, en la insigne Iglesia Colegial de nuestro Señor San Salvador de la Ciudad de Sevilla. SIENDO MAESTRO DE CAPILLA DON SALVADOR GARCIA. Año 1700.

En Sevilla: Por Francisco van Leesdael, en la calle de los boteros.

\section{VILLANCICO II.}

\section{Estrivillo.}

Cortesanos felizes, venid, y vereis

los prodigios que ostenta vn pensil, los milagros que oculta vn bergel, escuchad, atended, escuchad del amor el Concepto, atended à la voz de la Fè, venid, y vereis vna copia de Dios en M A R I A pues no puede ser que el sol sin la Aurora se dibuxe fiel.

\section{COPLAS.}

1. Mirad en esse pensil aquel prodigio de Oreb que en sabrosa lluvia el alva, lloro al primer rosicler. 2. Pues si ya veis el Mana tan bien el Alva atended que intacta observo, y gloriosa lavarà el Mana, y la Fè.

3. Mirad en aquessas flores, al Sol que parò Josue la primer vez que se viò la noche retroceder.

4. Mas si veis parar el Sol no menos prodigio fue 
en el valle de Asallon

parar la Luna tambien.

5. Y en el mismo Paraìso

hollando el dragon vereis,

la fuerte Muger sin sombra

de la primera Muger.

6. Ved al arbol de la vida,

que en esse hermosos plantel

es oy, antidoto aquella,

planta, que veneno fue

que no puede ser

que el Sol sin la Aurora,

se dibuge fiel.

\section{VILLANCICO III.}

Gallego.

Introduction.

Dos Gallegos esta noche

llegan justos a porfia

a celebrar muy gustosos

la Concepcion de M A R I A.

Todos juntos en su lengua,

y en Canciones muy distintas,

cantando y baylando à vn tiempo

dixeron con melodia.

Estrivillo.

Aa festa de M A R I A

entrar queren Galegos

con vna danza que tragen

arriba de Oporto belo,

y todos repiten con grande contentu

tange Domingueiro

vailare a chiquita porque la queiro.

COPLAS 
1. Ay, Pastorsiña bela,

Fermosa y agraciada,

feitiso de amoires

que robas las almas.

2.Filla de meos ollos,

ai, miña may de Deus,

a mi noticia viño

voso festejamento,

ai, faseme o son,

que queiro bailar a mi lindo amor.

3. Ay, tange as sonallas,

de boda y de festa,

Toribio a gaita

y Anton a corneta.

4. Vamos a ver a Estrela ${ }^{42}$,

que estai Concibida,

e mais que os ollos

fermosa i lucida.

5. Ai, que ia a Serpente

busco sua pranta,

e tubo en su Cabesa

que chorar cuitada.

6. Oy por suas victorias, que soun singulares,

se alegran os montes,

frorecen os valles.

7. Oi celebran todos

en aquesta Igreja

de aquesta minina

su Concepcion bela.

8. Tambien os galegos

poden Festejarla,

pois es galeguiña,

aqueista zagala,

faseme o son,

que queiro bailar ao mi lindo amor.

${ }^{42}$ En el impreso, a es Estrela. 


\section{VILLANCICO IV.}

\section{Estrivillo.}

Sol, Estrellas, y Luna,

Flores, y Plantas,

de M A R I A publiquen,

con quanta gracia,

al triunfar de la culpa

luze sin Mancha.

\section{COPLAS.}

1. Luzcan de oy mas por M A R I A,

la luna, y el Sol sus bentajas,

aqueste porque la viste,

y aquella porque la calza.

2. Lo remontado acredite,

a las Estrellas de vfanas,

que estan sobre su cabeza

y nunca mas levantadas.

3. Aquel Ciprez tan excelso, que la quarta esfera passa,

o lo funesto desmienta

o solo a la imbidia balga.

4. Aquella Palma que el aire, ni la tuerze, ni contrasta,

por esta vitoria logre,

el aver nacido palma.

5. Aquel Jardin defendido, de tanta fuerte Muralla,

a las Plantas mas felices

ofresca Flores, y Plantas.

6. En aquesta hermosa Fuente, que tanto cristal desata,

se retrate su preza

si acaso corre tan clara.

Biblioteca Nacional. Madrid. (R.34199(9) (535-2. ) "Cortesanos felizes, venid y vereis". 
Métrica: polimetría; polirrítmico, combinando variedades enfática, heroica, melódica y sáfica. Rima consonante. 
LETRAS DE LOS VILLANCICOS QVE SE CANTARON EN LOS

Maytines solemnes de la Transfiguración de Nuestro Redemptor Jesu-Christo, en la

Iglesia Colegial de nuestro Señor San Salvador, de la Ciudad de Sevilla, en este año de

1700.

SIENDO MAESTRO DE CAPILLA DE DICHA INSIGNE

Iglesia Colegial D. Salvador Garcia.

\section{VILLANCICO}

de Kalenda,

Y primero de Maytines.

ESTRIVILLO.

VIctoria por las luzes

pues vn monte eminente

oy triumpha de las sombras,

siendo Alcazar de Christo

reverente.

$\mathrm{Y}$ assi, en marcial estruendo

las luzes, y la nieve

convocan à batalla

à todos los vivientes.

Todos armados suban,

porque aunque glorias suenen

entre penas, y ansias,

se trata de la muerte.

Christo, Capitan grande,

oy triunfante se atiende,

coronado de luzes,

vestido de la nieve.

Nadie en sus fuerças fie,

pues tres caudillos fuertes

solo â vna voz que oyen

en pavor sus alientos se convierten.

Todos al monte suban,

todos al monte buelen. 
COPLAS

1. COn denuedo y arroga $[n]$ cia

Christo, Capitan valie $[n]$ te,

oy pone su Plaça de Armas

de vn mo[n]te en lo mas ardie $[n]$ te.

2. A tres caudillos oy lleva

à lo alto, y eminente,

que victorias sin trabajos

rara vez vemos se adquieren.

3. El Sol ostenta su rostro,

y sus vestidos la nieve,

que los efectos contrarios

los vne el amor â vezes.

4. Aunque triunfante se mira

solo trata de la muerte,

que aquesto es lo mas seguro

para conseguir laureles.

5. Fueron breves estas glorias, mas no admira â quie $[n]$ supiere

que las glorias de esta vida

fueron transitorias siempre.

6. Si á todos oy Christo llama,

ninguno escusarse puede,

pues â voz tan imperiosa

es preciso obedecerle.

\section{VILLANCICO II}

\section{ESTRIVILLO.}

PAxarillo que cantas

en vn monte con tanto rumor,

no cantes, no, suspira,

si fino pretendes mostrar tu passion,

que si en este monte atiendes

que glorias, y penas oy muestra el amor,

à tus passages suaves

mezclar es preciso el gozo, y dolor; 
no cantes, no, suspira, suspende el rumor.

\section{COPLAS}

1. SI aciertos pretende

paxarillo lograr tu rumor

cantando suspira,

pues el Sol que en el monte se mira

passages de glorias apenas te diò.

2. Requiebros entona,

que acompañe feliz el dolor,

pues suben al Cielo

las ternezas que forma el desvelo,

$\mathrm{q}[$ ue $]$ explica $[n]$ memorias de ama[n]te passion.

3. El Sol resplandece

$\mathrm{Y}$ ha querido obstentar su arrebol

su mas fino, y flamante,

acordando en las vozes de amante,

Eclipses que encienden sus luces mejor.

4. Vestido de nieve

en vn monte oy vè mi atencion

al Verbo divino,

que en aqueste dia previno

vestirle de nieve con luzes del Sol.

\section{VILLANCICO III.}

\section{ESTRIVILLO}

A mirar este dia

en gloria tanta

en vn monte â mi Dueño

vengan las almas.

COPLAS

1. SEpa $[n]$ todos q[ue $]$ oy â vn mo[n]te sube Christo co[ $n]$ gran ansia

con tres Amigos queridos

de los doze de la fama.

2. A trasfigurarse sube,

comunicando con gracia 
à su cuerpo de las glorias

que tenia allà en el alma.

3. Por mas bello de los hombres

este dia se declara,

con vn rostro como vn Sol,

$\mathrm{y}$ vna vestidura blanca.

4. Desde vna nube vna voz

oy por hijo lo declara,

y resonando en el ayre,

el eco dió en la Montaña.

5. Esto sucediò en este dia

en el monte de mas fama,

y aqueste es el Euangelio,

y la verdad apurada.

6. El que quisiere subir

à gozar glorias tan altas,

ha de ser sin embaraços

de las passiones humanas.

Biblioteca Nacional. Madrid.(V.E. 83-5) (533-1). "Victoria por las luzes".

Métrica: polimetría, rima asonante. Versos octosílabos, pentasílabos y heptasílabos. (Muy similar a los cantares de ciego.) Típico del romance, rima asonante. 


\section{LETRAS DE LOS VILLANCICOS QVE SE CANTARON EN LA SANTA Iglesia Metropolitana, y Patriarchal de Sevilla, en los Maytines de la Venida de los Santos Reyes.}

\section{VILLANCICO.}

Al Portal nueva luz sus Rayos forma y dexa con su Estrella nueva gloria ${ }^{43}$, huyen las sombras, huye la noche; porque sus luzes vencen los horrores. Venid a ver, llegad, ba[y]lad, que a vn Niño le adoran coronas sin par, $\mathrm{y}$ en dulces obsequios, en tiernos deseos, se abaten, se rinden, se postran humildes, siendo despojos oy de tanto incendio la Mirra, y el Oro, y en fuego el Incienso.

\section{COPLAS.}

Ofrecer holocaustos

donde ay merecimientos, es avivar las Aras, y hazer que en si se encienda el mismo fuego.

Lo altivo con lo humilde

hazen que en lo supremo

la humanidad mendig[u]en ${ }^{44}$,

divinidades muchas de su Cielo.

Rayo que se introduze a donde esta el incendio, déxa de ser estrella, y acredita de Sol el Emiferio:

Arrodillar coronas, es ensalzar los cetros, y tributar cariños, hazer aun mas seguros los Imperios.

Aceptar a losReyes vn Infante el obsequio

\footnotetext{
${ }^{43}$ En el impreso, gloría.

${ }^{44}$ En el impreso, mendigen.
} 
es admitir la jura

de ser de tantos Reynos heredero.

Entren oy la parte,

del Oro en el Mysterio,

la mirra por la pena,

y para vltima ofrenda es el Incienso.

\section{VILLANCICO.}

\section{ESTRIVILLO.}

GIlguero que en la selva de tanta luz te emboças, y en blandas armonias estas trinando glorias:

si tan lindo me enamoras basta lo hermoso, lo fino te sobra.

\section{COPLAS.}

Gilguero galan del Cielo, que del nido del Aurora para ser del alma echizo oy sale tu hermosa Pompa.

Divino cantor del alma $\mathrm{q}[u e]$ la encantas y enamoras, librando tanta Armonia en tu providencia sola. O que bien $\mathrm{q}[u e]$ me dispierta $[n]$ tus tiernas vozes sonoras de la noche de mis dudas, A las Luzes dellas proprias. A solicitarme baxas con vozes tan misteriosas, que informadas del oydo me dizen lo que me toca. Gran prodigio de finezas, con vuestra armonia sola logran los que contraputan, 
pues cantas que es vna gloria.

VILLANCICO III. Gallego.

\section{ESTRIVILLO.}

LEru, leru, leru, veñan a ver,

o fillo de Deus:

Ferrol, Coruña,

Ribadaiva, e Lemos,

Leru, leru, veñan a ver,

ò Fillo de Deus.

Pois Angeliños,

y os Pastorciños

ào Portaliño

venen a vello;

veñan a ver ò fillo de Deus.

\section{COPLAS.}

En suo sembrante Divino

me diz ò Infante que naze

con os Galegos faze

muito lindo Galegiño,

querenle por suo camino

as moças de Ribadeo.

Veñan a ver, ò fillo de Deus.

Veña Ore $[n]$ se e $\mathrm{Co}[m]$ postela

Vilafranca, e Monte Rey,

a ver, ò minino Rey,

que a nacido de vna Estrela,

dichosos seràn en bela,

y al garridiño Galego.

Vengan a ver, \&c.

Vein tres Reyes baroniles, de vna Estrela por consejos, e diz que veinen moy lexos, mais alla de los Madriles:

ellos son Homes Gentiles, 
mais tein cosas de omes buenos.

Venan, \&c.

Junto al Neno, Joben $\mathrm{Sa}[n]$ to

muito la Mula se pega,

bastavale ser Galega

para que se arrime tanto;

si la gente le dà espainto

tira couzes hasta ò Ceo.

Leru, venan, \&c.

Aunque parece estai ledo

el Boy, es de grain valor, pues no le tiene millor

o obispo de Mondoñedo;

calenta con suo valor

ào neno que està en o yelo.

Leru, veñan \&c.

La gente de nosa terra

fizo alli lo que le plugo,

è Domingos el de Lugo

presentole vna Bezerra,

con a gaita he con a perra

sè baylò con gran floreo.

Leru veñan $\& c$.

Biblioteca Nacional. Madrid. (V.E. 83-35) (412-1). "Al Portal nueva luz sus rayos forma" Métrica: polimetría, con predominio del octosílabo propio del villancico del siglo XVII. Presenta rima consonante en el estribillo con sonidos iguales (no grafias iguales). Aparece reforzada por la pausa versal. 


\section{LETRAS DE LOS VILLANCICOS QVE SE CANTARON EN LA Santa Metropolitana, y Patriarcal Iglesia de esta Ciudad de Sevilla, EN LOS MAYTINES SOLEMNES DEL \\ Nacimiento de Nuestro Señor Jesu-Christo. COMPVESTOS POR DON DIEGO}

Ioseph de Salazar, Racionero, y Maestro de Capilla de dicha S. Iglesia.

\section{PRIMERO NOCTVRNO. ESTRIVILLO.}

FAvor, piedad, clemencia, que me llevan las olas, y el amor que cautiva, qua $[n]$ do me engolfa.

Favor, piedad, que se encrespa erizado el mar, Clemencia, que ya toca la gabia en las Estrellas. Favor, piedad, clemencia; Mas ay que ya el Sol de candida esfera nace iluminando las obscuras nieblas.

\section{COPLAS.}

1. NAve del Sol cargada Capitana flamante, que del mundo el remedio en tu Thesoro traes; Ya la salva te hazen el ruydo de los bronzes sonorosos, el estruendo marcial de los metales.

2. En hora buena surques los procelosos mares, para que los peligros mayor el triunfo aclamen; Ya la salva te hazen, los ecos numerosos de la esfera, las vozes que del Cielo son plumages.

3. Ven Peregrina Flota, $\mathrm{y}$ en tu llegada clamen de nuestras vivas ansias 
los continuos combates;

Ya la salva te hazen,

las zozobras de nuestros corazones

en regozijos bueltos los pesares.

4. Para nuestro remedio

en tierra desembarque,

todo el caudal precioso

que de tu vientre nace;

Ya la salva te hazen,

alados esquadrones del Impireo

aplaudiendo tu arribo favorable.

5. Desembarca felice,

y la tierra se esmalte

de aljofares preciosos

de perlas orientales;

Ya la salva te hazen,

la municion hermosa de las flores

recien nacidas en la verde margen.

6. A tierra, á tierra gozos,

à fondo, á fondo males,

coronense los sustos

de glorias, y de pazes;

Ya la salva te hazen,

brilla[ $n]$ te Capitana de las luzes,

la tierra, el mar, el Cielo, el hombre, el Angel.

\section{VILLANCICO SEGVNDO.}

\section{ESTRIVILLO.}

NAzes mi Niño, naces mi dueño,

à buscar mis glorias en tus tormentos:

Ay que fineza de amor!

ò que milagro de afecto!

Fecunda la tierra, y llueven los Cielos,

que nace penando, y venze muriendo.

\section{COPLAS.}

NO me diràs Niño hermoso 
qual de los dos es mas tierno,

tu afecto apra los hombres

ò tu edad para los yelos?

Mas la respuesta, ya la prevengo,

todos son vnos, yelos, y pechos.

2. Dime quando, Niño mio,

mas fino llorarte debo,

aora que naces temblando,

ò quanto tiemblas muriendo?

Mas ya me imagino, que llorar puedo,

sie $[m]$ pre que al verte temblar no tie $[m]$ blo.

3. Dime, Niño de mi vida

qual es mas en tus afectos,

buscar humano la tierra,

ò dexar Divino el Cielo?

mas ya mi Niño, sè que el que tierno

busca à Maria, no dexa el Cielo.

4. Es Grammatica de amor,

que en la Oracion de tu afecto

seas la persona que haze

la que padece, y el Verbo;

pero ya miro, que en ti no es nuevo,

si hombre, y Dios eres, en vn supuesto.

VILLANCICO TERCERO.

\section{ESTRIVILLO.}

VN Gallego Pastorcillo

su Gayta estrenar dispone

porque al fin todo lo bueno

se hizo para questa noche.

Teño de alegrar à meu chicote

con mi Gaytiña nova aquesta noyte,

Ay, ay, ay,

que zumbe la Gaytiña sin cessar,

Ay, ay, ay,

ea Galeguiños à baylar,

andar, zumbar, brincar, saltar, 
Ay, ay, ay,

que ò meo garridiño,

poys nace pobreciño,

Galeguiño serà.

Ay, ay, ay,

que zumbe la Gaytiña sin cessar,

àò son de mi gaytiña

farey mil gorgoritas,

como las paxaritas

de ò Sol al despertar.

Ay, ay, ay,

ora, bravo, lindo, bono vay,

andar, zumbar, brincar, saltar,

ay, è todos à compas

diremos à montones.

Teño de alegrar à meu chicote

con mi Gaytiña nova aquesta noyte.

COPLAS.

1. Noso Señor me vala

que ò fillo de zagala

non cessa de chorar,

caray que verte perlas,

Galegos à cogerlas,

que muyto vos valdràn,

è yo con mi Gaytiña

farey mil gorgoritas,

como las paxaritas

de ò Sol al despertar.

2. Pasqual el de Betanzos

traerale vnos garbanzos

para le regalar,

que ò Crego dixo vn dia

que certa goloziña,

àò Neno à tierra tray,

E yo \&c.

3. Anton de Rebolledo

de ò Pan de Mondoñedo

traerale vn bon candeal, 
que ò Neno q[ue] està en palla

espiga es serenada

que ò Hebreo trillarà,

E yo \&c.

4. Endonele Pelayo

aquel pellico sayo

con que foy mayoral,

que ô Neno està desnudo,

è fay vn zierzo crudo

como por Navidad.

E yo, \&c.

5. Martin el de Coruña

traeralo sin que gruña

vn Gilguerin cerdal,

poys Deus fay boas migas

àò Demo malas figas

su bon olor darà.

E yo \&c.

6. Marina la de Lugo

le endonarà vn besugo

qual la nata fres[c]al, que oy chama los Pastores

dempoys los pescadores,

ò Neno chamarà.

E yo \&c.

7. Ginès el de Monforte

vn Galo, è sos consortes

àò Chico traerà,

que ò Neno de meus ollos

como Gallina àos Pollos

nos quiere cobixar.

E yo \&c.

En fin Galegos nobles,

donayle corazones,

fazenda è canto ay

mays non los zapatiños

que en boos Galeguiños

del cinto han de colgar. E yo \&c. 


\section{VILLANCICO QVARTO.}

\section{ESTRIVILLO.}

AY Amor mio, ay Amor!

$\mathrm{q}[u e]$ remontas al hombre, y humillas à Dios.

\section{COPLAS.}

1. SI acredita lo amante su merito al rigor, muy tiernamente amais pues dà gala à tu gloria tu dolor. Ay amor mio, ay amor.

2. Si amante, y soberano no se compadeció, oy lo vniò tu fineza que estremos mas distantes enlazò. Ay Amor mio, ay amor.

3. La ingratitud fue siempre causal del disfavor, pues como ancioso buscas à quien grosero te desconociò. Ay Amor mio, ay amor. 4. Pues a tu providencia la piedra se ablandò, segun te corresponde mas es que risco nuestro corazon. Ay amor mio, ay amor.

5. Si á provincias distantes luz tu eficazia diò, hazed que mis suspiros se exalen humos à tu adoracion. Ay Amor mio, ay amor.

\section{VILLANCICO QVINTO.}

\section{ESTRIVILLO.}

1. SI es que ha de aver Xacarilla cayga, compañeros, cayga. 
Todos. Tenga, camarada, tenga.

2. Que ha de caer, voto al agua de Mayo, quando el Diziembre està lloviendo garrafas?

1. Yo me entiendo, y Dios me entie $[n]$ de, cayga, compañeros, cayga.

Tod. Que ha de caer? 1. Mucho, y bueno, pues de las Esferas altas los Luzeros à razimos, y los Zefiros á cargas, vnivocaràn en luzes los candores de la escarcha, y aquesta noche en Sevilla?

2. Que ha de aver? 3. Las $\mathrm{Sa}[n]$ tas Pasquas.

3. Y que ay en el Paraiso?

1. La Manzana, que con esta nos han hecho siete causas, y pues ya estarà madura, cayga, compañeros, cayga. Todos. Cayga.

1. Cayga pues, y de la Historia con todas sus circunstancias, sepa el Niño qu esta fruta es quien le ha puesto en la paja.

Todos. Vaya pues.

4. Vaya pues de Xacarilla. cayga, compañeros cayga,

\section{COPLAS}

1. Hagamos, dixo el Eterno para las cosas criadas, hagamos al hombre, á nuestra Imagen, y semejanza.

2. Y dicho, y hecho alli luego, con las manos en la masa, armò de vn poco de tierra vn Adan como vna tapia.

3. Durmiose, y de vna costilla para que en amor compaña 
viviessen, le hizo vna Eva

que fue la parte contraria.

4. Hetelos aqui casados, gustosos, contentos, y hasta

solos como recien hechos

para padres de la patria.

5. Sin mas carga que vn precepto,

y muy ligero, pues para

dos casados de por vida,

que precepto ha de ser carga?

6. Viendo el diablo en tanta altura

la naturaleza humana,

en forma de Sierpe quiso

pegarle palo que cayga.

7. Come, dixo, de essa fruta

come, que aunque sea vedada,

si comiendo has de ser Diosa

quien lo manda lo desmanda.

8. En fin comio, y nada huviera

si entonces, como oy se vsara,

que entre dos que bien se quieren,

con vno que coma basta.

9. Pero ella se fue à su esposo

diziendo, prueba, que es brava,

y sobre ser linda cosa

poco rejalgar no mata.

10. Con que comiò como dizen, porque quiso no enojarla,

fabricando vna fineza,

y cayosele la casa.

11. Vino el Verbo Eterno, y vino

con tan amorosas ansias,

que fueron sus ojos fuentes

à vista de humildes pajas.

12. Y vino à que sepa el hombre, que està alegre como en Pasqua,

quando con toda su ciencia

el Diablo sabe que rabia. 


\section{VILLANCICO SEXTO.}

Estrivillo.

OY te adora, Dios Niño,

mi amante passion,

cantando, y temblando

porque tierra soy;

Ay amor, amor,

temblando de frio, estàs siendo Sol,

y al verte temblar, tambien tiemblo yo;

Ay amor mio, ay amor.

\section{COPLAS.}

1. Tiemblas mi amado Jesus, que has querido, siendo Dios, ser hombre, porque de tierra sea tambien el temblor, y al verte temblar, tambien tiemblo yo. 2. Tiemblas, y al mundo estremeces sin que sea admiracion, que tiemble oy mi flaqueza de ver temblar tu valor, y al verte temblar, tambien tiemblo yo.

3. Tiemblas, y entonces predicas como Verbo, aunque sin voz que estremecidos temblores vozes, y palabras son, y al verte temblar, tambien tiemblo yo.

4. Tiemblas con ser Inocente, si tu tiemblas que harè yo? que temblar es del culpado, del que està sin culpa no, $\mathrm{y}$ al verte temblar tambien tiemblo yo.

5. Tiemblas conociendo al mundo, y que su desatencion paga con ingratitudes las finezas de tu amor, y al verte temblar tambien tiemblo yo. 
6. Tiemblas piadoso, y naciendo

me hazes cargo desde oy,

para el dia en que juzgando

será tu piedad rigor,

y al verte temblar tambien tiemblo yo.

Biblioteca Nacional. Madrid. (V.E. 1309-95) 201-1. "Favor, piedad, clemencia". Se cantó en el Real Convento de la Encarnación en la noche de Reyes de 1682 (537-1) y en la Metropolitana Iglesia de Sevilla en el año 1700.

Métrica: versos octosílabos, con gran polimetría versal y rítmica. Aparece el endecasílabo dactílico con acentos en cuarta, séptima y décima, presentando los elementos propios del arte mayor. Rima asonante. 


\begin{tabular}{|c|c|c|c|c|}
\hline Orden & Parte & Año & Fragmento & $\begin{array}{c}\text { De } \\
\text { gallego }\end{array}$ \\
\hline 1 & 1 & 1621 & 1621 - Convento del Carmen & 1 \\
\hline 2 & 1 & 1626 & 1626 - Sevilla 1 & 1 \\
\hline 3 & 1 & 1626 & 1626 - Sevilla 2 & 1 \\
\hline 4 & 1 & 1629 & 1629 - Sin ubicación & 1 \\
\hline 5 & 1 & 1629 & 1629 - Sin ubicación - 2 & 2 \\
\hline 6 & 1 & 1632 & 1632 - Convento de las Mercedes & 1 \\
\hline 7 & 1 & 1633 & 1633 - Toledo & 2 \\
\hline 8 & 1 & 1642 & 1642 - Toledo & 1 \\
\hline 9 & 1 & 1644 & 1644 - Toledo & 1 \\
\hline 10 & 1 & 1646 & 1646 - Salamanca & 1 \\
\hline 11 & 1 & 1647 & 1647 - Cádiz & \\
\hline 12 & 1 & 1647 & 1647 - Toledo & 1 \\
\hline 13 & 1 & 1649 & $1649-$ Jerez & 1 \\
\hline 14 & 1 & 1649 & 1649 - Toledo & \\
\hline 15 & 1 & 1649 & 1649 - Toledo & \\
\hline 16 & 1 & 1651 & 1651 - Toledo & 1 \\
\hline 17 & 1 & 1654 & 1654 - Cadiz & 2 \\
\hline 18 & 1 & 1656 & 1656 - Toledo & 0 \\
\hline 19 & 1 & 1657 & 1657 - Capilla Real & 3 \\
\hline 20 & 1 & 1658 & 1658 - Toledo & 0 \\
\hline 21 & 1 & 1660 & 1660 - Capilla Real & 1 \\
\hline 22 & 1 & 1661 & $1661-$ Huesca & 1 \\
\hline 23 & 1 & 1661 & 1661 - Sevilla & 1 \\
\hline 24 & 1 & 1661 & 1661 - Toledo & 2 \\
\hline 25 & 2 & 1662 & 1662 - Capilla Real & \\
\hline 26 & 1 & 1662 & 1662 - Granada & 1 \\
\hline 27 & 1 & 1662 & 1662 - Granada & 1 \\
\hline 28 & 1 & 1664 & 1664 - Capilla Real & 1 \\
\hline 29 & 1 & 1665 & 1665 - Córdoba & 1 \\
\hline 30 & 1 & 1665 & 1665 - Madrid - Capilla Real & 1 \\
\hline 31 & 1 & 1666 & 1666 - Sevilla & 1 \\
\hline 32 & 1 & 1667 & 1667 - Capilla Real & 1 \\
\hline 33 & 1 & 1667 & 1667 - Malaga & 1 \\
\hline 34 & 1 & 1668 & 1668 - Convento de la Merced & 1 \\
\hline 35 & 1 & 1669 & 1669 - Capilla Real & 1 \\
\hline 36 & 1 & 1669 & 1669 - Cordoba & 1 \\
\hline 37 & 1 & 1670 & 1670 - Capilla Real & 1 \\
\hline 38 & 1 & 1670 & 1670 - Toledo & 1 \\
\hline 39 & 1 & 1671 & 1671 - Malaga & 1 \\
\hline 40 & 1 & 1671 & 1671 - Sevilla & 1 \\
\hline 41 & 1 & 1672 & 1672 - Capilla Real & 1 \\
\hline 42 & 1 & 1672 & 1672 - Granada & 1 \\
\hline 43 & 1 & 1672 & 1672 - Sevilla & 2 \\
\hline 44 & 1 & 1672 & 1672 - Toledo & 1 \\
\hline 45 & 1 & 1673 & 1673 - Capilla Real & 1 \\
\hline
\end{tabular}




\begin{tabular}{|c|c|c|c|c|}
\hline Orden & Parte & Año & Fragmento & $\begin{array}{c}\text { De } \\
\text { gallego }\end{array}$ \\
\hline 46 & 1 & 1673 & 1673 - Granada & 1 \\
\hline 47 & 1 & 1673 & 1673 - Granada & 1 \\
\hline 48 & 1 & 1673 & 1673 - Granada & 1 \\
\hline 49 & 1 & 1674 & $1674-$ Sevilla & 1 \\
\hline 50 & 1 & 1674 & 1674 - Zaragoza & 0 \\
\hline 51 & 1 & 1675 & 1675 - Capilla Real & 1 \\
\hline 52 & 1 & 1675 & $1675-$ Sevilla & 1 \\
\hline 53 & 1 & 1675 & 1675 - Sevilla 2 & 0 \\
\hline 54 & 1 & 1676 & 1676 - Capilla Real & 1 \\
\hline 55 & 1 & 1676 & 1676 - Convento de la Encarnacion & 0 \\
\hline 56 & 1 & 1676 & 1676 - Real Convento de la Encarnacion & 0 \\
\hline 57 & 1 & 1676 & 1676 - Zaragoza & 0 \\
\hline 58 & 1 & 1677 & 1677 - Capilla Real & 1 \\
\hline 59 & 1 & 1679 & 1679 - Convento de las Descalzas & 0 \\
\hline 60 & 1 & 1679 & 1679 - Convento de San Felipe & 1 \\
\hline 61 & 1 & 1679 & 1679 - Real Convento de la Encarnacion & 0 \\
\hline 62 & 2 & 1680 & 1680 - Capilla Descalzas & \\
\hline 63 & 2 & 1680 & 1680 - Capilla Real & \\
\hline 64 & 2 & 1680 & 1680 - Capilla Real-2 & \\
\hline 65 & 2 & 1680 & 1680 - Capilla Real-3 & \\
\hline 66 & 1 & 1680 & 1680 - Convento de la Encarnacion & 0 \\
\hline 67 & 1 & 1680 & 1680 - Convento de la Merced & 1 \\
\hline 68 & 1 & 1680 & 1680 - Convento de la Merced - 2 & 0 \\
\hline 69 & 1 & 1680 & 1680 - Córdoba & 1 \\
\hline 70 & 2 & 1680 & $1680-$ Sevilla & \\
\hline 71 & 2 & 1680 & 1680 - Valladolid & \\
\hline 72 & 2 & 1681 & 1681 - Capilla Real & \\
\hline 73 & 1 & 1681 & 1681 - Convento de la Merced & 1 \\
\hline 74 & 1 & 1681 & 1681 - Lerida & 1 \\
\hline 75 & 2 & 1681 & $1681-$ Sevilla & \\
\hline 76 & 2 & 1681 & 1681 - Zaragoza & \\
\hline 77 & 1 & 1682 & 1682 - Capilla de la Encarnacion & 2 \\
\hline 78 & 2 & 1682 & 1682 - Capilla Descalzas & \\
\hline 79 & 2 & 1682 & 1682 - Toledo & \\
\hline 80 & 2 & 1682 & 1682-83 - Capilla Descalzas & \\
\hline 81 & 2 & 1683 & 1683 - Calatayud & \\
\hline 82 & 2 & 1683 & 1683 - Capilla Real & \\
\hline 83 & 1 & 1683 & 1683 - Malaga & 1 \\
\hline 84 & 2 & 1683 & 1683-84 - Capilla Descalzas & \\
\hline 85 & 1 & 1685 & $1685-$ Sevilla & 1 \\
\hline 86 & 2 & 1685 & 1685 - Sevilla -2 & \\
\hline 87 & 2 & 1685 & 1685-86 - Capilla Descalzas & \\
\hline 88 & 2 & 1686 & 1686 - Calatayud & \\
\hline 89 & 1 & 1686 & 1686 - Lerida & 1 \\
\hline 90 & 2 & 1686 & $1686-$ Sevilla & \\
\hline 91 & 1 & 1687 & 1687 - Real Convento de la Encarnacion & 0 \\
\hline 92 & 2 & 1688 & 1688 - Capilla Real & \\
\hline 93 & 1 & 1688 & 1688 - Convento de la Encarnacion & 1 \\
\hline 94 & 1 & 1688 & 1688 - Convento de la Encarnacion - 2 & 1 \\
\hline 95 & 1 & 1688 & 1688 - Lérida & 1 \\
\hline 96 & 1 & 1688 & 1688 - Zaragoza & 1 \\
\hline
\end{tabular}




\begin{tabular}{|c|c|c|l|c|}
\hline Orden & Parte & Año & Fragmento & $\begin{array}{c}\text { De } \\
\text { gallego }\end{array}$ \\
\hline 97 & 1 & 1688 & 1688 - Zaragoza - 2 & 1 \\
\hline 98 & 2 & 1688 & 1688 - Zaragoza - 3 & 1 \\
\hline 99 & 1 & 1689 & 1689 - Colegial de N. Señor San Salvador & 1 \\
\hline 100 & 2 & 1691 & 1691 - Capilla Descalzas & \\
\hline 101 & 1 & 1691 & 1691 - Convento de la Encarnacion & \\
\hline 102 & 2 & 1691 & 1691 - Sevilla & \\
\hline 103 & 2 & 1691 & 1691 - Zaragoza & \\
\hline 104 & 2 & 1692 & 1692 - Sevilla & \\
\hline 105 & 2 & 1692 & 1692 - Sevilla-2 & 0 \\
\hline 106 & 2 & 1693 & 1693 - Capilla Real & 1 \\
\hline 107 & 2 & 1693 & 1693 - Sevilla & \\
\hline 108 & 2 & 1693 & 1693 - Sevilla-2 & \\
\hline 109 & 2 & 1693 & 1693 - Sevilla-3 & \\
\cline { 2 - 6 } & 1 & 1694 & 1694 - Convento de la Encarnacion & \\
\hline 111 & 1 & 1694 & 1694 - Granada & \\
\hline 112 & 2 & 1694 & 1694 - Valladolid & \\
\hline 113 & 1 & 1695 & 1695 - Iglesia Clerigos Reglares & \\
\hline 114 & 2 & 1695 & 1695 - Madrid & \\
\hline 115 & 2 & 1695 & 1695 - Sevilla & \\
\hline 116 & 2 & 1696 & 1696 - Capilla Real & \\
\hline 117 & 1 & 1697 & 1697 - Convento de la Merced & \\
\hline 118 & 2 & 1697 & 1697 - Sevilla & \\
\hline 119 & 2 & 1697 & 1697 - Sevilla-2 & \\
\hline 120 & 2 & 1697 & 1697 - Sevilla-3 & \\
\hline 121 & 1 & 1698 & 1698 - Capilla de la Encarnacion & \\
\hline 122 & 2 & 1699 & 1699 - Sevilla & \\
\hline 123 & 2 & 1699 & 1699 - Sevilla-2 & \\
\hline 124 & 1 & 1700 & 1700 - Iglesia de San Salvador & \\
\hline 125 & 2 & 1700 & 1700 - Sevilla & \\
\hline & & & & \\
\hline
\end{tabular}




\section{CONSIDERACIONES FINALES}

El individuo humano es un ser sumamente complejo y por ello los pensadores del Renacimiento decían de él que podía ser considerado como un Microcosmos, siendo así el resumen del Macrocosmos. Todo individuo humano está constituido por un cuerpo material viviente y animado, es decir provisto de ánima, psique o mente. Las tres capas ontológicas de la materialidad, la vivacidad y la psiquicidad coexisten entrelazándose y forman el individuo humano.

La creatividad está relacionada con lo que se denomina "experiencias cumbre" y la característica fundamental de la experiencia cumbre es una fascinación total con el asunto que se lleva entre manos, eso que solemos llamar "perderse en el presente"... Despegue respecto del momento y del lugar.

Podemos aducir que la versión más simplificada de la experiencia cumbre, la creatividad, consiste en la fascinación, concentración y absorción en cualquier cosa que sea lo suficientemente interesante como para retener completamente la atención.

Para poder expresar nuestras emociones y desarrollar nuestra capacidad de relación emocional, es necesario aprender a expresarlas de forma adecuada. Una manera de hacerlo es utilizar nuestro potencial creativo y lúdico. Los maestros de capilla eran maestros en toda la extensión de la palabra en las composiciones de los villancicos.

La espontaneidad la podemos definir como la manifestación de la coherencia, del equilibrio y del bienestar, entendiendo como bienestar la salud psíquica de una persona, no el confort en el que pueda vivir.

El estudio de la espontaneidad se produce sin que la persona deje de ser ella misma, ya que viene a ser una consecuencia de esto. De hecho, Maslow habla de no-aprendizaje y de liberación, puesto que no se aprende lo que uno es, sino lo que se es. De lo que se trata es de que la persona pueda liberarse de lo que no es. Se trata de que la persona se manifieste tal cual es en su misma esencia, favoreciendo de este modo que cada persona se manifieste tal como es y que siga su propio modo de ser. Así sucedía con los villancicos: la 
gente se manifestaba en libertad, porque lo sentía, y los autores de los villancicos conectaban con la sensibilidad de su público.

Podemos afirmar que la espontaneidad y la creatividad están consideradas como una misma realidad, ya que ambas surgen de una misma necesidad de autoexpresión, a partir de la cual el individuo puede sentirse distinto de los demás siendo siempre él mismo. De modo que los pasos a seguir de la creatividad son los siguientes:

1) La apertura a la experiencia, ya que el individuo vive en cada momento siendo consciente de ello, desplegando su propia experiencia en todas las dimensiones posibles, reuniéndolas aquí y ahora, en el momento presente. Esto se llama extensionalidad.

2) Lo que él produce es motivo de satisfacción y se convierte en un foco de evaluación interna de si mismo.

3) La capacidad de poder jugar con elementos y conceptos, de este juego y esta exploración libres, surgiendo así la intuición, la visión nueva y significativa de la vida.

Las personas creativas sin duda tienen algo especial que las caracteriza, una marcada personalidad y una entidad personal que no suele pasar desapercibida ya que llevan consigo el sello de la creación. De esta manera, los Maestros de Capilla potenciaban la expresión de los sentimientos, las sensaciones, las emociones y una infinidad de gestos relativos al lenguaje que nos dan buena fe de lo creativos que eran los compositores de los villancicos, tanto de las letras como de la música.

El teatro es un arte paradójico, es el arte de la paradoja; si por un lado es producción literaria, por otro es representación concreta. Es reproducible y renovable e instantáneo. Así, la flor de un día no es la de mañana ni la de ayer. Siempre habrá algo que será inmutable en el arte. El arte del refinamiento textual de la poesía más honda de Esquilo, de Víctor Hugo, de Lope de Vega, es un arte de grandes signos, es para ser contemplado, comprendido y amado. De modo que el arte de una sola persona como Molière, Sófocles, Racine, Shakespeare, es tanto o más que el cine del concurso activo, ya que es creativo sin contar con los espectadores. El espectador se convierte en público, de modo que Víctor Hugo veía en el teatro la posibilidad de conciliar las contradicciones sociales y, por su 
parte, Bertold Brecht veía en el teatro un instrumento para una toma de conciencia que puede dividir profundamente al público.

El teatro, por medio de la articulación texto-representación y por la importancia de la práctica de lo material y financiero, se nos muestra como una práctica social. El teatro no deja de ser un arte peligroso que, como simple medio de diversión, bien sea directo o indirecto, siempre a merced de los mecenas o altas clases sociales, se convierte en un arte fascinante, porque a través del teatro se pueden censurar las costumbres y los vicios de un pueblo, y no digamos del político de turno. En los villancicos se criticaban los viajes y las "andanzas" del mismo rey.

Existe una gran concidencia entre teatro y representación. Se trata de una ilusión, a veces de una ilusión óptica que se aleja de la realidad, pero otras veces el teatro profundiza en la esencia de la vida, en los problemas reales de los hombres. El conjunto de los signos visuales, auditivos, musicales, creados por el director, el decorador, los músicos, los actores, todo cobra un sentido o una pluralidad de sentidos. Siempre va más allá del conjunto textual, de las estructuras virtuales del mensaje poético, del texto literario, de las representaciones con ángeles, alas, en torno al Niño Dios. Aunque no se puede hablar de equivalencia semántica entre teatro y representación, es decir, entre el conjunto de los signos textuales y el conjunto de los signos representados (cf. Kristeva 1978).

La actitud privilegiada del texto literario se toma como lo primordial del hecho teatral, se identifica con la ilusión de una coincidencia, que por cierto nunca es llevada a cabo, entre el conjunto de los signos del texto y de los signos representados. Se suele caer en la tentación de sacralizar el texto (como es el caso de los villancicos) y de bloquear el sistema de la representación de los intérpretes (director y actores). Esto es prohibir cualquier progreso escénico. Dando tantos privilegios al texto escrito, podemos llegar a la esterilización del teatro. Paradójicamente, la falta de distinción entre texto y representación permite a los defensores del texto revertir sobre el efecto de la representación. Para Artaud, el texto es como una situación límite, el texto solo sería uno de los elementos de la representación, y precisamente el menos importante.

Dentro de la semiología teatral existe a veces una confusión que esencialmente proviene de lo que es el texto y de lo que es la representación, aunque lo esencial se refiere al texto teatral. Es decir: no se pueden disociar los signos teatrales de los signos no verbales 
de la representación (nos referimos al lenguaje kinésico). La sintaxis textual y la proxémica constituyen dos aproximaciones al hecho teatral y no se pueden confundir, sobre todo si tenemos que mostrar ulteriores relaciones, aunque en apariencia no sean inmediatamente visibles.

Roland Barthes afirma que la confusión anida en el interior de la noción de teatralidad. Nos hallamos ante una verdadera polifonía informacional, eso es la teatralidad: un espesor de signos (expresión que utilizamos para marcar el contraste entre la teatralidad y la monodia literaria). La teatralidad vendrá dada por el arte de la representación, puesto que el texto del teatro está presente en el interior de la representación bajo la forma de voz y tiene una doble existencia, pues precede a la representación y la acompaña.

En el teatro hay que distinguir dos componentes distintos e indisociables, el diálogo y las didascalias, considerando que éstas son escénicas o administrativas. La relación textual entre diálogo y didascalias varía según las épocas históricas del teatro. En Valle Inclán las didascalias tienen una importancia enorme tanto por su belleza como por las significaciones extremas, mientras que en el diálogo habla el ser que conocemos con el nombre de personaje, que es distinto del autor.

El autor dice quienes son los personajes y en cada momento quien habla, dándole a cada uno una parte del discurso y un espacio escénico para hablar, indicando los gestos, las acciones de los personajes, guardando la independencia de todo el discurso. También se suelen llamar acotaciones escénicas, pero el término didascalias parece mucho màs preciso (cf. Ubersfeld 1989).

Por otra parte, el texto teatral no puede ser nunca descifrado como la expresión de la personalidad, de los sentimientos y de los problemas que pudiera tener el autor, puesto que estos aspectos están en boca de los actores. El autor no habla en nombre propio, en confidencia, a no ser en esa parte textual constituida por las didascalias, que, a su vez, esencialmente pueden ser reducidas a un espacio mínimo. El diálogo es la voz del otro o de los otros.

El texto de los villancicos, propiedad del autor o autores, posee varias características:

1) Es la materia de la dimensión lingüística de la representación. 
2) Desde el punto de vista diacrónico, su lectura es lineal, contrasta con la polisemia de los signos de la representación.

3) El texto literario está dispuesto en capas paralelas que suponen una lectura siguiendo el orden del tiempo.

4) La percepción de lo representado conlleva que el espectador perciba simultáneamente la organización espacio-temporal de una multiplicidad de signos que son simultáneos.

En toda obra teatral hay que distinguir el texto del autor, que llamaremos T, y otro texto que es el de la puesta en escena, que también llamaremos T. Uno y otro son la oposición a $\mathrm{R}$, la representación: $\mathbf{T}+\mathbf{T}=\mathbf{R}$.

El texto del teatro puede ser analizado tanto desde el punto de vista de la lingüística tanto como desde el del proceso de comunicación y, sobre todo, desde la perspectiva del emisor.

Las seis funciones de Jakobson están presentes en el teatro. La función emotiva es de importancia capital, pues remite al emisor y el comediante la impone con todos sus medios físiscos. La conativa se dirige al destinatario-actor (personaje) y al destinatariopúblico, en este caso a los fieles que asistían a la representación de los villancicos.

La función referencial lleva al espectador a tener siempre presente el contexto histórico, social, religioso y político.

La función fática le indica al espectador las condiciones de la comunicación y su presencia como espectador teatral, de tal manera que texto y representación garantizan la concurrencia de la función fática.

La función metalingüística se presenta de lleno en todos los casos en los que se da la teatralización: estamos en el teatro, mi código es el código teatral.

La función poética no solo es un modo de análisis del discurso teatral, sino que se convierte en proceso de comunicación, pudiendo explicarnos la representación como práctica concreta. La función poética nos remite al mensaje propiamente dicho y nos aclara las relaciones entre las redes sémicas textuales.

El público espectador es el primer receptor en el proceso de comunicación. Los fieles no eran pasivos, a veces son el espejo que devuelve los signos emitidos expresamente 
para él indicando un funcionamiento fático: me gustáis o no me gustáis, de ahí los aplausos, los silbidos, los pataleos, los gritos, etc. etc. etc.

La ilusión teatral no existe, el teatro trata de exagerar los parecidos con la realidad humana, es decir, representa las acciones humanas de un universo concreto socio-cultural o socioeconómico. La ilusión revierte sobre la misma realidad escénica que intenta imitar con la mayor verosimilitud o inverosimilitud según sea la obra que se representa.

Szondi considera antidramáticas las obras de Ibsen argumentando que su tema es siempre el pasado.La palabra en el drama no es narrativa; su misión tiene mayor relevancia pues nos indica el intento de poder mostrar un riguroso presente situacional y ello nos indica la tesis de que el pasado no es dramático, puesto que lo podemos contar pero no mostrar (cf. Bobes Naves 1988).

El presente no debería ser acumulación del pasado, pero he aquí que el personaje dramático es también un ser histórico y conserva estratificados todos los momentos que ha vivido. Sencillamente se trata de hacer vivir a los personajes de Ibsen en el presente estricto y con toda la riqueza del paisaje interior de los mismos.

En el caso de los villancicos, los personajes tienen valores fijos, con una unidad gramatical y poemática, la unicidad del poema. El presente de una acción no es el presente actuante. La acción es puntual y reiterativa, durativa según el Aktionsart del verbo, teniendo límites temporales desde su inicio. Se trata de un presente temporal y espacial, es decir, de un presente con acumulación del pasado y en el que el actuante vive con las expectativas del porvenir.

Pensemos en la representación de los villancicos como si se tratara de óperas o minióperas con medios de expresión escénica como el baile, el canto, la música, el vestuario, el decorado y la iluminación, añadiendo las reacciones del público, un público hambriento de diversión y de cultura, de la que adolecia. Las manifestaciones en el orden mundano, la participación de la gente, hacían que todo un mundo se reuniese y se comunicase varais horas. Era por consiguiente un hecho teatral y un fenómeno sociológico.

En el caso de Shakespeare su fuerza radica en el mensaje y en la fuerza del lenguaje cargado de figuras retóricas y creadoras del lenguaje: "Mi ira es como la de Dios, que hiere donde más ama". El verdadero amor es más pródigo de obras que de palabras... 
Las conclusiones son muy breves y sencillas. Los villancicos eran compuestos y cantados para las representaciones de la iglesia, y fundamentalmente para hacer reír. Sin duda tenían una función docente, educadora, y otra de divertimento que lo embellecía todo y encandilaba al público.

Parece ser que el lenguaje kinésico y la expresión corporal tenían mucho que ver, debido a la importancia que tiene el lenguaje denotativo, y sobre todo la simbolización en las representaciones teatrales, en las que tiene mucha importancia la función estética, ligada a las funciones conativa, emotiva y fática.

Si en la actualidad los mass-media modifican a diario las dimensiones del mundo y transforman la vivencia del espacio y del tiempo y las relaciones con los otros, en el Barroco el teatro influía enormemente sobre la masa, la masa iletrada que seguía a pies juntillas con sumo interés el desarrollo y las manifestaciones de la Navidad, los villancicos, los cánticos de la Santa Iglesia de Dios, sabiendo que todo ello favorecía determinados aspectos de la comunicación. No cabe duda de que a través de la expresión corporal, que es lo único que nos permite conocernos unos a otros.

Con este trabajo con el que tanto nos hemos divertido, hasta hemos olvidado toda la nostalgia de nuestra vida, y, por cierto, hemos desembocado en la alegría. Estamos como el poeta Rafael Alberti al buscar ese mundo perdido que le ha separado de la infancia cerca del mar y exclama:

Ya mi sueño marinero

- ¡alegria!- va a zarpar.

Y siguiendo a San Juan de la Cruz, en su Cántico espiritual, como paráfrasis o comentario doctrinal de un poema místico y, desde la ficción poética del santo que escribe sus versos dentro del género de la égloga o pastoril, alcanzando en el Renacimiento un éxito que no tiene parangón, de esta manera todo se convierte a lo divino, a través de la presencia de la naturaleza y reviviendo el coro de los Cantares... Convirtiéndose todo en un universo lleno de símbolos y alegorías divinas. Así, los villancicos, con un trasfondo neoplatónico, nos conducen a una gran senda de la literatura española, un tipo de literatura fina, ejemplar, que culmina en la vida del cristiano como si estuviésemos viendo el discurrir 
de un río tranquilo, un río plácido que nos lleva a la esperanza de llegar con paz a nuestro destino.

El teatro que se reservó la Iglesia es un teatro didascálico, didáctico.

Nos anima a sintetizar los más variados recursos artísticos, llenos de variedades estilísticas, lo evangélico de los textos, la riqueza textual llena de infinidad de registros característicos del Barroco y el mensaje lírico y la musicalidad de los villancicos, nos hace exclamar: ¡Fascinante Barroco!

$\mathrm{Y}$, sobre todo, nos lleva a recordar que nuestras miradas son recíprocas en el mismo sentido en que lo son nuestras manos o nuestras palabras. Mirada de la mirada: veo al otro y veo que él me ve:

$$
\begin{aligned}
& \text { C'était le bonheur de ma vie } \\
& \text { de voir ses yeux me regarder }
\end{aligned}
$$

Mi felicidad era ver que sus ojos me miraban.

(V. Hugo : Les Contemplations, IV, 3)

En la ciudad de Valladolid, a dieciocho de febrero de dos mil diez

Fdo.: Generosa REY SÁNCHEZ. 


\section{BIBLIOGRAFÍA CONSULTADA}

Aguirre Baztán, Angel (ed.): Etnografía (Metodología Cualitativa en la Investigación Sociocultural). Barcelona, Boixareu Universitaria, 1995.

Alonso, Dámaso: Poesía española (Ensayo de métodos y límites estilísticos. Madrid, Editorial Gredos, 1958.

Alvar, Carlos y Beltrán, Vicente: Antología de la Poesía Gallego-Porutugesa. Selección, estudio y notas. Madrid, Editorial Alhambra, 1984.

Alvar, Manuel y otros: El comentario de textos. Madrid, Editorial Castalia, 1983.

Alvar, Manuel: Estructuralismo, Geografía y Dialectología actual. Editorial Gredos, 1983.

Alonso, Amado: Castellano, español, idioma nacional. Historia espiritual de tres nombres. Buenos Aires, Editorial Losada, 1968.

Artola, Miguel: Textos fundamentales para la historia. Madrid, Revista de Occidente, 1968.

Balconi, Lorenzo: Historia de la Música. Madrid, Ediciones Turner, 1998.

Bally, Charles: Linguistique générale et linguistique française. Berna, A. Francke, 1950.

Benhauer, Werner: El español coloquial. Madrid, Editorial Gredos, 1958.

Benhauer, Werner: El humorismo en el español hablado. Madrid, Editorial Gredos, 1973.

Bennett, Roy: Léxico de la Música. Madrid, Ediciones Akal, 2003.

Biblia de Jesrusalén. Edición revisada y aumentada. Edición española dirigida por José Angel Ubieta. Bilbao 1976.

Bickel, Ernst: Historia de la literatura romana, Madrid, Editorial Gredos, 1980.

Bobes Naves, María del Carmen: Estudios de semiología del teatro. Valladolid, Aceña, 1988. 
Borrego Nieto, Julio: Sociolingüística rural. Investigación en Villadepera de Sayago. Ediciones Universidad de Salamanca, 1981.

Bosque, Ignacio: Tiempo y aspecto en español. Madrid, Ediciones Cátedra, 1990.

Bynon, Theodora: Lingüística Histórica. Madrid, Editorial Gredos, 1981.

Caldwell, John: La Música Medieval. Madrid, Editorial Alianza Música, 1996.

Canavaggio, Jean: Historia de la iteratura española. Barcelona, Editorial Ariel, 1995.

Caro Baroja, Julio: Los pueblos de la Península Ibérica. Temas de etnografía española. Barcelona, Editorial Texertoa, 1991.

Catálogo de Villancicos de la Biblioteca Nacional, siglo XVII. Biblioteca Nacional. Ministerio de Cultura, Madrid, 1992.

Charles Lea, Henry: Los moriscos españoles, su conversión y expulsión. Universidad de Alicante, 2001.

Cicerón, Marco Tulio: La invención retórica. Madrid, Editorial Gredos, 1997.

Clercx, Suzannne: Le Baroque et la Musique. Bruxelles, Publications de la Societé de Musicologie, 1948.

Corominas J. y Pascual, J. A.: Diccionario crítico etimológico castellano e hispánico. 6 vols. Madrid, Editorial Gredos, 1984.

Corominas, Joan, Pascual, J.A.:Diccionario Crítico Etimológico Castellano E Hispánico, 1987-1991 .

Coseriu, Eugenio: El hombre y su lenguaje. Madrid, Editorial Gredos, 1985.

Coseriu, Eugenio: Sincronía, diacronía e historia. El problema del cambio Lingüístico. Madrid, Editorial Gredos, 1978.

Covarrubias, Sebastián: Diccionario Tesoro de la Lengua Castellana o Española. Edición de Martín de Riquer, de la Real Academia Española. Bbarcelona, Editorial Alta Fulla, 1993.

Dios, Salustiano de: Fuentes para el estudio del Consejo Real de Castilla. Editorial Diputación de Salamanca, 1987. 
Casa, Frank P., García Lorenzo, Luciano y Vega-Luengos, Germán (dirs.): Diccionario de la Comedia del siglo de Oro. Madrid, Editorial Castalia, 2002.

Documentos Selectos para el Estudio de los Orígenes del Romance en el Reino de León. Siglos X-XII. Edición Facsímil. León, Fundación MonteLeón, Obra Social de Caja España, 2003.

Domínguez Ortiz, Antonio y Bernard Vincent: Historia de los moriscos. Madrid, Editorial Revista de Occidente, 1978.

Elliot, John H.: España y su mundo, 1500-1700. Madrid, Tauris, 1990.

Escudero José Antonio: Administración y Estado en la España Moderna. Editorial Junta de Castilla y León, Consejería de Educación y Cultura, 2002.

Fernández, Luis: La Real Imprenta de Nuestra Señora del Prado. (1481-1835). Privilegios Reales y Bulas Apostólicas. Consejería de Cultura y Turismo, Junta de Castilla y León,1992.

Franco Grande, Xosé Luís: Diccionario Galego - Castelán. Vigo, Editorial Galaxia, 1972.

Frank Casa, P.: García Lorenzo, Luciano, Vega - Luengos, Germán:Diccionario de la Comedia del Siglo de Oro. Editorial Castalia, 2002.

Frenk Alatorre, Margit: La Lírica Popular, Madrid, Editorial Cátedra, 1989.

García de Enterría, Eduardo: La Lengua de los derechos, la formación del Derecho Público Europeo tras la Revolución Francesa. Madrid, Alianza Editorial, 1994.

García de Enterría, María Cruz y Rodríguez Sánchez de León, María José: Pliegos poéticos españoles en siete Bibliotecas Portuguesas (Siglo XVII). Universidad de Alcalá de Henares, 2000.

García de Enterría, María Cruz: Sociedad y poesía de cordel en el Barroco. Madrid, Editorial Taurus, 1973.

García Simón, Agustín: Castilla y León según la visión de los viajeros extranjeros. Siglos XV y XIX. Consejería de Educación y Cultura, Valladolid, 2001.

Gavilanes, José Luis y Apolinario, Antonio (eds.): Historia de la literatura portuguesa. 
Madrid, Editorial Cátedra, 2000.

Gil Fernández, Luis: Panorama Social del Humanismo Español (1500-1800). Madrid, Editorial Tecnos, 1997.

González -Doria, Fernando: Diccionario Heráldico y Nobiliario de los Reinos de España. San Fernando de Henares, Editorial Bitacora, 1987.

González Ollé, Fernando: El habla toledana, modelo de la lengua española. Toledo, Diputación Provincial, 1996.

González Ollé, Fernando: "El habla cortesana, modelo principal de la lengua española", Boletín de la Real Academia Española, LXXXII, 286, 2002.

Granda, Germán de (1960): "Las vocales finales del dialecto leonés", en A. Galmés de Fuentes (ed.): Trabajos sobre el dominio románico leonés. Madrid: Gredos, vol. 2, pp. 27-117.

Granda, Germán de: El español de tres mundos. (Retenciones y contactos lingüísticos en África y América). Universidad de Valladolid, 1991.

Granda, Germán de: Español de América, español de África y hablas criollas hispánicas. Cambios, contactos y contextos. Madrid, Editorial Gredos, 1994.

Guillén de Castro: Los mal casados de Valencia. Edición de Luciano García Lorenzo. Madrid, Editorial Castalia, 1976.

Humbert, J.: Mitología griega y romana. Barcelona, Editorial Gustavo Gili, 1990.

Kowzan, Tadeusz: Literatura y espectáculo. Madrid, Taurus Ediciones, 1992.

Kristeva, Julia: Semiótica. Editorial Fundamentos, 1978.

La Liturgie à la Chapelle royale de Versailles. Cecile Davy-Rigaux.: Plain Chant et Liturgie en France au XVII Siècle. Textes Réunis par Jean Duron, Paris 1997.

Lang, Mervyn F.: Formación de palabras en español: morfología derivativa productiva en el lenguaje moderno. Madrid, Ediciones Cátedra, 1992.

Lapa, M. Rodrigues: Os Vilancicos (O Vilancico Galego nos Séculos XVII e XVIII). Edição do autor. Lisboa, Depositario Seara Nova, 1930. 
Lapesa, Rafael: Historia de la Lengua española. Madrid, Editorial Gredos, 1991.

Lázaro Carreter, Fernando: Clásicos Españoles. De Garcilaso a los niños pícaros. Madrid, Alianza Editorial, 2003.

Le Guern, Michel: La metáfora y la metonimia. Madrid, Editorial Cátedra, 1976.

LLorente Maldonado, Antonio: Estudios sobre el habla de la ribera de Salamanca, comarca salmantina ribereña del Duero. Universidad de Salamanca, 1947.

López Calo, José: Historia de la Música española, 3. Siglo XVII. Madrid, Alianza Editorial, 2004.

López Morales, Humberto: Elementos leoneses en la lengua del teatro pastoril de los siglos XV y XVI. (Centro Virtual Cervantes).

Lyons, John: Semántica. Barcelona, Editorial Teide, 1980.

Maravall, José Antonio: Teatro y literatura en la sociedad barroca. Barcelona, Editorial Crítica, 1990.

Mariño Paz, Ramón: "Estudios, informacións e ideas sobre o galego entre os séculos XVI, XVII e XVIII", in M. Brea \& F. Fernández Rei (eds.): Homenaxe ó profesor Constantino García. Santiago de Compostela: Departamento de Filoloxía Galega Universidade de Santiago, vol. 2, 1991, pp. 125-133.

Mariño Paz, Ramón: "Presencia do galego na sociedade galega entre os séculos XVI, XVII e XVIII", Grial 110 (1991), pp. 263-274.

Mariño Paz, Ramón: “O sufixo número-persoal da P5 en galego: o retroceso moderno da solución cantás", Cadernos de Lingua 5 (1992), pp. 75-97.

Mariño Paz, Ramón: "Sobre a elaboración do galego escrito polo Padre Sarmiento", en Actas do Congreso Internacional do Tricentenario de Fr. Martín Sarmiento (16951995): O Padre Sarmiento e o seu tempo (Santiago de Compostela, 29 de maio - 3 de xuño de 1995). Santiago de Compostela: Consello do Cultura Galega / Universidade de Santiago de Compostela, vol. 2, 1997, pp. 89-119.

Mariño Paz, Ramón: Historia da lingua galega, $2^{\mathrm{a}}$ ed. Santiago de Compostela, Editorial Sotelo 
Blanco, 1999.

Mariño Paz, Ramón: “O idioma galego na vida, na obra e na época de Juan Antonio Posse (1766-1854), Manuel Pardo de Andrade (1760-1832) e Francisco del Valle Inclán (1736-ca. 1808)" (I), A Trabe de Ouro 41 (2000), pp. 27-48; (e II), A Trabe de Ouro 42 (2000), pp. 191-203.

Mariño Paz, Ramón: “A desnasalización vocálica no galego medieval”, Verba 29 (2002), pp. $71-118$.

Mariño Paz, Ramón: Historia de la lengua gallega. Muenchen, Lincom, 2008.

Martín Hernández, Francisco, Ortega, Alfonso y Hernández Martín, Ramón: Humanismo cristiano, Salamanca, Caja de Ahorros y Monte de Piedad de Salamanca, 1989.

Martínez, Elviro: Costumbres Asturianas. Barcelona, Editorial Everest, 1998.

Menéndez Peláez, Jesús (coord.): Historia de la literatura española. León, Editorial Everest, 1993.

Menéndez Pidal, Ramón: Mis páginas preferidas. Estudios lingüísticos e históricos. Madrid, Editorial Gredos, 1957.

Menéndez Pidal, Ramón: Orígenes del español. Madrid, Espasa Calpe, 1972.

Menéndez Pidal, Ramón: Manual de gramática histórica española. Madrid, Espasa Calpe, 1973.

Menéndez Pidal, Ramón: La lengua castellana en el siglo XVII. Madrid, Espasa Calpe, 1991.

Molho, Mauricio: Sistemática del verbo español. Madrid, Editorial Gredos, 1975.

Molho, Mauricio: Cervantes: raíces folklorícas. Madrid, Editorial Gredos, 1976.

Montero Cartelle, Enrique: "El influjo de la lengua cultual en la lengua gallega", Verba, 6 (1979), pp. 97-105.

Morala Rodríguez, José Ramón: "Del leonés al castellano", en Cano, Rafael (coord.), Historia de la lengua Española, Barcelona, Editorial Ariel, 2004, pp.555-568.

Navarro Tomás, Tomás: Métrica española. Madrid / Barcelona, Ediciones Labor, 1974. 
Nolting Hauff, Ilse: Visión, sátira y agudeza en Los Sueños de Quevedo. Madrid, Editorial Gredos, 1974.

Otterbach, Friedemann: Johann Sebastian Bach: vida y obra. Madrid, Alianza Editorial, 1990.

Paraíso, I. (2002): La Métrica Española En Su Contexto Románico, Madrid, Arco/Libros.

Pascual Rodríguez, José Antonio: Estado Actual de los Estudios del siglo de Oro. Ediciones Universidad de Salamanca, 1993.

Paz, Octavio: El Arco y la Lira. México, Editorial Fondo de Cultura Económica, 1983.

Paz, Octavio: Pasión crítica. Barcelona, Editorial Seix Barral, 1985.

Pensado Ruiz, Carmen: Cronología relativa del castellano. Universidad de Salamanca, 1984.

Pensado Tomé, José Luis: "La lexicología gallega en el siglo XVIII”, in R. Lorenzo / D. Kremer (eds.): Tradición, actualidade e futuro do galego. Actas do coloquio de Tréveris (13 a 15 de novembro de 1980), Santiago de Compostela, Xunta de Galicia, 1982, pp. 85-98.

Pensado Tomé, José Luis: "Los villancicos gallegos en Portugal”, La Voz de Galicia (A Coruña, 2-I- 1985).

Pensado Tomé, José Luis: El gallego, Galicia y los gallegos a través de los tiempos. A Coruña, La Voz de Galicia, 1985.

Pensado Tomé, José Luis: "Los villancicos gallegos y portugueses de la Catedral de Segorbe", Cuadernos de Estudios Gallegos, vol. XXXVII, núm.102, 1987, pp. 281307.

Pensado Tomé, José Luis: Galicia en su lengua y sus gentes (Ensayos). A Coruña, La Voz de Galicia, 1991.

Pierse, Frank: La Poesía épica del siglo de Oro. Madrid, Editorial Gredos, 1968.

Plain -Chant et Liturgie en France au XVII ${ }^{e}$ Siècle. Textes rèunis par Jean Duron. Editions de Klincksiek Fondations Royaumont, 1997. 
Pozuelo Yvancos, José María: Teoría del lenguaje literario. Madrid, Editorial Cátedra, 1998.

Querol Gavaldá, Miguel: La Música religiosa española del siglo XVII. Atti del Congreso Internacional Sacra Roma, 1950.

Querol Gavaldá, Miguel: Villancicos polifónicos del siglo XVII. Barcelona, Consejo Superior de Investigaciones Científicas, 1982.

Quevedo, Francisco de: Poesía Varia. Edición de James O. Crosby. Madrid, Editorial Cátedra, 1981.

Quillis, Antonio: Métrica Española. Barcelona, Editorial Ariel, 1984.

Redondo Aguayo, Anselmo: Historia de Becerril de Campos. Monografía Histórica de la villa de Becerril de Campos y Noticia Bibliográfica de sus Hijos Ilustres. Editorial Centro de Estudios Palentinos, 1952.

Riquer, Martín de: Los trovadores. Historia literaria y textos. Barcelona, Editorial Ariel, 1989-1992.

Ruiz de la Peña, Juan Luis: Teología de la Creación. Editorial Sal Terrae, 1985.

Saavedra, Pegerto: La vida cotidiana en la Galicia del Antiguo Régimen, Barcelona, Editorial Crítica, 1994.

Salvador Plans, Antonio: “La Fabla Antigua” en los dramaturgos del siglo de Oro. Cáceres, Universidad de Extremadura, 1992.

Salvador Plans, Antonio: "Los lenguajes especiales y de las minorías en el Siglo de Oro", en Cano Rafael (coord.): Historia de la lengua española, Barcelona, Editorial Ariel, 2004.

Sánchez Romeralo, Antonio: El villancico. Madrid, Gredos, 1969.

Sarmiento, Fr. Martín: Catálogo de voces vulgares y en especial de voces gallegas de diferentes vegetales. Edición y estudio por José Luis Pensado Tomé. Universidad de Salamanca, 1986.

Senabre Sempere, Ricardo: Literatura y público. Madrid, Paraninfo, 1987. 
Siguan, Miquel: España Plurilingüe, Madrid, Alianza Editorial, 1994.

Stevenson, Robert: La Música en las catedrales del Siglo de Oro. Madrid, Alianza Editorial, 1993.

Subirá, José: Historia universal de la música. Madrid, Editorial Plus Ultra, 1953.

Tavani, Giuseppe: A poesía lírica galego-portuguesa. Vigo, Editorial Galaxia, 1991.

Ubersfeld, Anne: Semiótica teatral. Madrid, Editorial Cátedra, 1989.

Valdeón Baruque, Julio: El conde Ansúrez. Cuadernos Vallisoletanos, Número 12. Vallladolid, 1988.

Vázquez Cuesta, Pilar y Mendes da Luz, María Albertina: Gramática portuguesa. $3^{\mathrm{a}}$ ed. Madrid, Editorial Gredos.

Villanueva, Carlos: Los villancicos gallegos. A Coruña, Fundación Barrie de la Maza, 1994.

Viñas Piquer, David: Historia de la crítica literaria. Barcelona, Editorial Airel, 2002.

Von Rad, Gerhard: Teología del Antiguo Testamento. Vol. II. Salamanca, Ediciones Sígueme, 1984.

Vossler, Karl: La soledad en la poesía española. Madrid, Visor Libros, 2000.

A. M. D. G. 